UNIVERSIDADE DE SÃO PAULO

Escola de Comunicações e Artes

Programa de Pós-Graduação em Música

\title{
Ornamentação barroca italiana em trio-sonatas: O Opus III de Arcangelo Corelli
}

Aluno: Roger Lins de Albuquerque Gomes Ribeiro

Orientadora: Profa. Dra. Mônica Lucas

São Paulo

Agosto de 2020 
Roger Lins de Albuquerque Gomes Ribeiro

Ornamentação barroca italiana em trio-sonatas: o Opus III de Arcangelo Corelli

Dissertação de Mestrado apresentada ao Programa de Pós-Graduação em Música da Universidade de São Paulo, como requisito para obtenção do grau de Mestre em Música.

Área de concentração: Musicologia.

Linha de pesquisa: Musicologia 1B.

Orientadora: Profa. Dra. Mônica Lucas

Versão corrigida (versão original disponível na Biblioteca da ECA/USP).

São Paulo

Agosto de 2020 
Autorizo a reprodução e divulgação total ou parcial deste trabalho, por qualquer meio convencional ou eletrônico, para fins de estudo e pesquisa, desde que citada a fonte.

\section{Catalogação na Publicação \\ Serviço de Biblioteca e Documentação \\ Escola de Comunicações e Artes da Universidade de São Paulo \\ Dados inseridos pelo(a) autor(a)}

Ribeiro, Roger Lins de Albuquerque Gomes

Ornamentação barroca italiana em trio-sonatas: : Opus

III de Arcangelo Corelli / Roger Lins de Albuquerque Gomes

Ribeiro ; orientadora, Mônica Isabel Lucas. -- São Paulo, 2020 .

234 p.: il. + Partitura.

Dissertação (Mestrado) - Programa de Pós-Graduação em Música

- Escola de Comunicaçōes e Artes / Universidade de São Paulo.

Bibliografia

Versão corrigida

1. Ornamentação livre 2. Trio-sonata 3. Corelli 4. violino

barroco 5. Música italiana I. Lucas, Mônica Isabel II.

Titulo.

CDD 21.ed. - 780 
Nome: Ribeiro, Roger Lins de Albuquerque Gomes

Título: Ornamentação barroca italiana em trio-sonatas: o Opus III de Arcangelo Corelli

Dissertação de Mestrado apresentada ao Programa de Pós-Graduação em Música da Universidade de São Paulo, como requisito para obtenção do grau de Mestre em Música.

Aprovado em:

Banca examinadora

$\operatorname{Prof}^{\circ} \operatorname{Dr}^{\circ}$ Instituição:

Julgamento: Assinatura:

$\operatorname{Prof}^{\circ} \operatorname{Dr}^{\circ}$ Instituição:

Julgamento: Assinatura:

$\operatorname{Prof}^{\circ} \operatorname{Dr}^{\circ}$ Instituição:

Julgamento: Assinatura: 
À Bia, a Vânia e Cícero, a Regina e Danilto Venturini, aos meus amados irmãos Àlec, Anderson e Caroline.

À minha vó Genyr, ao meu tio Jorge, a Lili, Mel, Rattata e Ted. 


\section{AGRADECIMENTOS}

Ao Dai Gohonzon Sama das três grandes Leis secretas do Supremo Santuário de Homon, ao Buda Original Nichiren Daishonin Sama e aos Sucessivos Reverendíssimos Soberanos da Lei;

À minha amada Vó Genyr Alves de Albuquerque Sama (in memorian) por todo amor e incentivo ao longo de minha trajetória;

Ao mestre de música Nicolau de Figueiredo (in memorian) por ter me incentivado a me apropriar do discurso musical com critério e respeito não somente ao texto, mas principalmente ao público;

À Prof ${ }^{a} \operatorname{Dr}^{\mathrm{a}}$ Mônica Isabel Lucas, pela generosidade, pelos ensinamentos, pelo entusiasmo, pelo incentivo, pela confiança, pela excelente orientação, pelo acolhimento, pela inspiração sonora e principalmente pela honra de compartilhar momentos acadêmicos e musicais tão ricos e valiosos;

À minha mestra e madrinha de música $\operatorname{Prof}^{a}$ Dr $^{\mathrm{a}}$ Laura Tausz Rónai, pelos valiosos ensinamentos, principalmente àqueles que se dão ao meio de seus generosos gestos, pelos incentivos, pela confiança e principalmente pelo deleite de realizar tanta música de câmara com tamanha cumplicidade, gosto, autoridade e humildade;

Ao $\operatorname{Prof}^{\circ} \operatorname{Dr}^{\circ}$ Luiz Henrique Fiamingui, pela generosidade em todo percurso e por todo o caminho desbravado de forma tão inspiradora;

Ao meu mestre de violino barroco Prof. Dr. Luis Otávio Santos, pela generosidade, por constantemente me desafiar à sair da zona de conforto, pelo modelo de musicalidade, elegância e discurso, pela cumplicidade, pela amizade, pela deliciosa construção de um artesanato ímpar e principalmente pelo maravilhoso modelo que me inspira constantemente em minha jornada;

À Prof ${ }^{a}$ Dr $^{a}$ Patrícia Michelini Aguilar, por acolher, incentivar e aconselhar esse projeto desde sua fase embrionária e pelo modelo de musicalidade;

Ao Prof. Dr. Cassiano Barros, pela generosidade ao longo de todo esse caminho.

Ao amigo e revisor André Esteves por sua benevolência, talento e ajuda imprescindível.

Aos Professores Doutores André Luis Micheletti, Mario Videira, Adriana Moreira, Fábio Cury, Ricardo Ballestero, Carin Zwilling, Benoît Dratwicki, Maya Suemi Lemos, Marcelo Fagerlande, Silvana Scarinci, Noara Paoliello, Eduardo Monteiro e André Cavazzoti.

Ao sr. Domenico, sr. Rafael e a toda a equipe da ECA/USP e do CMU.

À maestrina, violinista e mestra Stéphanie-Marie Degand que demonstrou com seu talento e ousadia como esse projeto era possível.

Às mestras de violino barroco, Amandine Beyer, e Mira Glodeanu, pela generosidade, acolhimento e incentivo.

Ao meu mestre de violino Prof. Bernardo Bessler, pela generosidade, musicalidade, técnica e critério exemplar. 
À minha amada esposa Beatriz Ventorini Lins de Albuquerque.

Aos meus amados pais, Vânia Lins de Albuquerque Gomes Ribeiro e Cicero Gomes Ribeiro Junior.

Ao meu amigo, irmão e companheiro de música de câmara, Eduardo Antonello.

Ao meu amigo, irmão e companheiro de música de câmara Luan Braga.

À minha amiga irmã e companheira de música, arte, vinho e incentivadora, escudeira e amazona Ana Clara da Veiga Miranda.

Aos meus amados irmãos Álec Lins de Albuquerque Gomes Ribeiro, Anderson Gomes Ribeiro e Caroline Figueredo Gomes Ribeiro.

Ao meu Tio Jorge Lins de Albuquerque (in memorian).

Aos meus amigos e companheiros de música de câmara Pedro Novaes, Átila de Paula, Carolina Faria, Carolina Collepicollo, Marcus Vinicius Sant'anna Held, Gabriel Ferrante, Daniel Prazeres, Natália Terra, Ladson Matos, Diego Nadra, Willian Coelho, Herman Schreiner, Mariela Mezza, Gabriel Pérsico, Claudio Frydman, Lucas Bracher, Clara Sawada, Kristina Augustin, Oswaldo Velasco, Matheus Prust, Claudio Yabrudi e Waldo Temporal.

Aos meus amigos, Ernesto Ett, Leornardo Ett, Isabel Ett, Marie Clement, Mauricio Pedrosa.

Aos professores e maestros Juliano Buosi, Marilia Vargas, Kátia Velletaz, João Guilherme Figueredo, Fernando Cordella, Rosana Lanzelotte.

Aos meus segundos pais, Regina e Danilto Venturini.

Aos Reverendos Seiki, Abiko (in memorian), Hirano, Isomura, Miaki, Ijiri, Sugano (in memorian) e Obaiashi (in memorian).

Ao maravilhoso Arcangelo Corelli, o Orfeu romano, Telemann, Mateo Fornari e ao Cardeal Ottoboni.

Aos amados Lili Laranja (in memorian), Mel a Lourinha (in memorian), Rattata (in memorian), Ted (in memorian) e Lilica. 


\section{RESUMO}

A partir do levantamento de tratados, outras fontes primárias como relatos de artistas e ouvintes, fontes secundarias e principalmente os modelos de ornamentação livre proposto em edições e manuscritos, principalmente o Opus V de Corelli, e do exemplo primário ornado em trio-sonatas por Telemann, esta dissertação apresenta uma discussão sobre modelos de ornamentação italiana, observando especificamente quais serão os critérios de adequação desses ornamentos ao contexto polifônico da trio-sonata. Ao fim, é apresentada uma proposta de ornamentação envolvendo três trio-sonatas do Opus III de Arcangelo Corelli. 


\begin{abstract}
This work presents a discussion on models of Italian ornamentation, starting from research of treaties, other primary sources and reports of artists and listeners from the baroque age, secondary sources and especially models of free ornamentation proposed in editions and manuscripts, mainly Corelli's Opus V, and the first model of ornamented trio-sonatas by Telemann, specifically observing which criteria of suitability could be applied in the polyphonic context of trio-sonata. Finally, an ornamentation proposal involving three of the trio-sonatas of Arcangelo Corelli's Opus III is presented.
\end{abstract}




\section{LISTA DE FIGURAS}

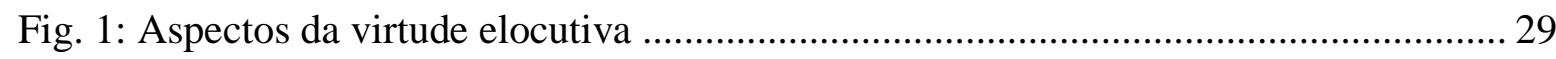

Fig. 2: Trecho de uma versão ornada da sonata Opus V n.3 .......................................... 39

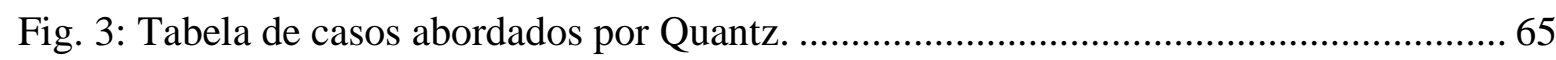

Fig. 4: Exemplo de ornamentações propostas por Quantz para um dos casos da tabela acima

Fig. 5: Trecho composto em terças e ornado em homofonia por Telemann ...................... 67

Fig. 6: Trecho em cânone na versão esqueleto com ornatos em imitação ........................... 68

Fig. 7: Trecho em cadência frígia no segundo Trietto de Telemann.................................. 70

Fig. 8: Cadência improvisada em baixo tetracordal proposta por Telemann no largo de seu

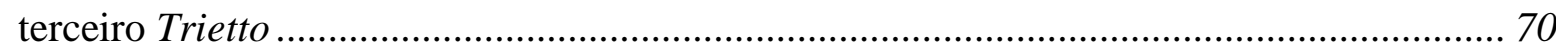

Fig. 9: Cadência ornamentável pela voz principal e solução proposta para o caso de não

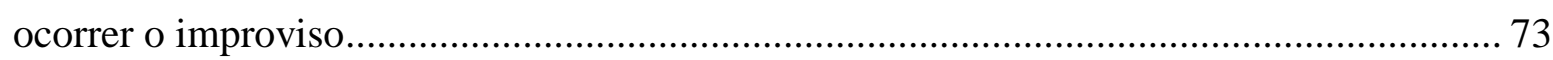

Fig. 10: Exemplo de cadência harmônica proposto por C.P.E. Bach ................................. 74

Fig. 11: Exemplo de cifragem em cadência Frígia proposto por Bach............................... 75

Fig. 12: Tabela de Ornamentos proposta por Geminiani .................................................. 77

Fig. 13: Primeira página da sonata V da terceira edição do Opus V de Corelli .................. 78

Fig. 14: Melodia ornada e com uma proposta de acompanhamento por Geminiani.............79

Fig. 15: Canção arranjada por Geminiani segundo os critérios do bom gosto ..................... 80

Fig. 16:Melodia arranjada em trio-sonata por Geminiani............................................... 81

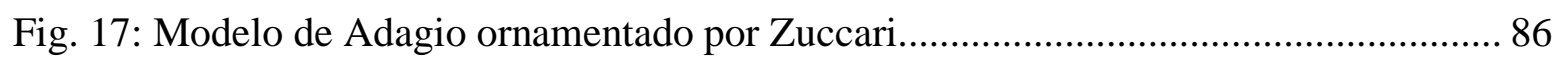

Fig. 18: Órgão de Cilindro ou realejo ............................................................................... 91

Fig. 19: Notação do compasso 1 do adágio inicial da Sonata Opus V n.4 de Arcangelo Corelli

Fig. 20: Notação do compasso 1 do adágio inicial da Sonata Opus V n.4 de Arcangelo Corelli,

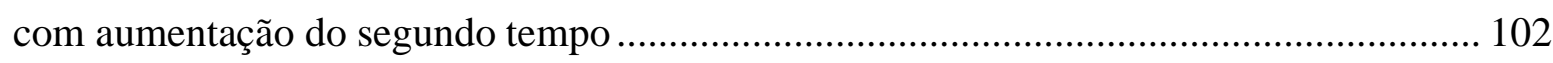

Fig. 21: Partitura do primeiro movimento da Sonata 3 de Corelli Opus 5 ........................ 103

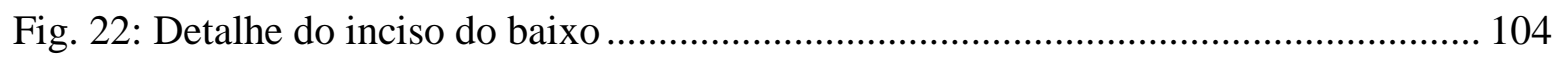

Fig. 23: Detalhe dos primeiros ornamentos com o inciso diminuído em destaque ............ 104

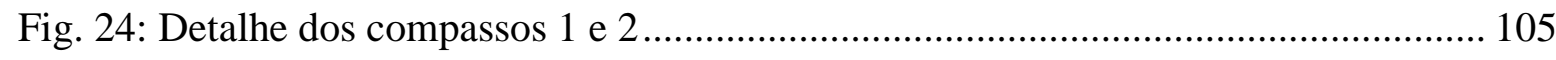

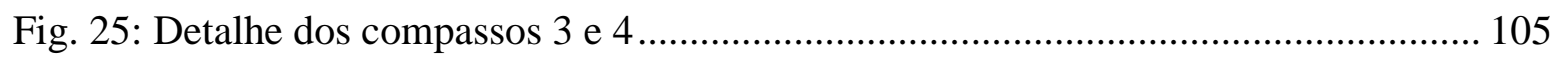

Fig. 26: Detalhe dos C. 5, 6 e 7 (parte inferior) comparados com os C. 1, 2 e 3 (parte de cima 


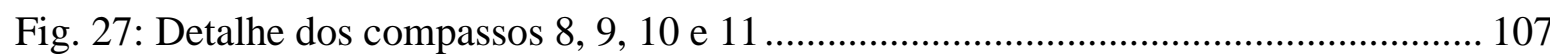

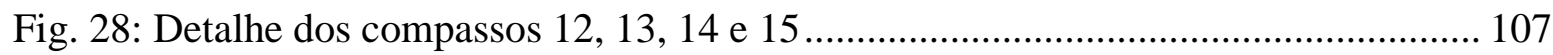

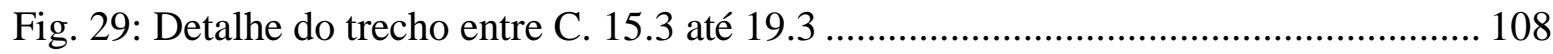

Fig. 30: Detalhe do trecho a partir de 19.3 até o final. ........................................................ 109

Fig. 31: Partitura do segundo movimento do Trietto II de Telemann, 1731 ..................... 110

Fig. 32: Partitura do primeiro mov. da son. 1 de Corelli Opus III...................................... 164

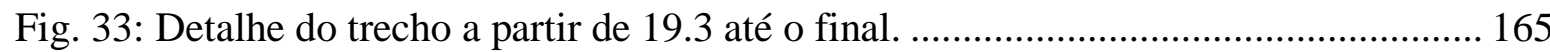

Fig. 34: Destaque a partir de 2.3 até o final do compasso 4 ............................................. 166

Fig. 35: Destaque a partir do início do quinto compasso até 8.3 ...................................... 167

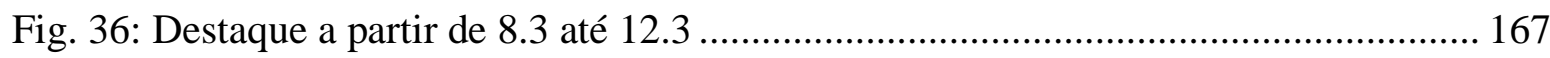

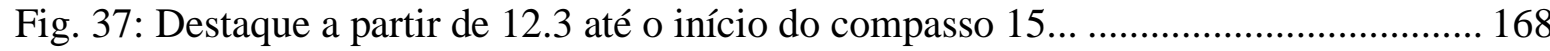

Fig. 38: Destaque a partir do compasso 14 até o final do movimento............................... 169

Fig. 39: O Grave do trio-sonata 2 do Opus III de A. Corelli ............................................... 169

Fig. 40: Adágio da sonata III do Opus V de Corelli ............................................................ 170

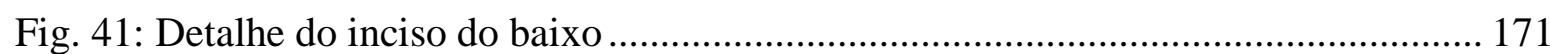

Fig. 42: Detalhe dos primeiros ornamentos com o inciso diminuído em destaque ............ 172

Fig. 43: Exemplo de ornamentação proposta para o Opus III ......................................... 172

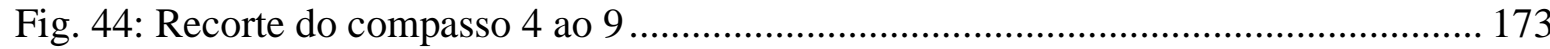

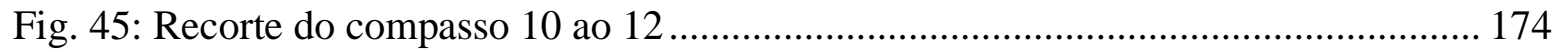

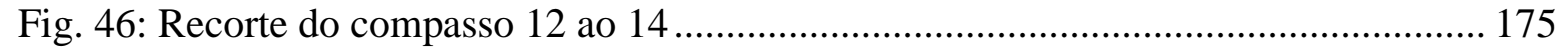

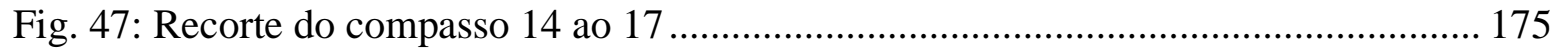

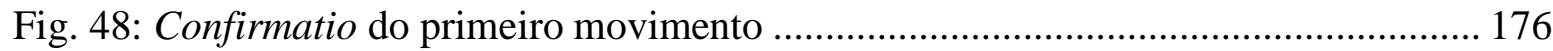

Fig. 49: O adágio do trio-sonata 2 do Opus III de A. Corelli ........................................... 177

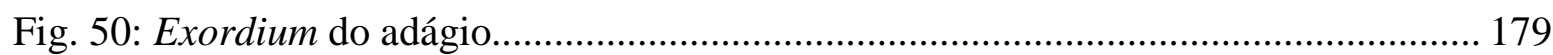

Fig. 51: Trecho do quarto movimento da sonata opus $\mathrm{V} \mathrm{n}{ }^{\circ} 1$ com destaque para os intervalos

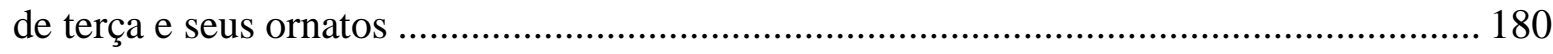

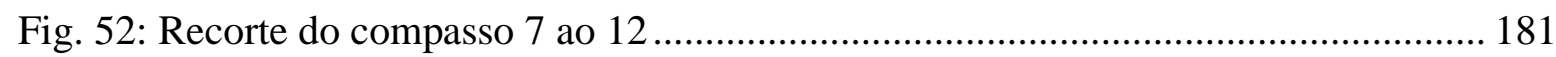

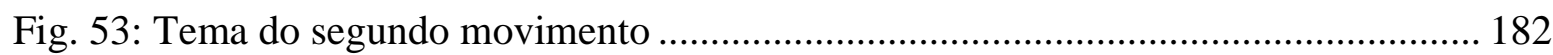

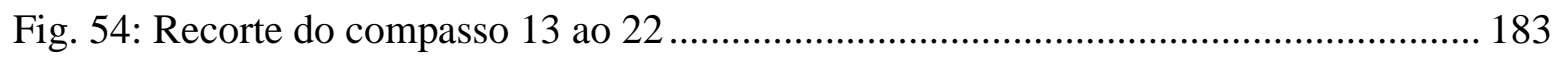

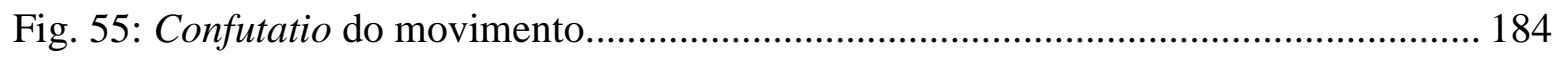

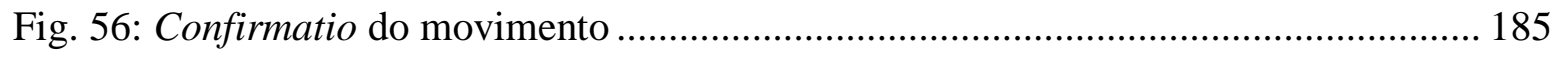

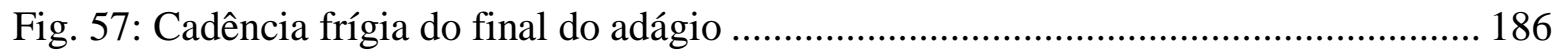

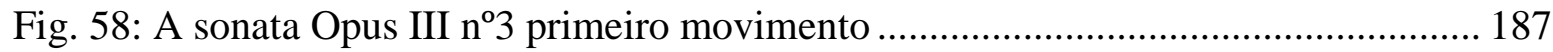


Fig. 59: Exordium do movimento (c.1 ec.2) e início da narrativo .................................. 188

Fig. 60: Trecho em destaque comparando duas edições do opus III ............................... 189

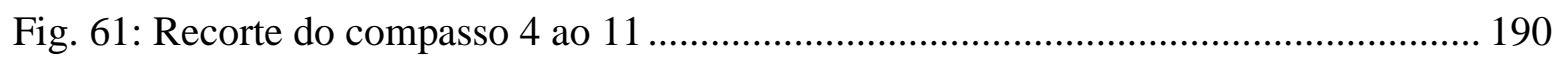

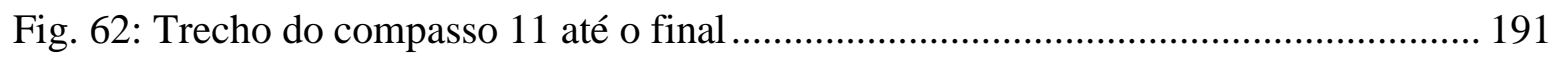

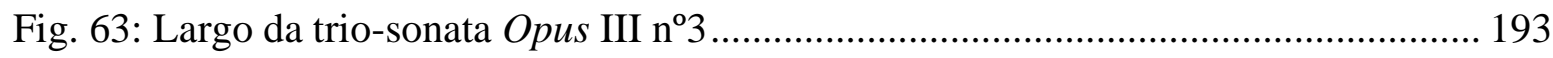

Fig. 64: Exordium do largo da terceira sonata do opus III de Corelli................................ 194

Fig. 65: Modelo de ornamentação do quarto movimento da sonata opus V nº 4 c. 17 ....... 194

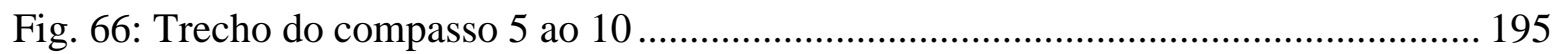

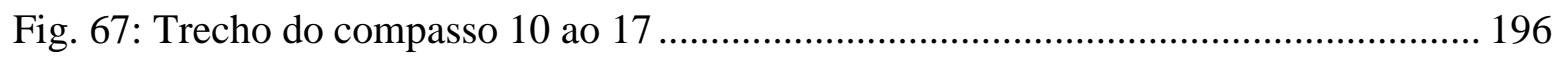

Fig. 68: Peroratio do primeiro movimento da sonata opus V nº 3 ................................... 196

Fig. 69: Trecho do compasso 17 até o final do terceiro movimento da trio-sonata Opus III n³ 197

Fig. 70: Proposta de edição didaticamente ornamentada para a sonata 1 opus III de Corelli

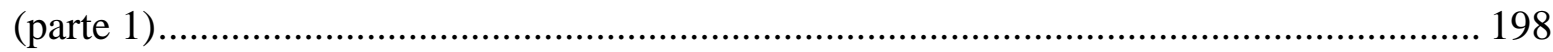

Fig. 71: Proposta de edição didaticamente ornamentada para a sonata 1 opus III de Corelli

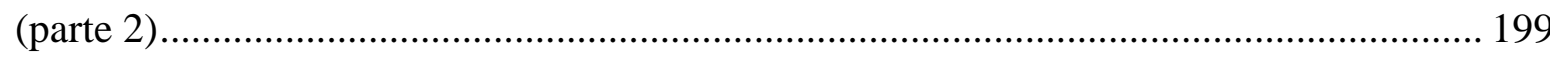

Fig. 72: Proposta de edição didaticamente ornamentada para a sonata 1 opus III de Corelli

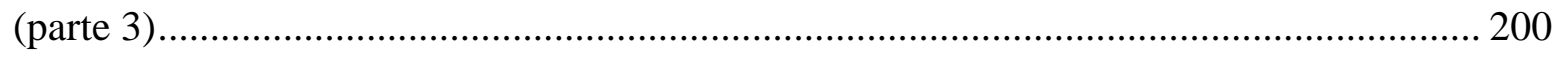

Fig. 73: Proposta de edição didaticamente ornamentada para a sonata 1 opus III de Corelli

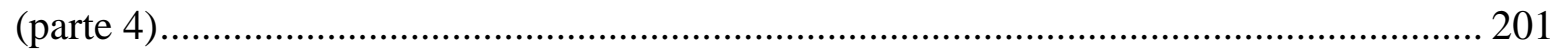

Fig. 74: Proposta de edição didaticamente ornamentada para a sonata 1 opus III de Corelli (parte 5) 202

Fig. 75: Proposta de edição didaticamente ornamentada para a sonata 1 opus III de Corelli

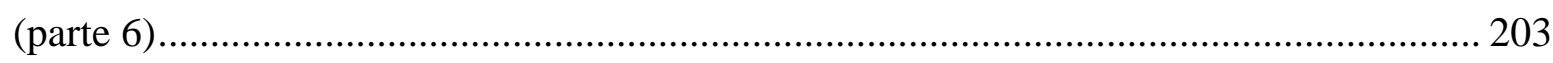

Fig. 76: Proposta de edição didaticamente ornamentada para a sonata 2 opus III de Corelli

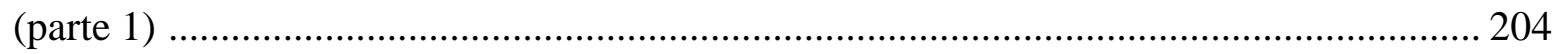

Fig. 77: Proposta de edição didaticamente ornamentada para a sonata 2 opus III de Corelli (parte 2) 205

Fig. 78: Proposta de edição didaticamente ornamentada para a sonata 2 opus III de Corelli (parte 3) 206

Fig. 79: Proposta de edição didaticamente ornamentada para a sonata 2 opus III de Corelli (parte 4) 
Fig. 80: Proposta de edição didaticamente ornamentada para a sonata 2 opus III de Corelli (parte 5) 208

Fig. 81: Proposta de edição didaticamente ornamentada para a sonata 2 opus III de Corelli (parte 6) 209

Fig. 82: Proposta de edição didaticamente ornamentada para a sonata 2 opus III de Corelli terceiro movimento (parte 7) 210

Fig. 83: Proposta de edição didaticamente ornamentada para a sonata 2 opus III de Corelli terceiro movimento (parte 8 )

Fig. 84: Proposta de edição didaticamente ornamentada para a sonata 2 opus III de Corelli terceiro movimento (parte 9) 212

Fig. 85: Proposta de edição didaticamente ornamentada para a sonata 2 opus III de Corelli terceiro movimento (parte 10) 213

Fig. 86: Proposta de edição didaticamente ornamentada para a sonata 2 opus III de Corelli terceiro movimento (parte11) 214 Fig. 87: Proposta de edição didaticamente ornamentada para a sonata 2 opus III de Corelli terceiro movimento (parte 12) 215

Fig. 88: Proposta de edição didaticamente ornamentada para a sonata 2 opus III de Corelli

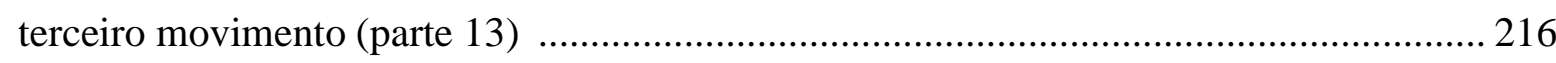
Fig. 89: Proposta de edição didaticamente ornamentada para a sonata 2 opus III de Corelli terceiro movimento (parte 14) 217 Fig. 90: Proposta de edição didaticamente ornamentada para a sonata 3 opus III de Corelli primeiro movimento (parte 1) 218 Fig. 91: Proposta de edição didaticamente ornamentada para a sonata 3 opus III de Corelli primeiro movimento (parte 2) 219

Fig. 92: Proposta de edição didaticamente ornamentada para a sonata 3 opus III de Corelli primeiro movimento (parte 3 ) .220

Fig. 93: Proposta de edição didaticamente ornamentada para a sonata 3 opus III de Corelli primeiro movimento (parte 4) 221 Fig. 94: Proposta de edição didaticamente ornamentada para a sonata 3 opus III de Corelli terceiro movimento (parte 5) 222

Fig. 95: Proposta de edição didaticamente ornamentada para a sonata 3 opus III de Corelli terceiro movimento (parte 6) 223 Fig. 96: Proposta de edição didaticamente ornamentada para a sonata 3 opus III de Corelli 
terceiro movimento (parte 7)

224

Fig. 97: Proposta de edição didaticamente ornamentada para a sonata 3 opus III de Corelli terceiro movimento (parte 8) 225

Fig. 98: Proposta de edição didaticamente ornamentada para a sonata 3 opus III de Corelli terceiro movimento (parte 9) 226

\section{LISTA DE TABELAS}

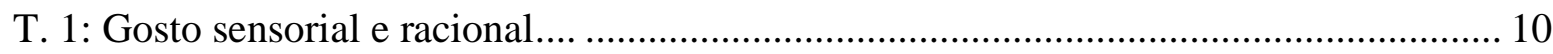

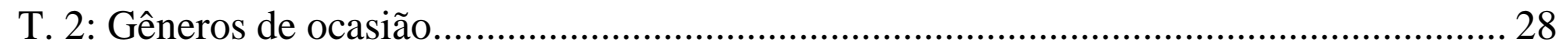

T. 3: Orquestra organizada para o oratório San Eustachio de Mansini na igreja San Giovanni

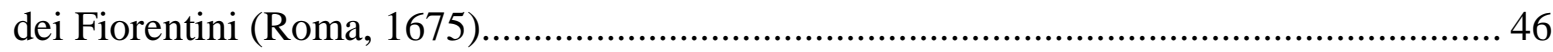

T. 4: Orquestra de Ópera Francesa do final do século XVII ............................................ 47

T. 5: Outras Orquestras Francesas (final do XVII e início do XVIII) ................................ 48

T. 6: Orquestras organizadas para a festa de São Luis na Igreja San Luigi dei Francesi (Roma,

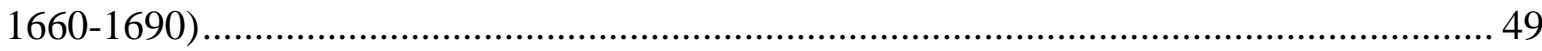

T. 7: Ornamentos da sonata Opus V n.1, primeiro movimento Grave-allegro-adágio-grave-

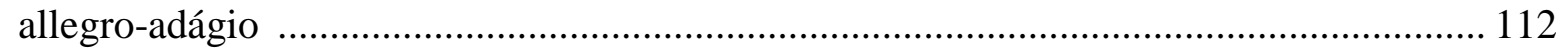

T. 8: Ornamentos da sonata Opus V n.1, quarto movimento adágio................................. 120

T. 9: Ornamentos da sonata Opus V n.2, primeiro movimento adágio ............................. 126

T.10: Ornamentos da sonata Opus V n.2, quarto movimento adágio............................... 130

T.11: Ornamentos da sonata Opus V n.3, primeiro movimento adágio ............................. 134

T.12: Ornamentos da sonata Opus V n.3, terceiro movimento adágio............................... 143

T.13: Ornamentos da sonata Opus V n.4, primeiro movimento adágio ............................. 152

T.14: Ornamentos da sonata Opus V n.4, quarto movimento adágio................................ 160 


\section{SUMÁRIO}

1 INTRODUÇÃ̃

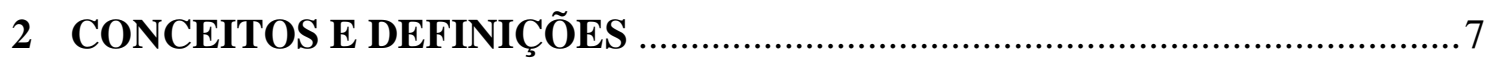

2.1 GOSTO SENSORIAL, RACIONAL, NATURAL, ADQUIRIDO,

PARTICULAR E UNIVERSAL...........................................................................

2.2 O GOSTO NACIONAL E O EUROBLOCO CULTURAL DOS SÉCULOS

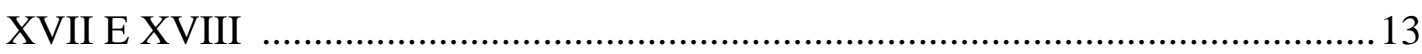

2.3 O SISTEMA RETÓRICO-MUSICAL ..................................................................

2.4 A ESTRUTURA DA RETÓRICA MUSICAL ………………………….........19

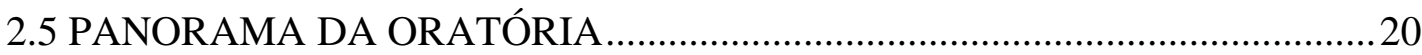

2.5.1 Pureza (Puritas) e Clareza (Perspicuitas) ……………………………......2 20

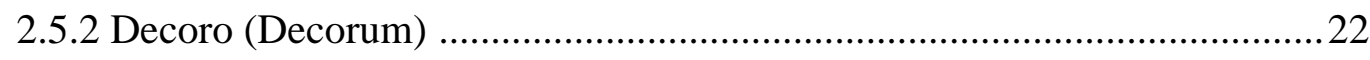

2.6 ORNATO COMO VIRTUDE ELOCUTIVA _.................................................29

2.7 OS MODELOS DE GOSTO NACIONAL: FRANÇA E ITÁLIA ………….......42

2.8 O GOSTO ITALIANO E CORELLI ..............................................................5

3 ORNAMENTAÇÃO E OS PRINCIPAIS MODELOS E TRATADOS .............61

3.1 OS PRINCIPAIS TRATADOS LEVANTADOS ..............................................61

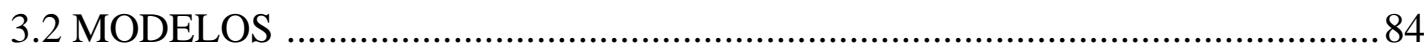

3.3 A ORNAMENTAÇÃO LIVRE COMO PRÁTICA INTERPRETATIVA _.......87

3.4 EVIDÊNCIAS DA ORNAMENTAÇÃO LIVRE NA PRÁTICA

INTERPRETATIVA CORELLIANA ……………………………………….....91

4 ANÁLISE DOS MODELOS............................................................................97

4.1 SONATA DA CHIESA E SONATA DA CAMERA DE CORELLI ....................97

4.2 METODOLOGIA DAS ANÁLISES DESCRITIVAS ......................................100

4.3 METODOLOGIA DE ANÁLISE DOS ORNAMENTOS E CONSTRUÇÂO DE

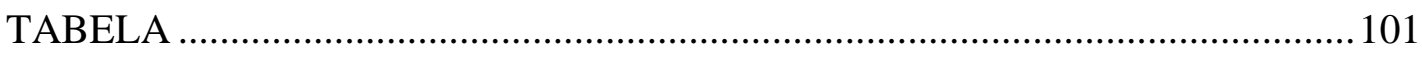

4.4 ANÁLISE DESCRITIVA DOS MODELOS DO OPUS V ................................ 103

4.5 ANÁLISE DESCRITIVA DOS MODELOS DOS TRIETTI DE TELEMANN

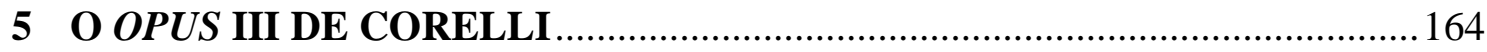

5.1 ANÁLISE DESCRITIVA DAS FORMAS ESQUELETO DOS MODELOS PROPOSTOS DO OPUS III 
5.1.1 Sonata Op. 3 n. 1 primeiro movimento Grave 164

5.1.2 Sonata Op. 3 n. 2 primeiro movimento Grave 169

5.1.3 Sonata Op. 3 n. 2 Terceiro movimento Adágio 177

5.1.4 Sonata Op. 3 n. 3 primeiro movimento 187

5.1.5 Sonata Op. 3 n. 3 terceiro movimento 192

6 PROPOSTA DE EDIÇÃO DIDATICAMENTE ORNAMENTADA 198 CONCLUSÃO .228

REFERÊNCIAS BIBLIOGRÁFICAS 230 


\section{INTRODUÇÃO}

A ornamentação livre — também chamada de italiana — é um componente essencial da música dos séculos XVII e XVIII, constituindo, assim, um relevante tema de estudo, tanto para musicólogos quanto para intérpretes que se dedicam a esse repertório.

Na Itália, exemplos modelares de ornamentação estão disponíveis, pelo menos, desde o século XV. No século XVIII, o assunto foi abordado detalhadamente em preceptivas teóricas, dentre as quais se destacam as de Quantz (1752), Tartini (1770), Geminiani (1748-1760) e Leopold Mozart (1756). Além dessas ricas fontes tratadísticas, foi possível identificar e reunir diversas edições setecentistas de sonatas solo (ou seja, para instrumento solista acompanhado de baixo contínuo) com versões extensamente decoradas, que já na época cumpriam uma importante função didática. Dentre essas edições pré-ornamentadas, destaca-se a terceira edição das sonatas Opus V de Arcangelo Corelli, por Estienne Roger (Amsterdam, 1711).

As 12 sonatas que constituem o Opus V dividem-se em dois gêneros: as primeiras seis conformam-se à escrita da chiesa, enquanto as últimas seis são sonatas da camera. Apenas os adágios das primeiras seis sonatas apresentam versões decoradas. Os ornamentos, realizados no estilo livre ou italiano, têm sua importância salientada pelo fato de que provavelmente remontam diretamente à pena de Corelli. Deste modo, estes adágios forneceriam pistas de enorme relevância sobre a interpretação do repertório contemporâneo ao mestre italiano.

A terceira edição do Opus V, segundo Zaslaw (1996), possui três valores didáticos, hoje em dia: primeiro, com os movimentos separados usados como estudos ${ }^{1}$; depois, como modelo composicional; e, finalmente, como base para a improvisação. Vamos nos ater ao terceiro atributo, em função do escopo desta dissertação. A partir dessa perspectiva, essa edição do Opus V motiva a aplicação de seus princípios nos movimentos lentos das doze sonatas de Corelli e em todo seu repertório contemporâneo, além de servir como base para a ornamentação livre do barroco tardio. No entanto, a aplicação desses princípios nas outras 48 trio-sonatas e em todo esse tipo de repertório torna-se uma questão cercada de incertezas, pois essas obras não foram reeditadas com exemplos ornados e trata-se de música em conjunto.

Segundo Zaslaw e Spitzer (2004), Corelli mantinha um corpo de músicos profissionais conhecedores de seu estilo e maneira de tocar. Dentre eles, destacava-se a figura de Matteo Fornari, amigo íntimo do compositor, que atuava majoritariamente como segundo violino e com quem tocava, muitas vezes, suas trio-sonatas. Dessa forma, uma questão prática e cultural

1 Contextualização da técnica mecânica do instrumentista na música. 
envolve esse assunto: como eles combinavam suas interpretações? Se a música do Opus V era notada sem ornamentos — havendo, no entanto, vários registros dessa prática —, não seria possível supor que Corelli, ao tocar, ornamentava os adágios das trio-sonatas? Consequentemente, Fornari, ao tocar o segundo violino, provavelmente também não se limitaria às notas escritas. Ainda, segundo Zaslaw e Spitzer (2004), Corelli era perfeccionista e ensaiava bastante sua orquestra. Seria a ornamentação uma das questões de ensaio?

Ao longo de alguns anos da minha experiência como camerista, pude perceber, em diversas situações, que um modelo de ornamentação destinado às trio-sonatas poderia contribuir muito com os estudos sobre composição, improvisação e elocução de ornamentos em grupo. Após um levantamento inicial da bibliografia - que aqui será referida - e a consulta a professores e músicos experientes, no Brasil e na Europa, constatou-se que esse é um tema de estudo que merece ser aprofundado.

A profusão de trechos ornamentados no repertório de sonatas solo exemplifica e evidencia claramente a prática da ornamentação e a liga especialmente ao estilo de Corelli. Entretanto, a existência de, pelo menos, uma instância de ornamentação aplicada à escrita de trio-sonatas pela pena de Georg Philipp Telemann (1731), mostra que a prática não se restringia apenas ao universo das peças solo. Contudo, este assunto é pouco abordado, uma vez que os estudos acerca da ornamentação italiana se concentram, na maior parte dos casos, no repertório solístico das sonatas a 2 para violino (ou outro instrumento solista) e baixo contínuo.

Sendo assim, esta dissertação apresenta - a partir do estudo dos tratados, das triosonatas ornamentadas por Telemann e dos exemplos de sonatas solo - uma discussão sobre modelos de ornamentação italiana, observando especificamente quais seriam os critérios de adequação dos mesmos ao contexto polifônico da trio-sonata. Ao fim, será apresentada uma proposta de ornamentação envolvendo a primeira trio-sonata do Opus III de Arcangelo Corelli. A relevância desta dissertação reside, dessa forma, na oportunidade de produzir e consolidar novos insumos sobre o tema, que poderão ser úteis a pesquisadores e intérpretes do repertório italiano do séc. XVIII. 


\section{CONCEITOS E DEFINIÇÕES}

Considerando a importância modelar da obra de Corelli em relação ao gosto barroco italiano — principalmente no que diz respeito à ornamentação livre —, para aprofundarmos melhor este assunto, é indispensável uma compreensão de alguns conceitos que eram senso comum ao músico barroco, mas que hoje em dia têm uma significação nebulosa e/ou não estão necessariamente contemplados pelo ensino de música comumente difundido no Brasil.

O estudo destes conceitos é bastante profundo e vasto, de forma a se tornar uma tarefa árdua expor o mínimo necessário ao leitor moderno sem transbordar o escopo desta dissertação.

\subsection{GOSTO SENSORIAL, RACIONAL, NATURAL, ADQUIRIDO, PARTICULAR E UNIVERSAL}

Os tratados do século XVIII expunham um senso comum da época: o gosto como o principal pilar na formação do artista, e também do público. Entre os temas amplamente discutidos nesses textos estavam aqueles relacionados ao efeito e ao prazer causado pela arte, através dos sentidos e da razão. Efeito esse que incidia diretamente sobre o juízo - a apreciação positiva ou negativa. Havia uma busca constante pelo aprimoramento do gosto, tanto do artista como do apreciador. Em meio a isto, a prática e apreciação da arte eram ditadas pelas normas do bom gosto e, ao mesmo tempo, visavam ao refinamento deste.

Paoliello (2017) afirma que o termo "gosto" tem como base a própria sensibilidade gustativa e que, transposto ao âmbito das artes, ele passa a ter um sentido metafórico, podendo ser aplicado também a sentidos além do paladar, como a visão e a audição. Segunda a autora, ao tratar do gosto nas artes, tanto no sentido literal como no metafórico, os autores setecentistas consideram tanto o lado sensorial como o lado racional implícitos no conceito, concentrandose essencialmente no prazer e nos efeitos causados pela obra de arte em seu espectador. A autora ainda complementa afirmando que era esperado, tanto do artista como do apreciador, uma busca pelo refinamento deste gosto, ou seja, desejava-se "que adquirissem o bom gosto através do estudo e da imitação dos modelos a fim de melhor produzir e apreciar a arte" (PAOLIELLO, 2017, pág.27). Dessa maneira, nortear o gosto por critérios racionais e por modelos considerados excelentes, permitia a artistas e ouvintes diferenciar, qualificar e ainda gozar de deleite, prazer e satisfação na medida em que o gosto distingue entre "o desagradável e o agradável."

Das nove definições da palavra "gosto" contidas no dicionário Houaiss (2001), quatro estão atreladas diretamente ao paladar, enquanto as outras cinco são metafóricas. Se excluirmos 
uma das definições que associa gosto à gorjeta e gratificação, temos quatro definições restantes que aproximam o conceito de gosto ao seu aspecto relacionado à arte:

5 opinião ou apreciação crítica sobre alguma coisa, baseadas em critérios subjetivos; preferência, entendimento, discernimento 〈seus g. não combinam com os meus〉〈a cultura apura o g. para as coisas do espírito>

6 modo de agir ou qualidade estética indicativa de tal apreciação ou julgamento 〈bom g.〉 〈mau g.〉 〈g. apurado〉〈g. exótico〉

6.1 abs. bom gosto; finura, elegância, discrição 〈a casa está decorada com g.〉

7 maneira, estilo, moda 〈escrevia ao g. romântico〉

9 ESTÉT capacidade de apreciação estética calcada em padrões e critérios intersubjetivos, e manifestada em juízos que atribuem beleza, harmonia, sublimidade etc. a formas, sons e objetos, ger. artísticos

É importante observar a forma clara como na definição de número 5 a apreciação crítica é associada a critérios subjetivos (ou seja, pessoais e não necessariamente ligados à razão), enquanto na definição 9, os critérios são intersubjetivos (ou seja, relacionam-se a uma opinião coletiva; porém, mesmo nesse caso, a ideia de subjetividade continua presente com o clássico antagonismo à de objetividade). A definição de número 6 indica, ainda, uma qualidade atrelada tanto à apreciação quanto ao julgamento - a primeira de caráter passivo, ligada à percepção e ao deleite, enquanto que a segunda ligada a um discernimento ativo - , sugerindo, dessa forma, uma definição mais racional do termo. Entretanto, pelo fato de as definições 5 e 9 explicitarem o uso de subjetividade nos critérios, o leitor é induzido a se basear nos mesmos parâmetros atrelados ao "julgamento e apreciação" da definição de número 6 (e por que não a 7 também?), o que mostra como a noção atual de gosto se encontra calcada menos na razão do que na emoção.

Ao consultarmos as sete definições para o vocábulo "gosto" no primeiro dicionário monolíngue da língua portuguesa, da autoria de Raphael Bluteau (1712), as três primeiras se referem ao paladar, as outras são tomadas em sentido metafórico:

Na definição de número 4 está escrito:

[4.] Gosto. Juízo na escolha, na aprovação de alguma coisa, bom gosto [...] [ex:] Homem de bom gosto. [...] Tem bom gosto em tudo. [...] Não tens mau gosto. [...] Este homem tem bom gosto. [...] Para o mais temos melhor gosto com o passar dos anos. [...] Discurso capaz para satisfazer a delicadeza do nosso gosto [...][ex:] não sabes que delicado é o gosto dos romanos. [...] Muito mau gosto tivera, quem não estimara versos tão elegantes. [...] dificultosamente se pode fazer coisa alguma ao gosto deste homem.[...] Fulano não tem mau gosto [...].

Essa enunciação está atrelada a "um juízo em uma escolha", com exemplos como "Para o mais temos melhor gosto com o passar dos anos" e "Discurso capaz para satisfazer a delicadeza do nosso gosto". Estes exemplos conduzem o leitor a acreditar em critérios de julgamento desenvolvidos com o passar dos anos, na primeira demonstração, e na delicadeza 
do gosto comum da segunda, ou seja, em um leque de critérios objetivos que norteiam este gosto. Já na definição de número 5 o autor propõe:

[5.] Gosto. Contentamento. Satisfação que te dá ou que te toma em alguma coisa, bom gosto. Medicamente falando, gosto é uma complacência, e alegria de algum bem, que te logra, te é moderado, é muito conveniente para a saúde. Se é muito grande e repentino, mata muitas vezes, pela grande evaporação dos espíritos e calor, que desamparam o coração, como sucedeu a Zêuxis, que morreu de riso olhando para as ridículas feições do retrato de uma velha, que acabara de fazer; ao poeta Philemon, vendo um burro, que se pôs a comer figos com ele na mesa; a Armonio (que segundo escreve Luciano) exalou a alma na flauta, que estava tangendo; a Diágoras famoso atleta de Rodes, vendo seus filhos e netos, vitoriosos e premiados.[...] Grande gosto de todos $[\ldots]$.

Bluteau inclui gosto como sinônimo de contentamento ou de satisfação, ou seja, algo emocional e atrelado à percepção, porém, ainda, na mesma definição ele diz que "Medicamente falando, gosto é uma complacência e alegria de algum bem, que te logra, te é moderado, é muito conveniente para a saúde" (grifo nosso) em seguida alertando através de exemplos para os riscos dos excessos do gosto, sugerindo uma definição que mesmo ligada a uma emoção está (ou ao menos deveria estar) sob o controle da razão. "[...]se é muito grande e repentino, mata muitas vezes, pela grande evaporação dos espíritos [...]”. As duas definições metafóricas restantes (6 e 7) são tidas como sinônimas de parâmetros mais subjetivos como divertimento (7) e comodidade (6):

[6.] Gosto (falando em coisas que se fazem cômodas e facilmente). Fareis isto ao vosso gosto; com vosso cômodo; sem vos apresardes; quando tiverdes tempo. [...] Estar deitado em uma cama, muito ao teu gosto. [...]

[7.] Gostos da vida. Divertimentos. Delícias, nome dado aos gostos da vida. [...][ex:] excogitar inventar novos gostos. [...] É o fiel do gosto do rei. [...] Dar-te aos gostos e passatempos do mundo. [...] Estar entregue aos gostos da vida. [...] Sempre está entre gostos. [...] dias de gosto.

Porém, no mesmo contexto das demais definições, tanto a noção de divertimento como a de comodidade podem ser associadas aos sentidos parâmetros de percepção bruta (gosto natural) ou atrelados a experiências predecessoras, ou vivências que as criaram (gosto adquirido). Dessa forma, no dicionário do século XVIII, vemos quatro parâmetros atrelados ao gosto: o sentido (gosto sensorial), a razão (gosto racional), a percepção bruta de um objeto (gosto natural) e a percepção refinada (gosto adquirido).

O compositor e teórico Johann Adam Hiller (1769) (apud PAOLIELLO, 2017, p. 24) define gosto racional e sensorial da seguinte maneira: "[...] por meio do primeiro [racional] percebemos as perfeições e erros de uma coisa claramente e por motivos racionais; através do segundo [sensorial], apenas indefinidamente e de maneira não tão clara".

Neste mesmo contexto, Paoliello (2017, p. 24) os diferencia: “Com isso, temos o gosto sensorial (percepção de algo através dos sentidos) e o [gosto] racional (discernimento e juízo 
sobre o que foi absorvido)". Ela ainda complementa a definição de gosto racional e sensorial da seguinte maneira:

Tabela 1: gosto sensorial e racional
a) Percepção de algo através dos sentidos
b) Efeito - sensação de prazer ou repulsa
gosto sensorial
c) Discernimento - distinguir e qualificar
d) Juízo - emissão de um julgamento

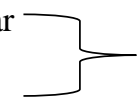
gosto racional

Fonte: Paoliello (2017, p. 24)

O termo gosto (principalmente no que diz respeito ao gosto racional) tem um campo semântico muito próximo do termo giudizio (juízo), essa associação é apontada em muitos escritos. Na recente tradução dos tratados de Geminiani, Marcus Held (2017) comenta, citando Robert Klein:

[...], sabe-se que a relação entre gosto e razão tem origem na Renascença. Klein (1998) direciona sua atenção para o termo giudizio (juízo), que, nessa época, "não era um ato de ordem puramente intelectual: pertencia a um domínio intermediário entre o intelecto e os sentidos" (p.333). O juízo, pois, é a reação ao percebido sensorialmente, [...]. Klein sustenta, ainda que, até o surgimento do termo conhecido como "gosto", a relação entre sensação e razão era realizada pela faculdade do juízo (KLEIN² 1998 apud HELD, 2017, p. 25).

Seguindo o rastro de Klein, podemos concluir que no século XVIII o gosto não era domínio exclusivo dos sentidos nem o juízo da razão, havendo um intercâmbio que justifique, e muito, o título da obra de Klein.

Aprofundando a discussão sobre gosto, no dicionário de Antonio Maria do Couto (1842), que utiliza extratos de La Méchanique des Langues (1751), de Noël Antoine Pluche, temos:

O gosto é bom, ou mau, segundo se aproxima, ou se afasta da natureza e beleza que ela, a arte, e a aprovação de muitos séculos nos fazem conhecer pelo estudo. Há três castas de gosto em pintura. 1 o gosto natural, isto é, a ideia, e o talento que um pintor adquire consultando somente a natureza sem recorrer às obras dos grandes mestres. Este gosto é baixo, ou elevado segundo a escolha, que se faz dos objetos. [...]. O 2 é o gosto artificial [adquirido], o qual se forma à vista dos quadros de outrem: é em suma o que se bebe com a educação. $O$ discípulo, que não tem bastante gênio para saber das maneiras do mestre, ou que as não pode exorbitar para de algum modo voar com as suas próprias asas não tem mais do que um gosto artificial. 3 chama-se gosto nacional, certas belezas, ou certos defeitos, que se perpetuarão nas obras dos artistas de um mesmo país. Gosto grande é o nome que se dá à escolha que um artista faz, nas suas obras, de objetos grandes, extraordinários e ao mesmo tempo inverossímeis. O bom gosto supõe muita arte, gênio e juízo para instruir, encantar e surpreender o expectador [...] ( $\mathrm{PLUCHE}^{3}$ apud COUTO, 1842, p. 179, grifo nosso).

2 KLEIN, Robert. Giudizio e Gusto na teoria da arte no Cinquecento.In: a forma e o inteligível. São Paulo: Edusp, 1998.

3 PLUCHE, Noël Antonie. La Méchanique des Langues. Paris: Chez la veuve Estienne et fils, 1751. 
Pluche expõe uma discussão bastante recorrente entre os teóricos do século XVIII, o gosto natural e o gosto adquirido, e antecipa a questão do gosto nacional, que será discutida adiante. No prefácio de suas Regras para tocar com verdadeiro gosto (1749), Geminiani, escreveu que:

O que é comumente denominado bom Gosto no cantar e no tocar foi considerado, por alguns anos no passado, como algo que destrói a verdadeira melodia e a intenção de seus compositores. Muitos supõem que não é possível adquirir o verdadeiro bom Gosto por meio de quaisquer regras de arte, pois trata-se de um dom particular da natureza, concedido apenas àqueles que têm naturalmente um bom ouvido..., e pode ser facilmente obtido por qualquer pessoa que não seja afeiçoada a sua própria opinião e que não resista obstinadamente à força da verdadeira evidência (GEMINIANI, 1749, p. 182).

Em outra passagem do mesmo prefácio, o autor faz mais uma referência ao gosto adquirido: "Aqueles que tocam violoncelo adquirirão o bom gosto ao praticar a linha superior destas composições, empenhando-se em executar com exatidão tudo o que encontrarem escrito nelas" (GEMINIANI, 1749, p. 156). Leopold Mozart (1756, p. 216) complementa, afirmando que "tudo o que pertence a uma interpretação de bom gosto de uma peça; que só pode ser aprendido pelo julgamento sólido e pela longa experiência". ${ }^{4}$

Ussher (1772), em seu compêndio sobre o gosto, afirma que "todos os espécimes que são perfeitos trazem ao mundo os primeiros princípios de gosto" ". Ou seja, o gosto natural. Em seguida, ele cita a seguinte passagem de General Reflections upon what is called Good Tafte, de Charles Rollin (1742, apud USSHER,1772, p. 3):

Um concerto que tem todas as suas partes bem compostas e bem executadas, tanto pelos instrumentistas, quanto pelos cantores, agrada universalmente, mas se surgir alguma dissonância, alguma voz que não se mistura direito com as demais, desagradará até àqueles absolutamente ignorantes em música. Eles não sabem o que os incomoda, mas sentem algo desagradável em seus ouvidos; e isso procede do gosto e do senso de harmonia implantado neles pela natureza. Da mesma maneira, uma bela pintura encanta e transporta um espectador que não tem conhecimento sobre pintura. Pergunte a ele o que o agrada e por que isso o agrada, e ele não saberá especificar a razão. ${ }^{6}$

4 Tradução nossa. Do original: "Whatever belongs to tasteful performance of a piece; which can only be learned from sound judgement and long experience."

5 Tradução nossa. Do original: "all our species that are perfect, bring the first principles of taste with them into the world."

6 Tradução nossa. Do original: A concert, says he, that has all its parts well composed and well executed, both as to instruments and voices, pleases universally: but if any discord arises, any ill tone of voice be intermixed, it shall displease even those who are absolutely ignorant of music. They know not what it is that offends them, but they find somewhat grating in it to their ears; and this proceeds from the taste and sense of harmony implanted in them by nature. In like manner a fine picture charms and transports a spectator who has no idea of painting. Ask him what pleases him, and why it pleases him, and he cannot easily give an account, or specify the real reason. 
Assim, a discussão sobre os limites dos gostos natural e adquirido também era relevante ao longo do final do século XVII e início do século XVIII.

Com relação ao gosto, além da questão da natureza e do aprendizado, textos setecentistas discorrem também sobre sua particularidade ou universalidade. Paoliello, baseada em Lord Kames ${ }^{7}$ (1761 apud PAOLIELLO, 2017, p. 44), afirma:

Lord Kames, ao discorrer sobre os princípios que devem governar o gosto de cada indivíduo, cita o provérbio já então conhecido "gosto não se discute". O autor procura entender o porquê de todos os prazeres oriundos do gosto - no que se refere apenas ao gosto sensorial, ou às artes - não serem isentos de críticas. Segundo o autor, nenhum homem de gosto aplicaria o provérbio acima no sentido figurado (nas artes) como verdade absoluta, pois todas as áreas das artes são passíveis de crítica.

E essa crítica parte por sua vez de critérios comuns a um determinado grupo ou país, assim também estando presente o senso comum. Assim, temos o gosto relacionado ao indivíduo subdividido em natural e adquirido, bem como aquele relacionado a um grupo, formando o conhecido gosto nacional.

Pluche (1751 apud COUTO, 1842, p. 179) define o conceito da seguinte maneira: "chama-se gosto nacional, certas belezas, ou certos defeitos, que se perpetuarão nas obras dos artistas de um mesmo país". Paoliello (2017, p. 45) afirma que os critérios comuns a um grupo, acima citados, "se baseiam em características predominantes tomadas como modelo e que se perpetuam nas respectivas nações". Assim, podemos compreender melhor as inúmeras referências aos gostos nacionais, recorrentes na literatura setecentista. Paoliello ainda cita Hume $^{8}$ (1757 apud PAOLIELLO, 2017, p. 45): “É interessante considerar que o gosto pessoal pode ser influenciado pelo ambiente cultural e as impressões de beleza podem derivar de relações com a sociedade". Dessa forma, a autora correlaciona o gosto individual de compositores e artistas ao gosto de um grupo, atrelando a esses artistas um julgamento com base em uma "convicção individual e ao mesmo tempo coletiva que resulta de um critério comum pertencente a um ambiente cultural". Assim, temos definido o gosto nacional ${ }^{9}$ em algumas de suas sutilezas, que são cruciais para o funcionamento na arte e na música barroca.

\subsection{O GOSTO NACIONAL E O EUROBLOCO CULTURAL DOS SECÚLOS XVII E XVIII}

Definido o "gosto" e a noção de "gosto nacional”, é importante ressaltar que, nos sécs. XVII e XVIII, duas nações se destacaram artisticamente, a ponto de seus gostos nacionais se

7 KAMES, Henry Home Lord. Standard of Taste. In: Elements of criticism: Londres: Andrew Millar, 1761.

8 HUME, David. Of the standard of taste.in: four dissertations. Londres: Andrew. Millar, 1757.

9 As definições de gosto nessa dissertação têm uma brevidade atrelada aos limites do escopo. 
tornarem modelares: são elas a França e a Itália. Essa relação era tão forte que o terceiro gosto a se destacar dos demais, o gosto alemão - surgido mais tardiamente, em meados do séc. XVIII -, era entendido como uma mistura dos dois primeiros, por isso denominado, significativamente, "gosto misto" (vermischter Geschmack) ou "gostos reunidos" (gouts réunis).

Obviamente, essa taxonomia pode ser polemizada em suas minúcias. Por exemplo, a Itália como país unificado remonta apenas ao final do século XIX, ou seja, durante o período alvo desta dissertação, o país era um conjunto de cidades-estado e países com territórios pequenos ou médios. Entretanto, o flautista alemão Johann Joachim Quantz (1757) já observa que, apesar das diferenças e sutilezas entre eles (que não são poucas!), existe um conjunto muito forte de características culturais e preferências artísticas, que, aos olhos de todas as demais nações, era visto como um gosto nacional italiano único. Esta concepção não era demolida por particularidades locais do gosto. Por exemplo: um compositor napolitano certamente teria detestado ter sua obra avaliada sob a ótica da música veneziana. As mesmas sutilezas ocorriam com relação ao gosto francês, apesar da unidade política longamente consolidada: uma obra composta para a academia real de Ópera em Paris tinha suas diferenças se comparada a uma obra composta em Lyon.

Esse mesmo tema é motor de diversas e vastas pesquisas sobre outros gostos nacionais. Dessa forma, também é possível discorrer, no século XVIII, sobre o gosto espanhol, o inglês, o luso-brasileiro e assim por diante. Mas, assim como temos a relação entre o gosto particular e o gosto coletivo, temos características de grupos maiores (ou, melhor que isso, grupos modelos) e aspectos que são comuns a um conjunto de grupos menores. Uma comparação útil é quando ampliamos o zoom de uma imagem de computador (ou inserimos uma lâmina em um microscópio). Nesse contexto, passamos a ver sutilezas e diferenças antes ocultas. Já ao diminuirmos o zoom, ou nos afastarmos do objeto, passamos a ver, no todo, mais as semelhanças do que as diferenças. Dessa forma, ao diminuirmos a "lupa de sutilezas" das distintas nações barrocas, os conjuntos de gostos mais antagônicos que sobram são o italiano e o francês.

Sobre isso Paoliello afirma:

Durante todo o século XVIII, obter o gosto, ou bom gosto, era essencial. Teóricos e compositores procuravam educar o gosto - o deles próprios, o dos instrumentistas e o do público - por meio de inúmeros tratados e através da imitação. O conceito clássico de imitação foi retomado pelas poéticas musicais e possuía papel marcante no processo de formação do gosto. Em consequência, o aspecto do gosto adquirido é fundamental para se entender a formação do Vermischter Geschmack, que é a imitação de gostos estrangeiros com o intuito de aprender, fazer igual e superar. (PAOLIELLO, 2017, p. 47) 
Assim como a imitação de modelos de gosto estrangeiros, um outro aspecto importante de destacar para a clareza do nosso estudo é a separação entre a nacionalidade de um determinado artista (país onde nasceu ou foi educado) do seu gosto (normalmente - mas nem sempre! - o mesmo do local onde ele fez carreira e/ou completou seus estudos), dessa forma temos compositores como Lully, que embora tenha nascido na Itália, se tornou um dos principais (se não o principal!) modelos do gosto francês; Händel, que nasceu na Alemanha, esteve em Roma e fez a maior parte da carreira em Londres, compondo uma música, na maior parte, de gosto italiano; e mesmo Corelli, que embora Italiano, com uma carreira e educação realizadas na Itália, sendo um dos principais modelos da música italiana (como veremos à frente), entre os subgostos italianos passou pelas mesmas transformações, nascendo na Emíliaromana, educando-se entre os bolonheses, fazendo carreira em Roma e, segundo a tese de D’Ovidio (2002), inspirado pela obra dos colegas em Roma, compôs uma nova música romana que passou a ser o modelo daquele grupo.

Exploraremos adiante as peculiaridades do modelo italiano, alvo de nosso estudo, e suas diferenças em relação ao francês. Antes, porém, é importante considerar alguns aspectos da relação entre música e retórica, importante chave para a música barroca.

\subsection{O SISTEMA RETÓRICO-MUSICAL}

Desde o surgimento das primeiras universidades na Idade Média, a música era vista como uma das sete artes liberales - um conjunto de disciplinas dignas de estudo divididas em dois grupos: quadrivium e trivium. No primeiro, se encontra a música, ao lado da aritmética, geometria e astronomia. No segundo, estavam a retórica, a gramática e a lógica. Essa ciência musical separava a prática da teoria. Segundo Santos (2012, p. 28):

No quadrivium, a música fazia parte do ofício do estudioso, dentro de um conjunto de técnicas de aplicação puramente intelectuais. Isso explica o enquadramento dessa disciplina no âmbito da theoría, o porquê de a tékhne musical estudada e preservada nas universidades ser de natureza especulativa; portanto, o estudo e o ensino da música com um enfoque puramente teórico (como estabelecido por Boécio), estão ligados também à tradição pedagógica artesanal igualmente mantida nas universidades medievais.

Essa música especulativa era de natureza matemática, mas é importante salientar que ao longo da própria Idade Média há uma divisão artificial entre a música matemática e a prática fora das universidades:

Esse é o contexto medieval que separa duas naturezas de ofício musical: a inculta (mecânica e prática) e a culta (intelectual e especulativa). É claro que essa categorização é fruto do pensamento cristalizado adotado dentro das próprias 
universidades, desde Boécio. A realidade era bem mais dinâmica do que isso. Guido d'Arezzo, por exemplo, se preocupava com uma educação musical mais unificada, no sentido de unir as duas tékhne; os avanços atribuídos a ele em relação à notação e a técnicas mnemônico-musicais refletem bem sua pedagogia artesanal, que acabaria por se tornar um novo paradigma (SANTOS, 2012, p. 28).

Segundo Lucas (2008, p. 23), essa música era "considerada como ciência de números que refletia a harmonia das esferas". A autora prossegue:

Porém, no século XVII, as artes práticas da composição e da execução musical passaram a ser compreendidas como um discurso de sons [Klangrede], cujas diretrizes eram as mesmas do discurso verbal. Sob este aspecto, a música era pensada como uma arte do trivium. Na poética musical dos séculos XVII e XVIII, a música é definida como um discurso retórico cuja matéria são as afecções humanas.

Conforme a música prática, considerada um ofício mecânico que não contemplava o estudo matemático da música do quadrivium, era absorvida por uma erudição, que agora vislumbrava não somente a teoria, mas também a prática, ela se aproximava de uma poética musical. As composições passam a ser pensadas sob essa ótica e os estudos e tratados passam a contemplar as nuances da prática e o objetivo de ambos passa ser a eficiência e o convencimento do discurso (a eloquência). Sobre esse processo, Santos (2012, p. 13) afirma:

\begin{abstract}
Assim, o retorno da influência aristotélica trouxe um novo enfoque e uma nova maneira de se documentar o estudo musical. Foi a partir de então que surgiu uma grande quantidade de obras enciclopédicas sobre música, na forma de tratados, como as summae de Johannes de Muris, Walter of Odington, Marchetto di Padova, Jacques de Liège e Johannes Tinctoris. Nas extensas obras desses autores já ocorre uma divisão do estudo musical com a dicotomia musica theorica e musica practica, onde são abordados não somente os princípios clássicos de Boécio sobre harmonia e proporção, mas também instruções sobre prática musical, como contraponto, métrica e gêneros musicais. Finalmente, foi com Gioseffo Zarlino (1517-1590) e sua Le Istituizioni Harmoniche de 1558 - a primeira obra teórica a combinar os gêneros musica practica e musica theorica num único tratado - que a visão dialética da música passou a prevalecer como base do pensamento musical, influenciando gerações de teóricos pelos duzentos anos seguintes.
\end{abstract}

$\mathrm{E}$, aos poucos, as rebuscadas divisões métricas e as peripécias contrapontísticas abrem espaço e/ou passam a servir com muito mais foco ao texto e seu discurso. Sendo importante ao músico, "prático ou teórico", ir além da música do quadrivium e buscar um domínio vasto da retórica, uma arte contida no trivium das setes artes liberais. Sobre essa arte Ellendersen (2020, p. 2) explica:

A retórica pode ser definida como um sistema avançado de comunicação de emoções e ideias. Na descrição de Aristóteles, o primeiro teórico de retórica, ela é a arte de extrair de todo assunto o grau certo de persuasão que ele permite, ou a faculdade da descoberta, por meio de especulação, dos meios de persuasão disponíveis em cada caso. Cícero estabelecia o propósito da retórica como ensinar, emocionar e deleitar docere, movere e delectare - e esta máxima foi aplicada à música na maioria dos tratados desta época. Como uma arte persuasiva, a retórica usa o som e o ritmo das palavras, tanto na forma escrita como falada. No entanto, assim como foi adaptada à música, também foi usada em dança, persuadindo por meio de movimento; e, com os seus elementos de forma, decoração e gesto, de maneiras diversas, foi também 
aplicada em pintura, escultura e arquitetura. A ligação da música com a palavra e a poesia era percebida muito fortemente na Renascença, e a organização e pronúncia de um texto passou a ser um dos principais modelos de composição e interpretação.

Em meio a essa discussão, é importante salientar como a retórica era um órgão vital da educação cortesã, eclesiástica e de alguns artesãos nesse período. Assim, prossegue o autor:

Junto com gramática e dialética, o estudo da retórica por meio das obras de Aristóteles, Cícero e Quintiliano era oferecido a todos aqueles que tinham acesso à educação. A retórica era cultivada nas academias e dominava as teorias humanistas de literatura e arte, e a sua influência no âmbito da música foi decisiva. $\mathrm{O}$ vocabulário de origem gramatical usado, desde o Medievo, para tratar da música revela este nexo forte com as artes dicendi (gramática, retórica e dialética). Exemplos são: sintaxe, motivo, tema, frase, período, sujeito, cesura, pausa e cadência, além de estilo, estrutura, figuração, articulação, declamação e acentuação (HARRÁN ${ }^{10}, 1988$ apud ELLENDERSEN, 2020, p. 3)

A importância da retórica para os tratadistas da época pode ser verificada em inúmeros testemunhos, como o de Quantz ${ }^{11}$ (1752 apud LUCAS, 2008, p. 23):

A execução musical deve ser comparada com a fala de um orador, O orador e o músico
têm como objetivo comum preparar e apresentar sua produção para se tornarem
mestres dos corações de seus ouvintes, incitando ou acalmando suas paixões e
transportando-os a um sentimento ou a outro. Portanto, é uma vantagem para ambos,
se cada um tem conhecimento do trabalho do outro.

Para Mattheson $^{12}$ (1739 apud LUCAS, 2008, p. 24), igualmente, “[...] a música instrumental não é outra coisa que uma linguagem de sons ou um discurso musical".

Dessa forma, os compositores barrocos emulavam princípios dos sistemas retóricos da antiguidade clássica. Muitas vezes, o intérprete era o próprio compositor, e mesmo quando um músico reproduzia uma composição alheia, o princípio de "culto ao texto" ${ }^{13}$ referido por Bruce Haynes (2007) não existia, de forma que o intérprete se apropriava das mesmas ferramentas que o autor da obra. Assim, a retórica também era uma ferramenta apropriada pelos intérpretes, que conforme vimos acima, recebiam seus fundamentos em sua própria educação.

Todavia, é importante ressaltar que a relação entre a retórica e a música no fim da Renascença e no Barroco varia ao longo das décadas e, principalmente, no contexto das nações onde essa música era produzida. Para Ellendersen (2020, p. 4):

10 HARRÁN, Don. Toward a Rhetorical Code of Early Music Performance. The Journal of Musicology, vol. 15, no. 1, p. 19-42, Winter, 1997.

11 QUANTZ, J. J. Versuch einer Anweisung die Flöte traversiere zu spielen. Berlim: Johann Friedrich Voß, 1752.

12 MATHESON, J. Der vollkommene Capellmeister. Hamburgo: Christian Herold, 1739.

13 Segundo Haynes (2007), o culto ao texto e à edição Urtext é uma prática consequência de diversos efeitos pósrevolução francesa, quando o intérprete musical, aqui claramente dissociado do compositor, passa a ver no texto mais do que uma bula ou receita, ele vê uma obra hermeticamente fechada e pronta. Assim, passa a ser dever do intérprete se tornar um meio para a realização da obra com o mínimo possível de interferência. 
Durante a Renascença e o Barroco a ênfase dada a cada um dos elementos da retórica variava conforme a época e a região. A racionalização e sistematização mais elaborada do seu uso em música aconteceu na Alemanha a partir do século XVI, tendo presença forte na maioria dos tratados sobre composição até o final do século XVIII. Na Itália do século XVI existem nos tratados sobre música poucas referências diretas à retórica, entretanto, a sua influência é evidente. O título do tratado Le istitutioni harmoniche, 1558 de Zarlino seria uma alusão à obra Institutio oratoria de Quintiliano (McCRELESS, 2002: 852 e PALISCA, 2006: 204) e o tratado Liber de arte contrapuncti, 1477 de Tinctoris (1435-1511) em grande parte se fundamenta na obra De oratore de Cícero (LUKO, 2008: passim).

Sobre a influência da Retórica no repertório italiano - o cerne do nosso estudo Bartel (1997, p. 10) afirma:

A música barroca italiana foi modelada mais de acordo com a arte da oratória do que da disciplina da retórica. Seu objetivo era imitar o ator e não o dramaturgo, o orador e não o retórico, refletindo uma desconfiança platônica de longa data em relação à retórica. $\mathrm{O}$ gesto dramático e o discurso carregado de pathos passaram a fornecer a inspiração necessária para a invenção musical. A rejeição italiana do significado numerológico e cosmológico da música em favor de seu princípio afetivo e estético direto de expressar e estimular o efeito afetivo e estético levou a uma forma de expressão musical que se concentrava mais em um princípio estético moderno de expressar e agitar os afetos. do que de explicar o texto. Embora o texto fosse central na composição musical, tornou-se o trampolim para a expressão musical, e não o objeto da composição. Os dispositivos musicais expressivos que caracterizam a nova música italiana foram desenvolvidos com um princípio estético e não exegético ${ }^{14} \mathrm{em}$ mente. Em vez de introduzir um nível intermediário de significado lingüístico e teológico nos fenômenos musicais, como era feito na Alemanha luterana, os artistas italianos procuravam falar direta e imediatamente aos sentidos ${ }^{15}$.

O autor ainda complementa, comparando a ênfase alemã a uma construção eloquente, ao passo que na Itália o foco era uma interpretação dramática naturalmente direcionada à emoção. Para Ellendersen (2020) a retórica musical alemã era calcada na inventio, dispositio e elocutio, ao passo que a italiana tinha uma ênfase maior na elocutio, memoria e actio $^{16}$. Como uma notável evidência disto, Galilei ${ }^{17}$ (1581 apud ELLENDERSEN, 2020, p. 89) afirma:

14 Exegético: exegese é uma interpretação ou explicação crítica de um determinado texto. Logo, o adjetivo se refere a essa mesma capacidade.

15 Tradução nossa do original: Italian Baroque music was modeled after the art of oratory rather than the discipline of rhetoric. Its goal was to imitate the actor rather than the playwright, the orator rather than the rhetorician, reflecting a longstanding Platonic mistrust of rhetoric. Dramatic gesture and pathos laden delivery was to supply the necessary inspiration for musical invention. The Italian rejection of music's numerological and cosmological significance in favor of its direct affective and aesthetic principle of expressing and strirring the affective and aesthetic effect led to a form of musical expression which focused on a modern aesthetic principle of expressing and stirring the affections rather than explaining the text. Although the text was central to musical composition, it became the springboard for musical expression rather than the object of the composition. The expressive musical devices which characterize the Italian nuove musiche were developed with an aesthetic rather than exegetic principle in mind. Instead of introducing an intermediate level of linguistic and theological significance to the musical phenomena as was done in Lutheran Germany, the Italian sought to speak directly and immediately to the senses.

16 Esses conceitos serão abordados no subcapítulo 2.4: Estrutura da Retórica Musical.

17GALILEI, Vincenzo. Dialogo della musica antica, et della moderna, Florença, 1581. 
Quando, para a sua diversão, vão às tragédias e comédias que os bufões declamam, deixem de vez em quando de lado o riso imoderado, e em seu lugar observem, por favor, de que maneira um cavalheiro quieto fala com outro, com que tipo de voz relativo à agudeza e gravidade, com que quantidade de som, com que tipo de acentos e gestos, como articula quanto à rapidez ou vagareza de movimento. Aguardem um pouco a diferença que ocorre entre tudo aquilo, quando um desses fala com um servo seu, ou então um com o outro destes; considerem o que acontece com o príncipe quando discorre com um súdito e vassalo seu, com o requerente ao recomendar-se; como o faz o furioso ou o excitado, a senhora casada, a mocinha, o menino singelo, a meretriz astuta, o amante ao falar com a sua amada para dispô-la à sua vontade, aquele que se lamenta, aquele que grita, o medroso, e aquele que regozija. Destes vários casos, sendo estes observados com atenção e examinados com cuidado, podem tomar como norma aquilo que sirva para a expressão de qualquer que seja o conceito que lhe venha em mãos.

Assim, enquanto na Alemanha temos uma escola, muitas vezes metalinguística, de retórica musical, com uma construção musical arquitetada de forma explicitamente consciente na retórica e seus mínimos detalhes, na Itália a música retórica se arquitetava de forma natural nesses moldes e era bastante focada em princípios da oratória.

Vale lembrar que para os dois autores, tanto os músicos franceses como os ingleses tinham com a retórica e a oratória a mesma relação que os italianos. Como exemplo, temos a seguinte citação de Rameau (1722, p. 156) que situa o músico no lugar de um orador, assim como um ator:

\begin{abstract}
Além disso, um bom músico deve se entregar a todos os personagens que deseja retratar; e como um ator habilidoso, se colocar no lugar do orador; acreditar que está nos lugares onde ocorrem os diferentes eventos que quer representar, e participar desses eventos da mesma maneira que seus principais interessados. Ele deve ser um bom declamador, ao menos ao declamar o texto para si mesmo; sentir quando, e em que medida, a voz deve subir ou descer para se conformar à sua melodia, sua harmonia, sua modulação e seu movimento ${ }^{18}$.
\end{abstract}

Com relação aos ingleses, Held afirma, sobre o importante violinista e tratadista Francesco Geminiani que, embora italiano, construiu sua carreira na Inglaterra: “Geminiani demonstrou, também, conhecer a retórica, uma vez que seus tratados contêm instruções semelhantes às encontradas na obra de Quintiliano" (HELD, 2017, p. 37).

Dessa forma, verificamos brevemente como a influência da retórica é variada em contextos europeus diversos. O objeto desta dissertação, ao se debruçar sobre a prática musical italiana, encontra-se, portanto, calcado principalmente na arte da oratória, tendo na elocutio um ponto de fundamental importância. Apresentaremos um panorama básico da retórica musical

18 Tradução nossa. Do original: Au reste, un bon Musicien doit se livrer à tous les caracteres qu'il veut dépeindre; et comme un habile Comedien, se mettre à la place de celuy qui parle; se croire être dans les lieux où se passent les differents évenements qu'il veut representer, et y prendre la même part que ceux qui y sont les plus interessez; être bon déclamateur, au moins en soy-même; sentir quand la voix doit s'élever ou s'abaisser plus ou moins, pour y conformer sa Melodie, son Harmonie, sa Modulation et son mouvement. 
para, em seguida, nos concentrarmos nas questões da elocução, de interesse específico para este texto.

\subsection{A ESTRUTURA DA RETÓRICA MUSICAL}

Definimos, anteriormente, o contexto das artes liberais, situando a música como disciplina matemática, pertencente ao âmbito do Quadrivium, e a retórica como estudo da palavra, situada no ramo do Trivium. Em seguida, tratamos da visão humanista da musica poetica que compreende a música como sendo análoga ao discurso, considerada sua capacidade retórica de mover o ouvinte. No sentido de situar o leitor, apresentamos o seguinte esquema, baseado no estudo referencial sobre retórica literária de Heinrich Lausberg (1990 [1960]), assim como sua transposição para o contexto musical e nos trabalhos de Bartel (1997), Tarling (2004) e Ellendersen (2020):

a) Inventio, incluindo os loci topici - invenção, definição de assuntos;

b) Dispositio - disposição e organização lógica;

i) exordium (proømium) - introdução;

ii) narratio - apresentação dos fatos;

iii) propositio (divisio ou partitio) - divisão, o argumento proposto;

iv) confirmatio - argumentos de sustentação, provas;

v) confutatio (argumentatio, refutatio ou reprehensio) - refutação, contestação;

vi) peroratio (conclusio) - conclusão;

c) Elocutio (decoratio, elaboratio) - estilo, aplicação de recursos diversos que fortalecem os argumentos. As quatro virtutes elocutionis:

i) puritas, latinitas - sintaxe correta, exatidão, precisão;

ii) perspicuitas - clareza de linguagem;

iii) ornatus (elegantia) - linguagem figurativa, tropos;

iv) aptum, decorum - compatibilidade entre forma e conteúdo;

d) Memoria - técnicas de memorização;

e) Actio (pronuntiatio, enuntiatio, executio) - apresentação, execução, interpretação ou declamação por meio de gestos e inflexões adequados.

Bartel (1997) resume a estrutura tradicional da retórica nos cinco itens acima: Inventio, Dispositio, Elocutio, Memoria e Actio. A Iventio é tida como a coleta das informações e argumentos pertinentes e ao assunto em si, seria como uma "brainstorm," a fonte das ideias. A dispositio por sua vez é a organização lógica de todo o material, na música instrumental muitas 
vezes define a forma da composição, sobretudo na Alemanha. Devido a esta propriedade, suas sete subdivisões serão abordadas mais para a frente em um subcapítulo à parte. Já a elocutio e suas quatro virtudes traduzem as ideias e pensamentos em diversas palavras e frases, adicionando recursos que enalteçam os argumentos. Memoria era ligada à memorização do discurso e a actio estava conectada à apresentação, à execução, à interpretação ou à declamação, assim como aos gestos e inflexões adequados.

Como vimos, as aproximações entre música e retórica ocorreram de maneira diversa em diferentes contextos locais e temporais. Na Alemanha, proliferaram as discussões sistemáticas sobre composição musical (musica poetica), descritas de acordo com princípios retóricos. Desta forma, a tratadística alemã concentra-se nos tópicos da inventio, dispositio e elocutio. Na Itália, diferentemente, as discussões não foram, de maneira geral, organizadas, como na Alemanha. No entanto, os escritos italianos, ao se concentrarem na oratória, ou seja, a declamação ou a interpretação, dedicam-se sobretudo à elocutio, com menções esporádicas à memória e à actio musical. Desta maneira, uma compreensão mais ampla das práticas de representação italiana sugere um estudo mais aprofundado da elocução, tanto no âmbito da retórica literária quanto em sua transposição musical.

\subsection{PANORAMA DA ORATÓRIA}

\section{Elocutio}

Conforme já dissertamos, a etapa elocutio na retórica é aquela em que traduzem as diversas ideias e pensamentos da inventio em palavras e frases concretas, adicionando recursos que enalteçam os argumentos. Desta forma, a elocutio apresenta um texto acabado, apto a ensinar, deleitar e mover o público. Para que este objetivo seja devidamente cumprido, tratados latinos discorrem sobre quatro virtudes na elocução: pureza (puritas), clareza (perspicuitas), ornato (ornatus), decoro (decorum).

\subsubsection{Pureza (Puritas) e Clareza (Perspicuitas)}

As duas primeiras virtudes da elocução - pureza e clareza - referem-se sobretudo à pronúncia, como veremos a seguir.

Pureza (Puritas), também traduzida como precisão, refere-se à condição da voz, bem como à pronúncia correta do discurso e ao controle da respiração. Quintiliano (Instituição oratória - XI, iii) afirma: 
Assim ainda se examine, caso a emissão das palavras for em princípio sadia, para dizê-lo assim, isto é, se não contiver nenhum daqueles vícios a que me referi há pouco; em seguida, se é absurda, grosseira, desproporcional, dura, rígida, roufenha, volumosa demais, ou leve, presunçosa, áspera, fraca inconsistente, efeminada (sic) e se a respiração não é curta nem de pouca sustentação, nem de difícil recuperação.

Como se pode observar, o autor define propriedades que, musicalmente, estão atreladas a parâmetros como a qualidade do timbre da voz ou instrumento. Quintiliano também nos fornece a seguinte observação, que ajuda ainda mais a esclarecer essa virtude:

Também a respiração não deve ser retomada tão constantemente a ponto de segmentar o período, como não convém estendê-la até que venha a faltar. Realmente, o som produzido pela falta dela é estranho e a respiração se torna semelhante à de alguém que se afoga, a inalação mais demorada e menos natural, como se acontecesse não onde queremos, mas, onde se faz necessária. Por isso, ao emitir um período mais longo, urge encher muito bem os pulmões, mas de tal modo que o façamos com rapidez e sem ruído, de tal maneira que se torne totalmente imperceptível; nas demais ocasiões, a respiração enquadrar-se-á melhor entre as pausas do fluxo do discurso.

(Ibidem XI, iii- 53)

\section{O pulmão do orador mencionado por Quintiliano é facilmente transposto para o}

pulmão de um cantor, de um instrumentista de sopro e/ou o fole de um instrumento, ou ainda o arco de um instrumento de corda. Sobre isso, é oportuno citar uma pequena anedota de Robert Bremner (1777), pupilo de Geminani que, por sua vez, foi aluno de Corelli:

Fui informado de que Corelli julgava que não eram dignos de tocarem em sua orquestra os músicos que não conseguissem sustentar um som grande e cheio com o arco tangendo duas cordas ao mesmo tempo, por 10 segundos, como um órgão. E no entanto, diz-se que o comprimento do arco daquela época não excedia $51 \mathrm{~cm}$. $\left(\right.$ BREMNER, 1777, p. VII, nota) ${ }^{19}$

A segunda virtude elocutiva, perspicuitas, ou clareza, está ligada à enunciação e à pontuação do discurso, com o intuito de proporcionar o máximo de inteligibilidade. Quintiliano diz:

[..] Em primeiro lugar, que corrija os defeitos de dicção, caso haja algum, para que as palavras sejam emitidas de modo que todas as letras sejam pronunciadas com os sons correspondentes. Pois algumas pronunciamos com demasiada tenuidade ou com maior volume, tornamos outras um pouco mais duras e trocamos por outras não totalmente diferentes, mas um tanto menos sonoras (QUINTILIANO, op.cit. Livro I, $\mathrm{xi}, 4)$

Ellendersen completa, relacionando o princípio de clareza ao fraseado do discurso musical tomado pelo intérprete:

O propósito da clareza — perspicuitas — era proporcionar a máxima inteligibilidade ao discurso, por meio de uma enunciação e pontuação bem cuidada, a fim de alcançar credibilidade [...] -importante para a clareza era a medida certa e natural dos meios

19 Tradução nossa. Do original: I have been informed that Corelli judged no performer fit to play in his band, who could not, with one stroke of his bow, give a steady and powerful sound, like that of an organ, from two strings at once, and continue it for ten seconds; and yet, it is said, the length of their bows at that time did not exceed twenty inches. 
aplicados. Excessos que levavam a um discurso afetado ou caricaturado prejudicavam a credibilidade. [...] Para obter a clareza era considerado necessário deixar evidente a estrutura sintática por meio de articulação e respiração corretas. Isto é, respirar entre as frases e regular o tamanho dos intervalos conforme as unidades de fala que são separadas por vírgulas e pontos. Supomos que estas observações eram recomendadas aos cantores pela correlação evidente, e novamente, por meio de imitação do canto, o violinista com o uso correto do arco deveria evidenciar o início e fim das frases musicais, além de dar contorno aos gestos musicais menores dentro das frases (ELLENDERSEN, 2020, p. 54).

Dessa forma, concluímos que um discurso musical bem dotado dessas duas virtudes exige um intérprete consciente dos "desenhos fraseológicos" adotados pelo compositor, um domínio técnico de uma boa emissão sonora de sua voz ou instrumento e - o principal! - o uso efetivo dessas habilidades no fazer musical.

\subsubsection{Decoro (Decorum)}

Segundo Lucas (2008), diretrizes setecentistas, sob orientação aristotélica, compreendem que a arte é uma imitação idealizada da natureza e essa imitação tem função ética e visa "edificar o indivíduo", incitando-o à virtude. A autora cita o próprio Aristóteles afirmando que "a virtude é a capacidade de deliberar bem acerca das espécies de coisas que levam a viver bem de um modo geral" (ARISTÓTELES apud LUCAS, 2008, p. 3). Nesse sentido, é necessária a "avaliação das circunstâncias, para que a ação sempre seja adequada à sua finalidade. A adequação conhecida entre os gregos por prepón é reconhecida pelo termo latino, decorum, ou seja, decoro" (LUCAS, 2008, p. 22).

Cícero também discorre sobre o decoro, quando elenca quatro virtudes essenciais à conduta moral, que incluem, ainda, a sabedoria, a justiça e a magnanimidade. Ao discorrer sobre o decoro no âmbito ético, o autor divide-o em duas categorias:

Há dois tipos de decoros, um geral e outro particular. O primeiro é a qualidade que combina com a excelência do ser humano naquilo em que sua natureza difere dos outros entes animados [o decoro geral une-se com a propriedade do homem naquilo em que ela é excelente]. O decoro particular é dependente do geral, é aquilo que está de tal modo conforme a natureza que nele aparecem a moderação e a temperança, com certo ar distintivo da condição livre (CICERO, De officiis).

Cícero traça um paralelo entre âmbito teatral (os poetas, ao criarem um personagem, avaliam o que convém a cada um) e o âmbito moral (somos personagens dotados, por natureza, de alta dignidade e superiores ao resto dos seres vivos). Assim como os personagens devem ser construídos segundo a conveniência (os virtuosos serão nobres, bons, belos, etc. ao passo que os viciosos serão vis, maus, feios de aparência etc.), os homens, no teatro do mundo, devem se portar convenientemente segundo as circunstâncias. O decoro é o critério que determina o justo- 
meio que tornará os demais deveres morais (sabedoria, justiça e magnanimidade) virtuosos ou viciosos: mediante a avaliação de decoro, o conhecimento será sabedoria (e não ignorância ou empáfia); a aplicação da lei será justiça (e não leniência ou injustiça), e a doação será generosa ou magnânima (e não mesquinhez ou perdulariedade ${ }^{20}$ ).

Os poetas avaliam que convém a cada um, segundo a personagem, ao passo que a nós, a própria natureza impôs uma personagem dotada de alta dignidade e superior ao resto dos seres vivos. [Mimese: os poetas têm de onde imitar]. Por isso, os poetas, na enorme variedade de personagens, determinarão o que melhor se ajusta até mesmo aos viciosos. Em nós, por outro lado, como nos foram dadas parcelas de constância, de moderação, de temperança e de discrição, e como a própria natureza nos ensina a não negligenciar o tratamento reservado a semelhantes, sucede manifestar-se não só o decoro pertinente a toda a honestidade, que é bastante evidente, mas também o que se observa em cada um dos tipos de virtude.

Sendo assim, para Cícero, decoro é sempre algum tipo de proporção, sujeita a equilíbrio (virtude) ou desequilíbrio (vício). Esta proporção encontra-se em todos os âmbitos da ação humana:

Assim como a beleza do corpo deleita pela harmonia, assim o decoro que brilha na vida acarreta a aprovação do nosso círculo se há constância e moderação nas palavras e ações.

Ao ler tal descrição, podemos perceber como os conceitos de decoro e gosto dialogam, já que ambos estão fundados na ideia de equilíbrio e proporção. O gosto, fundamentado na sensação, julga a adequação da obra e/ou da interpretação. $\mathrm{O}$ decoro determina, para o poeta (ou para o compositor) e para o orador (ou para o intérprete) quais são as proporções adequadas entre as matérias e as formas de expressão. E ter essa medida é uma virtude elocutiva.

Lucas (2008, p.25) comenta como a relação entre matéria e forma foi emulada no século XVIII:

\begin{abstract}
Autores do século XVIII, fundamentando-se em categorias instituídas pelo pensamento poético-retórico antigo, estabelecem que deve existir uma conveniência entre res (matéria) e verba (forma), que se opera em três níveis, resultando em diferentes estilos de representação retórica.
\end{abstract}

Em seguida, a autora cita os 3 estilos elencados por Cícero. O tênue:

O estilo tênue é adequado para a expressão de matérias baixas. Neste o ornato deve ser utilizado com parcimônia, para que não salte muito à vista. A finalidade deste discurso é a clareza do assunto tratado, e, por isso, ele se relaciona ao aspecto retórico do ensinamento (docere). Cícero sugere que ele apresente um certo "descuido cuidadoso" (LUCAS, 2008, p.29, grifo nosso)

O sublime:

20 Perdulário: Segundo Houaiss "condição ou qualidade de perdulário, [que por sua vez significa] aquele que gasta excessivamente, que é esbanjador ou gastador". 
O estilo sublime, ao contrário, é conveniente para a expressão de matérias elevadas. Nele, devem abundar as amplificações, figuras, ornatos de todo o tipo, que se bem empregados, "conduzem e movem o coração" do público, cumprindo a função retórica do movere (LUCAS, 2008, p. 29, grifo nosso).

E o médio:

"Há um estilo intermediário, definido por negação: não é tão ornamentado quanto o estilo sublime, nem tão simples e direto quanto o tênue. Cícero o denomina de estilo médio, e atribui a ele a função retórica de aprazer (delectare)" (LUCAS, 2008, p. 28, grifo nosso)

Lucas (2008, p. 30) ainda complementa:

Estabelecidos os gêneros da elocução, cabe ao orador expressar-se decorosamente, isto é, obedecendo a esses critérios de adequação. Segundo Cícero, e também para os teóricos musicais do século XVIII, o orador ideal é aquele que, em seu discurso, sabe mesclar convenientemente os três estilos sem ofender os protocolos decorosos.

A conveniência entre matéria e forma conforma, nas preceptivas oratórias bem como nas musicais do século XVIII, o termo “estilo," termo que segundo Bluteau (1712, p. 319-320), autor do já mencionado dicionário setecentista de português significa:

Estilo. Estilo, modo de escrever, compor ou falar qualquer língua; Antes da invenção do papel escreviam os antigos em lâminas de chumbo, em tábuas engessadas, ou cobertas de cera, com um ponteiro ou pena de ferro, a que chamavam stylus, donde procedeu, que a frase e o modo de compor também foi chamado Estilo. [...] Dividem os retóricos os estilos de bem dizer em três espécies que são, grácil, grande e médio, que podemos chamar humilde, grave e médio.

É importante frisar que o parâmetro estilo se refere a uma qualificação da maneira de escrever (discursar, compor, tocar, cantar). Brossard (apud PAOLIELLO, 2017, p. 51) em seu dicionário de música de 1708, também discorre sobre estilo, definindo o termo da seguinte maneira:

Estilo [em música] é entendido como a maneira que cada pessoa utiliza para compor, tocar, cantar ou ensinar; que é muito diferente, de acordo com o gênio [do autor], dos países, nações, e de acordo com as diferentes matérias, lugares épocas, assuntos, paixões e expressões etc.

Por fim, Paoliello (2017, p. 52) afirma: "Estilo se refere aos modos de escritas utilizados nos discursos verbais ou musicais. Essas escritas são variáveis e seguem um critério de adequação segundo a matéria e a finalidade do discurso, sendo reguladas pelo decoro".

Retóricos da antiguidade elencam três finalidades do discurso: comover (movere), ensinar (docere) e deleitar (delectare). A seguinte passagem de Quintiliano (op. cit. XII-X-59, p.513 $)^{21}$ esclarece bem a relação entre a maneira de escrita (estilo) e sua função:

A natureza deles [dos estilos] consiste, de modo geral, no seguinte: a função do primeiro [tênue ou baixo] é ensinar, a função do segundo [sublime ou alto], a de provocar emoções, e a do terceiro[médio], a de causar prazer, sendo que abrange a

21 É interessante notar que a mesma passagem se encontra escrita em latim na sequência da definição de estilo dada por Bluteau. 
dos outros dois, ou, como afirmam outros, a de conciliar os ânimos. Contudo, que transmita a impressão de agudeza de espírito ao comunicar conhecimentos, de suavidade ao conciliar os ânimos e de força ao provocar emoções. Segundo essas considerações, o modo de narrar e o de comprovar se fundamentará sobretudo na agudeza de espírito, mas muitas vezes precisará estar completo mesmo sem os aportes dos outros tipos de seu gênero.

Assim, o autor mostra que o estilo ideal para cada discurso, segundo sua finalidade, é uma questão muito mais ampla do que a divisão tríplice elencada por ele e por Cicero.

Contudo, a eloquência não se deixa restringir apenas a esses tipos [estilos], semelhantes a formas. Realmente, assim como dentro do terceiro tipo [médio], elegante e de grande importância, algo foi estabelecido, do mesmo modo existem entre eles espaços vagos e, no entremeio deles, há algo misto, proveniente de elementos dos dois tipos justapostos (QUINTILIANO, op. cit. XII-X-66 p.519).

Explicitamente há outros "subestilos" tão diversos quanto a matéria e a própria finalidade do discurso, como, em seguida o autor (ibidem, XII-X-67) explicita:

De fato, há um tipo algo mais rico e mais sutil que o meticuloso e outro tipo mais veemente e mais brando que o apenas brando, de modo que o suave está sujeito a elevar-se a tons mais fortes ou descer a tonalidades ainda mais suaves. Desse modo, encontram-se inumeráveis espécies, que com certeza se diferenciam entre si em algum momento: como aprendemos que os quatro ventos em geral sopram a partir de todos os quadrantes do mundo, ao passo que são conhecidos muitos outros de força média, inclusive seus vários nomes, e alguns até característicos de regiões e bacias hidrográficas.

Na sequência, o autor latino esclarece ainda mais o conceito de decoro da seguinte forma (ibidem, XII-X-69, p.519):

Assim também a eloquência tem muitos aspectos, mas seria grande tolice perguntar por qual deles o orador deveria se orientar, uma vez que qualquer espécie, desde que seja correta, tem seu uso e não depende, em si mesma, do orador, sendo comumente denominado genus dicendi, "espécie de oratória". Que se usem, pois, todos os tipos, conforme o assunto exigir, tendo em vista não só a causa como um todo, mas também suas partes.

Estes gêneros, segundo Reboul (1998, p. 44-63) e Paoliello (2017, p. 57), estão atrelados a três tipos de auditórios onde pode ocorrer o discurso. No âmbito da oratória política, em que transitaram Cícero e Quintiliano, são eles o Tribunal (ato de acusar ou defender), do qual decorre o gênero judiciário, a Assembléia (gesto de aconselhar ou desaconselhar) que se associa ao gênero deliberativo, e o Templo (ações de elogios, de louvor ou vitupério), relacionado ao gênero demonstrativo ou epidítico.

Com base nesses tipos de auditório, tratadistas musicais do século XVIII, como, por exemplo, Mattheson, reformulam essa divisão clássica discorrendo sobre três estilos de escrita musical, o estilo de igreja, o estilo de câmara, e o estilo teatral. Dessa forma, Mattheson em Der Vollkommene Capellmeister (1739 apud LUCAS, 2008, p. 26) estabelece:

A palavra igreja [...] tem seu significado relacionado com o serviço religioso, às funções sacras e às coisas de devoção e elevação. [...] O mesmo ocorre com o teatro 
e a câmara. [...] [É] bom qualificar o estilo de câmara com o epíteto caseiro, caso a intenção recaia sobre coisas e matérias da boa moral [sittlich]. [...] Esclarecemos o estilo dramático com o epíteto profano, quando a intenção se volta para negócios e casos mundanos das pessoas naturais [...], que fazem representar [entre si] tragédias ou comédias, alternadamente.

É importante perceber que a relação de adequação dos gêneros não se dá necessariamente com o local e sim com a finalidade representado pelo estilo de escrita. $\mathrm{O}$ autor adverte que é "[..] falso pensar que a palavra igreja seja utilizada apenas levando em consideração o simples lugar e o tempo para a divisão dos modos de escrita [..]" (MATTHESON, 1739 apud PAOLIELLO, 2017, p. 70) e sobre os outros dois estilos, teatro e camâra discorre: "nem o lugar nem o tempo devem ser primordialmente considerados. Numa sala pode ser apresentado tanto uma peça sacra quanto um concerto de câmara" (MATTHESON, 1739 apud PAOLIELLO, 2017, p. 70).

Quintiliano em sua obra Instituição Oratória (XII-x-70, pp. 519 e 521) nos apresenta uma visão semelhante, ao tratar dos gêneros de auditório da retórica clássica:

De fato, como não se expressará do mesmo modo em favor de um réu de sentença capital, numa disputa por herança, nos casos de interdito, de consignação judiciária e de empréstimos: saberá distinguir a diferença entre os discursos proferidos no senado e os das assembleias públicas e dos conselhos privados, alterará muitos pontos conforme as diferenças entre as pessoas, os lugares e os tempos, de modo a, no mesmo discurso, ora incentivar emoções, ora conciliar os ânimos; não buscará promover a ira ou a compaixão com os mesmos goles e empregará uma tática para informar ao juiz e outra diversa para comovê-lo.

Lucas afirma (2008, p. 26) que:

Para Mattheson, a ocasião determina o gênero. E, como a matéria da música são as paixões, a qualidade do afeto representado determina o estilo. Sendo assim, os estilos podem manifestar-se em qualquer gênero.

No que concerne, no entretempo, ao assim chamado alto, médio e baixo em todas as escritas [schreibarten], isto é comum no entendimento [...]: existem medidas das características acima citadas em cada estilo principal [igreja, teatral, câmara]. Apenas coisas secundárias e expressões acidentais indicam o alto, médio e baixo; é preciso enxergá-las apenas como partes acessórias, que por si só não podem definir o estilo de igreja, teatral, nem o de câmara, pois toda e qualquer expressão, represente ela algo elevado, médio ou baixo, precisa necessariamente guiar-se por um dos três gêneros de escrita [schreibarten], com todos os pensamentos, invenções e forças, como servos por seus senhores, sem exceção.

Assim, essa relação entre gênero de ocasião e estilo de finalidade são operadas de forma simultânea, mas independente, oferecendo ao orador uma infinidade de situações e decoros específicos. Paoliello (2017, p. 65) afirma: “Ao tratar da questão dos estilos na música, compositores e teóricos setecentistas abordam três aspectos principais: o gosto nacional, o 
decoro de ocasião e as especificidades técnicas de escrita". Com respeito ao decoro de ocasião, Paoliello cita Türk ${ }^{22}$ (1789 apud PAOLIELLO, 2017, p. 66):

$\mathrm{O}$ estilo é diverso de acordo com a circunstância e com as nações. Com relação à circunstância, diferenciamos o estilo de igreja, teatral e de câmara, com relação às nações, no entanto, principalmente o estilo (gosto) italiano, francês e alemão. [...] Além das divisões acima do estilo, diferenciamos comumente ainda a maneira de escrita estrita da livre.

O flautista Johann Joachim Quantz (1752 apud PAOLIELLO, 2017) diferencia dois tipos de decoro, sendo o primeiro advindo do conhecimento das regras e o segundo referente ao conhecimento dos gostos nacionais e das especificidades das circunstâncias de execução:

Para julgar adequadamente a composição e a performance musical como um todo. [...] é necessário, além de ter um perfeito bom gosto e um entendimento das regras de composição, possuir discernimento suficiente sobre a maneira e as características de cada peça, seja ela composta segundo o gosto desta ou daquela nação, para essa ou aquela finalidade, e ter discernimento para que não se confunda uma coisa com outra (QUANTZ, 1752 apud PAOLIELLO, 2017, p. 67).

Paoliello (2017, p. 69) afirma, ainda, que o decoro de ocasião ou escrita possui dois aspectos: "um externo (em relação à concordância entre matéria e ocasião ${ }^{23}$ ) e outro interno (entre a matéria e a escrita)".

Ou seja, a ocasião (os gêneros de auditório, sacro, teatral ou de câmara) determina o afeto (a matéria) e a maneira como esse afeto deve ser representado. Existem dois estilos de escrita: a estrita e a livre. Sobre isso, Heinrich Christoph Koch (2006 apud PAOLIELLO, 2017, p. 69) afirma:

[...] Em consideração à variedade de tratamento do material da arte, ou maneira de ligações entre os sons pelos quais emoções são expressas; neste caso temos dois tipos principais, que aparecem ora separados, ora misturados, e que denominamos o estilo estrito ou ligado, e o livre ou desligado.

A opção pela escrita adequada (estrita ou livre) é definida também em virtude da clareza e essa mesma escolha influencia o uso dos ornatos (que serão abordados em detalhes no próximo subcapítulo).

Algumas ocasiões de auditório ditam, preferencialmente, alguns gêneros musicais, os quais são conectados a uma escrita. Assim, um prelúdio é um dos gêneros musicais favoritos do estilo de câmara, tendo uma escrita preferencialmente livre e exigindo uma ornamentação bastante rica. Uma fuga ou moteto, ao contrário, se enquadram em um estilo de igreja, com uma

22 TÜRK, Daniel Gottlob. Klavierschule, oder Anweisung zum Klavierspielen für Lehrer und Lernende, mit kritischen Anmerkungen. Leipzig \& Halle: Schwickert; Hemmerde und Schwetschke, 1789.

23 Sacra, teatral e de câmara. 
escrita preferencialmente estrita, exigindo uma escolha mais básica dos ornamentos e optando somente pelo necessário.

A fim de diferenciar melhor os três gêneros de ocasião elencados por Mattheson, apresentamos o quadro abaixo, baseado nos trabalhos de Paoliello, Türk, Koch, e Lucas:

Tabela 2: Gêneros de ocasião

\begin{tabular}{|l|l|l|l|l|}
\hline $\begin{array}{l}\text { Gêneros de } \\
\text { ocasião }\end{array}$ & $\begin{array}{l}\text { Escrita } \\
\text { preferencial }\end{array}$ & $\begin{array}{l}\text { Finalidade } \\
\text { preferencial }\end{array}$ & Ornato & Gêneros musicais preferenciais \\
\hline $\begin{array}{l}\text { Estilo de } \\
\text { igreja }\end{array}$ & Estrita & Comover (alto) & $\begin{array}{l}\text { Somente o } \\
\text { necessário }\end{array}$ & $\begin{array}{l}\text { Oratórios, paixões, cantatas sacras, } \\
\text { missas, hinos, salmos, fugas e } \\
\text { motetos. }\end{array}$ \\
\hline Estilo Teatral & $\begin{array}{l}\text { Livre e/ou } \\
\text { estrita (atrelada } \\
\text { ao assunto) }\end{array}$ & $\begin{array}{l}\text { Algo entre } \\
\text { e comover } \\
\text { (alto) }\end{array}$ & $\begin{array}{l}\text { De acordo } \\
\text { com o que a } \\
\text { escrita exigir } \\
\text { no momento }\end{array}$ & $\begin{array}{l}\text { Óperas sérias, operetas cômicas, } \\
\text { pastorais, cantatas profanas e } \\
\text { serenatas }\end{array}$ \\
\hline $\begin{array}{l}\text { Estilo de } \\
\text { câmara }\end{array}$ & Livre & $\begin{array}{l}\text { Algo entre } \\
\text { deleitar (médio) } \\
\text { e instruir } \\
\text { (baixo) }\end{array}$ & À vontade & $\begin{array}{l}\text { Parte de cantatas, prelúdios, cantos e } \\
\text { canções, sinfonias, sonatas, duos, } \\
\text { trios, quartetos, concertos, solos, } \\
\text { divertimentos, partitas, parte das } \\
\text { danças }\end{array}$ \\
\hline
\end{tabular}

Fonte: do autor, 2020, inspirada nos trabalhos de Paoliello, Türk, Koch, e Lucas.

Por último, no intuito de resumir e esclarecer os principais aspectos desta virtude elocutiva, com base no que foi discutido até o momento e em toda bibliografia levantada, sobretudo os trabalhos de Lucas (2008) e Paoliello (2017), propomos o seguinte esquema (Figura 1): 
Figura 1: Aspectos da virtude elocutiva

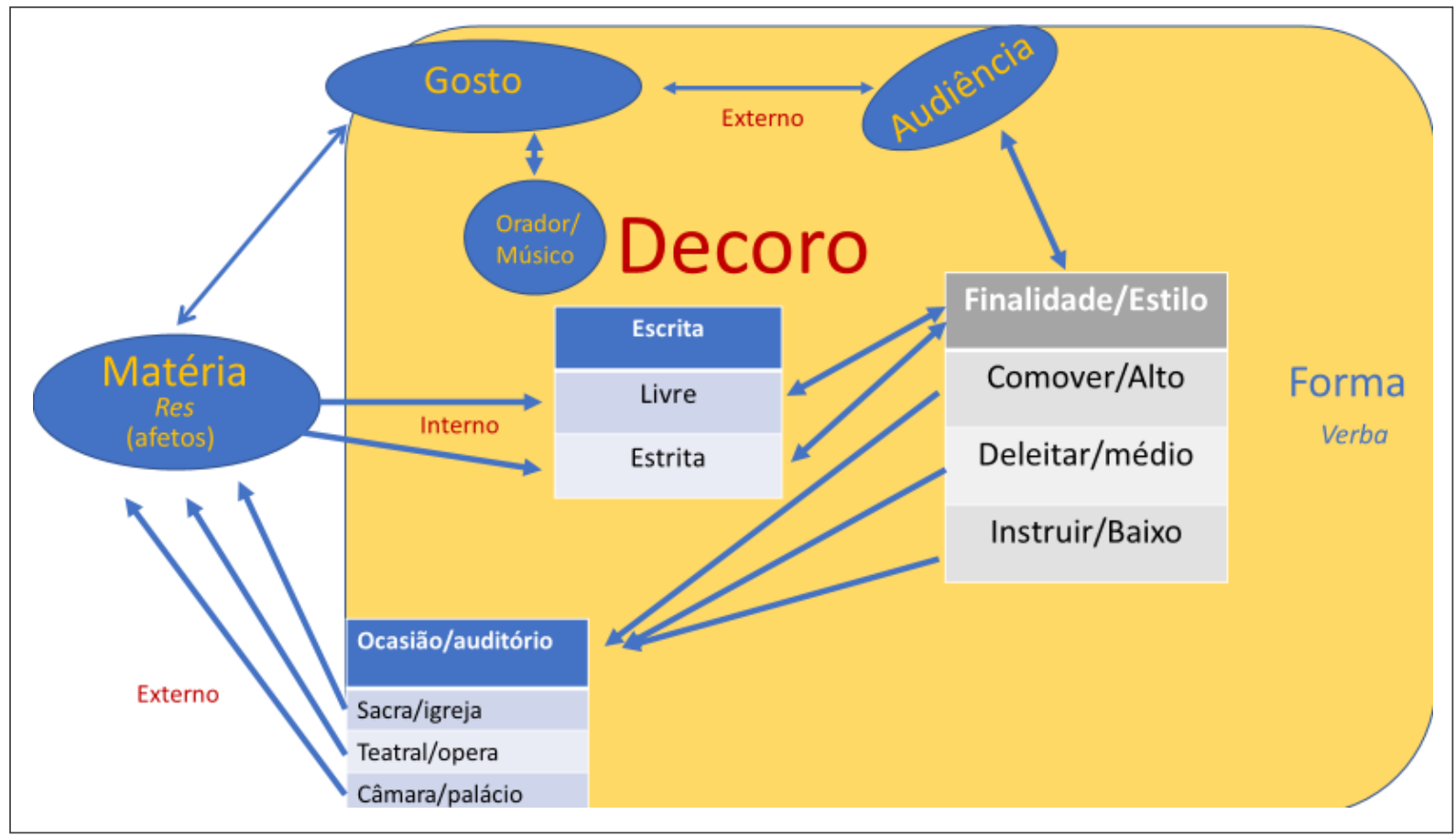

Fonte: Do autor,2020.

\subsection{ORNATO COMO VIRTUDE ELOCUTIVA}

A virtude da elocutio propositalmente deixada por último — ornatus - diz respeito às ferramentas que regulamentam a ornamentação do discurso. Quintiliano prezava tanto pela virtude do ornatus que cita uma importante defesa de Cícero:

Porventura, Cícero teria conseguido, na causa de Cornélio, apenas instruindo o juiz em ótimo latim, com precisão, objetividade e muita clareza, que o povo romano manifestasse sua admiração não só por aclamação, mas também com palmas? Sem dúvida alguma foram a sublimidade, a magnificência, o brilho e o vigor de sua eloquência que provocaram aquela explosão (QUINTILIANO op. cit. VIII-iii-3).

Em seguida, deixa claro sobre qual virtude está falando e qual o efeito o discurso bem dotado desta pode causar em seu ouvinte:

Um tão extraordinário enaltecimento não teria sido dado ao orador, se seu discurso tivesse sido apenas usual e semelhante aos outros. E eu creio que aqueles participantes não se deram conta do que estavam fazendo nem aplaudiram por determinação voluntária e racional, mas como mentalmente alienados e ignorando o lugar onde estavam $^{24}$, explodiram nessa manifestação de contentamento. (Ibidem, VIII-iii-4 grifo nosso.)

Ainda sobre a "contribuição do ornamento à causa", o retórico latino compara os efeitos do ornatus ao terror causado pelo reflexo de uma arma ou ao rebrilho de um raio, que,

24 Ou seja, sem entender o porquê. 
segundo o autor, não seriam tão temidos, ainda que com o mesmo efeito fatal, se não tivessem o ornamento do brilho. Em seguida, cita Cícero e Aristóteles:

Com razão Cícero escreve isso em uma carta a Bruto e com estas mesmas palavras: Em verdade, considero inexpressiva a eloquência que não provoque admiração. Também Aristóteles considera que provocar admiração deve ser o objetivo máximo do discurso. Entretanto, que esse ornamento (insisto nesse aspecto) seja másculo, vigoroso e nobre e não deixe entrever qualquer frivolidade efeminada ou falso colorido de púrpura, mas que rebrilhe como sangue e com vigor. (Ibidem, VIII-iii-6)

A virtude do ornatus é comparada às artes, nela reside boa parte da arte do discurso, e sobre isso Lausberg (2004, p. 138) diz:

$\mathrm{O}$ ornatus, corresponde à necessidade, que todo o homem (tanto sujeito falante, como ouvinte) sente, de que haja beleza nas expressões humanas da vida e na apresentação do próprio homem em geral. Deste modo, o ornatus, com a sua intenção criadora, atinge o domínio das artes elevadas.

As artes elevadas que Lausberg compara ao ornatus, têm em seus domínios a intenção do artista da "formação mimética de conteúdo, que aclaram a existência" e das mais altas aspirações da natureza humana”. Ou seja, reside aqui o mesmo princípio aristotélico ligado à arte como imitação idealizada da natureza. Se as virtudes da clareza, precisão e decoro conferem inteligibilidade, coerência e adequação ao discurso, a alma do princípio retórico de convencimento é essencialmente atingida pela surpresa lógica ou patética (emocional) do ornamento.

Lausberg (2004, p. 122) também compara o ornatus às "preparações adornadas de um banquete, no qual o próprio discurso é concebido como iguaria a consumir". O autor ainda cita outras denominações atribuídas a essa virtude, tal como flor da oração, floreio, gracejo, graça, luz do discurso, cor e condimento.Garavelli (1988, p. 157) afirma:

"Embora esteja incluído entre as virtudes oratórias, o ornatus requer tratamento individual devido à sua enorme amplitude de distinções e ao seu desenvolvimento histórico autônomo, que acabou transformando a retórica em uma teoria dos ornatus" ${ }^{, 25}$.

Os dois autores acima chamam a atenção para o significado do verbo ornare em latim que significa, além da ideia de embelezar, guarnecer, revestir com armas, aprontar um exército ou uma frota. Ou seja, há um protagonismo no ornamento que vai muito além do senso comum atual de um embelezamento acessório.

25 Tradução nossa. Do original: Aunque está incluído entre las virtudes oratorias, el ornatus requiere un tratamiento individual a causa de su enorme amplitud de sus distinciones y de su desarrollo histórico autonomo, que acabó por convertir la retórica en una teoria del ornatus. 
É interessante notar que o campo semântico do ornatus, apesar de fortemente ligado às virtudes da elocutio, também está atrelado à inventio (ou seja, um conceito que permeia a estrutura da composição e sua interpretação). Sobre isso Ellendersen (2019, p. 54) afirma:

O conceito ornatus se referia tanto ao campo da res quanto ao da verba. Na teoria retórica, res dizia respeito ao conteúdo, pensamento ou ideias - generalidades - do discurso, verba à forma ou palavra - particularidades - deste. Desta feita, a res pertence mais à inventio, enquanto a verba à elocutio.

Segundo o autor, o ornatus é elaborado tanto pelo compositor na criação da obra, como pelo intérprete na realização da mesma. Esse mesmo pensamento é defendido por Chico-Rico (2003, p. 210, grifo nosso):

Se focarmos na qualidade tradicional do ornatus - esse "plus", que garante o sucesso da persuasão por meio do adorno de palavras, excelência da expressão e, finalmente, eficácia artística - -, essa abordagem nos leva a considerar o ornatus como resultado da descoberta da realidade que se deseja comunicar. Portanto, também o consideramos como resultado da interação da elocutio com a inventio, da qual depende a descoberta das ideias para o discurso retórico, assim como para o discurso poético, e com a dispositio, o que permite e explica sua organização macroestrutural $^{26}$.

Além da relação do ornatus com as outras etapas da retórica, há o intercâmbio entre as quatros virtudes, sobretudo o decoro, ou seja: para o bom gosto na ornamentação é necessário o bom gosto na percepção da ocasião (decoro), o bom gosto na clareza ${ }^{27}$ e precisão do discurso ${ }^{28}$ (além da escolha dos argumentos, inventio, e boa disposição do discurso, dispositio) assim poderá surgir a virtude da escolha dos recursos certos que darão o brilho necessário ao discurso. Quintiliano divide o ato de ornamentar em duas etapas: a busca pelo tipo de elocução desejada e a maneira de expô-la.

A ornamentação dele [o discurso] divide-se nestes dois primeiros aspectos: que tipo de elocução queremos e de que maneira exporemos. Pois, antes de tudo se coloca que fique bem claro o que queremos, se é aumentar ou diminuir algo, falar de modo arrebatado ou calmo, com suavidade ou com severidade, ampla ou sucintamente, áspera ou brandamente, com magnificência ou sutileza, com gravidade ou espirituosidade. Em seguida, com que espécie de metáforas, com que figuras, reflexões, com que método e finalmente, com que ordenação possamos alcançar o que pretendemos (QUINTILIANO, op. cit., VII-iii-40 e 41, p. 245).

\footnotetext{
26 Tradução nossa. Do original: If the focus on the traditional quality of ornatus - - this "plus" which guarantees the success of persuasion by means of adornment of words, excellence of expression, and, finally, artistic efficacy - this approach makes us consider ornatus as the result of the discovery of the reality which one desires to communicate. Therefore, we also consider it as the result of the interaction of elocutio with inventio, upon which depends the finding of the ideas for rhetorical discourse as well as for poetic discourse, and with disposition, which permits and explains its macro-structural organization.
}

27 Organização das pontuações e respirações de forma a manter a inteligibilidade.

28 Ou seja, não se pode ornamentar nenhum discurso musical que não esteja bem realizado com um timbre adequado e "saudável". 
Dessa forma, conforme vimos na virtude do decoro, as medidas definidas pela proporção entre finalidade, escrita e os afetos da música (Matéria) irão (indireta ou diretamente) ditar ao orador a elocução e a maneira dele se expressar, que por sua vez ditarão a quantidade e, principalmente, a espécie (ou a qualidade, no sentido descritivo) de ornatos que serão utilizados no discurso.

Quintiliano elenca alguns vícios que podem deturpar o ornatus e o discurso como um todo: entre eles, há o kakénfanton, uso de termos de duplo sentido e/ou malsoantes que resultem em significado obsceno (se observamos, na música há inúmeras regras de harmonia e condução de vozes que buscam evitar vícios semelhantes) ${ }^{29}$; a tapéinosin, ou baixeza de estilo (na presente dissertação veremos, por exemplo, como a ornamentação excessiva de um movimento escrito em estilo alto e rebuscado se enquadra neste vício); a macrologia, "o discurso mais longo do que convém"; o pleonasmo, "onerar o discurso com palavras totalmente inúteis"; a perierghía ${ }^{30}$, que são os cuidados excessivos ou supérfluos, curiosidades excessivas e dispersão com minúcias. Há, ainda, outros vícios: anoikonómeton, dispositio inadequada (que em música podemos comparar com a forma); aschematistón, o uso inadequado das figuras; kakosýntheton, a má colocação das palavras ou tropos; finalmente, o kakódzelon, descrito por Quintiliano como o "vicío que evitar é uma exigência, dentre os demais [já elencados] que [por vezes,] poucos são evitados [e com mais frequência perdoados]":

Kakódzelon, isto é, o mau gosto e o rebuscamento de estilo pecam contra todos os gêneros oratórios. Realmente, são abrangidos sob a mesma denominação os empolados, os fracos, os demais amenos, os superabundantes, os rebuscados e os exultantes (QUINTILIANO, op. cit. VIII-iii-56).

Segundo Lausberg (2004, p. 139) a virtude do ornatus é o caminho do meio entre dois vícios: a insuficiência (oratio inornata) e a demasia (mala affectatio). Garavelli (1988), além de concordar, elucida as qualidades do próprio ornatus: vigoroso, tênue, elegante, nobre, artificioso, engenhoso, agudo, amplo, precioso, majestoso, fácil e difícil.

Quintiliano não apenas descreve vícios que dizem respeito a má adequação, ou seja, o uso inadequado segundo a ocasião e o estilo. Para ele, há ainda um subvício que pode, excepcionalmente, ser usado como figura, atrelado à mistura de linguagem (não respeitando um gosto nacional): "Designa-se ainda por Sardismós qualquer linguagem em que se misturam

29 Segundo o tradutor Basseto (ibidem, p.361): as cacofonias, resultantes de causas diversas, podem formar vocábulos inconvenientes ou obscenos: o kakénfanton (não é Kakófanton) diz respeito ao significado e não tanto ao som.

30 Ao elencar a perierghía, o autor diz (ibidem, VIII-iii-55): "E ainda, para encerrar de uma vez, toda palavra, que não esclarece a compreensão nem serve de ornamento de estilo, pode ser dita viciosa". 
vários idiomas por razões diversas, como se confundisses termos dóricos, jônicos e eólicos com outros áticos" (QUINTILIANO, op. cit., VIII-iii-59). Ele elenca também mais um vício ligado ao ato de misturar linguagens:

\footnotetext{
Vício semelhante a esse é o que existe entre nós, no caso de alguém colocar lado a lado palavras sublimes e triviais, arcaicas e recentes, poéticas e vulgares: disso resulta algo monstruoso, tal como Horácio imaginou na primeira parte de seu livro De arte poética:

Se um pintor quisesse juntar a uma cabeça humana

Um pescoço de cavalo...

E submeta os outros membros humanos a partes de animais diversos.

(Ibidem, VIII-iii-60)
}

Quintiliano menciona, ainda, o vício da mêiosis, que, ao ser transposto para a música, funciona como uma menção simplificada de uma orquestração maior e pode ser tanto aplicado à composição quanto à ornamentação livre:

Urge que se evite também a mêiosis, que faz com que pareça faltar algo ao discurso,
de modo que pareça menos completo, embora isso seja antes um vício do discurso
obscuro que do literário. No entanto, a mêiosis pode, quando empregada com
prudência, ser considerada uma figura, assim como a tautología, isto é, a repetição da
mesma palavra ou da mesma frase.
(QUINTILIANO, ibidem,VIII-iii-50)

O interessante é que uma adequação e uma dosagem correta podem transformar o mesmo vício em um bom ornato. Um bom exemplo disso está na ornamentação livre de uma ária ou adágio italiano. Neste caso, seria um vício uma ornamentação excessiva que chega a obscurecer parte do tema, comprometendo, assim, a compreensão da composição. Enquanto que uma ornamentação exuberante que respeite a estrutura e o sentido, ou mesmo seja acrescentada a uma repetição da capo, tem na mêiosis, ao invés de um vício, uma ferramenta de variação que pode surpreender o ouvinte sem perder a coerência.

Outro excelente exemplo é o vício do sardismos (mistura de gostos nacionais). Se fôssemos à França em meados do século XVII e emulássemos padrões atrelados exclusivamente ao gosto italiano em meio ao repertório, ou ainda a alguma corte alemã de gosto italiano de meados do século XVII, e misturássemos padrões franceses na arte proposta, provavelmente, estes sardismos seriam encarados como um vício, devido ao mau gosto. Contudo, se realizássemos uma obra napolitana, como o Stabat mater de Pergolesi, na série de concertos parisienses "le Concert Spirituel" no século XVIII, seríamos ovacionados (como realmente ocorreu!). Ou se compuséssemos uma ouverture francesa (gênero tipicamente francês) em meio a um concerto grosso (gênero tipicamente italiano) em 1695, como fez Muffat em sua série de Concerti grossi florigerium Primum, teríamos nesse sardismos, em vez de um vício, uma virtude. 
Sobre isso, o autor latino nos diz (ibidem, VIII-iii-45): "tal culpa, porém, deve ser evitada, pois que perdemos palavras honestas por maus costumes e é preciso ceder aos vicíos triunfantes". Ele deixa claro, portanto, que o sistema retórico é vivo e mutável, não 100\% imune à quebra de padrões conservadores, se modificando com o tempo, assim como as regras de harmonia e contraponto (como as das diversas línguas) foram ganhando suas exceções.

Quintiliano lista os vícios que confrontam os ornatos, e divide os ornatos em duas características primordiais, os tropos e as figuras. Além de revelar a importância dos livros VIII e IX da instituição oratória para o sistema retórico musical, Bartel (1997, p. 80) didaticamente explica sobre as duas categorias expostas:

\begin{abstract}
Os ensinamentos de Quintiliano sobre as figuras retóricas são indiscutivelmente os escritos mais significativos e influentes sobre o assunto, permanecendo oficiais durante as eras medieval, renascentista e barroca. Nos livros 8 e 9 de sua Institutio oratória, Quintiliano discutiu longamente os tropos e as figuras, explicando que enquanto tropos e figuras são usados para o mesmo propósito, a saber "adicionar força e charme" à oração, os dois tipos de enfeites não devem ser confundidos. Enquanto um tropo é "a alteração expressiva de uma palavra ou frase de seu significado próprio para outro", ele descreveu a figura como "uma conformação de nossa fala alterada do uso comum e óbvio ... Uma figura é, portanto, um nova e engenhosa maneira de falar." Enquanto o tropo empresta conteúdo novo para linguagem familiar, a figura usa construção de linguagem nova. As várias nuances literais do significado de figura como forma e imago tornam-se evidentes no uso retórico que Quintiliano fez do termo. O termo foi usado em referência a qualquer "forma" de expressão verbal, bem como a um uso intencionalmente alterado da linguagem da forma comum e simples. Por meio dessa alteração (mutatio), a expressão verbal é utilizada para denotar um sentido desviante ou ilusório, sendo, portanto, uma imago implícita daquilo que não é explicitamente declarado. Essa compreensão retórica de figura seria posteriormente transferida para a música, na medida em que a figura musical, por meio de sua estrutura única, torna-se uma expressão tanto da imagem (imago) do texto quanto da fonte (forma) da afeição pretendida. ${ }^{31}$
\end{abstract}

Sobre os tropos, Quintiliano (op. cit., VIII-vi-1, p. 313) afirma: "Tropo é a mudança do significado próprio de uma palavra ou de uma frase para outro com expressividade". O autor cita uma polêmica taxonômica com relação aos números de tropos (sobre alguns serem propriamente tropo ou figura) e enumera 13 tropos: Metáfora, Sinédoque, Antonomásia,

31 Tradução nossa. Do original: Quintilian's teachings on the rhetorical figures are indisputably the most significant and influential writings on the subject, remaining authoritative throughout the Medieval, Renaissance, and Baroque eras. In books 8 and 9 of his Institutio oratoria Quintilian discussed the tropes and figures at great length, explaining that while tropes and figures are used for the same purpose, namely "to add force and charm" to the oration, the two types of embellishments should not be confused. While a trope is "the expressive alteration of a word or phrase from its proper meaning to another," he described a figure as "a conformation of our speech altered from the common and obvious usage.... A figure is therefore a new and artful manner of speech." While the trope lends novel content to familiar language, the figure uses novel language construction. The various literal nuances of meaning of figure as forma and imago become evident in Quintilian's rhetorical use of the term. The term was used in reference to any "form" of verbal expression, as well as to an intentionally altered use of language from the ordinary and simple form. Through this alteration (mutatio) the verbal expression is used to denote a deviating or illusory meaning, thereby being an implicit imago of that which is not explicitly stated. This rhetorical understanding of figura would later be transferred to music, as the musical figure through its unique structure becomes an expression of both the image (imago) of the text and the source (forma) of the intended affection. 
Onomatopeia, Katáchresis, Metálepsis, Epítheton, Alegoria, Ironia, Perifrase, Hyperbatón e Hipérbole. Já sobre as figuras, “que em grego são chamadas schémata” (ibidem, IX i-1, p. 373), o autor afirma:

\begin{abstract}
Muitos autores consideram essas figuras como tropos, já que deles deduziram o nome delas e foram formados de modo semelhante, e ainda pelo fato de transformarem o discurso - e por isso denominadas também movimentações (motus) - é preciso reconhecer que esses dois aspectos se encontram também nas figuras; o emprego também é o mesmo: realmente, conferem vigor aos fatos e os revestem de elegância. Também não falta quem atribua aos tropos os nomes das figuras [...].
\end{abstract}

Bartel (1997, p. 79) ainda nos esclarece sobre as figuras:

O termo latino figura tem suas raízes no verbo fingere (formar ou modelar) e referese a uma "fabricação modelada". Embora figura originalmente significasse simplesmente "forma", ou formato, mais tarde se referiu à imagem da forma ou formato original. Assim, o termo assumiu o significado tanto de uma imagem ou reflexo de um objeto quanto de uma estrutura ou concepção independente. A terminologia retórica grega usava o termo schemata para designar tanto os estilos retóricos quanto as formas específicas de elaboração expressiva. Esse termo foi então traduzido para o latim como figura por Cícero (n. 106 a.C.), usando-o para designar certos recursos retóricos. ${ }^{32}$

Sobre a diferença entre tropo e figura, que já não era clara ao senso comum na época de Quintiliano, Justi (2013), citando White ${ }^{33}$ (1994), esclarece:

White (1994, p.14), [...] afirma que a palavra tropo significa no grego clássico "mudança de direção", "desvio". A palavra ingressa nas línguas indo-europeias modernas por meio de tropus, passando a significar "metáfora" ou "figura de linguagem" no latim clássico. Para White, os tropos geram figuras de linguagem ou de pensamento mediante a variação do que "normalmente" se espera deles e por via das associações que estabelecem entre conceitos que habitualmente se supõem estarem ou não relacionados de maneiras diferentes da sugerida no tropo utilizado (JUSTI, 2013, p. 2).

O arsenal retórico exposto por Quintiliano inclui, além dos 13 tropos já citados, duas categorias de figuras, as de pensamento e as de palavras, além de quatro técnicas de amplificação do discurso (incrementum, comparativo, ratiocinatio e congeries). Sobre a classificação do autor latino, Bartel (1997, p. 81) escreve: "palavras ou frases (pensamentos) podem ser alteradas ou repetidas de várias maneiras com a intenção de dar à oração maior poder e encanto [...]". Em seguida, justifica com o trecho grifado da citação da instituição oratória abaixo:

Todavia, além das figuras nada existe que mais provoque a emoção. Pois, se a fronte, os olhos e as mãos têm grande importância para mover os espíritos, quanto mais o aspecto do próprio discurso, se estruturado devidamente para aquilo que

32 Tradução nossa do original: "The Latin term figura is rooted in the verb fingere (to form or shape) and refers to a "modeled fabrication". While figura originally meant simply "shape" or "form", it later referred to the image of the original shape or form. Thus, the term assumed the meaning of both an image or reflection of an object as well as an independent structure or conception. Greek rhetorical terminology used the term schemata to designate both rhetorical styles as well as the specific forms of expressive elaboration. This term was then translated into Latin as figura by Cicero (b. 106 b.c.), using it to designate certain rhetorical devices".

33WHITE, H. Trópicos do Discurso - Ensaios Sobre a Crítica da Cultura. EDUSP, São Paulo, 1994. 
pretendemos realizar? Realmente, a figura reforça muito a recomendação, seja na conciliação das atitudes do agente, seja para aumentar a disposição favorável em relação ao processo, seja para suavizar o tédio através de variações, seja para apontar certos aspectos de modo mais conveniente e mais seguro (QUINTILIANO, op. cit., IX-i- 21, p.383, grifo nosso).

\section{A correlação das figuras de retóricas com as emoções é tanta que demandou de}

\section{Quintiliano a seguinte explicação:}

Devem ser rejeitados os que julgam serem tantas as figuras quantas são as emoções, não porque a emoção não seja uma qualidade da mente, mas porque a figura, como a entendemos de modo próprio e não à maneira comum, não é a simples enunciação de qualquer coisa (ibidem, IX-i-23, p. 385).

Essa correlação estreita entre as figuras e as emoções apontada como corrente em seu tempo por Quintiliano, permaneceu viva por mais de um milênio e este mesmo "arsenal retórico", como o brilho das espadas e as armaduras citadas por ele, municiou inúmeros discursos, ganhando novas dimensões. Como Bartel (1997, p. 81) nos revela:

O conceito de Quintiliano das figuras era convencer um público, fosse ele o senado ou uma multidão pública, por meio de uma forma de oração intensificada e animada. Este propósito utilitário foi substituído por outro, principalmente estético e artístico: emprestar à oração maior deleite e dignidade, força e encanto. Além disso, graças a séculos de retórica medieval, não foi apenas a língua falada, mas também a escrita, que se beneficiou dessa expressividade incomum. Uma composição eloquentemente intensificada, em vez de orações políticas convincentes, caracterizava o propósito renascentista das figuras retóricas. Com esse conceito alterado das figuras e da retórica em geral, foram preparadas as bases para a adoção pela música de princípios e técnicas retóricas ${ }^{34}$.

E em seguida nos revela como esse sistema foi emulado, originando inúmeros tratados

no mundo luterano:

O Renascimento foi marcado não apenas pelo reaparecimento de inspiração humanística de muitas fontes e textos clássicos, mas também por uma onda de textos contemporâneos sobre retórica. Uma coleção amplamente difundida de figuras e tropos é encontrada no Epitome de Johannes Susenbrotus. Susenbrotus definiu um embelezamento retórico, incluindo figuras e tropos, como "um desvio da forma simples ou normal da fala". Figura foi definida como uma forma artística e inovadora de escrever ou falar (BARTEL, 1997, p. 81). ${ }^{35}$

34 Tradução nossa. Do original: Quintilian's concept of the figures was to convince an audience, be it the senate or a public crowd, through a heightened and enlivened form of oration. This utilitarian purpose was replaced by a primarily aesthetic and artistic one: to lend the oration greater delight and dignity, force and charm. Moreover, thanks to centuries of medieval rhetoric, it was not only the spoken but also the written language which benefitted from this uncommon expressiveness. Eloquently intensified composition rather than convincing political oration characterized the Renaissance purpose of the rhetorical figures. With this altered concept of the figures and of rhetoric in general, the groundwork had been prepared for music's adoption of rhetorical principles and techniques.

35 Tradução nossa. Do original: The Renaissance was marked not only by the humanistically inspired reappearance of many classical sources and texts but also by a surge in contemporary texts on rhetoric. A widely circulated collection of figures and tropes is found in the Epitome by Johannes Susenbrotus. 30 Susenbrotus defined a rhetorical embellishment, including both figures and tropes, as "a deviation from the simple or normal form of speech." Figura was defined as an artful and novel form or manner of writing or speaking. 
Sobre as figuras de retórica há inúmeras e valiosas obras, incluindo, principalmente, as fontes primárias de Sunsenbrotus, Burmeister, Bernhard, Printz, Whalter e Matheson, todos muito bem comentados e elencados por fontes como o livro de Bartel, porém, o foco desta dissertação é estudar a música italiana do início do século XVIII, mais especificamente a música romana de Corelli. Conforme já mencionamos nos subcapítulos anteriores, a retórica musical italiana não era tão sistemática quanto a retórica alemã, porém dois fatores precisam ser considerados nessa equação. Primeiro, como Bartel explicou, o alcance de Quintiliano se estendeu por todo o mundo cristão europeu. E segundo, um detalhe biográfico do compositor italiano se revela fundamental: sua primeira patrona em Roma foi a ex-rainha Cristina da Suécia, uma ex-luterana convertida ao catolicismo, que reuniu um círculo enorme de artistas dos quais foi mecenas na cidade eterna. Este círculo incluiu Corelli que, após o falecimento da rainha, fundou um novo classicismo romano.

Dessa forma, vemos a importância de se entender o ornato sob o ponto de vista de Quintiliano diretamente. Assim, nós, músicos do século XXI, exploraremos alguns tropos e figuras elencados pelo autor latino com o intuito de aproximarmo-nos dessa atmosfera.

Sobre o primeiro ornato, a Metáfora, Aristóteles (apud JUSTI, 2013, p. 58) afirma: “A metáfora consiste no transportar para uma coisa o nome de outra, ou do gênero para a espécie, ou da espécie para o gênero, ou da espécie de uma para a espécie de outra, ou por analogia". Quintiliano (VIII-vi-4 p.315) afirma que além de "frequentíssimo, é o mais belo". O autor também o chama translationem (transferência), e relata:

[...] A metáfora ainda amplia a extensão do discurso com aquilo que não tem, por mutação ou troca, e, o que é mais difícil, colabora para que não fique parecendo faltar um nome a algum elemento. Assim se transfere um nome ou um verbo do lugar que lhe é próprio para aquele em que ou inexiste o próprio ou o transferido é melhor. Fazemos isso porque é necessário, ou porque é mais significativo, ou (como afirmei) porque é mais expressivo estilisticamente. Sempre que nenhum desses aspectos for aplicável, a metáfora será imprópria (Ibidem, VIII-vi-5 e 6, p. 315).

O segundo tropo citado pelo orador latino é a sinédoque, variação da expressão que agregue significados, aumentando, através do substituto do termo, a expressividade. Ela permite "variar as expressões, assim que consigamos entender várias coisas por meio de uma só, o todo pela parte, o gênero pela espécie, o consequente pelo precedente, ou vice-versa em todas essas possibilidades" (ibidem, VIII-vi-19, p. 323). Em outro trecho do Instituto oratoria o autor diz (ibidem, VIII-vi-21, p. 325):

"Alguns denominam sinédoque a figura pela qual deduzimos, pelo contexto, aquilo que não está expresso na frase, pois o termo oculto é entendido por meio das palavras ditas, o que se denomina elipse, entre os vícios, quando ocasiona obscuridade". 
Quintiliano lista exemplos positivos e viciosos de seu uso. Entre os de bom gosto se encontram ponta aguda no lugar de espada,${ }^{36}$ teto no lugar de casa, entre os negativos há popa ao invés de navio e ferro onde se quer dizer espada. É interessante observar que ponta aguda diz mais do que espada (ver nota 36), o termo teto transmite além da ideia de casa, um abrigo, uma sombra, um aconchego e vários outros significados dependendo do contexto, o termo popa diz uma parte do navio, mas dificilmente terá um contexto mais amplo do que o próprio substantivo navio, o mesmo ocorre com o material da maioria das espadas: o ferro.

Em música, embora não necessariamente de forma consciente (o termo nos dicionários monolíngues de português setecentistas como Bluteau (1728) e Silva (1789) não é encontrado, por exemplo), é um tropo muito utilizado na composição, sobretudo no arranjo, quando temos uma voz melódica simples que soa não somente como uma única linha e sim como uma harmonia completa. Exemplos bem claros seriam diversos trechos das partitas e sonatas para violino solo de Bach, das fantasias de Telemann (tanto as de violino como as de flauta) e peças para instrumentos melódicos solistas como um todo, trechos das fugas e dos moto perpetuo de Corelli, transposição de obras para violino com cordas duplas para instrumentos de sopro (as próprias sonatas de Corelli foram transpostas no século XVIII) e uma lista enorme de exemplos em que a escrita sugere ao ouvinte existirem mais vozes do que a que está sendo tocada. Este mesmo tropo, quando apropriado pelo intérprete, pode, além de ajudar na compreensão da obra interpretada, que estruturalmente possua a sinédoque, ser utilizado na ornamentação livre (já que muitas vezes se trata de uma parceria composicional), podendo dar à nova versão um significado harmônico ainda mais amplo. Um ótimo exemplo dela se encontra de forma persistente entre a ornamentação sugerida na terceira edição do Opus V de Corelli, tendo não somente as notas estruturais, mas uma voz extra, conforme podemos constatar na figura 2.

Figura 2: Trecho de uma versão ornada da sonata Opus V, n. 3

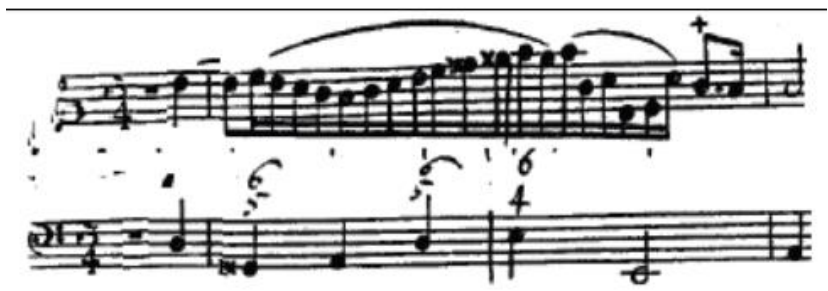

Fonte: Arcangelo Corelli Op. V edição Estienne Roger, Amsterdã, 1710.

36 O exército romano usava a Gladius, uma espada que possuía uma ponta aguda (e dois gumes não muito afiados) extremamente eficaz em lancetar seus alvos, de forma que ao usar o termo ponta aguda, o interlocutor transmite mais do que a ideia do próprio objeto inteiro, espada. Transmite, além do objeto, dependendo do contexto, a ideia de uma arma utilizada por uma legião romana (não qualquer espada na mão de um bárbaro) e, talvez, suas formações de batalha específicas, que, segundo Maquiavel (em A Arte da Guerra) eram utilizadas para favorecer o uso desse tipo de arma em conjunto e inúmeras outras ideias. 
A Metonímia de Quintiliano não varia da figura de linguagem de nosso senso comum:

Também a metonímia, que consiste na colocação de um nome por outro, não difere muito desse gênero; todavia, segundo afirma Cícero, os mestres de retórica a denominam hipálage. Esta figura faz a distinção entre as criações e o nome de seu criador, bem como a posse que é substituída pelo nome de seu possuidor (ibidem, VIIVI-23, p. 325).

É interessante notar que, assim como Quintiliano, Pinto (1828), em seu dicionário, dedica menos linhas à metonímia do que à sinédoque (que no senso comum do século XXI é tida como parte da primeira).

Há também a Antonomásia (VIII-vi-29), "pela qual se coloca algo relacionado em lugar do nome, $[\ldots]$ em que se suprime a palavra à qual se acrescentara um aposto e este passa a equivaler ao nome; [...] ou também pela indicação da mais destacada característica de alguém”. Um exemplo de fácil compreensão elencado pelo autor segue na seguinte descrição de Júpiter: "O pai dos deuses do rei dos homens".

Já a Onomatopeia (VIII-vi-31, p. 331), “[...], isto é, a invenção de um termo, tida em máximo apreço pelos gregos, [...] existem muitas criadas de tal modo pelos que por primeiro as usaram, que as acomodavam ao que escutavam. Sem dúvida, daí provieram mugido, silvo e murmúrio". O sentindo do tropo não dista do senso comum atual, e no início do século XVIII, seguia uma definição de Bluteau (1728, p. 80): “figura verbal, e ficção do nome que se inventa para imitar, e exprimir o som, ou ruído de qualquer coisa animada, ou sem alma".

Não é difícil transpor esse tropo sonoro para o âmbito musical e seu uso foi de tal forma difundido no século XVIII (e XVII) que o compositor e tratadista Geminiani, no prefácio de seu tratado A arte de tocar o violino, advertiu sobre seu uso exagerado:

[...] No entanto, uma vez que a imitação do galo, do cuco, da coruja e de outros pássaros; ou da percussão, da trompa, da tromba-marina e de similares; e, também, repentinas mudanças de posição de uma extremidade do espelho à outra, acompanhadas de contorções da cabeça e do corpo e todos outros truques desta espécie são mais próprios a professores de malabarismo e a mestres de postura do que à arte da Música [...] (GEMINIANI, 1749, p. 228).

A katáchresisv (Quintiliano, op. cit. VIII-vi-34), "corretamente traduzimos por 'abuso': aplica ao que não tem nome próprio ou de algo a ele relacionado”. O tradutor Bruno Basseto diz em uma nota (op. cit., p. 368) que o termo está atrelado "ao emprego [inicialmente] abusivo de uma palavra [...], mas [que] depois se torna corrente". Quintiliano prossegue (ibidem, VIII-vi-35, p.333) “[...] e é necessário distinguir da metáfora esse gênero todo, porque a catacrese consiste na transferência de um nome existente com determinado significado para outro, para o qual não há termo específico". 
A natureza da metálepsis, segundo o autor:

[...]é tal que exige certo grau intermédio entre o ponto de partida e o de chegada daquilo que se transfere, não tendo um significado próprio, mas apontando uma relação; empregamos esse tropo mais para darmos a impressão de o termos, do que para revelarmos a vontade de usá-lo em algum lugar. O exemplo mais comum é cano (eu celebro) como sinônimo de canto (eu canto) e canto é sinônimo de dico (eu digo); portanto, cano é sinônimo de dico, tendo canto como grau intermediário (ibidem, VIIIvi-37, p. 335).

Sobre o Epítheton: "as outras figuras não são buscadas com fins de significação, mas para embelezar e engrandecer o discurso. Assim, o epitheton que corretamente dizemos aposto" (ibidem VIII-vi-40 p.335). Essa Figura, extremamente artística, segundo Quintiliano, é usada com mais frequência e liberdade pelos poetas. Talvez seja uma das que mais se aproximam do conceito de ornamentação livre na música barroca italiana, na qual em inúmeras passagens os adágios são embelezados com apostos musicais. Entretanto, Quintiliano, sabiamente, emite um conselho, que facilmente pode ser emulado pelos intérpretes da música barroca em sua busca pelo bom gosto: "Nos oradores é redundante, a não ser que proporcione algum destaque. Contudo, só obtêm esse efeito, caso o que se diz for menos expressivo sem o aposto".

A figura da alegoria é dividida por Quintiliano em três categorias. A primeira, pelo uso de metáforas sucessivas tanto para o significado da oração como para as próprias palavras, como o exemplo de Horácio que ele fornece: “[...] ó embarcação, novas ondas te levarão de novo para o mar" (Ibidem, VIII-vi-44p. 339). A segunda, pelo não uso de tropos metafóricos e a terceira, pelo uso de metáforas no significado, mas com o uso de palavras não metafóricas, ao qual é denominada alegoria mista, como em: “[...] Milão haveria de enfrentar as tempestades [...]" (Ibidem, VIII-vi-48 p. 341). Basseto ainda compartilha uma esclarecedora nota: "[em grego significa] 'outro', e o substantivo do verbo [...] 'falar', 'pronunciar': daí, em seu primeiro significado, 'ato de falar de outro modo'; depois 'explicação por alegoria'; linguagem por metáfora. Latim Inversio, "transposição"” (ibidem, p.369).

Independentemente da polêmica taxonômica, tanto a metáfora como a alegoria são figuras bastante apropriadas pelos discursos artísticos como um todo e serviram de base para inúmeras figuras musicais de retórica que foram construídas no segundo milênio.

A ironia, segundo Quintiliano, "enquadra-se naquele gênero pelo qual se mostra o contrário do significado das palavras, a que os nossos denominam illusio" (ibidem, VIII-vi-54, pag. 345), não diferindo, assim, do senso comum do século XXI. O autor ainda complementa que ela “[..] é evidenciada quer pelo modo de expressão, quer pela pessoa, quer pela natureza do assunto. Assim, caso alguma dessas possibilidades discorde do significado das palavras, fica claro que a intenção é diferente do que se diz”(Ibidem, VIII-vi-54, p. 345). O autor ainda revela 
uma nova polêmica entre seus contemporâneos a respeito da ironia ser uma espécie de alegoria ou um tropo autônomo.

A Perifrase é elencada da seguinte maneira: “[...] a explicação com mais palavras daquilo que pode ser dito com apenas uma ou algumas se diz perífrasin, certo modo circular de expressão, que às vezes se faz necessária [..]” (ibidem, VIII-vi-59, p. 347). O autor cita exemplos de ornato literário como "Aproximava-se o tempo em que se inicia o primeiro descanso" (ibidem, VIII-vi-60, p. 347) e outros que evitem situações inconvenientes como: "atender às necessidades da natureza" (SALÚSTIO apud QUINTILIANO, op. cit. VIII-vi-59, p. 347). Quintiliano ainda complementa:

[...] Ora, tudo o que pode ser transmitido com mais brevidade e é possível mostrar com elegância de modo mais extenso é perífrase, a que se deu o nome latino de circunlocatio, circunlocução, certamente não bem adequado a essa característica da oratória.Em verdade, como se fala em perífrase, quando a figura aporta elegância, assim se diz perissología sempre que recair no desvio oposto. Ora o que quer que não contribua, atrapalha (Ibidem, VIII-vi-61, p. 349).

Em uma comparação livre, tanto o epitheton como a perífrase são emulados em forma de diminuição (no sentido de se acrescentar notas) do texto musical. A primeira figura se compararia a algo entre os ornamentos essenciais (gracias) e uma leve ornamentação mais livre (passaggi), enquanto a segunda a uma ornamentação livre mais rebuscada como passaggi e cadenzas.

Sobre o Hyperbatón:

Isto é, a transposição de uma palavra, por ser um modo de composição e exigir elegância artística, não sem mérito o colocamos entre os adornos de estilo. Pois, com muita frequência as frases se tornam desarmônicas, duras, desconexas e lacunosas, se as palavras forem dispostas sempre segundo a imposição de sua ordem natural e são então ligadas umas às outras como vierem a resultar, embora não haja entre elas um traço expresso de ligação (ibidem, VIII-vi-62).

O último ornato listado no livro VIII é a Hipérbole, que "é uma espécie de exagero adequado do verdadeiro; sua força expressiva pode ser usada tanto para aumentar como para diminuir; e pode ser imaginada de muitos modos" (ibidem, VIII-vi-67, p. 351). Sem muito distar do senso comum atual, o mesmo ornato pode aumentar ou diminuir uma situação, porém, conforme adverte o autor: "é suficiente lembrar que a hipérbole é enganosa, mas não até o ponto de querer tapear pela mentira. Por isso, urge levar bem em conta até que ponto convém exagerar, de modo que não venhamos a ser desacreditados” (ibidem, VIII-vi-74 p. 355).

Após oferecermos o conceito relacionado à virtude elocutiva do ornato, concluímos que essa virtude diz muito mais do que um simples embelezamento; se trata de um importante item de expressividade do discurso musical, conforme nos diz também a tese de Ellendersen 
(2020). Sendo mais específico ainda, é um item de expressividade do discurso musical barroco, sobretudo atrelado ao gosto italiano, que é vivo e fresco, e exige de seu orador uma consciência que amplifique suas virtudes, conforme veremos nos subcapítulos seguintes.

\subsection{OS MODELOS DE GOSTO NACIONAL: FRANÇA E ITÁLIA}

Conforme vimos no subcapítulo 1.5, um grupo, normalmente atrelado a uma nação, possui um gosto nacional. Este gosto perpetua determinadas características nas obras dos autores pertencentes a este mesmo grupo ou país. Paoliello (2017, p. 95) cita uma passagem interessante da obra Cisne de Apolo, de Luis Alfonso de Carvallo ${ }^{37}$ (1997[1602] apud PAOLIELLO, 2017, p. 95):

[o decoro da nação se guarda] pintando as pessoas segundo o rito e trato de sua nação e terra, porque muito diferentes são os trajes, os adornos, tratos e comércios de uma nação a outra, e muito diferentes os costumes e ainda as condições. (...) E assim deve pintar o Poeta, guardando a cada nação seu decoro.

E em seguida complementa: "da mesma forma, o músico setecentista tinha que ter em conta o decoro de cada nação ao utilizar as escritas e os adornos" (CARBALLO, 1602 apud PAOLIELLO, p. 95). Assim, o decoro entre a escrita e o gosto nacional mencionado é o principal responsável pelo estilo nacional. E essa forma específica de escrita de um gosto nacional poderia se tornar um modelo a ser emulado por artistas pertencentes a outras nações.

De fato, documentos e tratados dedicam bons parágrafos a esta discussão ao longo do século XVIII. Quantz (1752 apud PAOLIELLO, 2017, p. 97), em seu tratado de flauta, afirma:

A diversidade do gosto nas diferentes nações que ao menos tenham gosto pelas ciências exerce a maior influência sobre o julgamento musical e se manifesta muito mais no exame do acidental do que do essencial da música. Deste modo, é necessário investigar essa diversidade de gosto na música mais detalhadamente.

O célebre flautista compositor destaca as duas nações que se tornaram modelos de gosto em música, a italiana e a francesa:

Há dois povos em particular que têm alcançado estima considerável por sua melhoria do gosto musical, e que, conduzidos por suas inclinações naturais, têm percorrido caminhos diferentes para alcançar este fim. Estes dois povos são os italianos e os franceses. Outras nações têm aprovado o gosto desses dois povos, e procuram adotar e imitar o que lhes agradam mais em um ou em outro. Consequentemente, os dois povos têm se colocado como juízes soberanos do bom gosto na música; e como nenhum dos outros países tem sido capaz de contrapô-los, eles têm sido, em certo grau, os legisladores neste assunto por alguns séculos. A partir deles, o bom gosto tem sido transferido para os outros povos (QUANTZ, 1752 apud PAOLIELLO, 2017, p. 97). 
Em seu tratado, Quantz aprofunda a discussão dos dois modelos. Matheson escreveu uma discussão a respeito das diferenças entre os gostos italianos, franceses e, indo além desses modelos, fala sobre os gostos germânico e britânico, bem como detalha os subgostos italianos. O Compositor germânico, Georg Muffat, compôs duas séries de concertos grossos em forma de suítes de dança, florilegium primo e secundum, misturando características do gosto italiano, que até então era o adotado pelo principado alemão em que trabalhava, com características francesas que, segundo ele, foram observadas em suas viagens à França. No prefácio de sua obra, escrito pelo autor em quatro idiomas, há uma bula de como sua música deve ser tocada, focando nas características francesas que eram desconhecidas pelos músicos da corte, onde era mestre de capela, e que praticava hábitos musicais italianos até então.

O protagonismo musical da Itália e da França também suscitou discussões acaloradas. Uma bastante icônica ficou a cargo do abade e historiador François Raguenet (1660-1723) e do musicólogo Lecerf de la Viéville (1674-1707), ambos franceses. Raguenet viajou para Roma em 1698, e lá viveu dois anos a apreciar a arte da cidade papal. Em 1702, já de volta à Paris, escreveu uma pretensa comparação entre as músicas francesa e italiana (com notável parcialidade para a segunda). De la Viéville tratou de rapidamente se interpor no debate e advogar em favor da música francesa, publicando uma resposta à comparação do abade em 1704. Por fim, o abade publicou uma tréplica chamada Défense (1705). A Obra de Raguenet teve alguma aceitação na França, de forma que suas duas obras e a resposta de Viéville foram reimpressas e traduzidas por toda a Europa até 1759. Essa querela foi sucedida por outra, ocorrida na década de 50 do século XVIII (um pouco mais conhecida no século XXI), a "querela dos bufões" entre Rousseau (defensor da música italiana, sobretudo a napolitana) e Rameau (compositor de uma nova música francesa).

Segundo Paulo Kühl (2014, p. ?), o texto de Raguenet em muitos momentos "se aproxima mais de um relato de viagem" do que de um texto assinado por um historiador reconhecido pela autoria da biografia de Oliver Cromwell. Ele afirma que, das 124 páginas de sua comparação, o abade dedica apenas as 23 primeiras a enaltecer o gosto francês e a criticar o gosto italiano, quando escreve: "Eis tudo o que pode ser dito a favor da França, no que concerne à música e às óperas. Vejamos agora o que pode ser dito a favor da Itália nessas duas coisas".

À parte da querela, das hipérboles, possíveis falácias e outros ornatos retóricos apresentados em função da discussão, o texto nos fornece uma visão inquestionavelmente contemporânea de "trajes e adornos" musicais dessas duas nações. Assim, analisaremos algumas informações que, comparadas a outras fontes, podem ser extraídas a seguir: 
Nossas óperas [as francesas] têm, além disso, uma grande vantagem sobre as dos italianos, no que diz respeito às vozes, por causa dos baixos [basses-contres], que são tão comuns para nós e tão raros na Itália. Pois, ao juízo de todos os ouvidos, não há nada de mais encantador do que um belo baixo; o simples som desses baixos, que às vezes ouvimos precipitar-se num vazio profundo, tem algo que encanta. Essas grandes vozes fazem vibrar uma quantidade de ar muito maior do que as outras e, consequentemente, preenchem com uma harmonia muito mais vasta e agradável os personagens de deuses e de reis, quando é necessário falar em cena um Júpiter, um Netuno, um Príamo, um Agamenão. Nossos atores, com o som de suas vozes grossas, têm outra majestade, diferente da dos italianos, com seus falsetes ou seus falsos baixos, que não têm nem profundidade nem força. Além disso, a mistura dos baixos com os sopranos [dessus] forma um contraste agradável que faz sentir toda a beleza daqueles por oposição a estes, prazer que os italianos nunca experimentam, sendo as vozes de seus músicos, quase todos castrati, inteiramente semelhantes às de suas mulheres (RAGUENET, 1702, p. 29).

Raguenet aponta uma característica bastante importante da música vocal italiana do século XVII, na qual havia o domínio dos castrati, que representavam princesas, heróis e vilões e não deixavam muito espaço para cantoras, enquanto na França, havia sopranos leves para os papéis de princesas, sopranos pesadas para os papéis de rainhas e/ou vilãs. Nas duas tradições, aos baixos sempre coube o papel de reis, deuses e forças da natureza, mas Raguenet enfatiza como o gosto francês é mais enfático na pompa desses cantores e, ao falar dos solos, enfatiza uma característica muito importante na textura da música francesa coral e orquestral também, a predominância das vozes extremas soprano (dessus) e baixo (basse).

Kühl (2014) adverte que os dois gostos nacionais estão atrelados a características

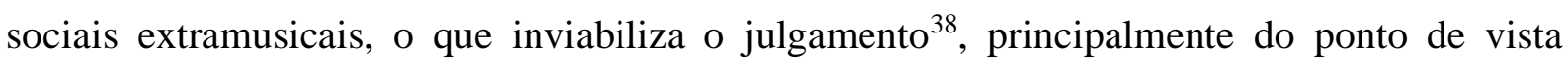
comparativo, proposto por Raguenet.

Ao procurar estabelecer um paralelo entre franceses e italianos, no que concerne à
ópera, percebemos que o termo ópera tem significados muito diferentes quando
aplicados às duas tradições de espetáculos teatrais com música. Certamente a ópera
francesa, a tragédie lyrique, muito deve à ópera italiana, tanto pelas apresentações de
espetáculos italianos na França a partir da década de 1640 , como pela própria origem
italiana de Lully, bem como por diversos outros elementos constitutivos do
espetáculo. Entretanto, a tragédie lyrique aproveita outras tradições francesas e, acima
de tudo, reporta-se a um diverso contexto social: ela serve para enaltecer o rei e faz
parte de uma série de atividades existentes na corte francesa. Já a ópera italiana,
especialmente a veneziana, está ligada a teatros públicos (abertos ao público pagante),
com diversas peculiaridades. Desse modo, percebe-se que, apesar de o termo ópera
ser usado tanto para o caso italiano como para o caso francês, existiam diversos pontos
discordantes que não permitiriam um paralelo muito claro (KÜHL, 2014, p. 4).

Além das diferenças entre a ópera nas duas nações modelos, outros estudos apontam mais aspectos extramusicais que merecem destaque. Spitzer e Zaslaw (2004, p. 105) escrevem sobre semelhanças e diferenças entre Paris e Roma no século XVII e inÍcio do XVIII:

As duas cidades certamente eram extremamente ricas e prósperas, as duas eram grandes capitais. [Enquanto a França absolutista contava com a soberania inquestionável de seu Rei, principalmente Luis XIV], o Papa era soberano absoluto

38 Conforme já mencionado, o foco da obra de Raguenet para o nosso trabalho se encontra exclusivamente na sua descrição que deve ser sempre contextualizada. E não em seu julgamento. 
dos estados papais que iam de Roma e a Campanha à cordilheira apenina [no centro da Itália continental] até Bolonha e com extensão até o mar Adriático. Além disso, Roma funcionava como capital e centro administrativo para as operações mundiais da Igreja Católica. Roma, como Paris, era um ímã de riqueza. O dinheiro fluía para os cofres papais de impostos e taxas dentro dos estados papais e também da venda de ofícios eclesiásticos e dispensas papais. Além da renda do papa, chegava a Roma dinheiro das ordens religiosas, cuja sede ficava na cidade, e de países estrangeiros que ali mantinham embaixadas. Os cardeais, em sua maioria vindos da nobreza italiana e quase todos morando em Roma, foram encarregados dos cargos administrativos superiores na Cúria Papal e desempenharam o papel de camponeses na corte papal. A pequena nobreza local e dignitários estrangeiros também aumentaram as fileiras da aristocracia. Roma no século XVII, como Paris, havia se tornado o local de uma cultura aristocrática, centralizada em uma capital sob domínio autocrático. ${ }^{39}$

Os autores enfatizam que, enquanto em Paris o Rei, e/ou seus ministros, pagam quase que a totalidade dos espetáculos ocorridos, se tornando patronos únicos, em Roma, os Papas não mantinham este monopólio cultural. Além disso, evitavam patrocinar artes seculares como a dança e o teatro, e essencialmente focavam em patrocinar artes sacras. Devido a isso, temos uma diferença muito importante entre as orquestras francesas e italianas. Enquanto as primeiras eram focadas na ópera e nos ballets, as segundas tinham como alvo, oratórios, cantatas sacras e música instrumental.

Voltando aos aspectos musicais, temos em Raguenet:

Passemos agora das árias simples para as peças compostas com várias partes. Que vantagem teriam os italianos sobre os franceses? Não vi nenhum músico, na França, que não convenha que os italianos sabem melhor inverter e cruzar [as vozes] do que os franceses. Entre nós, a voz de primeiro soprano [premier dessus] é comumente muito bela; mas o segundo só poderia descer tanto quanto o faríamos descer. Na Itália, o soprano [dessus] é três ou quatro tons mais alto do que na França, a ponto de o segundo soprano estar, por isso, em um tom alto o suficiente para ter tanta beleza quanto nossos próprios primeiros sopranos [premiers dessus]. Além disso, as três partes [de um trio] são igualmente tão belas, que não poderíamos dizer qual é o tema. Lully fez alguns trios com tal beleza, mas são em pequeno número; enquanto quase todos os italianos têm esse caráter (RAGUENET, 1702, p. 37).

No trecho acima, Raguenet nos aproxima de uma característica extremamente importante da música italiana: a predominância de duas vozes agudas dialogando e/ou dividindo a melodia. Essas duas vozes agudas foram emuladas na música instrumental, normalmente

39 Tradução nossa. Do original: Rome in the seventeenth century resembled Paris in several respects. Like Paris, it was capital city. The pope ruled as temporal and absolute sovereign over the papal states, stretching from Rome and the campagna across the apennines to Bologna and on to the Adriatic. In addition, Rome functioned as the capital and administrative center for the worldwide operations of the Catholic Church. Rome like Paris, was magnet for wealth. Money flowed into the papal coffers from taxes and duties within the papal states and also from the sale of ecclesiastical offices and papal dispensations. Besides the income of the pope, money came to Rome from the religious orders, whose headquarters were located in the city, and from foreign countries that maintained embassies there. The cardinals, most of them drawn from the Italian nobility and almost all of them living in Rome, were entrusted with the upper administrative positions in the Papal Curia and played the role of countries at the papal court. Local landed gentry and foreign dignitaries also swelled the ranks of the aristocracy. Rome in the seventeenth century, like Paris, had become the site of an aristocratic culture, centralized in a capital city under autocratic rule. 
tocadas por um violino em cada linha, e dispostas sobre um baixo contínuo às vezes concertante, o que se tornou a base de um dos gêneros mais frequentes do gosto italiano: a trio-sonata.

Frequentemente, a trio-sonata se encontrava escondida dentro de uma orquestração maior (a quatro vozes), na qual esse trio (dois violinos e baixo contínuo) chamado concertino exercia um papel protagonista e/ou de confronto perante um grupo grande chamado concerto grosso ou concertato, com uma distribuição das quatro vozes (violinos I e II, viola e baixos). Desse confronto, temos a origem da palavra "concerto" e também um outro gênero bastante caro ao gosto italiano (principalmente o romano): o concerto grosso.

Spitzer e Zaslaw (2004, p. 111) apontam como, ao longo do século XVII, a orquestração romana passou de uma tradição policoral — na qual os instrumentos, ao invés de compor um grupo à parte dos cantores, eram distribuídos como complemento instrumental entre coros distintos e em que o contraste ficava a cargo de uma separação espacial entre os coros, ou uma distinção timbrística - para a "instituição do concerto grosso", que tinha como foco o confronto entre muitos instrumentos (tutti) e poucos (soli), entre uma produção sonora mais leve e outra maior.

Tabela 3: Orquestra organizada para o oratório San Eustachio de Mansini na igreja San Giovanni dei Fiorentini (Roma, 1675)

\begin{tabular}{|c|c|c|c|c|c|c|}
\hline Grupo & Total & Violinos & Contralto & Tenor & Baixo & Contínuo \\
\hline Concertino & 6 & 2 & 0 & 0 & 2 violones & $\begin{array}{c}\text { Total: } 2 \\
1 \text { alaúde } \\
1 \text { cravo }\end{array}$ \\
\hline $\begin{array}{c}\text { Concerto } \\
\text { grosso } \\
\text { (ripieno) }\end{array}$ & 18 & 6 & 4 & 4 & 4 & 0 \\
\hline
\end{tabular}

Fonte: Do autor, 2020, baseada no trabalho de Spitzer e Zaslaw (2004, p. 111)

O concerto grosso, a partir da segunda metade do século XVII, passa a se tornar uma tradição instrumental, emulada de uma prática policoral, originada no início do século, quando os mestres de capelas elegiam um coro favorito, com um cantor por parte, com as melhores vozes, e um segundo coro chamada capella ou ripieni, com todas as outras. Assim, o acompanhamento de grandes Oratórios, compostos por músicos como Stradella, Masini (Tabela 3) e outros, passam a ter um pequeno grupo chamado concertino com dois violinos e violone, com o primeiro coro, e um grupo com todos os outros instrumentistas com o coro de ripieno. Até o final do século XVII esses dois grupos instrumentais passam a assumir um papel que vai além do de compor o acompanhamento de seus respectivos corais e se tornam uma tradição instrumental consolidada pela obra de Arcangelo Corelli. 
$\mathrm{Na}$ Ópera de Paris havia também dois efetivos contrastantes, chamados pequeno e grande coro (petit chœur e grand chœur), mas o contraste ficava mais a cargo da variação timbrística do que a um protagonismo ou confronto. Além disso, nas orquestras francesas, as vozes do soprano (dessus) eram reforçadas por colla parte de instrumentos de sopro.

Timbres variados se tornam uma tônica na orquestração francesa, ao passo que na Itália o efetivo era predominantemente de cordas friccionadas. Na orquestra de Arcangelo Corelli, em Roma, os sopros eram bastante raros. Spitzer e Zaslaw (2004, p. 115) mencionam, num período entre 1680 e 1713, duas ocasiões em que houve a contratação de quatro oboístas para a interpretação de uma obra de Händel e uma outra com a participação de um par de flautas, todas as três na primeira década do século XVIII. Além dessas três, são mencionadas, ainda, algumas outras ocasiões especiais, ao longo dos 33 anos, normalmente quando ocorriam grandes festas sacras nas igrejas, ou concertos ao ar livre nas praças da cidade. Nas folhas de pagamento das orquestras arregimentadas para essas ocasiões vê-se que foram contratados trompetistas (normalmente um par) e sacabuxistas, entretanto não há comprovação de que esses instrumentistas tenham tocado nas sinfonias e concertos simultaneamente com a orquestra.

Sobre esse aspecto, Raguenet (1702, p. 31, grifo nosso) diz:

Quanto aos instrumentos, nossos violinos são superiores aos da Itália, pela fineza e delicadeza da maneira de tocar. Todos os golpes de arco [coups d'archets] dos italianos são demasiado duros quando estão destacados uns dos outros. E quando eles os querem ligar, arranham [viellent] de uma maneira muito desagradável. De mais a mais, além de todos os tipos de instrumentos que estão em uso entre os italianos, nós ainda temos os oboés, que, por seu som igualmente macio e penetrante, têm muitas vantagens sobre os violinos nas árias de movimento. $\mathbf{E}$ as flautas, que tantos homens ilustres sabem fazer gemer de uma maneira tão tocante nas nossas árias lamentosas e suspirar tão amorosamente em nossas árias ternas.

As arcadas citadas pelo historiador francês são também uma característica observada por Georg Muffat em suas viagens à França e relatadas no prefácio de seus concertos grossossuítes. O compositor relata uma ordenação coreográfica nas arcadas da orquestra francesa, jamais observadas na Itália e na Alemanha de seu tempo, onde era comum as direções dos arcos serem dessincronizadas.

Nas orquestras, os números de instrumentos também eram variados. Segundo Zaslaw e Sptizer (2004), o número de músicos na orquestra de Lully tinha maior peso nas vozes de baixo e de soprano (dessus), conforme poderemos observar nas tabelas 4 e 5, baseada nos trabalhos de Zaslaw, Spitzer e Dratwicki.

Tabela 4: Orquestra de ópera francesa do final do século XVII

\begin{tabular}{|l|l|l|l|l|l|l|l|l|c|}
\hline Ano & Grupo & Total & $\begin{array}{c}\text { Dessus } \\
\text { (violinos) }\end{array}$ & Tailes & $\begin{array}{c}\text { H. } \\
\text { contres }\end{array}$ & Quinte & Basse & Sopros & Contínuo \\
\hline
\end{tabular}




\begin{tabular}{|c|c|c|c|c|c|c|c|c|c|}
\hline 1670 & $\begin{array}{l}\text { Petit } \\
\text { choeur }\end{array}$ & 10 & - & - & - & - & - & - & - \\
\hline 1670 & $\begin{array}{l}\text { Grand } \\
\text { choeur }\end{array}$ & $\begin{array}{l}\text { 36, sendo: } \\
35+ \\
1 \text { tímpano }\end{array}$ & 12 & 3 & 2 & 2 & 8 & 8 & 0 \\
\hline 1704 & $\begin{array}{l}\text { Petit } \\
\text { choeur }\end{array}$ & $\begin{array}{c}\text { 10, sendo: } \\
9+ \\
1 \text { maestro }\end{array}$ & 2 & 0 & 0 & 0 & 2 & & $\begin{array}{c}5, \text { sendo: } \\
1 \text { cravo } \\
1 \text { teorba } \\
2 \text { violas da } \\
\text { gamba } \\
\text { baixo }\end{array}$ \\
\hline 1704 & $\begin{array}{l}\text { Grand } \\
\text { choeur }\end{array}$ & 33 & 9 & 3 & 3 & 2 & 8 & $\begin{array}{c}\text { 8, sendo: } \\
2 \text { oboés e } \\
\text { flautistas } \\
2 \text { traversos } \\
2 \text { flautistas, } \\
\text { oboístas e } \\
\text { fagotistas } \\
2 \text { fagotistas }\end{array}$ & - \\
\hline
\end{tabular}

Fonte: Do autor, 2020.

Tabela 5: Outras Orquestras Francesas (final do XVII e início do XVIII)

\begin{tabular}{|c|c|c|c|c|c|c|c|c|}
\hline Ano & Grupo & Total & Dessus & Taile & Haute-contre & Quinte & Basse & Sopros \\
\hline 1636 & $\begin{array}{l}\text { Le vingt-quatre } \\
\text { violons du Roy. }\end{array}$ & 24 & 6 & 4 & 4 & 4 & 6 & 0 \\
\hline 1650 & $\begin{array}{l}\text { Le vingt-quatre } \\
\text { violons } d u \text { Roy. }\end{array}$ & 24 & 6 & 4 & 4 & 4 & 6 & 0 \\
\hline 1664 & $\begin{array}{l}\text { Les petits } \\
\text { violons du roy }\end{array}$ & 19 ou 20 & - & - & - & - & - & - \\
\hline 1681 & $\begin{array}{l}\text { Les petits } \\
\text { violons du roy }\end{array}$ & 22 & - & - & - & - & - & - \\
\hline 1690 & $\begin{array}{l}\text { Les petits } \\
\text { violons du roy }\end{array}$ & 21 & - & - & - & - & - & - \\
\hline 1692 & $\begin{array}{l}\text { Les petits } \\
\text { violons du roy }\end{array}$ & 22 & 7 & 2 & 3 & 2 & 4 & $\begin{array}{l}4, \text { sendo: } \\
2 \text { cromorne } \\
2 \text { fagotes }\end{array}$ \\
\hline 1692 & $\begin{array}{l}\text { Le vingt-quatre } \\
\text { violons } d u \text { Roy }\end{array}$ & 25 & 7 & 4 & 4 & 3 & 7 & 0 \\
\hline 1698 & $\begin{array}{l}\text { Les petits } \\
\text { violons du roy }\end{array}$ & 23 & 7 & 2 & 3 & 2 & 5 & $\begin{array}{l}\text { 4, sendo: } \\
2 \text { oboés } \\
2 \text { fagotes }\end{array}$ \\
\hline 1702 & $\begin{array}{l}\text { Les petits } \\
\text { violons du roy }\end{array}$ & 23 & 7 & 2 & 3 & 2 & 5 & $\begin{array}{l}\text { 4, sendo: } \\
2 \text { oboés } \\
2 \text { fagotes }\end{array}$ \\
\hline 1702 & $\begin{array}{l}\text { Le vingt-quatre } \\
\text { violons du Roy }\end{array}$ & 24 & 9 & 3 & 4 & 2 & 6 & 0 \\
\hline 1708 & $\begin{array}{l}\text { Le vingt-quatre } \\
\text { violons } d u \text { Roy }\end{array}$ & 24 & 10 & 2 & 3 & 2 & 7 & 0 \\
\hline 1712 & $\begin{array}{l}\text { Les petits } \\
\text { violons du roy }\end{array}$ & 25 & 8 & 2 & 3 & 2 & 5 & $\begin{array}{l}5 \\
3 \text { oboés } \\
2 \text { fagotes }\end{array}$ \\
\hline
\end{tabular}




\begin{tabular}{|l|l|l|l|l|l|l|l|l|}
\hline 1718 & $\begin{array}{l}\text { Le vingt-quatre } \\
\text { violons du Roy }\end{array}$ & 24 & 11 & 3 & 2 & 0 & 8 & 0 \\
\hline
\end{tabular}

Fonte: Do autor, 2020.

Na orquestra de Corelli (conforme exemplo do ano de 1680, na Tabela 6), vemos uma proporção em que violinos ocupam metade do número de instrumentos dividindo duas vozes de soprano (violino I e violino II), o baixo contínuo tem uma proporção que varia entre um quarto a um terço do efetivo e as violas em uma única voz preenchem o resto.

As vozes do soprano (ou dessus, na música francesa) tinham papel de protagonistas nos dois estilos nacionais, porém conforme já mencionado, era comumente dividida na Itália com um protagonismo e independência raro ao gosto francês tradicional. Os violinos se incumbiam dessas partes na Itália com os violinos I e II, e na França com o dessus, quando eram dobrados por flautas e oboés. Nas orquestras francesas, tradicionalmente, as vozes internas eram divididas em três partes distintas, cada qual com um tipo de viola específica. Assim, havia a haute-contre, a taille e a quinte, o que resultava numa orquestração a cinco vozes quando somadas ao baixo contínuo (basse) e ao dessus (sopranos). Já na Itália, havia na maior parte das ocasiões uma única voz de viola, que somada ao baixo e aos dois sopranos resultava na orquestração a quatro.

Tabela 6: Orquestras organizadas para a festa de São Luis na Igreja San Luigi dei Francesi (Roma, 1660-1690)

\begin{tabular}{|c|c|c|c|c|c|c|}
\hline Ano & Total & Violinos & violas & Baixo & Contínuo & Sopros \\
\hline 1660 & 13 & 4 & 0 & 2 & $\begin{array}{l}\text { 7, sendo: } \\
4 \text { orgãos } \\
3 \text { alaúdes }\end{array}$ & 0 \\
\hline 1665 & 21 & 4 & 1 & 4 & $\begin{array}{c}\text { 12, sendo: } \\
7 \text { orgãos } \\
1 \text { espineta } \\
2 \text { alaúdes } \\
2 \text { teorbas }\end{array}$ & 0 \\
\hline 1670 & 9 & 2 & 0 & 1 & $\begin{array}{c}5, \text { sendo: } \\
3 \text { órgãos } \\
1 \text { arqueluto } \\
1 \text { guitarra }\end{array}$ & 1 trompete \\
\hline 1675 & 12 & 3 & 0 & $\begin{array}{l}\text { 3, sendo: } \\
1 \text { cello } \\
2 \text { violones }\end{array}$ & $\begin{array}{c}4 \text {, sendo: } \\
3 \text { orgãos } \\
1 \text { arqueluto }\end{array}$ & 2 trompetes \\
\hline 1680 & 18 & 8 & 3 & $\begin{array}{c}\text { 4, sendo: } \\
1 \text { cello } \\
3 \text { contrabaixos }\end{array}$ & 3 orgãos & 0 \\
\hline 1685 & 18 & 10 & 0 & $\begin{array}{c}\text { 5, sendo: } \\
2 \text { violones } \\
3 \text { contrabaixos }\end{array}$ & 3 orgãos & 0 \\
\hline 1690 & 18 & 10 & 0 & 5, sendo: & 3 orgãos & 0 \\
\hline
\end{tabular}




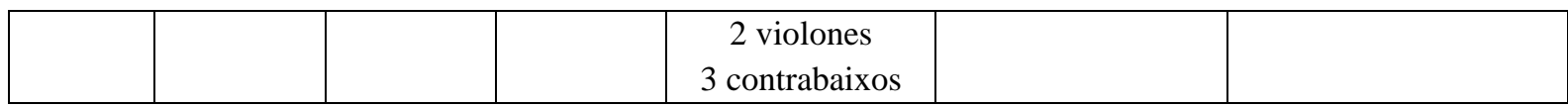

Fonte: Do autor, 2020.

Além das vozes e da orquestração, outra característica ditada pelo gosto nacional são os gêneros. Vimos acima, gêneros caros ao estilo italiano, como o concerto grosso e a triosonata. Já na França, um dos gêneros mais admirados pelos franceses e por outras nações são as aberturas (ouvertures). Sobre este gênero, Matheson (1739 apud PAOLIELLO, 2017, p. 107) discorre:

\begin{abstract}
Deixemos, no entanto, os italianos ostentarem e se vangloriarem o quanto quiserem a respeito de suas vozes e de suas artes. Em vão será pedido a eles que componham uma abertura francesa como se deve. Isto basta para dizer que, geralmente, a música instrumental dos franceses se destaca sobremaneira. Apesar de os italianos se empenharem muito nas suas sinfonias e concertos, que certamente são especialmente bonitos, uma ouverture francesa viva é preferível a estes. Pois, ao lado da composição de uma peça destas com sua suíte à la Françoise, sua execução no seu gênero, feita pelos próprios franceses, é tão admirável, tão unie e tão ferme, que nada pode sobrepôla.
\end{abstract}

As suítes e ballets franceses se destacavam por uma extensa lista de danças, como a allemande, courante, minuet, sarabande e passepied. Na Itália, havia suítes de danças, chamadas de partitas e, por vezes, suas danças eram inclusas em sonatas e trio-sonatas, como as sonatas da camera. Todavia, essa não era uma obsessão nacional, como na França, onde a quadratura regular, as molduras rítmicas de suas danças (regradas à perfeição como os típicos jardins franceses de seus palácios) ditavam até mesmo a composição de árias de ópera, que muitas vezes eram, na verdade, danças cantadas.

Na música operística francesa, entre as declamações dos recitativos e árias enquadradas em molduras de danças, eram comuns coros que enfatizassem a "moral da história" e, principalmente, a composição de mais ballets e danças em que o deleite da plateia ficava a cargo do virtuosismo de seus bailarinos. Sobre isso, Raguenet (1702, p. 31) afirma:

\footnotetext{
Além da vantagem da justeza das peças e das diferentes espécies de voz, nós temos ainda a dos coros, das danças e de outros divertimentos [divertissements], no que nossas óperas superam infinitamente as dos italianos. Estes, em vez de coros e divertimentos que geram uma variedade tão agradável em nossas óperas e que lhes dão até mesmo certo ar de grandeza e de magnificência, têm ordinariamente apenas cenas burlescas de um bufão; de alguma velha que estará apaixonada por um rapaz, ou de um mago que transformará um gato em um pássaro, um violino em uma coruja, e que fará outros rodeios semelhantes que poderiam apenas divertir a plateia [parterre]. E quanto às danças dos italianos, é a maior lástima do mundo, seus dançarinos são homens de uma só peça, sem braços, sem pernas, sem estatura e sem ar.
}

Conforme apontamos, Paris e Versalhes eram cidades prósperas, onde o Rei e seus ministros gastavam somas generosas patrocinando óperas e ballets; a metrópole italiana com prosperidade equivalente tinha uma nobreza eclesiástica com um decoro que não permitia o 
patrocínio de espetáculos seculares; e as outras cidades-estado seguiam o decoro romano, ou não possuíam os mesmos recursos que os franceses para a dança e para o teatro. Ratner ${ }^{40}(1980$ apud PAOLIELLO, 2017, p. 110) afirma:

A atividade musical francesa estava centralizada em Paris e Versalhes, enquanto a música italiana era exportada em todo o mundo ocidental. O teatro era o centro da vida artística francesa; a música era complementar à declamação e à dança, enfatizando o efeito da palavra e completando o sentido do movimento na coreografia, em contraste à ênfase na melodia e à excelência vocal italiana.

\section{E complementa:}

Enquanto a maneira de cantar francesa estava confinada principalmente aos salões e teatros franceses, as danças francesas eram exportadas constantemente durante o séc. XVIII; dançarinos e mestres de dança franceses viajaram por toda a Europa da mesma maneira que os compositores e instrumentistas italianos. (RATNER, 1980 apud PAOLIELLO, 2017, p. 111)

Do mesmo modo que, na França, o foco era essencialmente a dança, os italianos esperavam ouvir, após os recitativos, o virtuosismo de um cantor em uma ária bastante desafiadora. No gosto italiano, a "música pela música" começava a tomar uma nova direção, que extrapolava paulatinamente o caráter incidental.

Segundo Kühl (2014, p. 30), “era comum, na ópera italiana, a inclusão de árias pertencentes a outras óperas. Não se tratava de pastiches, mas das próprias óperas, que eram adaptadas segundo as necessidades de cada apresentação, as vontades dos cantores, etc".

Raguenet (1702, p. 32) afirma:

As óperas dos italianos [...] são mais propriamente esboços muito fracos e escassos: todas as cenas são compostas de alguns diálogos ou monólogos triviais, no fim dos quais eles encaixam alguma de suas mais belas árias, a qual finaliza a cena. As árias são muito frequentemente árias soltas, que de modo algum pertencem ao corpo da peça e que foram feitas por outros poetas, separadamente ou na sequência de alguma outra obra. Quando o empresário de ópera juntou sua trupe em alguma cidade, ele escolhe por tema de sua ópera a peça que lhe agrada, como Camila, Temístocles, Xerxes etc. Mas essa peça é apenas, como acabo de dizer, um esboço, que ele recheia com as mais belas árias que os músicos de sua trupe conhecem. Pois essas belas árias são selas para todos os cavalos, são declarações de amor feitas de um lado, aceitas ou rejeitadas de outro. São êxtases de amantes contentes, ou queixas de amantes infelizes, protestos de fidelidade, ou sentimentos de ciúmes, arroubos de prazer, ou prostração de dor; são furores ou desesperos. Não há cena no fim da qual os italianos não saibam encontrar um lugar para alguma dessas árias [...]. As árias italianas são mais extremas [detournés] e mais ousadas do que as árias francesas. O caráter é levado mais longe, seja pela ternura, seja pela vivacidade, ou por todas as outras espécies. Os italianos até mesmo unem, às vezes, caracteres que os franceses creem incompatíveis. Os franceses, nas peças com várias partes, trabalham comumente apenas aquela que é o tema; os italianos, ao contrário, fazem todas, normalmente, igualmente belas e elaboradas. Enfim, o gênio dos últimos é inesgotável para inventar, enquanto o dos primeiros é assaz estreitamente limitado.

40 RATNER, L. Classic Music: Expression, form and style. Nova Iorque: Schirmer Books, 1980. 
Retornando à música instrumental, há um outro gênero tipicamente italiano, a sonata da chiesa. Esse gênero, contraposto à sonata da camera, já mencionada, tem um nome atrelado ao decoro de ocasião de igreja, mas, como veremos mais detalhadamente (capítulo 4.1), possui um discurso próprio, que alterna escrita livre e estrita ao longo de seus movimentos. Dependendo do subgênero italiano (romano, bolonhês, veneziano, napolitano etc.), há entre três e cinco movimentos, enquanto as sonatas da camera geralmente eram compostas de quatro movimentos de danças.

O equilíbrio francês, já mencionado, em que as vozes do dessus alternam o protagonismo com o basse, tendo ambas muito mais peso que as vozes internas, se contrapõe ao equilíbrio italiano, que, mesmo com o advento da seconda pratica, nunca abandonou totalmente o contraponto. Dessa forma, comumente há duas vozes de soprano que ora disputam o protagonismo, ora entram em concordância, ou se alternam, mas não raramente, disputam espaço com o baixo e às vezes com outras vozes internas. Essa ousadia de todas as vozes não passou desapercebida por estrangeiros, como Raguenet (1702, p. 34):

\begin{abstract}
Mas é nas peças com mais partes que melhor aparece a vantagem que os músicos da Itália têm sobre os da França quanto à composição. Na França, já é muito quando o tema é belo; é raro que as partes que o acompanham tenham apenas um canto contínuo. Encontramos, às vezes, baixos-contínuos que tocam sempre e que os franceses acham admiráveis por causa disso. Mas, nessas ocasiões, as vozes superiores são pouca coisa, deixam de ser o tema, e então o baixo é que se torna o tema. Quanto aos acompanhamentos de violino, eles são, na maior parte, simples arcadas, ouvidas em intervalos, que nada têm de um canto ligado e contínuo e que servem apenas para fazer ouvir, de tempos em tempos, algum acorde. Na Itália, ao contrário, a primeira voz, a segunda, o baixo contínuo e todas as outras partes da composição das peças mais cheias [remplies] são igualmente trabalhadas. Os violinos tocam sempre partes cujo canto é comumente tão belo quanto a ária em questão; também acontece frequentemente de, depois de termos ouvido algo da ária que achamos encantadora, sermos imperceptivelmente conduzidos pelas partes acompanhantes, que não encantam menos e que fazem abandonar o tema para serem seguidas. Tudo é de uma beleza tão igual que não se poderia dizer qual é a parte predominante. Às vezes o baixo contínuo acompanha a tal ponto de, ao ouvi-lo, não pensarmos de modo algum no tema. Outras vezes, o tema conduz de tal maneira que não prestamos nenhuma atenção ao baixo contínuo; no momento seguinte, os acompanhamentos de violino encantam de tal maneira que não escutamos nem o baixo contínuo, nem o tema. Uma alma não é suficiente para sentir a beleza de todas as partes; seria necessário multiplicar-se para seguir e saborear, ao mesmo tempo, três ou quatro coisas igualmente tão belas. Somos arrebatados, encantados, extasiados de prazer; é necessário soltar um grito de espanto para se aliviar; ninguém pode evitá-lo; esperamos com impaciência o fim de cada ária para respirar. Com frequência não se pode esperar até o fim, interrompe-se o músico com gritos e aplausos infinitos; a música italiana produz, todos os dias, esses efeitos. Não há ninguém que tenha viajado à Itália e que não tenha sido mil vezes testemunha disso; nunca se experimentou nada de semelhante em nenhum outro país. São belezas de um grau de excelência que a imaginação não poderia atingir antes de ouvi-las; e além do que nada poderíamos imaginar, depois de as termos ouvido.
\end{abstract}

Raguenet, em seu "relato de viagem", revela, sob a ótica de um contemporâneo estrangeiro "convencido pelo discurso musical", algumas práticas bastante recorrentes por 
décadas entre os italianos, como o rebuscamento das partes de acompanhamento. Essas práticas chamaram a atenção de um outro francês, 60 anos antes da visita do abade à Roma: André Maugars. D’Ovidio cita o relato do gambista francês que descreve a música realizada na igreja de San Marcello, na década de 40 do século XVII em Roma:

A música instrumental é composta por um órgão, um grande cravo, uma lira, dois ou três violinos e dois ou três arquilutos. Uma vez que um violino toca apenas com o órgão, outro responde, outra vez eles executam as três partes diferentes juntas. Ocasionalmente, um arquiluto faz mil variações em dez ou doze notas, cada uma com cinco ou seis compassos; então o outro toca a mesma coisa, cada um de forma diferente. [...] acima de tudo, porém, foi esse grande frescobaldi (sic) que ofereceu mil tipos de invenções com o seu cravo, acima das notas mantidas firmes pelo órgão ${ }^{41}$ (MAUGARS $^{42}$ apud D'OVIDIO, 2002, p. 81).

O acompanhamento do contínuo era extensivamente decorado e a ousadia contrapontística captava os ouvidos atentos desses estrangeiros, mas além da ousadia contrapontística, Raguenet se admirou com a ousadia harmônica:

É verdade que nosso recitativo é muito mais belo do que o dos italianos, que é simples e unido demais, que é sempre igual, que não é propriamente um canto, pois eles apenas falam, por assim dizer, no recitativo. Quase não há nada de inflexão nem de modulação nesse pretenso canto. Contudo, o que há de admirável é que as partes que servem de acompanhamento a essa salmodia são excelentes, pois o gênio dos italianos para a composição é tão maravilhoso que eles sabem encontrar acordes encantadores, mesmo ao som da voz de uma pessoa que simplesmente fala sem cantar, o que nunca se viu nem se poderá ver em nenhum outro lugar do mundo. (RAGUENET, 1702, p. 39)

E discorre ainda mais sobre as dissonâncias italianas:

Os italianos, ao contrário, passam a todo momento do bequadro ao bemol e do bemol ao bequadro; eles arriscam as cadências [cadences] mais forçadas e as dissonâncias mais irregulares; e suas árias são de um canto tão extremo [détourné], que em nada parecem com todas as compostas por outras nações do mundo. [...]

Às vezes, ouve-se uma nota sustentada contra a qual os primeiros tons do baixo contínuo fazem uma dissonância que irrita o ouvido; mas o baixo, continuando a tocar, volta a essa nota sustentada com acordes tão belos, que bem se vê que o músico criou essas dissonâncias apenas para fazer sentir, com mais prazer, os belos acordes para onde rapidamente conduz a harmonia (RAGUENET, 1702, p. 33).

Um "traje” estilístico nacional que não pode deixar de ser mencionado, se encontra nas diferenças entre as línguas italiana e francesa. A respeito da língua italiana, Raguenet aponta implicações interessantes:

41 Tradução nossa do original: La musica strumentale è formata d'un organo, d'un clavicembalo grande, d'una lira, di due o tre violini e di due o tre arciliuti. Una volta un violino suona solo con l'organo, poi un altro risponde, un'altra volta eseguono tutti e tre insieme diverse parti. Ogni tanto un arciliuto fa mille variazioni sopra dieci o dodici note, ogni nota di cinque o sei battute; poi l'altro suona la stessa cosa, ognuno in modo diverso. [...] soprattutto pero fu questo grande frescobaldi (sic) a offrire mille sorte d'invenzioni sopra il suo clavicembalo, sopra delle note tenute ferme dall'organo.

42 MAUGARS, A. Response faite à un curieux sur le sentiment de la musique en Italie, escrite à Rome, le 1er octobre 1639. Lyon: Claudin, 1865. 
A língua italiana tem uma grande vantagem sobre a francesa para ser cantada, pois todas as suas vogais soam muito bem, enquanto a metade das de língua francesa são vogais mudas, que quase não têm som. De onde, primeiramente, acontece de não sabermos fazer nenhuma cadência [cadence] nem passagens ornamentadas [passages] agradáveis sobre as sílabas em que se encontram tais vogais. E, em segundo lugar, só ouvimos as palavras pela metade; de modo que é necessário adivinhar a metade do que cantam os franceses e que, ao contrário, ouvimos muito distintamente tudo o que dizem os italianos. Além disso, mesmo que todas as vogais da língua italiana soem perfeitamente bem, os músicos ainda escolhem aquelas que melhor se ouvem para fazer suas mais belas passagens ornamentadas. É sobre a vogal ' $a$ ' que eles fazem quase todas. E nisso têm razão, pois essa vogal, sendo a de som mais claro, a beleza das passagens ornamentadas aparece mais. Enquanto os franceses as fazem indiferentemente sobre todas as vogais, sobre as mais surdas como sobre as mais sonoras; eles até mesmo as fazem sobre ditongos, como nas palavras chaîne [corrente], gloire [glória], etc., cujo som, sendo confuso e misturado das duas vogais juntas, não poderia ter a clareza e a beleza das vogais simples (RAGUENET, 1702, p. $32)$.

Por fim, o historiador entra no assunto que é o alvo dessa dissertação, a ornamentação.

Sobre ela afirma:

Os músicos franceses se creriam perdidos se fizessem o mínimo contra as regras. Eles adulam, fazem cócegas, respeitam o ouvido, e ainda tremem com o medo de não ter sucesso depois de fazer as coisas com toda a regularidade possível. Os italianos, mais ousados, mudam bruscamente de tom e de modo, fazem cadências dobradas e redobradas [cadences doublées \& redoublées] de sete e oito compassos, sobre tons que não pensaríamos capazes de suportar o menor trinado [tremblement]. Fazem notas sustentadas [tenues] de uma duração tão prodigiosa, que aqueles que não estão acostumados não se poderiam impedir de, para começar, ficar indignados com tal ousadia, a qual, em seguida, acreditamos não poder jamais admirar suficientemente. [...] Fazem passagens ornamentadas de uma extensão que confunde todos os que as ouvem pela primeira vez. E às vezes eles as fazem até mesmo em tons tão irregulares, que lançam o pavor assim como a surpresa no espírito do ouvinte, o qual crê que todo o concerto vai cair em uma dissonância assustadora. E interessando-o, com isso, pela ruína em que toda a música parece ameaçada, eles o sossegam com cadências [chutes] tão regulares, que todos se surpreendem ao ver a harmonia como que renascer da própria dissonância, e tirar sua maior beleza dessas irregularidades que pareciam que iriam destruí-la. Eles arriscam o que há de mais duro e de mais extraordinário, mas o fazem como pessoas que têm o direito de fazê-lo e que têm certeza do sucesso. No sentimento que têm de serem os primeiros do mundo para a música, de dela serem os soberanos e senhores despóticos, eles transpõem suas regras com sobressaltos [saillies] temerários, mas felizes; eles se colocam acima da arte, mas como senhores da arte, que seguem suas leis quando querem e que as ofendem quando lhes agrada; eles insultam a delicadeza do ouvido, o qual os outros só ousariam tocar lisonjeando-a; eles a afrontam, forçam, dominam e a suprimem através de encantos que certamente tiram sua maior força da ousadia com que dela sabem se servir (RAGUENET, 1702, p. 33, grifo nosso)

Raguenet se refere à ornamentação livre, uma prática que veremos em detalhes no capítulo 3 e que contrasta com outra tradição de ornamentação, a francesa. Sobre os pequenos ornamentos, Ratner afirma:

Os italianos tinham habilidade especial para extrair figuras melódicas atrativas da harmônica. Nos allegros eles citaram frequentes padrões agradáveis bem ancorados de arpeggios para temas importante, e figurações mecânicas em notas rápidas para passagens brilhantes. Nos adágios eles têm uma tradição de ornamentação florida - 
trillos, appoggiaturas, mordentes, tiratas - e arranjos em padrões irregulares. Essa ornamentação livre é sustentada por uma pontuação regular e um baixo estável que fixa o andamento (RATNER,1980 apud PAOLIELLO, 2017, p. 101).

Após aproximar as características mais relevantes dos dois modelos de gosto nacional exaltados, vale destacar que, dentre eles, há os modelos de artitas ou auctoritas. Sobre isso, Paoliello escreve que:

o modo de compor determinado pelo gosto nacional segue um critério de adequação em relação a características perpetuadas por um país - e uma auctoritas. Na definição de estilo de Brossard, observamos que o termo é utilizado também para distinguir o modo de compor característico de uma auctoritas de um determinado país (PAOLIELLO, 2017, p.102).

E em seguida, cita Brossard (1706 apud PAOLIELLO, 2017, p. 102): “O estilo de Palestrina, Lully e Corelli; o estilo dos italianos, franceses e espanhóis etc.”. Assim, temos destacados como auctoritas dos modelos francês e italiano, respectivamente, Lully e Corelli. Essa mesma opinião de Brossard é compartilhada por Couperin, Muffat, Telemann, Matheson e Quantz.

Dessa forma, para o sucesso dessa dissertação, é imprescindível que investiguemos melhor a auctoritas, Corelli, como faremos no próximo subcapítulo.

\subsection{O GOSTO ITALIANO E CORELLI}

Segundo Houaiss (2020), "no direito romano é definida por auctoritas uma certa legitimação socialmente reconhecida, que procede de um saber e que se outorga a uma série de cidadãos". Na música, outorgamos a quem legitima um determinado estilo, conforme vimos em Brossard (1706 apud PAOLIELLO, 2017), que define Arcangelo Corelli como auctoritas do estilo italiano.

\footnotetext{
Em Fusignano, portanto, nasceu no ano de 1653, o famoso Arcangelo Corelli, de quem falamos, de outro Arcanjo, e de Santa Baruzzi, que mandou seu filho pequeno a Faenza, onde teve os primeiros conhecimentos de som com um sacerdote: então ele continuou o mesmo estudo em Lugo, e mais tarde em Bolonha, com um propósito muito diferente de seguir essa arte como profissão. Mas, ao aprender a tocar violino [em Bolonha], ele finalmente acabou se apaixonando tanto por ele que só pensava nisso; e permaneceu na mesma cidade de Bolonha por quatro anos, onde progrediu tanto, que em sua memória, quis receber o nome da mesma cidade, e se chamar il Bolognese (o Bolonhês) até o fim de sua vida ${ }^{43}$ (CRESCIMBENI, 1708, i, p. 250).
}

\footnotetext{
43 In Fusignano adunque nacque l'anno 1653. il famoso Arcangelo Corelli, di cui favelliamo, d'un altro Arcangelo, e di Santa Baruzzi, i quali mandarono il giovane figlio in Faenza, ove ebbe i primi erudimenti del suono da un prete: indi continuò lo stesso studio in Lugo, e poscia in Bologna, a tutto altro fine però, che di professare tal'arte. Ma in apprendendo il suono del viuolino, vi prese finalmente tal genio, che badò solo a questo; e trattennessi nella medesima città di Bologna quattro anni, ove fece sì alto progresso, che in memoria volle assumere la sua denominazionè dalla stessa città, essendosi fatto chiamare finchè visse il Bolognese.
} 
Assim como no registro acima, escrito por Crescimbeni (1708), presidente da Academia da Arcadia Romana (instituição à qual Corelli se filiou), Peter Allsop (1999, p. 35) revela "não ter registros concretos de quais são os exatos anos em que Corelli viveu em Bolonha (Estudos anteriores e alguns relatos bolonheses do século XVIII apontavam uma hipótese entre 1666 e 1670)", sendo bastante nebuloso o período exato em que o compositor deixou sua cidade natal, passou por Faenza, Lugo, Bolonha e chegou a Roma; o que temos de mais concreto até o presente momento é a menção mais antiga encontrada de sua presença em Roma, datada de 1675, participando como intérprete do mesmo oratório de Masini da tabela 3, na qual o "bolognese" se encontrava listado entre os violinos contratados para as filas do ripieno da orquestra.

Penna (1727, p. 23), ao escrever sobre a filarmonia de Bolonha (uma tradicional instituição da cidade já à época de Corelli), aponta como professores formais de Corelli, dois violinistas com os quais o compositor teve contato em Bolonha: o bolonhês Giovanni Benvenuti (membro da instituição) e o veneziano Leonardo Brugnoli. Segundo Sanna (2013), este último era famoso também por sua notável capacidade de improvisar. Outra referência apontada por Penna como o "professor de composição" do "jovem violinista bolonhês" é Pietro Matteo Simonelli, com quem Corelli teve contato já em Roma.

Entretanto, a discussão atual sobre os modelos que inspiraram Arcangelo Corelli, compositor reconhecido em Roma e em toda Europa no século XVIII, como auctoritas do modelo italiano, é muito mais vasta do que os relatos bolonheses sobre o compositor, que segundo Sanna (2013), são contraditórios em termos. Além disso, Sanna aponta que ainda não foram encontrados registros do impacto musical de Corelli em Bolonha. O autor afirma:

O desenvolvimento de Corelli como músico não seguiu um caminho gradual, de
origens obscuras e provincianas ao sucesso glamoroso em uma capital, triunfos por
toda a Europa e para o mundo em geral. Aconteceu em uma única localidade-
essencialmente restrito a Roma e seus arredores - e em um período de tempo
relativamente curto: a partir do final dos anos 1670 - - quando ele decidiu seguir
carreira na música, estabeleceu uma rede de relações profissionais em Roma e montou
seu op. 1 para publicação - até o início da década de 1690 , quando consolidou sua
posição como o principal instrumentista da cidade. Em Roma, ele teve o patrocínio
das poderosas famílias Colonna e Chigi; e entrou sucessivamente ao serviço da ex-
rainha da Suécia, Cristina Alexandra Maria, como músico de câmara em 1679, do
cardeal Pamphilj como mestre de música em 1688 e do cardeal Ottoboni como
maestro em $1690^{44}$ (SANNA, 2013, p. 7 ).

44 Tradução nossa. Do original: Corelli's development as a musician did not follow a path of ascendancy from obscure beginnings in provincial towns to glamorous success in a capital city, triumphs all across Europe and into the world at large. It took place at a more local level - Essentially restricted to Rome and its environs - and within a relatively short time-span: from the late 1670 s - when he resolved to pursue a career in music, established a network of professional relations in Rome and assembled his op.1 for publication - to the early 1690s, when he consolidated his position as the leading instrumentalist in the city. In Rome he enjoyed the patronage of the powerful Colonna and Chigi families; and he entered successively the service of the former Queen of Sweden, 
D’Ovidio (2002, p. 177) também corrobora essa opinião: “A chegada de Corelli a Roma é um marco essencial para sua carreira ${ }^{45 "}$. E o próprio compositor deixa revelado, em uma carta escrita em Roma para Fabrizio Lardechi em Faenza (Lardechi foi seu patrono quando o compositor estudava naquela cidade), como seu novo ambiente profissional e a vivência com esses mestres se tornou inspiradora para sua obra:

Minhas sinfonias são feitas apenas para destacar o violino, e as de outros professores não me parecem o que há. Agora estou compondo algumas Sonatas que serão executadas na primeira Academia de Sua Majestade da Suécia, da qual entrei para o serviço de músico de câmara e, quando as tiver, vou compor uma para Vossa Senhoria, em que o alaúde igualará o violino ${ }^{46}$ (CORELLI apud D’OVIDIO, 2002, p. 178).

Ao longo de sua carreira em Roma, tocou com artistas como Colista, Stradella, Lonatti e Manelli. Segundo D’ovidio (2002, p. 179):

Se certamente um papel de destaque na formação do jovem Corelli teve o cantor Matteo Simonelli, "o Palestrina de nossos tempos", "grande contrapontista, observador das boas regras e harmonioso", no entanto, não se pode ignorar o ensinamento que Corelli recebia regularmente da experiência diária de fazer música, muitas vezes nas mesmas instituições musicais e nas mesmas ocasiões em que vimos os nomes dos compositores analisados aqui aparecerem ${ }^{47}$

Mas de todos esses, D’Ovidio destaca a figura de Lelio Colista:

A investigação que propusemos até agora nos permite identificar precisamente nas composições instrumentais de Colista, e não em um "modelo romano" genérico, um antecedente importante da concretização de uma sonata a três que seja adequada ao estilo corelliano. No ambiente cultural modificado da academia de Cristina, torna-se essencial para Corelli se apropriar de certos modelos musicais que, mais do que outros, no panorama romano, poderiam ser funcionais para o desenvolvimento de novos módulos estilísticos no campo instrumental. As críticas rigorosas ao "estilo moderno, túrgido e pomposo" promovido por Cristina, de fato, sugeriam uma distância de certos recursos de composição que visavam principalmente estimular a esfera sensual do espectador, em favor de um novo universo sonoro baseado agora em princípios de ordem e simetria unidade e variedade, gravidade e prazer. Em termos musicais, isso implicava um distanciamento do mundo composicional de violinistascompositores, como Lonati e Mannelli, começando por deixar de lado a necessidade de "destacar o violino", em favor de uma abordagem mais equilibrada do todo da sonata. Mesmo do ponto de vista estritamente composicional, os fugati de Colista, muito mais do que os dos outros compositores e as lições de Simonelli, mostraram efetivamente como gerenciar o processamento do contraponto sem perder a clareza e

Christina Alexandra Maria, as chamber musician in 1679, Cardinal Pamphilj as music master in 1688 and Cardinal Ottoboni as concertmaster in 1690 .

45 Tradução nossa do original: L'arrivo a Roma di Corelli segna per la sua carriera una svolta essenziale.

46 Tradução nossa. Do original: Le mie Sinfonie sono fatte solo per fare campeggiare il violino, e quelle d'altri professori non mipaiono cosa a proposito. Sto adesso componendo certe Sonate che si fararmo nella prima Accademia di Sua Maestà di Svezia, della quale sono entrato in servizio per Musico da camera, e finite che le avro, ne comporrò una per Vossignoria dove il Leuto pareggerà il violino.

47 Tradução nossa. Do original: Se certamente un ruolo di spicco nella formazione del giovane Corelli ha avuto il cantore Matteo Simonelli, "il Palestrina de nostri tempi", "gran contrapuntista, osservante delle buone regole, e armonioso", tuttavia non si può non tener conto dell'insegnamento che Corelli riceveva regolarmente dall' esperienza quotidiana del far musica, spesso proprio nelle stesse istituzioni musicali e nelle medesime occasioni in cui abbiamo visto comparire i nomi dei compositori qui analizzati. 
a perspicácia (precisão). [...] As trio sonatas de Colista parecem responder perfeitamente ao conjunto de caracteres "arquitetônicos" que Pipperno identificou como uma das principais atrações de Corelli reconhecidas e apreciadas pelos contemporâneos em sua música ${ }^{48}$ (D’OVIDIO, 2002, p.181).

\title{
A autora aponta aspectos extramusicais da carreira do compositor de Fusignano:
}

Observando os fenômenos históricos e musicais sob essa perspectiva, não é irrelevante sublinhar como a figura de Lelio Colista - "excelente virtuoso" e compositor de belas sinfonias "- acabou representando aos olhos de Corelli um jovem violinista bolonhês que queria ser apreciado nos círculos culturais romanos mais graduados, um modelo de "compositor instrumental" não só do ponto de vista estritamente técnico-composicional, mas também mais especificamente cultural e social $^{49}$ (D’OVIDIO, 2002, p.182).

\section{Sanna (2013, p. 7) também fala sobre o ambiente romano em que se inseriu o jovem}

Corelli:

\begin{abstract}
Roma ostentava uma tradição venerável de música instrumental que datava da época da estada de Frescobaldi na cidade. Uma geração posterior de instrumentistas notáveis incluiu o alaudista Lelio Colista, os tecladistas Bernardo Pasquini e Alessandro Stradella e o Violinista Carlo Ambrogio Lonati. Para a vantagem de Corelli, Stradella e Lonati deixaram Roma em 1677, Colista morreu em 1680 e Pasquini voltou sua atenção para os gêneros vocais mais elegantes da ópera e oratório - um campo que tinha sido deixado em aberto com a partida de Stradella. Não havia escassez de competidores, é claro, mas foi Corelli quem finalmente conseguiu obter os favores dos patronos mais generosos. Como foi possível, então, para um violinista que não desempenhou nenhum papel importante na vida musical de Bolonha alcançar os mais altos escalões do patrocínio romano em tão pouco tempo? Parece que Corelli fez bom uso de uma rede de conexões das províncias do nordeste do Estado Papal para primeiro se mudar para Bolonha e, posteriormente, se estabelecer em Roma. Entre
\end{abstract}

48 Tradução nossa. Do original: L'indagine che abbiamo fin qui proposto, ci consente ora di individuare proprio nelle composizioni strumentali di Colista, piuttosto che in un generico "modello romano", un antecedente importante della concrezione di sonata a tre che sarà propria dello stile corelliano. Nel mutato ambiente culturale dell'accademia di Cristina, diventa essenziale per Corelli appropriarsi di determinati modeli musicali che più di altri, nel panorama romano, potevano rivelarsi funzionali alla messa a punto di nuovi moduli stilistici in campo strumentale. La rigorosa critica verso lo "stile moderno, turgido e ampolloso" promosso da Cristina, suggeriva, infatti, una presa di distanza da certe risorse compositive volte a stimolare primariamente la sfera sensuale del fruitore, a favore di un nuovo universo sonoro basato ora su principi di ordine e simmetria unità e varietà, gravità e piacevolezza. In termini musicali, questo implicava una presa di distanza dal mondo compositivo dei violinisticompositori, come Lonati e Mannelli, cominciando col mettere da parte l'esigenza di " far campeggiare il violino", a favore di una più mediata impostazione del disegno generale della sonata. Anche dal punto di vista strettamente compositivo, i fugati di Colista, assai più di quelli degli altri compositori e delle lezioni di Simonelli, mostravano con efficacia il modo in cui gestire l'elaborazione contrappuntistica senza perdere in chiarezza e perspicuità.[...] Le sonate a tre di Colista, infatti, sembrano rispondere perfettamente a quell'insieme di caratteri " aschitettonici" che Pipperno ha identificato come una delle principali attrattive di Corelli riconoscite e apprezzate dai contemporanei nella sua musica.

49 Tradução nosssa. Do original: A questo punto, riteniamo importante introdurre un ulteriore elemento di analogia tra i due compositori che ci conduce oltre i confini della pagina musicale scritta, per approdare piuttosto verso " un ordine del conoscere" in cui " il probabile, il verosimile, l'ipotetico, per quanto circoscritti e prudenti intendano essere, rivendicano i propri diritti nell'arte di recuperare non "fatti", ma modalitá dimenticate di percezione e comprensione". Osservando i fenomeni storici e musicali da questa prospettiva, non apporità irrilevante sottolineare come la figura di Lelio Colista - "eccellente virtuoso" e compositore di bellissime sinfonie" - finiva per rappresentare agli occhi di Corelli giovane violinista bolognese intenzionato a farsi apprezzare nel più altolocati ambienti culturali romani, un modelo di "compositore strumentale" non soltanto dal punto di vista strettamente tecnico-compositivo, ma anche da quello più propriamente culturale e sociale. 
essas conexões estavam as famílias Laderchi e Azzolini e os Oratorianos de São Filipe $\mathrm{Neri}^{50}$.

Um fato incontestável na carreira do compositor é que ele se lançaria a uma das mais prestigiadas carreiras de violinista no século XVII, em Roma; talvez a mais prestigiada do século, junto à de Lully na França. Buscaroli (1983) menciona que Corelli foi conhecido em vida como “o novo Orfeu”. Spitzer e Zaslaw (2004, p. 115) afirmam que "o nascimento da orquestra em Roma é estreitamente conectado à carreira e à obra de Corelli, que de 1680 a 1709 organizou orquestras, dirigiu e compôs músicas para elas tocarem". Segundo Richard Crocker (1986 apud PAOLIELLO, 2017, p. 103), “Corelli foi muito ativo em Roma e aclamado como modelo perfeito da música instrumental em toda a Europa por várias gerações”.

Piperno (1990, p. 359) contou 63 ocasiões documentadas em que Corelli reuniu e regeu 13 orquestras de vários tamanhos na execução do que, aparentemente, eram suas próprias composições. Há, além disso, evidências consideráveis de que, pelo menos, a partir de 1689, Corelli contribuiu com sinfonias incidentais para várias obras vocais de outros compositores.

Em 1713, Corelli faleceu em Roma, deixando um legado musical que inclui, além de um modelo orquestral a ser seguido por toda a Europa, princípios de uma nova escola de violino com discípulos como Valentini, Castruci e o mais famoso deles, Francesco Geminiani. Seu legado inclui, ainda, 48 trio-sonatas, 12 sonatas para violino e baixo contínuo e 12 concertos grossos editados em seis opus. Essa obra serviu como modelo para diversos músicos e circulou na Europa por gerações, ao longo do século XVIII.

De todas essas obras, uma das mais emblemáticas é o $O p u s \mathrm{~V}$, com as 12 sonatas para violino e baixo contínuo. Segundo Cook (1999, p. 179), “seria difícil pensar em mais apropriado símbolo de relevante trabalho na história da música para violino" "51. Ainda sobre essas sonatas, Paoliello (2017, p. 104) afirma:

Assim, as sonatas de Corelli foram modelo desse gênero no século XVIII, imitadas desde sua disposição até o estilo de cada movimento que compõe a sonata. Vale

\footnotetext{
50 Tradução nossa. Do original: Rome boasted a venerable tradition of instrumental music that dated back to the time of Frescobaldi's sojourn in the city. A later generation of outstanding instrumentalists included the lutenist Lelio Colista, keyboard players Bernardo Pasquini and Alessandro Stradella, and the 7 violinist Carlo Ambrogio Lonati. To Corelli's advantage, Stradella and Lonati left Rome in 1677, Colista died in 1680 and Pasquini turned his attention to the more fashionable vocal genres of opera and oratorio - a field that had been left open by Stradella's departure. There was no dearth of competitors of course, but it was Corelli who ultimately succeeded in gaining the favours of the most munificent patrons. How was it possible, then, for a violinist who had played no major part in the musical life of Bologna to reach the highest echelons of Roman patronage in such a short time? It appears that Corelli put to good use a network of connections from the north-eastern provinces of the Papal State in order first to move to Bologna and subsequently to settle in Rome. Key amongst these connections were the Laderchi and Azzolini families, and the Oratorians of St Philip Neri.
}

51 Tradução nossa. Do original: "It would be hard to think of a more appropriate symbol of the work`s significance in the history of violin music". 
lembrar que os adágios ornamentados pelo compositor representam importante registro da prática de ornamentação livre italiana, podendo ser aplicado a outras composições italianas que, em geral, não trazem as ornamentações escritas e devem ser improvisadas.

Paoliello se refere à terceira edição do Opus V, realizada por Etienne Roger, em Amsterdã, no ano de 1711, que contém seis das 12 sonatas, com um exemplo de ornamentação livre realizada atribuída ao próprio compositor italiano.

No entanto, o modelo corelliano não se resume ao âmbito da sonata para violino e baixo contínuo; já no século XVIII, autores como Mattheson (1713) afirmaram a autoridade dos modelos corellianos para a escrita da trio-sonata, e não há dúvida de que essas obras contribuíram para a consolidação desse gênero como o mais importante na escrita instrumental do séc. XVIII. O mesmo pode ser dito dos concertos grossos do Opus VI, emulados por discípulos como Geminiani e outros autores, incluindo Muffat que os toma como referência italiana.

Conforme vimos, Corelli, o "Orfeu romano," foi consagrado por italianos e estrangeiros de todo século XVIII como autocritas do modelo italiano. No próximo capítulo, nos debruçaremos sobre a prática interpretativa da ornamentação livre, um dos aspectos mais imitados de sua arte, conforme revela o artigo de Zaslaw (1996), para assim desenvolver, a partir deste importante referencial, uma proposta de estudo dos problemas apresentados na introdução. 


\section{ORNAMENTAÇÃO E OS PRINCIPAIS MODELOS E TRATADOS}

Quintiliano afirma: "Portanto, é útil ter primeiramente a quem imitar, caso queiras depois superá-lo: assim, aos poucos, haverá esperança de chegar a pontos mais altos” (op. cit., I ii, p. 29). O mesmo orador latino diz, em outra passagem: "Com efeito, que pintor aprendeu a esboçar tudo o que existe na natureza das coisas? No entanto, uma vez assimilada a técnica da imitação, copiará o que quer que tenha visto. Existe algum não oleiro que tenha feito algum vaso de certo modelo que nunca tivesse visto?” (idem, VII x, p.9).

O autor da Instituição Oratória (Institutio oratória) indiretamente nos diz sobre a importância da proposta tripartite de aprendizado apresentada em poéticas musicais ou literárias setecentistas, de matriz retórica: preceito, exemplo, imitação, como vimos também no capítulo 2.1 sobre gosto, mais especificamente no princípio do gosto adquirido. Assim, para chegarmos à imitação de forma satisfatória (um modelo de ornamentação didaticamente orientada), devemos nos munir dos preceitos (dos tratados) e observar os bons exemplos (diversos modelos de ornamentação encontrados). Dessa forma, este capítulo pretende levantar os principais tratados e modelos sobre ornamentação livre encontrados ao longo da pesquisa e selecionar alguns preceitos considerados relevantes para a confecção de uma imitação didática da prática de ornamentação livre.

\subsection{OS PRINCIPAIS TRATADOS LEVANTADOS}

Na Itália, exemplos modelares de ornamentação estão disponíveis, pelo menos, desde o surgimento do Codex Faenza (séc. XV), que inclui obras para teclado, acompanhadas de elaboradas diminuições. Nos séculos XVI e XVII, modelos para a decoratio musical são fornecidos por autores como Dalla Casa (1584), Taeggio (1620), Zacconi (1596), Bassano (1585), Ortiz (1553), entre outros (NEUMANN, 1983). No século XVIII, o assunto foi abordado detalhadamente em tratados, dentre as quais se destacam o método de flauta de Johann Joachim Quantz (1752), assim como parte substancial da extensa obra teórica dos violinistas Francesco Geminiani (1687-1762), Giuseppe Tartini (1692-1770) e Leopold Mozart (17191787). A predominância de informações sobre ornamentação em obras dedicadas ao violino parece indicar que a ornamentação era assunto especialmente relevante para a prática deste instrumento, italiano por excelência. 
Já no século XVIII, o livro de Johann Joachim Quantz devota um capítulo inteiro à ornamentação italiana. A relevância deste capítulo foi tal, que ele mereceu uma publicação específica na Inglaterra (John Welcker, 1780). O texto consiste de uma discussão teórica, que apresenta regras de decoro para a ornamentação livre, acompanhadas de exemplos para seu emprego em diferentes passagens e cadências, utilizando o modelo de seus predecessores dos séculos XVI e XVII.

Nesse mesmo capitulo o autor afirma que "Quase ninguém que se dedica a aprender a música, especialmente fora da França, contenta-se apenas com a execução dos ornamentos básicos; ao contrário, a maioria delas sente um desejo que lhes incita a fazer improvisações ou ornamentações livres. “(Quantz ,1754,Versuch einer Anweisung die Flöte traversiere zu spielen. Cap13 §2., p.70 tradução Roberto Dorigatti)

Além do capitulo 13 sobre a ornamentação livre, há um capítulo dedicado aos ornamentos franceses, bem como um inteiro dedicado à arte de se tocar o adágio, capítulo 14 e, por fim, no capítulo 15 entra em um novo ramo da improvisação, a cadência. (recentemente o pesquisador Roberto Dorigatti traduziu para o português quase todos esses capítulos).

Do ponto de vista da ornamentação e da música de câmara (trio-sonata), o foco desta dissertação, o tratado de Quantz, ganha uma dimensão ainda mais valiosa, sobretudo no trecho que o compositor diz sobre cadências duplas. Embora as cadências e a ornamentação livre guardem algumas diferenças essenciais, as cadências são ornadas sobre pausa ou uma nota sustentada pelo baixo e se tornam uma variatio mais ousada do que a ornamentação livre que simplesmente se coloca sobre a melodia escrita pelo compositor inserida em uma textura que muitas vezes pode ser contrapontística e exigem um uso mais cauteloso, suas recomendações podem ser aplicáveis ao ornato que as originou desde que respeitados suas limitações. Os preceitos de Quantz sobre cadências podem ser judiciosamente acolhidos em texturas homofônicas ou em que os solistas se encontrem em confronto dentro das trio-sonatas, principalmente em trechos em que o baixo ( ou a terceira voz) se encontra em pausa, em nota suspensa ou em um ostinato que não inviabilize o uso dos ornatos de diminuição (conforme poderá ser verificado nos modelos sugeridos por Telemann em seus trietti).

Essa relação entre as cadências e a ornamentação livre na preceptiva do tratadista alemão é tão profunda que ele cita, no capítulo sobre cadência, as ornamentações propostas por Corelli na terceira edição do Opus V: 
alguns anos antes do final do século passado, e nos dez primeiros anos do atual, faziase ao final de uma voz concertante uma pequena passagem, anexada a um bom trinado, sobre o baixo contínuo. (ibidem, cap. 15 §2. pag.130 tradução Dorigatti)

Nas recomendações (tanto para as cadências, principalmente as duplas, como para a ornamentação livre), Quantz enfatiza a necessidade de um conhecimento de regras de contraponto e harmonia (matérias comumente encontradas nas ementas dos cursos de bacharelado no Brasil):

As cadências a duas vozes não são tão livres como as de uma voz. As regras da composição têm sobre aquelas a duas vozes uma influência ainda maior: consequentemente, aqueles que querem lidar com este tipo de cadências, devem, no mínimo, compreender a preparação e a resolução das dissonâncias, e as leis da imitação, caso contrário, será impossível criar algo engenhoso. (ibidem cap. 15 §19 p. 136 tradução Roberto Dorigatti)

$\mathrm{Na}$ impossibilidade desse domínio o autor recomenda um ensaio específico para os ornatos: "Entre os cantores ${ }^{52}$, a maioria dessas mesmas cadências são estudadas com antecedência, e decoradas: uma vez que é uma grande raridade reunir dois cantores juntos, que entendem algo de harmonia ou de composição"(ibidem, p. 136)

Dois capitulos antes, Quantz já recomenda o estudo do baixo continuo, para o domínio da arte da ornamentação livre, mesmo para a ornamentação de sonatas solo por cantores e instrumentistas:

\begin{abstract}
Esse desejo não deve ser reprimido[o de fazer improvisações ou ornamentações livres em melodias italianas], porém, ele não pode ser alcançado sem que se entenda a composição ou, ao menos, o baixo contínuo. Já que à maioria lhes falta esta instrução, então isto progride muito lentamente, fazendo com que surjam muitas ideias equivocadas e inadequadas, de modo que às vezes seria melhor tocar a melodia como o compositor a escreveu, que, muitas vezes, estragá-la com essas ornamentações ruins. (ibidem, pag.70)
\end{abstract}

Ao longo desses capítulos Quantz demonstra uma valiosa tabela, figura 3, com casos de texturas a duas vozes que podem ser ornadas, os casos dessas tabela reaparecem em sua obra com variadas propostas de ornamentação, exemplo na figura 4 e são organizadas por relação intervalar entre as notas da melodia da versão não ornada (esqueleto) a exemplo dos tratadistas dos séculos XVI e XVII.

${ }^{52}$ Quantz ao final do parágrafo afirma não ser exclusividade dos cantores de seu tempo e ciclo o desconhecimento de composição e harmonia: "Encontram-se entre os instrumentistas ainda alguns aos quais não lhes falta este conhecimento sobre composição."( ibidem, p.136) 
De uma forma geral, os casos expostos por Quantz, são de cadências harmônicas escritas em homofonia da melodia não ornada com o baixo, e no final há vários exemplos com suspensão (quarta espécie), além disso o autor afirma não ser sua intenção limitar suas recomendações de ornamentação a esses casos, o que numa investigação mais ampla nos leva a concluir que a escolha destes casos foi fundamentalmente harmônica e em função das diferentes cadências harmônicas, e não tanto pelo contraponto. Por exemplo, no próprio modelo do opus $\mathrm{V}$ de Corelli como nas sonatas acadêmicas e nos trietti de Telemann há várias passagens com texturas contrapontísticas não comtempladas pela tabela de Quantz. (o que exige uma análise mais detalhada de cada caso de textura de adágios e melodias italianas que não se enquadrem na tabela). 
Figura 3: Tabela de casos abordados por Quantz.

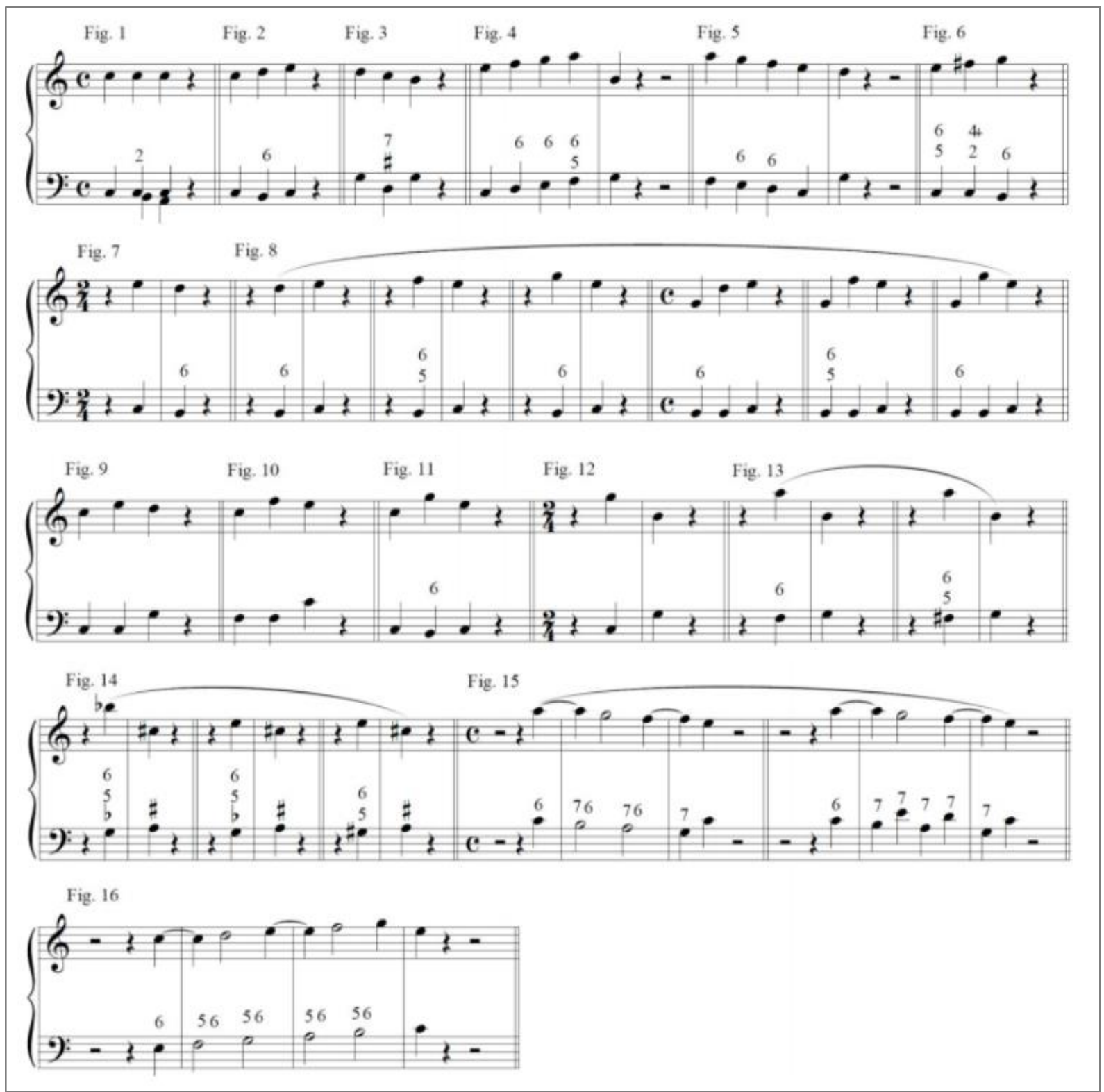

Fonte: Quantz, op. Cit. P. 71 edição: Roberto Dorigatti, 2019 
Figura 4: Exemplo de ornamentações propostas por Quantz para um dos casos da tabela acima:

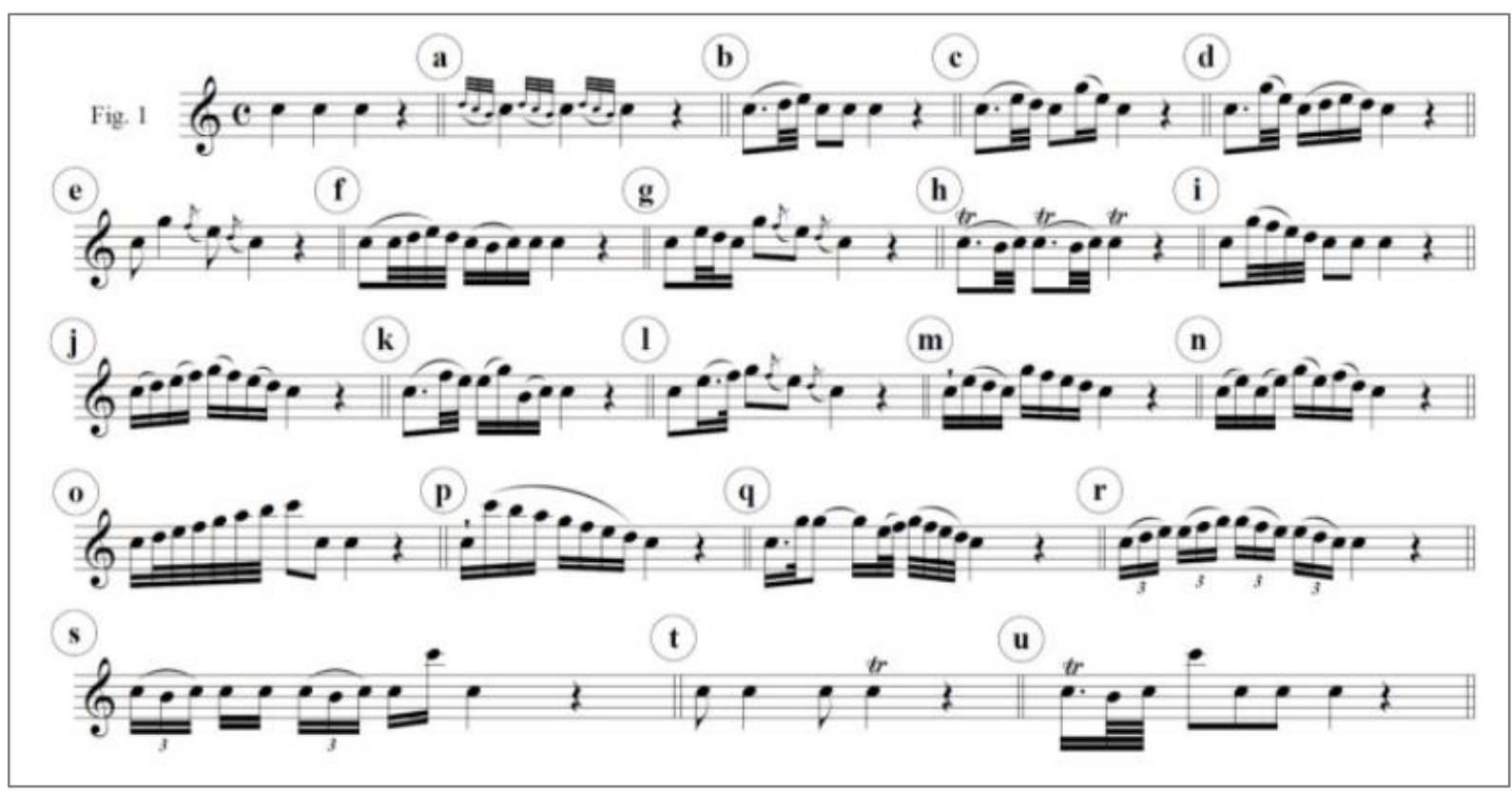

Fonte: Quantz, op. Cit. P. 75 edição: Roberto Dorigatti, 2019

O autor alerta para importância de se ter o decoro em mente, mediando as paixões (matéria) com a escrita (forma):

Os tipos de peças lentas diferem entre si. Alguns são muito lentos e melancólicos, outros, no entanto, um pouco mais alegres e por isso mais aprazíveis e agradáveis. A tonalidade na qual ela foi composta contribui muito para ambos os tipos. Lá menor, Dó menor, Mib146 maior e fá menor expressam muito mais o afeto melancólico que outros tons menores, é por esse motivo também que os compositores tratam de utilizar tais tonalidades, geralmente com essa intenção. Em contrapartida, as tonalidades maiores e menores restantes serão utilizadas para as peças aprazíveis, cantábiles e ariosas ( ibidem,cap. 14 §6.p.101 tradução Dorigatti)

Continuando nessas recomendações, o autor recomenda ao interpréte decoroso não se perder na monotonia e evitar mais do que três repetições seguidas de um determinado desenho musical, de forma a direcionar sua interpretação sempre no caminho da variedade.

No capítulo 16 sobre cadências, e mais especificamente no trecho onde ele aborda as cadências duplas o autor cita o uso de ornamentação em terças ou sextas, o que também pode ser verificado com muita frequência nos 3 modelos de adágios de trio-sonata propostos por Telemann em seus trietti: "Aqueles que não conhecem muito de harmonia contornam isso, na maioria das vezes, meramente com passagens em terças ou em sextas. Contudo, isso não é o bastante para causar admiração aos ouvintes”.(ibidem, Cap. 15 §21.p.137 tradução Roberto Dorigatti) 
Figura 5: trecho composto em terças e ornado em homofonia por Telemann

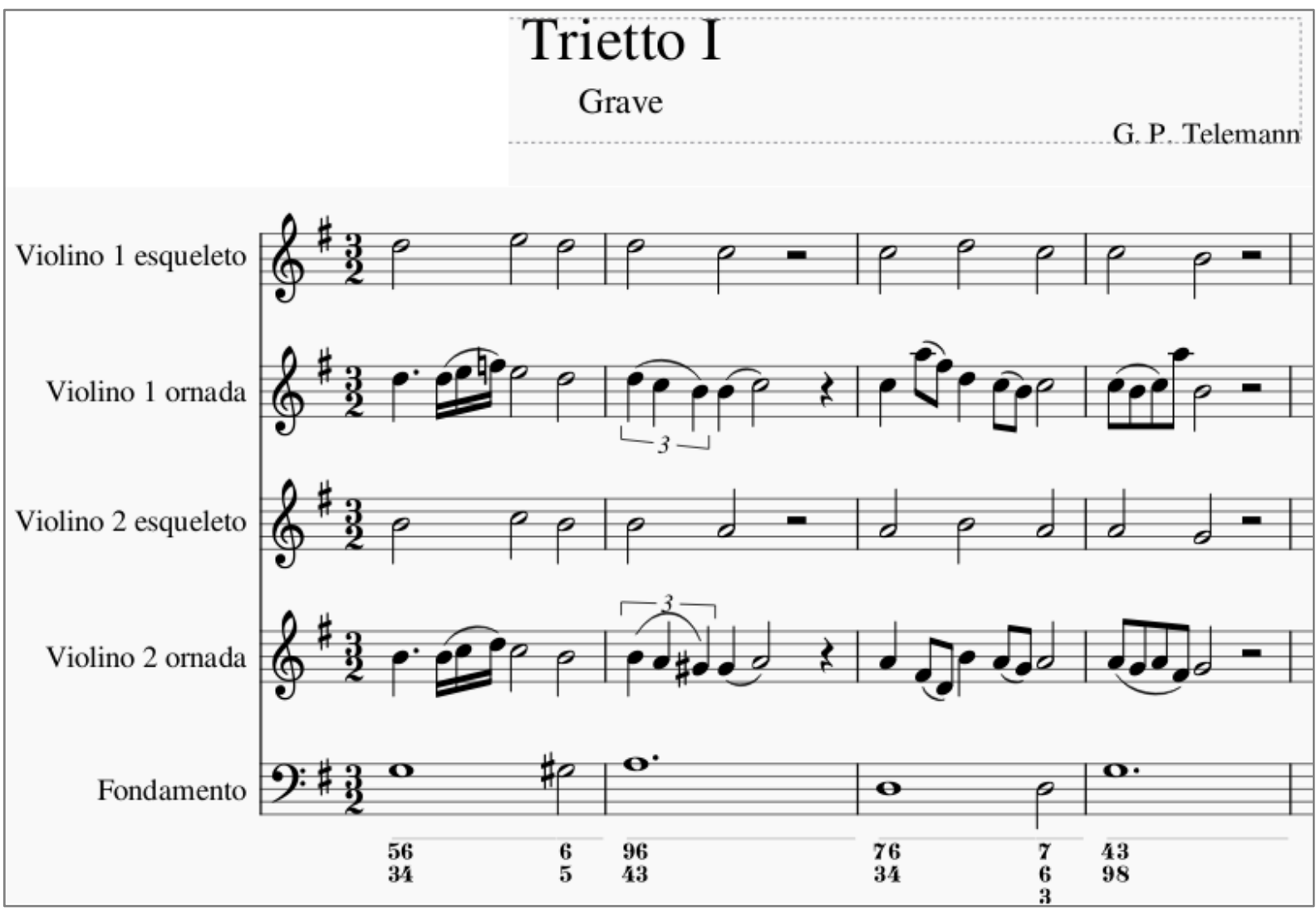

Fonte: Telemann, Trietti Metodichi, Trietto 1. Edição e recorte nosso.

Outro caminho bastante enfatizado pelo tratadista é o da imitação contrapontística:" Além das terças e sextas, que juntas caminham em movimento regular, as cadências a duas vozes são formadas principalmente por imitações, que uma voz apresenta, e a outra imita." (ibidem, Cap. 15 §22.p.137 tradução Roberto Dorigatti)Esse mesmo caminho também pode ser verificado com frequência nos trietti de Telemann: 
Figura 6: Trecho em cânone na versão esqueleto com ornatos em imitação

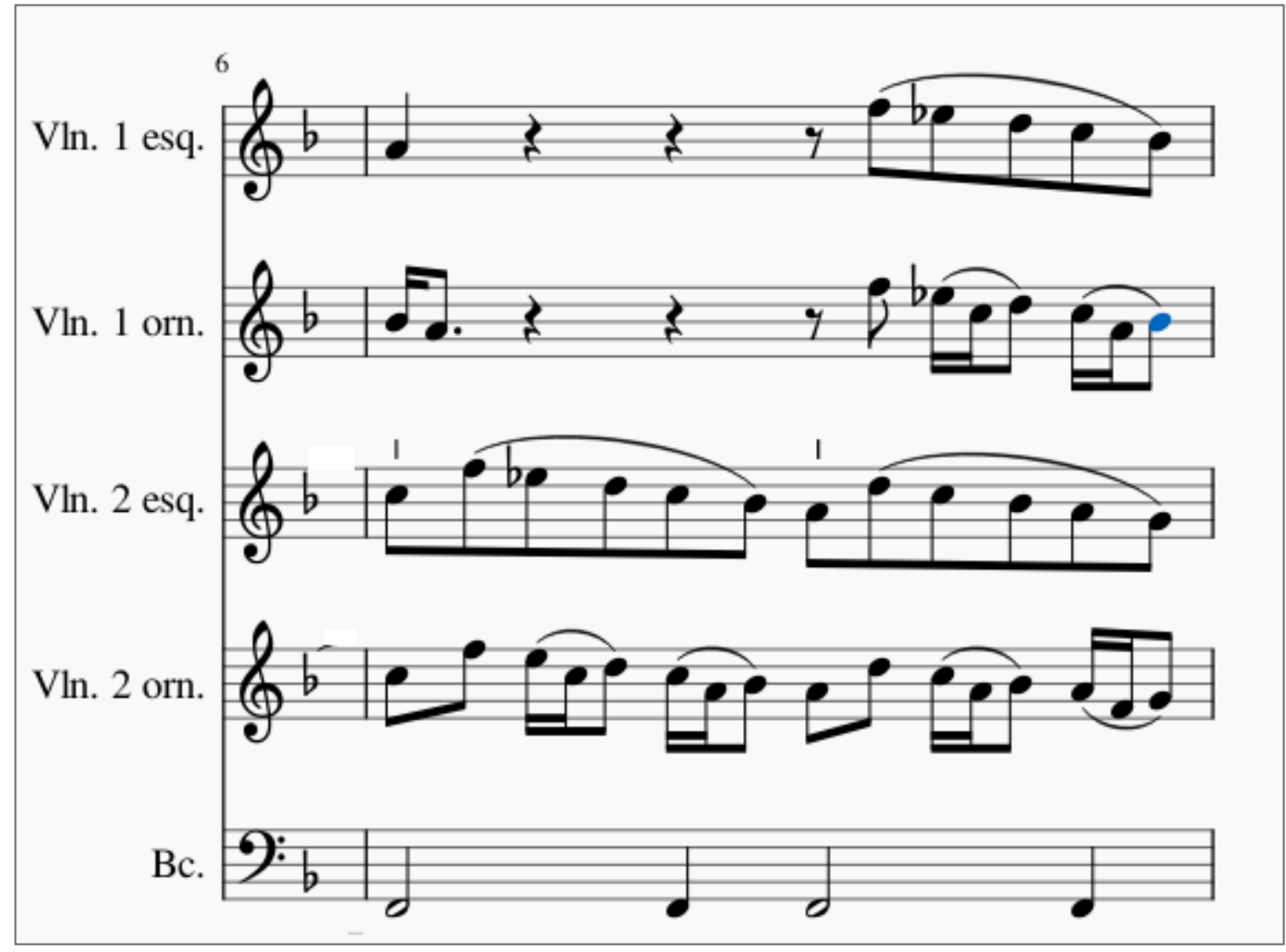

Fonte: Telemann, Trietti metodichi, Trietto III, edição e recorte nosso

Conforme vimos na tabela acima, figura 6, trechos musicais com textura em quarta espécie (suspensões) são bastante abordados no capítulo 13. Esse tipo de textura também é citada por Quantz em diversas passagens do trecho sobre cadencias duplas no capitulo 15:" Nestas imitações, as suspensões são de suma importância [...]Agora, caso duas pessoas tenham interiorizado esses regras, então elas podem, sem que tenham combinado antes, e sem exceder as regras da composição, caminhar de uma dissonância à outra.” (ibidem, Cap. 15 §23.p.137 tradução Dorigatti)

Outros valiosos preceitos de Quantz, também aplicáveis a ornamentação em trio-sonatas se encontra a respeito do decoro entre os músicos das vozes solísticas:

A primeira voz, que normalmente comanda a execução, não deve somente dar à segunda voz a oportunidade de responder, e depois esperar por ela; mas deve também, frequentemente, saber escolher um tal intervalo, sob a resposta da segunda voz, que permita uma nova suspensão; para que as suspensões não saiam todas iguais. (ibidem, Cap. 15 §26.p.139 tradução Roberto Dorigatti)

Quantz também faz recomendações específicas a segunda voz: 
[...]é normalmente responsabilidade da primeira voz, que em geral inicia a proposta, conduzir os trechos de tal modo que a segunda voz consiga imitar, tanto no que diz respeito à clareza, quanto também à tessitura, em particular. Caso a primeira voz nada entenda das regras requeridas aqui, a segunda voz também nada poderá ajudar com o seu conhecimento. Aquele que faz a segunda voz deve apenas procurar, tanto quanto possível, seguir a primeira em terça ou em sextas, e evitar as dissonâncias, pois ouvir dissonâncias sem resolução provoca uma sensação muito desagradável. (ibidem, Cap. 15 §28.p.141 tradução Roberto Dorigatti)

Outro caso bastante recorrente em trio-sonatas e que Quantz faz recomendações de como compor em conjunto e de forma improvisada nas cadencias é o das cadencias frígias:

Falta ainda considerar a meia-cadência [cadências frígias], em que a voz superior é suspensa com a voz fundamental por meio da sétima maior, e através da sexta, resolvida na oitava. Essa meia-cadência surge no meio ou no final de uma peça lenta em tonalidade menor. [...] Elas foram usadas à exaustão nos tempos passados, especialmente na música sacra, até se tornarem enfadonhas. Por essa razão, quase saíram de moda. Porém, elas ainda podem causar uma boa sensação nos tempos de hoje, quando utilizadas de modo escasso e em seu devido lugar. (ibidem, Cap. 15 §32.p.145 tradução Roberto Dorigatti)

A recomendação de Quantz do uso dessas cadências frígias como recurso no contexto das cadencias duplas é uma evidência da necessidade de, quando o interprete se deparar com uma cadencia frigia escrita, toca-las buscando um caráter improvisatório, no mínimo emulado nas notas escritas se ele não variar as notas, e mais ainda, uma evidência de que nelas reside uma boa oportunidade de ornamentação. Na Figura 7, temos um modelo proposto por Telemann em cima de uma cadencia frígia no seu segundo trietto e na figura 8 , um trecho do seu terceiro trietto em meia cadencia tetracordal interrompida. Ambos os casos demonstram uma distribuição de ornamentos entre as vozes da trio-sonata. 
Figura 7: Trecho em cadência frígia no segundo Trietto de Telemann.

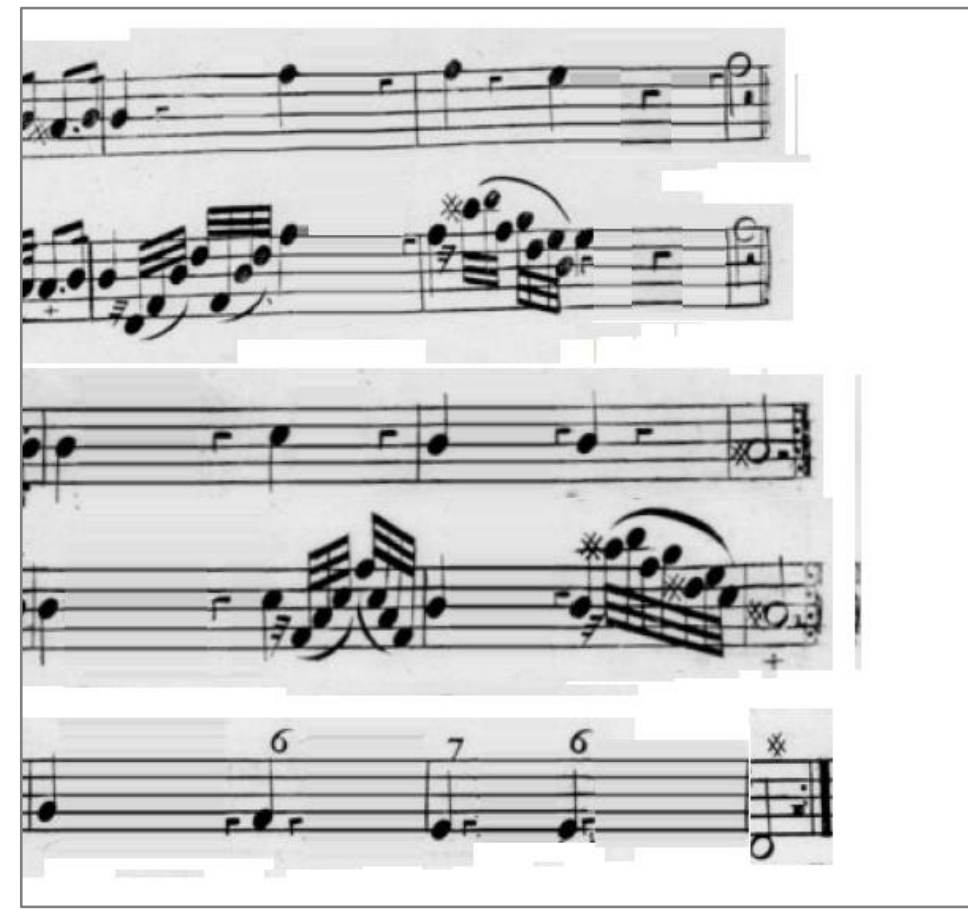

Fonte: Le Clerc 1737

Figura 8: Cadência improvisada em baixo tetracordal proposta por Telemann no largo de seu terceiro Trietto

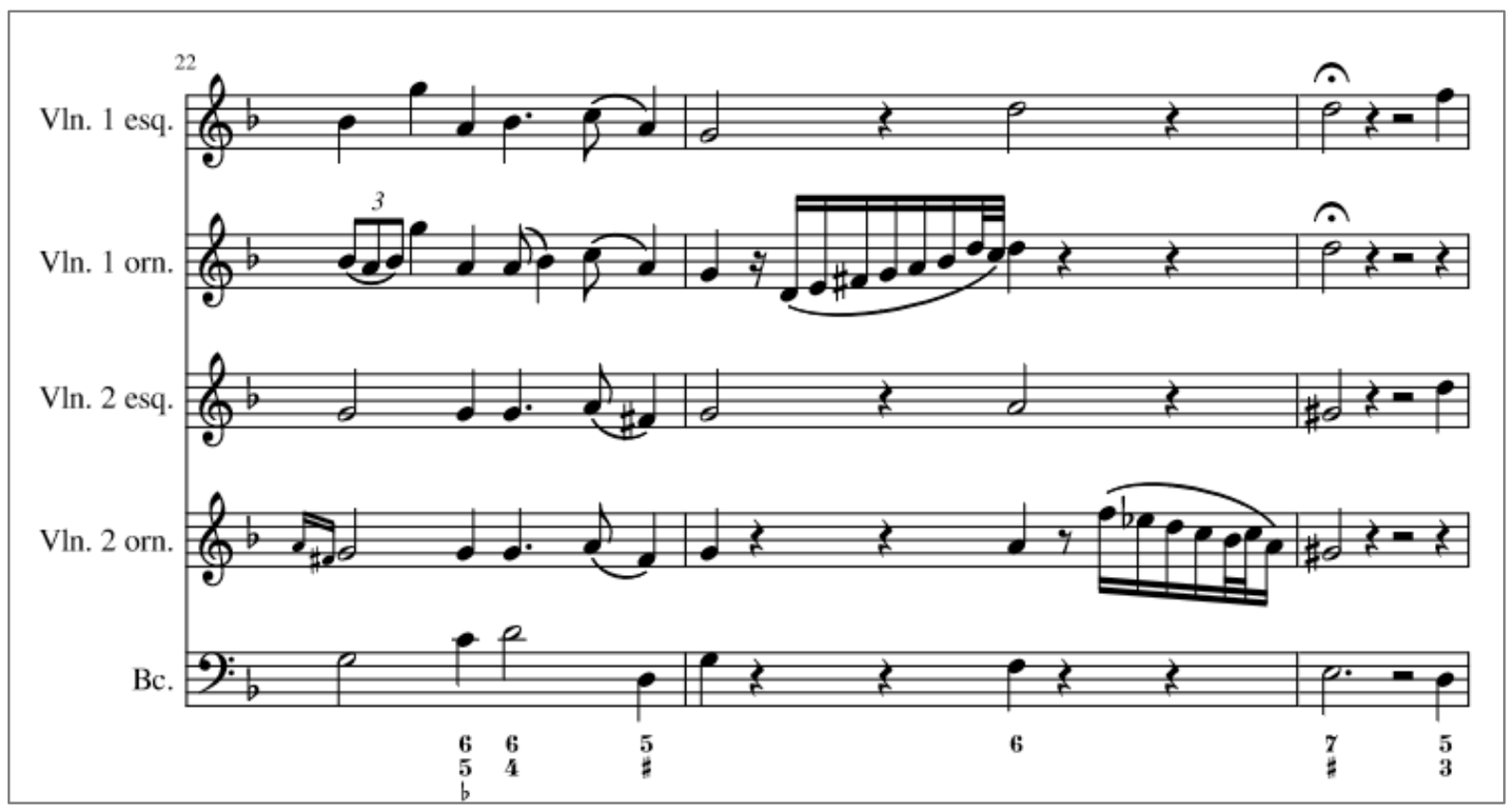

Fonte: Le Clerc 1737. Edição e recorte nosso.

Quantz afirma nesse capítulo que "Nos exemplos adicionados aqui, a maioria dos trechos é feita de modo que uma voz possa imitar a outra sem que tenha sido combinado antes." ( ibidem, p. 137) e sobre as recomendações para as cadencias duplas, um contexto de 
improvisação em conjunto muito mais complexo que o da ornamentação livre (já que a construção de uma cadência envolve mais do que as virtudes elocutivas), o flautista e tratadista deixa uma importante lição para os cameristas aspirantes à arte da ornamentação livre judiciosa:

\begin{abstract}
Embora seja muito fácil inventar as cadências duplas, e escrevê-las no papel; é muito difícil fazê-las sem combinação prévia, já que ninguém pode adivinhar os pensamentos do outro. Contudo, caso se tenha interiorizado um pouco dos proveitos que as imitações e o uso das dissonâncias dão em nossas mãos; desta forma será fácil superar essa dificuldade. A improvisação súbita das cadências é aqui o meu principal interesse. Quero, portanto, adicionar alguns exemplos como modelo, que devem ser considerados um esboço em que serão dadas as diferentes maneiras de imitação, bem como a preparação e resolução das dissonâncias que devem servir a isto aqui. Os ornamentos, todavia, que fluem da força inventiva, e não podem ser restringidos em alguns poucos exemplos, entrego ao gosto pessoal e à invenção de cada um. (ibidem, Cap. 15 §22.p.137 tradução Roberto Dorigatti)
\end{abstract}

Segundo o que podemos observar em Quantz, a construção de uma ornamentação em conjunto se revela algo desafiador, porém possível de ser atingido. Indicando, talvez, uma necessidade de se combinar (ensaiar), como qualquer outro critério do bom gosto.

Já em Leopold Mozart observamos um modelo semelhante ao de Quantz em seu tratado de violino (1756). Nele, três capítulos abordam o tema da ornamentação, dos quais pelo menos um contém uma importante discussão sobre a composição dos ornamentos livres; ele apresenta, ainda, alguns modelos de ornamentação em diferentes cadências, entretanto ao contrário do flautista tratadista, Mozart advoga que "Todos esses ornamentos são empregados, porém, apenas ao tocar um solo e, portanto, moderadamente, no momento certo, e somente para [proporcionar] variedade em passagens similares e frequentemente repetidas. ${ }^{53}$ " (Mozart, 1995[1756], p.214).

Porém, além de Leopold Mozart não estar alinhado com os modelos de ornamentação que veremos em breve, nem com outros tratadistas é importante ter em mente três aspectos, um deles é para quem Leopold direcionou sua publicação, - provavelmente intérpretes desprovidos de conhecimentos de composição, contraponto e/ou baixo continuo que, ao se aventurarem em ornar texturas contrapontísticas, não teriam um bom gosto, o que não comprova sua inviabilidade e apenas enfatiza uma dificuldade. $\mathrm{O}$ segundo aspecto a se observar é o próprio fato da prática estar sendo citada em seu tratado, mesmo do ponto de vista negativo, o que indica uma evidência de sua existência como prática de contemporâneos, quer ele goste ou não, e, por fim, a mais importante e valiosa reflexão de sua advertência, o bom gosto se encontra

\footnotetext{
${ }^{53}$ Tradução nossa do original: All these decorations are used, however, only when playing a solo, and then very sparingly, at the right time, and only for variety in often-repeated and similar passages.
} 
calcado no correto julgamento do material (escrita, textura, gênero, paixão a ser representada e etc...) e em uma escolha adequada dos parâmetros elocutivos. Desta forma, um bom intérprete de trio-sonatas tem o dever de analisar toda a obra e procurar de forma judiciosa separar escrita livre da estrita, trechos onde a textura inviabiliza o uso de ornamentação livre e outros que ela praticamente exige, saber quando sua voz se encontra na posição de dono da melodia ( se houver melodia) e quando está acompanhando e etc.. o que uma reflexão mais cuidadosa da afirmação de Mozart revela que ela está atrelada aos casos que realmente há uma impossibilidade de ornamentação livre (seja em sonata solo ou trio). Como pode ser observado em movimentos fugais e ou com contraponto muito carregado (o que, ainda assim, alguns mestres como Telemann, Tartini e Veracini desafiam em alguns dos próprios modelos de ornamentação). Além disso, a afirmação de Leopold Mozart sugere estar mais direcionada a um músico de orquestra, do que a um camerista, a um solista de uma sinfonia concertante ou a um músico do concertino de um concerto grosso. "[...]Em particular, nos protegemos contra todos os

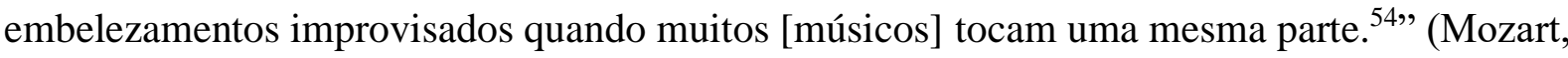
1995[1756], p.214)

Carl Philip Emanuel Bach já no primeiro volume do seu ensaio sobre a maneira correta de tocar teclado $(2010[1753,1756])$ dedica um capítulo de 59 páginas ao assunto da ornamentação, subdividido em nove partes. Sete delas são dedicadas, uma a uma, a um tipo diferente de ornamento essencial como a apojatura, os grupetos, os trinados, os mordentes e etc... um deles ao uso geral de ornamento e o último, assim como Quantz fez, dedicado às cadencias, as quais Bach denomina como ornamentação de fermatas.

Embora em seu tratado não haja recomendações tão ricamente detalhadas às cadências duplas, como em Quantz, ou à ornamentação em trio-sonatas, um aspecto bastante valioso, do ponto de vista da música de câmara, de seu tratado se revela nas recomendações aos baixocontinuístas. Fazendo um contraponto, enquanto Quantz geralmente direciona seu texto aos músicos solistas, C.P.E. Bach comtempla a outra parte, direcionando a parte de ornamentação de seu ensaio ao baixo continuo, conforme poderemos ver na seguinte passagem:

Em uma peça a mais de duas vozes, quando o baixo tem pausa na entrada da cadência
ornamentada, o acompanhador toca, no fim da cadência, a tríade sobre a dominante,
independentemente de essa cadência terminar com um trinado longo, ou sem este mas
com outra figura, ou com um pianíssimo. Em seguida, o baixo contínua em pausa, se
há outras pausas seguintes. (Bach,2010 [1753], p.383 tradução Fernando Cazarini)

\footnotetext{
${ }^{54}$ Tradução nossa do original: [...] in particular, guard against all improvised embellishments when several play from one part.
} 
Em outra recomendação Bach fala sobre o dever de se retomar o andamento no baixocontinuo:

Depois de uma cadência ornamentada, ou também depois de uma cadência que é apenas prolongada por um trinado longo [ou fioritura], quando o baixo deve ser tocado imediatamente após a cadência, isso deve ocorrer com muita firmeza e com uma retomada segura do andamento, tão logo se observe que o trinado na voz principal já foi prolongado suficientemente e que, se continuar, poderá enfraquecer. (ibidem, p.383)

Ainda sobre responsabilidades ativas do continuísta e dos solistas, Bach recomenda, para ambos, o seguinte, nos casos em que uma ornamentação esperada em uma voz principal não ocorrer:

As vezes falta disposição ao executante da voz principal para ornamentar a cadência, apesar da indicação de uma fermata sobre o baixo. Neste caso, o solista costuma informar seus acompanhantes através de um movimento da cabeça ou do corpo. Quando o acompanhador percebe isso, deve substituir o baixo longo e sustentado por uma sequiência de notas curtas, semelhantes às precendentes, para manter a ordem e para que os outros executantes percebam claramente que se dá continuidade ao andamento sem interrupção (figura 9) ( ibidem, p.384)

Figura 9: Cadência ornamenável pela voz principal e solução proposta para o caso de não ocorrer o improviso

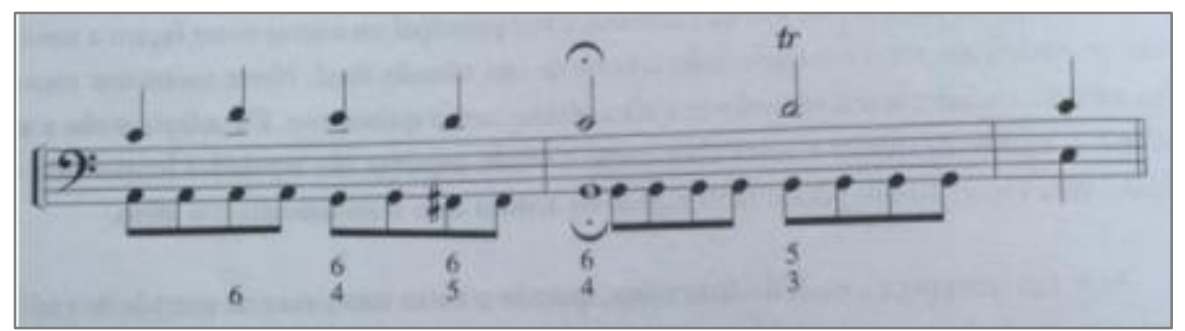

Fonte: Bach. Op.cit p. 384

Um outro princípio observado em seu tratado, coerente com outras fontes primárias, está no equilíbrio entre os ornamentos nas vozes.

No exemplo da figura [10], em que a cifragem não leva em conta o prolongamento da cadencia sobre o baixo, o acompanhador não toca a progressão indicada, mas realiza sobre o sol em vez de 4,3,6/5,5/355, logo que percebe que a voz principal se prolongará na cadencia, com ou sem ornamentação. Todos os casos semelhantes deveriam ser realizados desta maneira, independentemente de suas cifragens. (Bach,2010 [1753], p.387 tradução Cazarini)

\footnotetext{
${ }^{55}$ No baixo continuo essa cifragem se refere a uma suspensão de quarta ( em relação à nota do baixo, nesse caso em que o baixo esta em sol seria um dó), ou seja ao invés do continuísta tocar no ultimo tempo em colcheia 2 acordes ( o primeiro, sol, dó e ré e o segundo, sol, si e ré) a recomendação é que se toque apenas o acorde de sol maior ( Sol, si e ré) no tempo inteiro de forma a permitir que a voz solista improvise livremente sobre a harmonia, tanto em notas como no tempo.
} 
Figura 10: Exemplo de cadência harmônica proposto por C.P.E. Bach

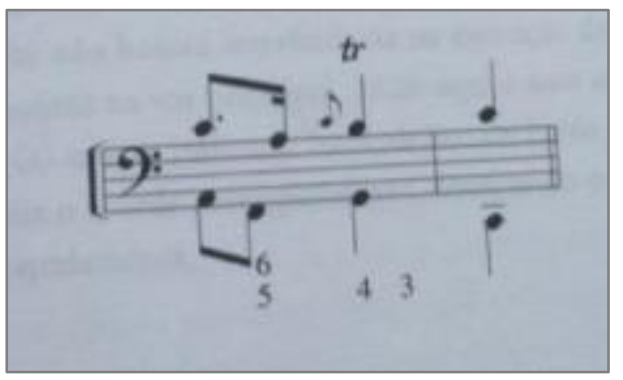

Fonte: Bach. Op.cit p. 387

\section{O exemplo acima diz respeito à harmonização (menos acordes ao perceber mais} ornamentos), mas este conceito de equilíbrio é facilmente aplicável tanto ao fondamento do continuo $^{56}$, como a outra voz que não esteja ornamentando naquele momento. Ainda sobre ele é bastante valiosa a seguinte recomendação:

Como o acompanhamento tem que esperar a tríade imediatamente junto com sua entrada, é preciso tomar cuidado em cadências que consistem de uma sequência de trinados para evitar que se toque o acorde na entrada de um trinado longo sobre a terça. Esse trinado geralmente é um sinal de que a cadênca ainda não terminou, e se o acompanhador toca a tríade prematuramente, há o perigo de que apareçam muitas notas subseqüentes que não combinam com a tríade. Um executante competente da voz principal fará todo esforço neste caso para executar e concluir sua parte de forma que não se ouçam sons desagradáveis. Contudo, os acompanhadores não deveriam provocar essa restrição. Se um executante, por gosto pessoal, quiser concluir sua cadência com um trinado sobre a terça do baixo [4-3], então o acompanhador deverá tocar sua tríade imediatamente [sem trinar também], devendo ouvir o trinado por um momento para ter certeza de que a cadência será concluída com ele. Alguns executantes da voz principal têm grande satisfação em tocar um trinado longo sobre a quinta [do baixo], fazendo com que o acompanhador entre com sua resolução do acorde de quarta e sexta. Depois disso eles continuam com ornamentações que frequentemente não se harmonizam com a resolução. $\mathrm{O}$ acompanhador deve conterse diante de tamanha ousadia, ficando tranquilo, pois nenhuma crítica justificável pode lhe ser dirigida. Ele não deve contrariar seu condutor, de quem deve ser todo o mérito dessa variação. (ibidem, p. 385)

\section{Bach também cita a cadência frígia (usual na literatura corelliana) e faz uma importante} recomendação ao continuísta da peça:

As meias-cadências [frígias], em que as cifras 7, 6 ou 76 ocorrem sobre a penúltima nota da peça, não ocorrem mais tão frequentemente como costumavam. $\mathrm{O}$ acorde de sétima é sustentado até que ocorra a resolução na voz principal que, geralmente, se dá através de um trinado longo sobre a terça do baixo, depois de ser precedido por alguns ornamentos. O acompanhador então toca imediatamente seu acorde de sexta, sustentao e, quando o andamento é lento, pode arpejá-lo. (figura 11) (ibidem, p. 386)

\footnotetext{
${ }^{56} \mathrm{O}$ baixo continuo é dividido em dois grupos o primeiro chamado de baixo continuo de ornamento se enquadram os instrumentos harmônicos como a teorba, a guitarra, o cravo, o órgão e etc.. o segundo conhecido como fondamento se refere aos instrumentos que sustentam a linha melódica escrita do baixo como o cello, o violone, o contrabaixo e etc...
} 
Figura 11: Exemplo de cifragem em cadência Frígia proposto por Bach.

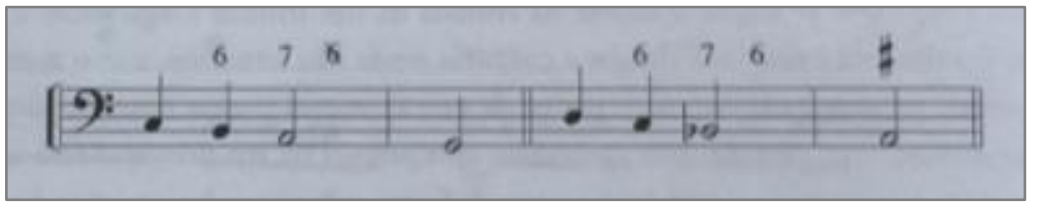

Fonte: Bach. Op.cit p. 386

Ainda em suas recomendações Bach diz ser preferível (mais por costume de seu tempo [aproximadamente 1750]) a voz que tem uma quinta sobre o baixo trinar, nas tonalidades maiores e a voz que tem a sexta por sua vez nas menores. "O trinado com que se termina a cadência ornamentada é executado sobre a quinta do baixo, ou nas tonalidades menores, sobre a sexta, mais por costume do que por necessidade." (ibidem, p.385) Entretanto como ele mesmo enfatiza não é uma necessidade e só deve ser observada (de forma consciente) por interpretes que se aventurem em um repertorio mais tardio.

Giuseppe Tartini devotou mais da metade de seus tratados à questão da ornamentação (NEUMANN, 1983, p 561). Apesar de não ter sido aluno formal de Corelli, Tartini conhecia sua obra (principalmente o Opus V) muito bem e claramente tinha Corelli como mentor; ele foi autor de uma das mais exuberantes versões-modelos de ornamentação dos adágios do Opus $V$, preservada apenas em manuscrito (Zaslaw, 1996). Em sua célebre carta de instruções didáticas a Maddalena Lombardini (1760, com publicação póstuma em 1779), o autor sugere à sua aluna que estude as fugas e os motos perpétuos das sonatas do mesmo opus; em 1758, o violinista francês Jean Marie Leclair editou uma série de 58 variações sobre uma das gavottas do Opus V de Corelli, conhecidas como "L'arte dell'arco", com autoria atribuída a Tartini. Em seu regole per arrivare a saper bem suonar Il violino (1772) e seu Traité des agréments de la musique traduzido para o francês por Pierre Denis (1771), Tartini conduz, de maneira bastante didática, uma discussão sobre decoro de ornamentação livre, bem como sistematiza o estudo desta, com riqueza de exemplos de ornamentação livre em passagens e cadências.

A obra de Geminiani foi recentemente traduzida e comentada pelo pesquisadorviolinista Marcus Held. Um dos assuntos principais é a ornamentação livre, que é discutida sob a égide do bom-gosto. Geminiani foi aluno de Corelli, o que faz supor que represente um dos maiores testemunhos da prática desse grande violinista. Em seu corpus teórico, ele discute pormenorizadamente a prática dos ornamentos, abordando inclusive seus efeitos na comoção do público, o que torna as informações contidas em suas obras únicas em toda a tratadística setecentista (HELD, 2017, p. 23). De sua tratadística, cinco obras se destacam sob esse ponto de vista: o seu A arte de tocar violino (Londres, 1751), A arte do Acompanhamento I e II 
(Londres 1756/57), Regras para tocar com verdadeiro gosto ao violino, traverso, violoncelo e cravo, particularmente o baixo continuo (Londres, 1748) e o Tratado sobre o bom gosto na arte da música (Londres, 1749)

Tanto no tratado sobre bom gosto como no de violino, o autor elenca uma lista de ornatos de expressão e a exemplo de Quitiliano enfatiza a necessidade de se utilizar desses recursos para tornar o discurso musical expressivo com auxílios de todas as quatro virtudes elocutivas, afim de poder se tornar um músico que toca, compõe ou canta de maneira judiciosa.

Held assertivamente sugere uma proximidade da ornamentação contida nos tratados de Geminiani com uma tradição inglesa, que por sua vez, do ponto de vista da ornamentação, está muito atrelada ao gosto francês, com um uso bastante detalhado de sinais de ornamentação.

[...]deve-se ter em mente que essa prática, embora não tão acentuada nas obras de seus compatriotas, era recorrente no século XVIII, sobretudo em países como França, Alemanha e a própria Inglaterra. Nas obras teóricas de Geminiani, em especial, o estilo de ornamentação empregado pelo compositor se relaciona fortemente com a tradição das músicas britânicas e irlandesa. ( Held, 2017, p. 47)

De fato, os longos anos que separam a chegada do compositor a Londres em 1714 e a publicações de seus tratados a partir do final da década de 40 do século XVIII podem ser observados em inúmeras características de suas publicações que evidenciam um gosto inglês que tem em Geminiani um dos principais modelos que por sua vez se emprestou de Playford, Rizzio e outros . Entretanto, uma investigação detalhada de sua tabela de ornamentação constata algumas semelhanças entre suas propostas de ornamentação (mesmo notadas como códigos de ornamentos franceses) e algumas propostas do modelo de ornamentação do Opus V elaboradas por Corelli, e editadas por Roger em 1711, que têm padrões de ornamentos, quando decantados ( ver tabela de ornamentos do opus $V$ desta dissertação), muito parecidos com os das tabelas de Geminiani, principalmente no que diz respeito as combinações da segunda parte da tabela que podem gerar extensas fiorituras. ${ }^{57}$ Conforme podemos notar comparando as figuras $12 \mathrm{e}$ 13.

\footnotetext{
${ }^{57}$ Do Italiano Fioritura, que significa floração ou metáfora de ornamento. É um termo normalmente utilizado para se referir às diminuições, porém no contexto setecentista mais tardio, diferentemente dos ornamentos que eram utilizados nas músicas dos séculos XVI e XVII.
} 
Figura 12: Tabela de Ornamentos proposta por Geminiani

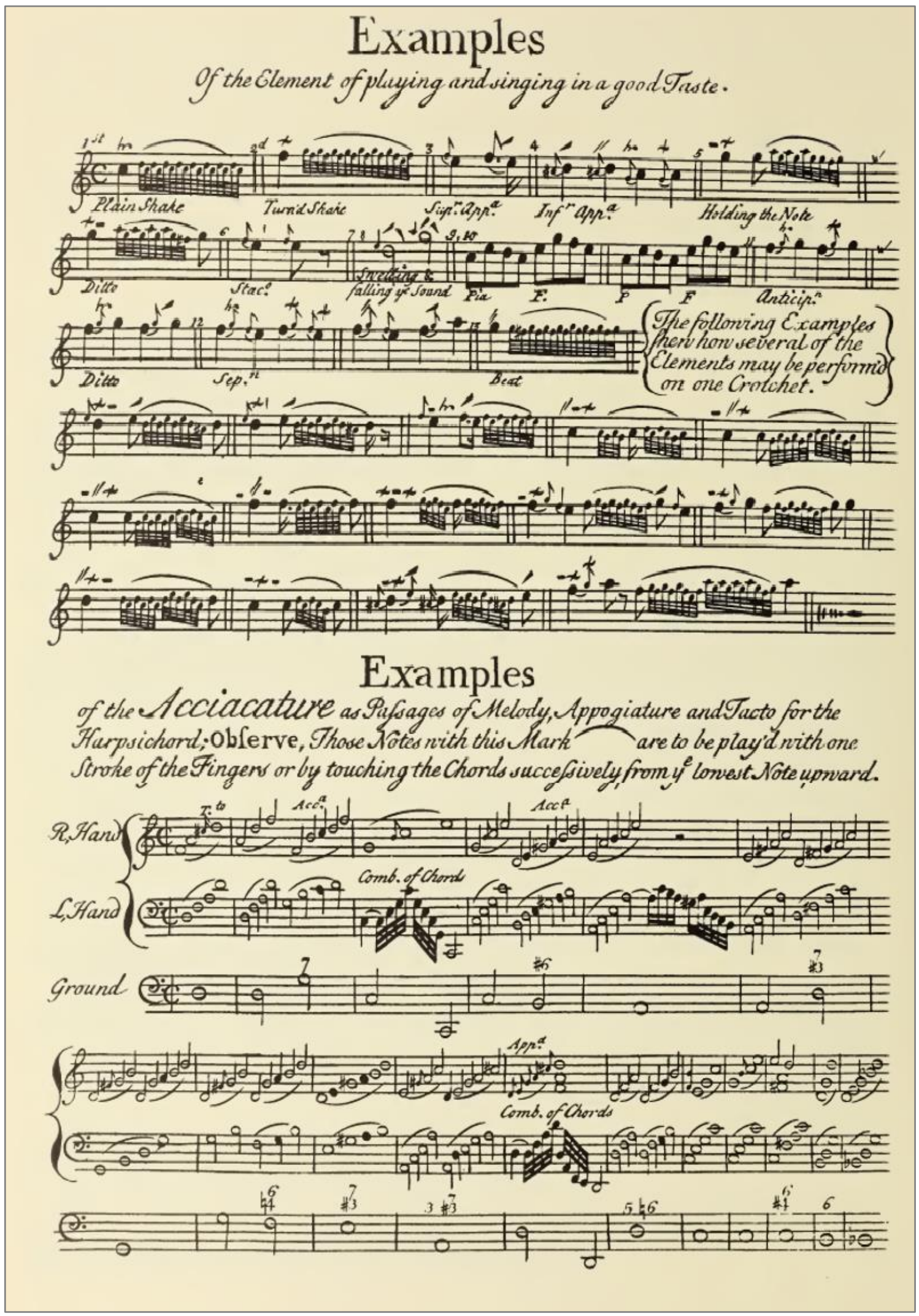

Fonte: Regras para tocar com verdadeiro gosto ao violino, traverso, violoncelo e cravo, particularmente o baixo contínuo (Londres, 1748) 
Figura 13: Primeira página da sonata V da terceira edição do opus V de Corelli

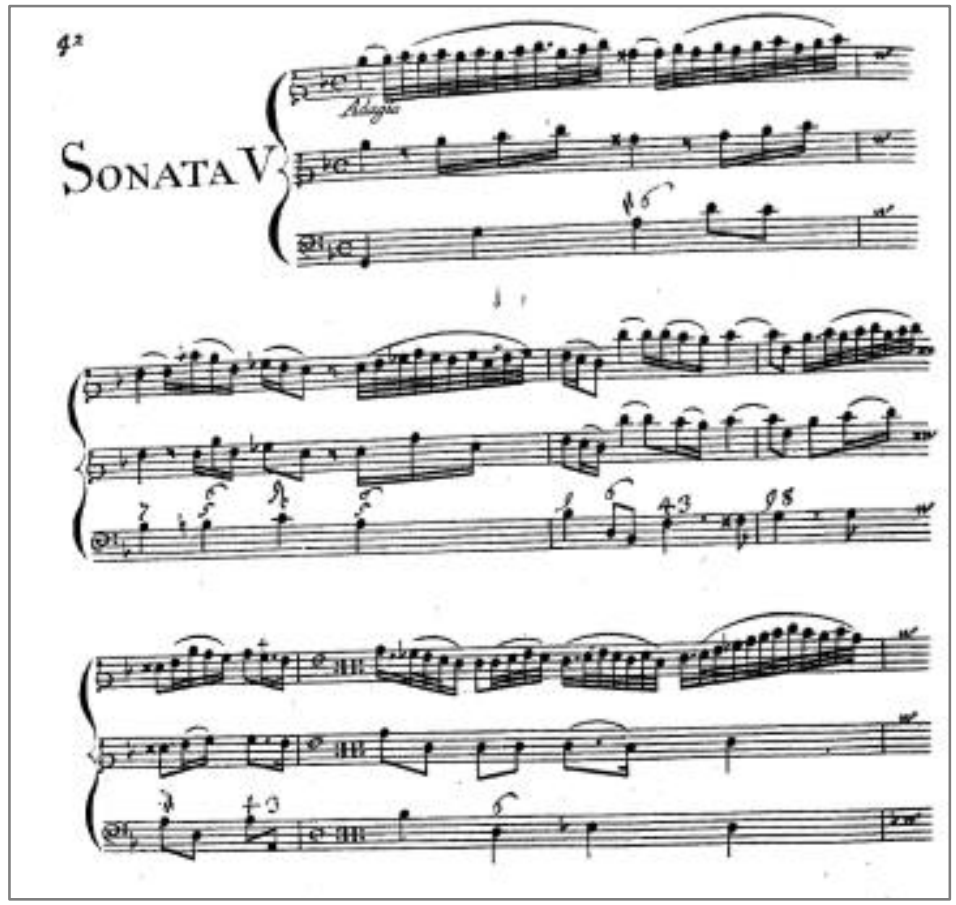

Fonte: Corelli, Opus V, terceira edição

Outros exemplos de fiorituras geminianescas em sua preceptiva se encontram notados explicitamente nas variações sobre as melodias escolhidas no Regras para tocar com verdadeiro gosto (1748) a exemplo da figura 14. 
Figura 14 :Melodia ornada e com uma proposta de acompanhamento por Geminiani

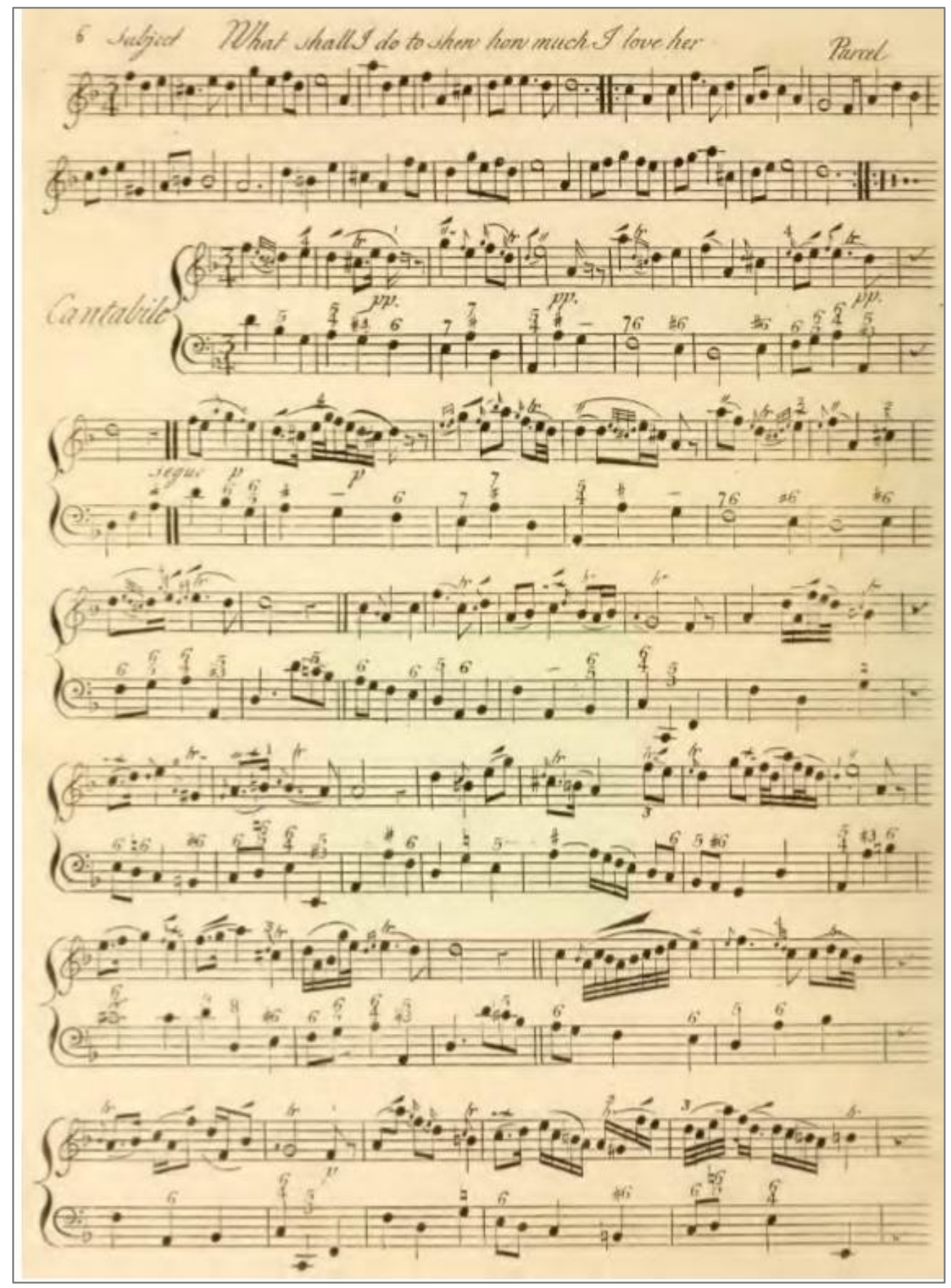

Fonte: Geminiani, Regras para tocar com verdadeiro gosto, p.163

Na obra composta no ano seguinte, Tratado sobre o bom gosto na arte da música (1749) Geminiani se mostra um verdadeiro mestre na arte da variatio musical e na ornamentação de bom gosto. Nessa obra, algumas canções são, não somente, ricamente decoradas com ornatos de expressão como o autor compõe um exuberante acompanhamento para mais de uma voz( 
figura 15) e no final repete a proposta modelar da obra de 1748 desta vez com melodias ornadas em trio-sonatas ( dois violinos e continuo) ao invés de violino e baixo, o que se revela um ótimo modelo de ornamentação ( figura 16) neste contexto:

Figura 15: Canção arranjada por Geminiani segundo os critérios do bom gosto

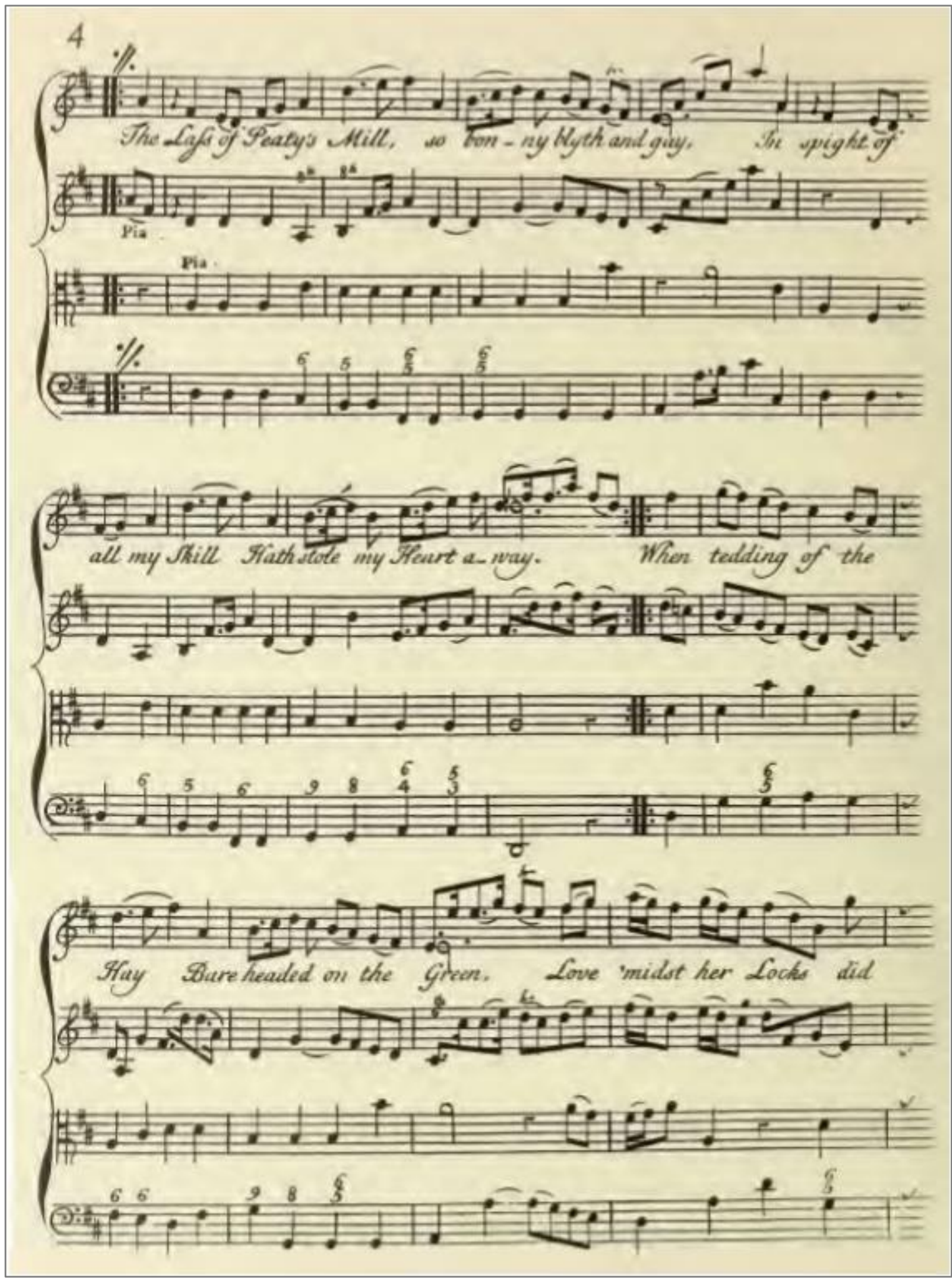

Fonte: Geminiani, Tratado sobre o bom gosto na arte da música p.200 
Figura 16: Melodia arranjada em trio-sonata por Geminiani

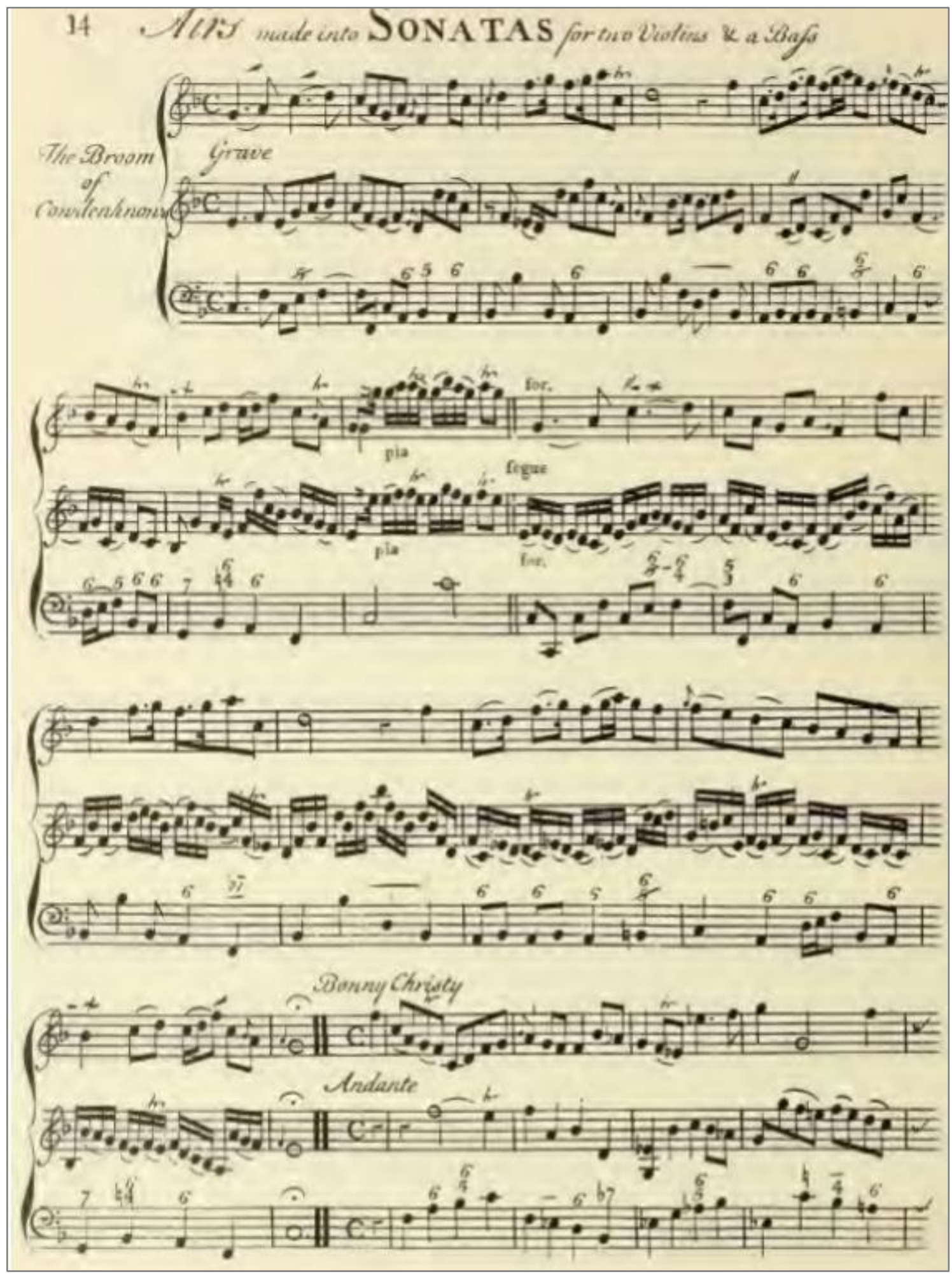

Fonte: Geminiani, Tratado sobre o bom gosto na arte da música p.210

Esses temas com variações ornadas contidos nesses dois tratados, se revelam, à parte dos valiosos preceitos, importantes modelos de ornamentação, e é interessante observar como Geminiani admite na figura de Corelli uma autocritas neste assunto: 
Não tenho a pretensão de ser o inventor destes [estilo e maneira incomuns], pois outros compositores da mais alta classe foram aventureiros desta mesma Voyage, e ninguém com maior êxito que o celebrado Corelli, como pode ser visto em sua quinta composição sobre a Aria dela Follia di Spagnia. ( Geminiani, op.cit. p. 181 trad. Held)

Do ponto de vista da música de câmara, seus preceitos podem ser igualmente úteis ao intérprete que visa um bom uso da ornamentação. Numa trio-sonata há uma disputa proporcional entre as duas sopranos (violinos I e II) e o baixo continuo. Não raramente o intérprete que no compasso anterior era dono soberano da melodia se vê na posição de acompanhador no compasso seguinte. Intérprete, compositor, violinista e baixo continuísta no século XVIII, muitas vezes eram a mesma pessoa e uma tendência a especialização de cada um desses papeis se tornava paulatinamente mais frequente até sua consolidação no século seguinte, de forma que o domínio ao menos genérico de cada uma dessas áreas se torna imprescindível ao intérprete que visa uma eloquência baseada no bom gosto. E curiosamente, instruções dedicadas a todas essas funções são encontradas juntas nos preceitos destes tratados sobre gosto. Os preceitos de Geminiani, ainda, se revelam uma poderosa ferramenta democrática na mão de qualquer especialista ainda desprovido de faculdades genéricas importantes, conforme revela o próprio compositor: "Enganam-se enormemente os que dizem poder ser posto em prática apenas por aqueles que entendem de composição o que já foi dito aqui, pois a experiência mostra o contrário.”(Geminiani op. Cit. P.158 tradução Held)

Neste sentido quatro tratados de Geminiani (os dois de acompanhamento e os dois com variações ornadas) dão ao camerista uma oportunidade de refletir sobre o decoro do papel de acompanhamento e se tornam uma ferramenta útil não somente na mão de quem desempenha o papel de baixo-contínuista corriqueiramente, mas na mão de todo e qualquer camerista, visto que o papel de um instrumento em música de câmara pode se inverter a todo o instante. Sobre a isso o autor fez as seguintes recomendações que parecem estar em consonância com os demais tratadistas analisados:

[...]eu dei as seguintes regras breves para o uso daqueles que desejam acompanhar com bom gosto: [...] às vezes devem soar muitos acordes e, outras, poucos, porque nosso deleite advém da variedade. Sempre que a parte superior para e o baixo continua, aquele que acompanha deve produzir alguma variação melódica sobre a mesma harmonia, de modo a despertar a imaginação do intérprete, seja o que canta ou o que toca, e, ao mesmo tempo, deleitar o ouvinte. (ibidem, p.174)

O aspecto frisado acima, demonstra ao acompanhador e ao camerista, um caminho a se buscar em uma interpretação judiciosa e no uso de suas virtudes elocutivas como interprete: usar da variedade, buscar um equilíbrio entre as partes ( como recomendado por Bach, Mozart e Quantz) dosando mais ou menos acordes, mais ou menos variações melódicas de acordo com 
o que ocorre e utilizar de seus recursos expressivos para fornecer aos colegas o despertar da imaginação, soprando bons argumentos musicais que devem ser emprestados ao condutor da melodia posteriormente e isso tudo sem deixar de deleitar o ouvinte.

Ainda do ponto de vista dos ornatos, Geminiani enfatiza uma explicação detalhada de seus 15 ornados contidos na tabela de ornamento e seus efeitos na audiência, lembrando ao interprete constantemente que o brilho desta virtude só virá se acompanhada de todas as virtudes elocutivas.

\begin{abstract}
Muitos supõem que não é possível adiquirir o verdadeiro bom gosto por meio de quaisquer regras da arte, pois trata-se de um dom particular da natureza, concedido apenas àqueles que têm naturalmente um bom ouvido. Como a maioria se exibe por possuir essa perfeição, tem-se, por consequência, aquele que canta ou que toca pensa apenas em fazer continuamente suas diminuições e ornamentos favoritos, acreditando que, por isso, será reconhecido como um bom intérprete, não percebendo que tocar com bom gosto não consiste em frequentes ornamentações, mas em expressar com força e elegância a intenção do compositor. Essa expressão é o que todos devem se esmerar para adquirir e pode, ser facilmente obtida por qualquer pessoa que não seja afeiçoada a sua própria opinião e que não resista obstinadamente à força da verdadeira evidência. No entanto, não nego as capacidades marcantes de um bom ouvido, [...] (Ibidem, p.182)
\end{abstract}

Essa observação encontra a já mencionada observação de Garavelli (op.cit. p.77) sobre o fato da virtude elocutiva do ornato ter um desenvolvimento histórico autônomo a ponto de por vezes transformar a retórica em "teoria do ornato." Ou seja, a busca por um bom ornato tornou-se tão grande ao ponto de um tratadista como Geminiani precisar criticar o seu mau uso ou o conformismo daqueles que acreditavam ser suficiente ao interprete ter um repertório de ornato sem se preucupar com as demais virtudes.

Essa comparação do ornato com expressão foi bastante observada ao consultar fontes primárias mais antigas como Quintiliano, Cícero e Aristóteles. Indicando uma corrente de pensamento sólida entre as preceptivas e o valor de pesquisa-las atentamente.

Nos séculos XX e XXI, o tema da ornamentação também foi alvo de inúmeros estudos, dentre os quais, se destacam os de Frederick Neumann (1978), Neal Zaslaw (1996), Nicholas Cook (1999) e Francis Ellis Benson (2003). O estudo de Neumann oferece um panorama genérico da ornamentação barroca. Em seu excelente artigo, Zaslaw dedica-se especificamente à ornamentação de Corelli e realiza uma comparação exaustiva entre as diferentes versões ornadas do Opus V, surgidas ao longo do século XVIII. Cook também comparou as diferentes versões do Opus $\mathrm{V}$, entretanto, isto é feito a partir de um método de análise schenkeriano. Benson, por sua vez, dedica um livro inteiro à fenomenologia do improviso no discurso musical, embora não se concentre especificamente nas práticas setecentistas. 


\subsection{MODELOS}

Apesar das ricas fontes tratadísticas, os documentos que mais chamam atenção com relação à existência dessa prática, sua importância e aplicabilidade são as músicas permissivas ao uso de ornamentação livre editadas com proposta de realização dos ornatos. Neste âmbito, destacam-se The true method of playing an Adagio (1762), de Carlo Zuccari (que consiste em uma série de 12 adágios ornamentados); as 33 sonatas de Franz Benda com adágios ornamentados para violino (1780); a edição ornamentada das sonatas do Opus I de Francesco Geminiani (editadas pelo autor, 1739); as sonatas metódicas de Georg Philipp Telemann (publicadas, também pelo autor, em dois volumes, um para violino e outro para flauta, 17281732); as seis sonatas para violino e baixo-contínuo pertencentes ao Opus V, de Arcangelo Corelli (editadas por Estienne Roger, 1711). Foi possível, ainda, localizar um único trabalho que apresenta versões ornamentadas contemplando o gênero da trio-sonata, os Trietti Metodichi de Telemann (editadas pelo autor em 1731).

De todas essas obras, o Opus V de Corelli é, sem dúvida, a mais emblemática. Segundo Cook (1999, p. 179), "seria difícil pensar em símbolo mais apropriado de trabalho relevante na história da música para violino.” A obra, pelo prelo de Estienne Roger, surgiu em Amsterdam, 1711. Sobre essa edição, Paoliello afirma:

\footnotetext{
Assim, as sonatas de Corelli foram modelo desse gênero no século XVIII, imitadas desde sua disposição até o estilo de cada movimento que compõe a sonata. Vale lembrar que os adágios ornamentados pelo compositor representam importante registro da prática de ornamentação livre italiana, podendo ser aplicado a outras composições italianas que, em geral, não trazem as ornamentações escritas e devem ser improvisadas (PAOLIELLO, 2017, p. 104).
}

As 12 sonatas que constituem o op. $\mathrm{V}$ dividem-se em dois gêneros: as primeiras seis conformam-se à escrita da chiesa, enquanto as últimas seis são sonatas da camera. Apenas os adágios das primeiras seis sonatas apresentam versões decoradas nesta edição. Os ornamentos, realizados no estilo livre ou italiano, têm sua importância salientada pelo fato de que os mesmos possam remontar diretamente à pena de Corelli. Deste modo, estes adágios forneceriam pistas de enorme relevância sobre a interpretação do repertório contemporâneo ao mestre italiano.

Para Rónai (2008), a motivação para a publicação de sonatas ornamentadas seria essencialmente didática, já que a prática de ornamentação livre em movimentos lentos era normalmente um processo puramente interpretativo:

\footnotetext{
Além de seu mérito intrínseco, tais obras nos fornecem uma pista importantíssima para desvendarmos os segredos da prática de interpretação instrumental do Barroco. Uma das constatações surpreendentes a que se pode chegar a partir destas sonatas é que movimentos lentos costumavam ser copiosamente ornamentados, numa escala muito maior do que poderíamos imaginar.
} 
O músico do século XVIII, no entanto, estava perfeitamente habituado ao que hoje achamos demasiado extravagante. E o profissional sensível nem precisava de muitas instruções para saber que devia ornamentar movimentos lentos. Afinal, esta era a prática comum entre seus pares. Talvez por esta razão as fontes que sobreviveram aos nossos dias frequentemente tratam a questão apenas de modo tangencial, supondo por parte do leitor um conhecimento prévio do assunto (RÓNAI, 2008, p .222).

\section{A autora cita Georg Christoph Weitzler (1756) em defesa de seu ponto de vista:}

[...] com relação aos ornamentos, acho recomendável escrevê-los apenas quando são passagens comuns rápidas; com outras que surgem parcialmente da natural facilidade dos dedos, parcialmente de invenção luxuriante, é inútil fazer isso. Ou não podem ser indicados por notas, ou então o bom-gosto irá rejeitar tais ornamentos logo que percebermos que deveriam ser esses e não quaisquer outros, desta maneira e não de outra em um dado lugar; em resumo, logo que se perca a espontaneidade tão essencial a eles. Uma pessoa dotada musicalmente, com bons poderes interpretativos jamais irá tocar da mesma maneira, mas sempre fará modificações de acordo com o estado de seus sentimentos (WEITZLER ${ }^{58}, 1756$, apud RÓNAI, 2008, p. 223).

ZASLAW (1996) também enfatiza esse argumento:

$\mathrm{O}$ senso comum sugere, portanto, que qualquer ornamento que Corelli enviou a Amsterdã para ser publicado teria sido um exemplo mínimo, que poderia servir para muitos tipos de violinistas em uma sorte de locais. Isso teria sido destinado primariamente a músicos inexperientes que precisavam ver o que era desejado neste tipo de música, não para virtuosos, que seriam capazes de cuidar de si mesmos nesse assunto (ZASLAW, 1996, p. 109). ${ }^{59}$

O autor prossegue dizendo que essa teoria não surgira apenas de uma "suposição de senso-comum do objetivo didático das edições ornamentadas, mas também dos anúncios publicados por Roger enquanto preparava sua edição dos ornamentos na época" (Ibidem, p $109)^{60}$ :

Ele está transcrevendo os ornamentos dos adágios dessas sonatas, que o próprio senhor Corelli teve a gentileza de compor uma vez mais, como ele os toca. Estes serão verdadeiras lições de violino para todos os amadores (ROGER, 1710, citado por ZASLAW, 1996 p. 109). ${ }^{61}$

À parte dessa discussão, esse registro sobreviveu até hoje e no século XVIII motivou diversos outros violinistas a fazerem suas versões. Segundo o artigo de Zaslaw (1996), mesmo com alguns manuscritos perdidos, como o de Nicolas Matteis citado por Quantz em seu tratado, foram encontrados 20 diferentes manuscritos e edições setecentistas sobre parte das sonatas do

\footnotetext{
${ }^{58}$ WEITZLER, G. C., IN: Marpurg. Historisch-Kritische Beyträge, Berlim: III,2,1,1756.

${ }^{59}$ Tradução nossa. Do original: “Common sense suggests, therefore, that any ornaments Corelli sent to Amsterdam to be published would have been minimal, all-purpose examples that could work for many types of violinists in a variety of venues. These would have been intended primarily for inexperienced player who needed to be shown what was wanted in this type of music, not for virtuosos, who would be well able to take care of themselves in that department."

60 Trad nossa. Do original: "This emerges not only from a general understanding of the function of ornamented editions, but from Roger's announcement, while his ornamented edition of op.5 was being prepared, that,..."

${ }^{61}$ Trad nossa. Do original: "He is presently engraving the ornaments of the adagios of these sonatas, which Mr. Corelli himself has been good enough to compose completely afresh, as he plays them. These will be true violin lessons for all amateurs."
} 
Opus V. Essas edições ilustram como a prática de ornamentar os adágios na música italiana era bem disseminada. Segundo Harnoncourt:

[...] quando a ornamentação não é fixada: caso fosse ser escrita, estar-se-ia limitando a fantasia criativa do músico; e esta é exatamente exigida na ornamentação livre (para tocar bem um adágio, nos séculos XVII e XVIII, um músico deveria improvisar livremente ornamentos que correspondessem à expressão da peça e a reforçassem.) (HARNONCOURT, 1998, p 36).

Em um levantamento inicial, tendo como principal referência o Ornamentation in Baroque and Post-Baroque Music de Frederick Neumann (1983), foram encontradas outras peças editadas em duas versões: com e sem os ornamentos notados. Além do Opus V, destacamse as sonatas metódicas de Telemann, escritas em dois volumes, um para violino e outro para flauta, e a única obra encontrada nesse modelo, escrita para trio-sonata, os Trietti Metodichi de Telemann (1731).

Figura 17: Modelo de Adagio ornamentado por Zuccari

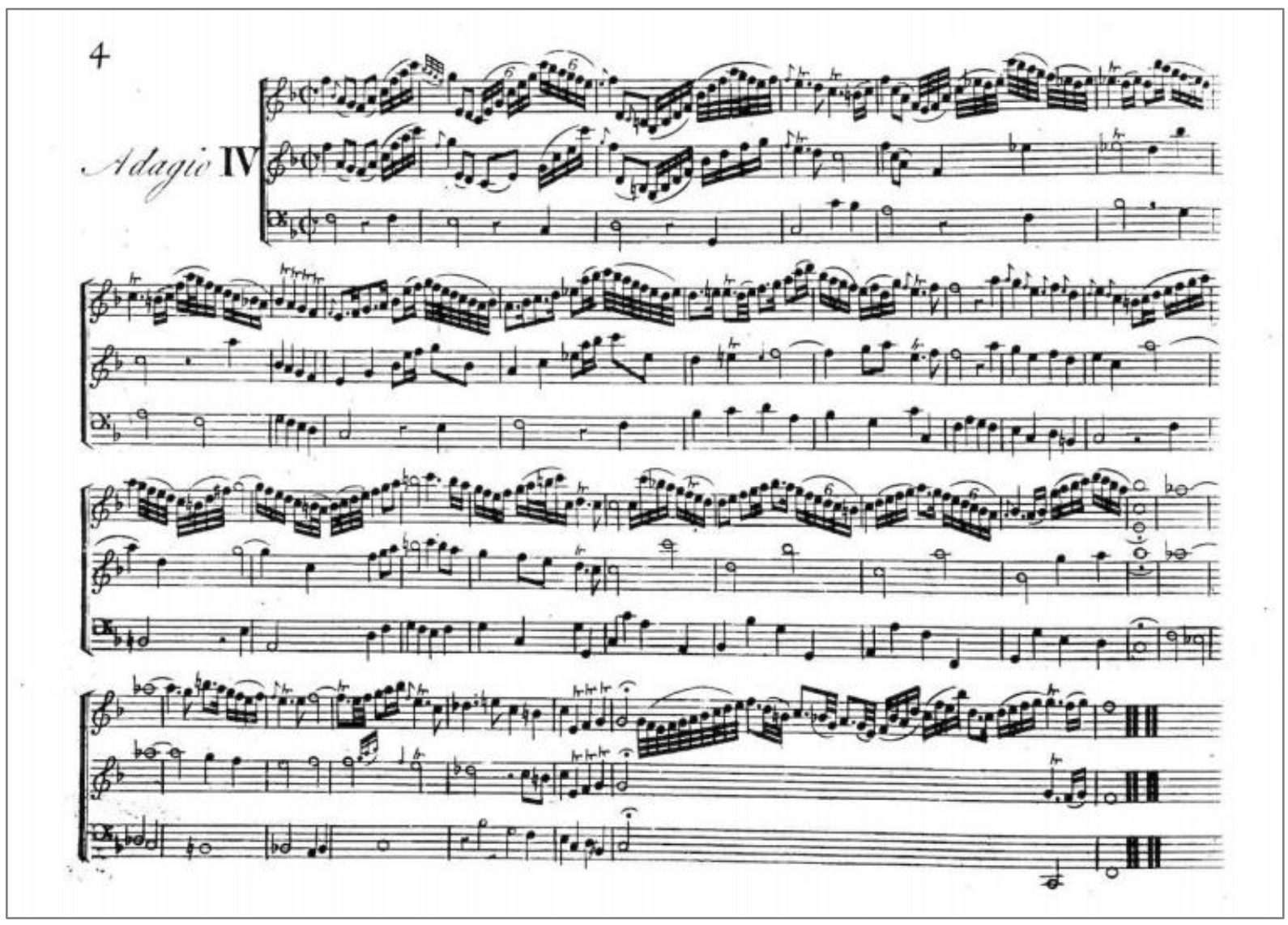

Fonte: Zuccari, The true method of playing an Adagio 1762 p.5 


\subsection{A ORNAMENTAÇÃO LIVRE COMO PRÁTICA INTERPRETATIVA}

Zenobi, um famoso cornetista do século XVI, deixou registrado, a pedido de um anônimo príncipe italiano, uma carta (não é possível precisar sua data, mas estima-se ser algo entre 1570 e 1600) com recomendações de critérios para se selecionar um bom músico; em um trecho com orientações especificas para instrumentistas de cordas friccionadas, segue:

Os instrumentistas de cordas como viola, viola da gamba e violino devemos julgar pela perfeição da arcada, pela qualidade da força do instrumento e pela variedade das cordas, pela riqueza da propriedade e excelência das diminuições e do trilo, do striscio e pela facilidade e segurança do lirare. (Zenobi apud Ellendersen. Op. cit. 2020 p.93, grifo nosso)

Em outro trecho desta carta, o cornetista sugere que a voz do soprano seja cantada ou tocada por instrumentos com tessitura semelhante:

Resta o soprano que é verdadeiramente o ornamento de todas as outras partes assim como o baixo é o fundamento. O soprano, portanto, tem a obrigação e liberdade plena para diminuir, brincar e, em suma, adornar um corpo musical; mas se não o fizer com arte, com graça e com sensatez, se torna entediante de ouvir, duro de digerir e repugnante de suportar [...]Deve saber muito bem contraponto, porque sem este, canta ao acaso e comete mil tolices. Ao cantar, deve fazer entender as palavras nitidamente e não as deturpar com diminuições, nem as cobrir com ressonância excessiva da voz, seja como sino, seja rouca ou áspera. Deve ter um groppo granito (trilo articulado) e um groppo posato (trilo calmo). O groppo granito é aquele que toca duas notas como sol e fá ou lá e sol em semicolcheias separadas. Groppo posato é aquele que se faz de colcheias simples, tocando também as duas notas claramente. O trillo é aquele que não para nem na linha, nem no espaço (mas sempre move) com velocidade. Tremolo é aquilo que toca na linha e no espaço da maneira que se o queira executar [...] (Ibidem, p.91)

Ellendersen (op. cit.2020,p.155) liga o desenvolvimento técnico de cantores e instrumentistas ao improviso e à ornamentação:

Defendemos que a forte tradição de improviso, por meio de fórmulas memorizadas de
diminuições, provavelmente foi um dos principais fatores a contribuir para o
desenvolvimento técnico de cantores e instrumentistas durante os séculos XVI e XVII.
O aspecto de improvisação é tão fundamental, que refletir sobre interpretação musical
nesta época sem levá-la em conta não faz sentido. Apesar de que o fator essencial e
natural que caracteriza a improvisação seja a sua imprevisibilidade, invenção e criação
instantânea no momento da apresentação, ela inicialmente era guiada por certas regras
passadas oralmente de mestre para aluno que as assimilava no seu subconsciente -
armazenadas como loci topici, por assim dizer - e ativadas no decorrer da execução.
No entanto, estas 'regras' passaram a ser registradas em uma série de publicações e a
lista de manuais de diminuições, a partir da segunda metade do Quinhentos, é extensa.
Alguns autores como Diego Ortiz, Bassano e Bismantova curiosamente sugerem que
o músico escreva os ornamentos dentro da partitura ou executem a ornamentação
impressa nos manuais.

Desta maneira, o autor aponta possíveis origens para tantas demandas por tratados sobre ornamentação na virada do século XVI para o XVII e, principalmente, o porquê de muitos 
tratados sobre música e instrumentos se ocuparem tanto deste tema ou ainda serem, na verdade, tratados de diminuição e/ou ornamentação.

A partir da segunda década do século XVII até o século XVIII, Neumann (1983) Aponta uma escassez de métodos sobre decorativo musical na Itália. O autor cita passagens de compositores como Caccini reclamando da "demasia" dos intérpretes. A ornamentação tinha alcançado um patamar exagerado, uma prática muito comum no início do século XVII chamada Passaggi, que consistia em ornamentos com inúmeras notas.

Em 1602, Caccini reafirma, em nome da camerata florentina, a proibição de extensas diminuições. Sendo ele mesmo um cantor virtuoso, ele achava difícil renunciar a todas as oportunidades de exibição e, compreensivelmente, suas regras eram mais flexíveis do que as de Cavalieri. Caccini condena as passagi, aqueles "longos giros da voz" que servem apenas para fazer cócegas no ouvido, já que nada poderia ser mais contrário à comunicação de um afeto. No entanto, ele admite breves até um quarto ou metade do tempo por uma questão de graça adicional, na medida em que passam rapidamente e também porque o julgamento considerado impõe exceções a todas as regras. As cadências finais parecem isentas de quaisquer restrições, como se depreende de muitos exemplos da sua música. ${ }^{62}$ (Neumann, op. cit. p. 26)

Entretanto, ao longo do século, a ornamentação gradualmente foi reivindicando um novo espaço:

\begin{abstract}
A postura doutrinária dos fundadores da monodia em relação ao primado da palavra não poderia durar muito. Sendo a parceira mais forte, a música logo se rebelou contra sua submissão à palavra. Flores melódicas começaram a brotar em passagens ariosas para aliviar a secura de intermináveis recitativos, e os lugares se multiplicaram onde pistas textuais apropriadas eram tomadas como ocasiões para passagens ornamentais. Embora por um tempo ambos os tipos de acontecimento musical tenham permanecido a serviço da projeção dramática, eles pagaram o caminho para a emancipação tanto da melodia pura e cantável quanto do ornamento lúdico puro. Essa emancipação é amplamente realizada no chamado estilo bel canto de meados do século 17, pelas mãos de mestres como Cavalli, Carissimi, Cesti e Stradella. Nesse estilo, os ocasionais botões melódicos da monodia se expandiam em plena floração das árias, imbuídos daquela melodiosidade sensual e sedutora, a dolcezza italiana, que encantaria o mundo nos séculos vindouros. De mãos dadas foi a liberação gradual de ornamentos gratuitos, um desenvolvimento que ocorreu mais rápido no norte da Itália do que no sul. $\mathrm{Na}$ Roma de Carissimi, de acordo com o testemunho de Christoph Bernhard, as pequenas graças, os accenti e trilli, ainda eram preferidos às passaggi. A era do bel canto, no entanto, produziu cantores virtuosos e viu os castrati ascenderem à vanguarda da proeminência e poder musicais. Eles então usaram esse poder para se arrogar o direito de esbanjar enfeites sem a necessidade de um pretexto declamatório. ${ }^{63}$ (Ibidem, p.27)
\end{abstract}

${ }^{62}$ Trad. nossa do original: In 1602, Caccini reaffirms, in the name of the Florentine Camerata, the ban against extensive diminutions. Being a virtuoso singer himself, he found it difficult to renounce all opportunities of display, and understandably his rulings were more flexible than Cavalieri's. Caccini does condemn passaggi, those "long gyrations of the voice" that serve only to tickle the ear since nothing could be more contrary to the communication of an affect. However, he admits brief ones up to a quarter or half of the beat for the sake of added grace, inasmuch as they pass quickly and also because considered judgment imposes exceptions to every rule. Final cadences seem to be exempt from any restrictions, as can be gathered from many examples in his music.

${ }^{63}$ Trad. nossa do original: The doctrinaire stance taken by the founding fathers of monody with regard to the primacy of the word could not last very long. Being the stronger partner, music soon rebelled against its subjugation to the word. Melodic blossoms began to spring up in arioso passages to relieve the dryness of endless recitative, and the places multiplied where appropriate textual clues were taken as occasions for ornamental passages. Though for a while both types of musical happening remained in the service of dramatic projection, they nevertheless paved the way for the emancipation of both pure, singable melody and pure, playful ornament. This 
Além disso, no que diz respeito à música instrumental, os próprios monodistas revelam ter uma opinião diferente:

Os instrumentos não estão envolvidos no antagonismo da palavra-música, e Caccini só é consistente quando declara "que as diminuições são mais apropriadas para ventos e cordas do que para as vozes ..." portanto, as ondas de choque emanadas da revolução monódica afetaram ornamentação instrumental apenas indiretamente por meio da mudança geral de estilo. ${ }^{64}$ (Ibidem, p.27)

\section{E o repertório para violino revela uma relação ainda mais específica:}

Entre a ornamentação vocal e as cordas havia, compreensivelmente, um paralelismo maior. O violino, nascido na primeira metade do século 16 , não se consolidou como um instrumento solo independente até que o século 17 estava bem adiantado. A sua literatura desenvolveu-se em torno dos dois focos da sonata e do concerto, que compunham nos seus estilos correntes eminentemente simpáticas à natureza do instrumento: os ritmos vivos da dança e a vibração do bel canto. Assim, como era de se esperar, os movimentos vívidos derivados da dança acrescentavam graça e elegância. Quando a sonata, seguida mais tarde pelo concerto, atingiu a maturidade a partir de meados do século XVII, o bel canto e a ária da capo tinham voltado a crescer as asas cortadas dos passaggi. Agora os mestres do violino, seguindo a deixa da voz, esperavam que o executante adicionasse diminuições aos movimentos lentos e pequenas graças (accenti e trili) em quase qualquer lugar. A forma de atuação resultante permaneceu viva até o final do século XVIII. ${ }^{65}$ (Ibidem, p.27)

\section{Essa reflexão nos coloca diante de uma \\ Neumann, em seguida, explica como foi surgindo um componente tão essencial ao gosto italiano (como vimos em Raguenet no capítulo anterior):}

Este segundo florescimento de passaggi atingiu seu pleno desenvolvimento em uma época em que tais enfeites em grande escala haviam saído de moda na França, onde

\footnotetext{
emancipation is largely realized in the so-called bel canto style of the mid $17^{\text {th }}$ century at the hands of such masters as Cavalli, Carissimi, Cesti, and Stradella. In this style the occasional melodic buds of monody expanded into the full blom of arias, imbued with that sensually beguiling melodiousness, the Italian dolcezza, that was to enchant the world for centuries to come. Hand in hand went the gradual liberation of free ornaments, a development which proceeded faster in the north of Italy than in the south. In the Rome of Carissimi, according to the testimony of Christoph Bernhard, the small graces, the accenti e trilli, were still preferred to the passaggi. The bel canto era, however, produced virtuoso singers and saw castrati rise to the forefront of musical prominence and power. They then used this power to arrogate the right to lavish embellishment without the need of a declamatory pretext.

64 Trad. nossa do original: Instruments are not involved in the word-music antagonism, and Caccini is only consistent when he declares "that diminutions are more appropriate for winds and strings than they are for the voices..." therefore, the shock waves emanating from the monodic revolution affected instrumental ornamentation only indirectly through the overall change of style.

${ }^{65}$ Trad. nossa do original: Between vocal and string ornamentation there was understandably a greater parallelism. The violin, born in the first half of the $16^{\text {th }}$ century, did not come into its own as an independent solo instrument until the $17^{\text {th }}$ century was well on its way. Its literature developed around the two focal points of the sonata and the concerto, both of which comprised in their styles currents that were eminently sympathetic to the nature of the instrument: the lively rhythms of the dance and the songfulnes of the bel canto. Thus, as could be expected, the lively dance-derived movements those that added grace and elegance. When the sonata, followed later by the concerto, grew into maturity after the middle of the $17^{\text {th }}$ century, bel canto and the da capo aria had regrown the clipped wings of the passaggi. now the violin masters, taking their cue from the voice, expected the performer to add diminutions to slow movements and small graces (accenti and trili) almost anywhere. the resulting performance manner remained alive until late into the $18^{\text {th }}$ century.
} 
princípios semelhantes aos da monodia foram entronizados pelo formidável Lully. Assim, a partir dessa época, o generoso embelezamento improvisado de melodias esqueléticas passou a ser associado ao estilo italiano em contraste com o estilo francês, no qual as adições ornamentais geralmente se limitavam a pequenas graças. ${ }^{66}$

Essa ornamentação dos movimentos lentos italianos do final do século XVII e início do século XVIII é essencialmente o escopo desta dissertação. Assim, vamos nos debruçar sobre a prática interpretativa corelliana através dos estudos que reunimos sobre o compositor. Porém, antes de avançarmos, vale relembrar um último registro da prática interpretativa da ornamentação italiana, além dos já listados dentre tratados e modelos: a gravação londrina do funcionamento de um barrel organ (realejo, em tradução livre) construído em 1763 pelo fabricante de órgãos mecânicos John Langshaw (1718-1798).

Esse órgão, conforme a figura 18, possui um cilindro com gravações que permitem uma execução mecânica automática. Nesses cilindros foram gravadas diversas obras, incluindo alguns concertos de câmara de Handel para órgão; o músico encarregado de auxiliar Langshaw nessas gravações foi o discípulo de Handel e seu assistente pessoal John Christopher Smith (1712-1795). Nesse registro há uma ornamentação bastante exuberante dos movimentos lentos cuidadosamente gravada nos rolos, que eram gravados mecanicamente e não com uma execução musical, funcionando como uma partitura mecânica capaz de reproduzir sons. À parte das limitações do órgão de cilindro e do seu processo de confecção, é interessante notar como a prática de ornamentação estava presente entre as preocupações dos músicos envolvidos no registro.

\footnotetext{
${ }^{66}$ Trad. nossa do original: this second flowering of the passaggi came to full development at a time when such large-scale embellishments had gone out of fashion in France, where principles akin to those of the monody were enthroned by the formidable Lully. Hence from that time on, generous improvised embellishment of skeletal melodies became associated with the Italian style as contrasted to the French style, in which ornamental additions were generally limited to small graces only.
} 
Figura 18: Órgão de Cilindro ou realejo

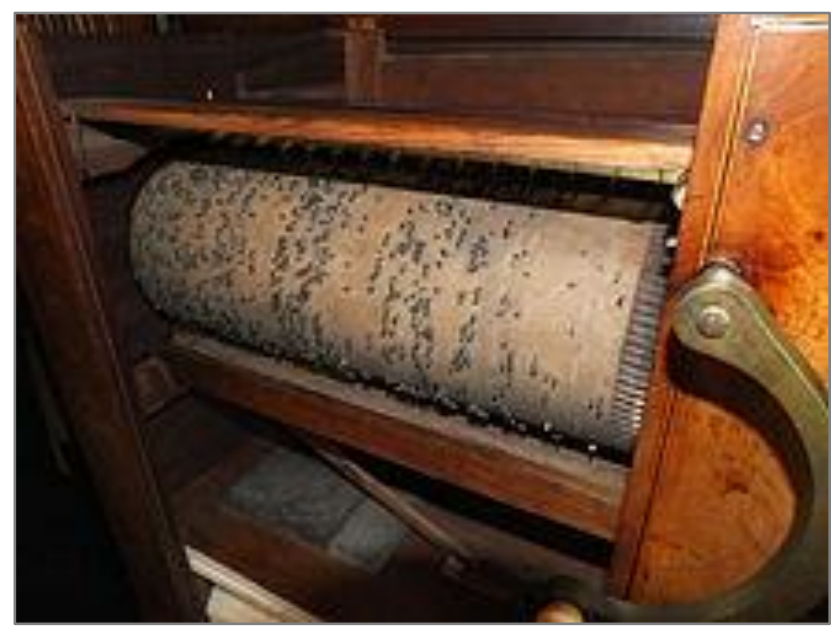

Fonte: Clean Rutter (2014)

A história dessa prática ainda avança sobre os séculos seguintes, mas para não incorrermos no vicio da perierghía (onerar o discurso com detalhes desnecessários) não fugiremos ao escopo proposto.

\subsection{EVIDÊNCIAS DA ORNAMENTAÇÃO LIVRE NA PRÁTICA INTERPRETATIVA CORELLIANA}

A principal evidência dessa prática em Corelli se encontra na terceira edição do Opus V, bastante abordada neste presente estudo. Segundo Zaslaw (1996), ela possui três valores didáticos hoje em dia: primeiro, com os movimentos separados usados como estudos ${ }^{67}$; depois, como modelo composicional; e, finalmente, como base para a improvisação. Nos ateremos ao terceiro atributo, em função do escopo deste trabalho. A partir dessa perspectiva, essa edição do Opus V motiva a aplicação de seus princípios nos movimentos lentos das doze sonatas de Corelli e em todo seu repertório contemporâneo, e também serviu como base para a ornamentação livre do barroco tardio. Porém, sua aplicação nas outras 48 trio-sonatas e em todo esse tipo de repertório se torna uma questão cercada de incertezas, pois elas não foram reeditadas com exemplos ornados e trata-se de música em conjunto. $\mathrm{O}$ modelo encontrado de Telemann nos Trietti metodichi duas décadas depois do Opus V nos fornece uma boa pista,

\footnotetext{
${ }^{67}$ Contextualização da técnica mecânica do instrumentista na música.
} 
porém sua distância geográfica e temporal nos obriga a procurar outras evidências que endossem o estudo.

Segundo Zaslaw e Spitzer (2004), Corelli mantinha um corpo de músicos profissionais conhecedores do seu estilo e maneira de tocar. Dentre eles, como já dissemos, se destacava quase sempre como seu segundo violino e amigo pessoal a figura de Matteo Fornari, com quem Corelli muitas vezes tocava suas trio-sonatas. Uma questão prática e cultural ronda esse assunto: como eles combinavam suas interpretações? Se a música do Opus V era inicialmente notada sem ornamento, mas há vários registros da prática, será que ao tocar os adágios das trio-sonatas Corelli não improvisava? E Fornari? Segundo os mesmos autores, Corelli era perfeccionista e ensaiava bastante sua orquestra; Desta forma retomamos a pergunta exposta na introdução desta dissertação: Seria a ornamentação uma das questões de ensaio? Segundo o que podemos verificar nas preceptivas barrocas, é bastante provável e, a parte disso, os tratados e modelos disponíveis indicam como estudar a ornamentação é tão imprescindível para uma execução judiciosa quanto as outras virtudes elocutivas como o decoro, a clareza e a precisão. Entretanto, resta nos aproximar do ambiente romano em que Corelli construiu sua carreira no final do século XVII e inicio do XVIII.

Desde a década de 60 do século XX, um círculo de musicólogos foi reunido ao longo de diversos simpósios realizados em Fusignano (cidade natal do compositor). Dentre eles se destacam Nuovissimi studi corelliani (1980), Studi corelliani IV (1990), Congreso inernazionale di studi (2003) e o mais recente realizado, batizado com o mesmo nome que Corelli recebeu na Academia Arcadiana de Roma: Arcomelo ${ }^{68}$ 2013, Studi nel terzo centenário dela morte di Arcangelo Corelli (1653-1713), publicado em 2015. Esses estudos cresceram bastante e nos últimos 30 anos muitos avanços foram realizados nos mais diversos temas relacionado ao autocritas italiano; dentre eles se destacam as obras de Oliveri, Spitzer, Zaslaw, Piperno, Allosp, D’ovidio, Seta, Sanna e muitos outros.

Um pouco antes de 1980, a coleção de manuscritos da Academia da Arcadia Romana tornou-se parcialmente acessível na Biblioteca Angelica em Roma, o que motivou Fabrizio Della Seta a escrever um artigo em 1980 sobre a participação de músicos na instituição fundada por Giovanni Mario Crescimbeni e 14 poetas do círculo da Rainha Cristina da Suécia que a elevaram ao posto de patrona. Segundo o autor, essa academia essencialmente poética seguia moldes racionais aristotélicos vendo a arte como imitação da natureza. Dentre essas artes, a

\footnotetext{
${ }^{68}$ Corelli foi rebatizado como poeta arcade com o nome de Arcomelo Erimanteo em 1706, ano de seu ingresso na academia.
} 
música não era vista como arte autônoma. Curiosamente, a mesma academia teve como membros Corelli, Pasquini e Scarlatti, importantes modelos da construção do que seria futuramente conhecido como a "música pela música." Seta comenta como, por meio de cartas de importantes mecenas da Academia, como o cardeal Ottoboni (um dos mais importantes mecenas de Corelli), como a música, mesmo a instrumental, recebia um apreço mais elevado por parte nobreza papal. ${ }^{69}$ que viam essa arte como uma arte mais próxima da arquitetura.

Retornando a questão da improvisação e da ornamentação livre e à parte desta discussão filosófica, em um trecho em que o autor descreve os registros de prática musical na Academia, temos: “[...]o concerto na cabana Metaureo, com a consequente competição de improvisação entre Thyrsis e Terpandro (descrito na famosa passagem da Arcadia del Crescimbeni), representa o único sinal de uma certa importância da actividade musical.[...] ${ }^{70 "} \mathrm{O}$ fato de o único relato concreto da prática de música durante as sessões da Academia, uma instituição que sem dúvida alguma é uma das principais validadoras do gosto romano deste período, ser uma competição de improviso, sugere que essa habilidade [a de ornar e mais ainda ornar em uma disputa, algo recorrente numa trio-sonata] é um critério bastante apreciado pelo bom gosto desta nação e uma prática realizada a um nível bastante judicioso ao ser realizado com bom gosto e mereceu destaque nos anais desta instituição;

Em 2002, D’Ovidio, em sua tese de doutorado, escreveu sobre os modelos romanos que serviram como inspiração para o compositor de Fusignano e, conforme já vimos no sub-capítulo 2.8, dentre eles se destaca a figura de Lelio Colista. Ao analisar em detalhes os trio-sonatas desse autor, que foram publicadas no segundo volume de sua tese em edição critica, D’Ovidio nos revela:

As sonatas a três de Colista são destacadas em comparação com as dos outros compositores romanos de trio sonatas, também pela presença de seções de alcume, colocadas entre um movimento e outro, nas quais os dois violinos e o baixo de fondamento[violone] são chamados a improvisar partir de um esquema fornecido pelo baixo[continuo]. Mais precisamente, são passaggi, notadas em clave de fá em todas as vozes, consistindo em um número variável de semibreves (de seis a nove) sem divisão de barra, distinguida no manuscrito de Münster pela indicação Solo se piace.71 (D’Ovidio op. cit p.77)

\footnotetext{
${ }^{69}$ Franco Piperno em 2015 publicou um rico artigo sobre a participação Corelliana na academia.

${ }^{70}$ Della Seta, 1980, p.127. trad. Nossa do original: [...]il concerto nella capanna di Metaureo, con la conseguente gara di improvvisazione tra Thyrsis e Terpandro (descritto nel famoso passo dell"Arcadia del Crescimbeni), rappresenta l'unico segnale di una certa importanza di attività musicale, $[\ldots]$

71 Tradução nossa do original: Le sonate a tre di Colista si caratterizzano rispetto a quelle degli altri compositori romani di sonate a tre anche per la presenza di alcume sezioni, poste tra un movimento e l'altro, in cui i due violini e il basso melodico sono chiamati ad improvvisare a turno su uno schema fomito dal basso. Si tratta più esattamente di passagi, notati in chiave di basso in tutte le voci, constituiti da un numero variabile di semibrevi (da sei a nove) senza divisione di battuta, contraddistinte nel manoscritto di Münster dall'indicazione Solo se piace.
} 
O exemplo de Colista, evidencia como em meados do século XVII, mesmo com uma diminuição do uso de passaggi em favor dos ornamentos essenciais, a prática não só não desapareceu, como foi utilizada em caráter experimental e com bastante ousadia por um compositor que se tornaria uma das principais inspirações de Corelli. Mais do que isso, apesar de ser uma obra relativamente cativa ou especial, os trios de Colista são um registro da prática de improvisar em trio-sonatas, muito antes do modelo proposto por Telemann no século XVIII. Indicando uma prática improvisatória que vai além da ousadia da ornamentação livre em seu conceito mais puro e aproxima esse repertorio ao conceito de cadência abordado por Quantz mais tarde no século XVIII.

D’Ovidio explica como deveriam ser tocadas essas sessões nas trios colistianas:

[...]O manuscrito Giordano 15 não contém nenhuma indicação explícita de como essas seções devem ser executadas, mas a maneira como elas são organizadas na partitura sugere uma apresentação, por sua vez, dos três instrumentos envolvidos, cada um deles. acompanhada por baixo contínuo, na ordem indicada de tempos em tempos. Encontramos confirmação disso se formos verificar a maneira pela qual no manuscrito em partes separadas essas mesmas seções são anotadas. Em cada uma das três partes superiores (os dois violinos e o baixo melódico), encontramos, geralmente colocado no final de um movimento, um asterisco com a indicação "solo se piace[somente se você quiser]", que se refere à parte inferior da página em que é notada, também é a chave aqui o baixo, a sucessão de semibreves acima da qual era preciso improvisar. ${ }^{72}$

O manuscrito descrito por D’Ovidio contém evidências de práticas de improvisação em música em conjunto, assim como as trio-sonatas, e ele vai além das vozes solísticas dos instrumentos sopranos:

\begin{abstract}
Na parte do baixo contínuo, no entanto, todas as fórmulas de baixo nas quais são necessárias improvisações dos instrumentos superiores, dispostas na ordem de rotação dos dois violinos e do baixo melódico. É importante sublinhar, a esse respeito, como, neste caso, o alaúde é tratado como um instrumento melódico como os dois violinos, portanto, cada instrumento tem seu próprio "solo" acompanhado pela linha estrita do continuo. Particularmente evidente é o caso do Sonata $17 \mathrm{~W}-\mathrm{K}$, caracterizado por um desenho do baixo no qual é necessária a improvisação do solo que, portanto, longe de ser um simples enriquecimento do continuo, desempenha um papel de "concertante". O carater opcional é bem destacado pela expressão "se place" que acompanha a sinalização, dos "apenas" três movimentos e do outro. Sua função na sonata parece dar destaque aos instrumentistas individuais, garantindo que, em um desenho de baixo
\end{abstract}

\footnotetext{
72 Tradução nossa do original: [...] Il manoscritto Giordano 15 non contiene alcuna indicazione esplicita su come debbano essere eseguite queste sezioni, ma il modo in cui esse sono disposte in partitura fa supporre un'esecuzione a turno dei tre strumenti coinvolti, ognuno dei. quali accompagnato dal basso continuo, secondo l'ordine di volta in volta indicato. Si trova conferma di ciò se andiamo a verificare il modo in cui nel manoscritto in parti staccarte sono notate queste stesse sezioni. In ciascuna della tre parti superiori (i due violini e il basso melodico) troviamo, di solito collocate alla fine di un movimento, un asterisco con l'indicazione "solo se piace" che rimanda in fondo alla pagina dove è notata, anche qui chiave di basso, la successione di semibrevi sopra la quale bisognava improvvisare.
} 
idêntico, cada um deles possa improvisar livremente de acordo com modulos em constante mudança. $\mathrm{O}$ desenho melódico proposto a partir do baixo dificilmente remonta a uma das fórmulas derivadas das danças, com exceção da Sonata $16 \mathrm{~W}-\mathrm{K}$, que evoca, embora com variações, um baixo de chaconne com a inclusão do III grau entre o VI e o V. 73.

\section{Por fim, D'Ovidio nos revela sobre uma prática bastante difundida entre os romanos no}

\section{período em que Corelli chegou a Roma:}

A última sonata apresenta, no desenho do baixo contínuo em que as vozes altas são chamadas a improvisar, a indicação responde [sic] que com toda a probabilidade, como pode ser visto no Dicttionaire de musique de Sebastien de Brossard sob o termo $<$ Reposta> refere-se às "respostas" das várias vozes que se imitam na fuga. Essa interpretação, portanto, parece sugerir uma execução dessas partes solo, por sua vez, da mesma forma proposta a partir do baixo. Podemos, portanto, pensar que essas partes foram executadas com a intenção de criar uma espécie de efeito "eco", no qual o segundo e o terceiro instrumento repetem exatamente o design melódico improvisado pelo primeiro, ou propuseram, mesmo com o mesmo desenho do baixo, sempre variações diferentes. A prática de inserir intervenções "solísticas" no efetivo das sonatas à três foi abundantemente difundida na produção instrumental italiana das décadas de 60 e 70 do seicento e além, tanto no repertório impresso quanto no manuscrito. As partes solísticas podem ser anotadas na íntegra ou, como no caso de Colista, indicadas apenas pelo desenho do baixo. É interessante, no entanto, sublinhar a existência de alguns testemunhos que documentam essa prática executiva em Roma já nos anos 10 do século XVII. No primeiro livro de sinfonias com quatro com o baixo contínuo (1615) do compositor e compositor Girolamo Kapsberger, com quem Colista esteve em contato nos primeiros anos de sua formação na corte Barberini, muitas composições, por sua vez, foram confiadas a cada uma delas. as partes agudas em um desenho de baixo que podem ser idênticas a cada entrada das vozes superiores ou apresentar um caminho modulador da tônica para o quinto grau e vice-versa, como acontece, por exemplo, na Sinfonia duodecima a 2 canti, totalmente estruturada de acordo com uma alternância de partes solo -ora da primeira voz, ora da segunda -e das seções 'a 2'.74

\footnotetext{
73 Tradução nosssa do original: Nella parte del basso continuo, invece, vengono riportate tutte le formule di basso su cui è richiesta l'improvvisazione degli strumenti superiori, disposti secondo l'ordine di avvicendamento dei due violini e del basso melodico. E' importante sottolincare a questo proposito come in questo caso il liuto sia trattato come uno strumento melodico alla stregua dei due violini.Ogni strumento dunque ha il suo "assolo"acompagnato dalla stressa linea del continuo. Particolarmente evidente il caso della Sonata $17 \mathrm{~W}-\mathrm{K}$, caratterizzata da un disegno del basso su cui e richiesta l'improvvisazzione del solo liusto che quindi, lungi dall' essere un semplice arricchimento del continuo, ricopre un ruolo "concertante" Il carattere opzionale è ben messo in risalto dall'espressione " se place" che accompagna la segnalazione, del "solo" tre um movimento e l'altro. La loro funzione all'interno della sonata sembra quella di conferire risalto al singoli strumentisti, facendo sí che su un identico disegno del basso, ognuno di essi potesse improvvisare liberamente secondo moduli sempre diversi. Difficilmente l'andamento melodico proposto dal basso può essere ricondotto ad una delle formule derivante da danze, ad eccezione della Sonata $16 \mathrm{~W}-\mathrm{K}$ che evoca, sia pur con delle varianti, un basso di ciaccona con l'inserimento del III grado tra VI e V.
}

74 Tradução nossa do original: Quest'ultima sonata presenta, nel disegno del basso continuo su cui le voci acute sono chiamate ad improvvisare, l'indicazione risposte [sic] che con tutta probabilità, cosi come si evince dal dictionaire de musique di Sebastien de Brossard alla voce <Riposta> si riferisce alle "risposte" delle diverse voci che nel fugato si susseguono tu imitazione. Questa interpretazione, dunque, sembrerebbe suggerire una esecuzione di queste parti solistiche a turno su uno stesso modulo proposto dal basso. Si può quindi pensare che queste parti fossero eseguite con l'intento di creare una sorta di effetto "in eco", in cui cioè il secondo e terzo strumento ripetono esattamente il disegno melodico improvvisato dal primo, oppure proponevano, pur sullo stesso disegno del basso,variazioni sempre diverse. La prassi di inserire degli interventi "solistici" nell'organico della sonata a tre era abbastanza diffusa nella produzione strumentale italiana degli anni '60- 70 del Seicento e oltre, sia nel repertorio a stampa che in quello manoscritto. Le parti solistiche possono essere notate per esteso o, come nel caso di Colista, segnalate solamente dal disegno del basso. È interessante pero sottolineare l'esistenza di alcune testimonianze che documentano proprio a Roma questa pratica essecutiva già a partire dagli anni '10 del seicento. Nel Libro primo 
Esses relatos são correspondidos pelo mesmo relato de Raguenet, que esteve em Roma nos dois últimos anos do século XVII (quando Corelli estava com suas atividades musicais a pleno vapor), exposto no subcapítulo 2.7, bem como os tratados e modelos expostos neste capítulo e nos sugerem a importância de se abraçar o risco da ornamentação livre nos movimentos lentos das trio-sonatas italianas e que a prática, assim como sugerem a preceptiva e mais ainda os modelos, apesar das dificuldades, pode ser desenvolvida de forma bastante efetiva.

di sinfonie a quattro con il basso continuo (1615) del liustista - compositore Girolamo Kapsberger con il quale Colista era stato in contatto nei primi anni della sua formazione presso la corte barberiniana, molte composizioni presentano delle sezioni solistiche affidate a turno a ciascuna delle parti acute su un disegno del basso che può riproporsi identico ad ogni entrata delle voci superiori, oppure presentare un percoso modulante dalla tonica al quinto grado e ritorno, come accade ad esempio nella Sinfonia Duodecima à 2 canti, interamente strutturata secondo un alternarsi di parti solistiche - ora del canto primo, ora canto secondo - e di sezioni ' a 2'. 


\section{ANÁLISE DOS MODELOS}

O presente capítulo se destina às análises dos modelos de ornamentação propostos por Corelli em seu Opus V, bem como a apresentar as metodologias de análise utilizadas. Foi escolhida como modelo de análise o primeiro movimento da sonata $\mathrm{n} .3$ em dó maior e o adágio do segundo trietto de Telemann.

\subsection{SONATA DA CHIESA E SONATA DA CAMERA DE CORELLI}

Conforme já vimos, a obra de Corelli editada pelo compositor em vida possui seis opus, quatro dedicados à trio-sonata, um opus de sonata (o Opus V) e o último com concertos grossos. Cada volume foi editado com 12 obras, sendo que os últimos dois foram editados com as 12 obras dispostas em duas partes: as seis sonatas (Opus V) ou concerto (Opus VI) iniciais da chiesa e as outras seis da camera. Já os quatro livros iniciais dedicados às trio-sonatas foram editados com um único estilo de trio-sonata por livro, sendo os opus I e III de obras da chiesa e os opus II e IV de trios da camera.

Brossard (1703, p.43) diz que os italianos dividiam a sonata em dois gêneros:

O primeiro compreende, as sonatas da chiesa, ou seja, próprias para a igreja, que começam normalmente por um movimento grave e majestoso, proporcional à dignidade e santidade do lugar. Em seguida são tocadas algumas fugas alegres e rápidas e a isso chamamos sonatas. O segundo gênero, compreende as sonatas chamadas da camera, ou seja, próprias para o quarto. Elas são propriamente suítes de diversas pequenas peças próprias à dança, e compostas no mesmo tom e modo. Esse tipo de sonata começa normalmente por um prelúdio, ou pequena sonata que servem de preparação para os outros. Em seguida vêm a allemande, a pavana, a courante e outras danças ou árias sérias, na sequencia as gigas, as passacalhas, as gavotas, os minuetos, a chacona e outras árias alegres [rápidas]., e tudo isso composto na mesma tonalidade ou modo, e tocado sequencialmente , constitui uma sonata da camera. ${ }^{75}$

${ }^{75}$ Trad. Nossa do original: Le premier comprend, les Sonates da Chiesa, c'est à dire, propres pour l'Eglise, qui commencent ordinairement par um nouvement grave \& majesteux, proportionné à la dignitè \& saintetè du lieu; ensuite duquel on prend quelque Fugue gay \& animée, \& ce sont - là proprement ce qu'on apele Sonates. Le second genre, comprend les sonates qu'ils apellent da camera, c'est à dire, propres pour la chambre. Ce sont proprement des suítes de plusieurs petites pieces propres à faire danser, \& composèes sur le même Mode ou Ton. Ces sortes de Sonates se commencent ordinairement par un prelude, ou petite sonate qui sert comme de préparation à toutes les autres; Aprés viennent l'Allemande, la Pavane, la Courante, \& autres danses ou air serieux, ensuite viennent les gigues, les passacailles, les gavottes, les Menuets, les Chacones, \& autres airs gays, \& tout cela composé sur le même ton ou mode \& joué de suíte, composse une sonate da camera. 
A partir da edição de 1708 (por Estienne Roger) Brossard adiciona a seguinte definição ao vocábulo sonata:

\begin{abstract}
As sonatas contêm ordinariamente uma sequência de 4,5 ou 6 movimentos, mais frequentemente sobre um mesmo tom; às vezes encontramos alguns [compositores] que mudam de tom um ou dois movimentos da peça, mas sempre retornam ao tom principal e compõem ao menos um movimento nessa tonalidade antes de acabar. A sonata da chiesa se distingue daquela chamada da camera ou balleti quando os movimentos das da chiesa são os adágios, os largos e misturam-se com fugas que são os allegros, no lugar que daquelas que são da camera são compostos, após os adágios, de arias, de movimentos regrados como uma allemande, uma courante uma sarabanda e uma giga, ou bem depois de um preludio, uma allemande, um adágio, uma gavota, uma bourrée e um minueto. Vejam como modelo a obra de Corelli. $^{76}$
\end{abstract} (BROSSARD, 1708, p.140)

A definição parece ser calcada na forma corelliana. À parte dessa relação do compositor como autocritas, Brossard nos aponta como uma relação direta do estilo das sonatas (da chiesa ou da camera) com um decoro de ocasião. Entretanto uma sonata, trio-sonata ou concerto ser escrito em um determinado estilo de ocasião não necessariamente significa que a obra inteira terá todos os seus movimentos com o mesmo decoro.

Vimos (no subcapítulo 1.5.2) como o decoro media a relação entre matéria e forma. Vimos como são constituídos os estilos (baixo, médio e alto), suas finalidades (comover, deleitar e ensinar), suas ocasiões conectadas às paixões do discurso (igreja, teatro e câmara) e suas escritas (estrita ou livre), porém faltou considerar a relação do discurso com um contexto ainda mais amplo que sua própria dispositio (ou forma) comporta, a relação de um discurso com outro. Sobre isso Olivier Reboul (1998), explicita: “(...) se a retórica é a arte de persuadir pelo discurso, é preciso ter em mente que o discurso não é e nunca foi um acontecimento isolado. Ao contrário, opõe-se a outros discursos que o precederam ou que lhe sucederão"

Assim devemos ter a consciência que uma série de 12 composições editadas são dispostas como discursos que dialogam constituindo cada uma um argumento de um discurso maior, sendo elas partes de uma dispositio da série inteira, da mesma maneira que diferentes

\footnotetext{
${ }^{76}$ Trad nossa do original: La sonate contient ordinairement une suitte de 4, 5 ou 6 mouvemens, le plus solvente sur um même ton; quoi qu'on em trouve quelques unes quichangent de Ton à um ou deux des mouvemens de la piece, mais on reprend le premier Ton \& on composse du moins um mouvement dessus avant de finir, La sonate da Chiesa se distingue de cella quón nome da camera ou Balletti, em ce que les mouvemens de celles da chiesa sont des Adagio, des large \&, mèlez de fugues qui em sont les Allegros, au lieu que les mouvements de celles da camera sont composez; aprés les Adagio, d'airs d'um mouvement reglé, comme une Allemande, une Courante, une Sarabande \& une gigue, ou bien après um prelude, une Allemande, um Adagio une Gavotte, une Bourèe, et un Menuet. Voyez pour modele les ouvrages de Corelli.
} 
árias, danças, interlúdios, recitativos fazem parte de um oratório, uma ópera, um ballet ou outro gênero maior. Indo além de uma publicação de séries de sonatas, de cantatas ou qualquer gênero disposto em um mesmo livro, um programa de concerto poderia ter (e na verdade até hoje ainda tem!) uma dispositio variada. por exemplo: em um programa hipotético, uma sonata poderia ser o exordium precedendo uma ária em afeto condizente com a narratio daquele discurso, uma ou mais suítes podiam ser a partitio, uma outra cantata disposta como um confutatio e uma outra cantata uma peroração que poderia preceder uma conclutio coincidente com uma outra sonata e este repertório podia ser a música de um jantar que iria deleitar uma família nobre, ou a música que iria comover os convidados de um mecenas afirmando seu poder, sua erudição, suas virtudes e etc..

Assim como podemos encontrar uma boa disposição de diferentes sonatas em uma publicação ou no programa de uma ocasião, também é possível achar uma boa disposição entre os movimentos de uma sonata, ou entre as diferentes seções de um mesmo movimento.

Dessa forma ao analisar uma sonata como por exemplo a Opus V n. 1 de Corelli em ré maior, temos um exordium no primeiro movimento, uma narratio no segundo, uma partitio no moto perpetuo do terceiro movimento, uma confutatio no adágio do quarto movimento e por fim uma confirmatio na giga final. Cada mini discurso ou parte do discurso da sonata inteira possui seu próprio estilo, à parte do estilo "de igreja" da sonata toda, Dessa maneira podemos ter um estilo médio no primeiro movimento, um estilo alto e estrito no segundo (a fuga aqui como narratio é o principal argumento da sonata e portanto é o cerne do discurso), o moto perpetuo um estilo médio porém estrito, o quarto um escrita livre com um estilo entre o médio e o baixo e por fim a giga ainda em estilo médio, porém com um caráter mais estrito e fugal. Assim a sonata como um todo tem um estilo entre o teatral e a igreja. ${ }^{77}$

Isso explica, por exemplo, porque a terceira edição do Opus V, comtemplou seis sonatas que são da igreja. Todas essas obras possuem uma ocasião de igreja no seu argumento principal em escrita estrita (fugal), mas a fuga se encontra no segundo e no último movimento da sonata. Em geral o primeiro e o terceiro (dependendo da dispositio especifica, o quarto) movimentos possuem uma escrita livre, exigindo do intérprete (ou “orador" musical) uma ornamentação rebuscada, conforme podemos verificar no exemplo com a pena do próprio Corelli.

Assim o decoro das demais obras (as seis sonatas da camera, as 48 trio-sonatas e os 12 concertos grossos) podem ou não ter partes em escrita livre ou estrita e em estilo alto, médio ou baixo, o que exige de um intérprete "decoroso" uma análise adequada que envolva, a parte da 
própria dispositio, quais são os discursos distintos em cada movimento da sonata e em cada sonata no livro.

\subsection{METODOLOGIA DAS ANALISES DESCRITIVAS}

Uma análise descritiva foi aplicada nos movimentos lentos das três primeiras triosonatas do Opus III de Corelli escolhidas como modelo e em dois movimentos dos modelos utilizados (um dos triettis e outro das sonatas do opus V de Corelli), com especial foco no modelo do Trietto de Telemann escolhido. Nesse último, o principal objetivo foi elucidar a aplicação dos ornamentos em contexto de trio-sonatas e sua distribuição pelas vozes; outro foco foi o de compreender melhor a distribuição dos ornamentos ao longo da estrutura dos movimentos lentos, sendo este foco aplicável a todos os modelos de ornamentação livre escolhidos. Por fim, a análise da estrutura dos esqueletos do Opus III possibilitou, por meio de uma comparação com a estrutura dos outros modelos, lançar uma luz sobre a construção do modelo didático de ornamentação para essas trio-sonatas.

São elementos dessas análises, porém não seu único foco, a condução harmônica e melódica das peças e das vozes, as cadências e, principalmente, as diferentes texturas ao longo da obra. Para tipificar as texturas musicais analisadas nesta dissertação, foi considerada a tipificação clássica contida no Grove (1994); homofônica, heterofônica, coral e melodia acompanhada; além da importação dos conceitos de espécie contrapontística do Gradus ad Parnassum de Johann Joseph Fux (1725). Dessa forma, em pequenos trechos podemos classificar uma estrutura polifônica heterorítmica de acordo com a relação das vozes dos violinos em relação ao baixo ou entre eles (entretanto, consideraremos como cantus firmus a segunda voz utilizada na comparação). O conceito de espécie foi aplicado aos trechos destacados: a primeira espécie se refere a uma nota contra outra (sem polirritmia entre as vozes observadas); a segunda implica uma diminuição de duas notas da primeira voz da análise contra uma da voz estipulada como cantus firmus; na terceira espécie, serão quatro notas contra uma; e, por último, o mais importante conceito, que é o de quarta espécie, em que uma voz está sincopada em relação a outra preparando dissonâncias, em especial nos tempos fortes.(suspensão) $)^{78}$

\footnotetext{
78 Não consideraremos o contraponto florido, pois os termos não serão utilizados para designar o todo do movimento e sim trechos destacados.
} 
Foi edificada também, para o caso de obras com modelos de ornamentação propostos, uma confrontação descritiva entre modelo e esqueleto, a fim de elucidar a aplicação dos ornamentos sob o ponto de vista da forma e da textura musical.

Para a comparação de forma musical, optamos pelo conceito de dispositio, de matriz retórico-musical. Por ser um dos principais recursos de composição do barroco, empresta uma poderosa medida formal de análise, muito mais próxima do pensamento composicional da época, sobretudo na composição das sonatas da chiesa, forma em que se encontram a maioria dos modelos analisados e que não estão conectados aos movimentos de dança das suítes com esquemas formais mais difundidos na atualidade.

\subsection{METODOLOGIA DE ANÁLISE DOS ORNAMENTOS E CONSTRUÇÂO DE TABELA}

Uma análise e catalogação dos ornamentos, foram aplicados a quatro das seis sonatas editadas com ornamentação proposta do Opus $V$ de Corelli (edição de Estienne Roger no século XVIII).

Adotando alguns critérios semelhantes ao do artigo de Luiz Beduschi (2012), o objetivo primordial dessa análise foi procurar identificar padrões de ornamentações que possam ser utilizados como referência para criar um repertório de ornamentos livres a ser utilizado na interpretação de outras obras e, principalmente, na aplicação dessa maneira de ornamentar as trio-sonatas do Opus III. O resultado dessa análise foi consolidado na tabela de ornamentação anexada no próximo sub-capítulo. Como critério de comparação, buscamos as menores estruturas ornamentadas em cada discurso musical, que se revelam na observação das relações intervalares entre as notas estruturais da versão esqueleto ${ }^{79}$; porém, a ornamentação livre é um componente tão enraizado no gosto italiano que, muitas vezes, ao compor uma obra e notar sua versão esqueleto para edição, o compositor já propõe uma camada inicial de ornamentos, muitas vezes quase imperceptível. Neumann (1983) argumenta que a ornamentação pode ser tocada e notada em diferentes camadas e que a maioria das versões editadas já tem uma camada inicial, podendo essas camadas, quase sempre, serem aumentadas ou mais diminuídas. Isso foi identificado nas obras analisadas e, dessa forma, como critério para a escolha de relações intervalares relevantes da versão esqueleto, foram também considerados os casos de notas que, apesar de não notadas sequencialmente, poderiam conectar-se harmonicamente caso fossem

\footnotetext{
${ }^{79}$ Versão com ausência completa de ornamentos. O termo normalmente designa a edição da peça na qual se espera que o intérprete adicione seus ornamentos.
} 
aumentadas. A Figura 19 apresenta o exemplo de notação do primeiro compasso do adágio inicial da Sonata Opus V n.4 de Arcangelo Corelli, editada e ornada pelo compositor em parceria com Estienne Roger.

Figura 19: Notação do compasso 1 do adágio inicial da Sonata Opus V n.4 de Arcangelo Corelli

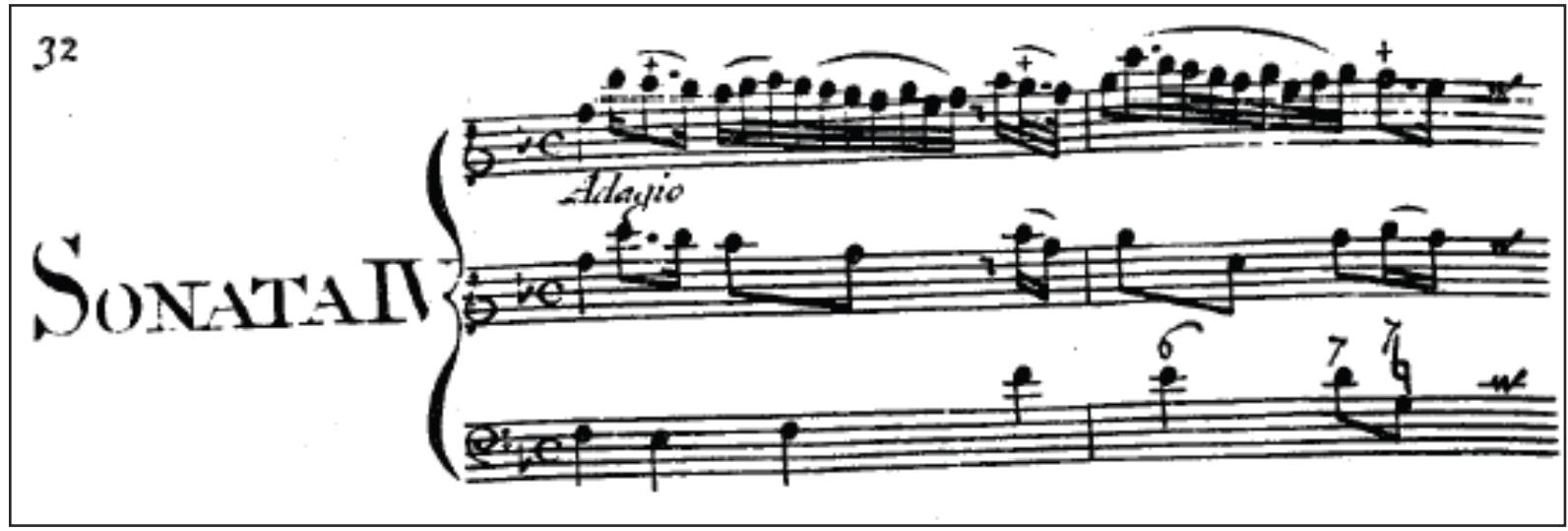

Fonte: Corelli Opus V, edição de Estienne Roger (1711).

Na versão esqueleto, apresentada no segundo pentagrama (Fig. 19), ao fá inicial se sucede um dó que, no primeiro pentagrama, é embelezado com uma apoggiatura, categorizando, dessa maneira, um exemplo de ornamentação em um salto de quinta. No segundo tempo, temos esse dó precedendo um si bemol, que tem em sua própria apoggiatura da versão ornada com o trilo um embelezamento dessa relação de segunda maior; porém, harmonicamente esse dó está diretamente conectado ao lá do terceiro tempo, o que permitiria claramente a aumentação indicada na Figura 20.

Figura 20: Notação do compasso 1 do adágio inicial da Sonata Opus V n.4 de Arcangelo Corelli, com aumentação do segundo tempo

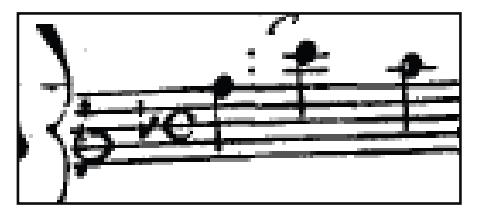

Fonte: Elaboração nossa, a partir do compasso 1 do adágio inicial da Sonata Opus V n.4 de Arcangelo Corelli (1711)

Assim, esse mesmo dó do segundo tempo pode produzir um exemplo de ornamentação de terça menor (dó-lá), além do exemplo de segunda maior já explícito na versão esqueleto (dó- 
si bemol) da edição, e assim por diante. Porém, o fá do primeiro tempo não pode se conectar diretamente ao lá do terceiro, pois teríamos uma dissonância não concluída e não disposta na cifragem, o que faz com que consideremos apenas a quinta entre ele e o dó no segundo tempo.

Além da tabela de ornamentos classificada por relações intervalares entre as notas da versão esqueleto, trabalhamos numa outra que separe as cadências, classificadas pelos seus tipos, com o confronto entre a versão esqueleto e a proposta de cada modelo. A finalidade dessa segunda tabela é a de observamos o repertório de ornamentos da primeira tabela combinados em estruturas um pouco maiores, mas não tão grandes como as que precedem as cadências, seguindo o exemplo de Quantz (1753), que em seu tratado provê seu leitor de um repertório de cadências ornadas.

\subsection{ANÁLISE DESCRITIVA DOS MODELOS DO OPUS V}

\section{Sonata Op. 5 n.3 primeiro movimento - Adágio:}

Figura 21: Partitura do primeiro movimento da Sonata 3 de Corelli Opus 5

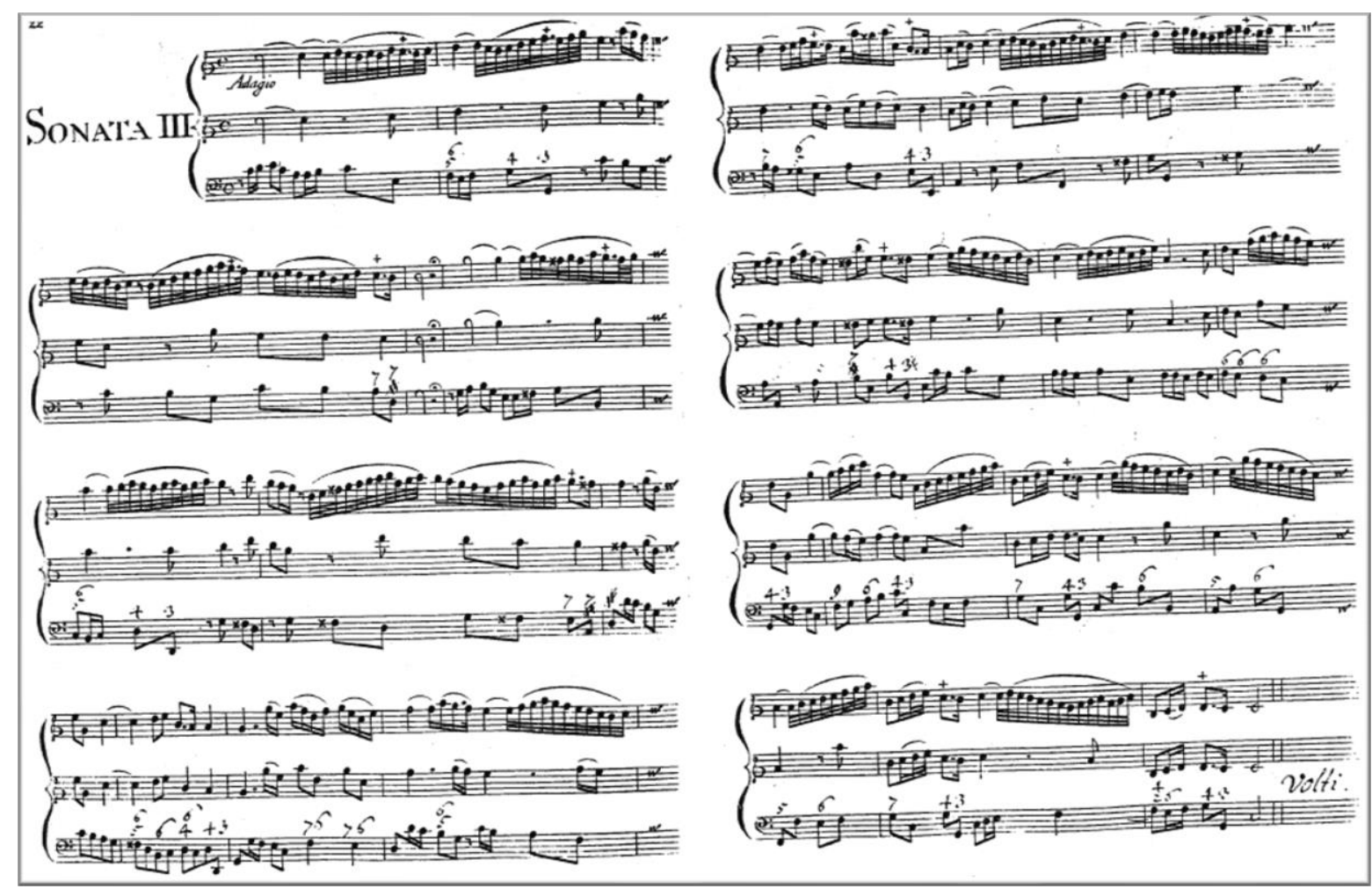

Fonte: Corelli, A Opera quinta, 1700. Estienne Roger, 1711. 
Do início até a segunda metade do compasso 2 (Fig. 21), as notas longas dos violinos seguem uma progressão ascendente em segundas, do dó até o mi, enquanto o baixo caminha, com a insistente repetição da combinação de pausa de colcheia precedendo duas semicolcheias e duas colcheias (suspiratio ${ }^{80}$ ). Essa combinação gera o seguinte inciso em anapeste ${ }^{81}$, que permeia as duas vozes e impulsiona todo o movimento (Figura 22):

Figura 22: Detalhe do inciso do baixo

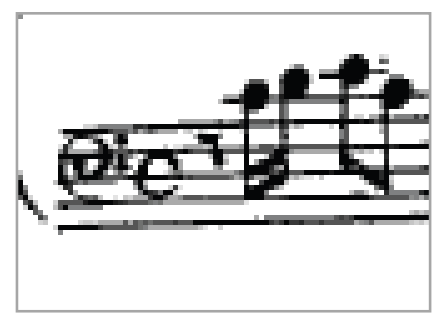

Fonte: Corelli, A Opera quinta, 1700. Estienne Roger, 1711. Edição nossa.

É interessante observar que os ornamentos que conectam essas notas longas na voz do violino, na versão de 1711, terminam com uma diminuição do mesmo inciso, conforme observamos na Figura 23:

Figura 23: Detalhe dos primeiros ornamentos com o inciso diminuído em destaque.

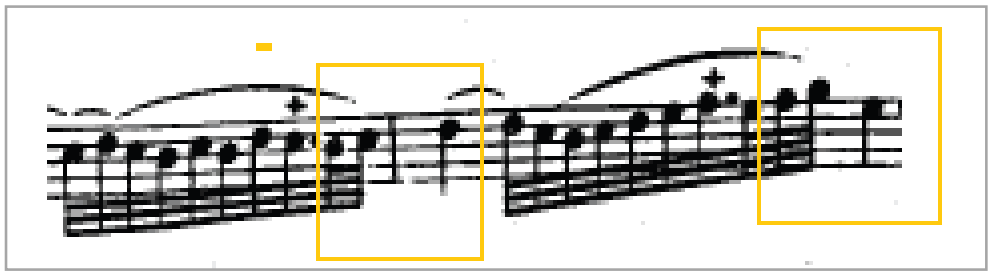

Fonte: Corelli, A Opera quinta, 1700. Estienne Roger, 1711. Edição nossa.

No detalhe desse membro de frase (Figura 24) e no movimento como um todo (Figura 21), a ornamentação sugerida ao violino é aplicada onde não entre em competição com o inciso principal quando este é tocado pelo baixo, de forma a permitir uma linha de regência que alterne os incisos, diminuições ou ainda diminuições do próprio inciso. Esses compassos iniciais ainda encerram o Captatio benevolentiae, apresentando o argumento principal do discurso, seu inciso,

\footnotetext{
${ }^{80}$ Suspiratio: segundo Bartel (1985) é uma figura de retórica musical com o uso deliberado de pausas, normalmente um inciso escrito de forma acéfala e se relaciona ao efeito de suspirar e de saudade.

${ }^{81}$ Anapeste: é um dos pés métricos do poema formado por duas sílabas átonas e uma tônica; Segundo George Houle (1987), os ritmos do poema, ou pés métricos da antiguidade clássica, emprestaram insumos aos músicos para o sistema de organização de métrica musical conhecido como Rythmopoeia.
} 
a tonalidade e o afeto da obra; a utilização desse inciso diminuído dentro dos ornamentos sugeridos ainda empresta mais força para o caráter esperado desse item da dispositio do discurso.

Figura 24: Detalhe dos compassos 1 e 2.

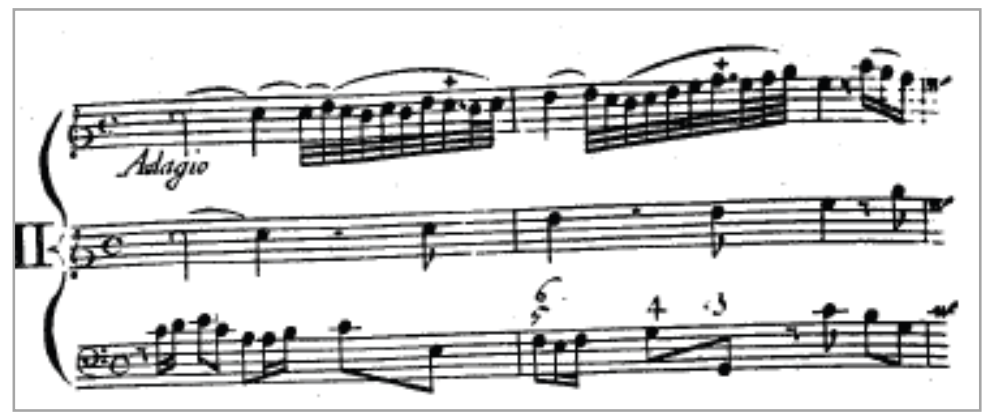

Fonte: Corelli, A Opera quinta, 1700. Estienne Roger, 1711. Edição nossa.

Nos dois compassos seguintes (Fig. 25), a frase se encerra numa exuberante cadência à dominante. Neste segundo membro de frase, a textura imitativa, com um inciso de três colcheias que se alternam entre as vozes, é extensamente decorada por Corelli/Roger e culmina numa fórmula cadencial em que a voz soprano tem um trilo sobre uma sétima resolvendo na terça, ${ }^{82}$ conforme observamos na figura 24.

Figura 25: Detalhe dos compassos 3 e 4.

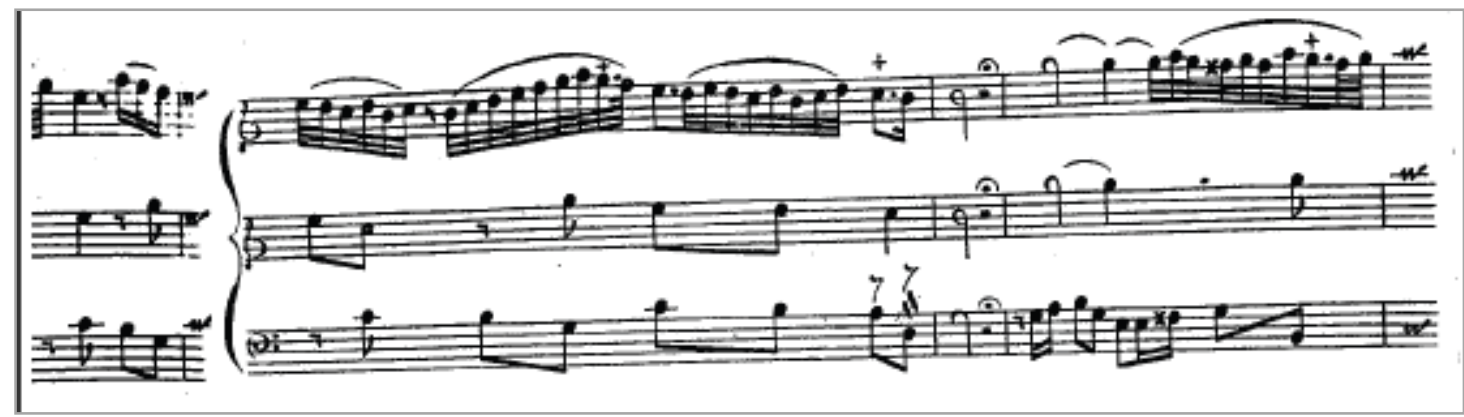

Fonte: Corelli, A Opera quinta, 1700. Estienne Roger, 1711. Edição nossa.

O fim dessa primeira frase (Figura 25) gera um caráter suspensivo que permeia o movimento como um todo e encerra o exordium e a elaboração do partitio. Novamente é interessante observar como a ornamentação dos compassos 3 e 4 empresta uma maior elaboração à matéria do partitio desse discurso.

\footnotetext{
${ }^{82}$ Nesse caso é recomendável começar o trilo pela nota real, a fim de não comprometer a dissonância.
} 
Em seguida (Figura 26), todo material apresentado nos primeiros compassos é novamente exposto, dessa vez na tonalidade da dominante, separados por uma grande pausa. Ao ornamentar o novo trecho, Corelli/Roger se utiliza dos mesmos ornamentos, com o inciso principal diminuído nos primeiros dois compassos, porém lança mão de repetir o padrão no compasso seis, conforme a figura a seguir (Figura 26):

Figura 26: Detalhe dos C. 5, 6 e 7 (parte inferior) comparados com os C. 1, 2 e 3 (parte de cima)

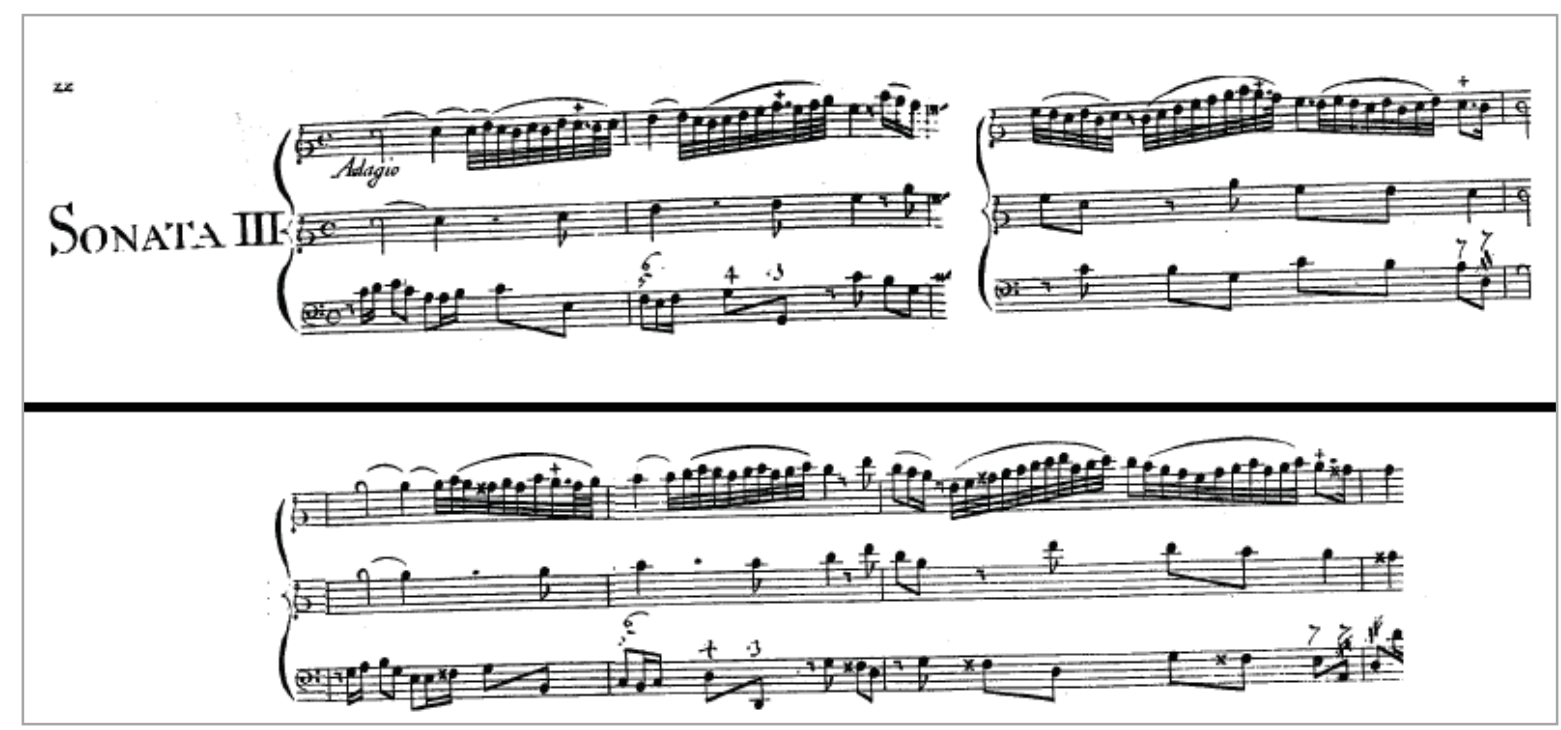

Fonte: Corelli, A Opera quinta, 1700. Estienne Roger, 1711. Edição nossa.

Duas hipóteses são levantadas a respeito da não padronização desses ornamentos. A primeira se relaciona a uma tentativa retórica de não repetir o que foi dito de forma tão literal; a segunda é de ordem mais prática e menos poética: simplesmente evitar que o violinista precise tocar o mi agudo (especialmente o músico amador, principal consumidor da edição) e tenha de tocar o trecho na quarta posição do violino. ${ }^{83}$

Os compassos 8 e 9 (Figura 27) preparam uma cadência em sol, com o diálogo de incisos entre o baixo e o violino cortado por uma caminhada em colcheias elaborada na voz do baixo até a cadência. Esse movimento numa cadência tão conclusiva reforça o caráter da narratio,

\footnotetext{
${ }^{83}$ No violino, os dedos da mão esquerda encurtam as cordas para produzir notas diferentes; porém, os 4 dedos não conseguem permear todo o braço sem que a mão esquerda se mexa, o que torna necessário que a mão ora esteja mais próxima à pestana, ora mais próxima do fim do espelho, para notas mais agudas. A posição próxima à pestana (posicionada de forma diatônica) é chamada primeira posição e é a mais utilizada; ao trocar o segundo dedo pelo primeiro, afastando mais da pestana, tem-se a segunda posição, e assim por diante. Em 1700, era raro o músico diletante passar da terceira posição.
} 
remetendo a uma história que precede a propositio nos compassos 10 e 11, onde os incisos aparecem 6 vezes.

Figura 27: Detalhe dos compassos 8, 9, 10 e 11.

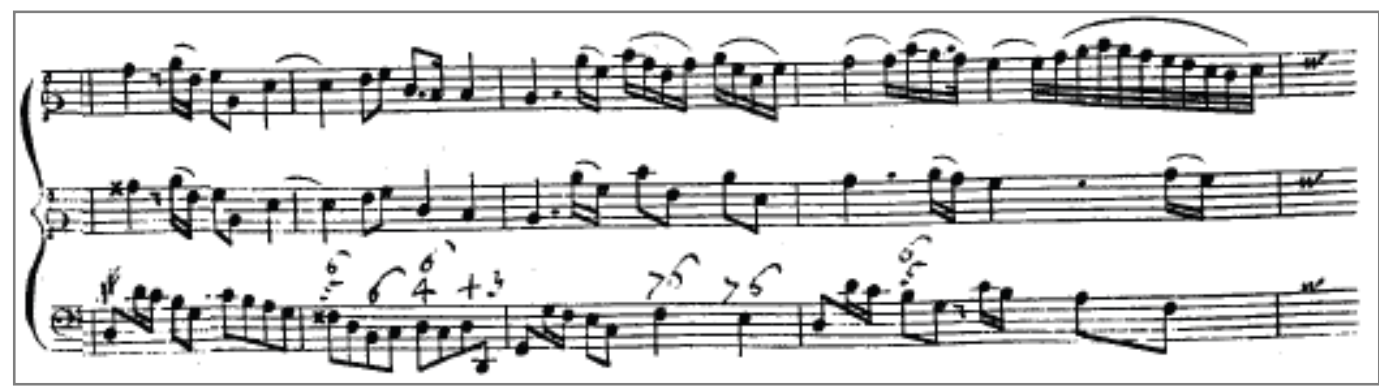

Fonte: Corelli, A Opera quinta, 1700. Estienne Roger, 1711.

Em 8 e 9 (Figura 27) é interessante observar que a ornamentação é mínima, talvez para não correr o risco de um diletante diminuir, ao se arriscar a improvisar, de forma a competir com as colcheias do baixo, ou esperar que o caráter dos incisos que aparecem 6 vezes na versão esqueleto de C.10 e C.11 - e ainda são reforçados pelos ornamentos de C.10.3 e C.10.4 que o combinam em stretto - sejam prejudicados por uma ornamentação de "mau gosto" onde o primeiro trecho fique mais exuberante que o segundo. Ainda no compasso 11, é interessante observar variadas diminuições do inciso principal.

O próximo trecho é o confutatio do movimento (Figura 28), que vai do compasso 12 até a cadência em C.15.3 e se trata de uma tortuosa caminhada modulante, passando por tons menores como o relativo (lá menor) e encerrando em mi menor. Em contraste a este afastamento tonal (tendo em consideração este contexto), o inciso principal é reforçado pelas vozes em mais 8 repetições, sendo em 12.3 , dessa vez já na versão esqueleto, o mesmo tipo de diminuição de 10.3 .

Figura 28: Detalhe dos compassos 12, 13, 14 e 15.

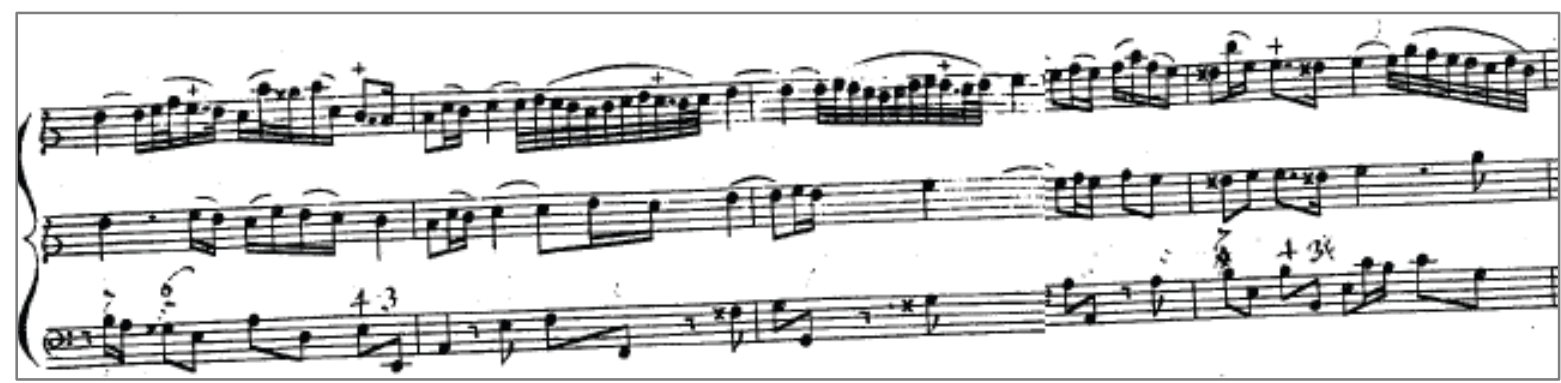

Fonte: Corelli, A Opera quinta, 1700. Estienne Roger, 1711. Edição nossa.

Quanto à ornamentação, um novo tipo de diminuição do inciso principal, no compasso 12 (Figura 28), parece ampliar seu efeito, ao combinar diferentes diminuições dessas duas 
semicolcheias; ora em fusas conectadas a uma semicolcheia pontuada, ora com a semicolcheia pontuada precedendo uma fusa (como num pontê ${ }^{84}$ francês), o trecho empresta à cadência perfeita em lá menor, de 12 para 13, uma exuberância. De 13 até a cadência de 15 há uma progressão harmônica em segundas, onde o violino utiliza o inciso principal na notação de 1700 . $\mathrm{Na}$ versão ornada, o autor opta por variar o padrão, não ornando na primeira vez, repetindo na segunda e na terceira vez o mesmo padrão de ornamento de 5.4 e, finalmente, quebrando o padrão por não ornar na quarta (C.14.3.2) e diminuindo em semicolcheias as colcheias do último tempo, preparando a cadência de 15 .

Figura 29: Detalhe do trecho entre C. 15.3 até 19.3

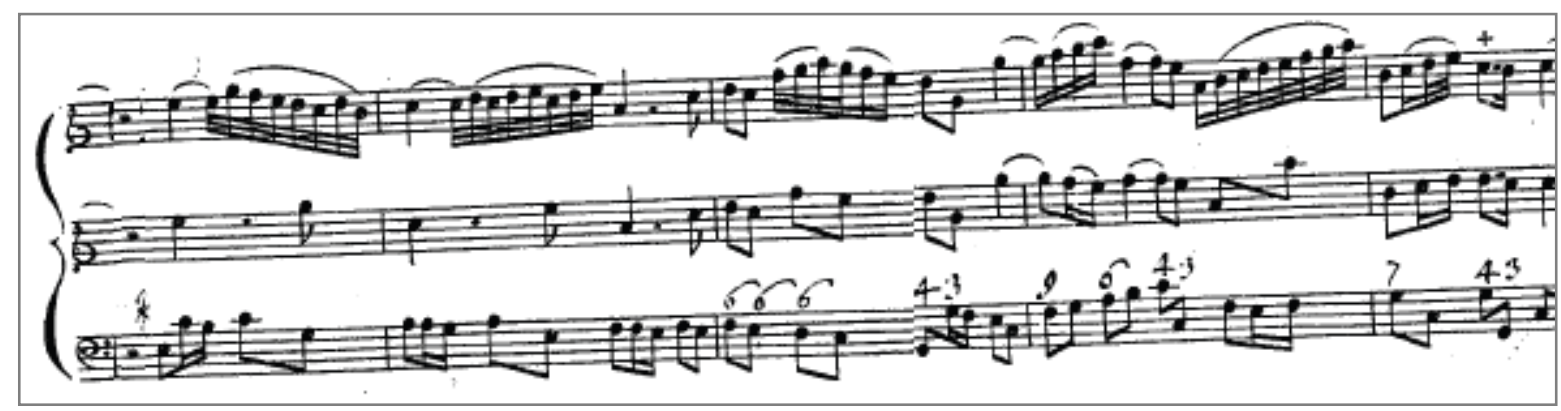

Fonte: Corelli, A Opera quinta, 1700. Estienne Roger, 1711. Edição nossa.

De c.15.3 até a cadência maior em dó maior em 19.3 (Figura 29), temos o peroratio, com uma retomada da tonalidade principal e a textura inicial, onde o baixo caminha em colcheias permeadas pela repetição do inciso principal e o violino possui notas longas que são diminuídas onde o baixo não possui uma repetição do inciso. Na ornamentação desse trecho, Corelli abandona o padrão de repetição das figuras (muito comum em outras sonatas) do início do movimento e provê seu leitor com um rico repertório de novos ornamentos.

\footnotetext{
${ }^{84}$ Pontê: um tipo de inegale, um recurso utilizado em overtures franceses, onde uma sequência de notas possui um padrão irregular de distribuição rítmica. No pontê há um exagero da pontuação da nota longa, utilizado normalmente em peças de caráter pomposo.
} 
Figura 30: Detalhe do trecho a partir de 19.3 até o final.

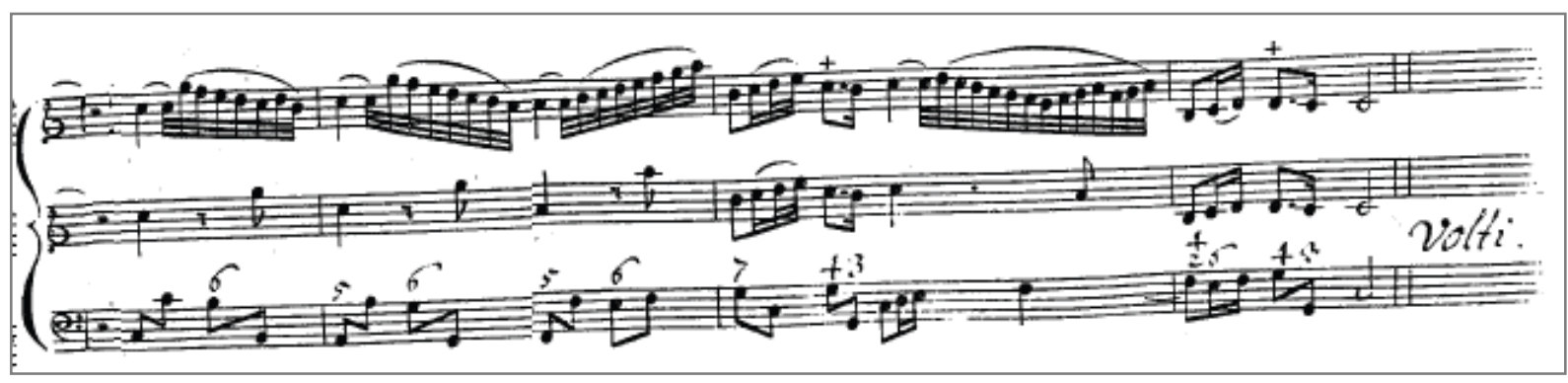

Fonte: Corelli, A Opera quinta, 1700. Estienne Roger, 1711. Edição nossa.

No último trecho, a partir da cadência de 19 até o final (Figura 30), há a confirmatio do movimento, em que a textura imitativa volta a assumir um papel; entretanto, o inciso dos compassos 2 e 3 passa a ser substituído no baixo por um contraponto a duas vozes conduzido por padrões melódicos quebrados, enquanto o violino segue o padrão de uma semínima com uma anacruse de colcheia para a próxima semínima, que ao longo das repetições ganha intensidade nos saltos que passam de quinta (sol-dó do C.19.4 para C.20) para sétima nas próximas repetições. Na versão ornada, esses saltos ganham ornamentos variados a cada repetição, até que, em 21 e 22, a grande cadência final da obra seja preparada. Em 21 há um retorno do inciso principal - dessa vez diminuído desde a primeira edição em C.21.1 - que precede uma cadência perfeita - dessa vez modestamente ornada por um único trinado em C.21.2 -, a fim de contrastar com a exuberância do salto de nona na grande cadência final, no qual a edição de 1711 sugere sua maior fioritura (serão 13 notas; as maiores até então exigem 11 notas). Essa fioritura se encerra na cadência de 22, que além de ser ornada apenas com um trilo no segundo tempo, carrega um detalhe importante: em todo o movimento, será a única vez que o compositor insere seu inciso principal com o violino e o baixo juntos em homofonia. 


\subsection{ANÁLISE DESCRITIVA DOS MODELOS DOS TRIETTI DE TELEMANN}

Devido a sua complexidade foi escolhido o andante do segundo trietto de Telemann para essa análise:

Trietto II segundo movimento, Andante:

Figura 31: Partitura do segundo movimento do Trietto II de Telemann, 1731

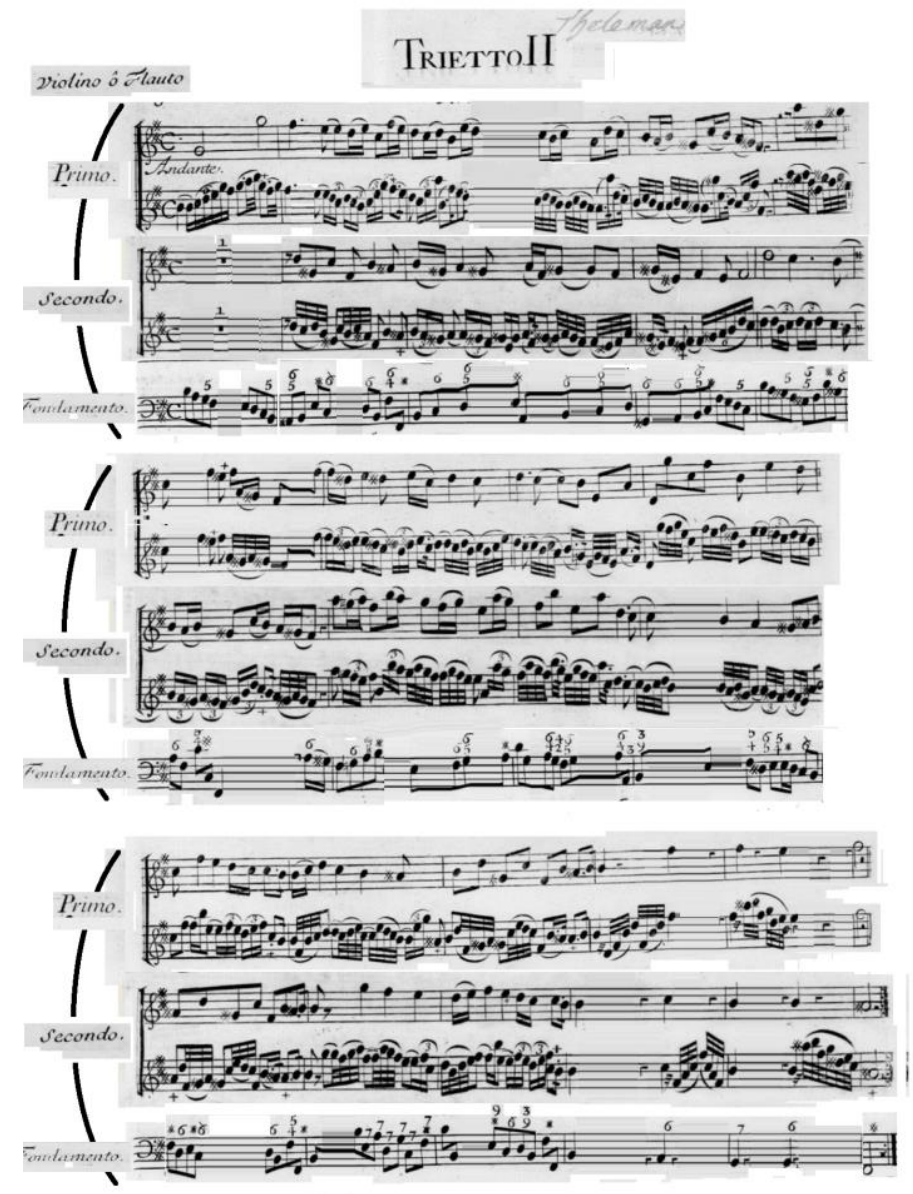

Fonte: Le Clerc 1737.

Os três triettos do Telemann são dividos em três movimentos cada, com a forma rápidolento-rápido. Em termos de dispositio temos nos movimentos lentos um confutatio da obra, as tonalidades são trocadas e nesse trietto com o tom original em ré maior nos movimentos rápidos, esse padrão se repete com o andante se apropriando da tonalidade relativa, si menor. 
O baixo do movimento inteiro é regular com um ritmo em colcheias com exceção dos últimos quatros compassos em que o compositor faz uma típica cadencia a dominante com um baixo descendente de tetracorde pontuando esse ritmo harmônico em mínimas.

O exordium do movimento apresenta o tema em si menor pelo primeiro violino e é respondido com um contratema do segundo violino a partir do segundo compasso essa longa frase é encerrada no meio do quarto compasso quando, em elisão, o segundo violino assume o mesmo tema do inicio na nova tonalidade. O tipo de textura encontrada nesse exemplo é tardia em relação aos modelos corellianos, se aproximam mais de um estilo germânico muito apropriado por Quantz, onde um movimento começa com um tema exposto com o primeiro ou segundo violino acompanhado do baixo e depois repetido pela outra voz acompanhada além do baixo pela primeira em um contratema. Apesar desta distancia temos alguns bons trechos nas sonatas corellianas onde há uma imitação (normalmente com frases mais curtas) semelhantes, como o adágio da sonata op. II n.2, ou trechos da peroração do primeiro movimento da sonata n. 3. Essa analogia nos revela uma ferramenta bastante útil, podemos supor que a imitação exata do embelezamento realizado pela primeira voz a apresentar o tema crie um efeito em eco semelhante aos descritos por D’Ovidio (op. cit) na realização das sonatas de Collista.

A partir do sexto compasso as duas vozes entram em uma marcha descendente em quarta espécie buscando a dolência dessas dissonâncias até a cadencia em si menor no décimo terceiro compasso que inicia a ponte em tetracorde para a dominante. É interessante observar que Telemann não se intimida com elas e não só já propõe uma ornamentação de primeira camada na versão esqueleto como incentiva os intérpretes a se arriscarem em uma exuberante ornamentação do mesmo trecho, sempre respeitando as dissonâncias. Nesse movimento temos um valioso exemplo de textura em quarta espécie, bastante recorrente nas trio-sonatas corellianas e italianas de uma forma geral, ornado pelas duas vozes solistas.

Por fim a ponte revela uma prática de alternância entre os solistas neste tipo de cadência que encerra esse movimento, preparando ao retorno da tonalidade de ré maior no futuro terceiro movimento que encerrará o trietto. 


\subsection{BIBLIOTECA DE ORNAMENTOS DO OPUS V}

Tabela 7: Ornamentos da sonata Opus V n.1, primeiro movimento Grave-allegro-adágiograve-allegro-adágio:

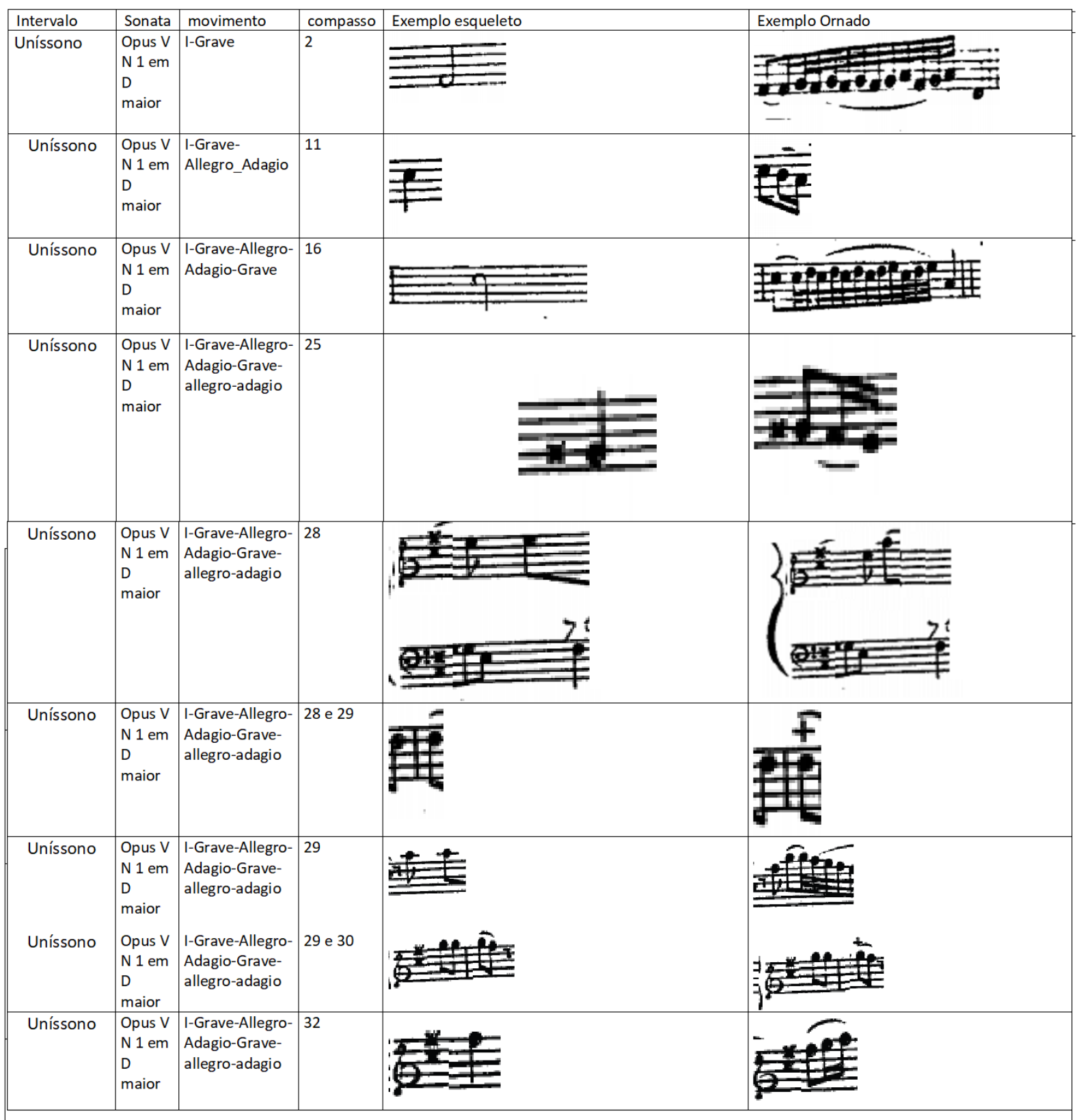




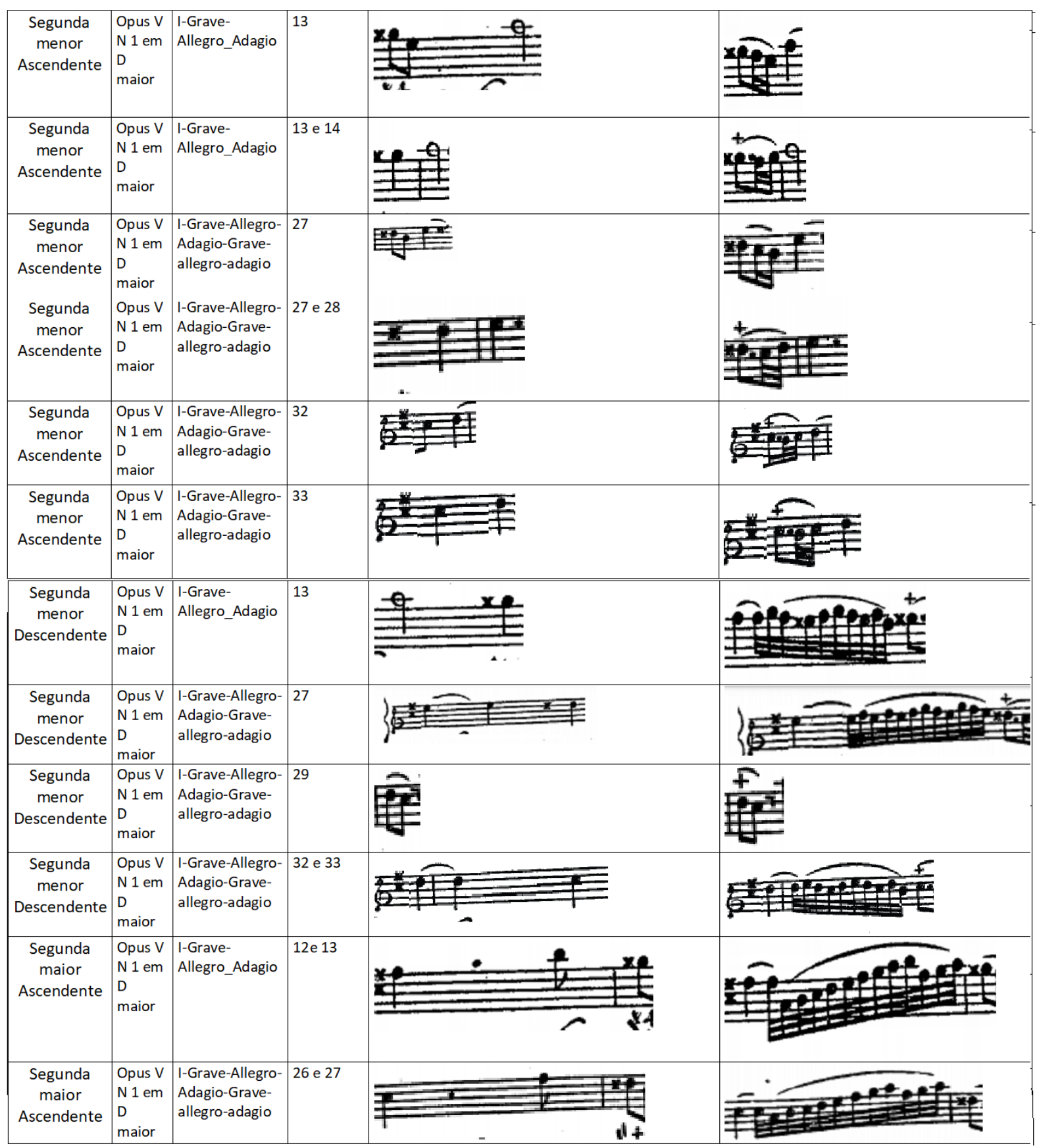




\begin{tabular}{|c|c|c|c|c|c|}
\hline $\begin{array}{l}\text { Segunda } \\
\text { maior } \\
\text { Ascendente }\end{array}$ & \begin{tabular}{|l} 
Opus V \\
N1 em \\
D \\
maior
\end{tabular} & \begin{tabular}{|l|} 
I-Grave-Allegro- \\
Adagio-Grave- \\
allegro-adagio
\end{tabular} & 33 e 34 & W & 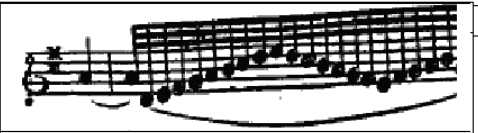 \\
\hline $\begin{array}{l}\text { Segunda } \\
\text { maior } \\
\text { Ascendente }\end{array}$ & $\begin{array}{l}\text { Opus V } \\
\text { N1 em } \\
\text { D } \\
\text { maior }\end{array}$ & \begin{tabular}{|l|} 
I-Grave-Allegro- \\
Adagio-Grave- \\
allegro-adagio
\end{tabular} & 35 & 凐 & 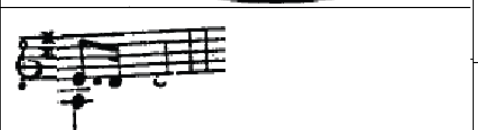 \\
\hline $\begin{array}{l}\text { Segunda Maior } \\
\text { Descendente }\end{array}$ & $\begin{array}{l}\text { Opus V } \\
\text { N1 em } \\
\text { D } \\
\text { maior }\end{array}$ & \begin{tabular}{|l|} 
I-Grave-Allegro- \\
Adagio-Grave- \\
allegro-adagio
\end{tabular} & 33 e 34 & 車 & 氺 \\
\hline $\begin{array}{l}\text { Segunda Maior } \\
\text { Descendente }\end{array}$ & $\begin{array}{l}\text { Opus V } \\
\text { N1 em } \\
\text { D } \\
\text { maior }\end{array}$ & 1-Grave & 1 & WI & $\frac{2+1}{10.7}$ \\
\hline $\begin{array}{l}\text { Segunda } \\
\text { Maior } \\
\text { Descendente }\end{array}$ & $\begin{array}{l}\text { Opus } \\
\text { VN1 } \\
\text { em D } \\
\text { maior }\end{array}$ & I-Grave & 2 & $\Longrightarrow+\frac{1}{\equiv \equiv}$ & $=$ \\
\hline $\begin{array}{l}\text { Segunda } \\
\text { Maior } \\
\text { Descendente }\end{array}$ & $\begin{array}{l}\text { Opus } \\
\text { VN1 } \\
\text { em D } \\
\text { maior }\end{array}$ & $\begin{array}{l}\text { I-Grave- } \\
\text { Allegro_Adagio }\end{array}$ & 10 e 11 & 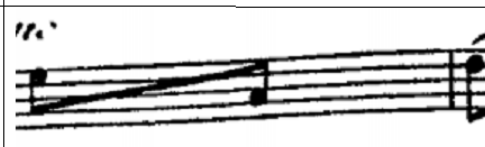 & $\frac{7}{2 x}$ \\
\hline $\begin{array}{l}\text { Segunda } \\
\text { Maior } \\
\text { Descendente }\end{array}$ & $\begin{array}{l}\text { Opus } \\
\text { VN } 1 \\
\text { em D } \\
\text { maior }\end{array}$ & $\begin{array}{l}\text { I-Grave- } \\
\text { Allegro_Adagio }\end{array}$ & 11 e 12 & 㘫 & \\
\hline $\begin{array}{l}\text { Segunda } \\
\text { Maior } \\
\text { Descendente }\end{array}$ & $\begin{array}{l}\text { Opus } \\
\text { VN 1 } \\
\text { em D } \\
\text { maior }\end{array}$ & $\begin{array}{l}\text { I-Grave- } \\
\text { Allegro- } \\
\text { Adagio-Grave }\end{array}$ & 15 & 11 & \\
\hline $\begin{array}{l}\text { Segunda } \\
\text { Maior } \\
\text { Descendente }\end{array}$ & $\begin{array}{l}\text { Opus } \\
\text { VN1 } \\
\text { em D } \\
\text { maior }\end{array}$ & $\begin{array}{l}\text { 1-Grave- } \\
\text { Allegro- } \\
\text { Adagio-Grave }\end{array}$ & 16 & $\not \equiv$ & \\
\hline $\begin{array}{l}\text { Segunda } \\
\text { Maior } \\
\text { Descendente }\end{array}$ & $\begin{array}{l}\text { Opus } \\
\text { VN1 } \\
\text { em D } \\
\text { maior }\end{array}$ & $\begin{array}{l}\text { 1-Grave- } \\
\text { Allegro- } \\
\text { Adagio-Grave- } \\
\text { allegro-adagio }\end{array}$ & 24 e 25 & 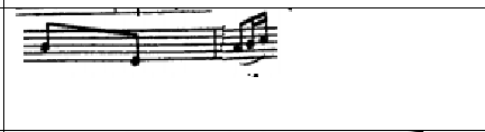 & 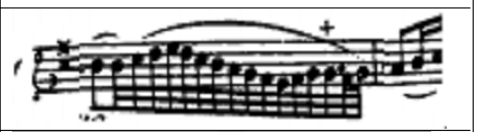 \\
\hline $\begin{array}{l}\text { Segunda } \\
\text { Maior } \\
\text { Descendente }\end{array}$ & $\begin{array}{l}\text { Opus } \\
\text { VN1 } \\
\text { em D } \\
\text { maior }\end{array}$ & $\begin{array}{l}\text { I-Grave- } \\
\text { Allegro- } \\
\text { Adagio-Grave- } \\
\text { allegro-adagio }\end{array}$ & 25 e 26 & $\Longrightarrow$ & 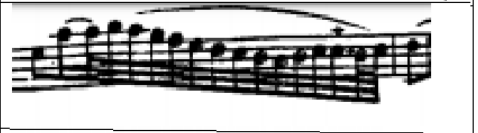 \\
\hline $\begin{array}{l}\text { Segunda } \\
\text { Maior } \\
\text { Descendente }\end{array}$ & $\begin{array}{l}\text { Opus } \\
\text { VN 1 } \\
\text { em D } \\
\text { maior }\end{array}$ & $\begin{array}{l}\text { I-Grave- } \\
\text { Allegro- } \\
\text { Adagio-Grave- } \\
\text { allegro-adagio }\end{array}$ & 28 & 2 & 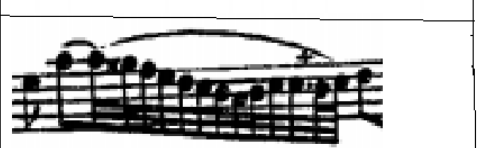 \\
\hline
\end{tabular}




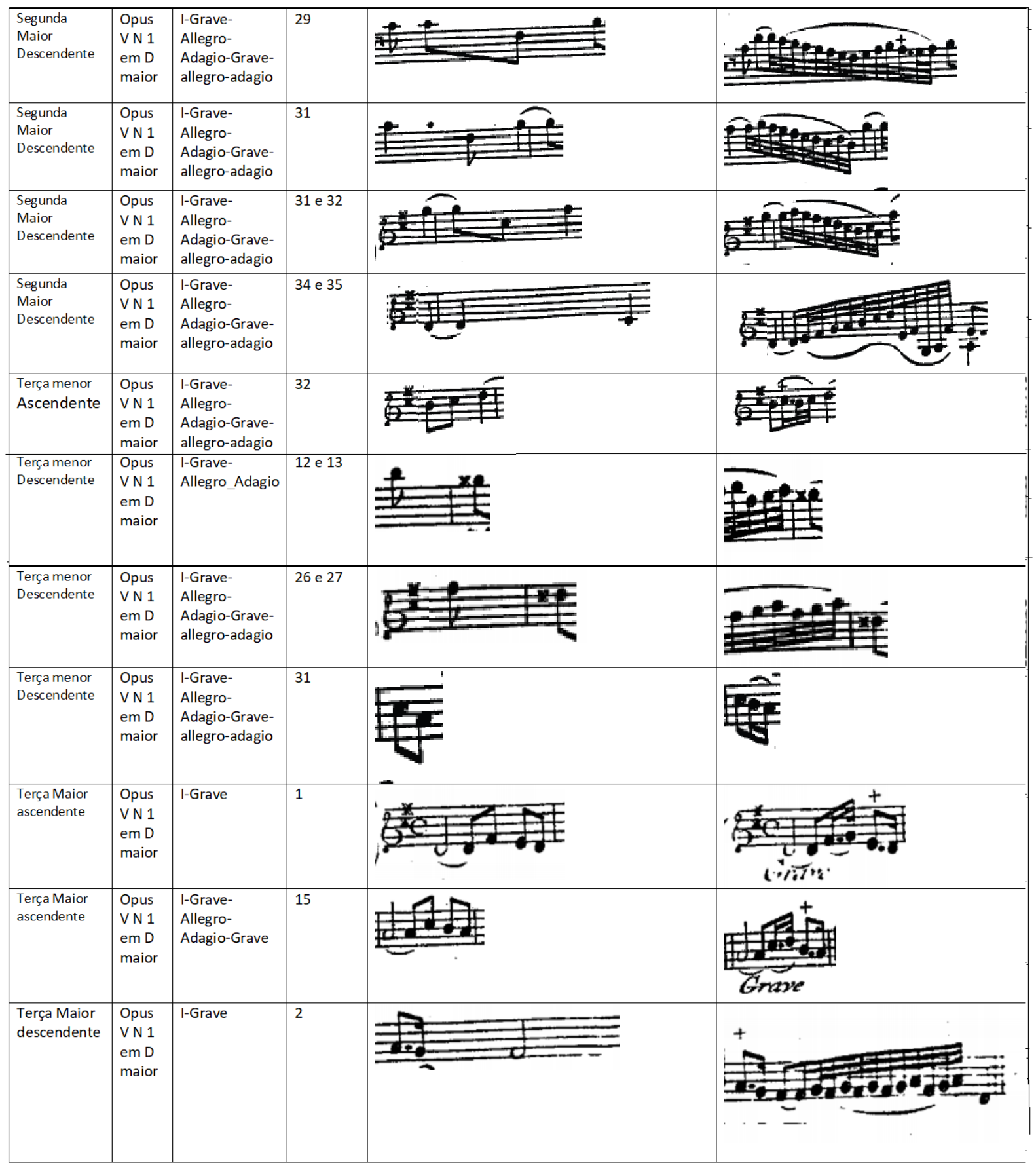




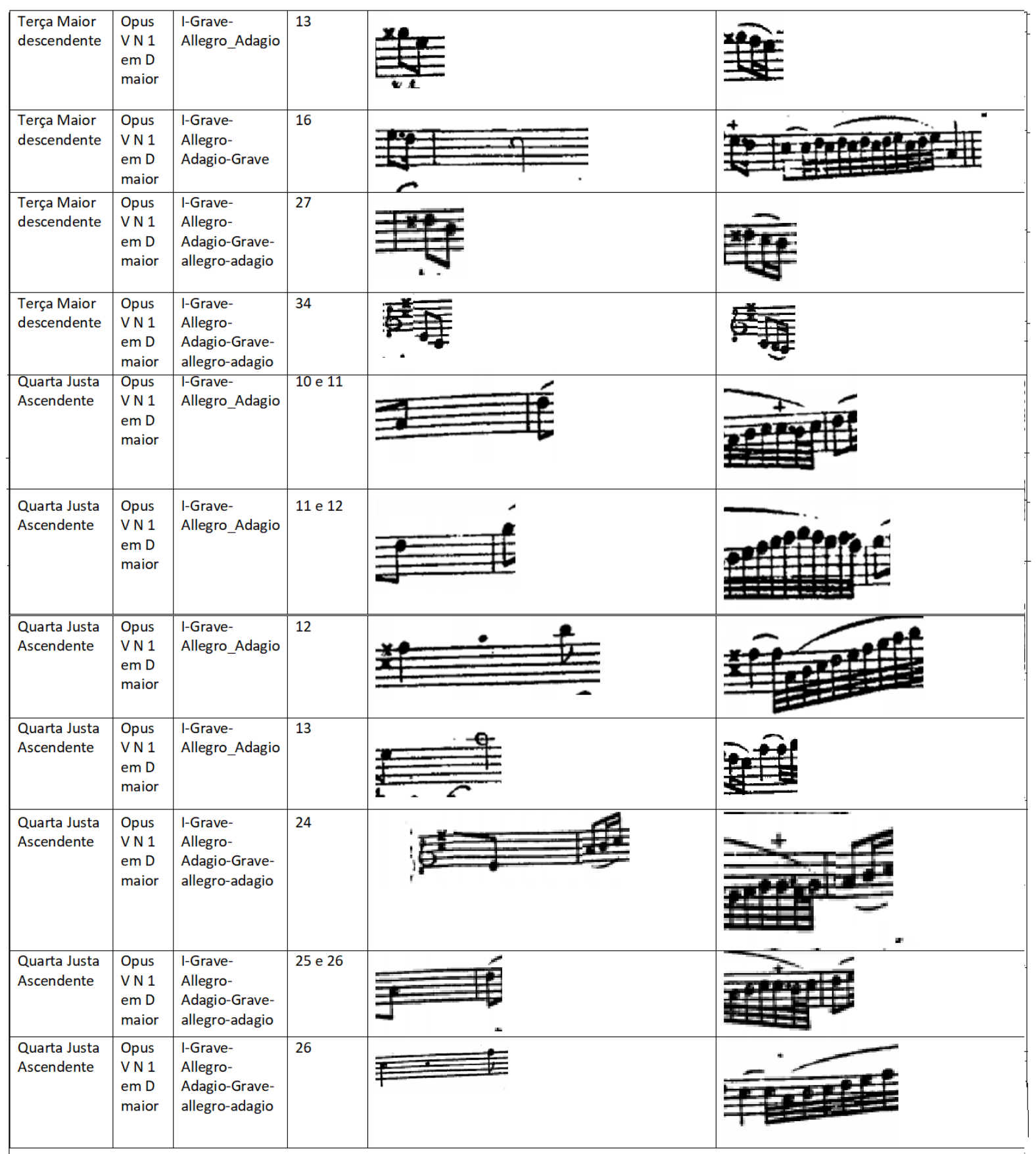




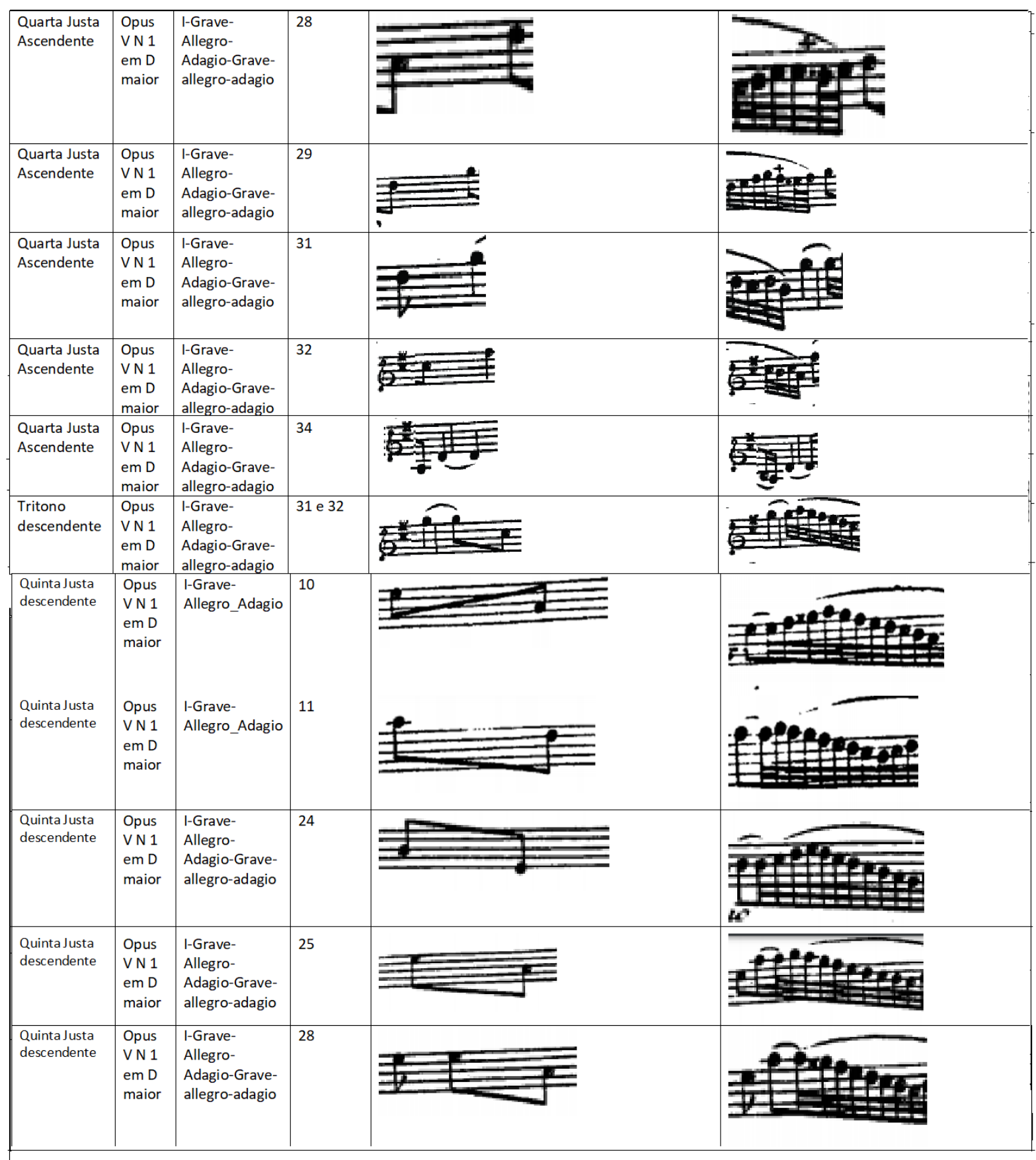




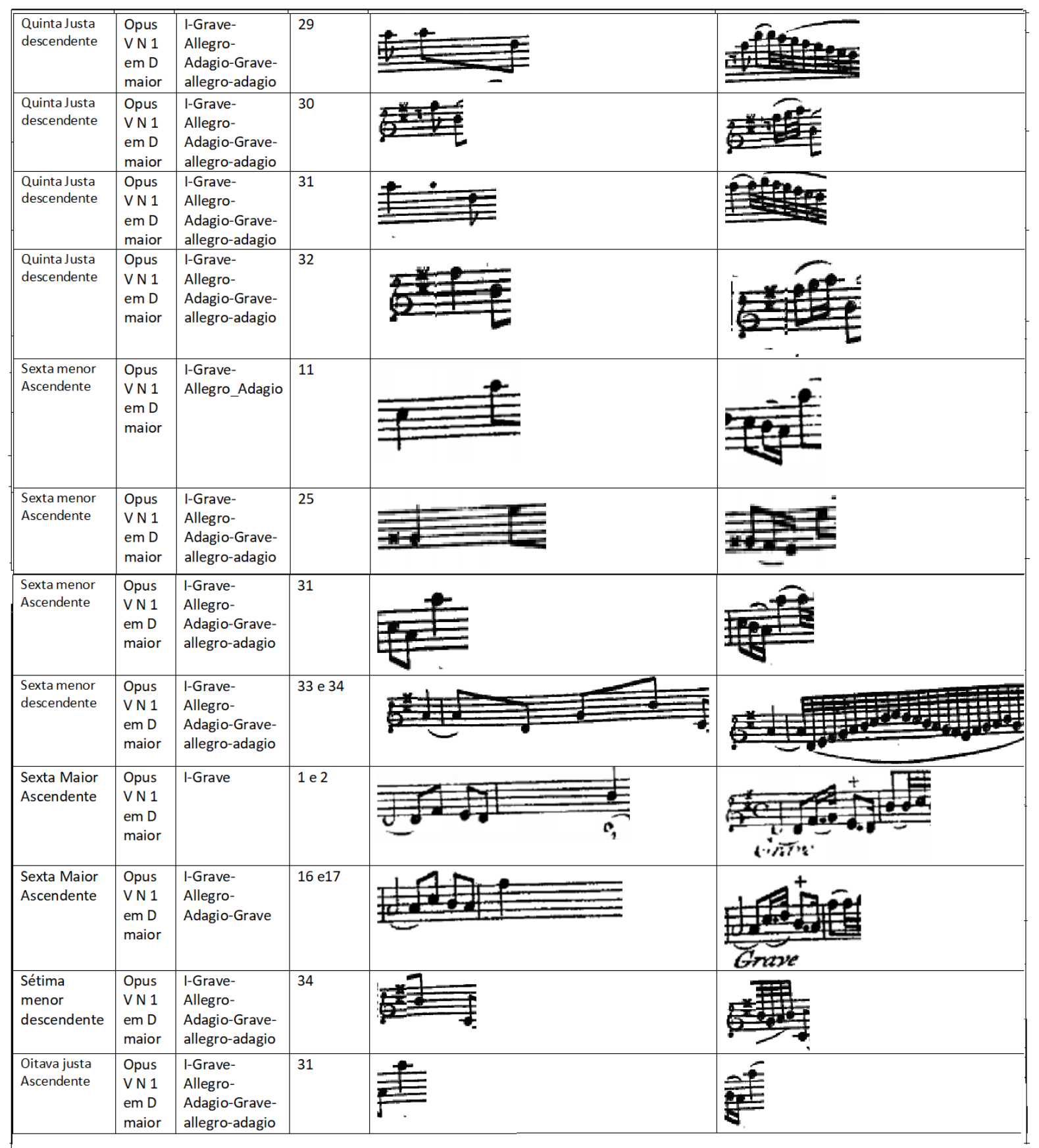



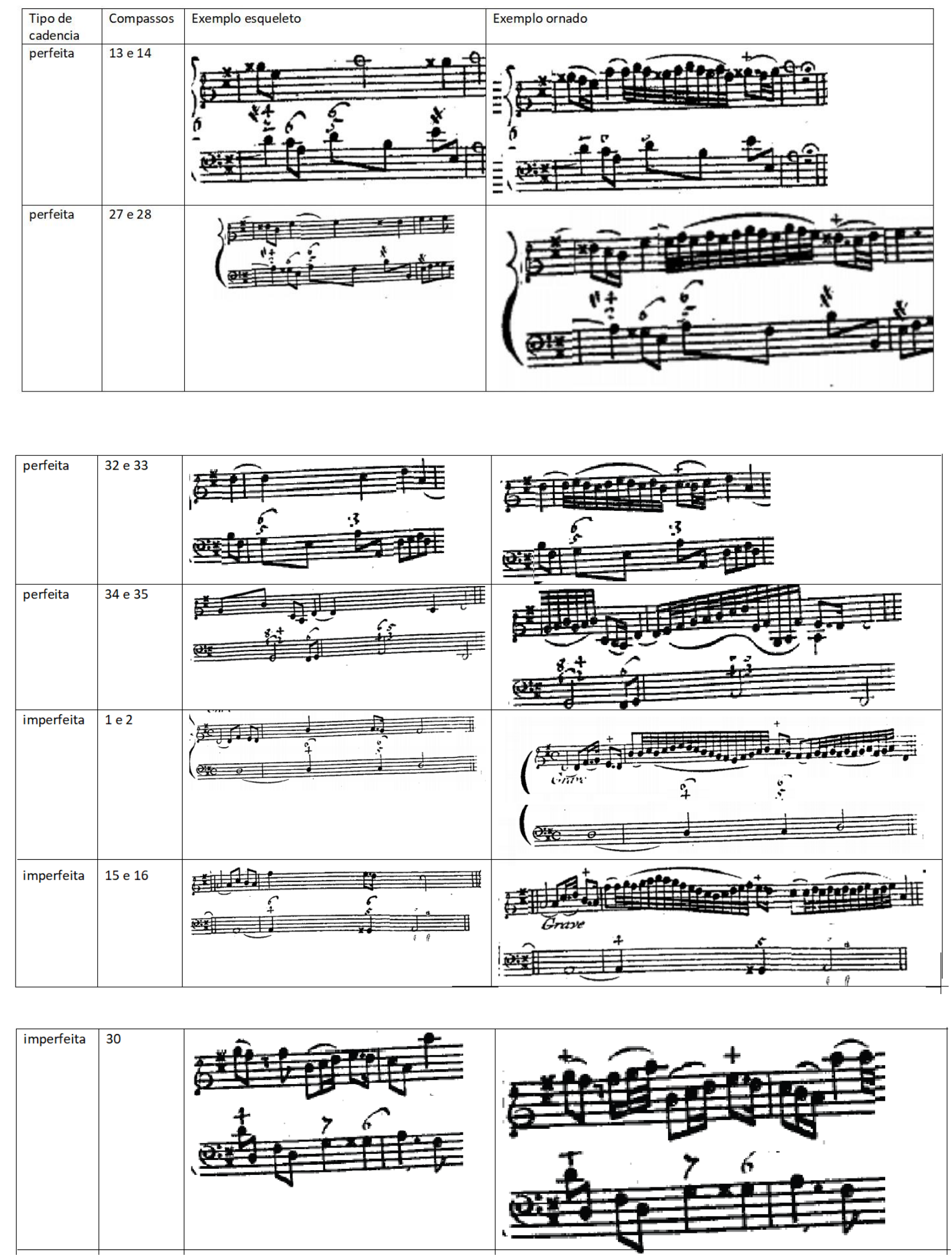
Tabela 7: Ornamentos da sonata Opus V n.1, quarto movimento adágio:

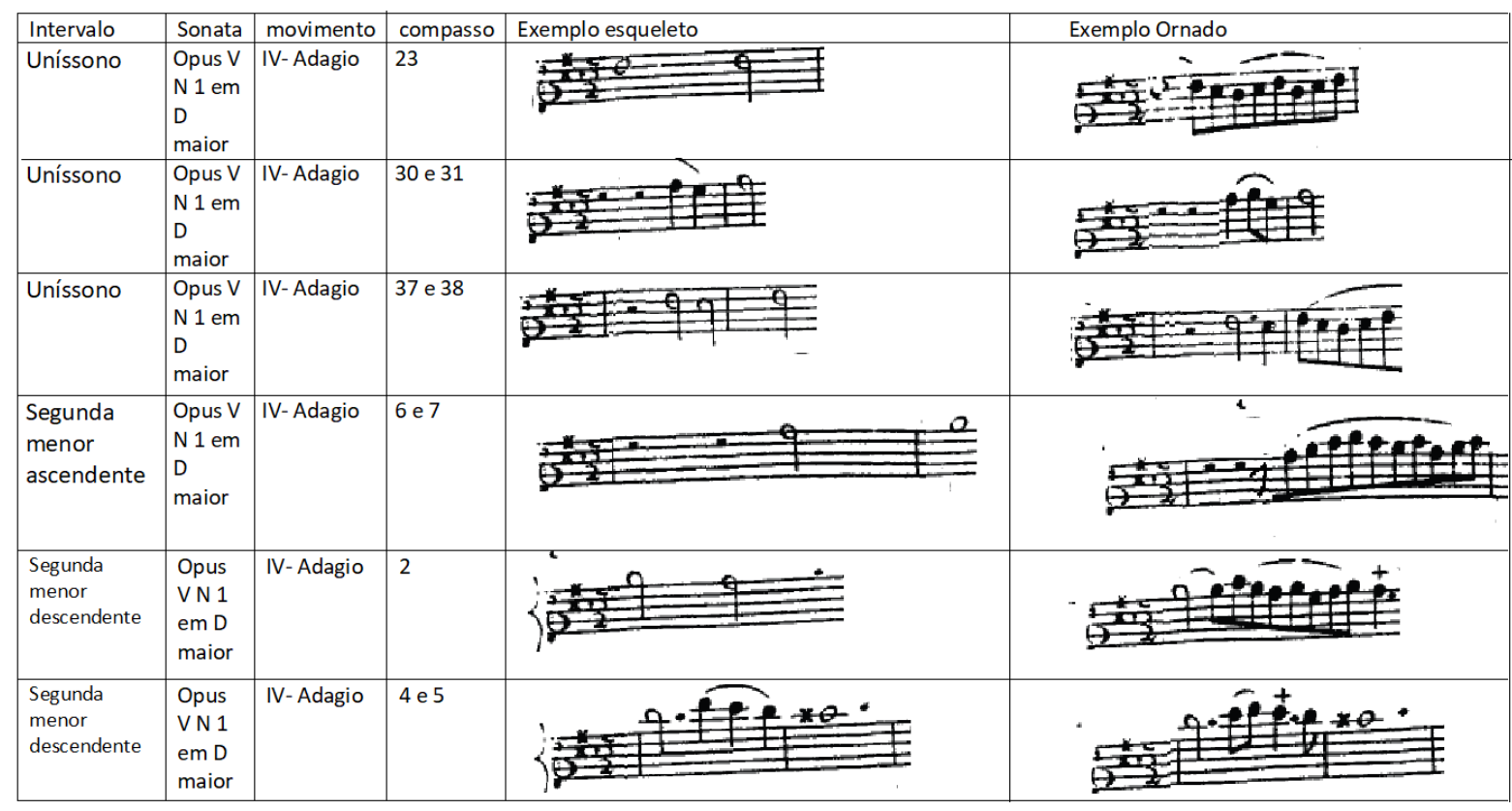

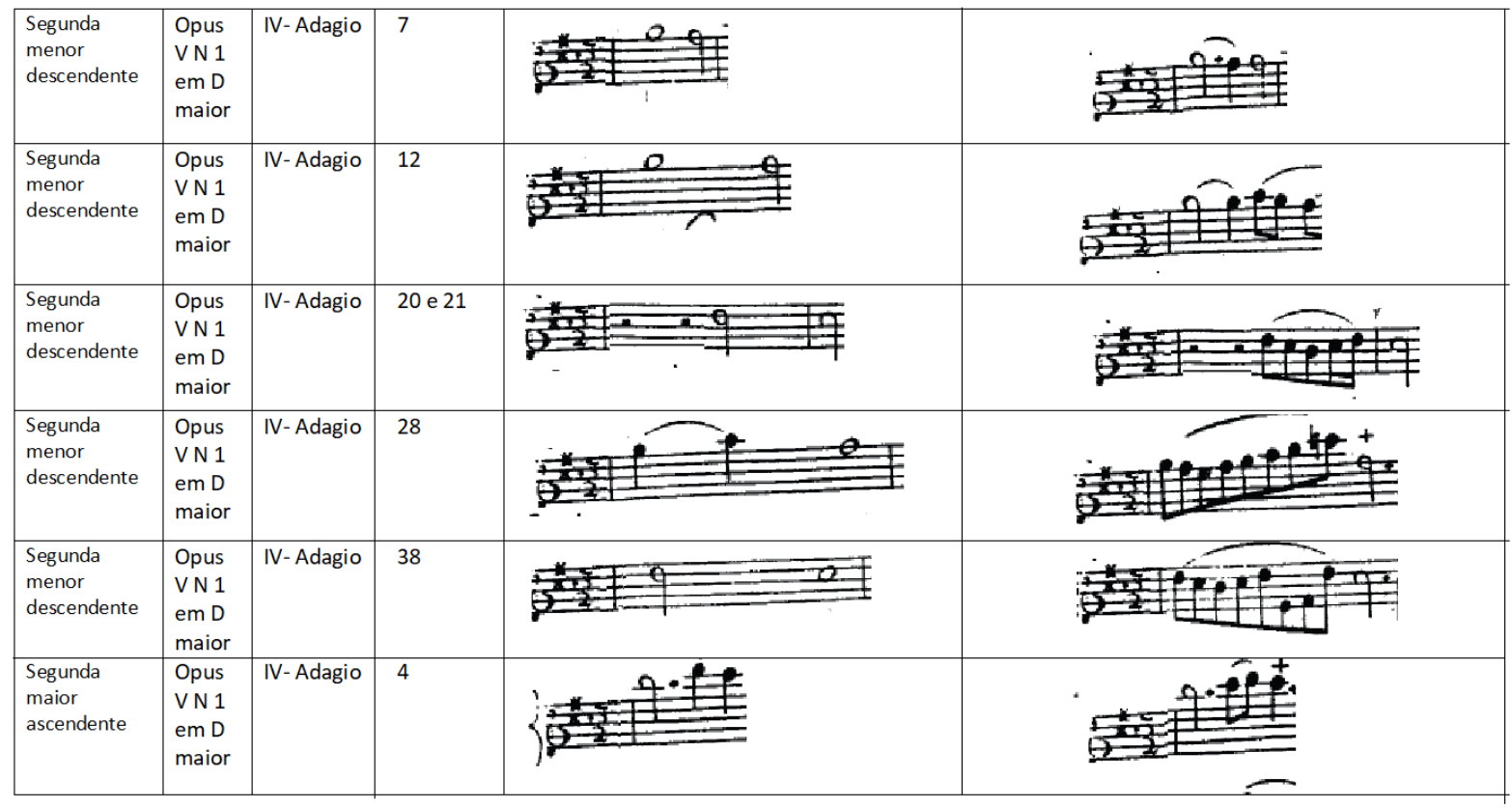




\begin{tabular}{|c|c|c|c|c|c|}
\hline $\begin{array}{l}\text { Segunda } \\
\text { maior } \\
\text { ascendente }\end{array}$ & $\begin{array}{l}\text { Opus } \\
\text { V N } 1 \\
\text { em D } \\
\text { maior }\end{array}$ & IV-Adagio & 8 e 9 & 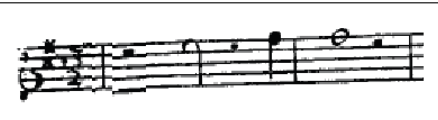 & 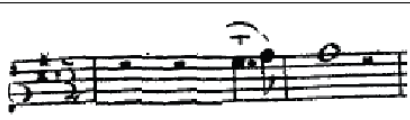 \\
\hline $\begin{array}{l}\text { Segunda } \\
\text { maior } \\
\text { ascendente }\end{array}$ & $\begin{array}{l}\text { Opus } \\
\text { V N } 1 \\
\text { em D } \\
\text { maior }\end{array}$ & IV-Adagio & 17 e 18 & 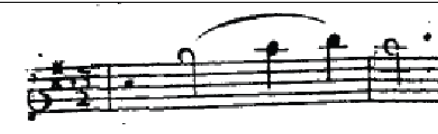 & $\frac{2+2}{2+2}$ \\
\hline $\begin{array}{l}\text { Segunda } \\
\text { maior } \\
\text { ascendente }\end{array}$ & $\begin{array}{l}\text { Opus } \\
\text { V N } 1 \\
\text { em D } \\
\text { maior }\end{array}$ & IV-Adagio & 28 & & \\
\hline $\begin{array}{l}\text { Segunda } \\
\text { maior } \\
\text { ascendente }\end{array}$ & $\begin{array}{l}\text { Opus } \\
\text { V N } 1 \\
\text { em D } \\
\text { maior }\end{array}$ & IV-Adagio & 30 e 31 & 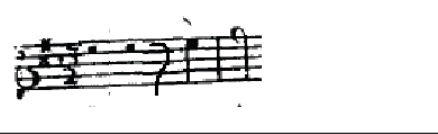 & $\frac{5+2=}{3}=$ \\
\hline $\begin{array}{l}\text { Segunda } \\
\text { maior } \\
\text { ascendente }\end{array}$ & $\begin{array}{l}\text { Opus } \\
\text { V N } 1 \\
\text { em D } \\
\text { maior }\end{array}$ & IV-Adagio & 45 & 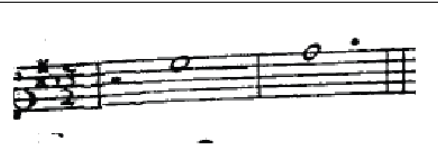 & - \\
\hline $\begin{array}{l}\text { Segunda } \\
\text { maior } \\
\text { descendente }\end{array}$ & $\begin{array}{l}\text { Opus } \\
\text { V N } 1 \\
\text { em D } \\
\text { maior }\end{array}$ & IV-Adagio & 11 e 12 & $\operatorname{lic}_{2}+\frac{e}{2+2}$ & Enf? \\
\hline $\begin{array}{l}\text { Segunda } \\
\text { maior } \\
\text { descendente }\end{array}$ & $\begin{array}{l}\text { Opus } \\
\text { V N } 1 \\
\text { em D } \\
\text { maior }\end{array}$ & IV-Adagio & 22 e 23 & 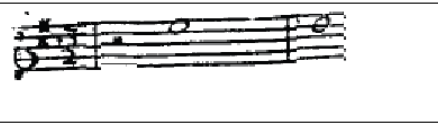 & $x^{4}=2+20$ \\
\hline
\end{tabular}

\begin{tabular}{|c|c|c|c|c|c|}
\hline $\begin{array}{l}\text { Segunda } \\
\text { maior } \\
\text { descendente }\end{array}$ & $\begin{array}{l}\text { Opus } \\
\text { VN } 1 \\
\text { em D } \\
\text { maior }\end{array}$ & IV-Adagio & 24 e 25 & 2 & 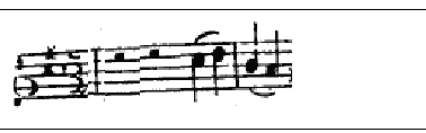 \\
\hline $\begin{array}{l}\begin{array}{l}\text { Segunda } \\
\text { maior } \\
\text { descendente }\end{array} \\
\end{array}$ & $\begin{array}{l}\text { Opus } \\
\text { VN 1 } \\
\text { em D } \\
\text { maior }\end{array}$ & IV-Adagio & 30 & =1 & 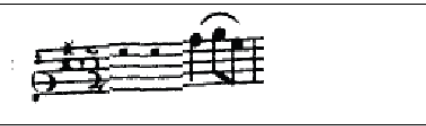 \\
\hline $\begin{array}{l}\begin{array}{l}\text { Segunda } \\
\text { maior } \\
\text { descendente }\end{array}\end{array}$ & $\begin{array}{l}\text { Opus } \\
\text { VN 1 } \\
\text { em D } \\
\text { maior }\end{array}$ & IV-Adagio & 36 e 37 & $\%=0 \Rightarrow 9$ & 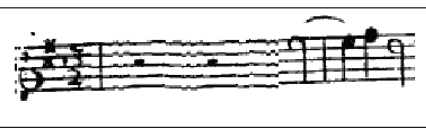 \\
\hline $\begin{array}{l}\text { Segunda } \\
\text { maior } \\
\text { descendente }\end{array}$ & $\begin{array}{l}\text { Opus } \\
\text { VN 1 } \\
\text { em D } \\
\text { maior }\end{array}$ & IV-Adagio & 38 e 39 & 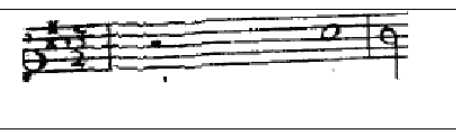 & 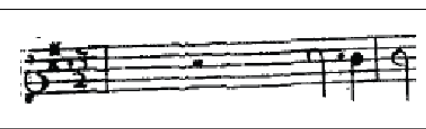 \\
\hline $\begin{array}{l}\text { Segunda } \\
\text { maior } \\
\text { descendente }\end{array}$ & $\begin{array}{l}\text { Opus } \\
\text { VN } 1 \\
\text { em D } \\
\text { maior }\end{array}$ & IV-Adagio & 42 e 43 & 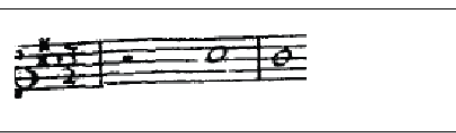 & $\frac{+}{2}=0$ \\
\hline $\begin{array}{l}\text { Segunda } \\
\text { maior } \\
\text { descendente }\end{array}$ & $\begin{array}{l}\text { Opus } \\
\text { VN 1 } \\
\text { em D } \\
\text { maior }\end{array}$ & IV- Adagio & 43 e 44 & $\approx 00=01$ & *0 \\
\hline $\begin{array}{l}\text { Terça menor } \\
\text { ascendente }\end{array}$ & $\begin{array}{l}\text { Opus } \\
\text { VN 1 } \\
\text { em D } \\
\text { maior }\end{array}$ & IV- Adagio & 15 & $\div 2$ & 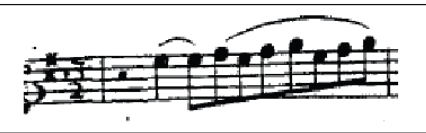 \\
\hline
\end{tabular}




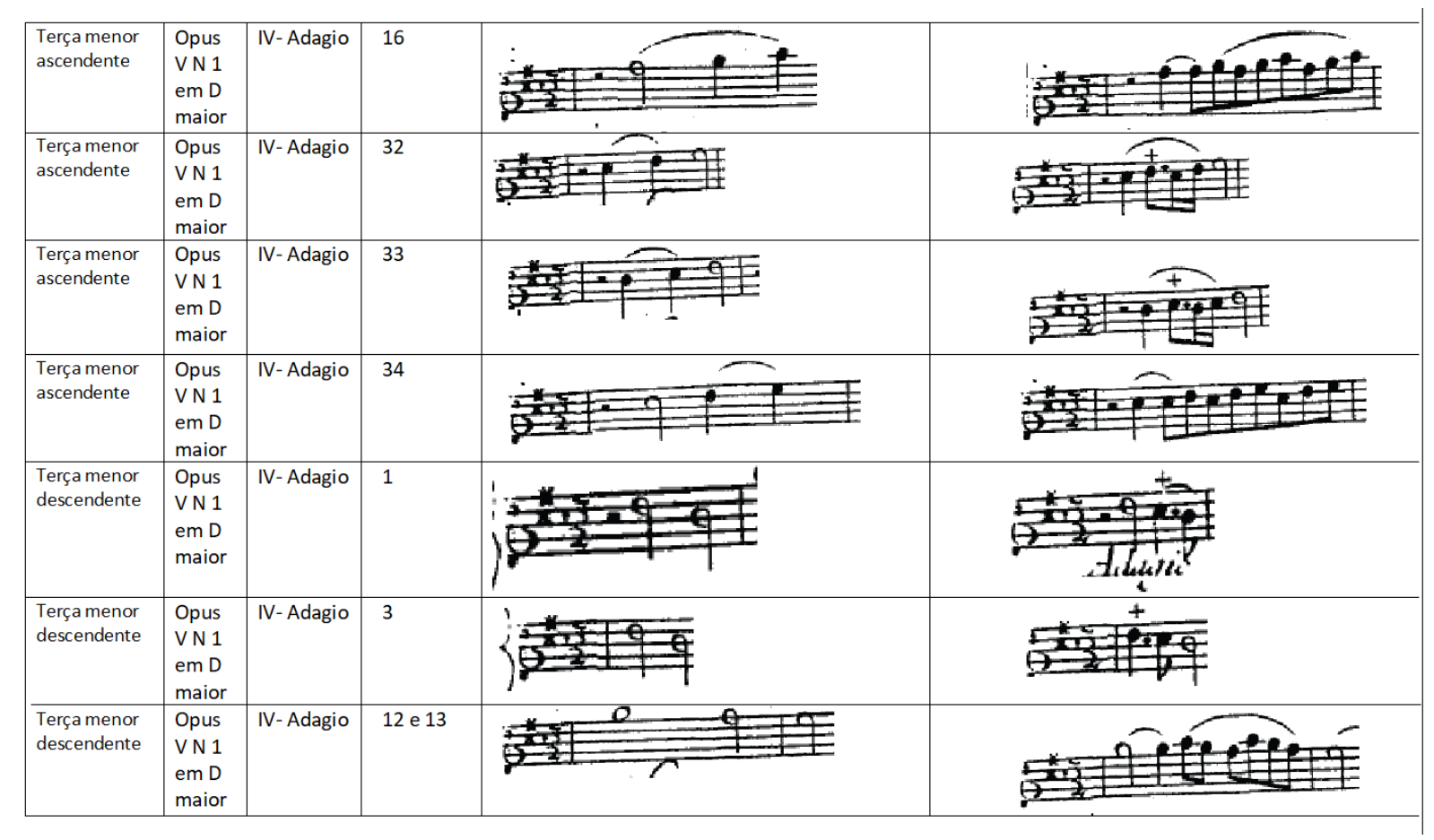

\begin{tabular}{|c|c|c|c|c|c|}
\hline $\begin{array}{l}\text { Terça menor } \\
\text { descendente }\end{array}$ & $\begin{array}{l}\text { Opus } \\
\text { V N } 1 \\
\text { em D } \\
\text { maior }\end{array}$ & IV- Adagio & 14 e 15 & 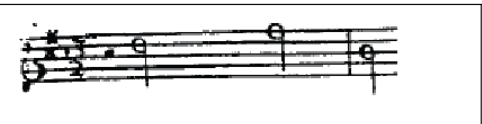 & $\overbrace{}^{2+29 q}$ \\
\hline $\begin{array}{l}\text { Terça menor } \\
\text { descendente }\end{array}$ & $\begin{array}{l}\text { Opus } \\
\text { VN } 1 \\
\text { em D } \\
\text { maior }\end{array}$ & IV-Adagio & 34 e 35 & 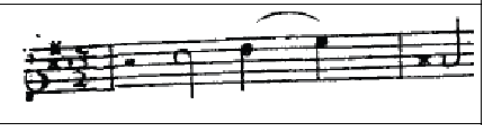 & 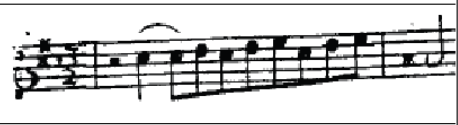 \\
\hline $\begin{array}{l}\text { Terça menor } \\
\text { descendente }\end{array}$ & $\begin{array}{l}\text { Opus } \\
\text { V N } 1 \\
\text { em D } \\
\text { maior }\end{array}$ & IV- Adagio & 38 e 39 & 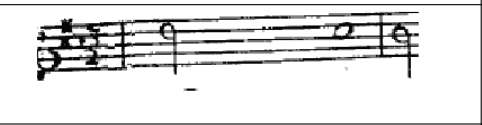 & $\frac{2}{9}+7295$ \\
\hline $\begin{array}{l}\text { Terça maior } \\
\text { ascendente }\end{array}$ & $\begin{array}{l}\text { Opus } \\
\text { V N } 1 \\
\text { em D } \\
\text { maior }\end{array}$ & IV- Adagio & 17 & 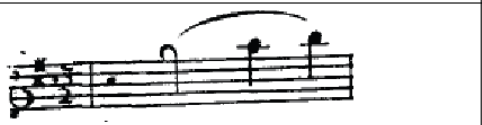 & 塹 \\
\hline $\begin{array}{l}\text { Terça maior } \\
\text { ascendente }\end{array}$ & $\begin{array}{l}\text { Opus } \\
\text { VN } 1 \\
\text { em D } \\
\text { maior }\end{array}$ & IV-Adagio & 31 & 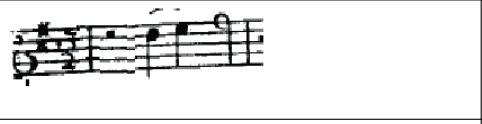 & 年王 \\
\hline $\begin{array}{l}\text { Terça maior } \\
\text { descendente }\end{array}$ & $\begin{array}{l}\text { Opus } \\
\text { V N } 1 \\
\text { em D } \\
\text { maior }\end{array}$ & IV- Adagio & 2 e 3 & $\left\{\operatorname{lom}_{1}^{*}=099\right.$ & $\begin{array}{c}+\infty \\
+14 \\
+14\end{array}$ \\
\hline $\begin{array}{l}\text { Terça maior } \\
\text { descendente }\end{array}$ & $\begin{array}{l}\text { Opus } \\
\text { V N } 1 \\
\text { em D } \\
\text { maior }\end{array}$ & IV- Adagio & 2 e 3 & 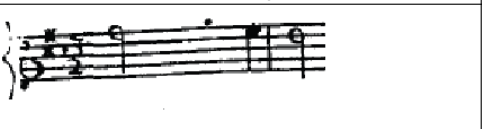 & 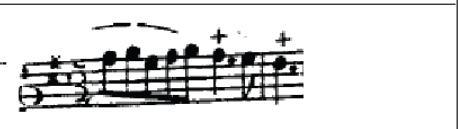 \\
\hline
\end{tabular}




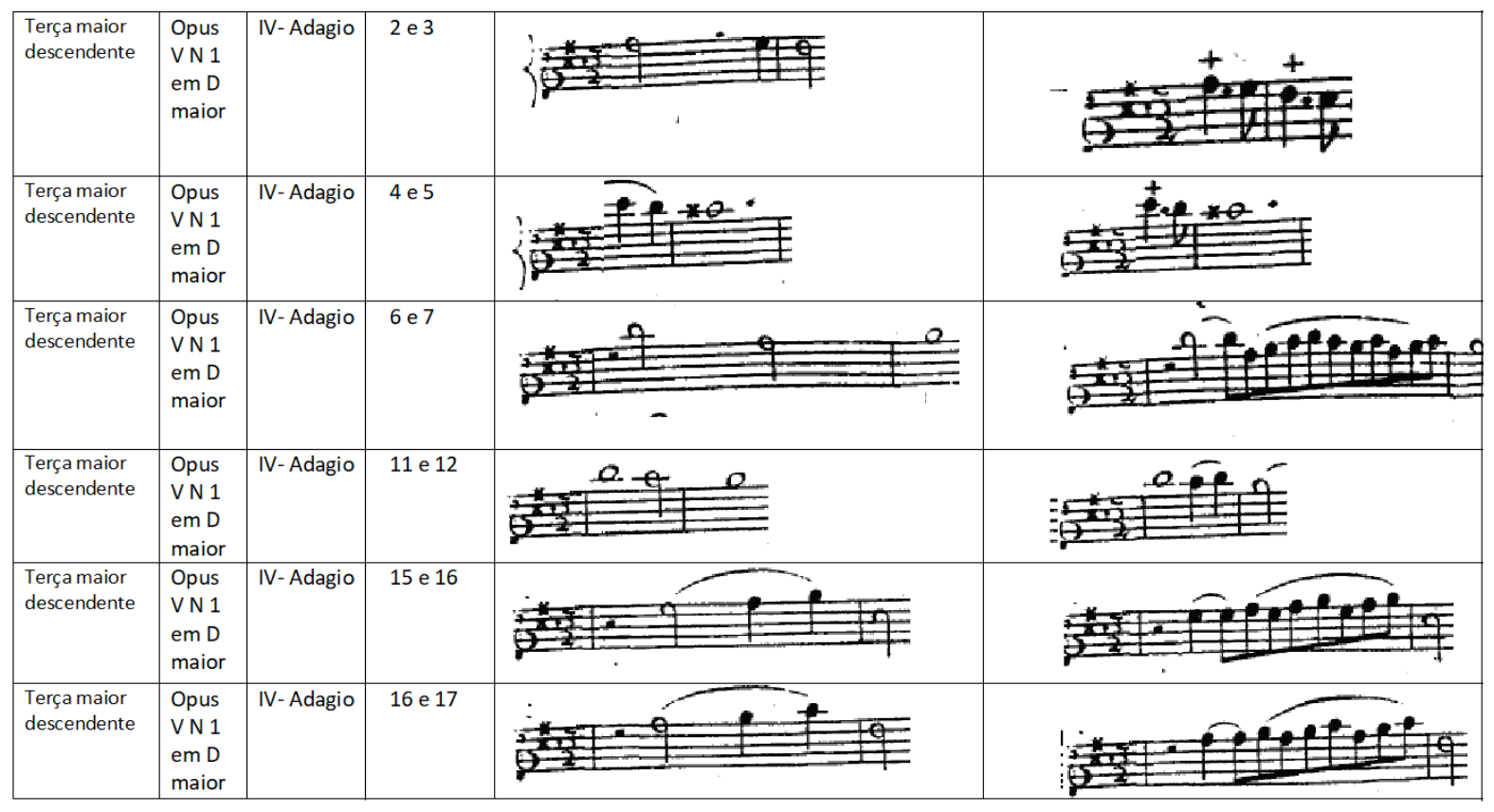

\begin{tabular}{|c|c|c|c|c|c|}
\hline $\begin{array}{l}\text { Quarta Justa } \\
\text { Ascendente }\end{array}$ & $\begin{array}{l}\text { Opus } \\
\text { VN 1 } \\
\text { em D } \\
\text { maior }\end{array}$ & IV-Adagio & 36 & 政程 & 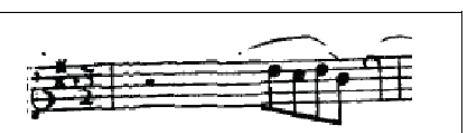 \\
\hline $\begin{array}{l}\text { Quarta justa } \\
\text { descendente }\end{array}$ & $\begin{array}{l}\text { Opus } \\
\text { VN1 } \\
\text { em D } \\
\text { maior }\end{array}$ & IV-Adagio & $8 \mathrm{e} 9$ & \% & 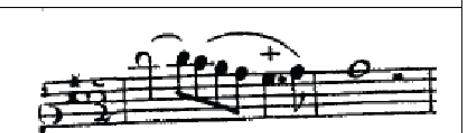 \\
\hline $\begin{array}{l}\text { Quarta justa } \\
\text { descendente }\end{array}$ & $\begin{array}{l}\text { Opus } \\
\text { VN 1 } \\
\text { em D } \\
\text { maior }\end{array}$ & IV-Adagio & $18 \mathrm{e} 19$ & 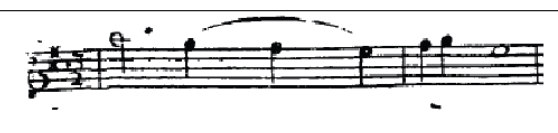 & 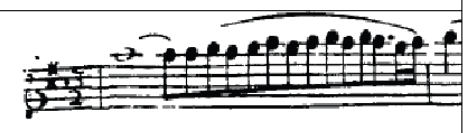 \\
\hline $\begin{array}{l}\text { Quinta justa } \\
\text { ascendente }\end{array}$ & $\begin{array}{l}\text { Opus } \\
\text { VN1 } \\
\text { em D } \\
\text { maior }\end{array}$ & IV-Adagio & $1 \mathrm{e} 2$ & \$9 & Alute \\
\hline $\begin{array}{l}\text { Quinta justa } \\
\text { descendente }\end{array}$ & $\begin{array}{l}\text { Opus } \\
\text { VN 1 } \\
\text { em D } \\
\text { maior }\end{array}$ & IV-Adagio & 8 & ॠी & 番 \\
\hline $\begin{array}{l}\text { Quinta justa } \\
\text { descendente }\end{array}$ & $\begin{array}{l}\text { Opus } \\
\text { VN 1 } \\
\text { em D } \\
\text { maior }\end{array}$ & IV-Adagio & 13 & $=0=1$ & 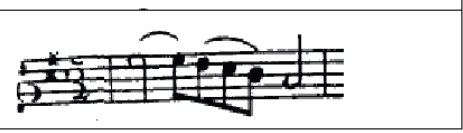 \\
\hline
\end{tabular}




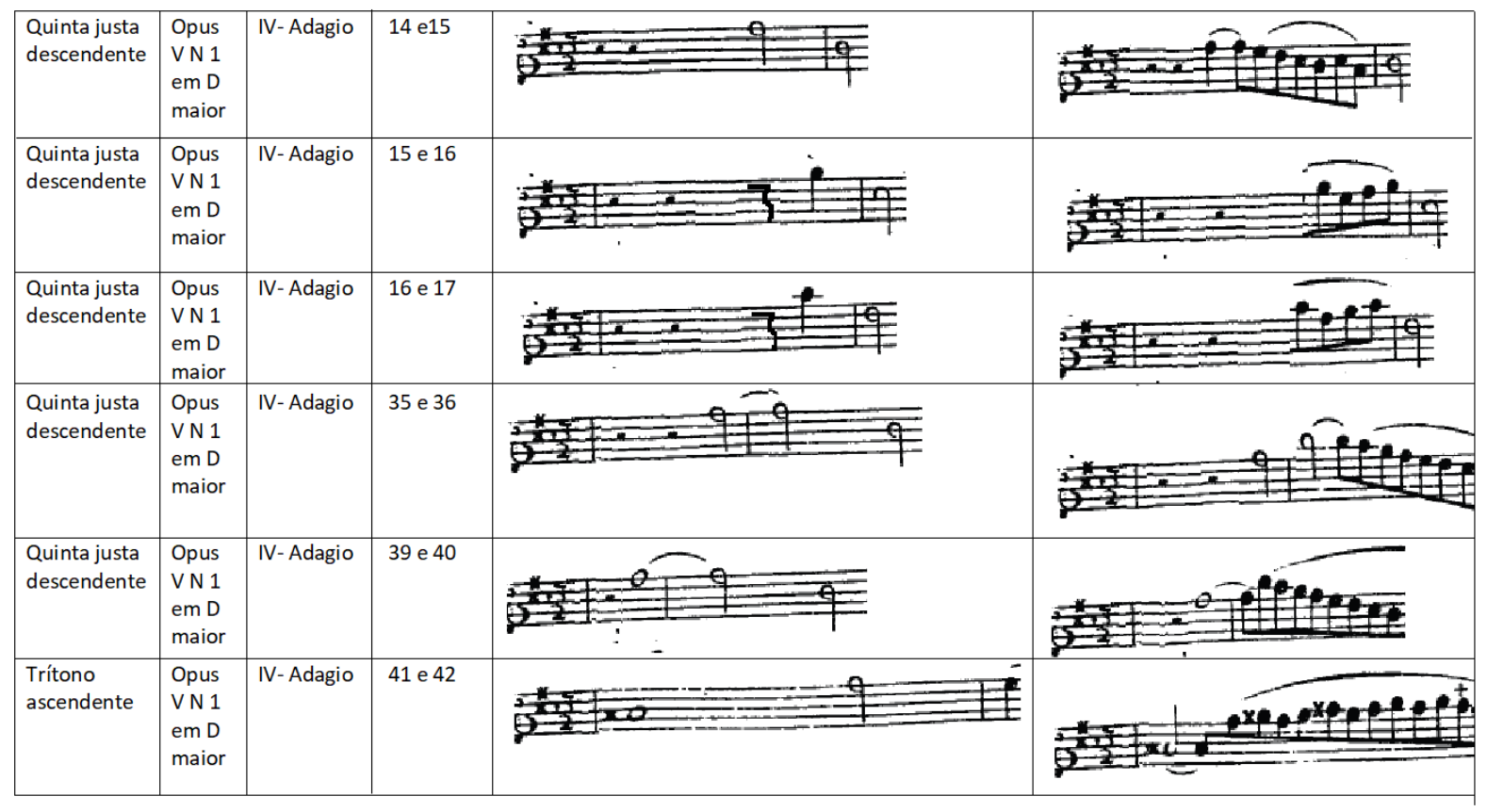

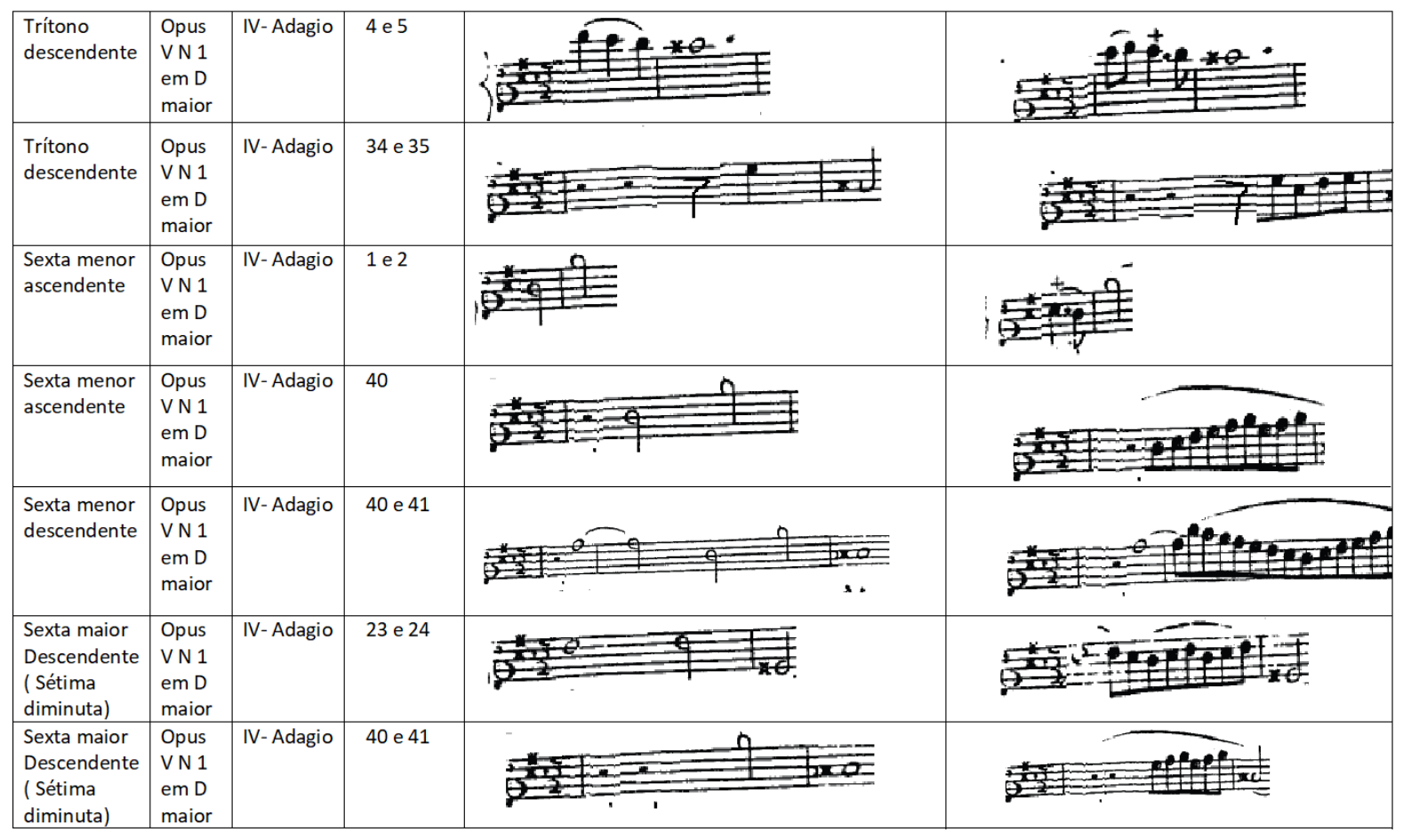

\begin{tabular}{|l|l|l|l|l|l|l|}
\hline $\begin{array}{l}\text { Sexta maior } \\
\text { Descendente } \\
\text { ( Sétima } \\
\text { diminuta) }\end{array}$ & $\begin{array}{l}\text { Opus } \\
\text { V N } 1 \\
\text { maior }\end{array}$ & IV- Adagio & 40 e 41 & & & \\
\hline
\end{tabular}




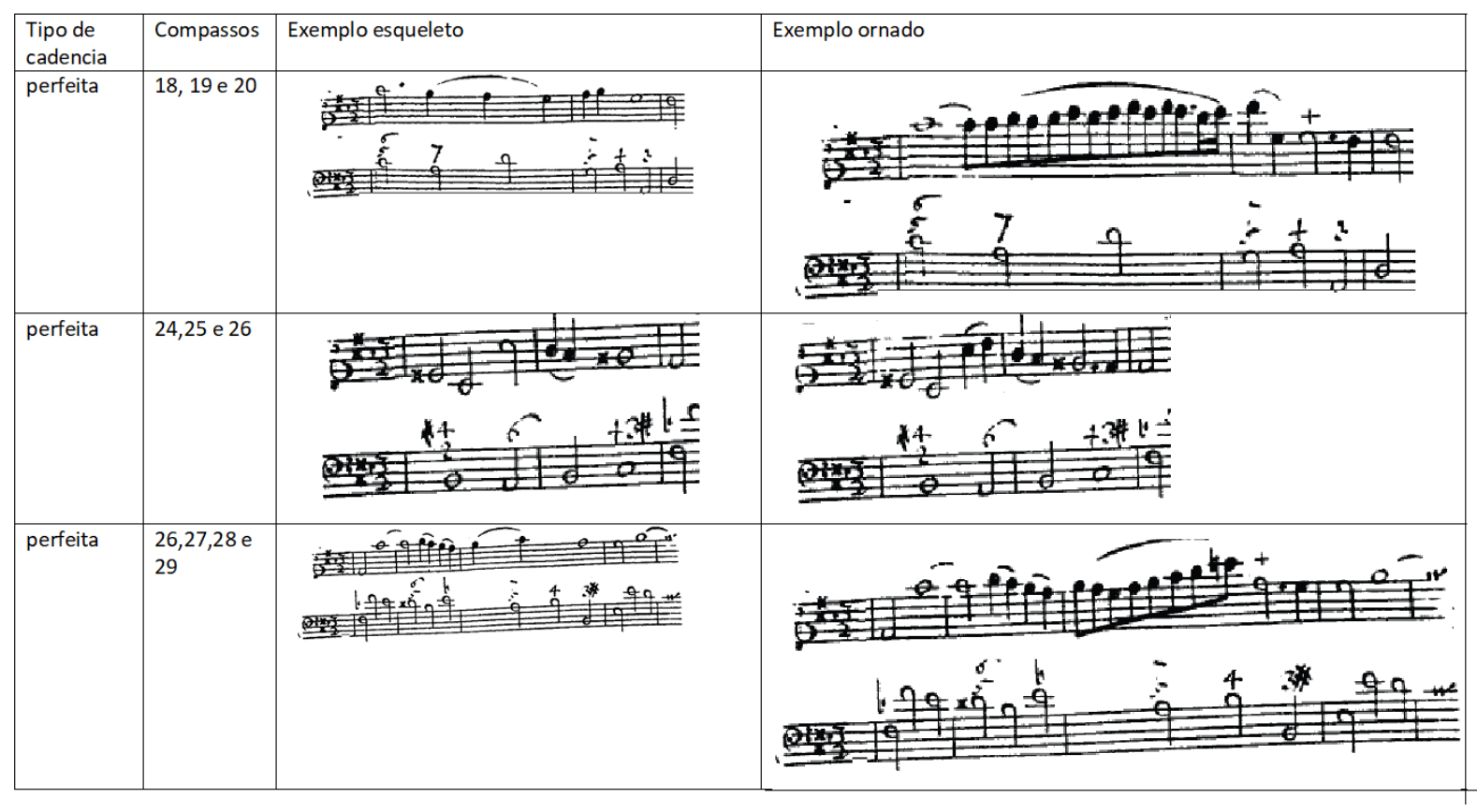

\begin{tabular}{|c|c|c|c|}
\hline perfeita & 41,42 e 43 & 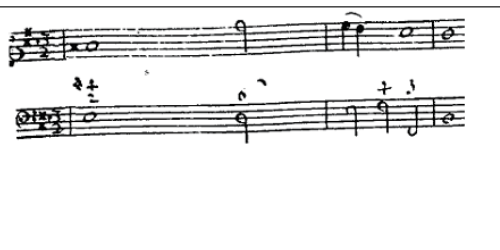 & 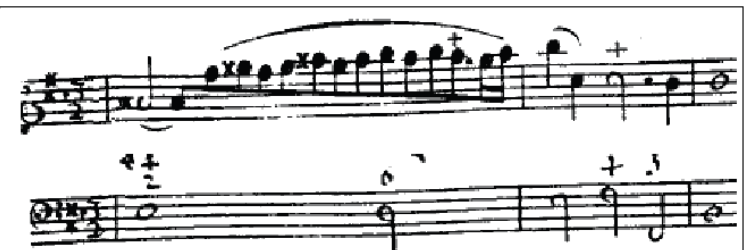 \\
\hline Imperfeita & $1,2 \mathrm{e} 3$ & $\left\{\begin{array}{l}9 \\
g \\
g\end{array}\right.$ & 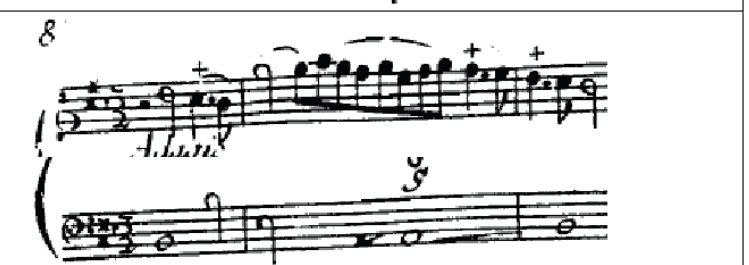 \\
\hline imperfeita & $6,7,8 \mathrm{e} 9$ & $\begin{array}{lll}6 & 9 \\
6 & 0\end{array}$ & $\frac{6}{6}+\frac{1}{2}$ \\
\hline
\end{tabular}

\begin{tabular}{|c|c|c|c|}
\hline $\begin{array}{l}\bar{A} \\
\text { dominante }\end{array}$ & 3,4 e 5 & 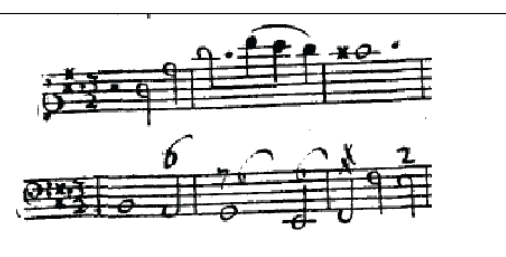 & 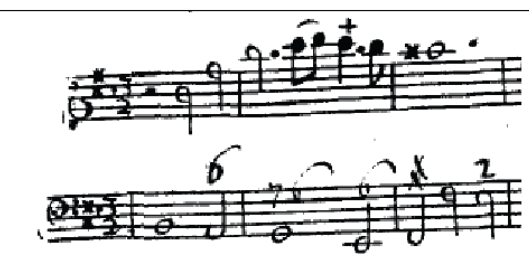 \\
\hline $\begin{array}{l}\text { À } \\
\text { dominante }\end{array}$ & 43,44 e 45 & 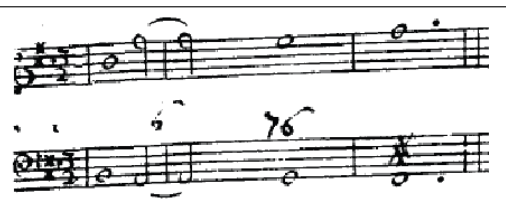 & 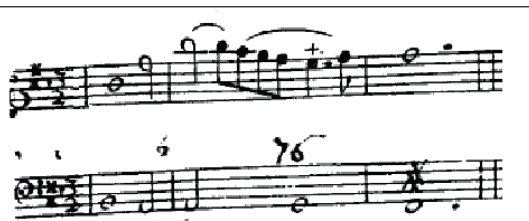 \\
\hline
\end{tabular}


Tabela 8: Ornamentos da sonata Opus V n.2, primeiro movimento grave:

\begin{tabular}{|c|c|c|c|c|c|}
\hline $\begin{array}{l}\text { Intervalo } \\
\text { Segunda } \\
\text { menor } \\
\text { ascendente }\end{array}$ & \begin{tabular}{l|} 
Sonata \\
Opus \\
Vn2 \\
emSi \\
bernol \\
maior \\
\end{tabular} & $\begin{array}{l}\text { movimento } \\
1-\text { Grave }\end{array}$ & \begin{tabular}{l|l} 
compasso \\
$1 \mathrm{e} 2$
\end{tabular} & Exemplo esqueleto & Exemplo Ornado \\
\hline $\begin{array}{l}\text { Segunda } \\
\text { menor } \\
\text { ascendente }\end{array}$ & $\begin{array}{l}\text { Opus } \\
\mathrm{Vn} 2 \\
\text { emsi } \\
\text { bemol } \\
\text { maior }\end{array}$ & I-Grave & 3 & 制 & +2 \\
\hline $\begin{array}{l}\text { Segunda } \\
\text { menor } \\
\text { ascendente }\end{array}$ & $\begin{array}{l}\text { Opus } \\
\text { Vn2 } \\
\text { emsi } \\
\text { bermol } \\
\text { maior }\end{array}$ & I-Grave & 4 e5 & $=1 \pm$ & I. \\
\hline $\begin{array}{l}\text { Segunda } \\
\text { menor } \\
\text { ascendente }\end{array}$ & $\begin{array}{l}\text { Opus } \\
V \text { pu2 } \\
\text { emsi } \\
\text { bemol } \\
\text { maior }\end{array}$ & 1-Grave & 6 & $\frac{12}{3}$ & 菓告 \\
\hline $\begin{array}{l}\text { Segunda } \\
\text { menor } \\
\text { ascendente }\end{array}$ & $\begin{array}{l}\text { Opus } \\
\mathrm{Vn} 2 \\
\text { emsi } \\
\text { bemol } \\
\text { maior }\end{array}$ & I-Grave & 7 & 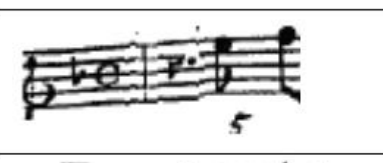 & 玨 \\
\hline $\begin{array}{l}\text { Segunda } \\
\text { menor } \\
\text { ascendente }\end{array}$ & $\begin{array}{l}\text { Opus } \\
\text { Vn2 } \\
\text { emSi } \\
\text { bemol } \\
\text { maior }\end{array}$ & I-Grave & 9e 10 & F० & 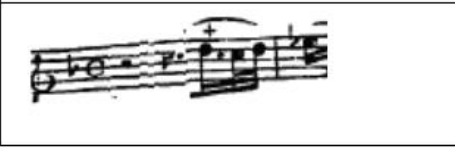 \\
\hline
\end{tabular}

\begin{tabular}{|c|c|c|c|c|c|}
\hline $\begin{array}{l}\text { Segunda } \\
\text { menor } \\
\text { ascendente }\end{array}$ & $\begin{array}{l}\text { Opus } \\
\text { Vn } 2 \\
\text { emsi } \\
\text { bermol } \\
\text { maior }\end{array}$ & 1-Grave & 10 & ? & 20101010 \\
\hline $\begin{array}{l}\text { Segunda } \\
\text { menor } \\
\text { ascendente }\end{array}$ & $\begin{array}{l}\text { Opus } \\
V n n 2 \\
\text { emsi } \\
\text { bemol } \\
\text { mior }\end{array}$ & I-Grave & 11 e 12 & 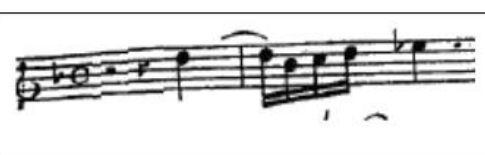 & का किएव \\
\hline $\begin{array}{l}\text { Segunda } \\
\text { menor } \\
\text { ascendente }\end{array}$ & $\begin{array}{l}\text { Opus } \\
\mathrm{Vn} 2 \\
\text { emsi } \\
\text { bemol } \\
\text { maior }\end{array}$ & I-Grave & 15 e 16 & 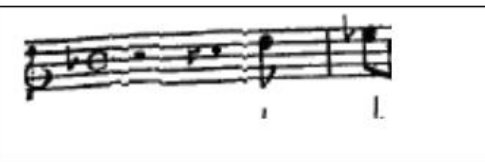 & 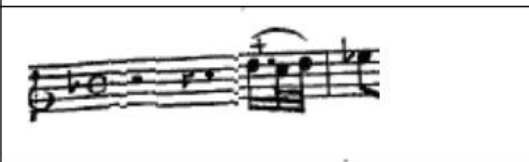 \\
\hline $\begin{array}{l}\text { Segunda } \\
\text { menor } \\
\text { descendente }\end{array}$ & \begin{tabular}{|l|} 
Opus \\
Vn2 \\
emsi \\
bemol \\
mior
\end{tabular} & 1-Grave & $2 \mathrm{e} 3$ & III & $\ldots$ \\
\hline $\begin{array}{l}\text { Segunda } \\
\text { menor } \\
\text { descendente }\end{array}$ & $\begin{array}{l}\text { Opus } \\
\text { Vn2 } \\
\text { emsi } \\
\text { bernol } \\
\text { maior }\end{array}$ & I-Grave & $5 \mathrm{e} 6$ & $\div$ & 传 \\
\hline $\begin{array}{l}\text { Segunda } \\
\text { menor } \\
\text { descendente }\end{array}$ & $\begin{array}{l}\text { Opus } \\
\text { Vn2 } \\
\text { emsi } \\
\text { bernol } \\
\text { mior }\end{array}$ & I-Grave & $20 \mathrm{e} 21$ & 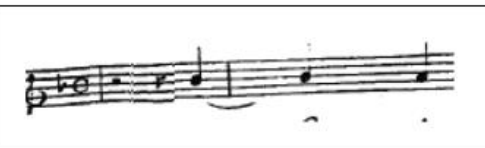 & 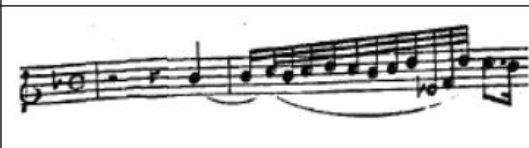 \\
\hline
\end{tabular}




\begin{tabular}{|c|c|c|c|c|c|}
\hline $\begin{array}{l}\text { Segunda } \\
\text { maior } \\
\text { ascendente }\end{array}$ & \begin{tabular}{l|} 
Opus \\
$\mathrm{Vn} 2$ \\
emsi \\
bemol \\
maior
\end{tabular} & \begin{tabular}{|l} 
1-Grave \\
\end{tabular} & 2 & 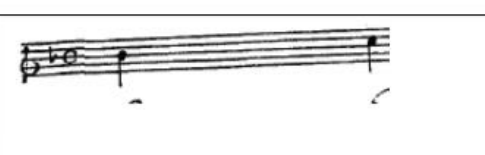 & 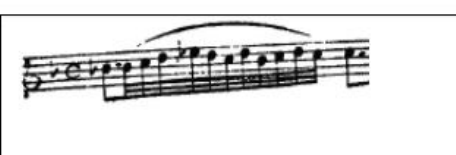 \\
\hline $\begin{array}{l}\text { Segunda } \\
\text { maior } \\
\text { ascendente }\end{array}$ & $\begin{array}{l}\text { Opus } \\
\text { Vn2 } \\
\text { emsi } \\
\text { bermol } \\
\text { maior }\end{array}$ & I-Grave & 2 & $\angle 1$ & W \\
\hline $\begin{array}{l}\text { Segunda } \\
\text { maior } \\
\text { ascendente }\end{array}$ & $\begin{array}{l}\text { Opus } \\
\text { Vn2 } \\
\text { emsi } \\
\text { bernol } \\
\text { maior }\end{array}$ & I-Grave & 5 & 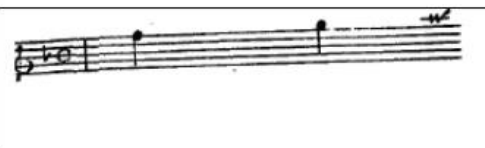 & 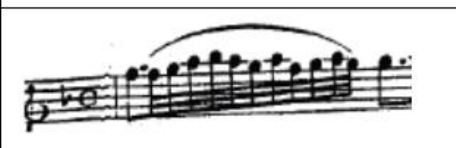 \\
\hline $\begin{array}{l}\text { Segunda } \\
\text { maior } \\
\text { ascendente }\end{array}$ & $\begin{array}{l}\text { Opus } \\
\mathrm{Vn} 2 \\
\text { emsi } \\
\text { bernol } \\
\text { maior }\end{array}$ & 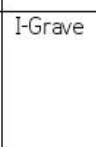 & 5 & 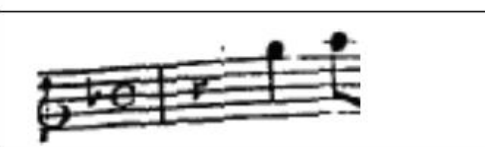 & 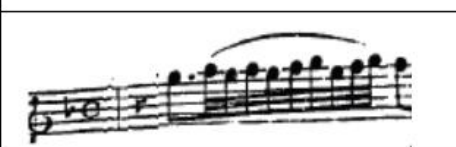 \\
\hline $\begin{array}{l}\text { Segunda } \\
\text { maior } \\
\text { ascendente }\end{array}$ & $\begin{array}{l}\text { malor } \\
\text { Opus } \\
\mathrm{Vn} 2 \\
\text { emsi } \\
\text { bemol } \\
\text { maior }\end{array}$ & I-Grave & 10 & $\quad 1$ & $1 \quad 1+$ \\
\hline $\begin{array}{l}\text { Segunda } \\
\text { maior } \\
\text { ascendente }\end{array}$ & $\begin{array}{l}\text { Opus } \\
\text { Vnn } 2 \\
\text { emsi } \\
\text { bernol } \\
\text { maior }\end{array}$ & I-Grave & 11 & 1) & 10 \\
\hline
\end{tabular}

\begin{tabular}{|c|c|c|c|c|c|}
\hline \begin{tabular}{l|}
$\begin{array}{l}\text { Segunda } \\
\text { maior } \\
\text { descendente }\end{array}$ \\
der
\end{tabular} & $\begin{array}{l}\text { Opus } \\
\mathrm{Vn} 2 \\
\text { emsi } \\
\text { bernol } \\
\text { maior }\end{array}$ & 1-Grave & $7 \mathrm{e} 8$ & 乎 & 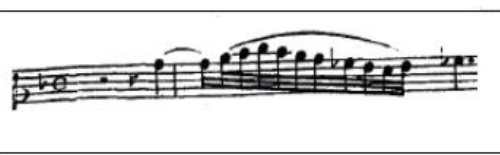 \\
\hline $\begin{array}{l}\begin{array}{l}\text { Segunda } \\
\text { maior } \\
\text { descendente }\end{array} \\
\end{array}$ & $\begin{array}{l}\text { Opus } \\
\text { Vn2 } \\
\text { emsi } \\
\text { bemol } \\
\text { maior }\end{array}$ & I-Grave & $8 \mathrm{e}^{9}$ & 位 & - \\
\hline $\begin{array}{l}\text { Segunda } \\
\text { maior } \\
\text { descendente }\end{array}$ & $\begin{array}{l}\text { Opus } \\
\mathrm{Vn} 2 \\
\text { emsi } \\
\text { bermol } \\
\text { maior }\end{array}$ & I-Grave & $8 \mathrm{e} 9$ & थी & 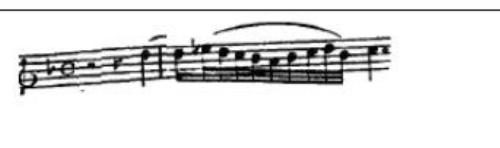 \\
\hline $\begin{array}{l}\text { Segunda } \\
\text { maior } \\
\text { descendente }\end{array}$ & $\begin{array}{l}\text { malor } \\
\text { Opus } \\
\text { ens } 2 \\
\text { bemol } \\
\text { maior }\end{array}$ & I-Grave & 10 & $=1$ & $\stackrel{+}{2}=$ \\
\hline $\begin{array}{l}\text { Segunda } \\
\text { maior } \\
\text { descendente }\end{array}$ & $\begin{array}{l}\text { Opus } \\
\mathrm{Vn} 2 \\
\text { emsi } \\
\text { bemol } \\
\text { maior }\end{array}$ & \begin{tabular}{|l} 
I-Grave \\
\end{tabular} & 19 & 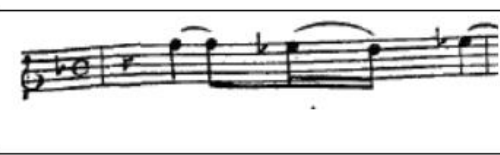 & 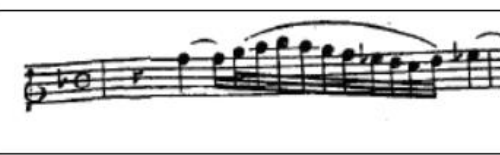 \\
\hline $\begin{array}{l}\text { Terca menor } \\
\text { ascendente }\end{array}$ & $\begin{array}{l}\text { Opus } \\
\mathrm{Vn} 2 \\
\text { emSi } \\
\text { bernol } \\
\text { maior }\end{array}$ & I-Grave & 2 & $\Rightarrow$ 毦 & 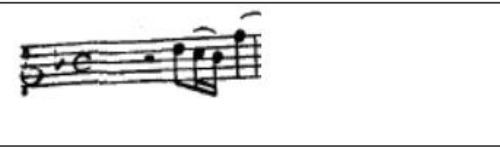 \\
\hline
\end{tabular}




\begin{tabular}{|c|c|c|c|c|c|}
\hline \begin{tabular}{l|} 
Terca menor \\
ascendente
\end{tabular} & $\begin{array}{l}\text { Opus } \\
\text { Vnn2 } \\
\text { emsi } \\
\text { bernol } \\
\text { maior }\end{array}$ & \begin{tabular}{|l|l} 
I-Grave \\
\end{tabular} & 5 & 起羊 & 南素 \\
\hline $\begin{array}{l}\text { Terca menor } \\
\text { ascendente }\end{array}$ & $\begin{array}{l}\text { Opus } \\
V \text { Vn2 } \\
\text { emsi } \\
\text { bermol } \\
\text { maior }\end{array}$ & I-Grave & 7 & क्ष: & 年 \\
\hline $\begin{array}{l}\text { Terca menor } \\
\text { ascendente }\end{array}$ & $\begin{array}{l}\text { Opus } \\
\text { Vn2 } \\
\text { emsi } \\
\text { bemol } \\
\text { maior }\end{array}$ & I-Grave & 10 & - & 15 \\
\hline $\begin{array}{l}\text { Terca menor } \\
\text { ascendente }\end{array}$ & $\begin{array}{l}\text { Opus } \\
\text { Vn2 } \\
\text { emsi } \\
\text { bemol } \\
\text { maior }\end{array}$ & \begin{tabular}{|l|l} 
I-Grave \\
\end{tabular} & 10 & 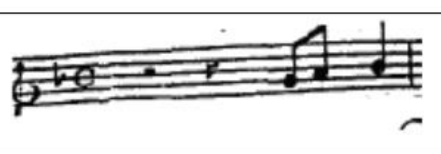 & 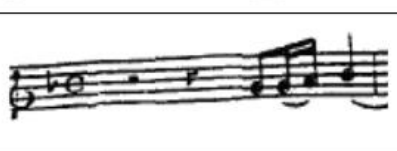 \\
\hline $\begin{array}{l}\text { Tercamenor } \\
\text { descendente }\end{array}$ & $\begin{array}{l}\text { Opus } \\
\text { Vn2 } \\
\text { emsi } \\
\text { bernol } \\
\text { maior }\end{array}$ & I-Grave & 1 & 0 & $\frac{\text { Grare }}{\text { Graper }}$ \\
\hline $\begin{array}{l}\text { Terca menor } \\
\text { descendente }\end{array}$ & $\begin{array}{l}\text { Opus } \\
\text { Vnn } \\
\text { emsi } \\
\text { bemol } \\
\text { maior }\end{array}$ & I-Grave & 2 & 争 & 迹 \\
\hline
\end{tabular}

\begin{tabular}{|c|c|c|c|c|c|}
\hline $\begin{array}{l}\text { Terca menor } \\
\text { descendente }\end{array}$ & $\begin{array}{l}\text { Opus } \\
\text { Vn2 } \\
\text { emsi } \\
\text { bermol } \\
\text { maior }\end{array}$ & \begin{tabular}{|l|l|} 
I-Grave \\
\end{tabular} & 4 & 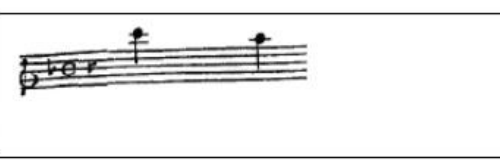 & . \\
\hline $\begin{array}{l}\text { Tersa monor } \\
\text { descendente }\end{array}$ & $\begin{array}{l}\text { Opus } \\
\text { Vn2 } \\
\text { emsi } \\
\text { bemol } \\
\text { maior }\end{array}$ & \begin{tabular}{|l|l} 
I-Grave \\
\end{tabular} & 5 & $\Rightarrow$ & $=$ \\
\hline $\begin{array}{l}\text { Tercamonor } \\
\text { descendente }\end{array}$ & $\begin{array}{l}\text { Opus } \\
\mathrm{Vn} 2 \\
\text { emsi } \\
\text { bermol }\end{array}$ & \begin{tabular}{|l} 
1-Grave \\
\end{tabular} & $8 \mathrm{e} 9$ & 层 & 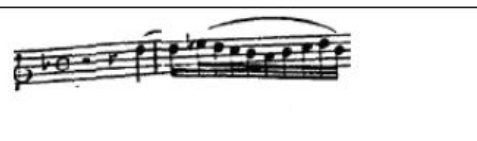 \\
\hline $\begin{array}{l}\begin{array}{l}\text { Terca menor } \\
\text { descendente }\end{array} \\
\end{array}$ & $\begin{array}{l}\text { Opus } \\
\mathrm{Vnn} 2 \\
\text { emsi } \\
\text { bermol } \\
\text { maior }\end{array}$ & \begin{tabular}{|l} 
1-Grave \\
\end{tabular} & 14 & 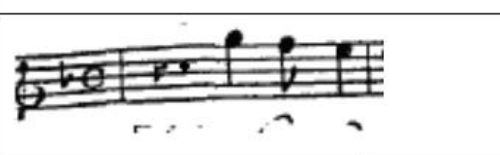 & 我色蛙 \\
\hline $\begin{array}{l}\text { Quarta justa } \\
\text { descendente }\end{array}$ & $\begin{array}{l}\text { Opus } \\
\mathrm{Vn} 2 \\
\text { emsi } \\
\text { bemol } \\
\text { maior }\end{array}$ & \begin{tabular}{|l} 
1-Grave \\
\end{tabular} & 1 & 12 & Grare \\
\hline $\begin{array}{l}\text { Quarta justa } \\
\text { descendente }\end{array}$ & $\begin{array}{l}\text { Opus } \\
\text { Vn2 } \\
\text { emsi } \\
\text { bernol } \\
\text { maior }\end{array}$ & \begin{tabular}{|l|l} 
1-Grave \\
\end{tabular} & 4 & 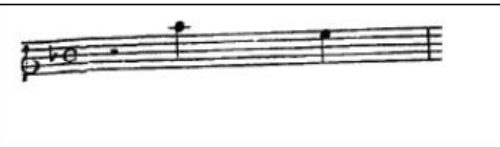 & 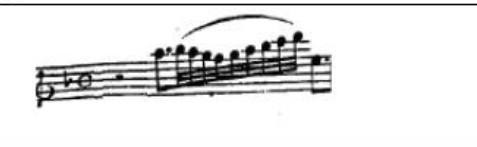 \\
\hline
\end{tabular}

\begin{tabular}{|c|c|c|c|c|c|}
\hline $\begin{array}{l}\text { Quinta justa } \\
\text { ascendente }\end{array}$ & $\begin{array}{l}\text { Opus } \\
\text { Vnn2 } \\
\text { emsi } \\
\text { bemol } \\
\text { maior }\end{array}$ & I-Grave & 9 e 10 & III & 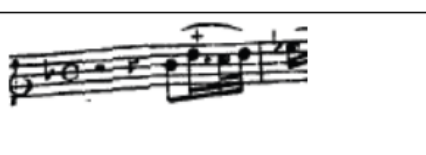 \\
\hline $\begin{array}{l}\text { Quinta justa } \\
\text { descendente }\end{array}$ & $\begin{array}{l}\text { Opus } \\
\text { Vn2 } \\
\text { emsi } \\
\text { bemol } \\
\text { maior }\end{array}$ & I-Grave & $7 \mathrm{e} 8$ & 理 & \% \\
\hline $\begin{array}{l}\text { Quinta justa } \\
\text { descendente }\end{array}$ & $\begin{array}{l}\text { Opus } \\
\text { Vn2 } \\
\text { emsi } \\
\text { enemol } \\
\text { rmaior } \\
\end{array}$ & I-Grave & 18 & 5omal & 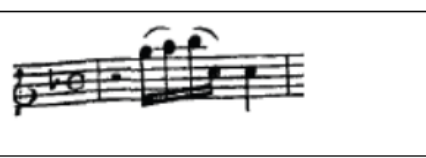 \\
\hline $\begin{array}{l}\text { Trítono } \\
\text { descendente }\end{array}$ & $\begin{array}{l}\text { Opus } \\
\text { On2 } \\
\text { emsi } \\
\text { bernol } \\
\text { maior }\end{array}$ & I-Grave & 10 & $\quad 1$ & \% \\
\hline
\end{tabular}




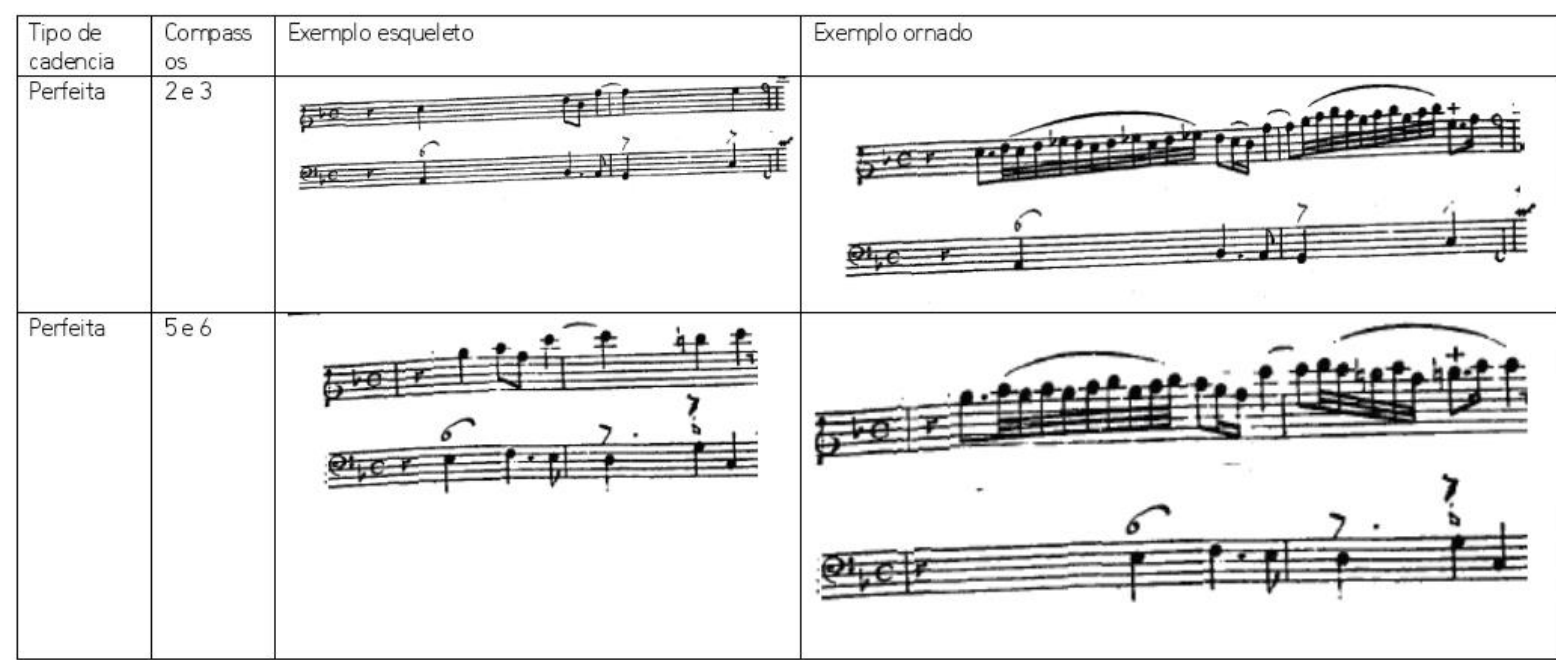

\begin{tabular}{|c|c|c|c|}
\hline Perfeita & 9 e 10 & $\begin{array}{l}4 \\
4\end{array}$ & 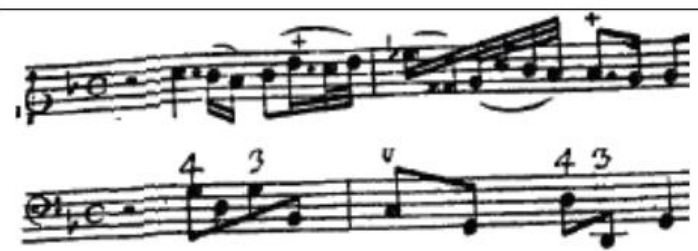 \\
\hline perfeita & 15 e 16 & 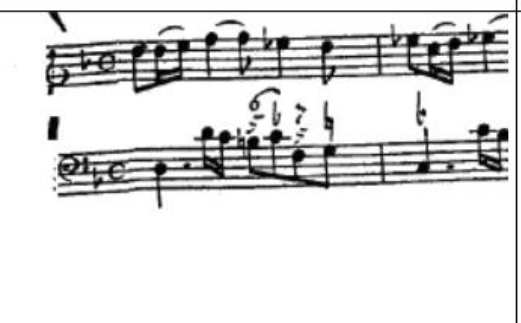 & 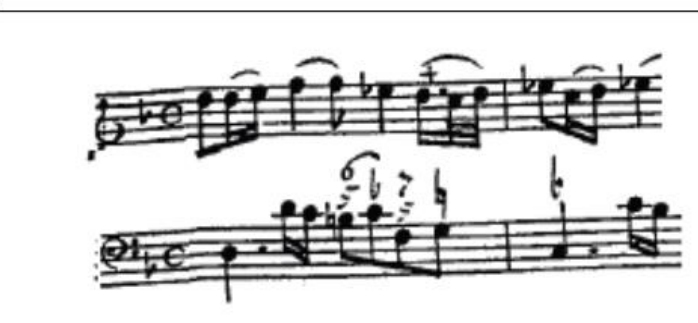 \\
\hline
\end{tabular}


Tabela 9: Ornamentos da sonata Opus V n.2, quarto movimento adágio:

\begin{tabular}{|c|c|c|c|c|c|}
\hline Intervalo & Sonata & \begin{tabular}{|l|} 
movimento \\
\end{tabular} & compassos & Exemplo esqueleto & Exemplo Omado \\
\hline Unissono & $\begin{array}{l}\text { Opus } \\
\text { Vn2 } \\
\text { emsi } \\
\text { bemol } \\
\text { maior }\end{array}$ & N-Adágio & 8 & 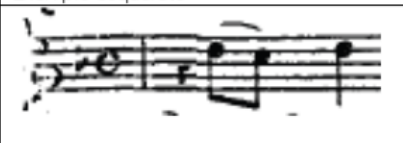 & 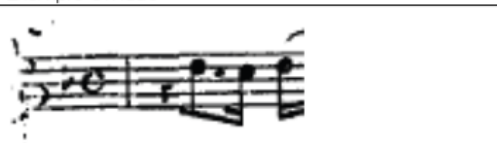 \\
\hline Uníssono & $\begin{array}{l}\text { Opus } \\
\mathrm{Vn} 2 \\
\text { emSi } \\
\text { bernol } \\
\text { maior }\end{array}$ & N-Adágio & 19 & 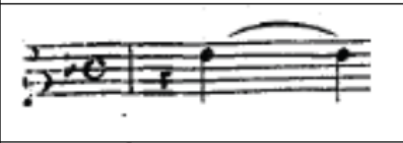 & expente \\
\hline $\begin{array}{l}\text { Segunda } \\
\text { menor } \\
\text { ascendente }\end{array}$ & $\begin{array}{l}\text { Opus } \\
V n 2 \\
\text { emSi } \\
\text { bemol } \\
\text { maior }\end{array}$ & N-Adágio & 2 & 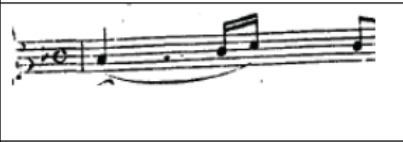 & 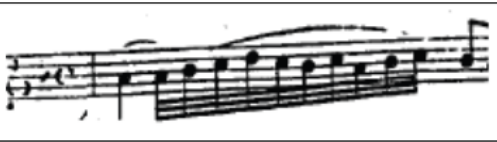 \\
\hline $\begin{array}{l}\text { Segunda } \\
\text { menor } \\
\text { ascendente }\end{array}$ & $\begin{array}{l}\text { Opus } \\
V \cap 2 \\
\text { emSi } \\
\text { bemol } \\
\text { maior }\end{array}$ & IV-Adágio & 4 e 5 & 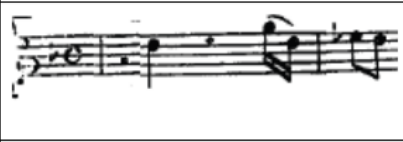 & IOE \\
\hline $\begin{array}{l}\text { Segunda } \\
\text { menor } \\
\text { ascendente }\end{array}$ & $\begin{array}{l}\text { Opus } \\
V \cap 2 \\
\text { emSi } \\
\text { bernol } \\
\text { maior }\end{array}$ & N-Adágio & 9 & 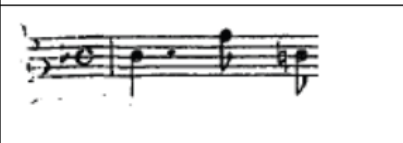 & $x^{2+2}=0$ \\
\hline $\begin{array}{l}\text { Segunda } \\
\text { menor } \\
\text { ascendente }\end{array}$ & $\begin{array}{l}\text { Opus } \\
\mathrm{V} n 2 \\
\text { emSi } \\
\text { bernol }\end{array}$ & N-Adágio & 9 & 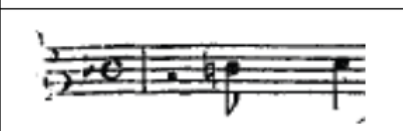 & $x^{2}=9 e^{\frac{1}{2}}$ \\
\hline
\end{tabular}

\begin{tabular}{|c|c|c|c|c|c|}
\hline & maior & & & & \\
\hline $\begin{array}{l}\text { Segunda } \\
\text { menor } \\
\text { ascendente }\end{array}$ & $\begin{array}{l}\text { Opus } \\
V \cap 2 \\
\text { emSi } \\
\text { bemol } \\
\text { maior }\end{array}$ & N-Adágio & 10 & $x+\frac{9 x}{5 x}$ & $\frac{x+2}{2}+\frac{2}{2}$ \\
\hline $\begin{array}{l}\text { Segunda } \\
\text { menor } \\
\text { ascendente }\end{array}$ & $\begin{array}{l}\text { Opus } \\
V n 2 \\
\text { emSi } \\
\text { bemol } \\
\text { maior }\end{array}$ & N-Adágio & 10 e 11 & 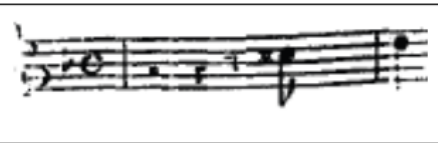 & 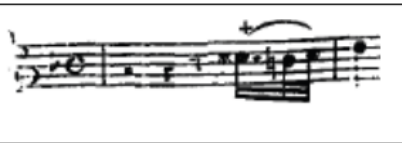 \\
\hline $\begin{array}{l}\text { Segunda } \\
\text { menor } \\
\text { ascendente }\end{array}$ & $\begin{array}{l}\text { Opus } \\
V n 2 \\
\text { emSi } \\
\text { bernol } \\
\text { maior }\end{array}$ & N-Adágio & 11 e 12 & $\underbrace{20}_{1 .}$ & क्ष \\
\hline $\begin{array}{l}\text { Segunda } \\
\text { menor } \\
\text { ascendente }\end{array}$ & $\begin{array}{l}\text { Opus } \\
V \cap 2 \\
\text { emSi } \\
\text { bemol } \\
\text { maior }\end{array}$ & N-Adágio & 18 e 19 & 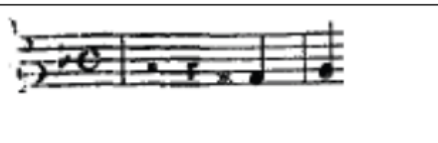 & Iक्व \\
\hline $\begin{array}{l}\text { Segunda } \\
\text { menor } \\
\text { descendente }\end{array}$ & $\begin{array}{l}\text { Opus } \\
V n 2 \\
\text { emSi } \\
\text { bernol } \\
\text { maior }\end{array}$ & N-Adágio & $7 e^{8} 8$ & 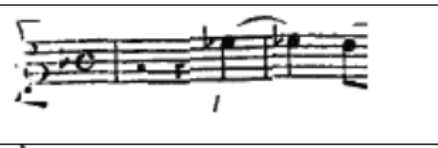 & Ifer \\
\hline $\begin{array}{l}\text { Segunda } \\
\text { menor } \\
\text { descendente }\end{array}$ & $\begin{array}{l}\text { Opus } \\
V n 2 \\
\text { emSi } \\
\text { bemol } \\
\text { maior }\end{array}$ & N-Adágio & 9 & 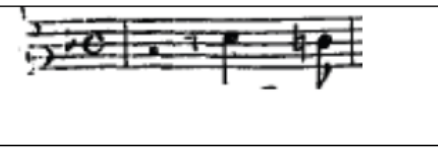 & 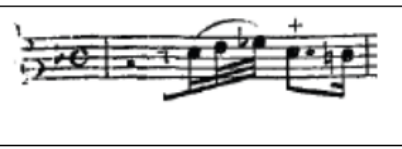 \\
\hline
\end{tabular}




\begin{tabular}{|c|c|c|c|c|c|}
\hline & maior & & & & \\
\hline $\begin{array}{l}\text { Segunda } \\
\text { menor } \\
\text { ascendente }\end{array}$ & $\begin{array}{l}\text { Opus } \\
\text { Vn } 2 \\
\text { emsi } \\
\text { bernol } \\
\text { mior }\end{array}$ & V-Adágio & 10 & wet? & If \\
\hline $\begin{array}{l}\text { Segunda } \\
\text { menor } \\
\text { ascendente }\end{array}$ & $\begin{array}{l}\text { Opus } \\
\text { Vn2 } \\
\text { emsi } \\
\text { bemol } \\
\text { maior }\end{array}$ & N-Adágio & 10 e 11 & 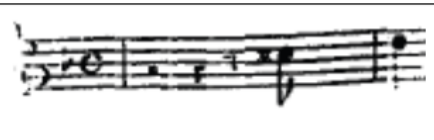 & 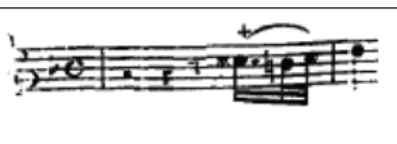 \\
\hline $\begin{array}{l}\text { Segunda } \\
\text { menor } \\
\text { ascendente }\end{array}$ & $\begin{array}{l}\text { Opus } \\
\text { Vnn } \\
\text { emsi } \\
\text { bemol } \\
\text { maior }\end{array}$ & V-Adágio & 11 e 12 & ${ }_{1}$ & 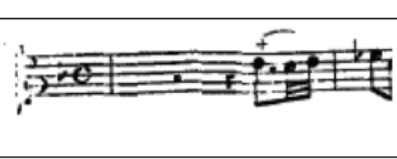 \\
\hline $\begin{array}{l}\text { Segunda } \\
\text { menor } \\
\text { ascendente }\end{array}$ & $\begin{array}{l}\text { Opus } \\
\text { Vn2 } \\
\text { emsi } \\
\text { bermol } \\
\text { maior }\end{array}$ & N-Adágio & $18 \mathrm{e} 19$ & Ifect & 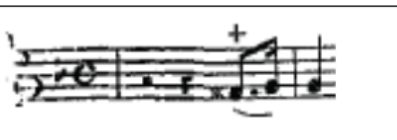 \\
\hline $\begin{array}{l}\text { Segunda } \\
\text { menor } \\
\text { descendente }\end{array}$ & $\begin{array}{l}\text { Opus } \\
\text { Vnn2 } \\
\text { emsi } \\
\text { enemol } \\
\text { maior }\end{array}$ & N-Adágio & $7 \mathrm{e} 8$ & $\frac{1}{1}$ & 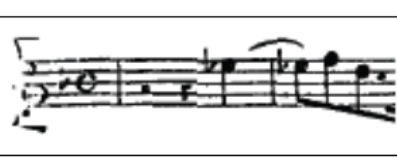 \\
\hline $\begin{array}{l}\text { Segunda } \\
\text { menor } \\
\text { descendente }\end{array}$ & $\begin{array}{l}\text { Opus } \\
\text { Vnn } \\
\text { emsi } \\
\text { bernol } \\
\text { mior }\end{array}$ & N-Adágio & 9 & 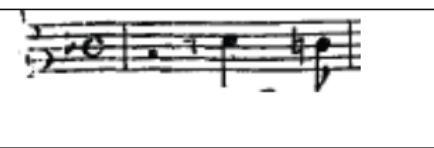 & 是 ${ }^{+}$ \\
\hline
\end{tabular}

\begin{tabular}{|c|c|c|c|c|c|}
\hline $\begin{array}{l}\text { Segunda } \\
\text { menor } \\
\text { descendente }\end{array}$ & \begin{tabular}{|l|} 
Opus \\
Vn2 \\
emsi \\
bemnol \\
maior
\end{tabular} & N-Adágio & 11 & 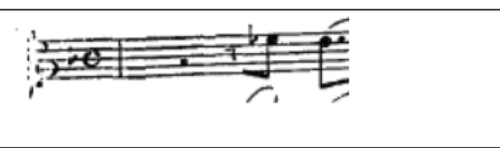 & 制告 \\
\hline $\begin{array}{l}\text { Segunda } \\
\text { menor } \\
\text { descendente }\end{array}$ & $\begin{array}{l}\text { Opus } \\
\text { Vn2 } \\
\text { emsi } \\
\text { bemol } \\
\text { maior }\end{array}$ & V-Adágio & 18 & ${ }^{2}=0$ & 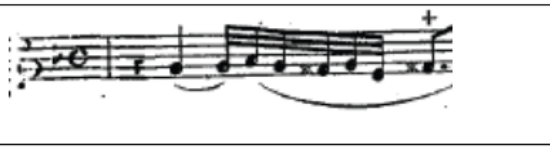 \\
\hline $\begin{array}{l}\text { Segunda } \\
\text { maior } \\
\text { ascendente }\end{array}$ & $\begin{array}{l}\text { Opus } \\
\mathrm{Vn} 2 \\
\text { emsi } \\
\text { bernol } \\
\text { maior }\end{array}$ & IV-Adágio & $1 \mathrm{e} 2$ & $l^{2}=\ldots$ & Adagio \\
\hline $\begin{array}{l}\text { Segunda } \\
\text { maior } \\
\text { ascendente }\end{array}$ & $\begin{array}{l}\text { Opus } \\
\text { Vnn } \\
\text { emsi } \\
\text { bermol } \\
\text { maior }\end{array}$ & V-Adágio & 3 & $\underbrace{}_{0}$ & 1 \\
\hline $\begin{array}{l}\text { Segunda } \\
\text { maior } \\
\text { ascendente }\end{array}$ & $\begin{array}{l}\text { Opus } \\
V \mathrm{n} 2 \\
\text { emSi } \\
\text { bermol } \\
\text { maior }\end{array}$ & N-Adágio & 3 e 4 & 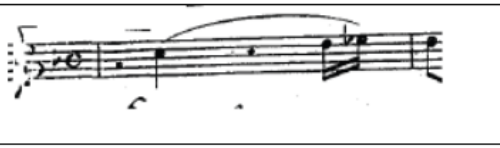 & $\sqrt{20^{+}}$ \\
\hline $\begin{array}{l}\text { Segunda } \\
\text { maico } \\
\text { ascendente }\end{array}$ & $\begin{array}{l}\text { Opus } \\
V \mathrm{n} 2 \\
\text { emSi } \\
\text { bermol } \\
\text { maior }\end{array}$ & N-Adágio & $12 \mathrm{e} 13$ & 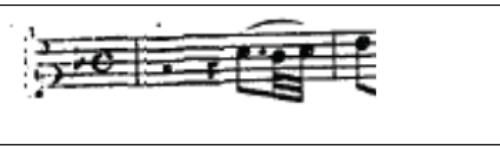 & $x^{2} \frac{f}{20}$ \\
\hline
\end{tabular}




\begin{tabular}{|c|c|c|c|c|c|}
\hline $\begin{array}{l}\text { Segunda } \\
\text { maior } \\
\text { ascendente }\end{array}$ & $\begin{array}{l}\text { Opus } \\
\text { Vn2 } \\
\text { emsi } \\
\text { bermol } \\
\text { maior }\end{array}$ & IV-Adágio & 19 e 20 & 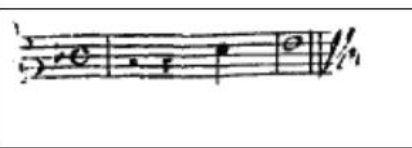 & 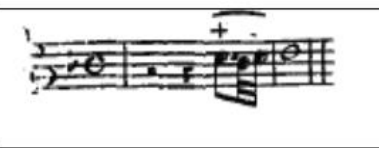 \\
\hline \begin{tabular}{l|l}
$\begin{array}{l}\text { Segunda } \\
\text { maior } \\
\text { descendente }\end{array}$ & \\
\end{tabular} & $\begin{array}{l}\text { malor } \\
\text { Opus } \\
V n 2 \\
\text { emsi } \\
\text { bemol } \\
\text { maior }\end{array}$ & N-Adágio & 8 & - & wet \\
\hline \begin{tabular}{l|l}
$\begin{array}{l}\text { Segunda } \\
\text { maior } \\
\text { descendente }\end{array}$ & \\
\end{tabular} & $\begin{array}{l}\text { Opus } \\
\text { Vn } 2 \\
\text { emsi } \\
\text { bernol } \\
\text { maior }\end{array}$ & N-Adágio & $8 \mathrm{e}^{9}$ & $\frac{x+90}{2}$ & क्ष \\
\hline \begin{tabular}{l|l}
$\begin{array}{l}\text { Segunda } \\
\text { maior } \\
\text { descendente }\end{array}$ \\
\end{tabular} & $\begin{array}{l}\text { Opus } \\
V \text { Vn } \\
\text { emsi } \\
\text { bemol } \\
\text { maior }\end{array}$ & N-Adágio & 11 & $x^{2}$ & $\mathrm{Le}^{2}$ \\
\hline \begin{tabular}{l|l}
$\begin{array}{l}\text { Segunda } \\
\text { maior } \\
\text { descendente }\end{array}$ & \\
\end{tabular} & $\begin{array}{l}\text { Opus } \\
\text { Vn2 } \\
\text { em Si } \\
\text { bernol } \\
\text { maior }\end{array}$ & IV-Adágio & 12 & 轨 & 程 \\
\hline $\begin{array}{l}\text { Segunda } \\
\text { maior } \\
\text { descendente }\end{array}$ & $\begin{array}{l}\text { Opus } \\
\text { Vn2 } \\
\text { emsi } \\
\text { bemol } \\
\text { maior }\end{array}$ & N-Adágio & 14 & 告送e & Ea:e \\
\hline
\end{tabular}

\begin{tabular}{|c|c|c|c|c|c|}
\hline $\begin{array}{l}\text { Segunda } \\
\text { maior } \\
\text { descendente }\end{array}$ & $\begin{array}{l}\text { Opus } \\
V \mathrm{~V} 2 \\
\text { emsi } \\
\text { bemol } \\
\text { maior }\end{array}$ & N-Adágio & 17 & 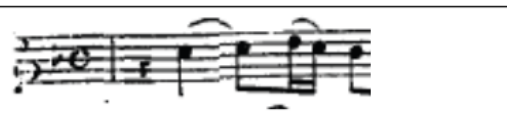 & स्था \\
\hline $\begin{array}{l}\text { Segunda } \\
\text { maior } \\
\text { descendente }\end{array}$ & $\begin{array}{l}\text { Opus } \\
\text { Vn } 2 \\
\text { emsi } \\
\text { bemol } \\
\text { maior }\end{array}$ & N-Adágio & 19 & 作 & 象 \\
\hline $\begin{array}{l}\begin{array}{l}\text { Segunda } \\
\text { maior } \\
\text { descendente }\end{array} \\
\end{array}$ & $\begin{array}{l}\text { Opus } \\
\text { Vn2 } \\
\text { emsi } \\
\text { bermol } \\
\text { maior }\end{array}$ & N-Adágio & 19 & 政 & $\frac{x}{2+c t a t}$ \\
\hline $\begin{array}{l}\text { Terca menor } \\
\text { descendente }\end{array}$ & $\begin{array}{l}\text { Opus } \\
\text { Vn2 } \\
\text { emsi } \\
\text { bermol } \\
\text { maior }\end{array}$ & V-Adágio & 2 & 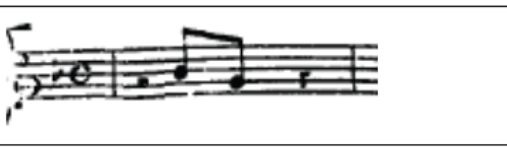 & $x^{2}=x^{2}$ \\
\hline $\begin{array}{l}\text { Tersa menor } \\
\text { descendente }\end{array}$ & $\begin{array}{l}\text { Opus } \\
\text { Vn2 } \\
\text { emsi } \\
\text { bemol } \\
\text { maior }\end{array}$ & N-Adágio & 6 & 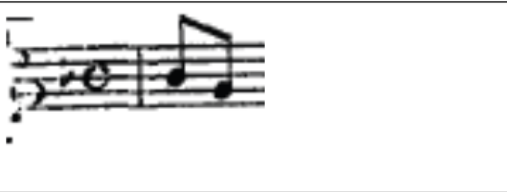 & $\frac{5+2 x=5}{5}$ \\
\hline
\end{tabular}




\begin{tabular}{|c|c|c|c|c|c|}
\hline $\begin{array}{l}\text { Tersa menor } \\
\text { descendente }\end{array}$ & $\begin{array}{l}\text { Opus } \\
V n 2 \\
\text { emsi } \\
\text { bermol } \\
\text { maior }\end{array}$ & IN-Adágio & 6 & 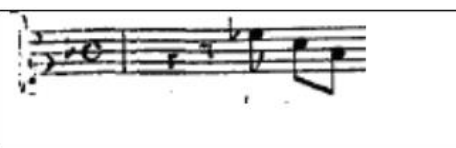 & क्वि \\
\hline $\begin{array}{l}\text { Terca menor } \\
\text { descendente }\end{array}$ & $\begin{array}{l}\text { Opus } \\
\text { Vn2 } \\
\text { emsi } \\
\text { bemol } \\
\text { maior }\end{array}$ & N-Adágio & $6 \mathrm{e} 7$ & 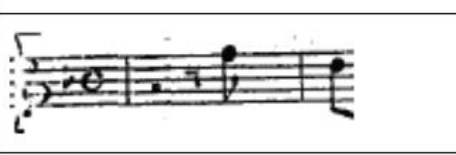 & एक्षण \\
\hline $\begin{array}{l}\text { Terca menor } \\
\text { descendente }\end{array}$ & $\begin{array}{l}\text { Opus } \\
\text { Vn2 } \\
\text { ensi } \\
\text { bernol }\end{array}$ & N-Adágio & 11 & $\Rightarrow e^{2}$ & क्षा \\
\hline $\begin{array}{l}\text { Tersa menor } \\
\text { descendente }\end{array}$ & $\begin{array}{l}\text { Opus } \\
\text { Vn2 } \\
\text { emSi } \\
\text { bernol } \\
\text { maior }\end{array}$ & N- Adágio & 11 & 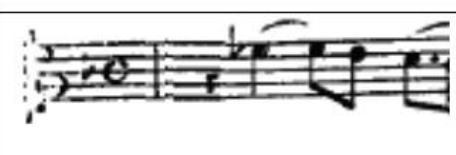 & 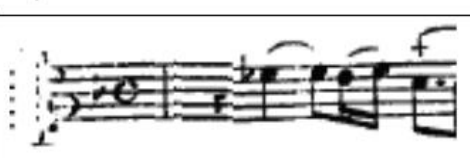 \\
\hline $\begin{array}{l}\text { Tersamenor } \\
\text { descendente }\end{array}$ & $\begin{array}{l}\text { Opus } \\
V n 2 \\
\text { emsi } \\
\text { bernol } \\
\text { maior }\end{array}$ & N-Adágio & 15 e 16 & 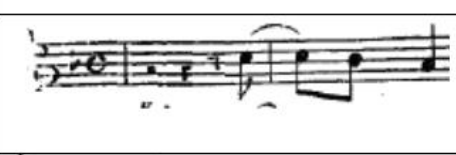 & 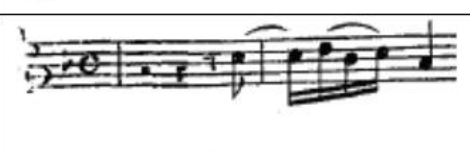 \\
\hline $\begin{array}{l}\text { Terca maior } \\
\text { ascendente }\end{array}$ & $\begin{array}{l}\text { Opus } \\
\text { Vn2 } \\
\text { emsi } \\
\text { bernol } \\
\text { maior }\end{array}$ & N-Adágio & 5 & 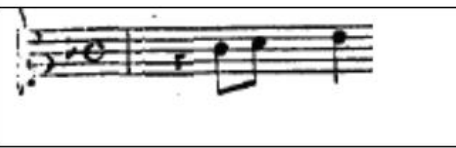 & icte \\
\hline
\end{tabular}

\begin{tabular}{|c|c|c|c|c|c|}
\hline $\begin{array}{l}\text { Sexta menor } \\
\text { Ascendente }\end{array}$ & $\begin{array}{l}\text { Opus } \\
V \cap 2 \\
\text { em Si } \\
\text { bemol } \\
\text { maior }\end{array}$ & IV-Adágio & 13 & 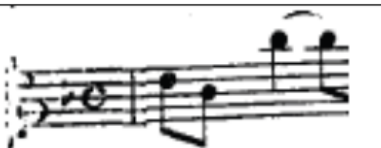 & $x^{2+\infty}=2+2$ \\
\hline $\begin{array}{l}\text { Sexta menor } \\
\text { Ascendente }\end{array}$ & $\begin{array}{l}\text { Opus } \\
V \cap 2 \\
\text { em Si } \\
\text { bernol } \\
\text { maior }\end{array}$ & IV-Adágio & 16 e 17 & 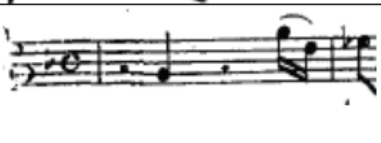 & 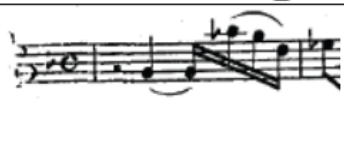 \\
\hline $\begin{array}{l}\text { Oitava justa } \\
\text { Ascendente }\end{array}$ & $\begin{array}{l}\text { Opus } \\
V \cap 2 \\
\text { emSi } \\
\text { bemol } \\
\text { maior }\end{array}$ & IV-Adágio & 13 & $\frac{2+2+2}{2+2}$ & 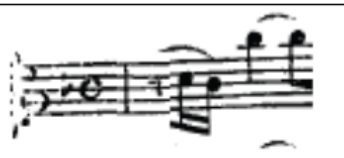 \\
\hline
\end{tabular}

\begin{tabular}{|c|c|c|c|}
\hline $\begin{array}{l}\text { Tipo de } \\
\text { cadencia }\end{array}$ & Compassos & Exemplo esqueleto & Exemplo ornado \\
\hline Perfeita & $7,8 \mathrm{e}^{9}$ & 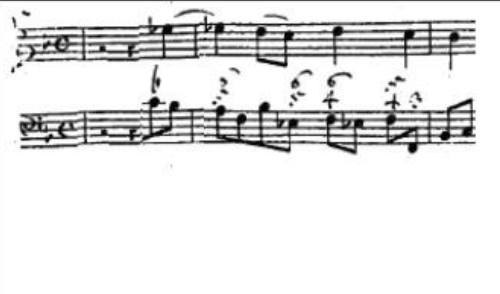 & 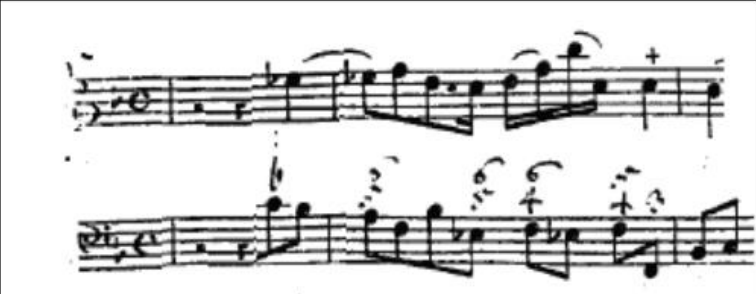 \\
\hline Perfeita & 9 e 10 & 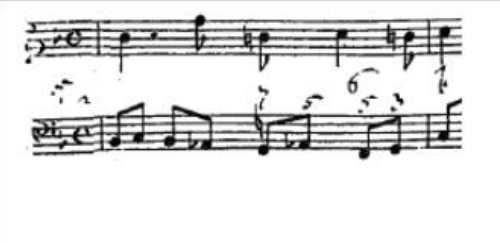 & 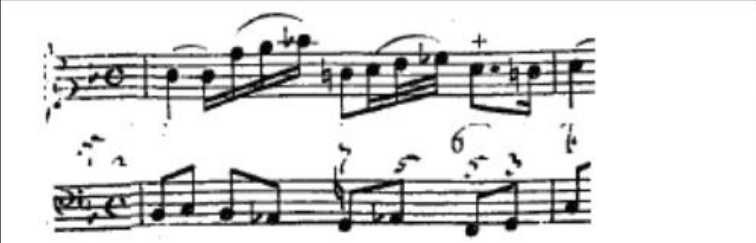 \\
\hline $\begin{array}{l}\text { Perfeita } \\
\end{array}$ & $10 \mathrm{e} 11$ & 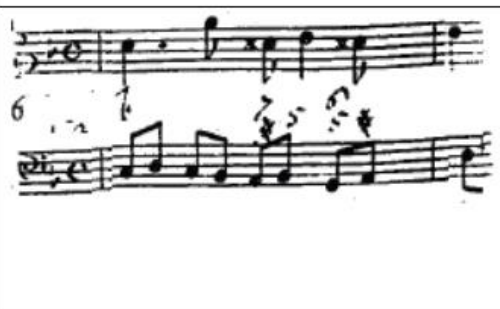 & 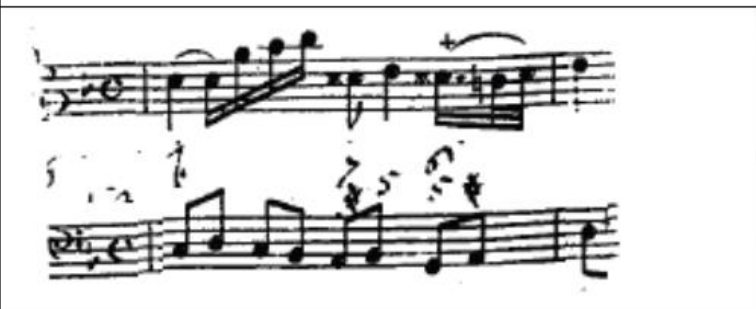 \\
\hline
\end{tabular}




\begin{tabular}{|c|c|c|c|}
\hline Perfeita & 11 e 12 & 皮 & 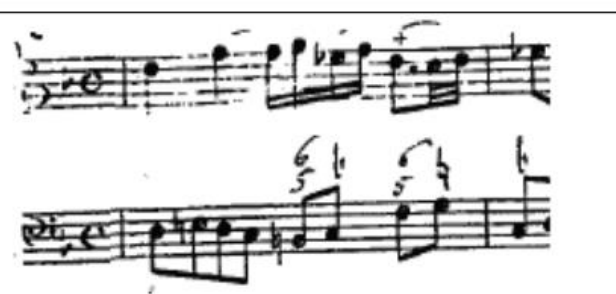 \\
\hline Perfeita & $12 \mathrm{e} 13$ & 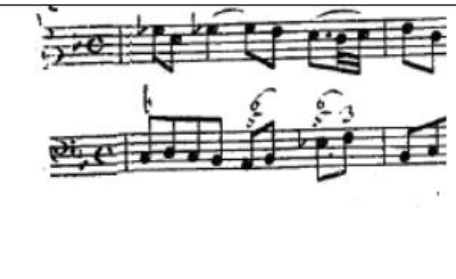 & 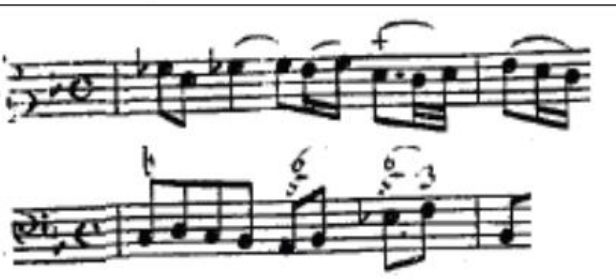 \\
\hline Perfeita & $18 \mathrm{e} 19$ & 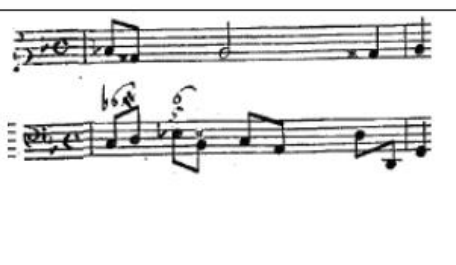 & 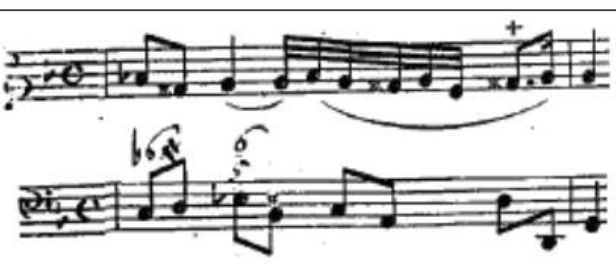 \\
\hline
\end{tabular}

Tabela 10: Ornamentos da sonata Opus V n.3, primeiro movimento adágio:

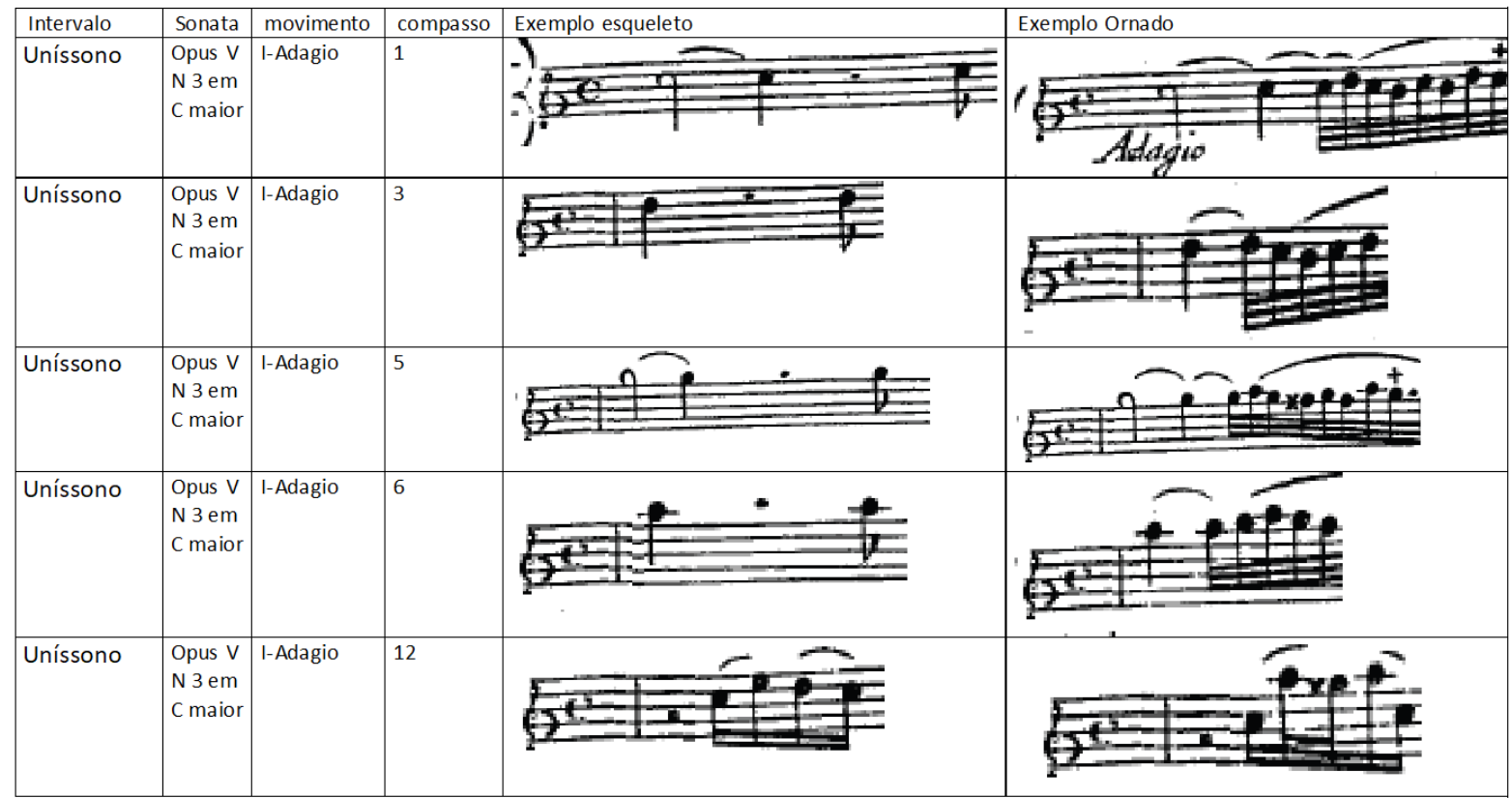




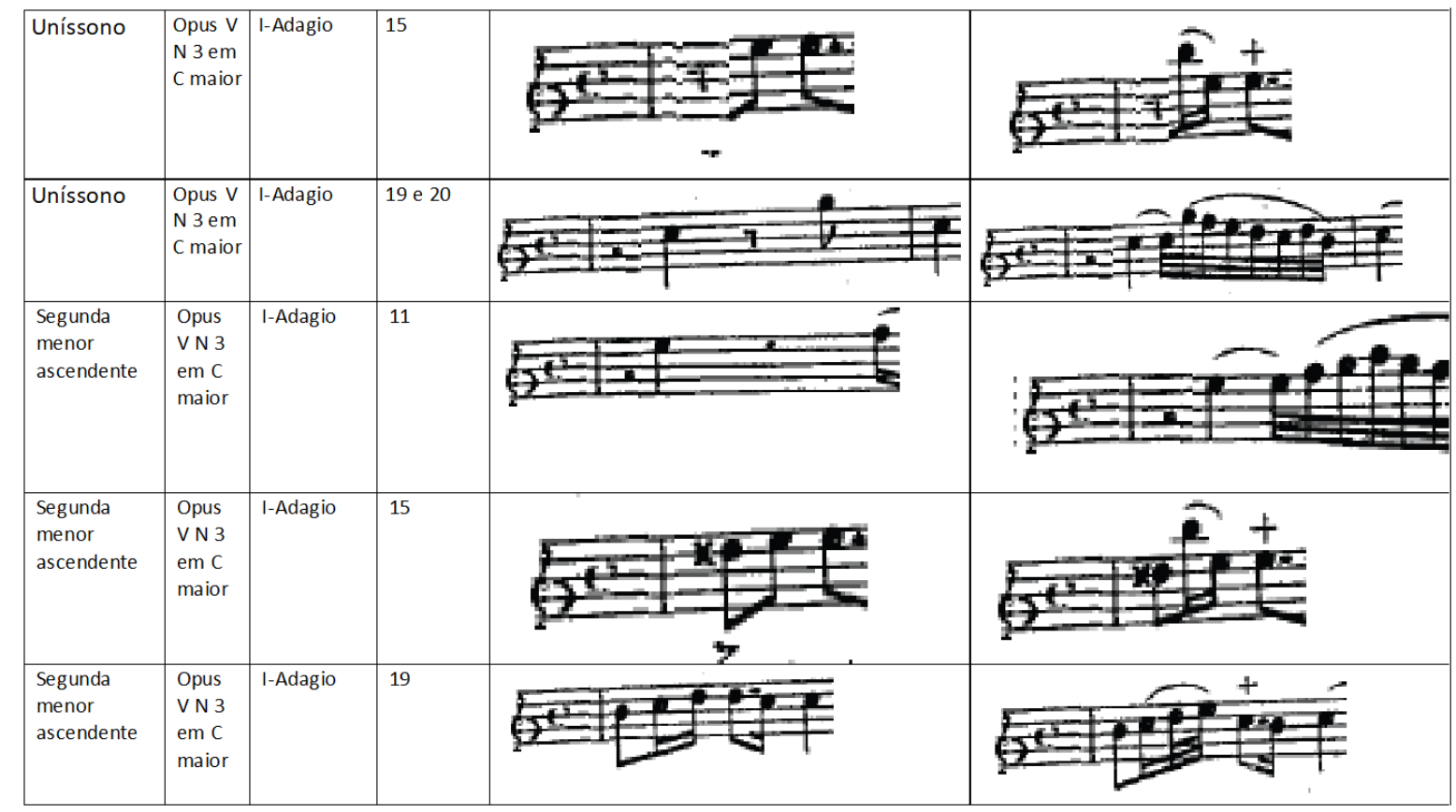

\begin{tabular}{|c|c|c|c|c|c|}
\hline $\begin{array}{l}\text { Segunda } \\
\text { menor } \\
\text { descendente }\end{array}$ & $\begin{array}{l}\text { Opus } \\
\text { VN } 3 \\
\text { em C } \\
\text { maior }\end{array}$ & I-Adagio & 7 e 8 & $5^{2}=F^{2}+7^{*}$ & $y^{2}=0$ \\
\hline $\begin{array}{l}\text { Segunda } \\
\text { menor } \\
\text { descendente }\end{array}$ & $\begin{array}{l}\text { Opus } \\
\text { VN } 3 \\
\text { em C } \\
\text { maior }\end{array}$ & \begin{tabular}{|l|} 
I-Adagio \\
|
\end{tabular} & 10 & Ex & 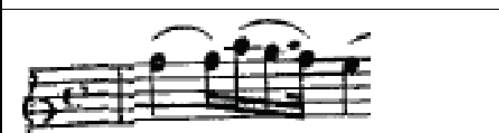 \\
\hline $\begin{array}{l}\text { Segunda } \\
\text { menor } \\
\text { descendente }\end{array}$ & $\begin{array}{l}\text { Opus } \\
\text { VN } 3 \\
\text { em C } \\
\text { maior }\end{array}$ & \begin{tabular}{|l|} 
I-Adagio \\
|-Adio
\end{tabular} & 12 & $5^{2}=F^{2} \Rightarrow F$ & $x_{-1}^{2+}$ \\
\hline $\begin{array}{l}\text { Segunda } \\
\text { menor } \\
\text { descendente }\end{array}$ & $\begin{array}{l}\text { Opus } \\
\text { VN } 3 \\
\text { em C } \\
\text { maior }\end{array}$ & \begin{tabular}{|l|l} 
I-Adagio \\
Idiodi
\end{tabular} & 14 e 15 & $x^{2}= \pm 17$ & $i \div$ \\
\hline $\begin{array}{l}\text { Segunda } \\
\text { menor } \\
\text { descendente }\end{array}$ & $\begin{array}{l}\text { Opus } \\
\text { VN } 3 \\
\text { em C } \\
\text { maior }\end{array}$ & \begin{tabular}{|l|} 
I-Adagio \\
\end{tabular} & 14 e 15 & 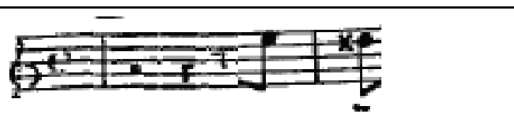 & $5^{2}=7$ \\
\hline $\begin{array}{l}\text { Segunda } \\
\text { menor } \\
\text { descendente }\end{array}$ & $\begin{array}{l}\text { Opus } \\
\text { VN } 3 \\
\text { em C } \\
\text { maior }\end{array}$ & 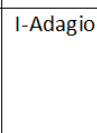 & 17 & $\rho^{2}+7=$ & 5 \\
\hline
\end{tabular}




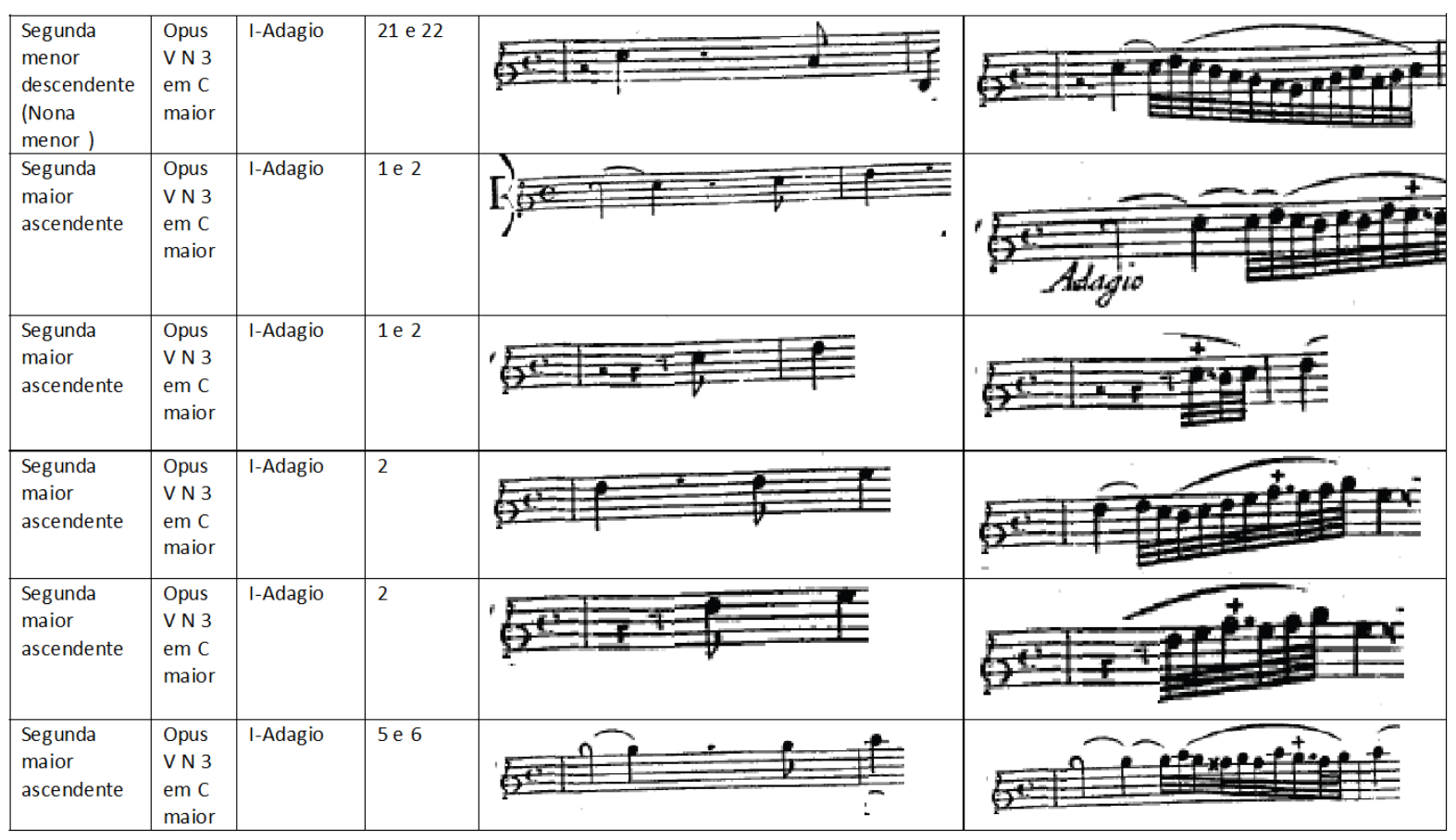

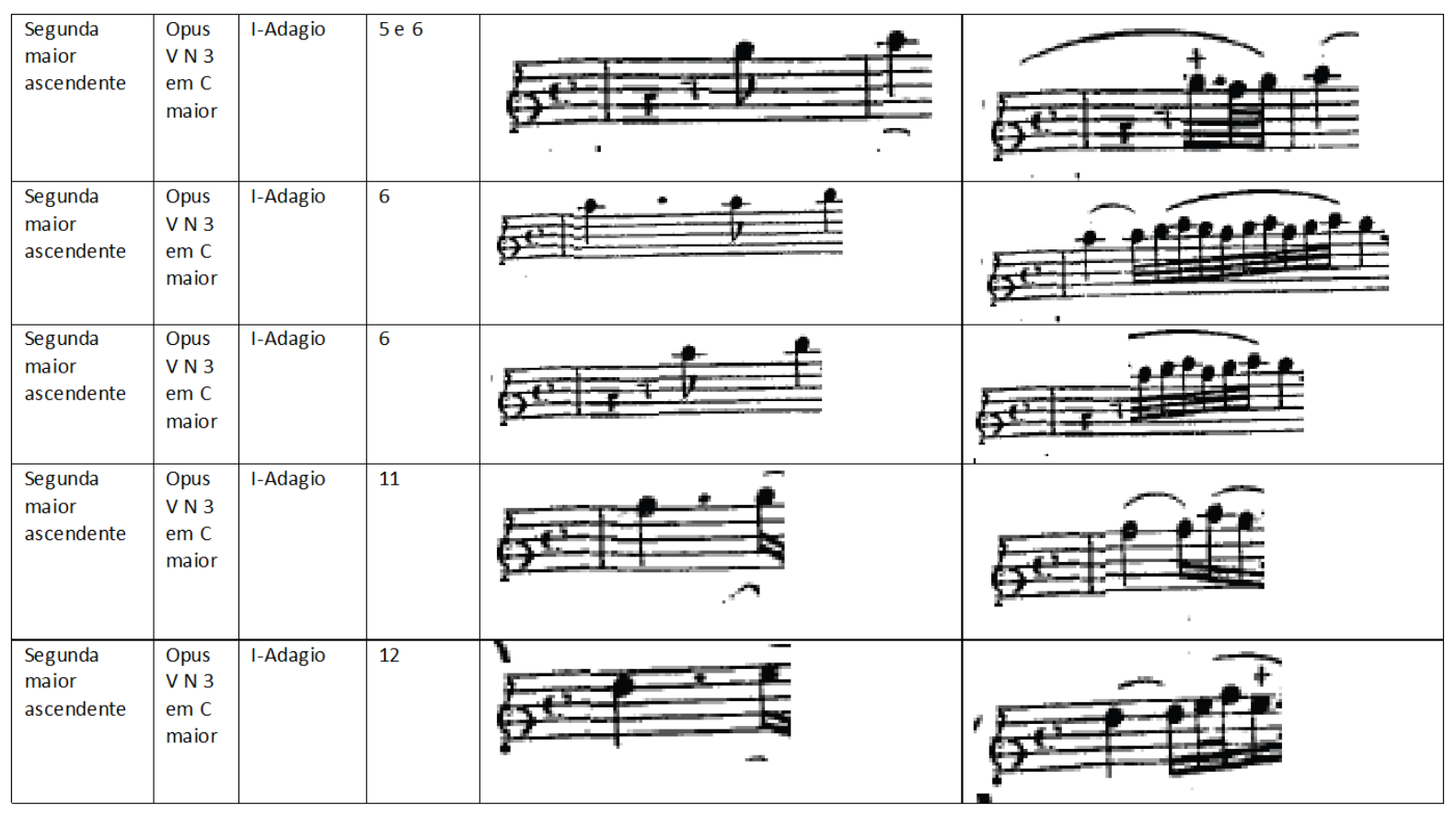




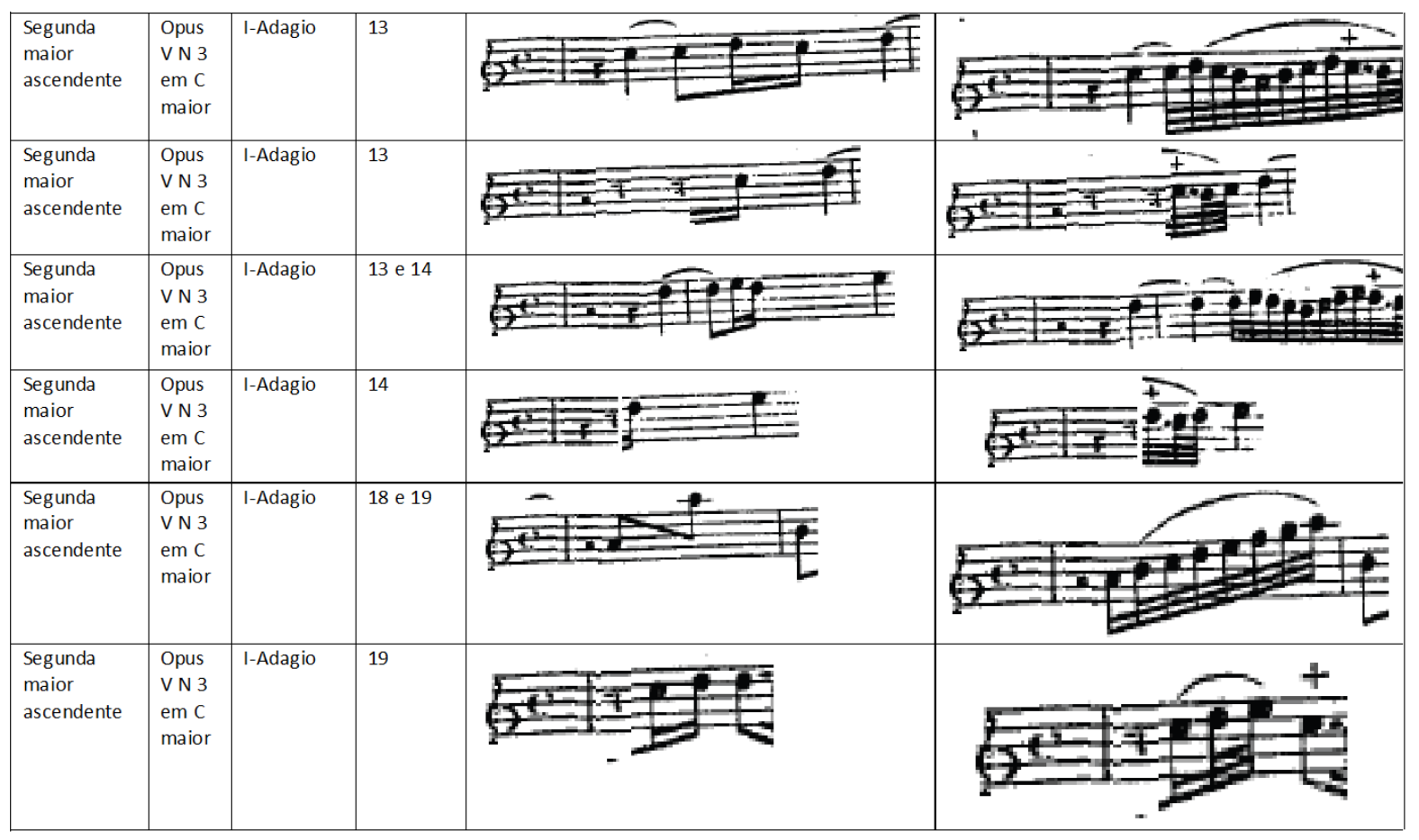

\begin{tabular}{|c|c|c|c|c|c|}
\hline $\begin{array}{l}\text { Segunda } \\
\text { maior } \\
\text { ascendente }\end{array}$ & $\begin{array}{l}\text { Opus } \\
\text { VN3 } \\
\text { em C } \\
\text { maior }\end{array}$ & I-Adagio & 20 e 21 & 汪地 & $y^{2}=-2+0$ \\
\hline $\begin{array}{l}\text { Segunda } \\
\text { maior } \\
\text { descendente }\end{array}$ & $\begin{array}{l}\text { Opus } \\
\text { VN } 3 \\
\text { em C } \\
\text { maior }\end{array}$ & \begin{tabular}{|l|l|} 
I-Adagio \\
\end{tabular} & 3 & 'DI=: & $5^{2}=$ \\
\hline $\begin{array}{l}\text { Segunda } \\
\text { maior } \\
\text { descendente }\end{array}$ & $\begin{array}{l}\text { Opus } \\
\text { VN } 3 \\
\text { em C } \\
\text { maior }\end{array}$ & \begin{tabular}{|l} 
I-Adagio \\
\end{tabular} & 3 & $a^{2}=-\div 2$ & $5^{2}= \pm$ \\
\hline $\begin{array}{l}\text { Segunda } \\
\text { maior } \\
\text { descendente }\end{array}$ & $\begin{array}{l}\text { Opus } \\
\text { VN } 3 \\
\text { em C } \\
\text { maior }\end{array}$ & \begin{tabular}{|l} 
I-Adagio \\
\end{tabular} & 3e 4 & 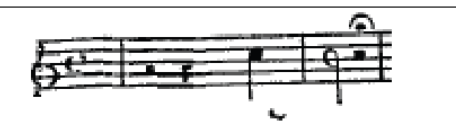 & $+\frac{a}{a^{2}+a^{2}}$ \\
\hline $\begin{array}{l}\text { Segunda } \\
\text { maior } \\
\text { descendente }\end{array}$ & $\begin{array}{l}\text { Opus } \\
\text { VN } 3 \\
\text { em C } \\
\text { maior }\end{array}$ & \begin{tabular}{|l|l|} 
I-Adagio \\
\end{tabular} & 7 & tक & teot \\
\hline $\begin{array}{l}\text { Segunda } \\
\text { maior } \\
\text { descendente }\end{array}$ & $\begin{array}{l}\text { Opus } \\
\text { VN } 3 \\
\text { em C } \\
\text { maior }\end{array}$ & \begin{tabular}{|l|l|} 
I-Adagio \\
\end{tabular} & 7 & 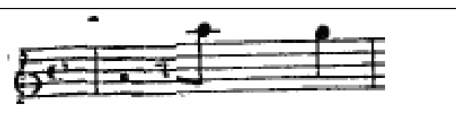 & $\varepsilon^{2}=-0^{-1}$ \\
\hline
\end{tabular}




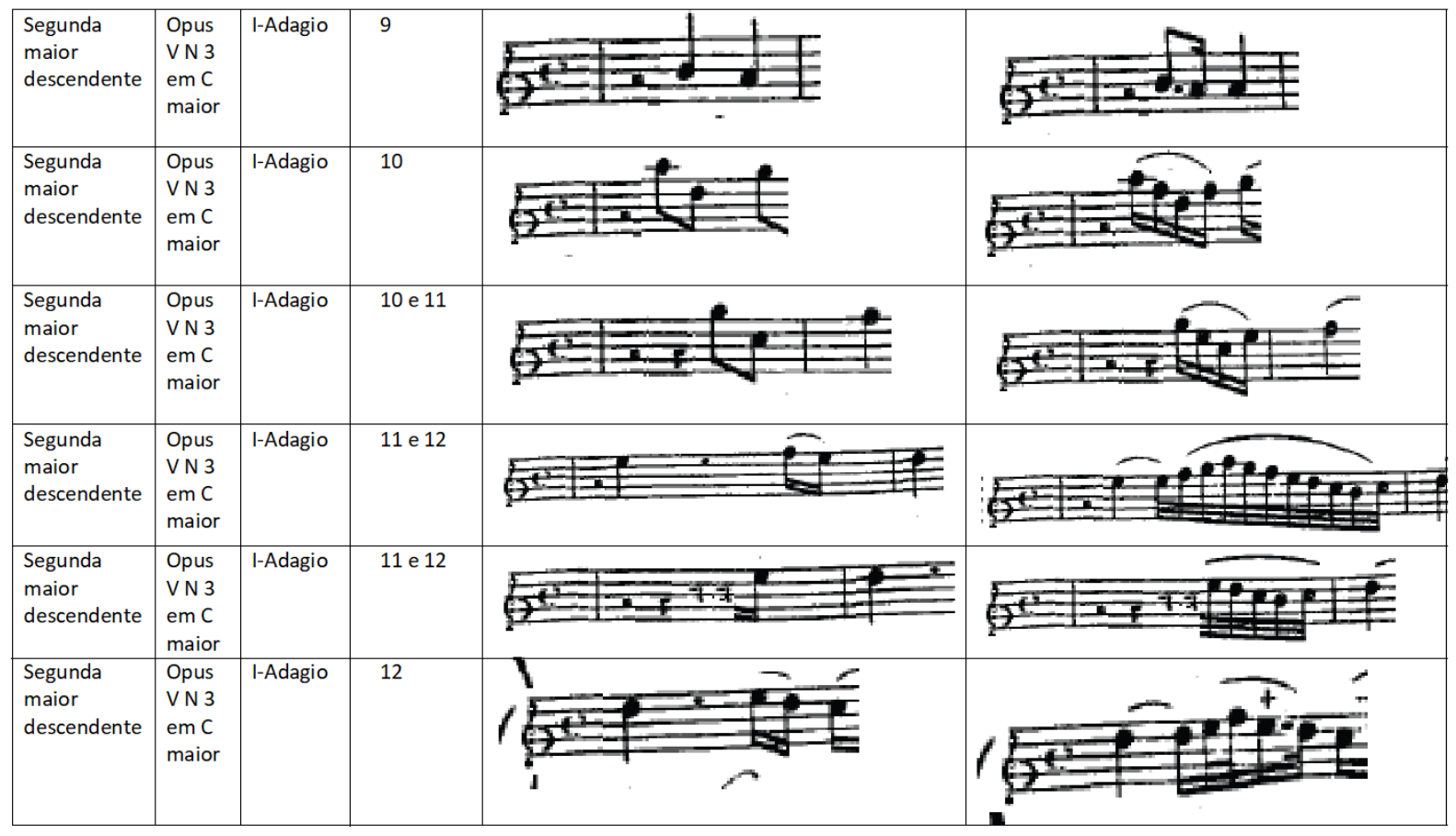

\begin{tabular}{|c|c|c|c|c|c|}
\hline $\begin{array}{l}\text { Segunda } \\
\text { maior } \\
\text { descendente }\end{array}$ & $\begin{array}{l}\text { Opus } \\
\text { VN3 } \\
\text { em C } \\
\text { maior }\end{array}$ & I-Adagio & 12 e 13 & $\rho^{2}=1=1+1$ & ${ }_{2=12}$ \\
\hline $\begin{array}{l}\text { Segunda } \\
\text { maior } \\
\text { descendente }\end{array}$ & $\begin{array}{l}\text { Opus } \\
\text { VN3 } \\
\text { em C } \\
\text { maior }\end{array}$ & |-Adagio & 13 & 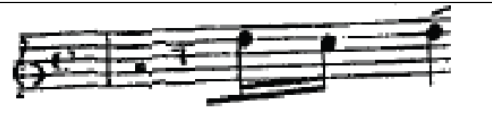 & $S^{2}=-19 x^{ \pm}$ \\
\hline $\begin{array}{l}\text { Segunda } \\
\text { maior } \\
\text { descendente }\end{array}$ & $\begin{array}{l}\text { Opus } \\
\text { VN3 } \\
\text { em C } \\
\text { maior }\end{array}$ & I-Adagio & 14 & $=1$ & $s^{2}=79$ \\
\hline $\begin{array}{l}\text { Segunda } \\
\text { maior } \\
\text { descendente }\end{array}$ & $\begin{array}{l}\text { Opus } \\
\text { VN3 } \\
\text { em C } \\
\text { maior }\end{array}$ & I-Adagio & 17 & $\rho^{2}=17 \pm=7$ & $\Phi^{2}=1=$ \\
\hline $\begin{array}{l}\text { Segunda } \\
\text { maior } \\
\text { descendente }\end{array}$ & $\begin{array}{l}\text { Opus } \\
\text { VN } 3 \\
\text { em C } \\
\text { maior }\end{array}$ & |-Adagio & 17 e 18 & $S^{2}=1 \pm 1$ & $5 E^{2}=7$ \\
\hline
\end{tabular}




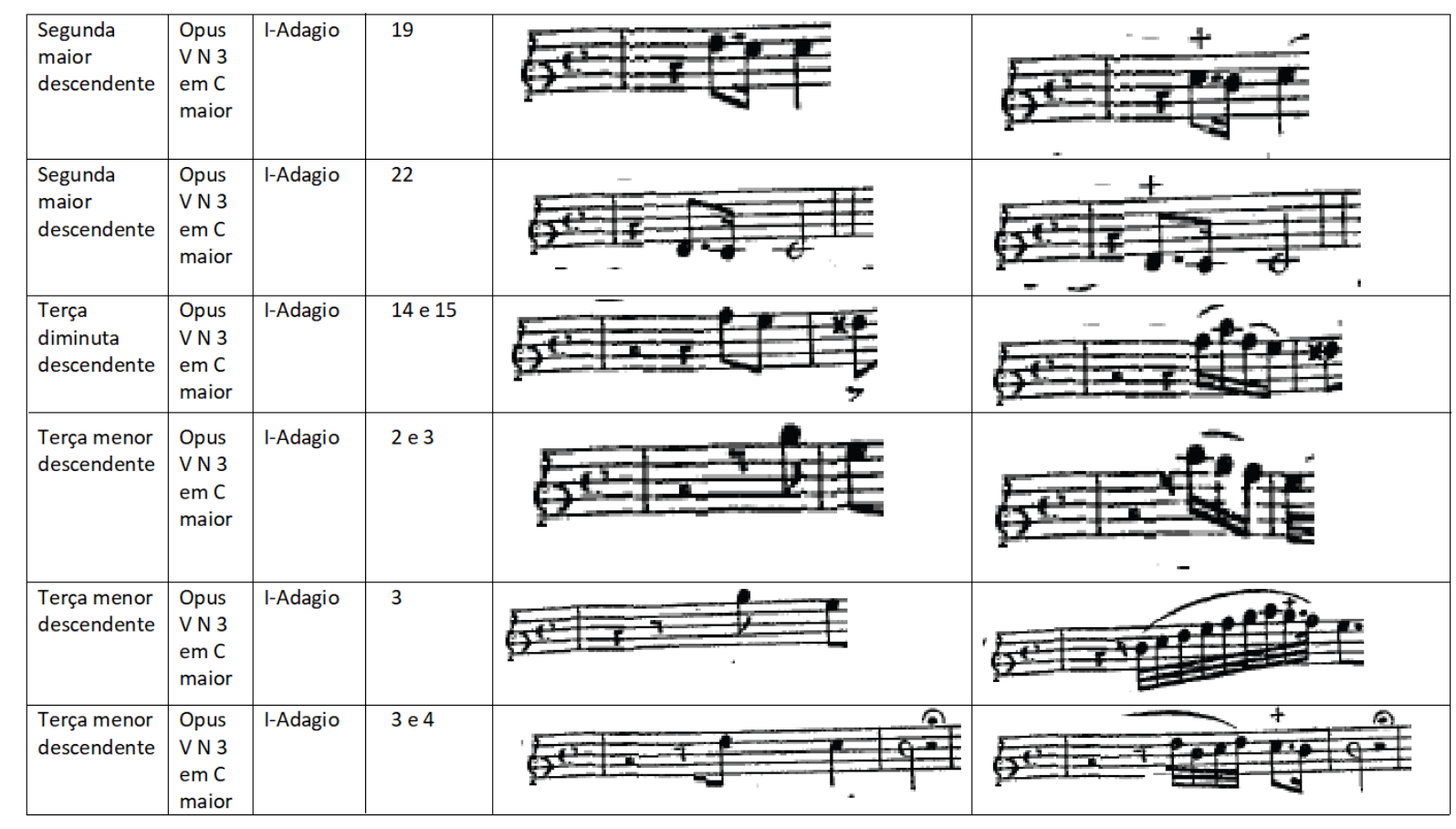

\begin{tabular}{|c|c|c|c|c|c|}
\hline $\begin{array}{l}\text { Terça menor } \\
\text { descendente }\end{array}$ & $\begin{array}{l}\text { Opus } \\
\text { VN3 } \\
\text { em C } \\
\text { maior }\end{array}$ & 1-Adagio & 11 & 正平 & $5^{2}+7+2=$ \\
\hline $\begin{array}{l}\text { Terça menor } \\
\text { descendente }\end{array}$ & $\begin{array}{l}\text { Opus } \\
\text { VN3 } \\
\text { em C } \\
\text { maior }\end{array}$ & |-Adagio & 17 & $5^{2}=17=7$ & $\sigma^{2}+1$ \\
\hline $\begin{array}{l}\text { Terça menor } \\
\text { descendente }\end{array}$ & $\begin{array}{l}\text { Opus } \\
\text { VN3 } \\
\text { em C } \\
\text { maior }\end{array}$ & I-Adagio & 20 & 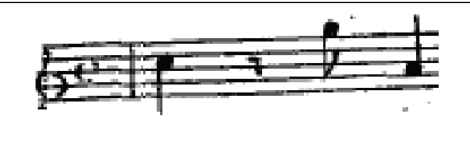 & क्षेत्र \\
\hline $\begin{array}{l}\text { Terça maior } \\
\text { descendente }\end{array}$ & $\begin{array}{l}\text { Opus } \\
\text { VN3 } \\
\text { em C } \\
\text { maior }\end{array}$ & I-Adagio & 3 & $\Phi^{2}=2$ & $\underline{\bar{z}}$ \\
\hline $\begin{array}{l}\text { Terça maior } \\
\text { descendente }\end{array}$ & $\begin{array}{l}\text { Opus } \\
\text { VN3 } \\
\text { em C } \\
\text { maior }\end{array}$ & 1-Adagio & 3 & 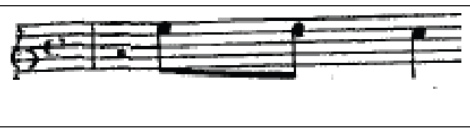 & $\rho ^ { 2 } \longdiv { \operatorname { c o c } ^ { 2 } }$ \\
\hline $\begin{array}{l}\text { Terça maior } \\
\text { descendente }\end{array}$ & $\begin{array}{l}\text { Opus } \\
\text { VN3 } \\
\text { em C } \\
\text { maior }\end{array}$ & 1-Adagio & 7 & $5 t^{2}=1$ & $t^{2}+2$ \\
\hline
\end{tabular}




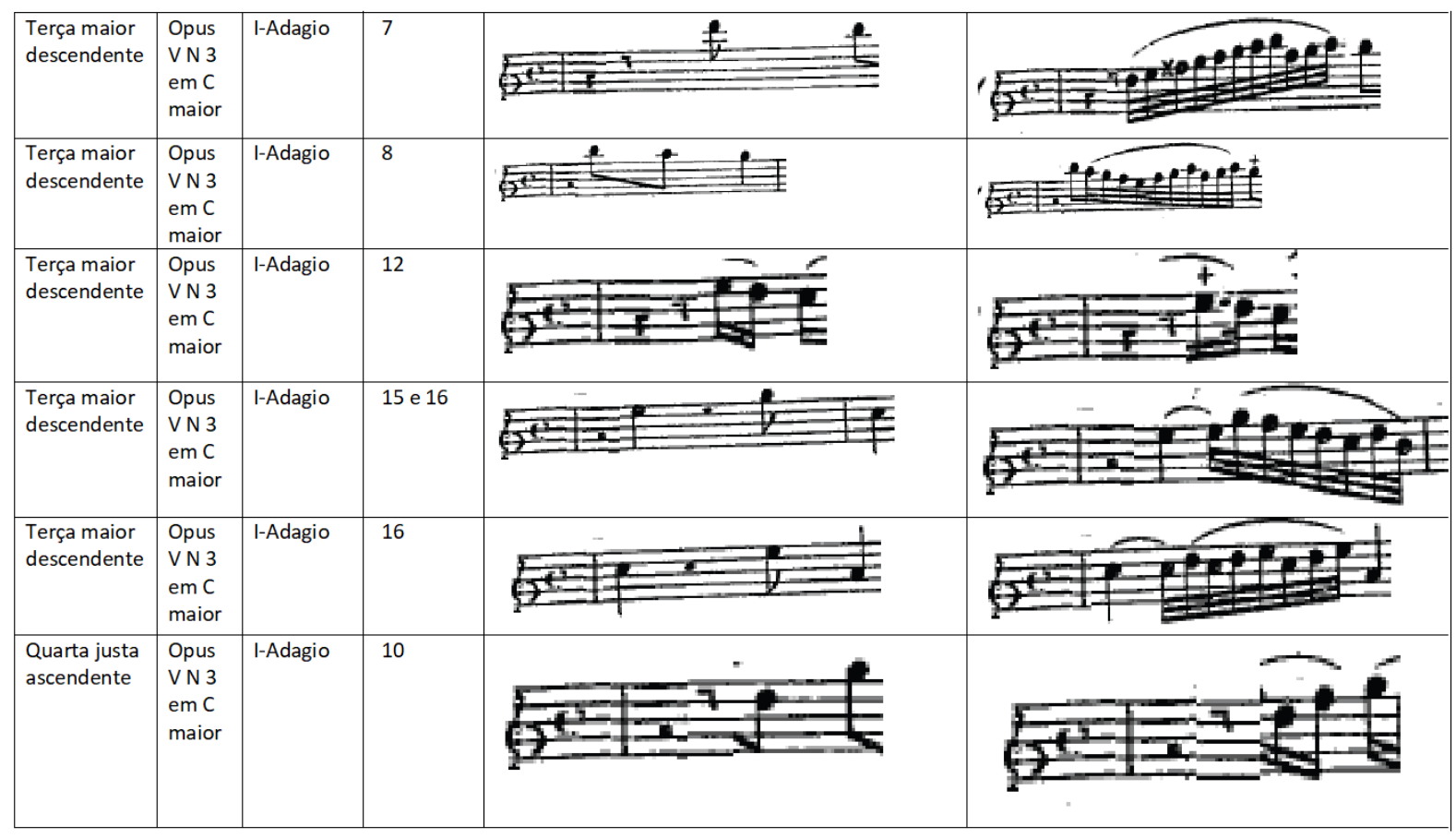

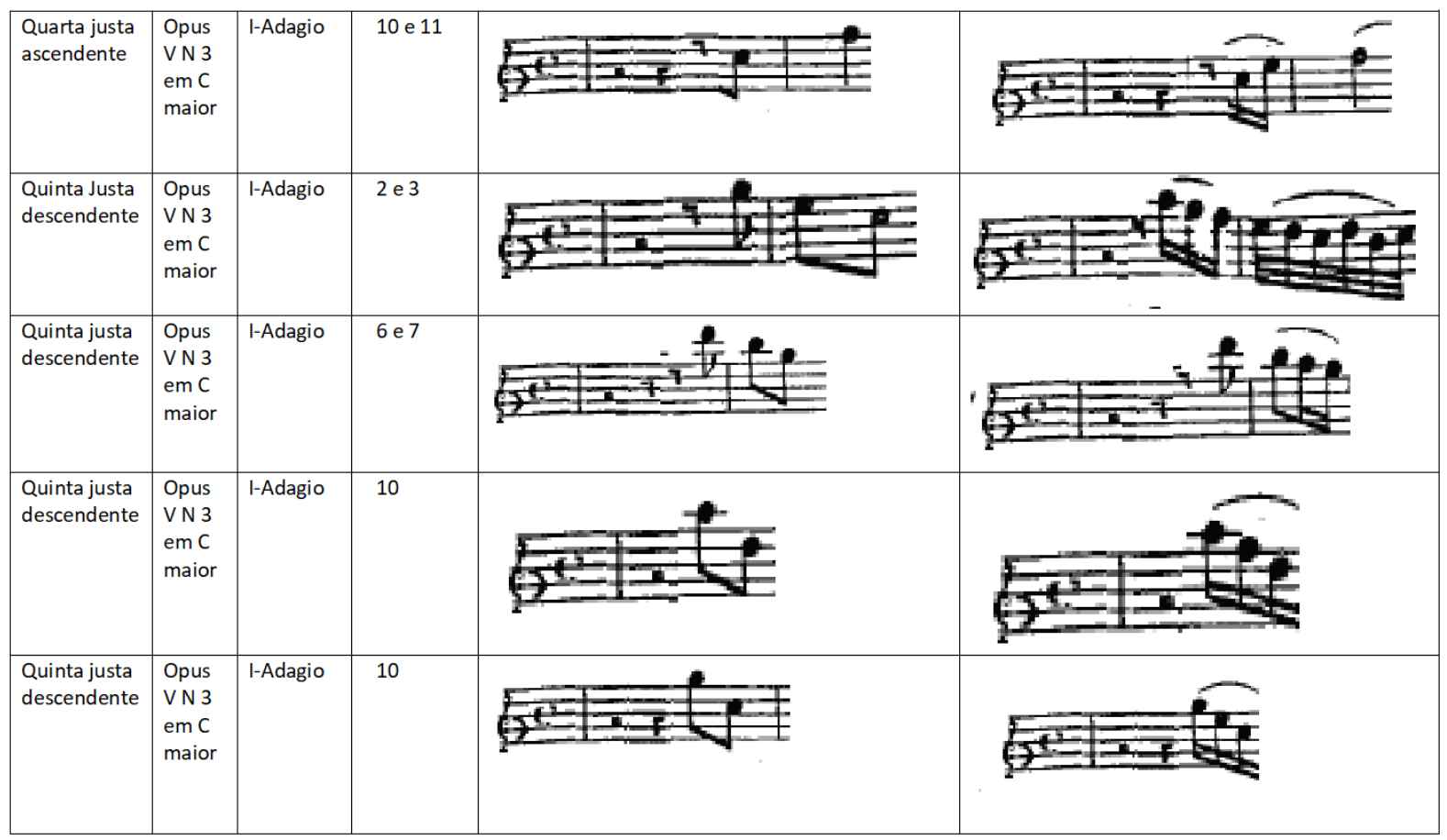




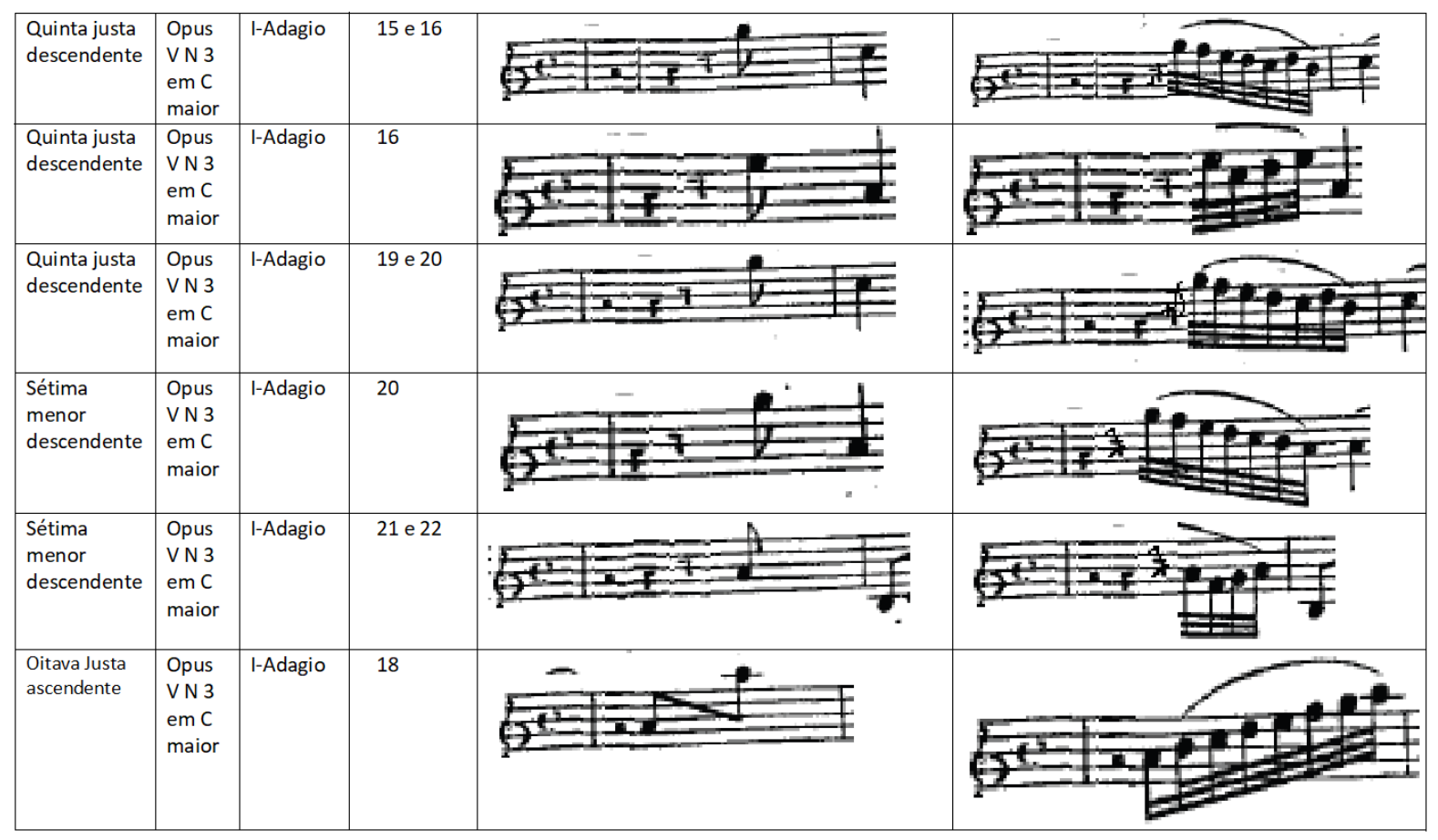

\begin{tabular}{|c|c|c|c|c|c|}
\hline $\begin{array}{l}\text { Oitava Justa } \\
\text { ascendente }\end{array}$ & $\begin{array}{l}\text { Opus } \\
\text { VN } 3 \\
\text { em C } \\
\text { maior }\end{array}$ & |-Adagio & 20 & 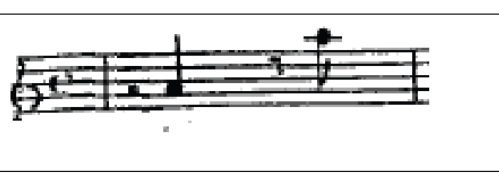 & $\rho^{2}=1=$ \\
\hline $\begin{array}{l}\text { Nona menor } \\
\text { descendente } \\
\text { ( Segunda } \\
\text { menor) }\end{array}$ & $\begin{array}{l}\text { Opus } \\
\text { VN } 3 \\
\text { em C } \\
\text { maior }\end{array}$ & I-Adagio & $21 \mathrm{e} 22$ & $50=0$ & $\mathrm{c}^{2}=2$ \\
\hline
\end{tabular}

\begin{tabular}{|c|c|c|c|}
\hline $\begin{array}{l}\text { Tipo de } \\
\text { cadencia }\end{array}$ & Compassos & Exemplo esqueleto & Exemplo ornado \\
\hline Perfeita & 9 e 10 & 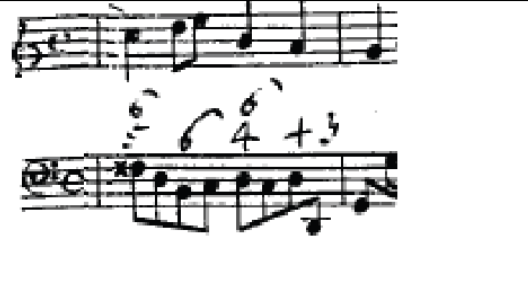 & 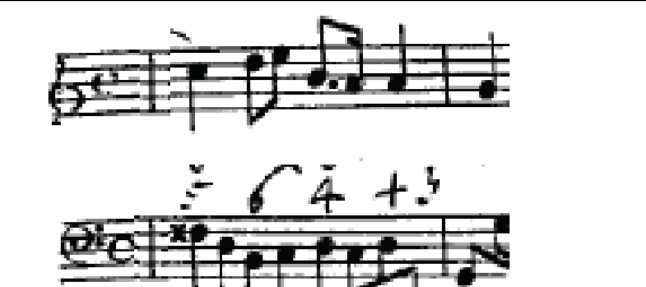 \\
\hline Perfeita & 12 e 13 & 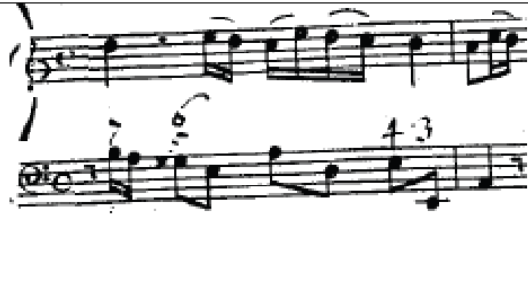 & 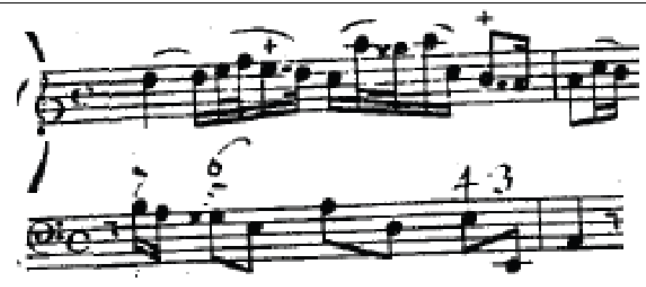 \\
\hline
\end{tabular}



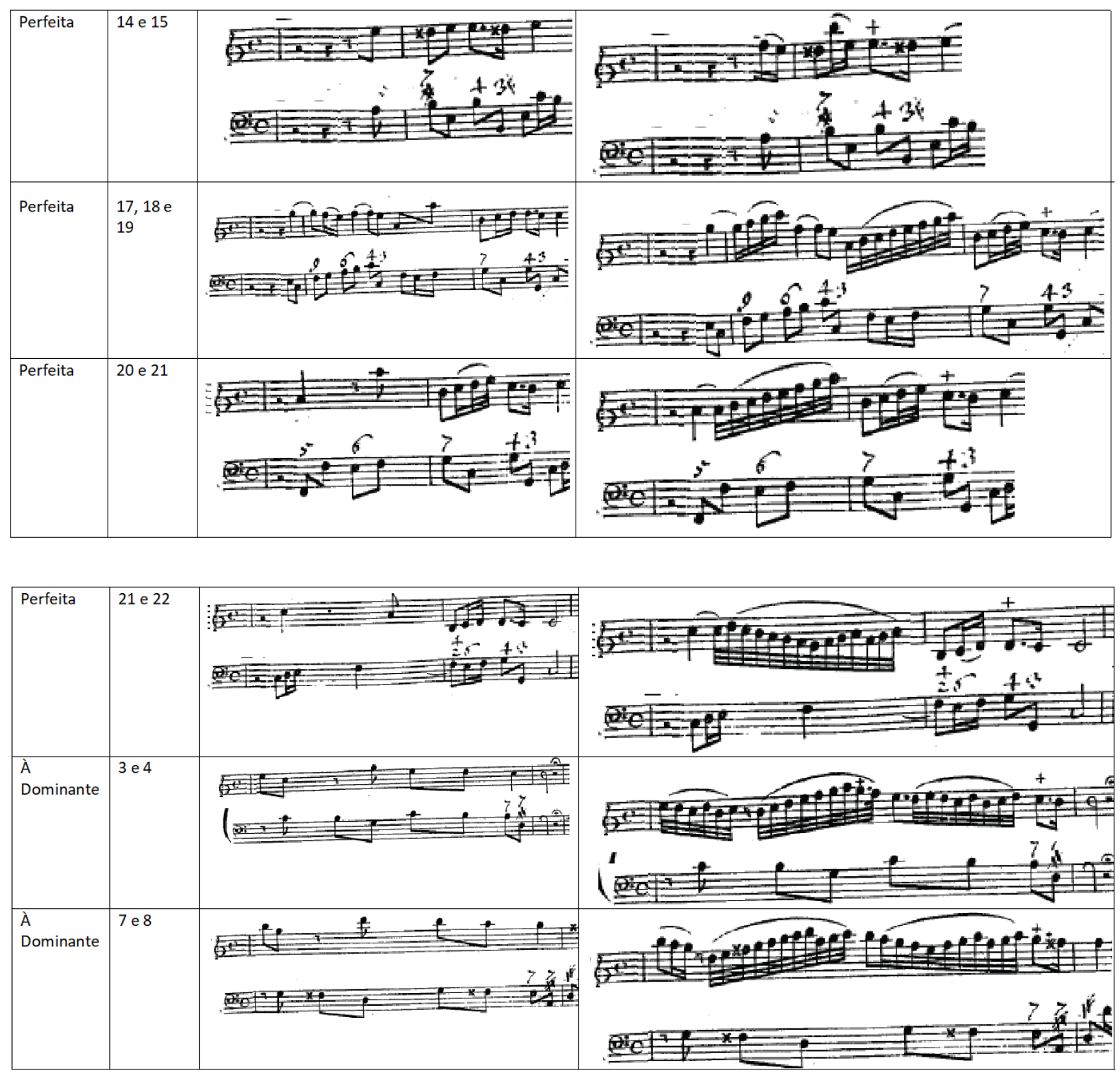
Tabela 11: Ornamentos da sonata Opus V n.3, terceiro movimento, Adágio:

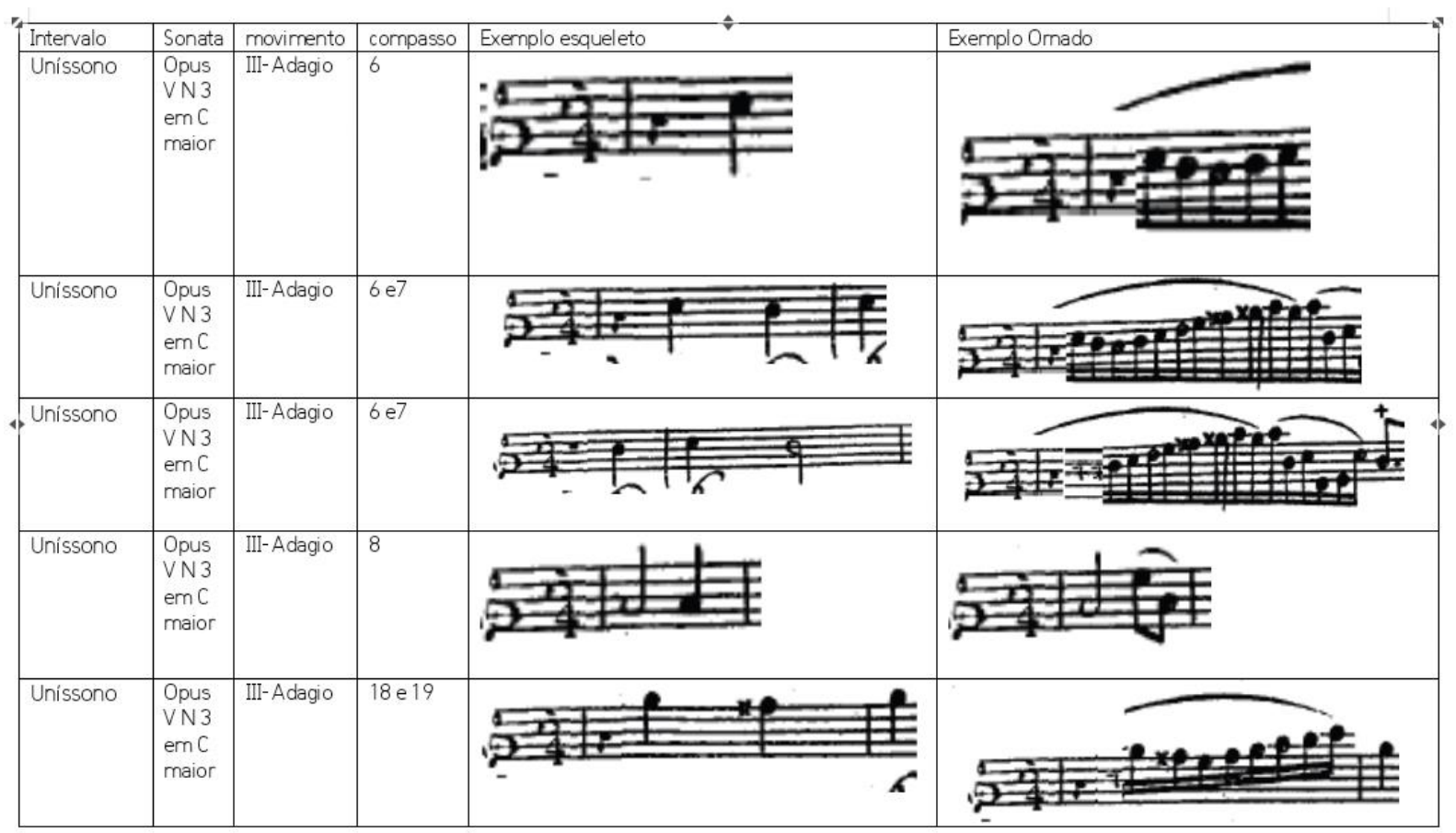

\begin{tabular}{|c|c|c|c|c|c|}
\hline Unissono & $\begin{array}{l}\text { Opus } \\
\text { VN3 } \\
\text { emC } \\
\text { maior }\end{array}$ & III-Adagio & $20 \mathrm{e} 21$ & 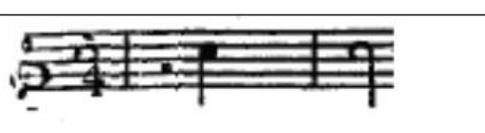 & 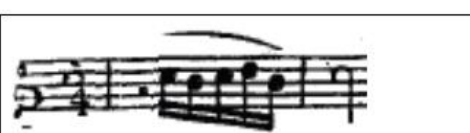 \\
\hline Unissono & $\begin{array}{l}\text { Opus } \\
\text { VN3 } \\
\text { emC } \\
\text { maior }\end{array}$ & III-Adagio & 40 e 41 & 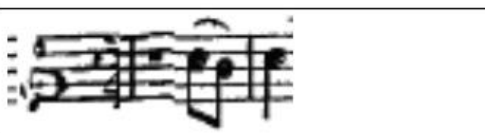 & F科 \\
\hline Unissono & $\begin{array}{l}\text { Opus } \\
\text { VN3 } \\
\text { emC } \\
\text { maior }\end{array}$ & III-Adagio & 41,42 & & \\
\hline Unissono & $\begin{array}{l}\text { Opus } \\
\text { VN3 } \\
\text { em C } \\
\text { maior }\end{array}$ & III-Adagio & 42 e 43 & 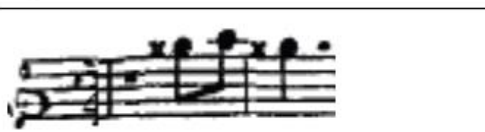 & fefeñe \\
\hline $\begin{array}{l}\text { Segunda } \\
\text { menor } \\
\text { ascendente }\end{array}$ & $\begin{array}{l}\text { Opus } \\
\text { VN3 } \\
\text { enc } \\
\text { maior }\end{array}$ & III-Adagio & 1 & 事 & 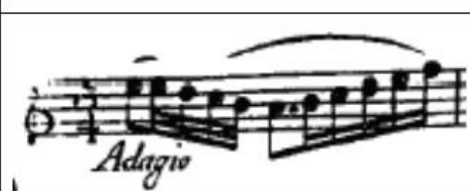 \\
\hline
\end{tabular}




\begin{tabular}{|c|c|c|c|c|c|}
\hline $\begin{array}{l}\text { Segunda } \\
\text { menor } \\
\text { ascendente }\end{array}$ & $\begin{array}{l}\text { Opus } \\
\text { VN3 } \\
\text { emC } \\
\text { maior }\end{array}$ & III-Adagio & $6 \mathrm{e} 7$ & 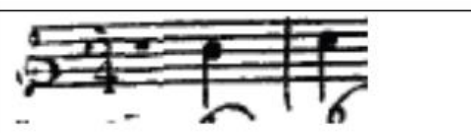 & 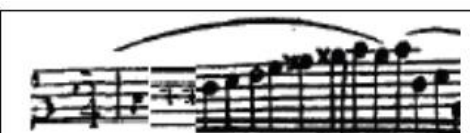 \\
\hline $\begin{array}{l}\text { Segunda } \\
\text { menor } \\
\text { ascendente }\end{array}$ & $\begin{array}{l}\text { Opus } \\
\text { VN3 } \\
\text { emC } \\
\text { maior }\end{array}$ & III-Adagio & 9 e 10 & ${ }_{4}=8$ & 政 \\
\hline $\begin{array}{l}\text { Segunda } \\
\text { menor } \\
\text { ascendente }\end{array}$ & $\begin{array}{l}\text { Opus } \\
\text { VN3 } \\
\text { emC } \\
\text { maior }\end{array}$ & III-Adagio & $\begin{array}{l}\text { 13( sic Fá } \\
\text { bequadro } \\
\text { ) }\end{array}$ & 辕平年 & \\
\hline $\begin{array}{l}\text { Segunda } \\
\text { menor } \\
\text { ascendente }\end{array}$ & $\begin{array}{l}\text { Opus } \\
\text { VN3 } \\
\text { enc } \\
\text { maior }\end{array}$ & III-Adagio & 18 e 19 & 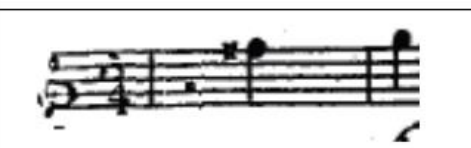 & 左 \\
\hline $\begin{array}{l}\text { Segunda } \\
\text { menor } \\
\text { ascendente }\end{array}$ & $\begin{array}{l}\text { Opus } \\
\text { VN3 } \\
\text { enc } \\
\text { maior }\end{array}$ & III-Adagio & 29 e 30 & 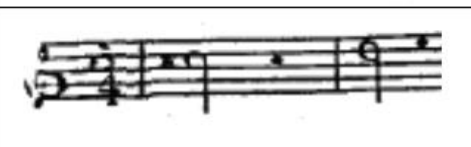 & 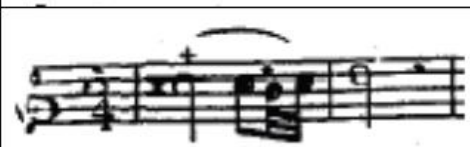 \\
\hline $\begin{array}{l}\text { Segunda } \\
\text { menor } \\
\text { ascendente }\end{array}$ & $\begin{array}{l}\text { Opus } \\
\text { VN3 } \\
\text { em C } \\
\text { maior }\end{array}$ & III-Adagio & 31 e 32 & 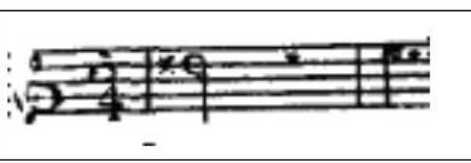 & F \\
\hline
\end{tabular}

\begin{tabular}{|c|c|c|c|c|c|}
\hline $\begin{array}{l}\text { Segunda } \\
\text { menor } \\
\text { ascendente }\end{array}$ & $\begin{array}{l}\text { Opus } \\
\text { VN3 } \\
\text { emc } \\
\text { maior }\end{array}$ & \begin{tabular}{|l|l|l} 
III-Adagio \\
\end{tabular} & 40 e 41 & 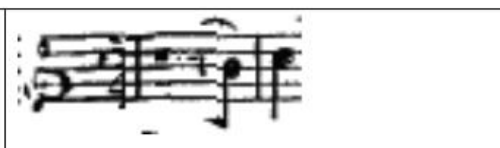 & 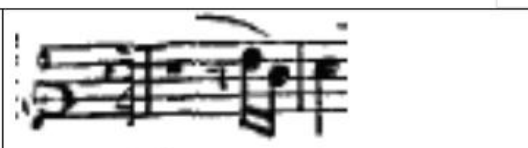 \\
\hline $\begin{array}{l}\text { Segunda } \\
\text { menor } \\
\text { ascendente }\end{array}$ & $\begin{array}{l}\text { Opus } \\
\text { VN3 } \\
\text { emc } \\
\text { maior }\end{array}$ & III-Adagio & 42 & 呲 & 致 \\
\hline $\begin{array}{l}\text { Segunda } \\
\text { menor } \\
\text { ascendente }\end{array}$ & $\begin{array}{l}\text { Opus } \\
\text { VN3 } \\
\text { emc } \\
\text { maior }\end{array}$ & \begin{tabular}{|l|l|} 
III-Adagio \\
\end{tabular} & 43 & 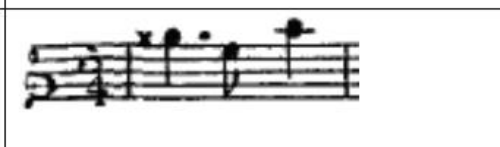 & 进 \\
\hline $\begin{array}{l}\text { Segunda } \\
\text { menor } \\
\text { ascendente }\end{array}$ & $\begin{array}{l}\text { Opus } \\
\text { VN3 } \\
\text { emC } \\
\text { maior }\end{array}$ & III-Adagio & $\begin{array}{l}45,46 \mathrm{e} \\
47\end{array}$ & 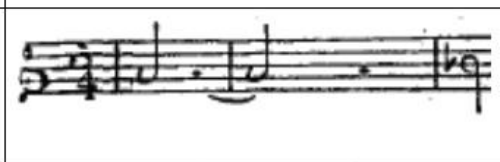 & 告 \\
\hline $\begin{array}{l}\text { Segunda } \\
\text { menor } \\
\text { ascendente }\end{array}$ & $\begin{array}{l}\text { Opus } \\
\text { VN3 } \\
\text { em C } \\
\text { maior }\end{array}$ & III-Adagio & 48 & 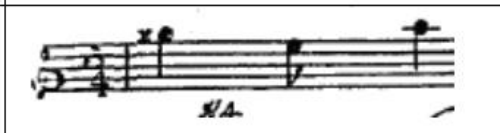 & 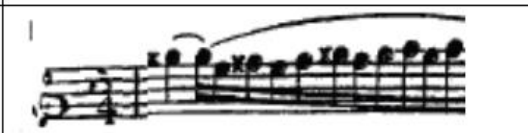 \\
\hline
\end{tabular}




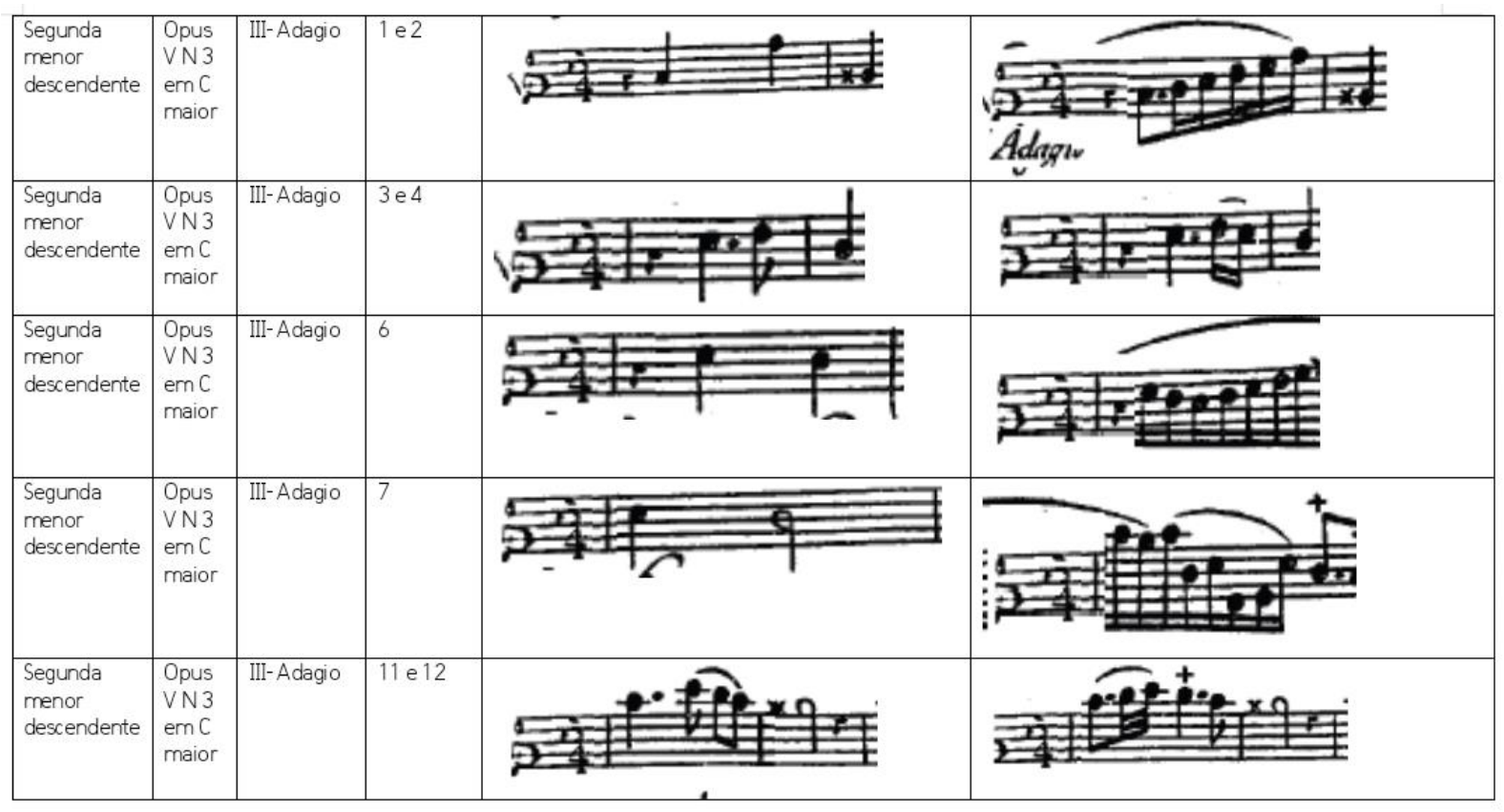

\begin{tabular}{|c|c|c|c|c|c|}
\hline \begin{tabular}{l|}
$\begin{array}{l}\text { Segunda } \\
\text { menor } \\
\text { descendente }\end{array}$ \\
\end{tabular} & $\begin{array}{l}\text { Opus } \\
\text { VN3 } \\
\text { enc } \\
\text { maior }\end{array}$ & III-Adagio & $13 \mathrm{e} 14$ & 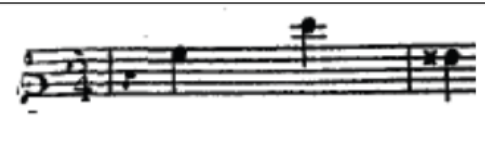 & 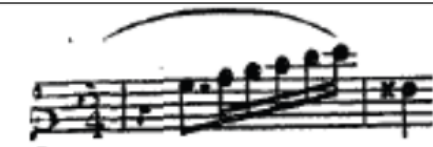 \\
\hline $\begin{array}{l}\begin{array}{l}\text { Segunda } \\
\text { menor } \\
\text { descendente }\end{array} \\
\end{array}$ & $\begin{array}{l}\text { Opus } \\
\text { VN3 } \\
\text { enc } \\
\text { maior }\end{array}$ & III-Adagio & 15 e 16 & 争落 & 转舟前 \\
\hline $\begin{array}{l}\begin{array}{l}\text { Segunda } \\
\text { menor } \\
\text { descendente }\end{array} \\
\end{array}$ & $\begin{array}{l}\text { Opus } \\
\text { VN3 } \\
\text { emC } \\
\text { maior }\end{array}$ & III-Adagio & 18 & 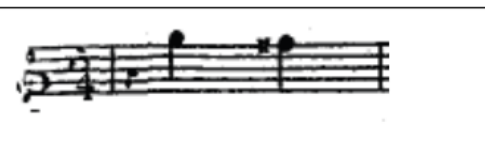 & 政 \\
\hline $\begin{array}{l}\begin{array}{l}\text { Segunda } \\
\text { menor } \\
\text { descendente }\end{array} \\
\end{array}$ & $\begin{array}{l}\text { Opus } \\
\text { VN3 } \\
\text { enc } \\
\text { maior }\end{array}$ & III-Adagio & 18 & 盗 & 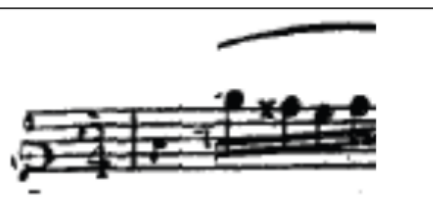 \\
\hline \begin{tabular}{l|}
$\begin{array}{l}\text { Segunda } \\
\text { menor } \\
\text { descendente }\end{array}$ \\
\end{tabular} & $\begin{array}{l}\text { Opus } \\
\text { VN3 } \\
\text { emC } \\
\text { maior }\end{array}$ & III-Adagio & 40 & 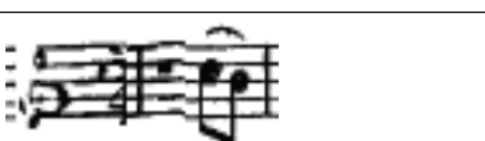 & \\
\hline
\end{tabular}




\begin{tabular}{|c|c|c|c|c|c|}
\hline $\begin{array}{l}\text { Segunda } \\
\text { menor } \\
\text { descendente }\end{array}$ & \begin{tabular}{|l|} 
Opus \\
VN3 \\
emC \\
maior
\end{tabular} & III-Adagio & $42 \mathrm{e} 43$ & If & 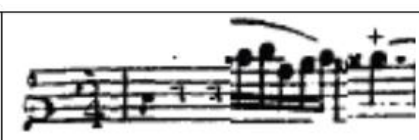 \\
\hline $\begin{array}{l}\text { Segunda } \\
\text { maior } \\
\text { ascendente }\end{array}$ & $\begin{array}{l}\text { Opus } \\
\text { VN3 } \\
\text { emC } \\
\text { maior }\end{array}$ & III-Adagio & 2 & 翌主 & 整理 \\
\hline $\begin{array}{l}\text { Segunda } \\
\text { maior } \\
\text { ascendente }\end{array}$ & $\begin{array}{l}\text { Opus } \\
\text { VN3 } \\
\text { emc } \\
\text { maior }\end{array}$ & III-Adagio & $8 \mathrm{e} 9$ & $2=$ & 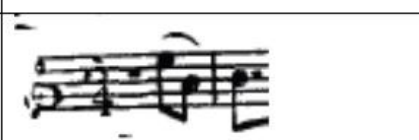 \\
\hline $\begin{array}{l}\text { Segunda } \\
\text { maior } \\
\text { ascendente }\end{array}$ & $\begin{array}{l}\text { Opus } \\
\text { VN3 } \\
\text { emc } \\
\text { maior }\end{array}$ & III-Adagio & 11 & 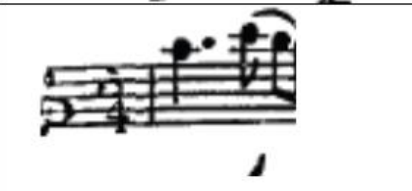 & \\
\hline $\begin{array}{l}\text { Segunda } \\
\text { maior } \\
\text { ascendente }\end{array}$ & $\begin{array}{l}\text { Opus } \\
\text { VN3 } \\
\text { emc } \\
\text { maior }\end{array}$ & III-Adagio & 14 e 15 & 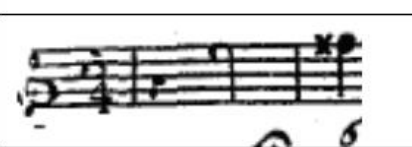 & 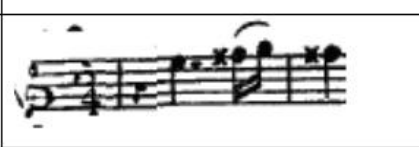 \\
\hline $\begin{array}{l}\text { Segunda } \\
\text { maior } \\
\text { ascendente }\end{array}$ & $\begin{array}{l}\text { Opus } \\
\text { VN3 } \\
\text { emc } \\
\text { maior }\end{array}$ & III-Adagio & 21 e 22 & 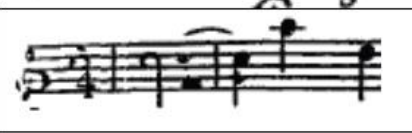 & 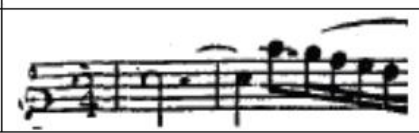 \\
\hline
\end{tabular}

\begin{tabular}{|c|c|c|c|c|c|}
\hline $\begin{array}{l}\text { Segunda } \\
\text { maior } \\
\text { ascendente }\end{array}$ & $\begin{array}{l}\text { Opus } \\
\text { VN3 } \\
\text { emC } \\
\text { maior }\end{array}$ & III-Adagio & $\begin{array}{l}2_{21,22 \mathrm{e}} \\
23\end{array}$ & 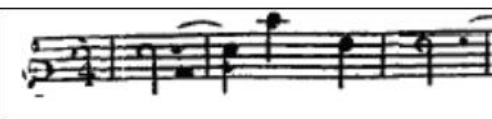 & 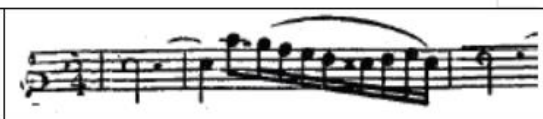 \\
\hline $\begin{array}{l}\text { Segunda } \\
\text { maior } \\
\text { ascendente }\end{array}$ & $\begin{array}{l}\text { Onus } \\
\text { VN3 } \\
\text { emC } \\
\text { maior }\end{array}$ & III-Adagio & 42 & 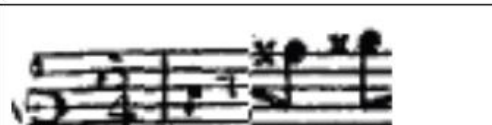 & \\
\hline $\begin{array}{l}\text { Segunda } \\
\text { maior } \\
\text { ascendente }\end{array}$ & $\begin{array}{l}\text { Opus } \\
\text { VN3 } \\
\text { em C } \\
\text { maior }\end{array}$ & IIII-Adagio & 42 e 43 & 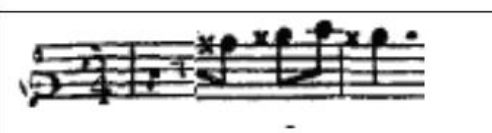 & \\
\hline $\begin{array}{l}\text { Segunda } \\
\text { maior } \\
\text { ascendente }\end{array}$ & $\begin{array}{l}\text { Opus } \\
\text { VN3 } \\
\text { emC } \\
\text { maior }\end{array}$ & III-Adagio & 51 e 52 & 轻理事 & 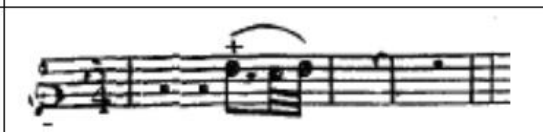 \\
\hline $\begin{array}{l}\text { Segunda } \\
\text { maior } \\
\text { descendente }\end{array}$ & $\begin{array}{l}\text { Opus } \\
\text { VN3 } \\
\text { emC } \\
\text { maior }\end{array}$ & III-Adagio & $4 \mathrm{e} 5$ & 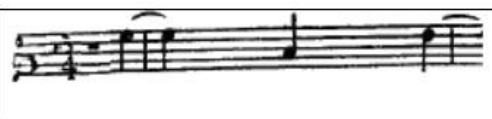 & $\frac{+}{2-1}$ \\
\hline $\begin{array}{l}\text { Segunda } \\
\text { maior } \\
\text { descendente }\end{array}$ & $\begin{array}{l}\text { Opus } \\
\text { VN3 } \\
\text { emC } \\
\text { maior }\end{array}$ & \begin{tabular}{|l|l|} 
III-Adagio \\
\end{tabular} & $5 \mathrm{e} 6$ & 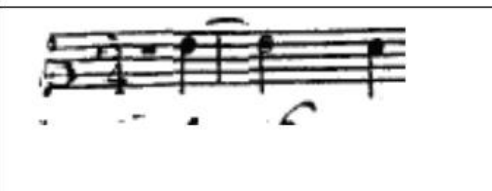 & क्2 \\
\hline
\end{tabular}




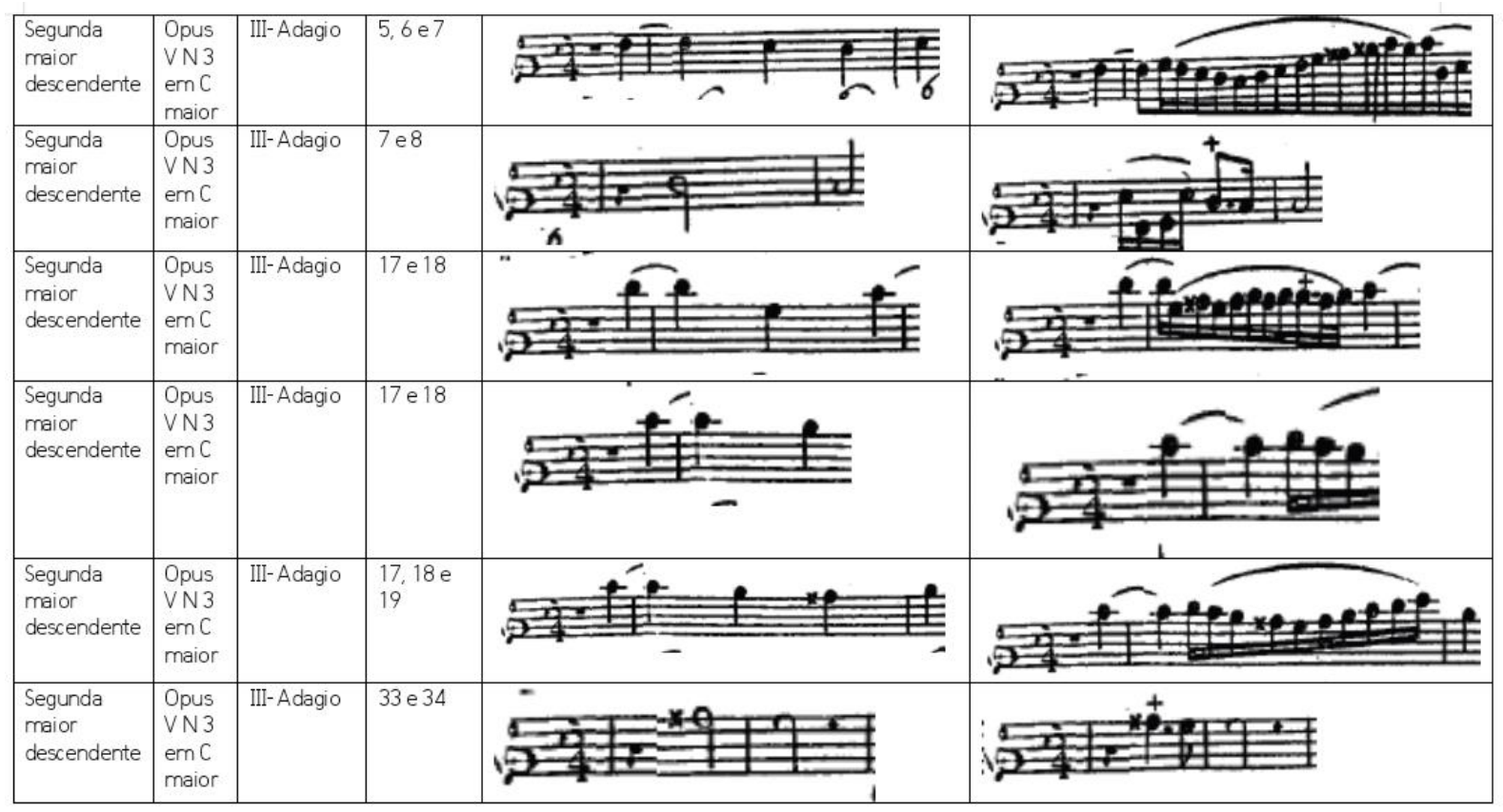

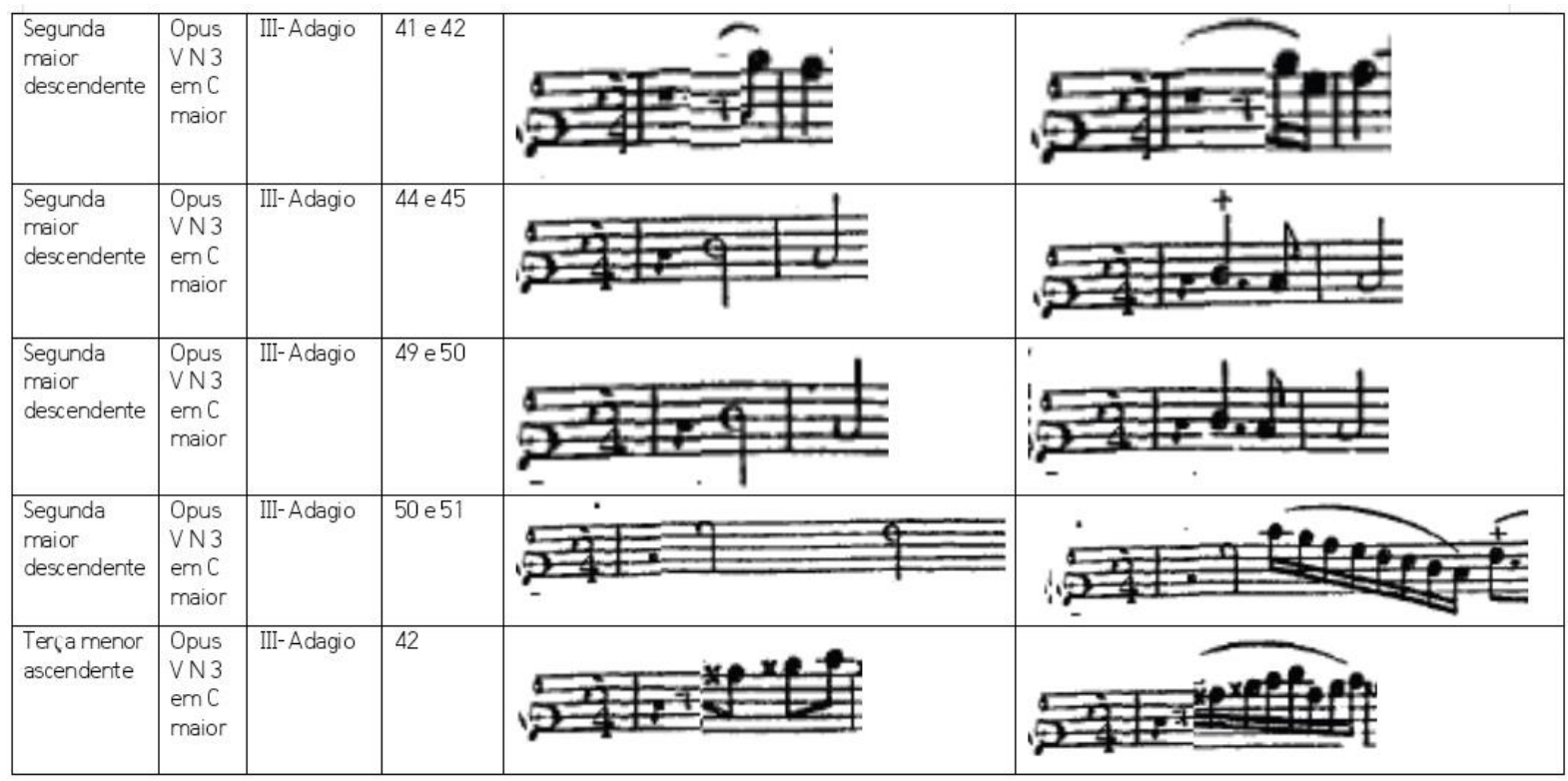




\begin{tabular}{|c|c|c|c|c|c|}
\hline $\begin{array}{l}\text { Terca menor } \\
\text { descendente }\end{array}$ & \begin{tabular}{|l} 
Opus \\
VN3 \\
enc \\
maior
\end{tabular} & III-Adagio & $3 \mathrm{e} 4$ & 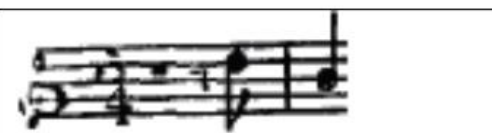 & 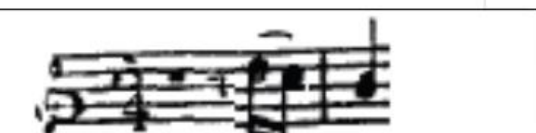 \\
\hline $\begin{array}{l}\text { Terca menor } \\
\text { descendente }\end{array}$ & \begin{tabular}{|l} 
Opus \\
VN3 \\
enc \\
maior
\end{tabular} & III-Adagio & 5 e 6 & 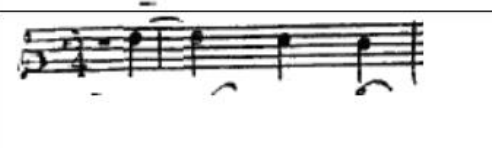 & 車 \\
\hline $\begin{array}{l}\text { Terca menor } \\
\text { descendente }\end{array}$ & $\begin{array}{l}\text { Opus } \\
\text { VN3 } \\
\text { emC } \\
\text { maior }\end{array}$ & III-Adagio & $5,6 \mathrm{e}^{2}$ & 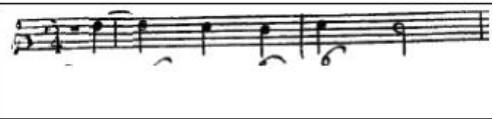 & 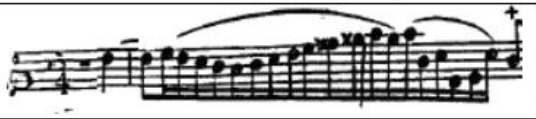 \\
\hline $\begin{array}{l}\text { Terca menor } \\
\text { descendente }\end{array}$ & $\begin{array}{l}\text { Opus } \\
\text { VN3 } \\
\text { enc } \\
\text { maior }\end{array}$ & III-Adagio & 15 e 16 & 政空 & $8=$ \\
\hline $\begin{array}{l}\text { Terca menor } \\
\text { descendente }\end{array}$ & $\begin{array}{l}\text { Opus } \\
\text { VN3 } \\
\text { enc } \\
\text { maior }\end{array}$ & III-Adagio & 17 e 18 & 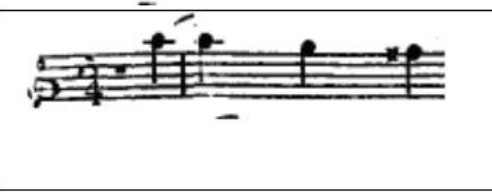 & 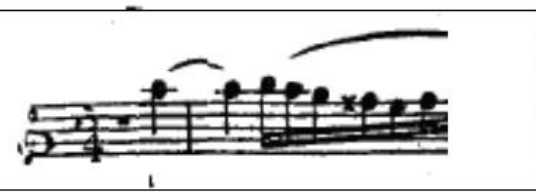 \\
\hline
\end{tabular}

\begin{tabular}{|c|c|c|c|c|c|}
\hline $\begin{array}{l}\text { Terca menor } \\
\text { descendente }\end{array}$ & \begin{tabular}{|l} 
Opus \\
VN3 \\
emC \\
maior
\end{tabular} & III-Adagio & 42 & 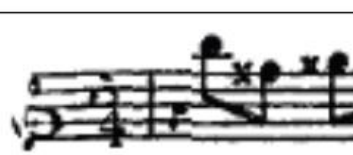 & 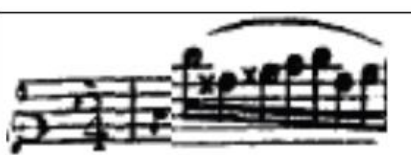 \\
\hline $\begin{array}{l}\text { Terca menor } \\
\text { descendente }\end{array}$ & $\begin{array}{l}\text { Opus } \\
\text { VN3 } \\
\text { emC } \\
\text { maior }\end{array}$ & III-Adagio & $42 \mathrm{e} 43$ & +2 & 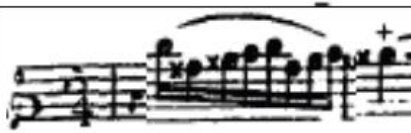 \\
\hline $\begin{array}{l}\text { Terca maior } \\
\text { descendente }\end{array}$ & $\begin{array}{l}\text { Opus } \\
\text { VN3 } \\
\text { em C } \\
\text { maior }\end{array}$ & III-Adagio & 43 & & \\
\hline $\begin{array}{l}\text { Terca maior } \\
\text { descendente }\end{array}$ & $\begin{array}{l}\text { Opus } \\
\text { VN3 } \\
\text { emC } \\
\text { maior }\end{array}$ & III-Adagio & 48 & 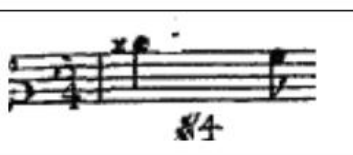 & 空 \\
\hline $\begin{array}{l}\text { Terca maior } \\
\text { descendente }\end{array}$ & $\begin{array}{l}\text { Opus } \\
\text { VN3 } \\
\text { em C } \\
\text { maior }\end{array}$ & III-Adagio & 48 & 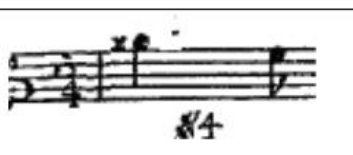 & 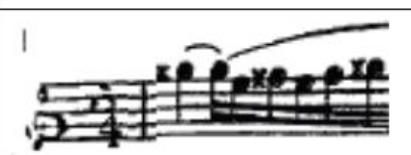 \\
\hline
\end{tabular}




\begin{tabular}{|c|c|c|c|c|c|}
\hline $\begin{array}{l}\text { Quarta Justa } \\
\text { ascendente }\end{array}$ & $\begin{array}{l}\text { Opus } \\
\text { VN3 } \\
\text { emc } \\
\text { maior }\end{array}$ & III-Adagio & 9 & 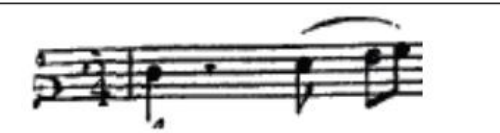 & 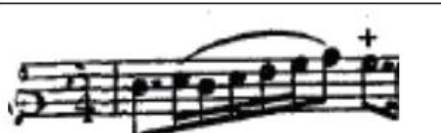 \\
\hline $\begin{array}{l}\text { Quarta Justa } \\
\text { ascendente }\end{array}$ & $\begin{array}{l}\text { Opus } \\
\text { VN3 } \\
\text { emc } \\
\text { maior }\end{array}$ & III-Adagio & 17 & 重击 & 实 \\
\hline $\begin{array}{l}\text { Quarta Justa } \\
\text { ascendente }\end{array}$ & $\begin{array}{l}\text { Opus } \\
\text { VN3 } \\
\text { emc } \\
\text { maior }\end{array}$ & III-Adagio & 43 & 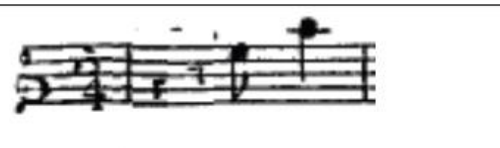 & 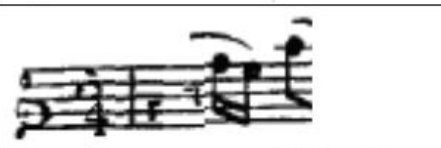 \\
\hline $\begin{array}{l}\text { Quarta Justa } \\
\text { ascendente }\end{array}$ & $\begin{array}{l}\text { Opus } \\
\text { VN3 } \\
\text { emc } \\
\text { maior }\end{array}$ & III-Adagio & 48 & 事事 & 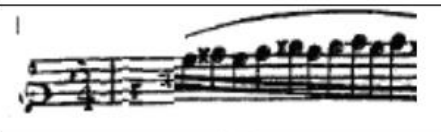 \\
\hline $\begin{array}{l}\text { Quarta justa } \\
\text { Descendente }\end{array}$ & $\begin{array}{l}\text { Opus } \\
\text { VN3 } \\
\text { enc } \\
\text { maior }\end{array}$ & III-Adagio & 26 e 27 & 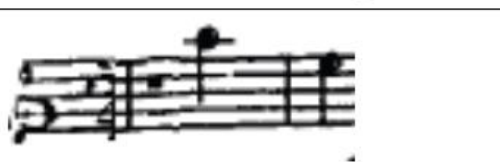 & 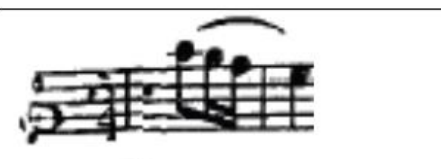 \\
\hline $\begin{array}{l}\text { Quarta justa } \\
\text { Descendente }\end{array}$ & $\begin{array}{l}\text { Opus } \\
\text { VN3 } \\
\text { emc } \\
\text { maior }\end{array}$ & III-Adagio & $\begin{array}{l}39,40 \mathrm{e} \\
41\end{array}$ & 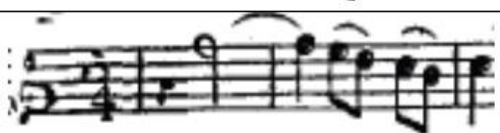 & से \\
\hline
\end{tabular}

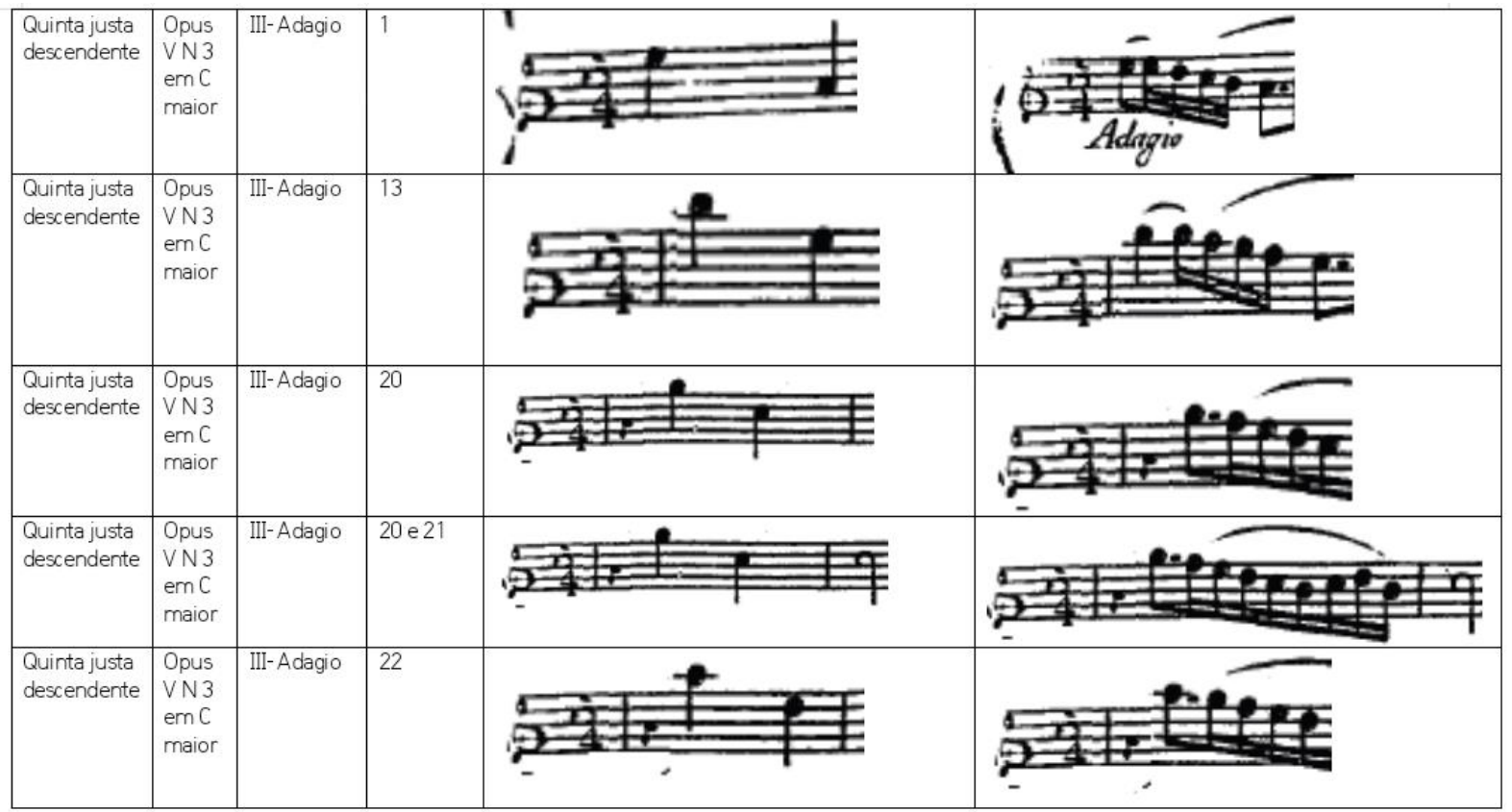



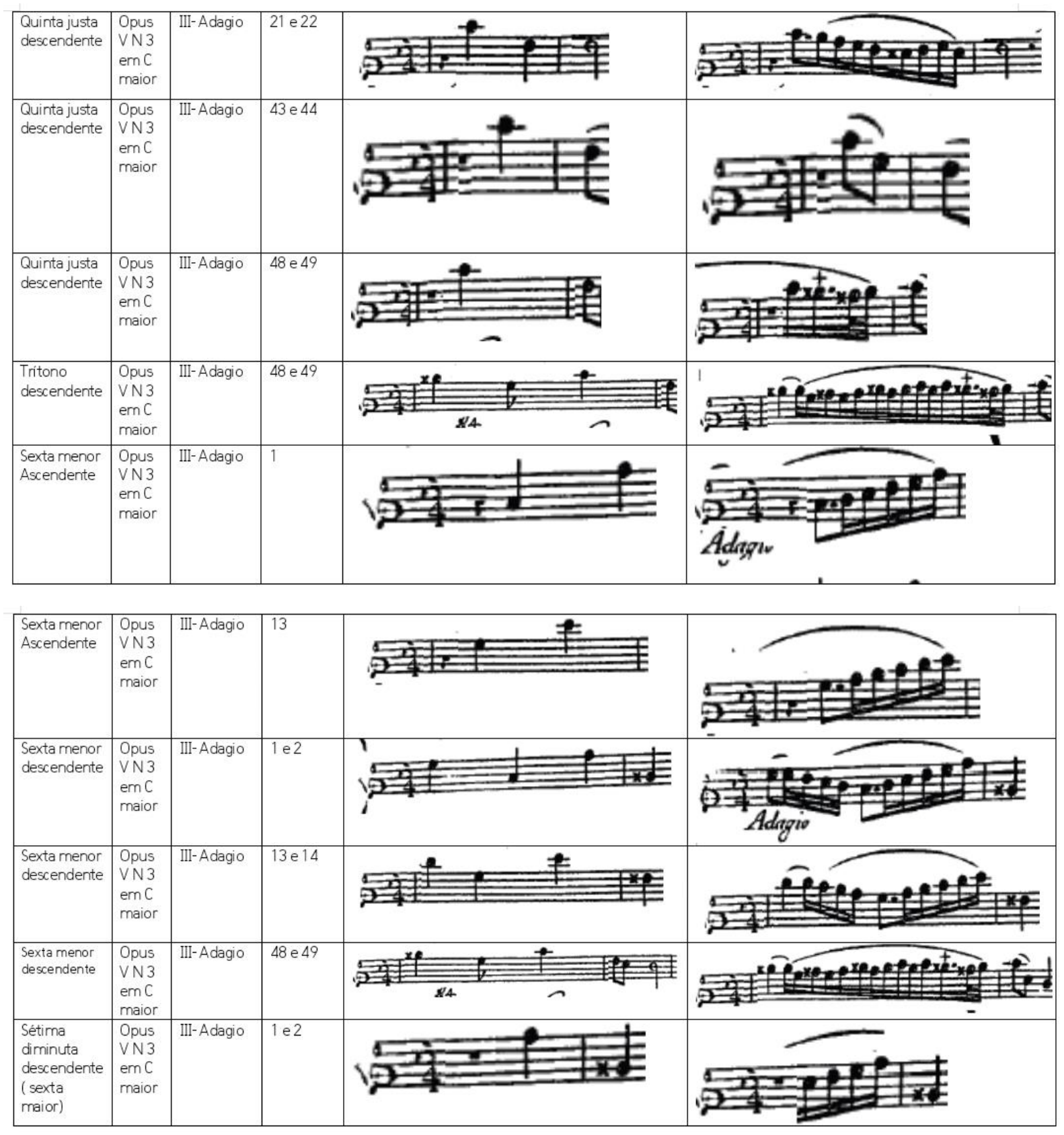

\begin{tabular}{|c|c|c|c|c|c|}
\hline $\begin{array}{l}\text { Sétima } \\
\text { diminuta } \\
\text { descendente } \\
\text { ( seta maior) }\end{array}$ & $\begin{array}{l}\text { Opus } \\
\text { VN3 } \\
\text { enc } \\
\text { maior }\end{array}$ & III-Adagio & $13 \mathrm{e} 14$ & $\frac{f}{4=1}$ & 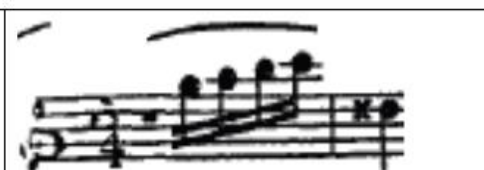 \\
\hline $\begin{array}{l}\text { Sétima } \\
\text { menor } \\
\text { descendente }\end{array}$ & $\begin{array}{l}\text { Opus } \\
\text { VN3 } \\
\text { emC } \\
\text { maior }\end{array}$ & III-Adagio & 47 e 48 & 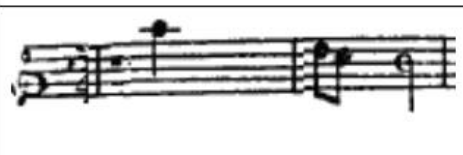 & singe \\
\hline
\end{tabular}




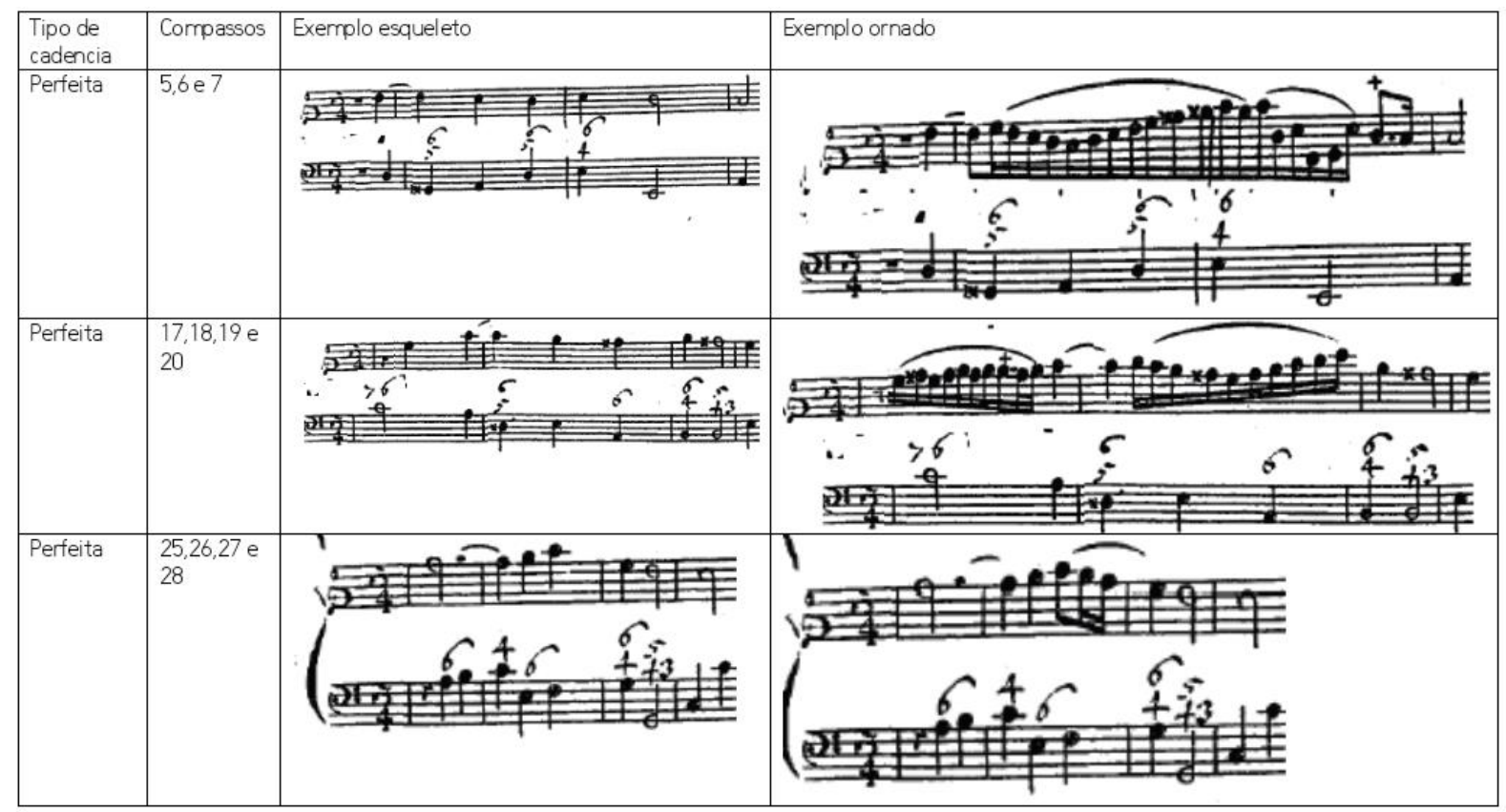

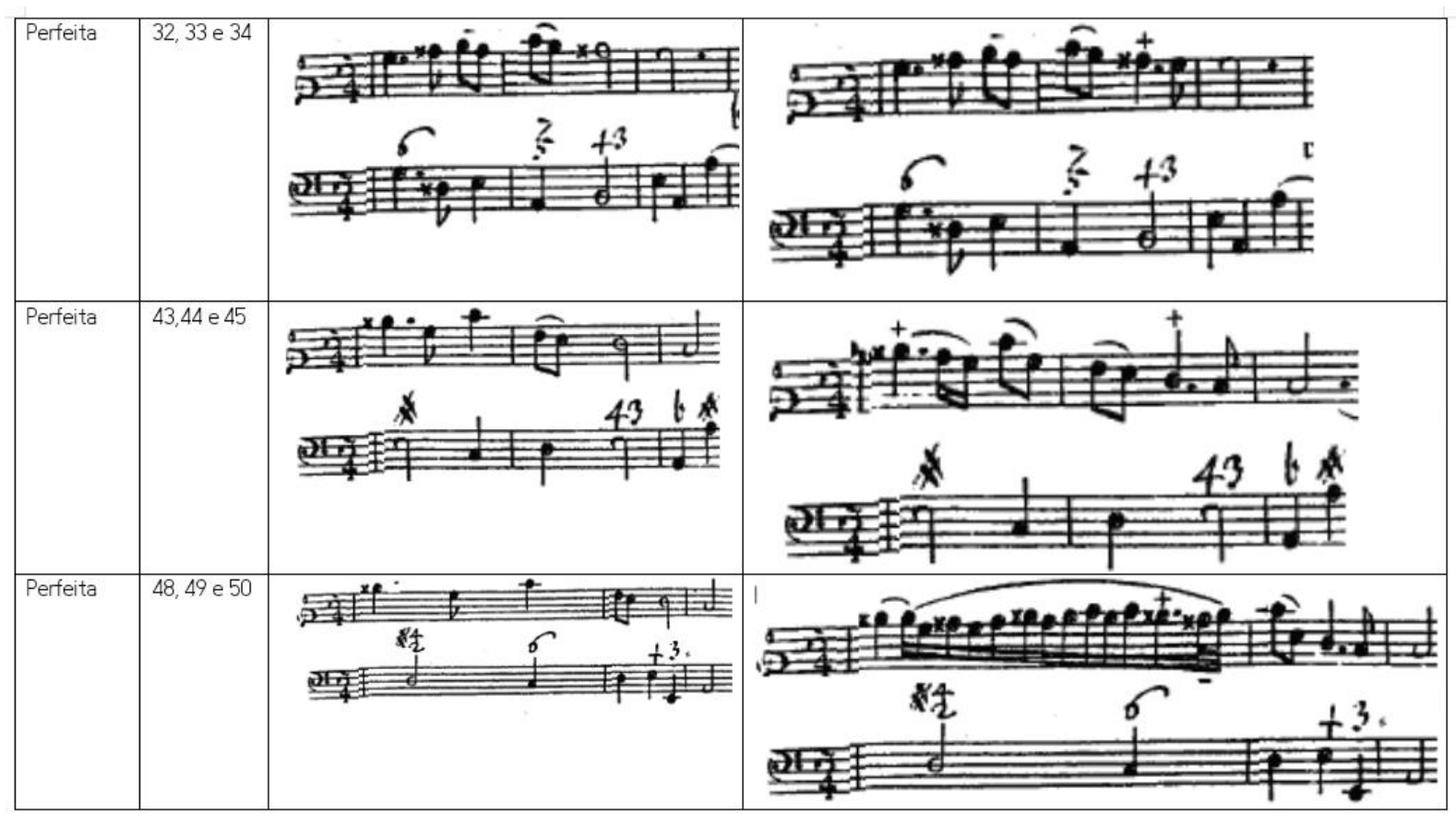




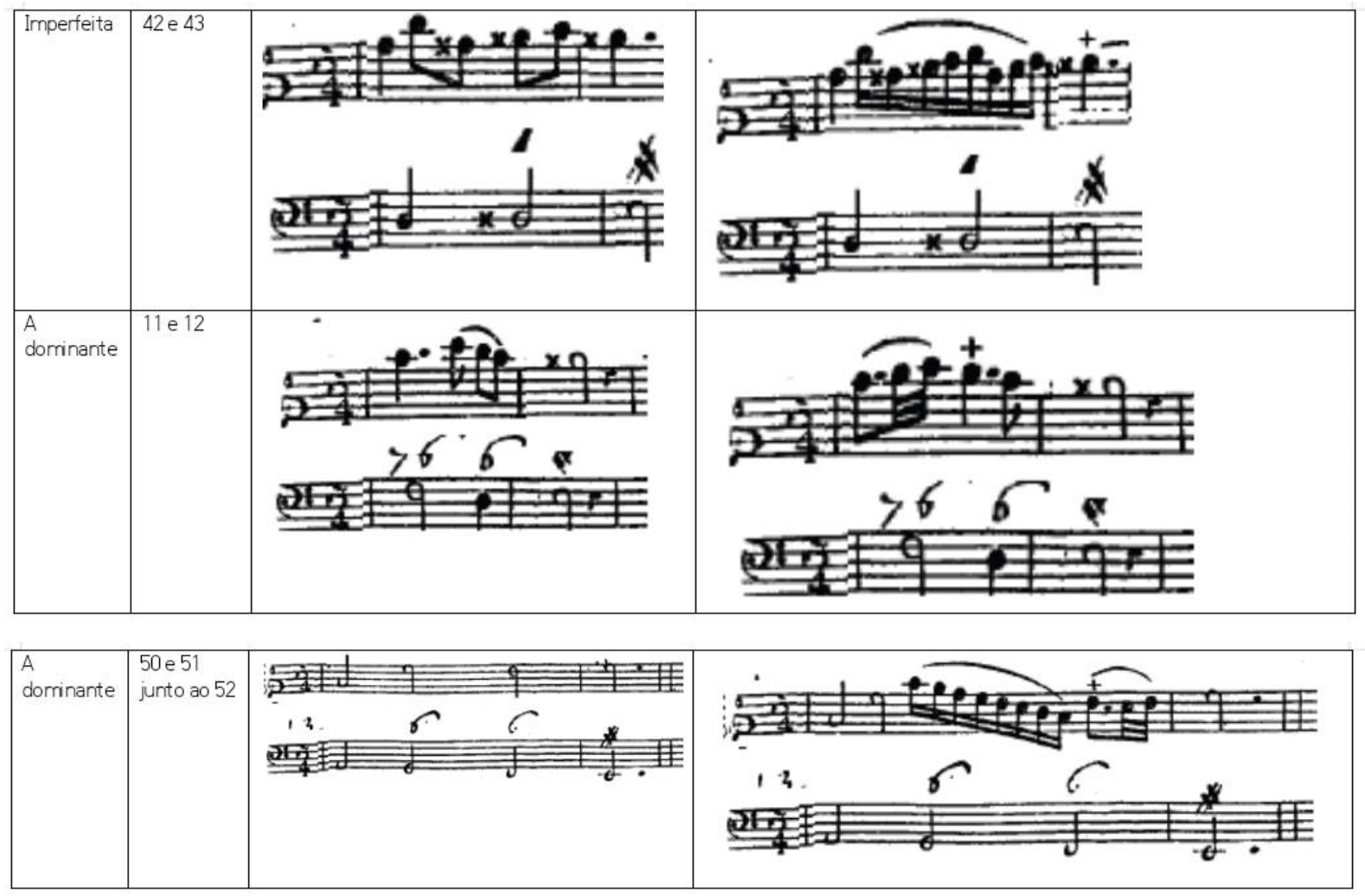

Tabela 12: Ornamentos da sonata Opus V n.4, primeiro movimento adágio:

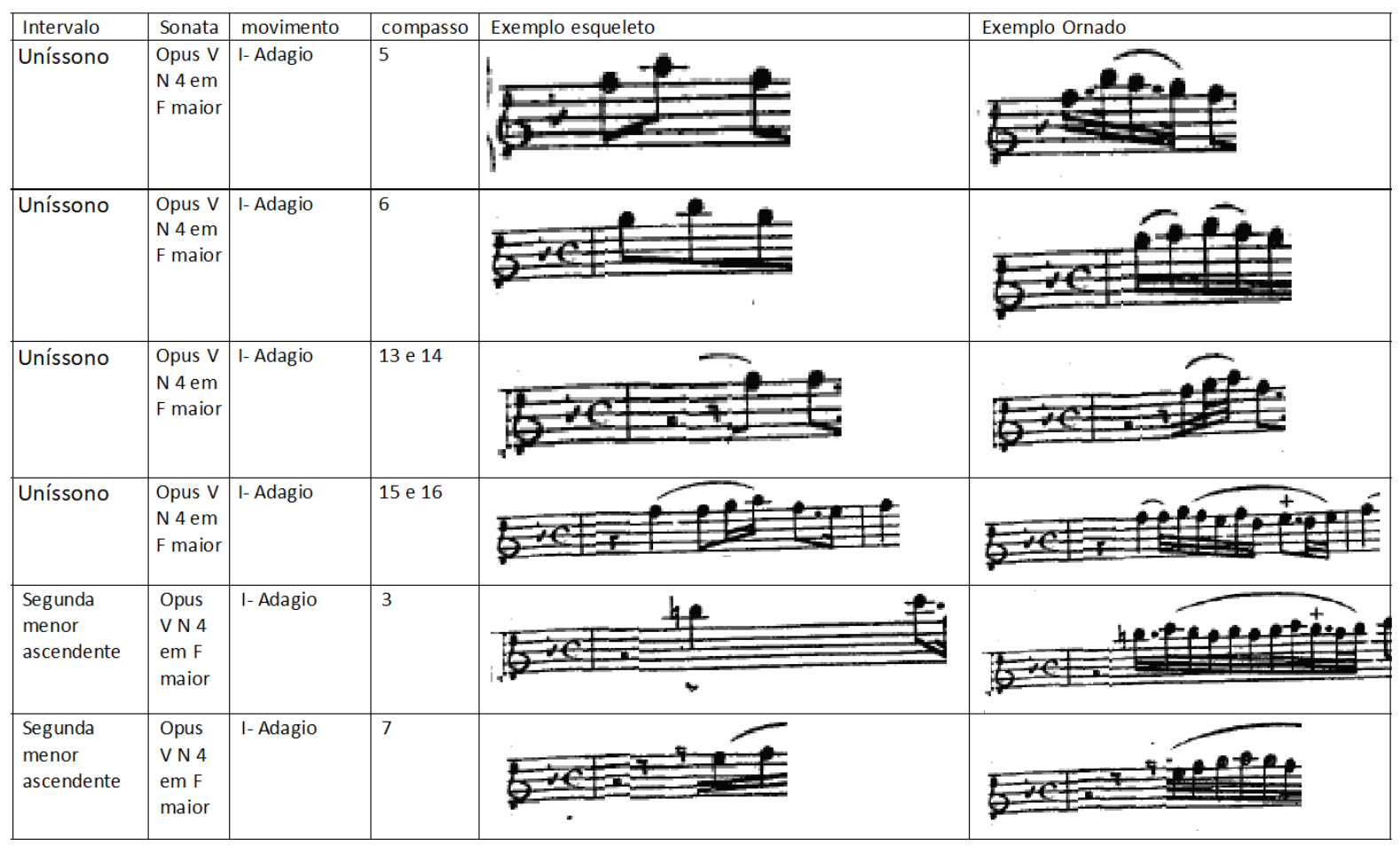




\begin{tabular}{|c|c|c|c|c|c|}
\hline $\begin{array}{l}\text { Segunda } \\
\text { menor } \\
\text { ascendente }\end{array}$ & $\begin{array}{l}\text { Opus } \\
\text { V N } 4 \\
\text { em F } \\
\text { maior }\end{array}$ & I- Adagio & 7 & $8+6 x^{2}=$ & 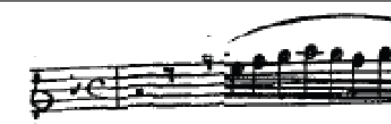 \\
\hline $\begin{array}{l}\text { Segunda } \\
\text { menor } \\
\text { ascendente }\end{array}$ & $\begin{array}{l}\text { Opus } \\
\text { V N } 4 \\
\text { em F } \\
\text { maior }\end{array}$ & I- Adagio & 8 e 9 & करet & 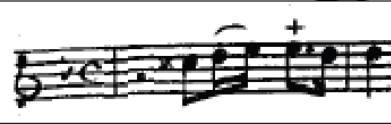 \\
\hline $\begin{array}{l}\text { Segunda } \\
\text { menor } \\
\text { ascendente }\end{array}$ & $\begin{array}{l}\text { Opus } \\
\text { V N } 4 \\
\text { em F } \\
\text { maior }\end{array}$ & I- Adagio & 9 e 10 & $y=-2$ & $\varepsilon$ \\
\hline $\begin{array}{l}\text { Segunda } \\
\text { menor } \\
\text { ascendente }\end{array}$ & $\begin{array}{l}\text { Opus } \\
\text { V N } 4 \\
\text { em F } \\
\text { maior }\end{array}$ & I- Adagio & 10 e 11 & $\sum_{t=212}$ & + \\
\hline $\begin{array}{l}\text { Segunda } \\
\text { menor } \\
\text { ascendente }\end{array}$ & $\begin{array}{l}\text { Opus } \\
\text { V N } 4 \\
\text { em F } \\
\text { maior }\end{array}$ & I- Adagio & 15 & . & + \\
\hline $\begin{array}{l}\text { Segunda } \\
\text { menor } \\
\text { descendente }\end{array}$ & $\begin{array}{l}\text { Opus } \\
\text { V N } 4 \\
\text { em F } \\
\text { maior }\end{array}$ & I- Adagio & 2 & $\frac{7+2}{2}$ & \\
\hline $\begin{array}{l}\text { Segunda } \\
\text { menor } \\
\text { descendente }\end{array}$ & $\begin{array}{l}\text { Opus } \\
\text { V N } 4 \\
\text { em F } \\
\text { maior }\end{array}$ & I- Adagio & 6 & $5+20+7$ & 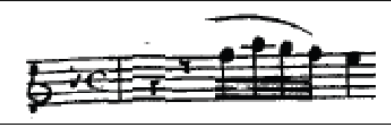 \\
\hline
\end{tabular}

\begin{tabular}{|c|c|c|c|c|c|}
\hline $\begin{array}{l}\text { Segunda } \\
\text { menor } \\
\text { descendente }\end{array}$ & $\begin{array}{l}\text { Opus } \\
\text { VN 4 } \\
\text { em F } \\
\text { maior }\end{array}$ & I- Adagio & 9 & 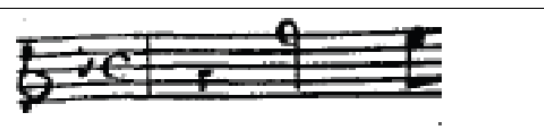 & tre \\
\hline $\begin{array}{l}\text { Segunda } \\
\text { menor } \\
\text { descendente }\end{array}$ & $\begin{array}{l}\text { Opus } \\
\text { VN 4 } \\
\text { em F } \\
\text { maior }\end{array}$ & I- Adagio & 10 & 更理 & 理理 \\
\hline $\begin{array}{l}\text { Segunda } \\
\text { menor } \\
\text { descendente }\end{array}$ & $\begin{array}{l}\text { Opus } \\
\text { VN } 4 \\
\text { em F } \\
\text { maior }\end{array}$ & I- Adagio & $11 \mathrm{e} 12$ & 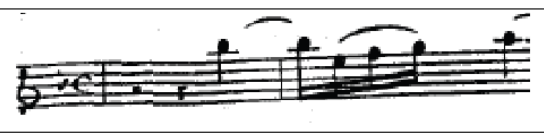 & \\
\hline $\begin{array}{l}\text { Segunda } \\
\text { menor } \\
\text { descendente }\end{array}$ & $\begin{array}{l}\text { Opus } \\
\text { VN } 4 \\
\text { em F } \\
\text { maior }\end{array}$ & 1- Adagio & 14 & 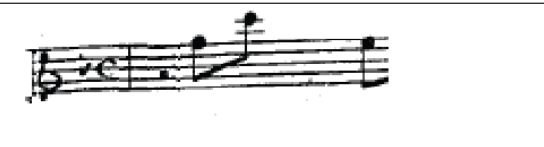 & 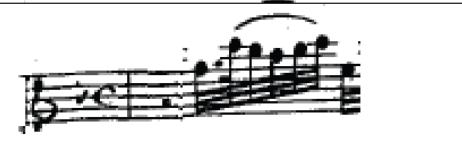 \\
\hline $\begin{array}{l}\text { Segunda } \\
\text { menor } \\
\text { descendente } \\
\text { (nona) }\end{array}$ & $\begin{array}{l}\text { Opus } \\
\text { VN 4 } \\
\text { em F } \\
\text { maior }\end{array}$ & 1- Adagio & 16 & tef & बe्च \\
\hline $\begin{array}{l}\text { Segunda } \\
\text { maior } \\
\text { ascendente }\end{array}$ & $\begin{array}{l}\text { Opus V } \\
\text { N 4 em } \\
\text { F maior }\end{array}$ & 1- Adagio & $2 \mathrm{e} 3$ & $+e^{4}=1 \pm$ & 7 \\
\hline
\end{tabular}




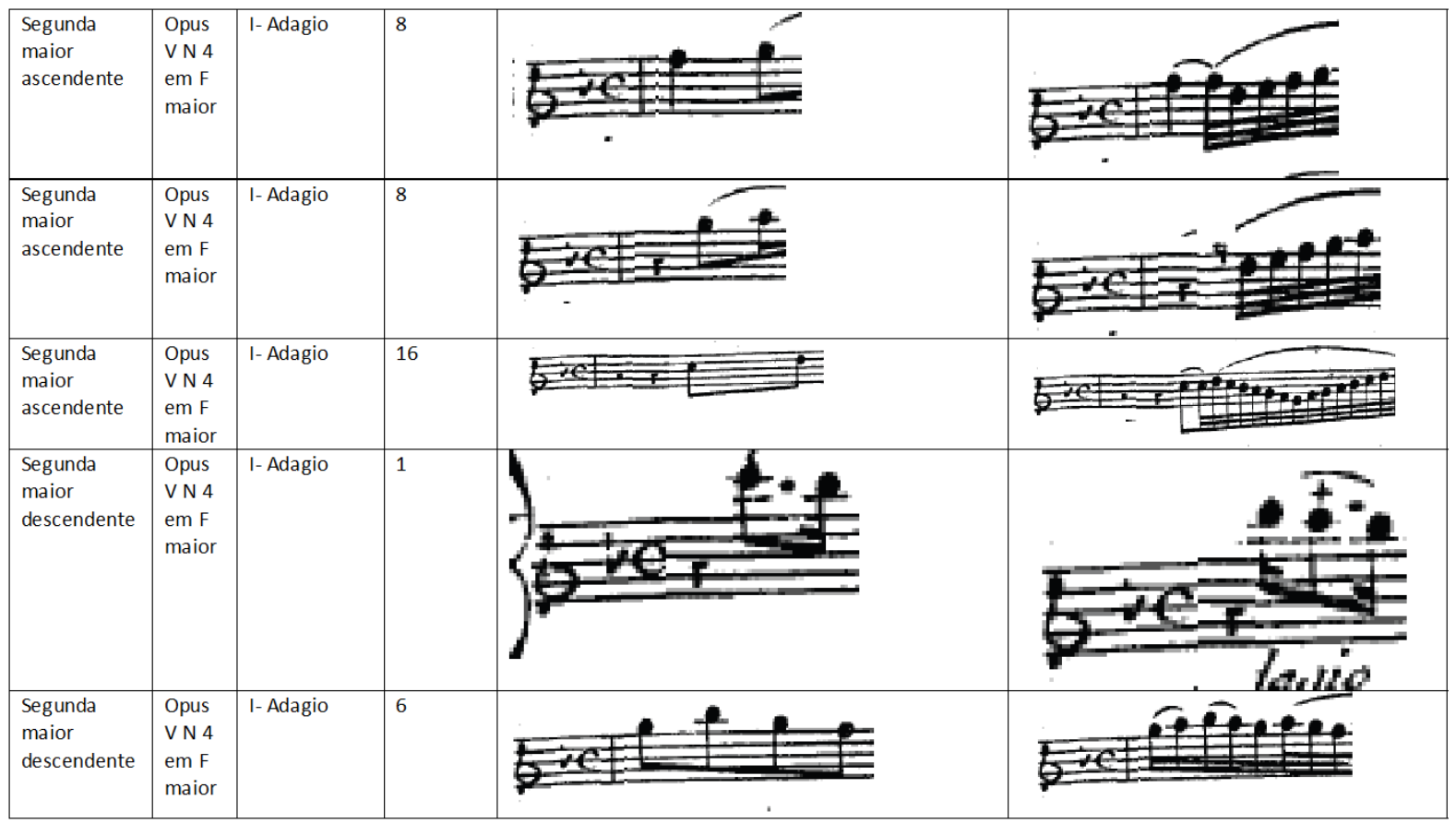

\begin{tabular}{|c|c|c|c|c|c|}
\hline $\begin{array}{l}\text { Segunda } \\
\text { maior } \\
\text { descendente }\end{array}$ & $\begin{array}{l}\text { Opus } \\
\text { VN } 4 \\
\text { em F } \\
\text { maior }\end{array}$ & I- Adagio & 6 & 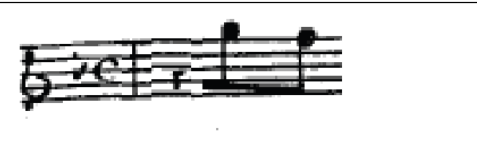 & refFete \\
\hline $\begin{array}{l}\text { Segunda } \\
\text { maior } \\
\text { descendente }\end{array}$ & $\begin{array}{l}\text { Opus } \\
\text { VN4 } \\
\text { em F } \\
\text { maior }\end{array}$ & 1- Adagio & 1 e 2 & $\frac{1}{2+2}$ & $t \Rightarrow e=$ \\
\hline $\begin{array}{l}\text { Segunda } \\
\text { maior } \\
\text { descendente }\end{array}$ & $\begin{array}{l}\text { Opus } \\
\text { VN } 4 \\
\text { em F } \\
\text { maior }\end{array}$ & I- Adagio & 2 & $t_{102}=$ & \\
\hline $\begin{array}{l}\text { Segunda } \\
\text { maior } \\
\text { descendente }\end{array}$ & $\begin{array}{l}\text { Opus } \\
\text { VN4 } \\
\text { em F } \\
\text { maior }\end{array}$ & I-Adagio & 3 & 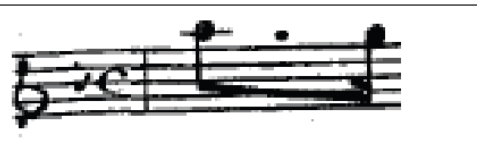 & Fe生 \\
\hline $\begin{array}{l}\text { Segunda } \\
\text { maior } \\
\text { descendente }\end{array}$ & $\begin{array}{l}\text { Opus } \\
\text { VN4 } \\
\text { em F } \\
\text { maior }\end{array}$ & 1- Adagio & 3 & 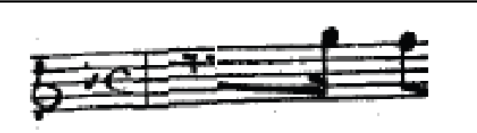 & retat \\
\hline
\end{tabular}




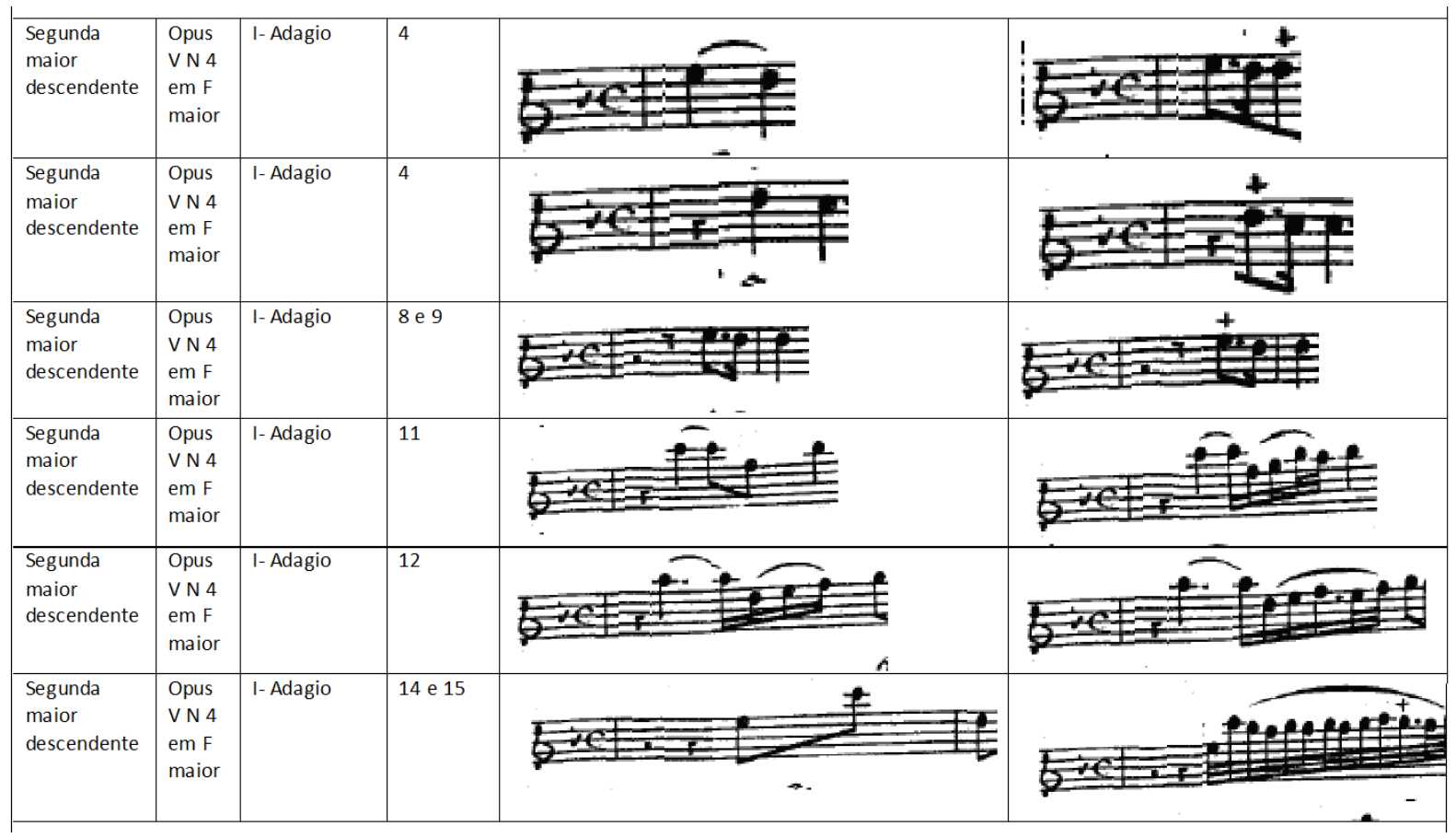

\begin{tabular}{|c|c|c|c|c|c|}
\hline $\begin{array}{l}\text { Segunda } \\
\text { maior } \\
\text { descendente }\end{array}$ & $\begin{array}{l}\text { Opus } \\
\text { VN4 } \\
\text { em F } \\
\text { maior }\end{array}$ & 1- Adagio & 17 & 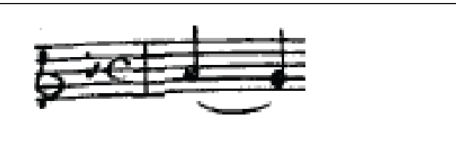 & 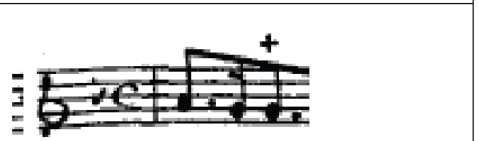 \\
\hline $\begin{array}{l}\text { Segunda } \\
\text { maior } \\
\text { descendente }\end{array}$ & $\begin{array}{l}\text { Opus } \\
\text { VN } 4 \\
\text { em F } \\
\text { maior }\end{array}$ & 1-Adagio & 17 & we玨 & 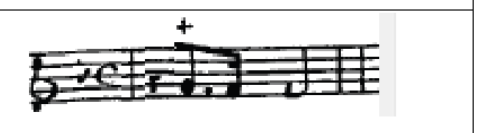 \\
\hline $\begin{array}{l}\text { Terça menor } \\
\text { ascendente }\end{array}$ & $\begin{array}{l}\text { Opus } \\
\text { VN4 } \\
\text { em F } \\
\text { maior } \\
\end{array}$ & I- Adagio & 6 & 䒠击 & 年 \\
\hline $\begin{array}{l}\text { Terça menor } \\
\text { ascendente }\end{array}$ & $\begin{array}{l}\text { Opus } \\
\text { VN4 } \\
\text { em F } \\
\text { maior }\end{array}$ & I- Adagio & 7 & 5 ceta $\Rightarrow$ & $+\mathrm{C}$ \\
\hline $\begin{array}{l}\text { Terça menor } \\
\text { ascendente }\end{array}$ & $\begin{array}{l}\text { Opus } \\
\text { VN } 4 \\
\text { em F } \\
\text { maior }\end{array}$ & I- Adagio & 8 & $\frac{2+2}{2+2}$ & 5 \\
\hline $\begin{array}{l}\text { Terça menor } \\
\text { ascendente }\end{array}$ & $\begin{array}{l}\text { Opus } \\
\text { VN 4 } \\
\text { em F } \\
\text { maior }\end{array}$ & I- Adagio & 8 & $\frac{\pi}{2}$ & $\frac{5 e \pm}{2}$ \\
\hline
\end{tabular}




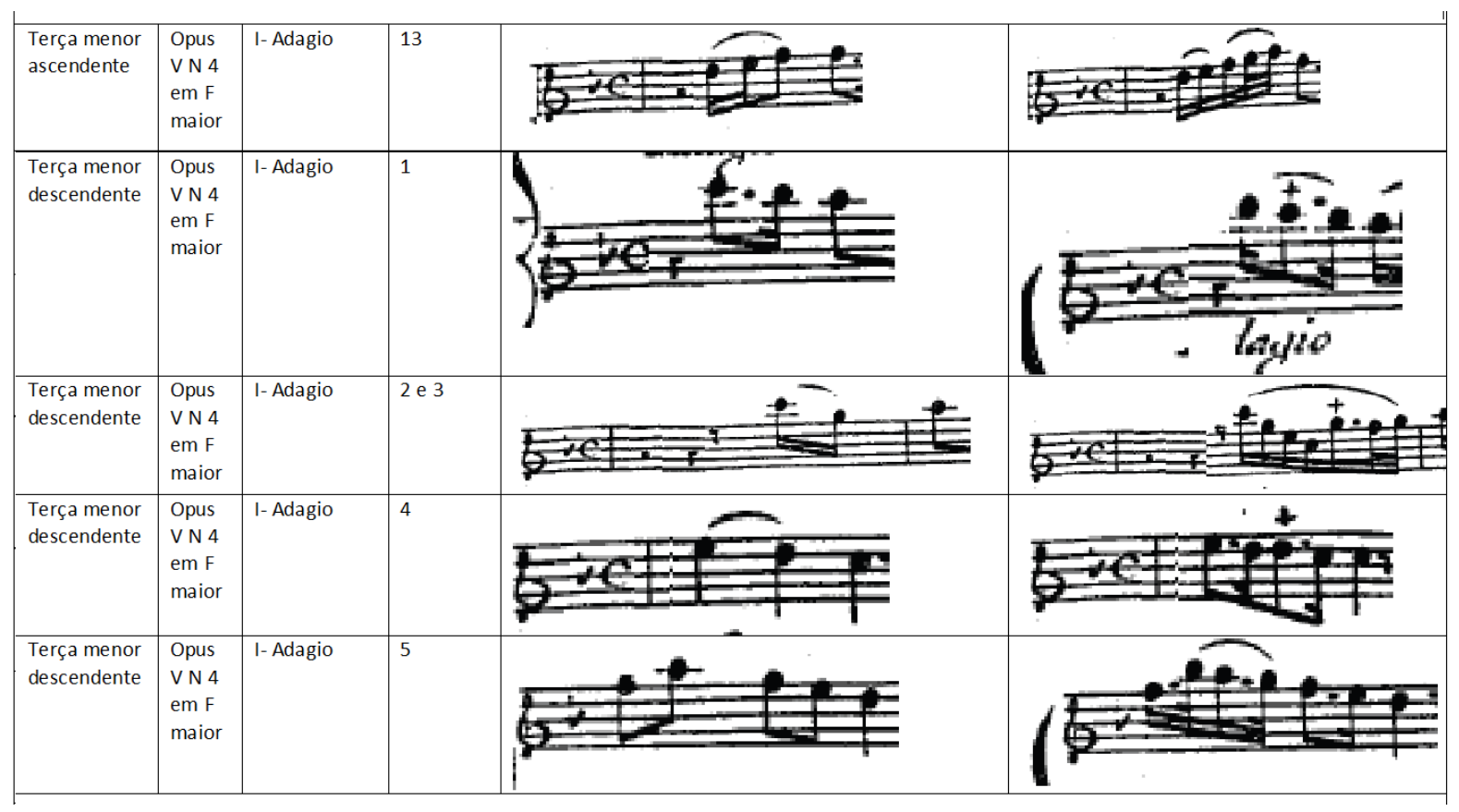

\begin{tabular}{|c|c|c|c|c|c|}
\hline $\begin{array}{l}\text { Terça menor } \\
\text { descendente }\end{array}$ & $\begin{array}{l}\text { Opus } \\
\text { VN4 } \\
\text { em F } \\
\text { maior }\end{array}$ & 1- Adagio & 5 & FefFet & $5+97$ \\
\hline $\begin{array}{l}\text { Terça menor } \\
\text { descendente }\end{array}$ & $\begin{array}{l}\text { Opus } \\
\text { VN4 } \\
\text { em F } \\
\text { maior }\end{array}$ & I- Adagio & 6 & 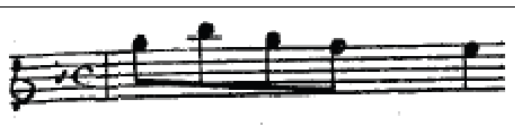 & \\
\hline $\begin{array}{l}\text { Terça menor } \\
\text { descendente }\end{array}$ & $\begin{array}{l}\text { Opus } \\
\text { VN4 } \\
\text { em F } \\
\text { maior }\end{array}$ & I- Adagio & 6 & 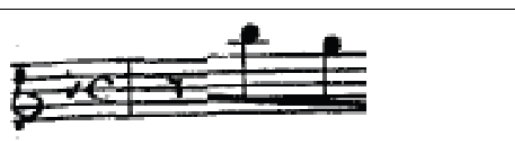 & $5+e \pm=2$ \\
\hline $\begin{array}{l}\text { Terça menor } \\
\text { descendente }\end{array}$ & $\begin{array}{l}\text { Opus } \\
\text { VN } 4 \\
\text { em } F \\
\text { maior }\end{array}$ & I- Adagio & 6 & 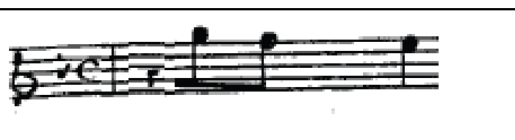 & $5+e$ \\
\hline $\begin{array}{l}\text { Terça menor } \\
\text { descendente }\end{array}$ & $\begin{array}{l}\text { Opus } \\
\text { VN4 } \\
\text { em F } \\
\text { maior }\end{array}$ & I- Adagio & 7 & 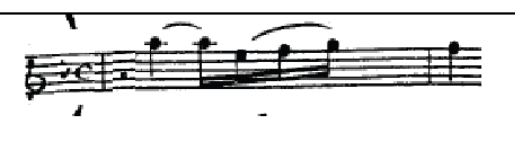 & + \\
\hline $\begin{array}{l}\text { Terça menor } \\
\text { descendente }\end{array}$ & $\begin{array}{l}\text { Opus } \\
\text { VN } 4 \\
\text { em F } \\
\text { maior }\end{array}$ & 1- Adagio & 16 & peet $=\Rightarrow$ & Fete \\
\hline
\end{tabular}




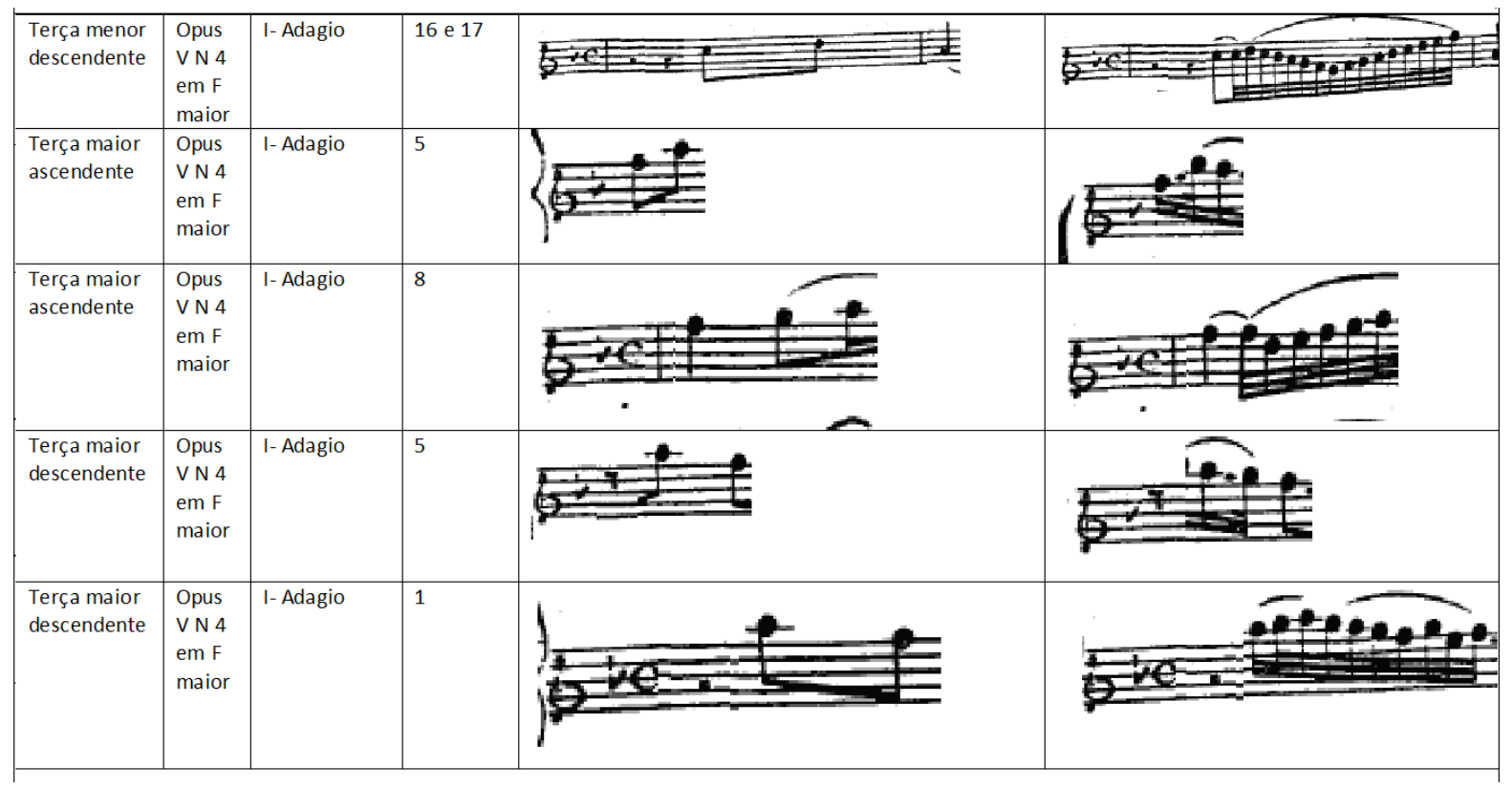

\begin{tabular}{|c|c|c|c|c|c|}
\hline $\begin{array}{l}\text { Terça maior } \\
\text { descendente }\end{array}$ & $\begin{array}{l}\text { Opus } \\
\text { VN4 } \\
\text { em F } \\
\text { maior }\end{array}$ & I- Adagio & 1 & 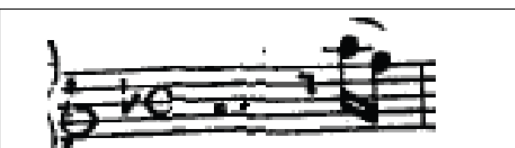 & 50 \\
\hline $\begin{array}{l}\text { Terça maior } \\
\text { descendente }\end{array}$ & $\begin{array}{l}\text { Opus } \\
\text { VN } 4 \\
\text { em F } \\
\text { maior }\end{array}$ & I- Adagio & 3 & $5 \mathrm{set}^{2}=1$ & $5 x{ }^{2}=-2-1$ \\
\hline $\begin{array}{l}\text { Terça maior } \\
\text { descendente }\end{array}$ & $\begin{array}{l}\text { Opus } \\
\text { VN } 4 \\
\text { em F } \\
\text { maior }\end{array}$ & I- Adagio & 17 & 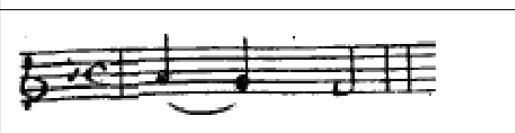 & 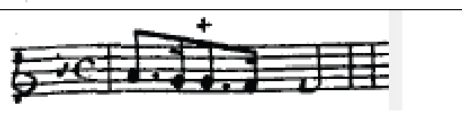 \\
\hline $\begin{array}{l}\text { Quarta } \\
\text { diminuta } \\
\text { descendente }\end{array}$ & $\begin{array}{l}\text { Opus } \\
\text { VN } 4 \\
\text { em F } \\
\text { maior }\end{array}$ & I-Adagio & 8 & 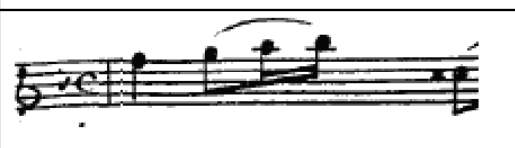 & 啁主 \\
\hline $\begin{array}{l}\text { Quarta justa } \\
\text { ascendente }\end{array}$ & $\begin{array}{l}\text { Opus } \\
\text { VN } 4 \\
\text { em F } \\
\text { maior }\end{array}$ & I-Adagio & 5 e 6 & $5+e \pm=7$ & ret \\
\hline $\begin{array}{l}\text { Quarta justa } \\
\text { ascendente }\end{array}$ & $\begin{array}{l}\text { Opus } \\
V N 4 \\
\text { em F } \\
\text { maior }\end{array}$ & I- Adagio & 8 & 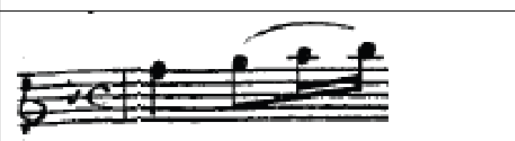 & 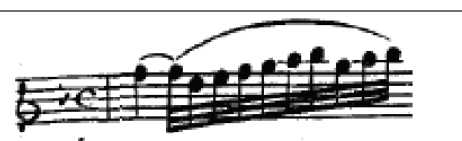 \\
\hline
\end{tabular}




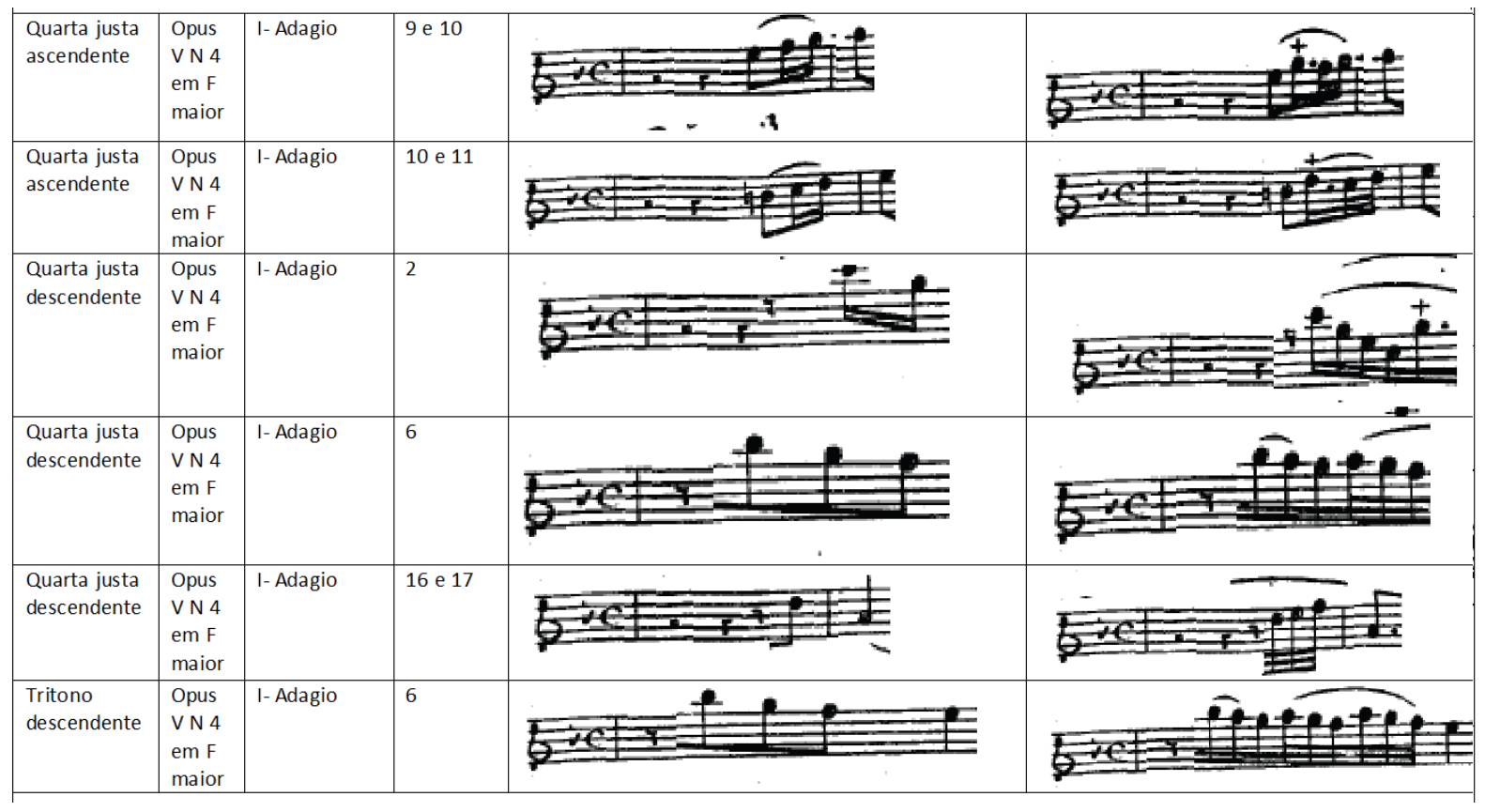

\begin{tabular}{|c|c|c|c|c|c|}
\hline $\begin{array}{l}\text { Tritono } \\
\text { descendente }\end{array}$ & $\begin{array}{l}\text { Opus } \\
\text { VN } 4 \\
\text { em F } \\
\text { maior }\end{array}$ & \begin{tabular}{|l|} 
1-Adagio \\
\end{tabular} & 8 & 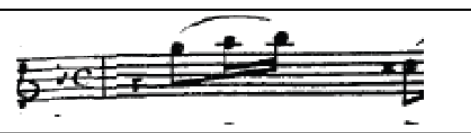 & 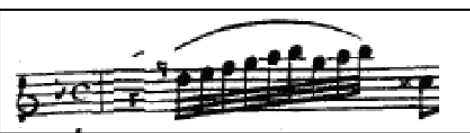 \\
\hline $\begin{array}{l}\text { Tritono } \\
\text { descendente }\end{array}$ & $\begin{array}{l}\text { Opus } \\
\text { VN } 4 \\
\text { em F } \\
\text { maior }\end{array}$ & 1- Adagio & 8 & Fetetat & 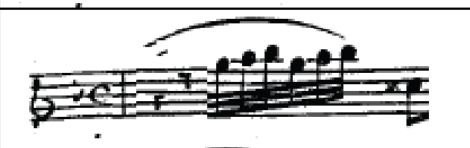 \\
\hline $\begin{array}{l}\text { Quinta justa } \\
\text { ascendente }\end{array}$ & $\begin{array}{l}\text { Opus } \\
\text { VN4 } \\
\text { em F } \\
\text { maior }\end{array}$ & I- Adagio & 1 & & 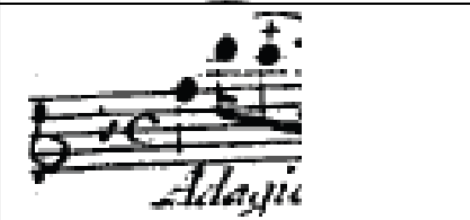 \\
\hline $\begin{array}{l}\text { Sexta menor } \\
\text { descendente }\end{array}$ & $\begin{array}{l}\text { Opus } \\
\text { VN 4 } \\
\text { em F } \\
\text { maior } \\
\end{array}$ & 1-Adagio & 14 & LI & 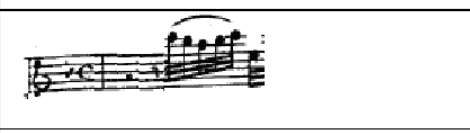 \\
\hline $\begin{array}{l}\text { Sétima } \\
\text { diminuta } \\
\text { descendente }\end{array}$ & $\begin{array}{l}\text { Opus } \\
\text { VN } 4 \\
\text { em F } \\
\text { maior }\end{array}$ & 1- Adagio & 8 & act & 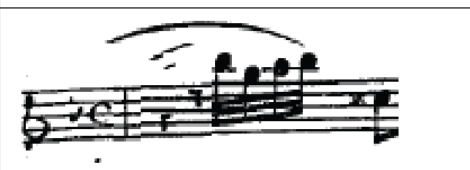 \\
\hline $\begin{array}{l}\text { Sétima menor } \\
\text { descendente }\end{array}$ & $\begin{array}{l}\text { Opus } \\
\text { VN 4 } \\
\text { em F } \\
\text { maior }\end{array}$ & I- Adagio & $14 \mathrm{e} 15$ & 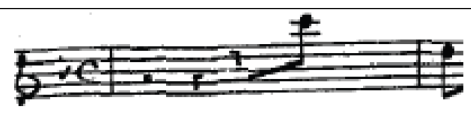 & Fe \\
\hline
\end{tabular}

\begin{tabular}{|l|l|l|l|}
\hline Sétima menor & Opus & I- Adagio & 16 \\
descendente & $\begin{array}{l}\text { V N } \\
\text { em F } \\
\text { maior }\end{array}$ & & \\
\hline
\end{tabular}
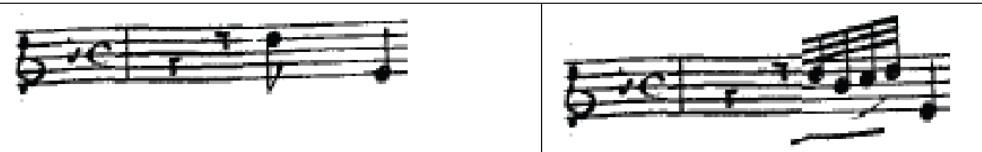

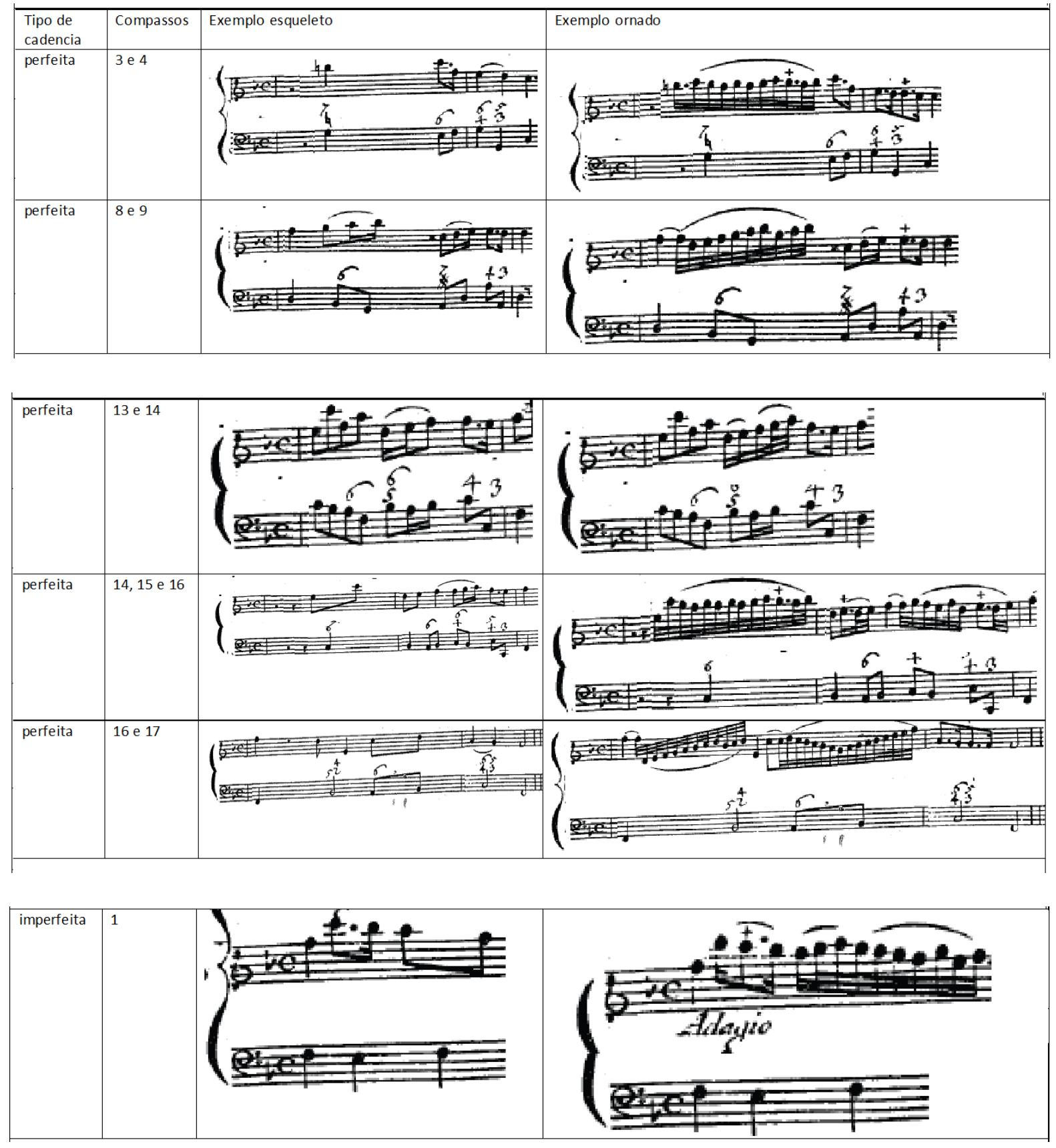
Tabela 13: Ornamentos da sonata Opus V n.4, quarto movimento, Adágio:

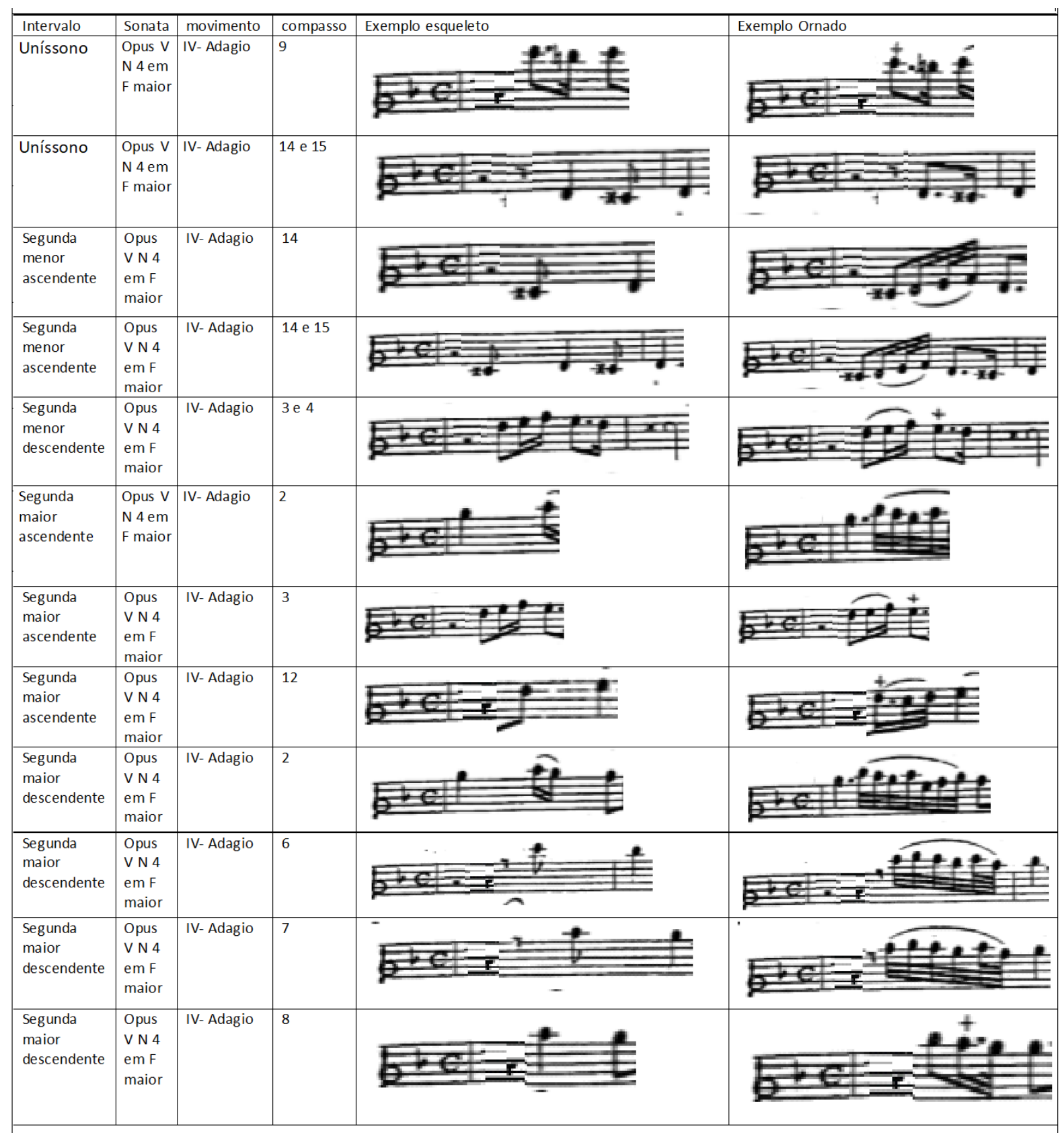




\begin{tabular}{|c|c|c|c|c|c|}
\hline $\begin{array}{l}\text { Segunda } \\
\text { maior } \\
\text { descendente }\end{array}$ & $\begin{array}{l}\text { Opus } \\
\text { VN4 } \\
\text { em F } \\
\text { maior }\end{array}$ & IV- Adagio & 10 e 11 & $\frac{2+1+1}{-C}$ & 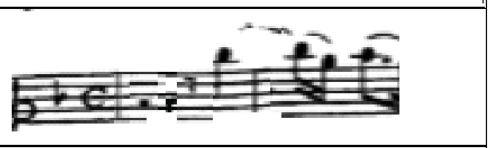 \\
\hline $\begin{array}{l}\text { Segunda } \\
\text { maior } \\
\text { descendente }\end{array}$ & $\begin{array}{l}\text { Opus } \\
\text { VN4 } \\
\text { em F } \\
\text { maior }\end{array}$ & IV- Adagio & 11 & 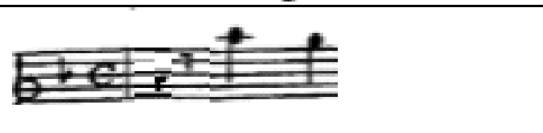 & Lexta \\
\hline $\begin{array}{l}\text { Segunda } \\
\text { maior } \\
\text { descendente }\end{array}$ & $\begin{array}{l}\text { Opus } \\
\text { VN4 } \\
\text { em F } \\
\text { maior }\end{array}$ & IV- Adagio & 11 & :at: & 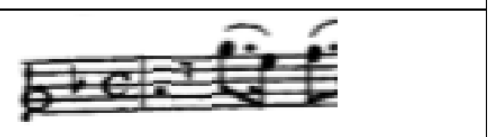 \\
\hline $\begin{array}{l}\text { Segunda } \\
\text { maior } \\
\text { descendente }\end{array}$ & $\begin{array}{l}\text { Opus } \\
\text { VN4 } \\
\text { em F } \\
\text { maior }\end{array}$ & IV- Adagio & 11 & Ex=ि & 2E: \\
\hline $\begin{array}{l}\text { Segunda } \\
\text { maior } \\
\text { descendente }\end{array}$ & \begin{tabular}{|l} 
Opus \\
VN 4 \\
em F \\
maior
\end{tabular} & IV- Adagio & 12 & 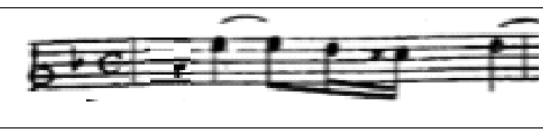 & 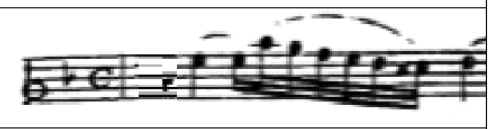 \\
\hline $\begin{array}{l}\text { Terça menor } \\
\text { ascendente }\end{array}$ & $\begin{array}{l}\text { Opus } \\
\text { VN4 } \\
\text { em F } \\
\text { maior }\end{array}$ & IV- Adagio & 6 & 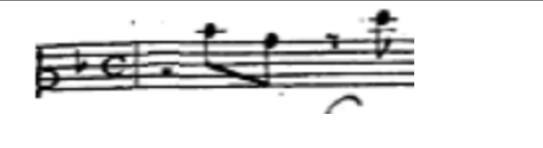 & 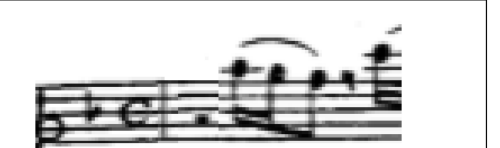 \\
\hline
\end{tabular}

\begin{tabular}{|c|c|c|c|c|c|}
\hline $\begin{array}{l}\text { Terça menor } \\
\text { ascendente }\end{array}$ & $\begin{array}{l}\text { Opus } \\
\text { VN4 } \\
\text { em F } \\
\text { maior }\end{array}$ & IV-Adagio & 10 & 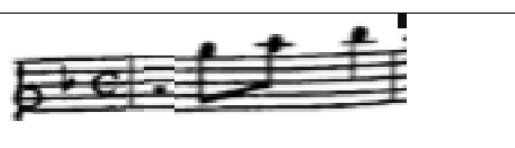 & 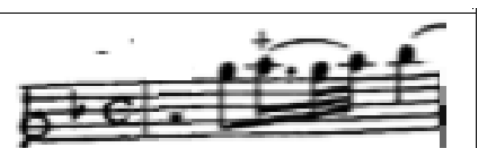 \\
\hline $\begin{array}{l}\text { Terça menor } \\
\text { ascendente }\end{array}$ & $\begin{array}{l}\text { Opus } \\
\text { VN4 } \\
\text { em F } \\
\text { maior }\end{array}$ & IV- Adagio & 12 & 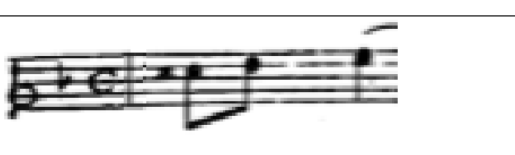 & $\bar{E}=$ \\
\hline $\begin{array}{l}\text { Terça menor } \\
\text { descendente }\end{array}$ & $\begin{array}{l}\text { Opus } \\
\text { VN } 4 \\
\text { em F } \\
\text { maior }\end{array}$ & IV- Adagio & 5 e 6 & 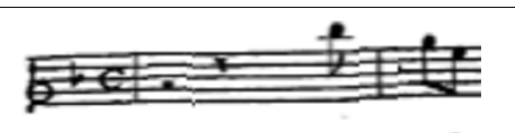 & 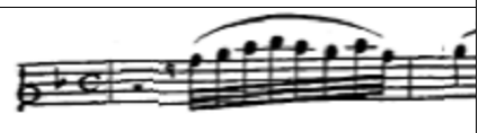 \\
\hline $\begin{array}{l}\text { Terça menor } \\
\text { descendente }\end{array}$ & $\begin{array}{l}\text { Opus } \\
\text { VN4 } \\
\text { em F } \\
\text { maior }\end{array}$ & IV- Adagio & 6 & 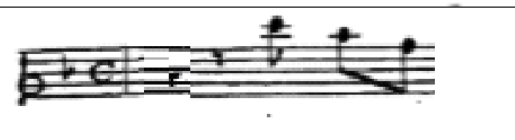 & $12+1$ \\
\hline $\begin{array}{l}\text { Terça menor } \\
\text { descendente }\end{array}$ & $\begin{array}{l}\text { Opus } \\
\text { VN 4 } \\
\text { em F } \\
\text { maior }\end{array}$ & IV-Adagio & 9 & 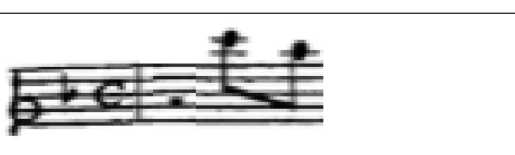 & te $=2$ \\
\hline $\begin{array}{l}\text { Terça menor } \\
\text { descendente }\end{array}$ & $\begin{array}{l}\text { Opus } \\
\text { VN } 4 \\
\text { em F } \\
\text { maior }\end{array}$ & IV-Adagio & $9 \mathrm{e} 10$ & 展走圭 & $\neq=$ \\
\hline
\end{tabular}




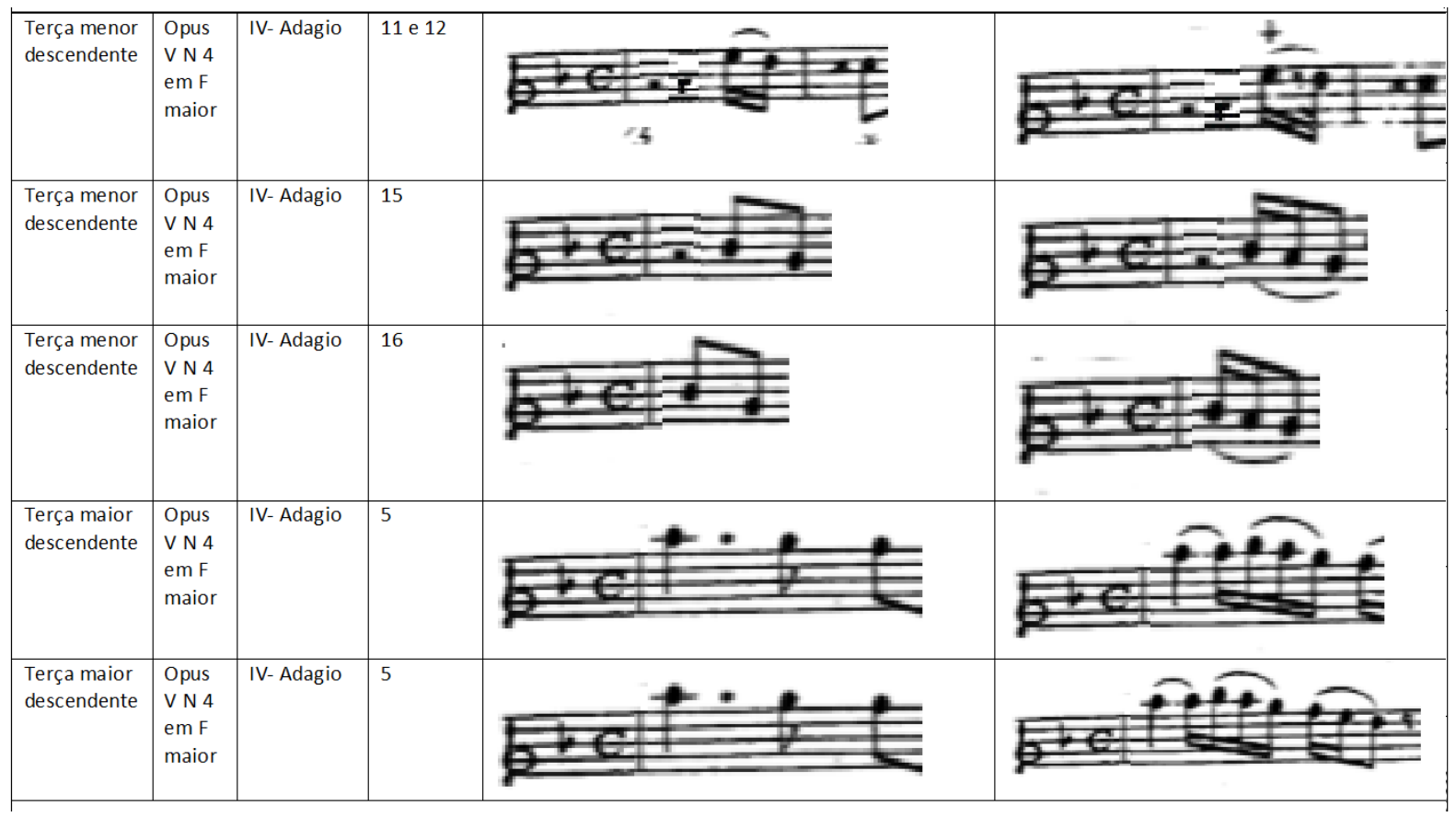

\begin{tabular}{|c|c|c|c|c|c|}
\hline $\begin{array}{l}\text { Terça maior } \\
\text { descendente }\end{array}$ & $\begin{array}{l}\text { Opus } \\
\text { VN } 4 \\
\text { em F } \\
\text { maior }\end{array}$ & IV- Adagio & 6 & $2+1=$ & $+6=2-2$ \\
\hline $\begin{array}{l}\text { Terça maior } \\
\text { descendente }\end{array}$ & $\begin{array}{l}\text { Opus } \\
\text { VN } 4 \\
\text { em F } \\
\text { maior }\end{array}$ & IV- Adagio & 15 e 16 & $p e=5$ & ${ }^{2}=I^{x}$ \\
\hline $\begin{array}{l}\text { Terça maior } \\
\text { descendente }\end{array}$ & $\begin{array}{l}\text { Opus } \\
\text { VN } 4 \\
\text { em F } \\
\text { maior }\end{array}$ & IV- Adagio & 16 & $\frac{1}{7} \div$ & $x$ \\
\hline $\begin{array}{l}\text { Quarta justa } \\
\text { ascendente }\end{array}$ & $\begin{array}{l}\text { Opus } \\
\text { VN } 4 \\
\text { em F } \\
\text { maior }\end{array}$ & IV- Adagio & 1 & 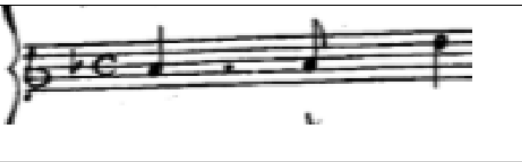 & $\frac{\infty}{\text { Adasio }}$ \\
\hline $\begin{array}{l}\text { Quarta justa } \\
\text { ascendente }\end{array}$ & $\begin{array}{l}\text { Opus } \\
\text { VN } 4 \\
\text { em F } \\
\text { maior }\end{array}$ & IV- Adagio & $1 \mathrm{e} 2$ & 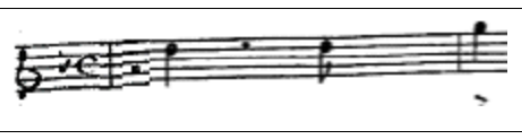 & we $=$ \\
\hline $\begin{array}{l}\text { Quarta justa } \\
\text { ascendente }\end{array}$ & $\begin{array}{l}\text { Opus } \\
\text { VN } 4 \\
\text { em F } \\
\text { maior }\end{array}$ & IV- Adagio & 6 & $20 \div$ & tec \\
\hline
\end{tabular}



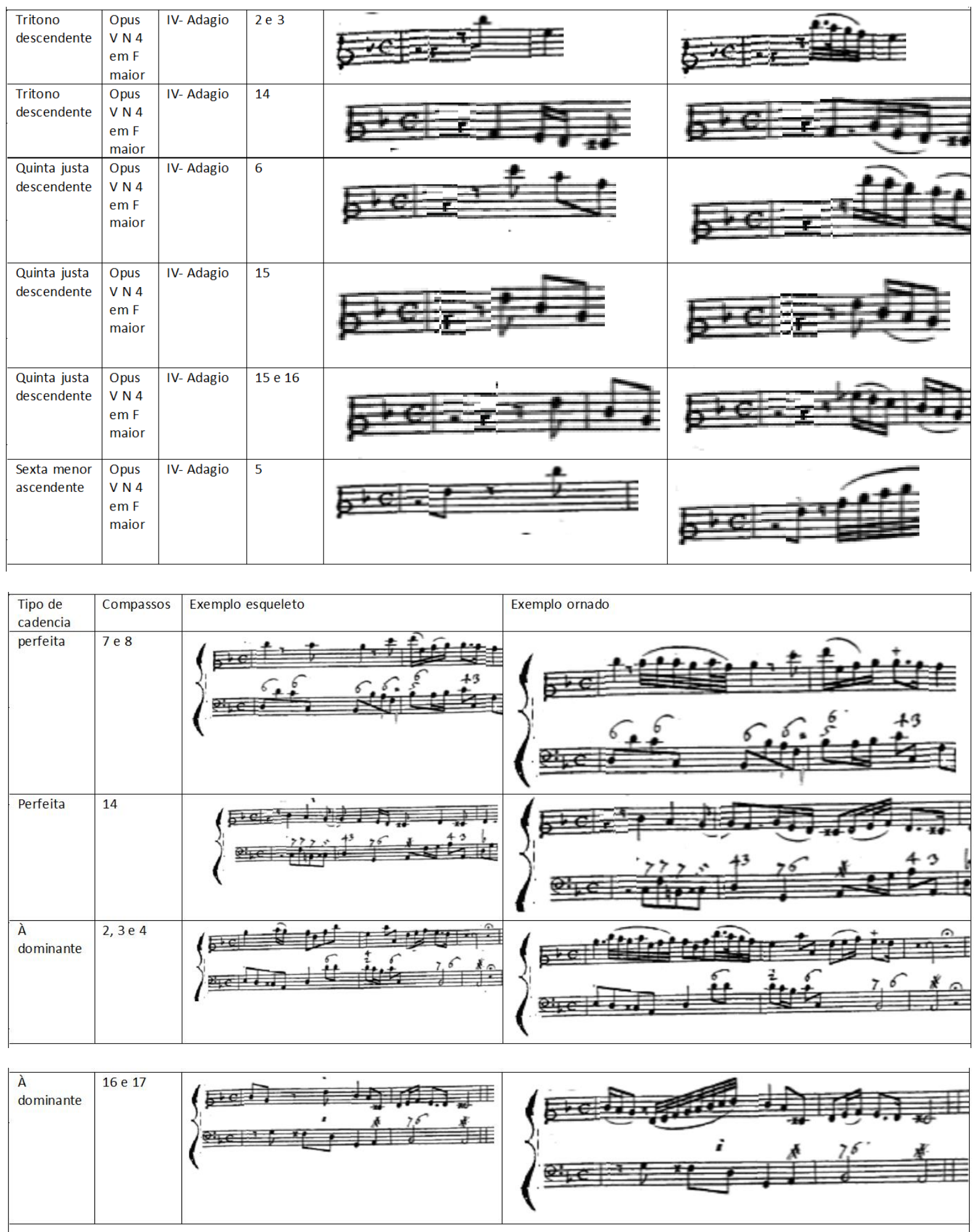


\section{O OPUS III DE CORELLI}

Neste capítulo serão apresentados os resultados da aplicação, à primeira sonata do Opus III de Corelli, da metodologia discutida no capítulo anterior.

\subsection{ANÁLISE DESCRITIVA DAS FORMAS ESQUELETO DOS MODELOS} PROPOSTOS DO OPUS III

\subsubsection{Sonata Op. 3 n. 1 primeiro movimento Grave}

Figura 32: Partitura do primeiro movimento da sonata n. 1 de Corelli Opus 3

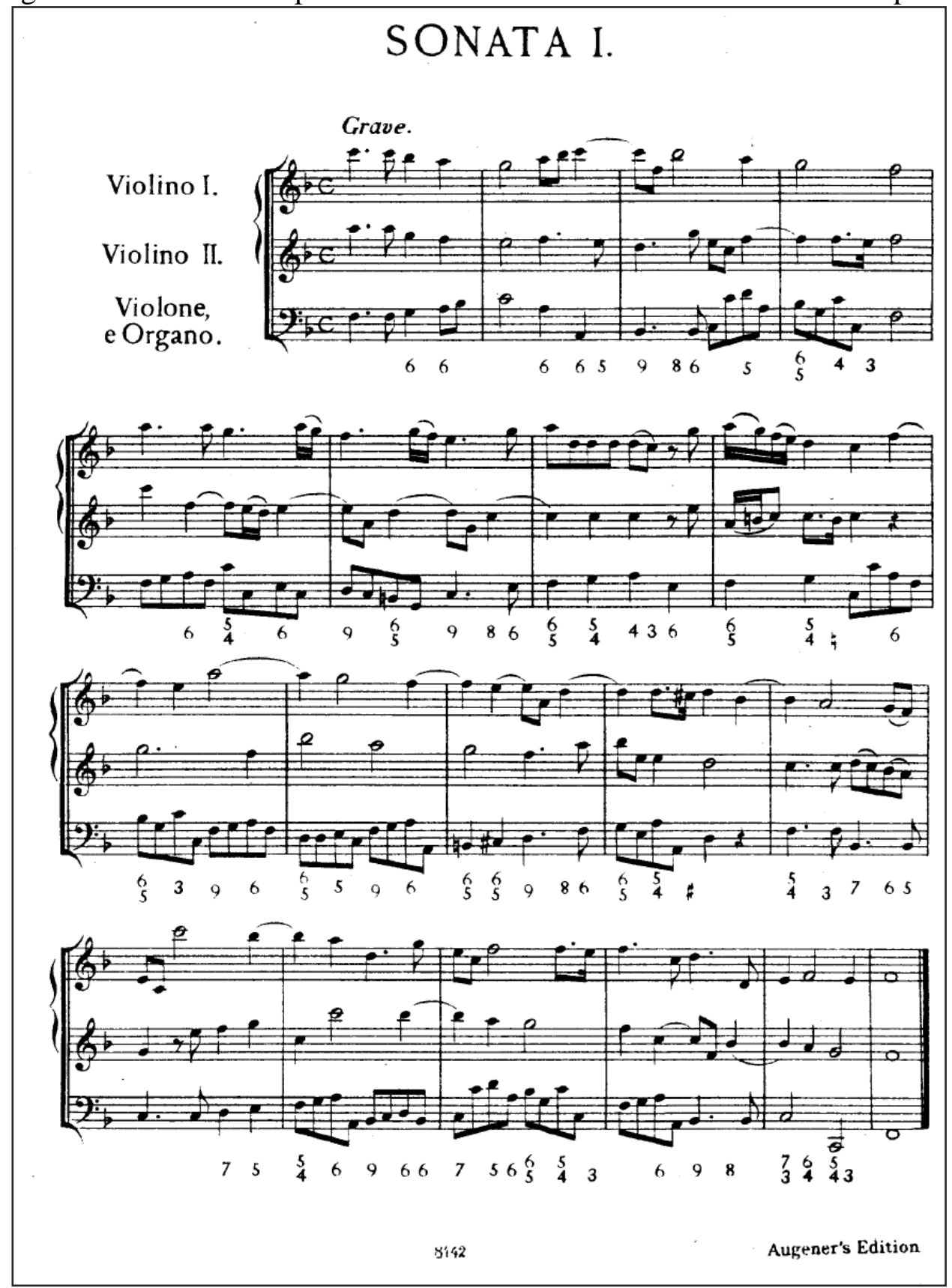

Fonte: Corelli, A Opera terza, 1689. Joachim, J. e Chrysander, F., 1888. 
Do início até a segunda metade do compasso 2 (Figura 32 e 33), as vozes caminham em homofonia: os violinos, em terças paralelas com movimento descendente; e o baixo, em movimento contrário a eles, quebrando rapidamente a homofonia com uma diminuição em colcheia no último tempo do compasso 1. Essa pequena semi-frase ganha um caráter suspensivo ao resolver em cadência imperfeita.

Figura 33: Destaque do compasso 1 e dos primeiros 3 tempos do compasso 2

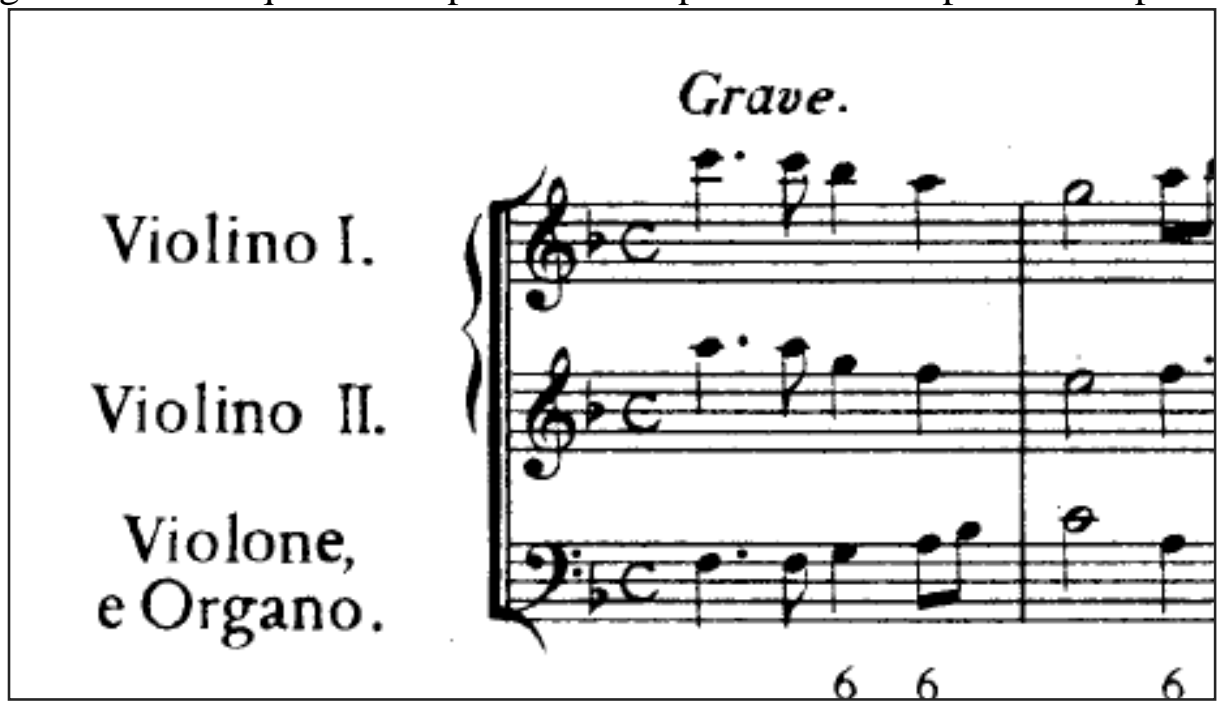

Fonte: Corelli, A Opera terza, 1689. Joachim, J. e Chrysander, F., 1888. Edição nossa.

O segundo membro da primeira frase (Figigura 34) é caracterizado pela busca de uma conclusão na cadência perfeita do compasso 4. A textura é tipicamente de quarta espécie nos violinos, com um diálogo de dissonâncias nos tempos principais; já o baixo passa a se movimentar em colcheias conforme se aproxima da cadência (a partir de 3.3), dando um caráter de diminuição inquieta que enfatiza o efeito de repouso após a cadência. 
Figura 34: Destaque a partir de 2.3 até o final do compasso 4.

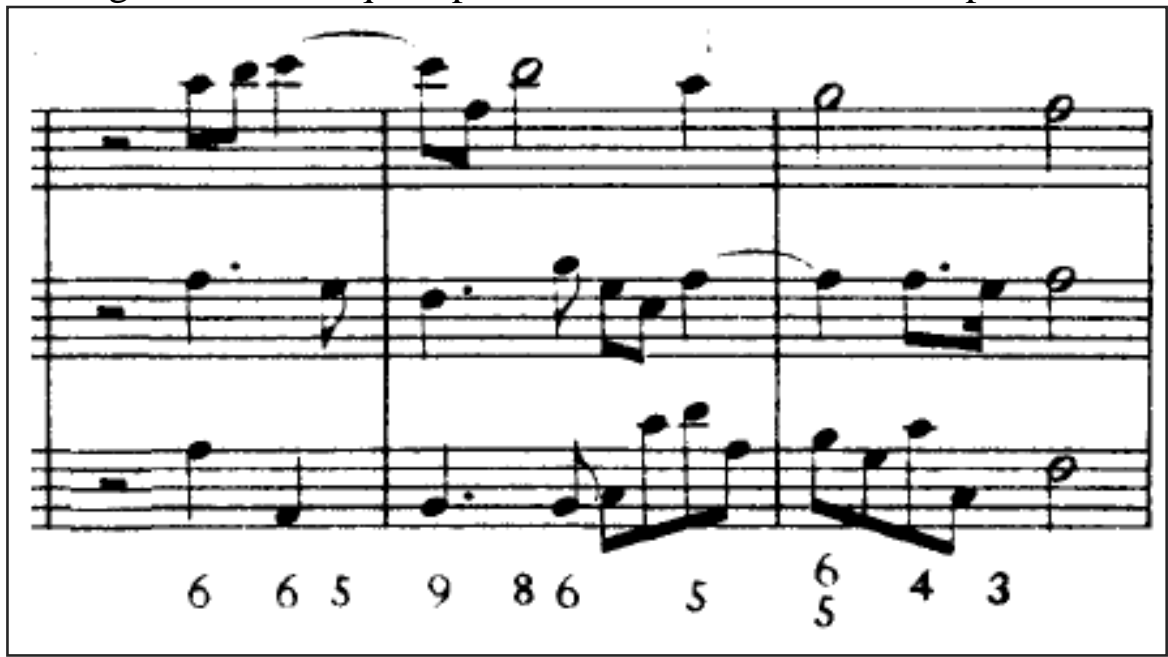

Fonte: Corelli, A Opera terza, 1689. Joachim, J. e Chrysander, F., 1888. Edição nossa.

A frase inteira (Figuras 33 e 34) caracteriza o exordium da peça, sendo o primeiro membro (Figura 33) o Captatio benevolentiae que, através de sua potente homofonia, abre o discurso, seduz o ouvinte e expõe o inciso principal da obra. No segundo membro da frase (Figura 34), segue o partitio que, com seu caráter conclusivo, estabelece o afeto e a tonalidade de fá maior utilizada no primeiro compasso, preparando a narrativa do discurso que segue.

No trecho que compreende o intervalo entre os compassos 5 e 8 (Figura 35), se inicia a narratio, onde o principal inciso da obra - uma semínima pontuada com uma colcheia buscando a próxima nota longa (exemplo nos 3 primeiros tempos da obra) - é trabalhado nos violinos em contraponto de quarta espécie, com uma tendência melódica descendente e imitativa; essa textura se dá sobre um movimentado baixo de colcheias, que segue até a cadência à dominante em 6.3. Essa cadência inicia com uma dissonância de nona no segundo violino, fruto de um ritardo da quarta espécie que antecede o trecho. Nesse momento, há uma inversão na subdivisão rítmica entre o baixo e o primeiro violino, que passa a assumir as colcheias, enquanto o segundo violino entra em contraponto de primeira espécie com o baixo até 7.3, de onde, até a cadência de 8.3, os violinos seguem com uma diminuição em terceira espécie (semi-colcheias) contra o baixo contínuo até a cadência perfeita em $\mathrm{C}$ maior no fim do trecho relatado. É interessante notar que essa cadência é a única com escrita em quarta espécie na forma esqueleto desse movimento; assim, é desejável que essa cadência contenha mais diminuições do que as outras, com exceção da cadência final. Quanto à textura de 8 até 10 , o trecho que a precede pede uma 
ornamentação mais modesta no primeiro violino, pois sua voz tem o movimento de ir em direção à dissonância junto com o baixo. ${ }^{85}$

Figura 35: Destaque a partir do início do quinto compasso até 8.3.

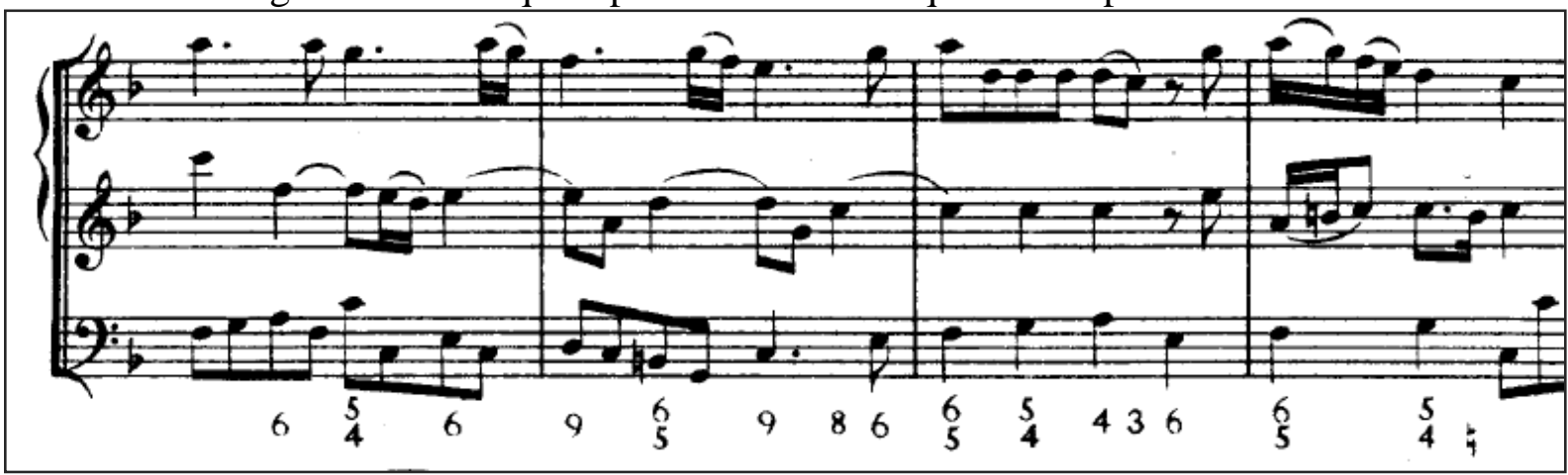

Fonte: Corelli, A Opera terza, 1689. Joachim, J. e Chrysander, F., 1888. Edição nossa.

A partir de 8.3 até o compasso 11 (Figura 36), o baixo volta a realizar uma caminhada em colcheias até sua ida para a tonalidade de ré menor em 11 e a cadência perfeita na nova tonalidade em 12.3, encerrando o confutatio do movimento, caracterizado pela busca da tonalidade relativa menor (nesse contexto, uma tonalidade distante).

Aos violinos, compete uma nova sessão de notas longas em quarta espécie, dessa vez com mínimas, sendo apenas o compasso 9 do segundo violino uma aparente aumentação do inciso principal com mínima precedendo semínima; dessa vez, o movimento melódico começa com inclinação ascendente, tendo ponto culminante no si bemol do segundo violino no compasso 10, onde começa uma nova descida em direção à cadência perfeita em ré menor no compasso 12. Podemos observar esse novo trecho na figura 33:

Figura 36 - Destaque a partir de 8.3 até 12.3

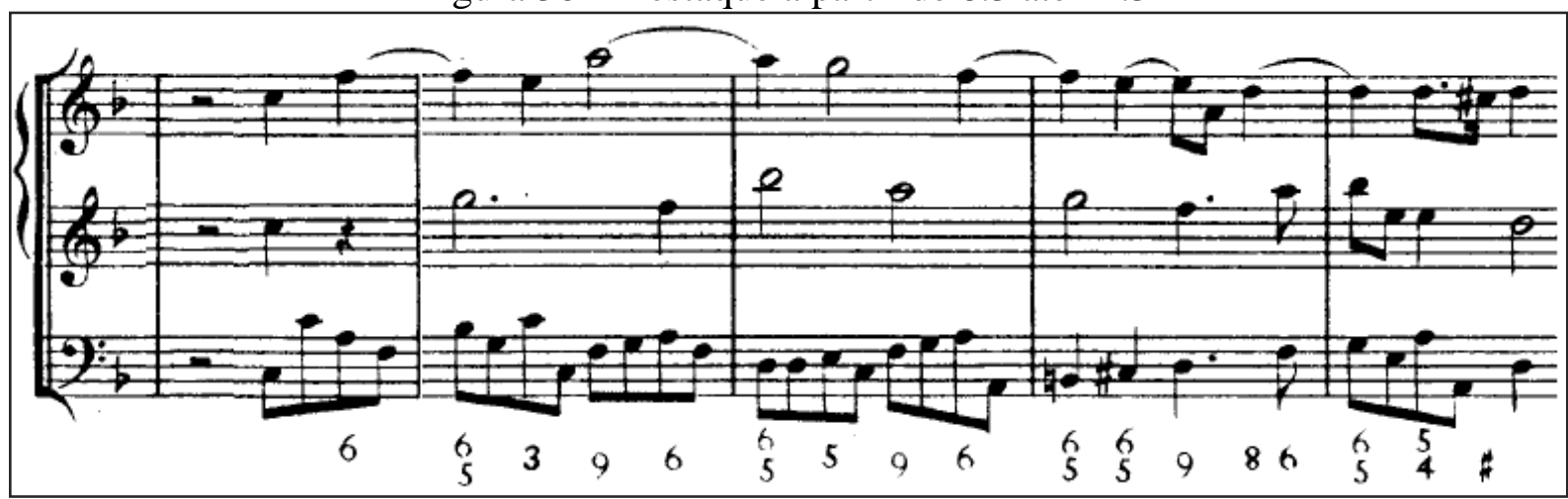

Fonte: Corelli, A Opera terza, 1689. Joachim, J. e Chrysander, F., 1888. Edição nossa.

\footnotetext{
${ }^{85}$ Ao analisar as sonatas do Op. 5, verificamos que a ornamentação de trechos em quarta espécie, costuma ser mais exagerada quando o movimento do violino é partindo das dissonâncias para as consonâncias do que no das consonâncias para as dissonâncias.
} 
Da resolução de 12.3 até a cadência perfeita em 17 (Figura 37) há, além de um retorno à tonalidade principal, uma retomada do inciso principal da obra, que é sobreposto nos compassos 13 e 14 pelo baixo, quase caracterizando um stretto, com o segundo violino em primeira espécie, diminuída em colcheias de 13.3 até o inciso de 14. O movimento entre as duas vozes neste trecho, segundo violino e baixo, em geral é obliquo ou contrário, sendo direto apenas nos dois últimos tempos de 14. Esse retorno da tonalidade e do uso do inciso de forma sistemática caracteriza a confirmatio da obra com o epílogo do discurso.

Ainda em 13 e 14, os violinos seguem em uma imitação em stretto, alternando o tema, com algumas diminuições em segunda espécie (colcheias), nas resoluções da dissonância, enquanto o segundo está com o baixo, o primeiro responde e no final prepara a grande troca de registro, uma hipérbole musical, observada em 15.2, com o retorno do dó 5, a primeira nota do movimento e a mais aguda usada na versão esqueleto.

Figura 37: Destaque a partir de 12.3 até o início do compasso 15.

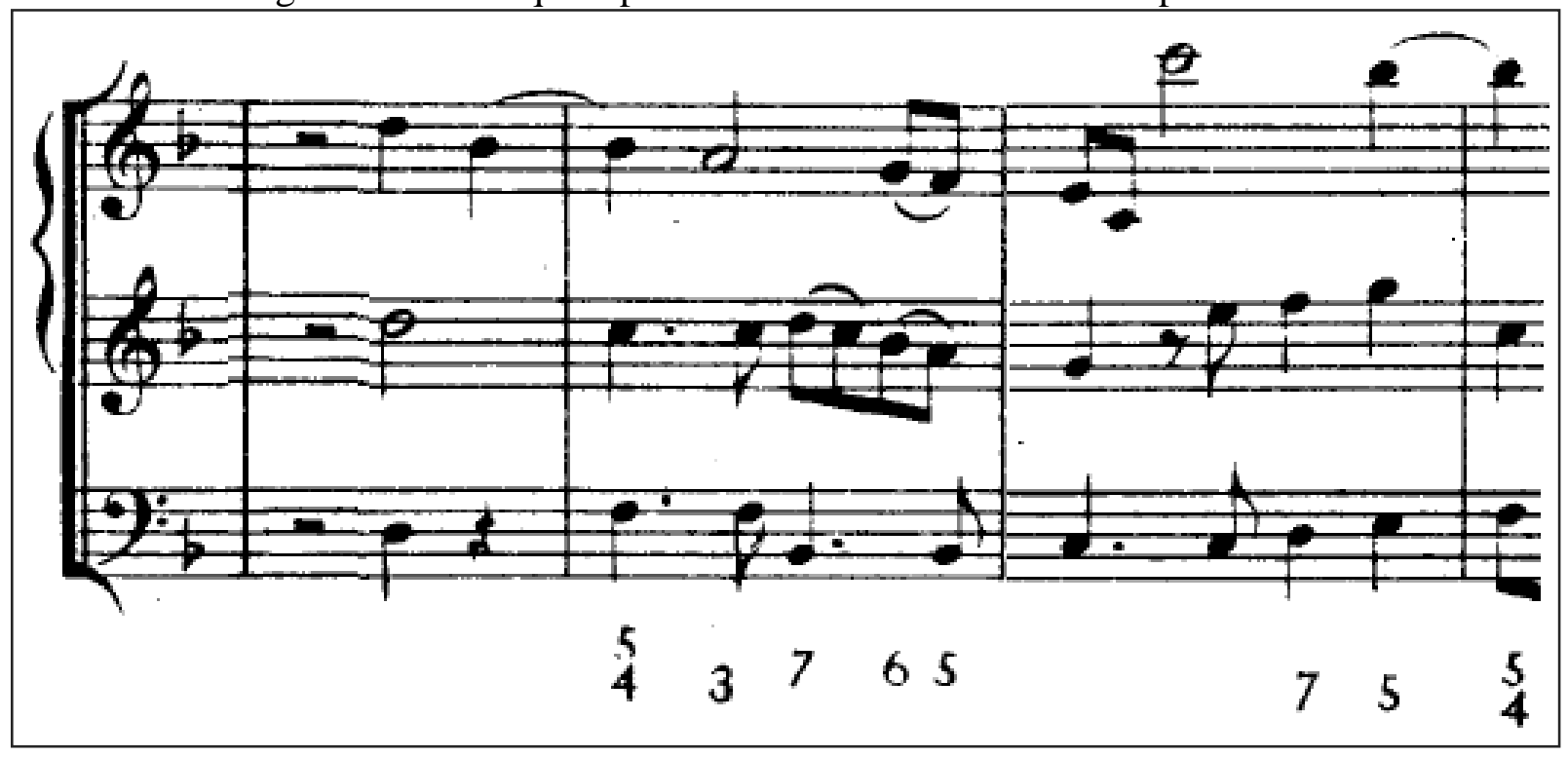

Fonte: Corelli, A Opera terza, 1689. Joachim, J e Chrysander, F, 1888. Edição nossa.

A partir do compasso 15 (Figura 38), o baixo contínuo é disposto em um movimento de colcheias até a cadência perfeita de 17 e os violinos seguem em quarta espécie. Os três últimos compassos, com uma cadência perfeita (visivelmente alargada em mais dois tempos em 17, o que requer uma exuberância da imaginação dos solistas), reafirmam a tonalidade da obra, em um peroratio que encerra o movimento. O Grave analisado, constitui um grande exordium ao se considerar a sonata como um todo e prepara a fuga do segundo movimento, narratio. 
Figura 38: Destaque a partir do compasso 14 até o final do movimento.

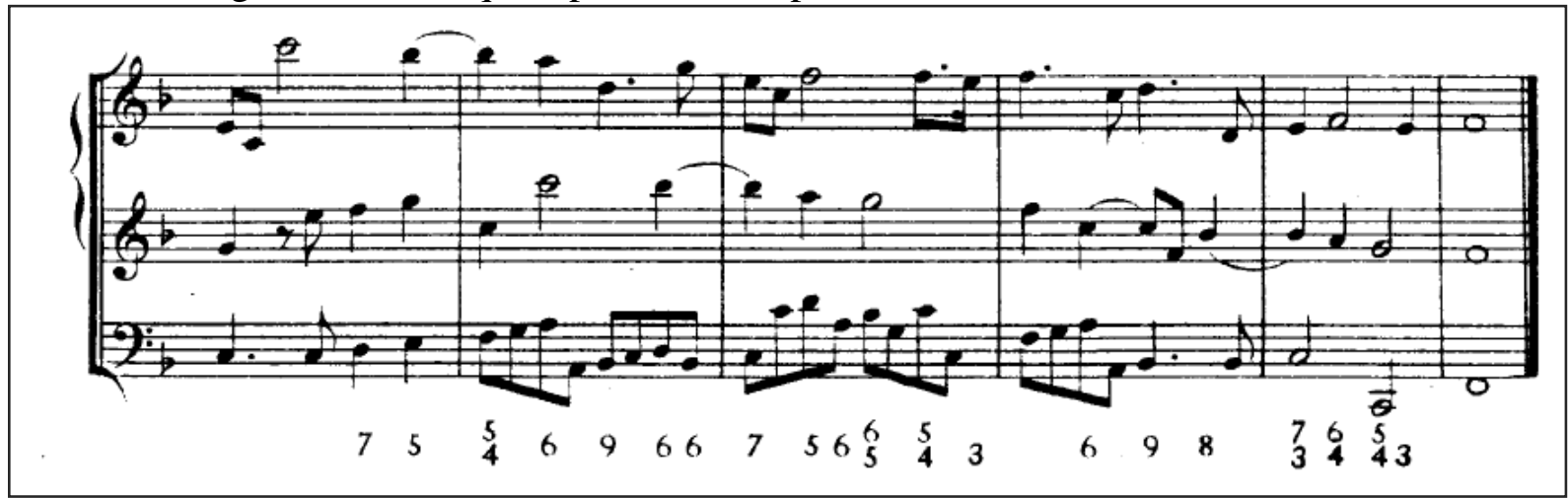

Fonte: Corelli, A Opera terza, 1689. Joachim, J. e Chrysander, F., 1888. Edição nossa.

\subsubsection{Sonata Op. 3 n. 2 primeiro movimento Grave}

Figura 39: O Grave do trio-sonata 2 do Opus III de A. Corelli

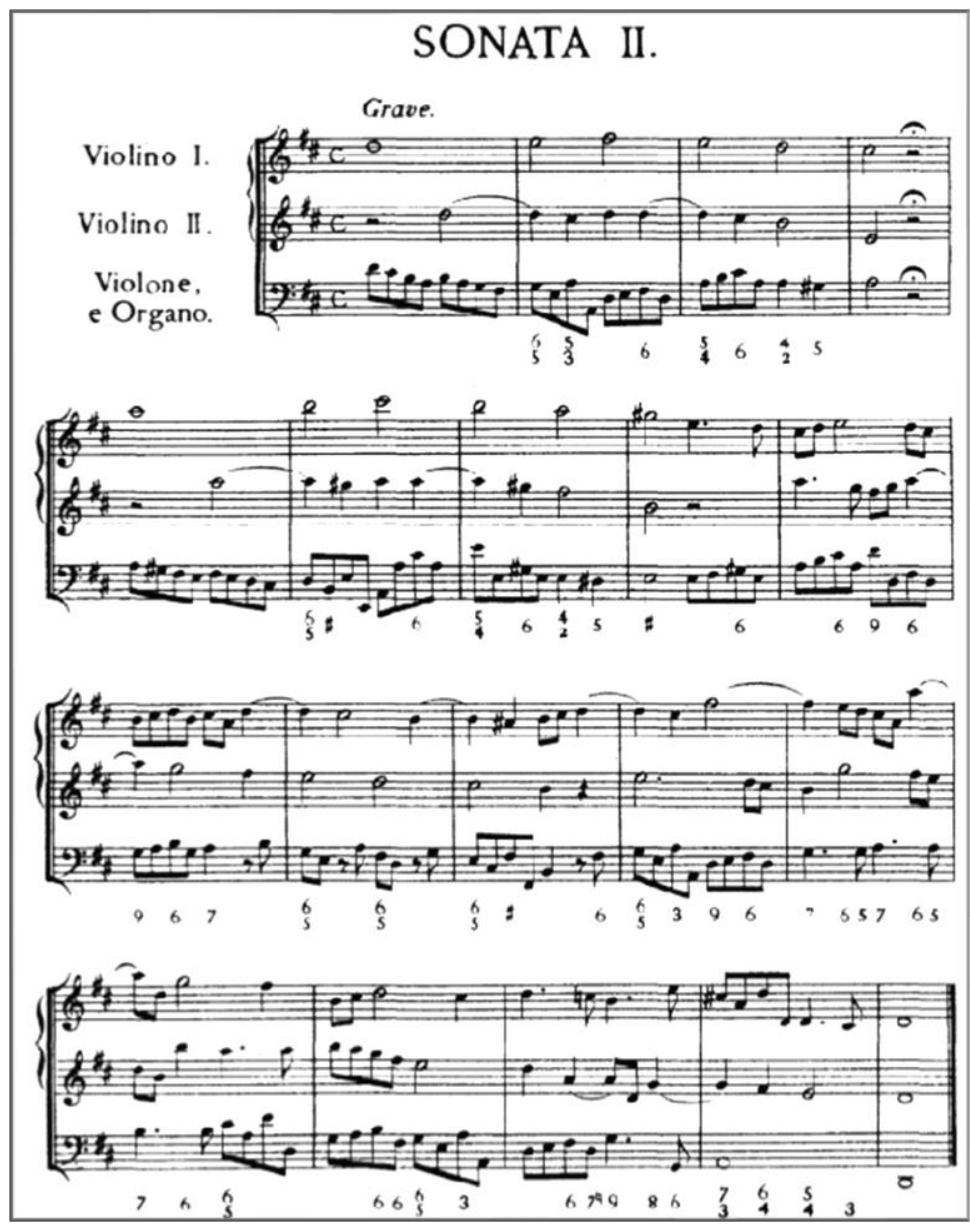

Fonte: Opera terza. Londres: Joseph Joachim e Friedich Chrysander, 1888 
O grave da figura acima, tem uma estrutura, um afeto e uma dispositio similar ao primeiro adágio da terceira sonata do Opus V

Figura 40: Adágio da sonata III do Opus V de Corelli.

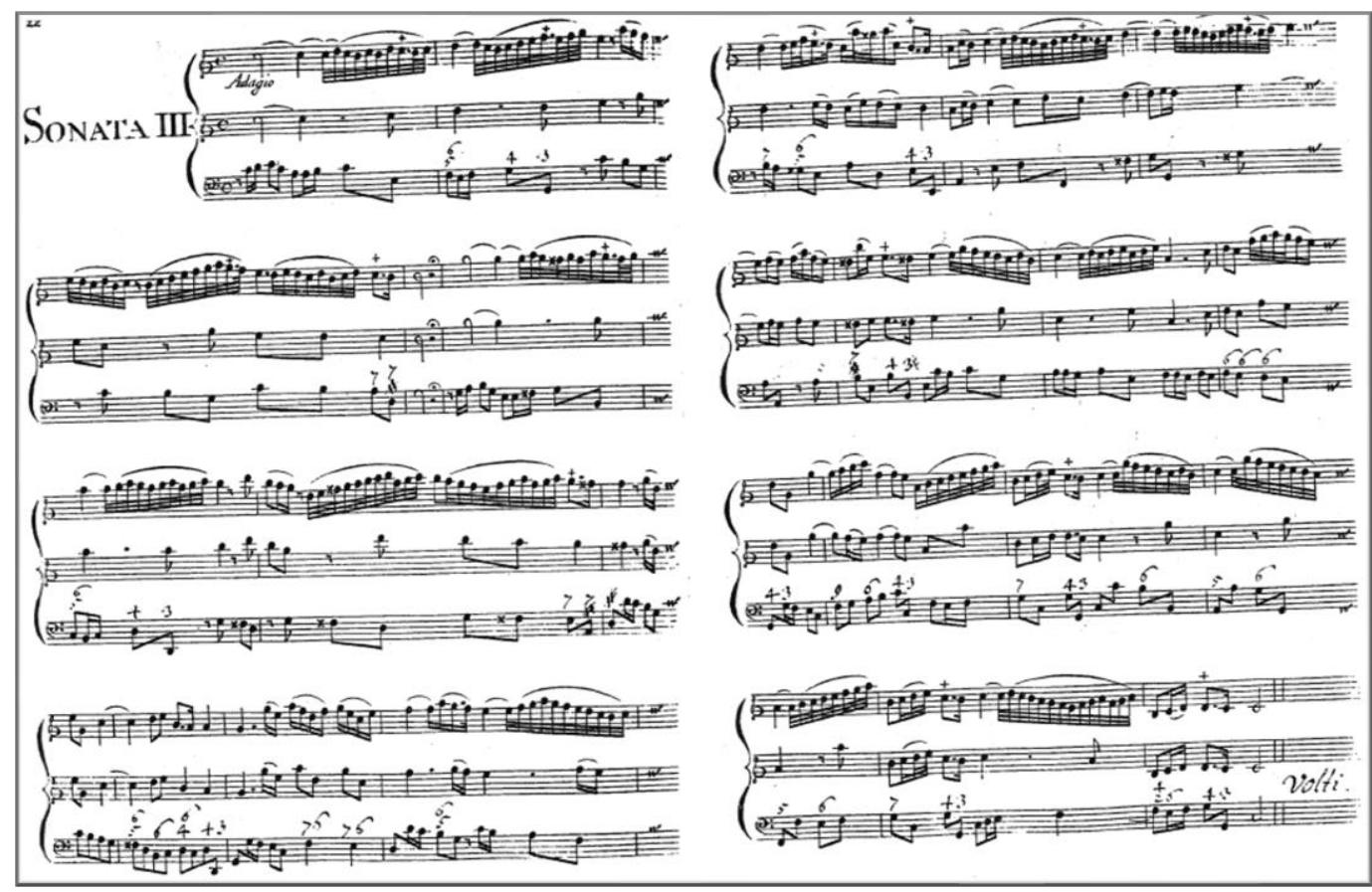

Fonte: Corelli, A Opera quinta, 1700. Estienne Roger, 1711.

Nos dois movimentos de sonata acima, os violinos, na versão esqueleto, seguem linhas melódicas com notas longas que buscam dissonâncias enquanto o baixo faz uma condução rítmica, além disso, os dois são o primeiro movimento da sonata, correspondendo ao exordium de suas respectivas sonatas inteiras, tendo ambos os movimentos, em seus primeiros quatro compassos uma frase terminando em suspensão. Apesar de ao longo do discurso haver desenvolvimentos com harmonias mais intensas, essa primeira fase, que funciona como captatio benevolenciae, dita o afeto delicado do movimento como um todo, uma informação indispensável ao intérprete não só na composição de seus ornamentos, mas também durante a escolha de outros parâmetros interpretativos.

Se observarmos as linhas do primeiro violino da trio-sonata e do violino do adágio do Opus V, perceberemos uma melodia esqueleto muito parecida com um movimento ascendente em grau conjunto, que atinge o ápice no segundo compasso e passa lentamente a retornar em grau conjunto ao longo dos dois próximos, porém com um encaminhamento à sensível. $\mathrm{O}$ segundo violino do trio, entra na metade do primeiro compasso em uníssono e em contraponto de quarta espécie, ajudando a enfatizar as dissonâncias, sendo, dessa forma indesejável aos 
interpretes que sua inventividade os afaste dessas dissonâncias (sobretudo os primeiros tempos do segundo e do terceiro compasso). Talvez esse seja um dos motivos pelos quais alguns interpretes optem por confortavelmente evitar o risco da ornamentação, porém ao analisar a obra, ele se mostra um obstáculo de interpretação facilmente contornável se os interpretes estiverem atentos.

Um impulso natural ao confrontar as duas obras seria o primeiro violinista do trio transpor exatamente os mesmos ornamentos contidos na sonata em dó maior, dessa forma teríamos uma ornamentação com exemplos tirados da pena do próprio Corelli (esses exemplos estão catalogados no capítulo 4.6), porem há de cuidar para não tornar os ornamentos uma “repetição repulsiva" conforme adverte Quantz (1752), limitando seu uso a duas repetições sequenciais. Algo que pode ser comparado ao uso excessivo da mesma palavra, sem o recurso da ornamentação por sinônimos, em um mesmo parágrafo.

Na sonata do Opus $\mathrm{V}$, além de cumprir uma função didática, o uso obsessivo do mesmo ornamento se encontra respaldado pela anáfora ${ }^{86}$ observada na linha do baixo, onde a insistente repetição da combinação de pausa de colcheia precedendo duas semicolcheias e duas colcheias ( suspiratio $^{87}$ ), é frequentemente copiada na voz do violino e também na ornamentação proposta pela edição de 1711. Essa combinação gera o seguinte inciso, que permeia as duas vozes e impulsiona todo o movimento (Figura 41):

Figura 41: Detalhe do inciso do baixo

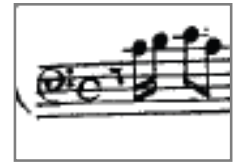

Fonte: Corelli. Opera quinta, 1700. Estienne Roger, 1711.

É interessante observar que os ornamentos que conectam essas notas longas na voz do violino, na versão de 1711, terminam com uma diminuição do mesmo inciso:

Figura 42 :Detalhe dos primeiros ornamentos com o inciso diminuído em destaque

\footnotetext{
${ }^{86}$ Anáfora: Figura de retórica literária que consiste na repetição sistemática de uma mesma palavra no início de cada verso de um poema.

${ }^{87}$ Suspiratio: segundo Bartel (1985) é uma figura de retórica musical com o uso deliberado de pausas, normalmente um inciso escrito de forma acéfala que se relaciona ao ato de suspirar e ao sentimento de saudade.
} 


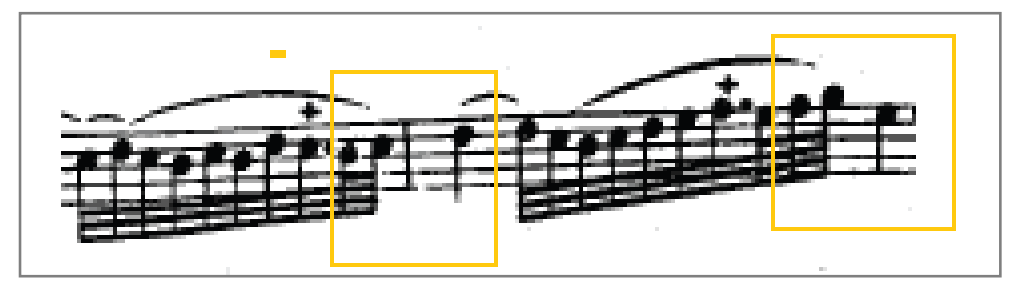

Fonte: Corelli. Opera quinta, 1700. Estienne Roger, 1711.

Pelo fato de o mesmo inciso não ser um elemento estrutural da trio-sonata, há um descompromisso de utilizá-lo na ornamentação. Dessa forma é desejável que o intérprete se inspire no exemplo do Corelli, sem deixar de manter uma ornamentação variada ao longo do movimento.

O segundo violino da trio-sonata ganha um pequeno espaço para uma ornamentação discreta nas resoluções das dissonâncias da quarta espécie nos três primeiros compassos (C2.2 e C3.2), sendo desejável que assuma a liderança da ornamentação nos dois últimos tempos do terceiro compasso. Nessa parte novamente utilizar o Opus V como fonte de ornamentos pode ser um caminho de resultados bem substanciais. Assim temos o seguinte exemplo:

Figura 43: Exemplo de ornamentação proposta para o Opus III

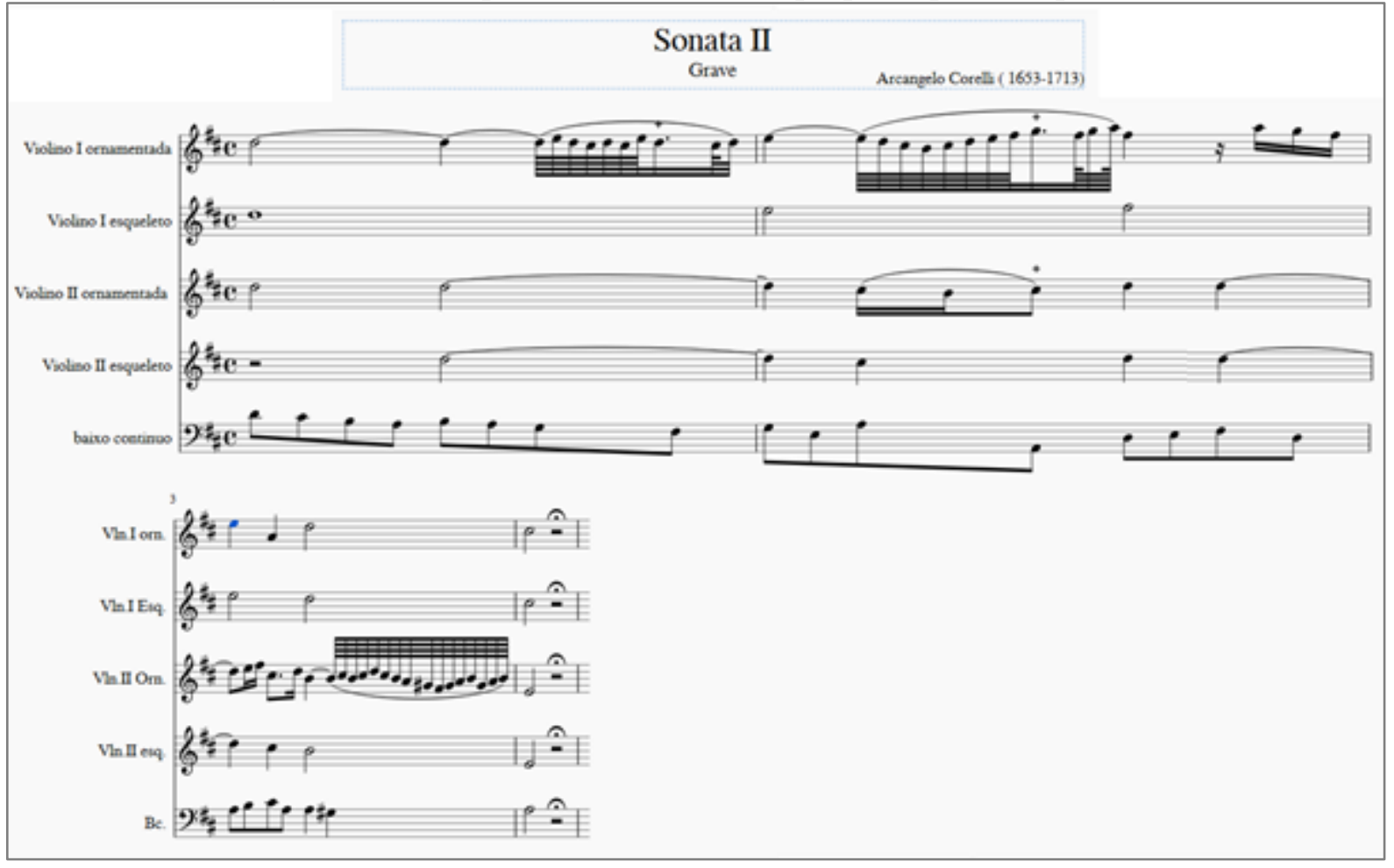

. Fonte: A. Corelli Opus III, 2020. Edição e recorte nosso. 
Após uma pausa no compasso 4, digna de uma fermata ${ }^{88}$, o tema é novamente apresentado na tonalidade de lá maior abrindo a narratio. A frase do exordium termina de ser reexposta no compasso 7, quando, a partir do segundo tempo o baixo continuo reinicia seu movimento em colcheias com caráter cada vez mais modulante. O primeiro violino apresenta um novo tema que é logo imitado pelo segundo. Neste contexto, seguindo a tradição proposta por Colista e os Trietti de Telemann, é desejável que o segundo violino ouça bem o que o primeiro toca para ser capaz de copiar seus ornamentos.

Figura 44: Recorte do compasso 4 ao 9.

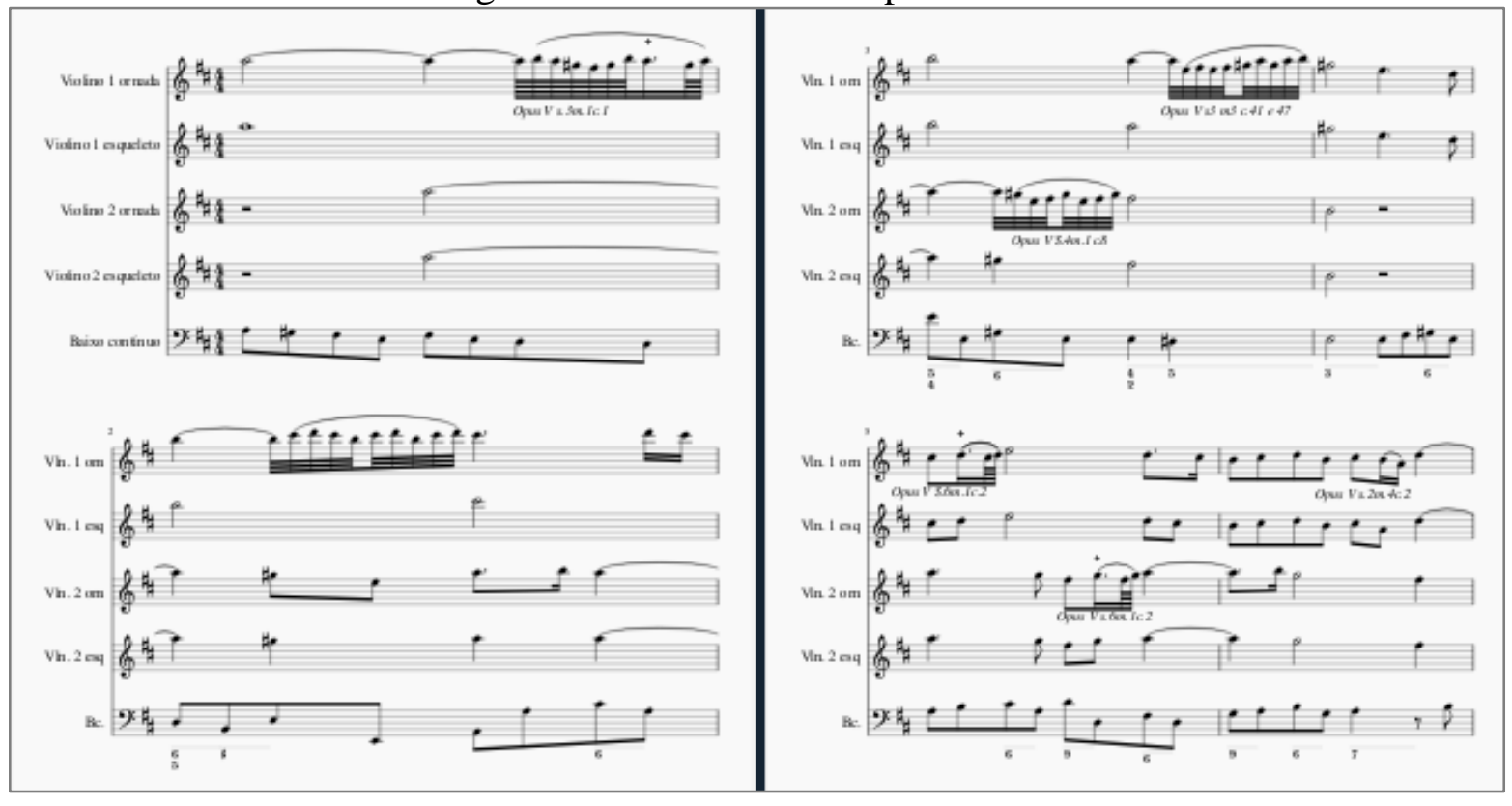

Fonte: A. Corelli Opus III, 2020. Edição e recorte nosso.

No compasso 9, os violinos passam a duelar em quarta espécie, quando respeitando sempre a regra da dissonância e de suas resoluções em saída, o espaço para ornamentação se torna um campo fértil.

\footnotetext{
${ }^{88}$ Não entraremos na discussão sobre caber ou não uma cadencia nessa grande pausa, pois o modelo proposto por Corelli em 1711 não comtemplava explicitamente esta sugestão.
} 
Figura 45: Recorte do compasso 10 ao 12.

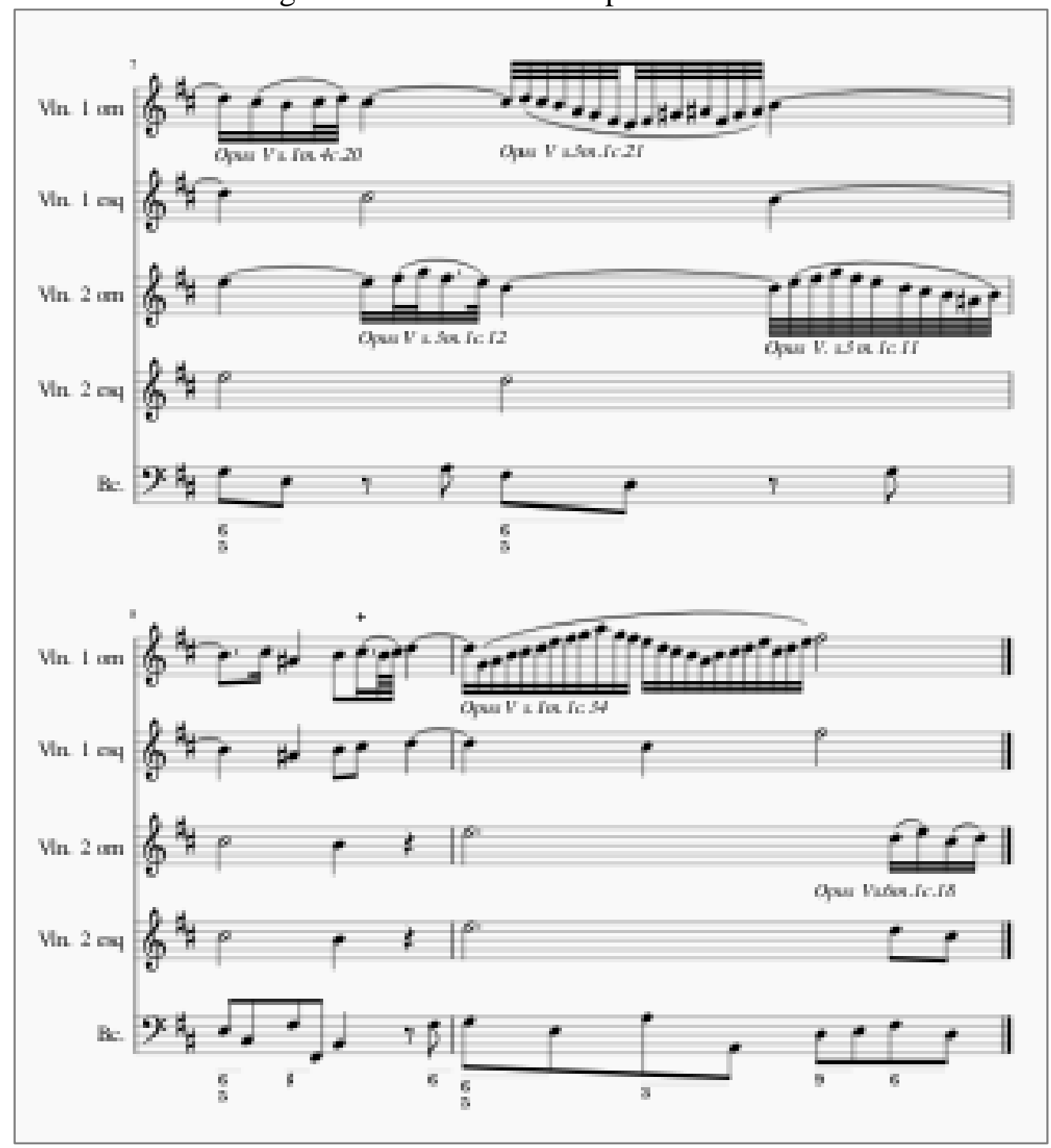

Fonte: A. Corelli Opus III, 2020. Edição e recorte nosso.

No compasso 12 uma nova sessão conflitante se inicia, o confutatio, partindo da tonalidade de si menor(neste contexto distante). As quartas espécies entre as vozes do violino se acentuam e fazem um movimento ascendente que amplifica a tensão harmônica. 
Figura 46: Recorte do compasso 12 ao 14

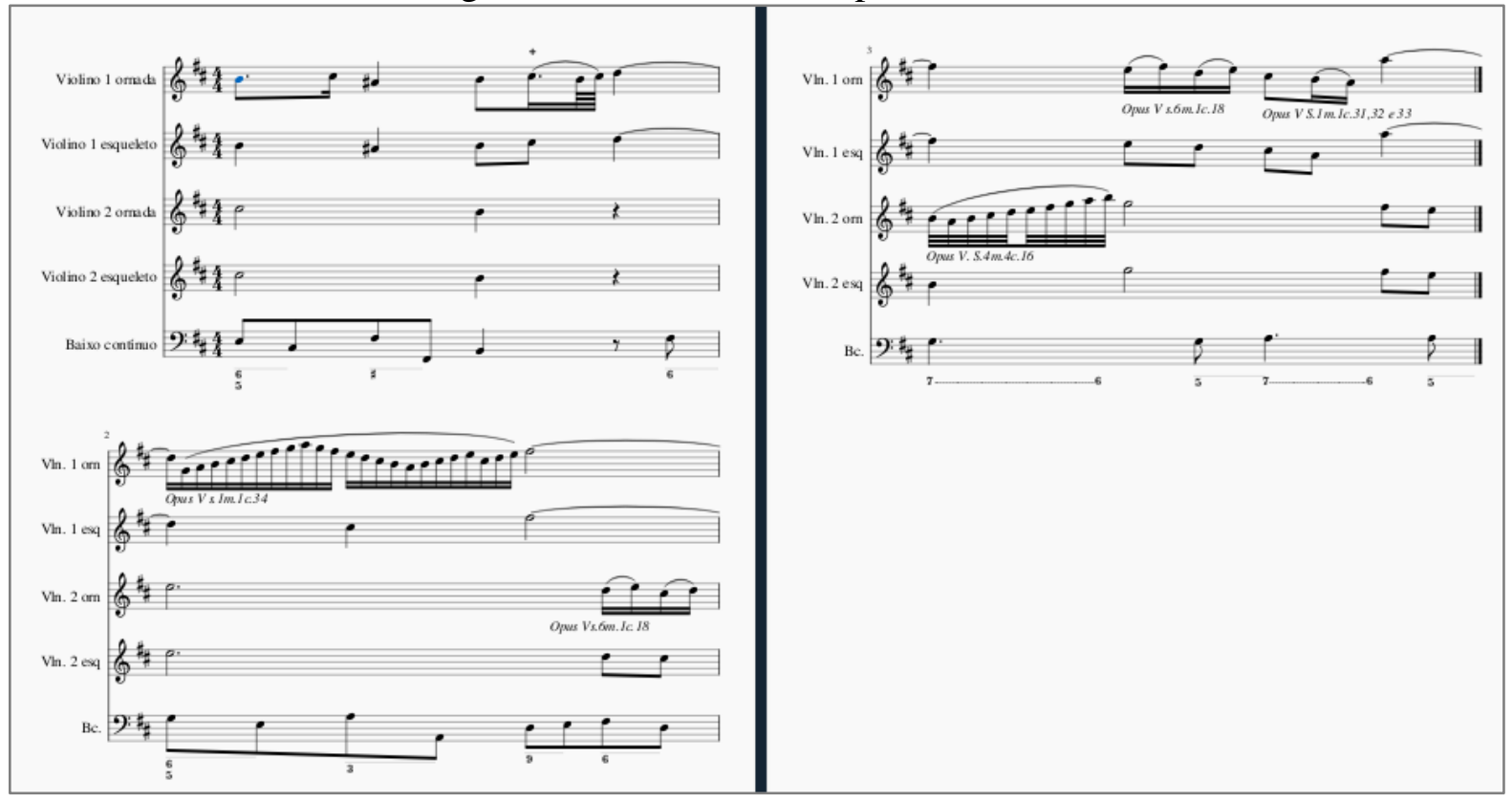

Fonte: A. Corelli Opus III, 2020. Edição e recorte nosso.

A partir do terceiro tempo do compasso 14, a trio-sonata foi composta novamente em ré maior, preparando uma grande cadencia em 16 e 17.

Figura 47: Recorte do Compassos 14 ao 17.

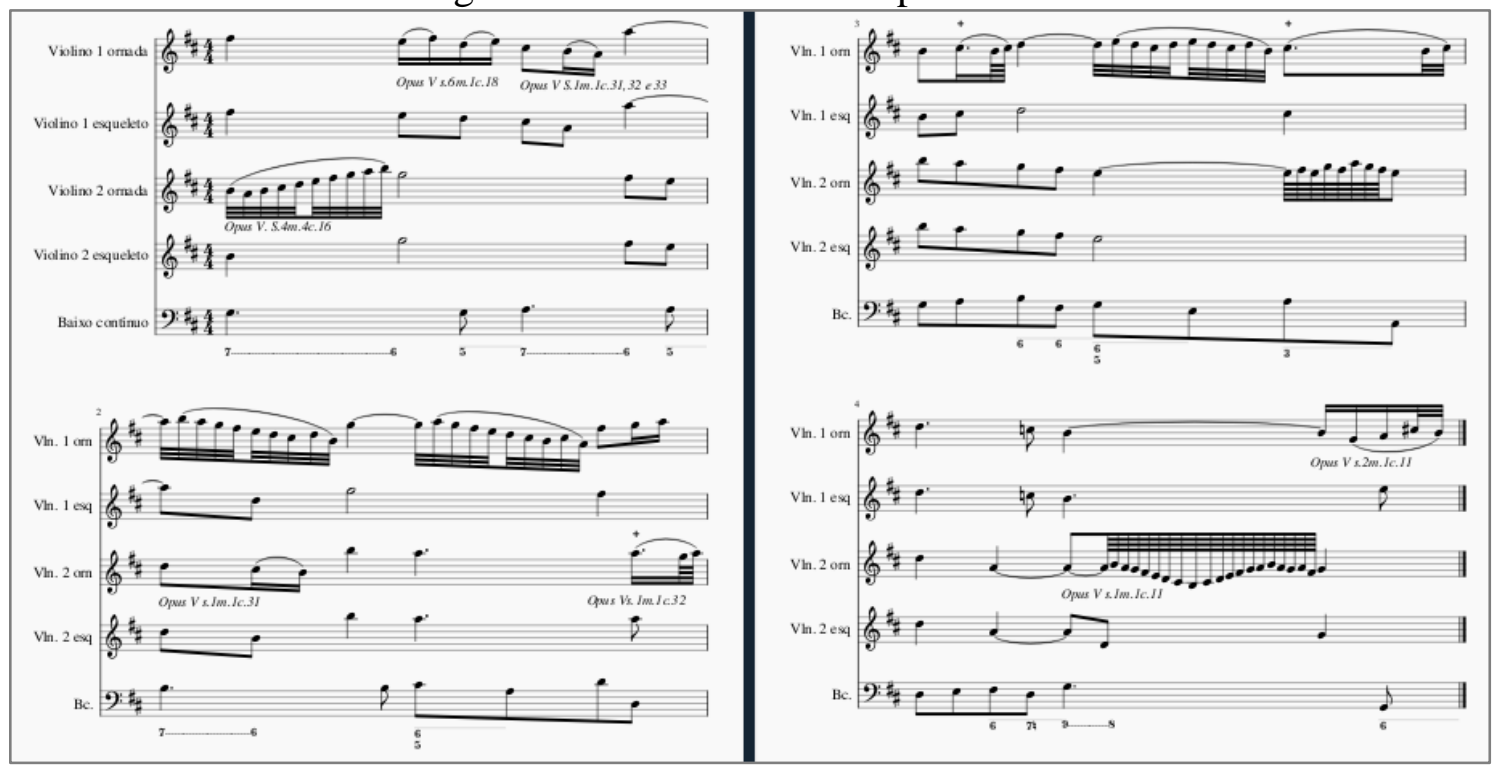

Fonte: A. Corelli Opus III, 2020. Edição e recorte nosso. 
Por fim os três últimos compassos são o epílogo do discurso desse movimento, encerrando o movimento com a confirmatio, exigindo dos interpretes uma elaboração grande de seus ornatos que encerrarão o discurso do movimento, o exordium da sonata como um todo e prepararão o segundo movimento, o Allegro com material fugal que comporá a narratio da obra inteira.

Figura 48: Confirmatio do primeiro movimento

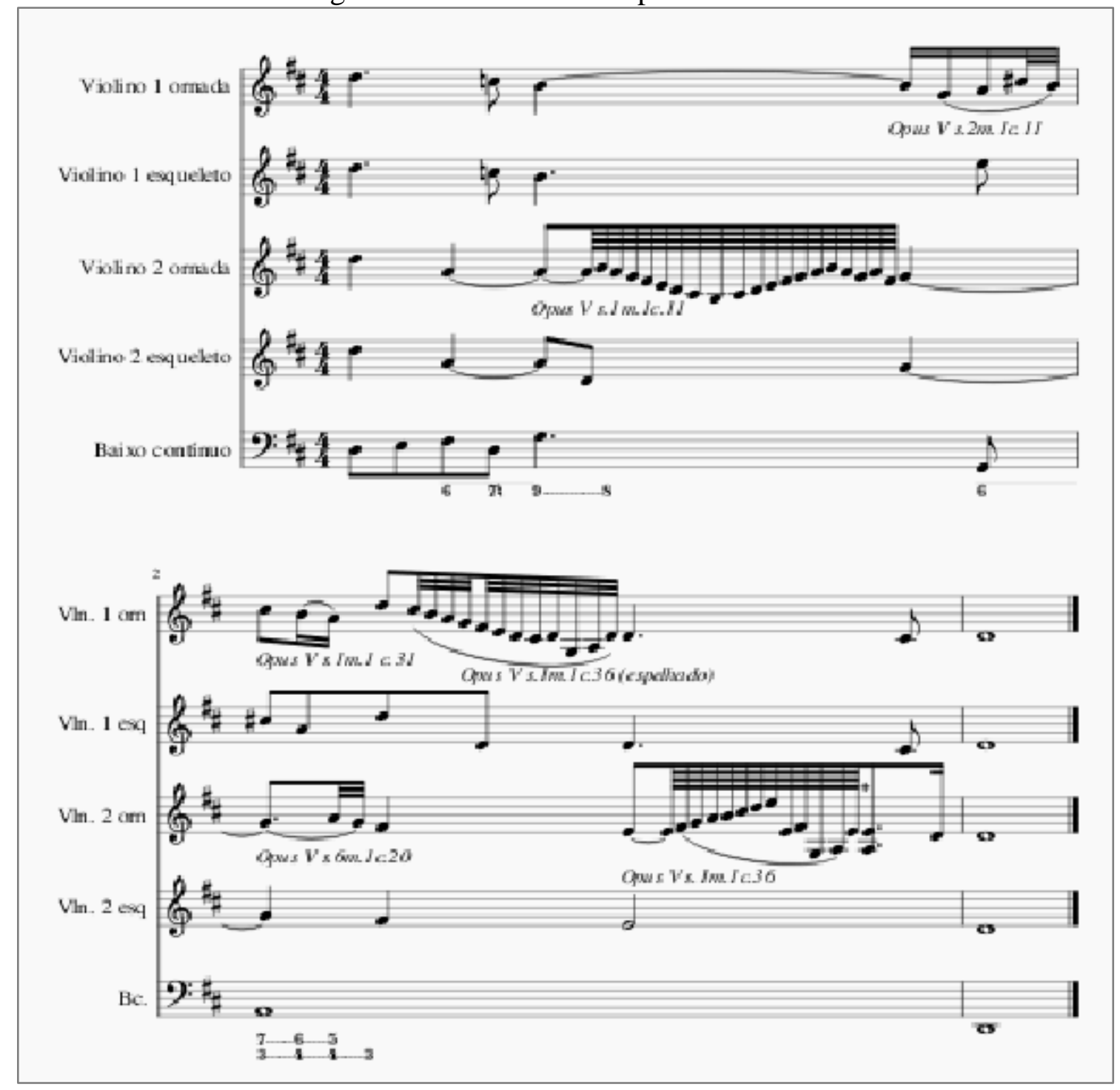

Fonte: A. Corelli Opus III, 2020. Edição e recorte nosso. 
5.1.3 Sonata Op. 3 n. 2 Terceiro movimento Adágio

Figura 49: O adágio do trio-sonata 2 do Opus III de A. Corelli

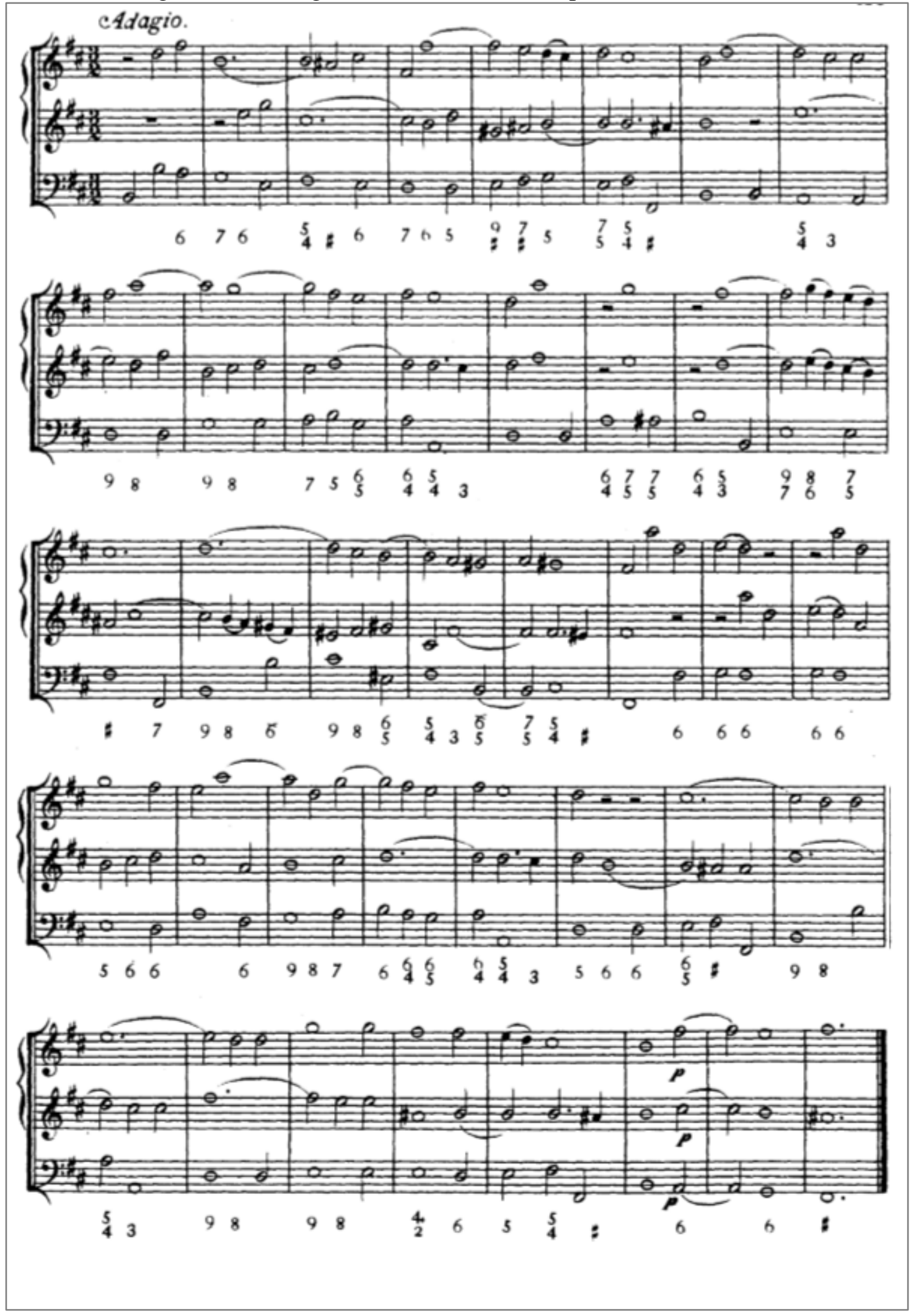

Fonte: Opera terza. Londres: Joseph Joachim e Friedich

Chrysander, 1888 
Esse movimento cumpre a função de confutatio do discurso da sonata da chiesa inteira e contrapondo a fuga que o precede (narratio da sonata) seu estilo e escrita demanda dos interpretes um uso eloquente dos ornamentos. Como inspiração para os ornatos é sugerido a escolha do terceiro movimento da primeira sonata do opus $\mathrm{V}$, pois esse movimento de sonata se encontra no mesmo afeto, mesma formula de compasso (3/2) e mesma tonalidade (si menor) de forma que os ornatos de seu modelo de 1711 podem emprestar boas ideias para se aplicar neste movimento.

O exordium do adágio, que compreende os primeiros sete compassos, está disposto em contraponto imitativo entre os violinos. Um motivo que compreende um intervalo de terça entre duas mínimas postas no segundo e terceiro tempo de cada compasso é repetida alternadamente entre os dois violinos em quatro versões (figura 50). Na figura $24 \mathrm{M}$ vemos o movimento da sonata do opus $\mathrm{V}$ comentada com destaques para intervalos de terça ornados que podem ser utilizados no exordium do adágio. É sugerido aos interpretes um equilíbrio entre dois preceitos de Quantz: buscar a variedade não repetindo o mesmo ornato mais do que 3 vezes seguidas, o que justifica a escolha por outro ornato no segundo compasso pelo segundo violino, e o uso da imitação como recurso (primeiro violino compasso 3 imitando o compasso 2 e segundo violino no compasso 4 retornando ao primeiro ornato proposto pelo primeiro no início). Já na cadencia que encerra o exordium cabe um ornato na primeira voz, que tem mais liberdade em sua condução. 
Figura 50: Exordium do adágio

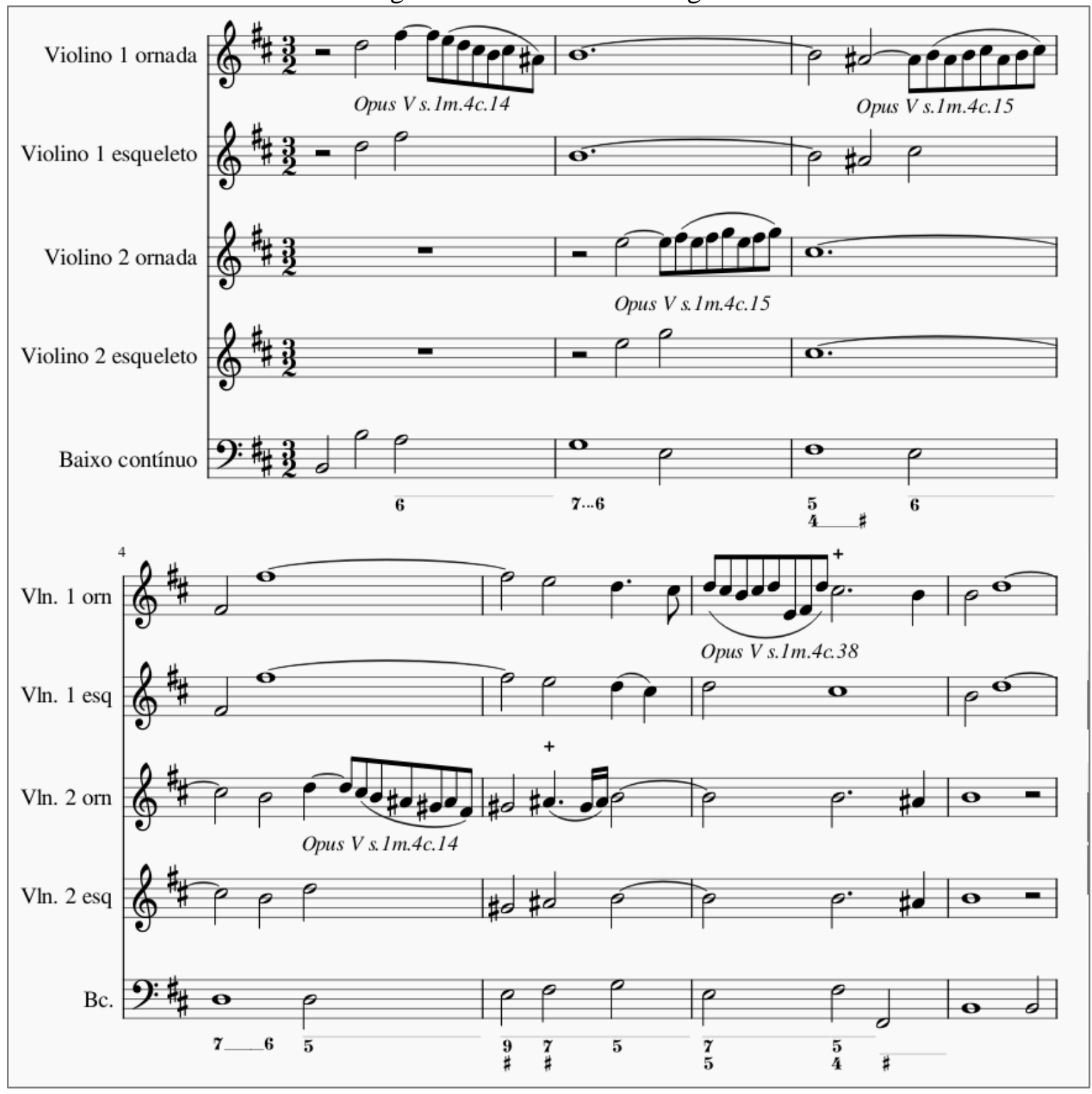

Fonte: A. Corelli Opus III, 2020. Edição e recorte nosso. 
Figura 51: Trecho do quarto movimento da sonata opus $\mathrm{V} \mathrm{n}{ }^{\circ} 1$ com destaque para os intervalos de terça e seus ornatos.

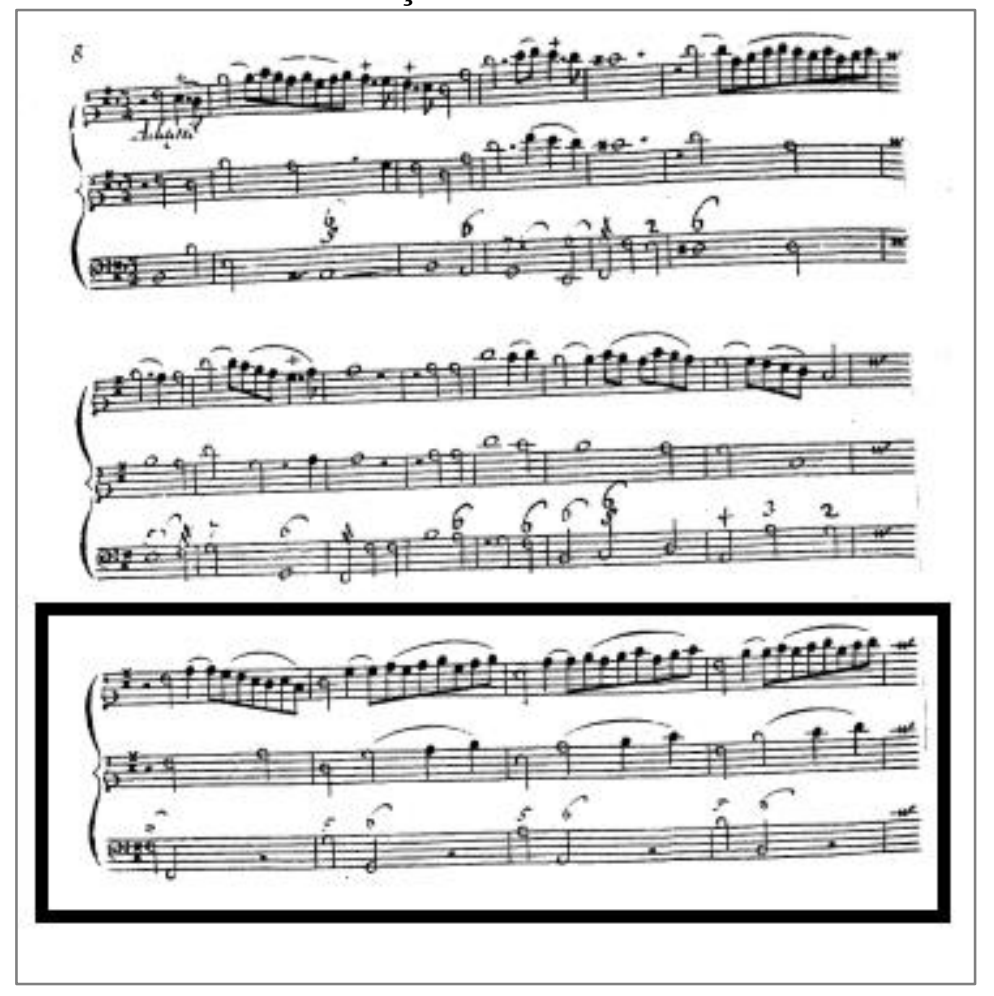

Fonte: Corelli opus V, 1711,edição por Estienne Roger

A partir desta cadência o movimento entra em sua narratio evoncando uma textura que adense suas suspensões (quarta espécie) até a cadência do compasso 13. Respeitando as dissonâncias e suas resoluções uma ornamentação rebuscada pode ser obtida e distribuída entre as vozes a exemplo da figura 52. 
Figura 52: Recorte do compasso 7 ao 12

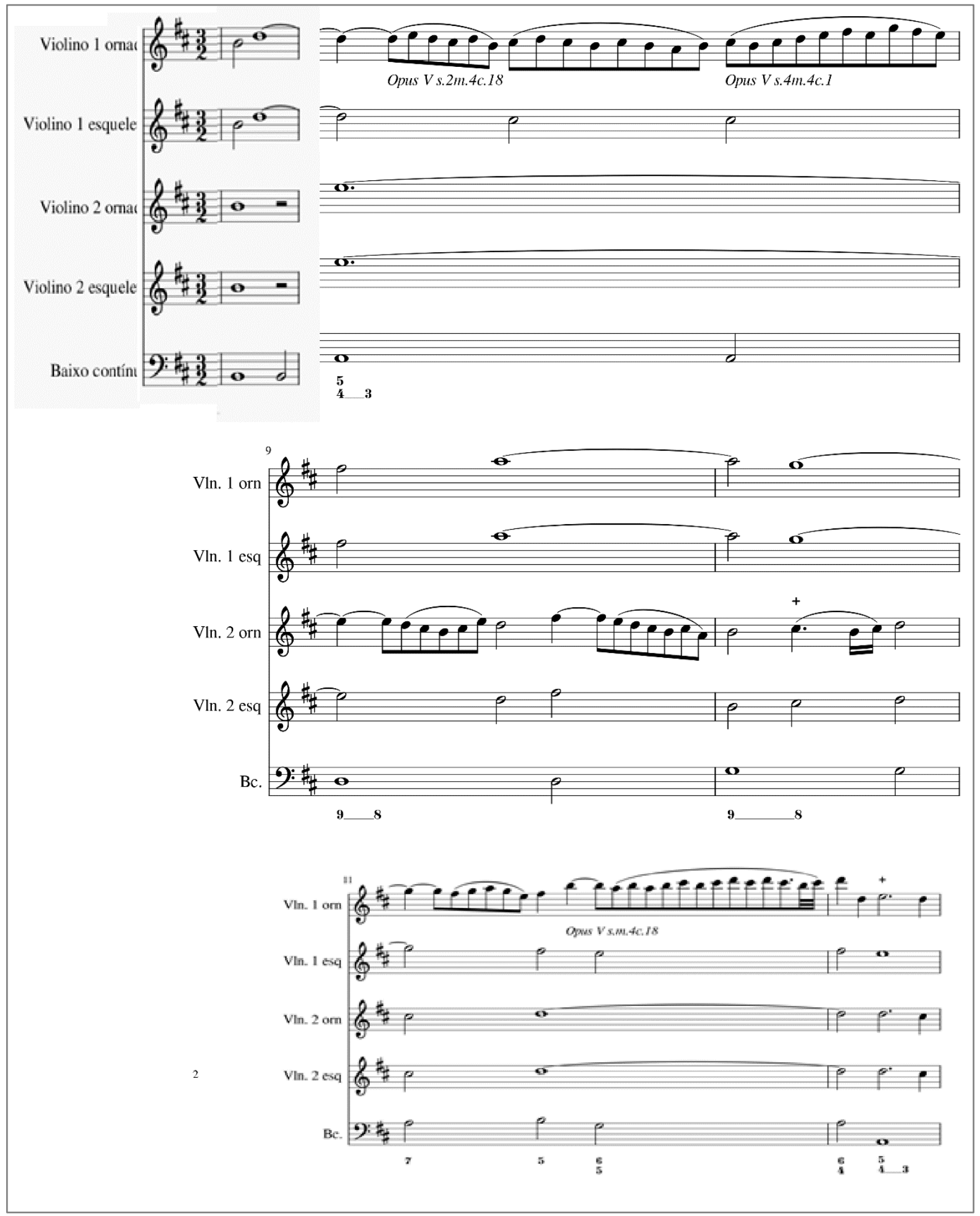

Fonte: A. Corelli Opus III, 2020. Edição e recorte nosso.

A cadência perfeita em ré maior, no compasso 13, inicia um novo argumento musical, com uma figura de retórica musical bastante recorrente, a suspiratio. Esses suspiros são ordenados pela primeira vez em homofonia entre os violinos. Apesar da tonalidade dessa frase 
se iniciar em ré maior (tonalidade antagônica ao si menor do movimento neste contexto), dois aspectos precisam ser levados em consideração: O primeiro é que a narratio da sonata se encontra na fuga do segundo movimento com um tema em grau conjunto parecido com o do Grave da peça (exordium) e este trecho possui ainda desenho antagônico a esse, tendo na suspiratio retórica e na textura com uma polirritmia mais simples uma ênfase do mesmo afeto do movimento (que como um todo é uma contestação da sonata); o segundo é seu caráter modulante que apesar de ensaiar uma contestação do terceiro movimento, novamente apela para as suspensões (quarta espécie) recorrente no movimento no trecho do compasso 17 até a cadencia do compasso 19.

Figura 53: Tema do segundo movimento

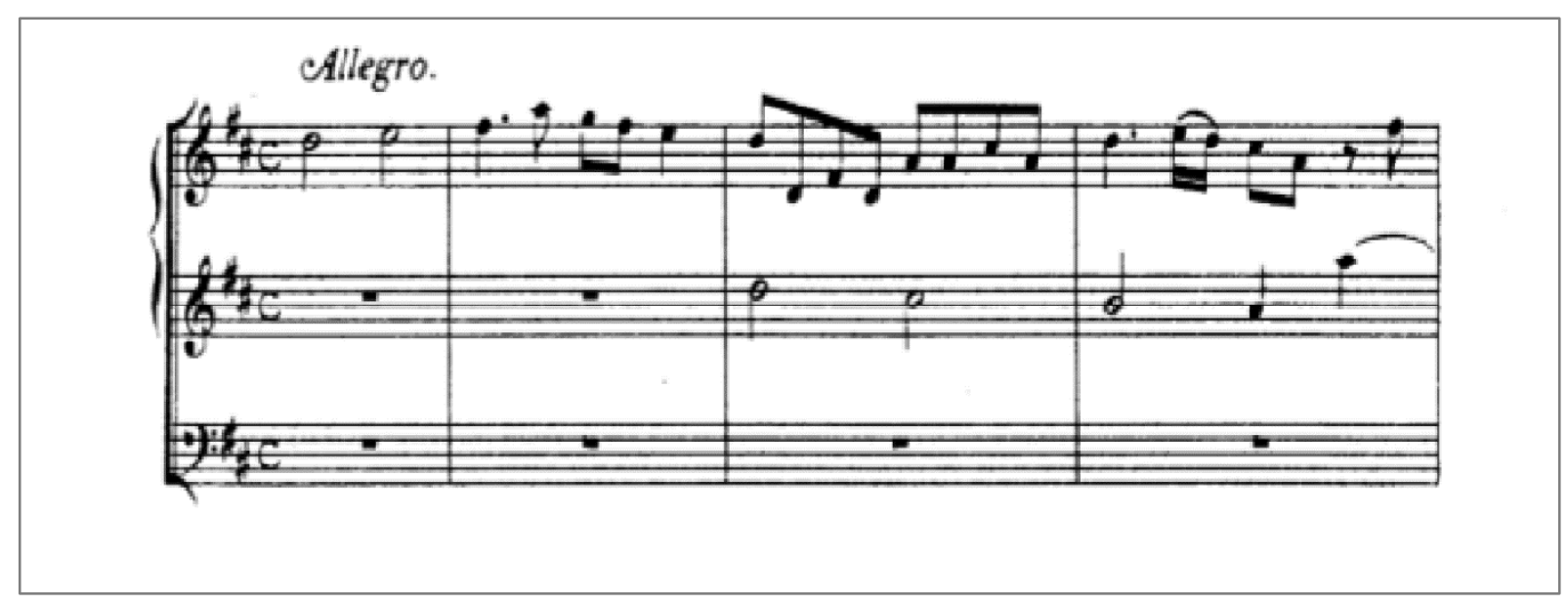

Fonte: Opera terza. Londres: Joseph Joachim e Friedich Chrysander, 1888

Do ponto de vista da ornamentação, é facultativo, nos trechos homofônicos, a intérpretes que toquem bastante juntos o uso de pequeno ornatos em terça ( a exemplo dos trietti de Telemann) desde que o caráter suspirado da figura escrita na versão esqueleto continue presente (e a escolha dos ornatos sejam condizente com o estilo Corelliano), conforme foi optado na elaboração do modelo proposto no próximo capítulo desta dissertação. 
Figura 54: Recorte do compasso 13 ao 22.

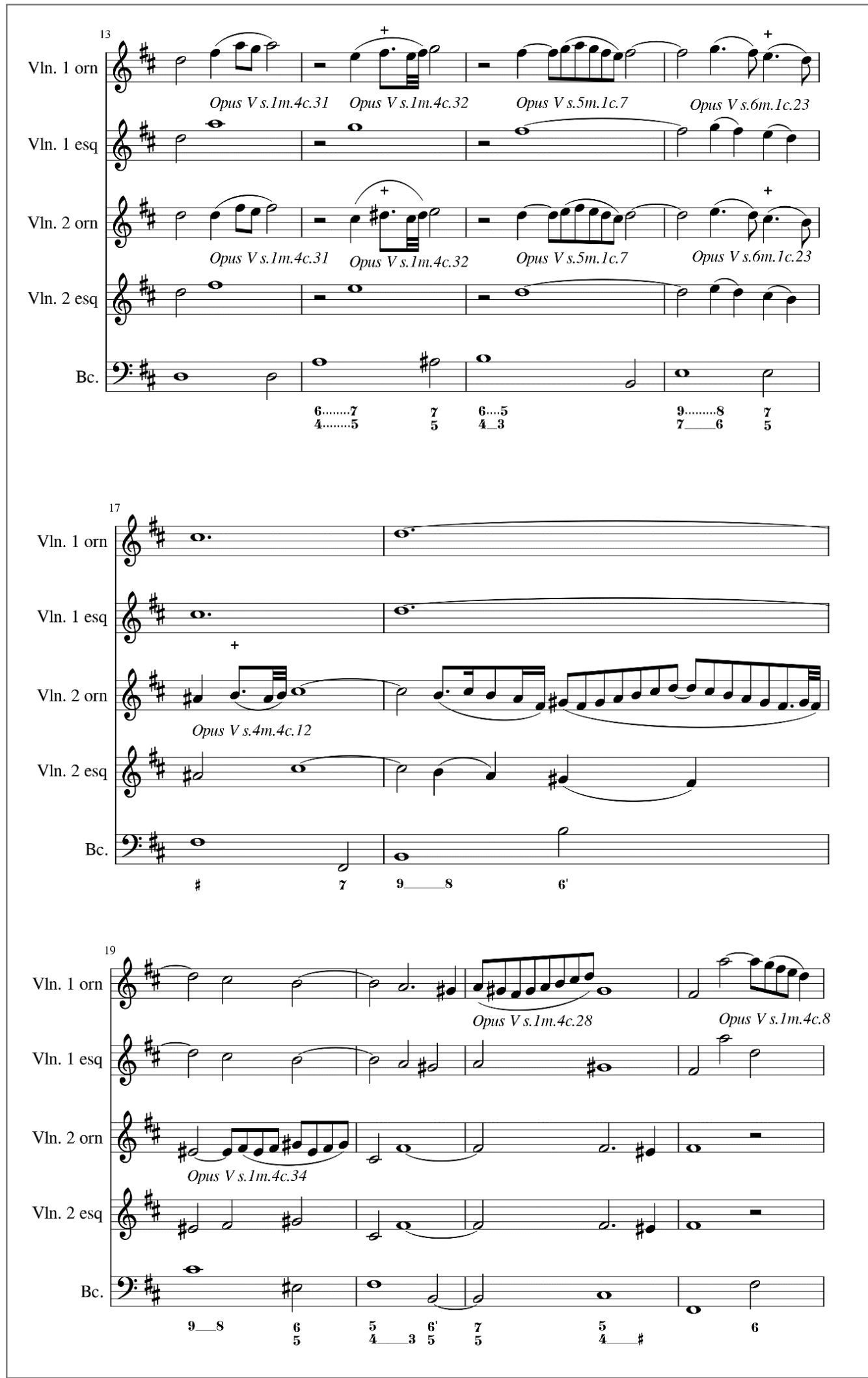

Fonte: A. Corelli Opus III, 2020. Edição e recorte nosso. 
Do compasso 22 até o 30 têm-se a contestação do movimento, confutatio, com um retorno à tonalidade de ré maior e o uso de uma figura imitativa que relembre o movimento anterior. Do ponto de vista da ornamentação cabe ao um segundo violinista judicioso seguir a preceptiva e buscar imitar o que foi tocado pelo primeiro violino que por sua vez deve conduzir aos demais sua ornamentação. O modelo proposto, utilizando-se de ornatos da literatura Corelliana, se mostram ousados, mas um bom caminho a se seguir nesta sessão.

Figura 55: Confutatio do movimento

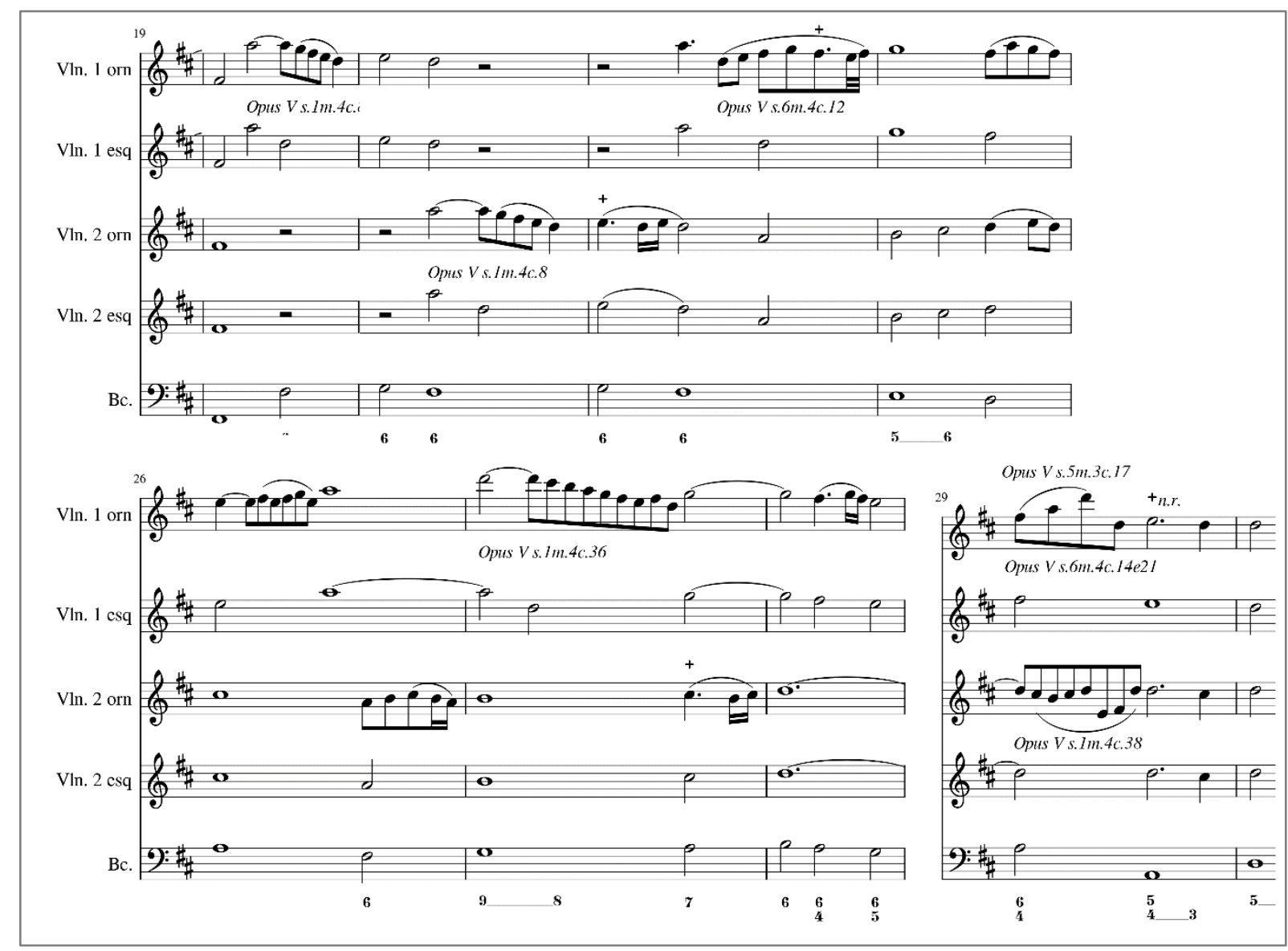

Fonte: A. Corelli Opus III, 2020. Edição e recorte nosso.

Por fim no compasso 30 foi composta a confirmatio deste movimento, com um retorno claro da tonalidade de Si menor e de suas dissonâncias tortuosas em quarta espécie. O tom de confronto entre os violinos nesta suspensão exige uma ousadia que desafie e mantenha vivo esse caráter, confronto este que pode ser muito beneficiado pelo incremento de fiorituras colocadas logo após cada resolução que busquem o apoio da próxima dissonância. 
Figura 56: Confirmatio do movimento

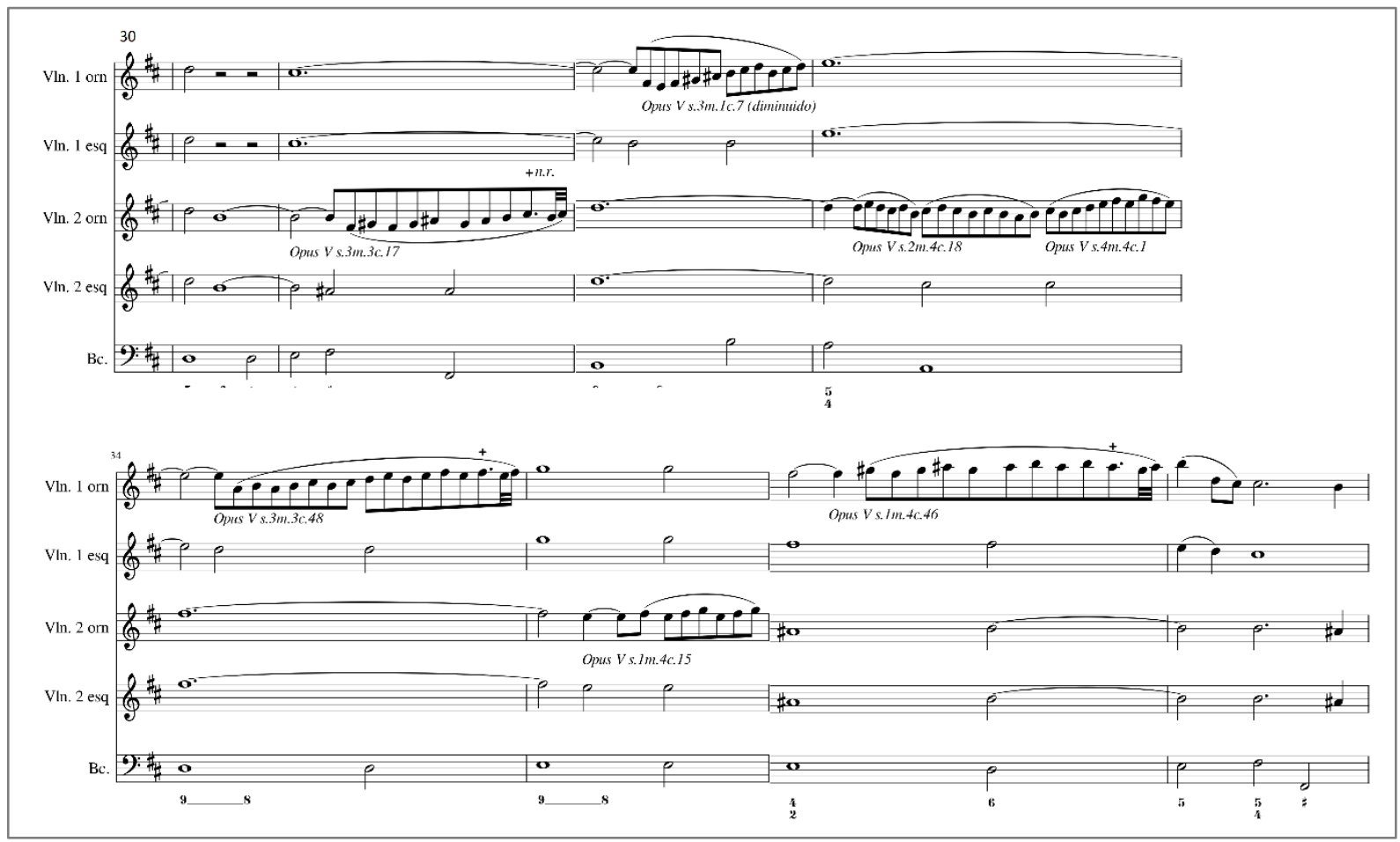

Fonte: A. Corelli Opus III, 2020. Edição e recorte nosso.

O movimento acaba com a cadência do compasso 38 (que preferencialmente deve ser realizada pelo primeiro violino e de forma exuberante). A partir desta cadência, no lugar da peroração se inicia uma cadência frígia que tem a função de preparar o retorno ao argumento principal da sonata no quarto movimento e deve ser realizada com bons ornatos alternados entre as vozes, conforme os modelos do trietti e o opus V e a preceptiva de Quantz e CPE Bach sugerem. 
Figura 57: cadencia frígia do final do adágio.

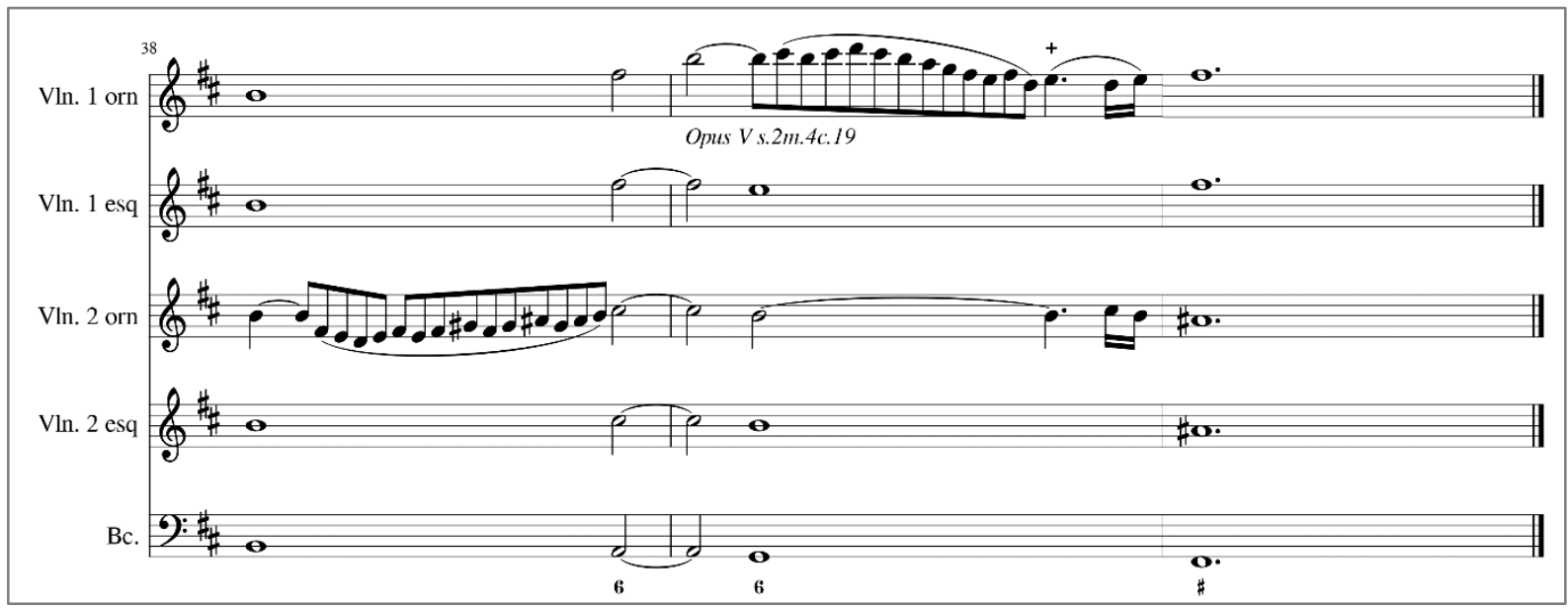

Fonte: A. Corelli Opus III, 2020. Edição e recorte nosso. 
5.1.4 Sonata Op. 3 n. 3 primeiro movimento

Figura 58: A sonata Opus III $\mathrm{n}^{\circ} 3$ primeiro movimento

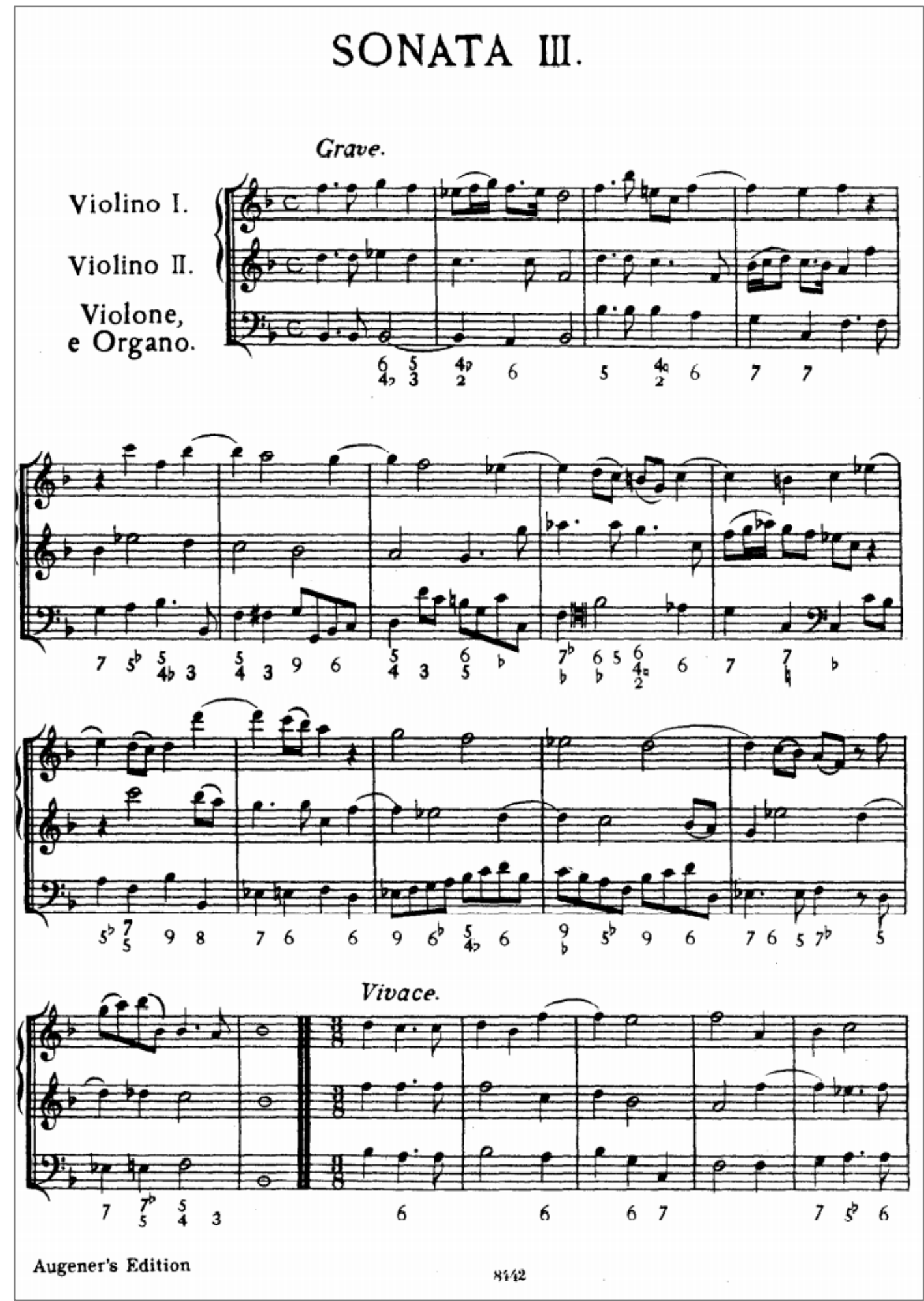

Fonte: Opera terza. Londres: Joseph Joachim e Friedich Chrysander, 1888 
Essa trio-sonata embora inserida no Opus III, foge ao padrão de uma sonata da chiesa típica, se aproximando mais ao modelo de sonata da camara. A sonata é aberta com um grave solene e no lugar da típica fuga foi escrito um vivace dançante em 3 por 8 no seu segundo movimento. Essa combinação remete a uma abertura, de forma que os dois primeiro movimentos cumprem o papel de exordium da trio-sonata, o largo no terceiro movimento escrito em contraponto imitativo e na tonalidade principal passa a ser o argumento principal do discurso sendo a narratio, por fim a confirmatio da obra fica a cargo de uma dançante fuga em 6 por 4 .

O Grave dessa sonata é um movimento curto e cumpre o papel solene de abrir a atenção do ouvinte para a sonata (captatio benevolenceae). E dentro do movimento seu exordium fica a cargo da curta frase de dois compassos figura 59.

Figura 59: Exordium do movimento (c.1 ec.2) e início da narratio

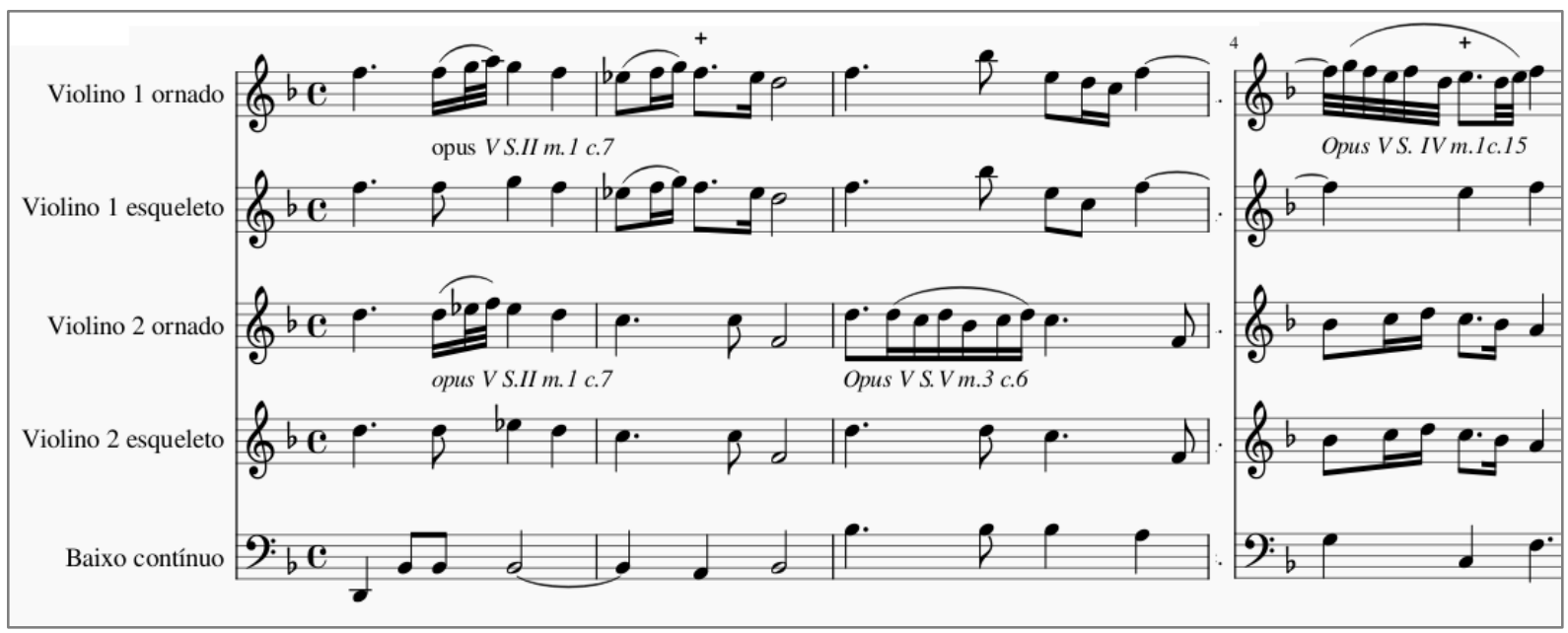

Fonte: A. Corelli Opus III, 2020. Edição e recorte nosso.

Do ponto de vista da ornamentação a versão esqueleto já possui um elegante ornato no segundo compasso do primeiro violino de forma a não exigir muito dos interpretes. Entretanto um pequeno ornato em terça (ou somente do primeiro violino) é possível de ser realizado no primeiro compasso conforme o modelo acima.

A narratio do movimento se inicia com uma pequena cadência à dominante nos compassos 3 e 4 e permitem aos interpretes mais ousados o risco de alguns ornamentos. Entretanto sua densa movimentação pede bastante cautela. No compasso quatro, há um exemplo da importância da consulta à fontes como manuscritos e fac-simile na voz do segundo violino. 
A escolha pela edição de Joseph Joachim e Friedich Chrysander, 1888 para os exemplos desta dissertação ocorreu pela facilidade da edição ser em urtext e principalmente está disposta em grade (a publicação de 1689 por Corelli, somente comtemplava as partes individuais e fora prensada com uma tipografia antiga), porém no exemplo em destaque da figura 60 verificamos um pequeno erro de notação dos editores em 1888 que empresta ao interprete ( também do ponto de vista da ornamentação) uma dificuldade facilmente resolvida ao consultar of fac-simile de 1689. Resolvida a questão do pequeno ornato notado na versão esqueleto por corelli é possível se propor uma ornamentação substancial na cadência em F maior, com os ornatos distribuídos entre as vozes conforme o modelo proposto na figura 59.

Figura 60: Trecho em destaque comparando duas edições do opus III.

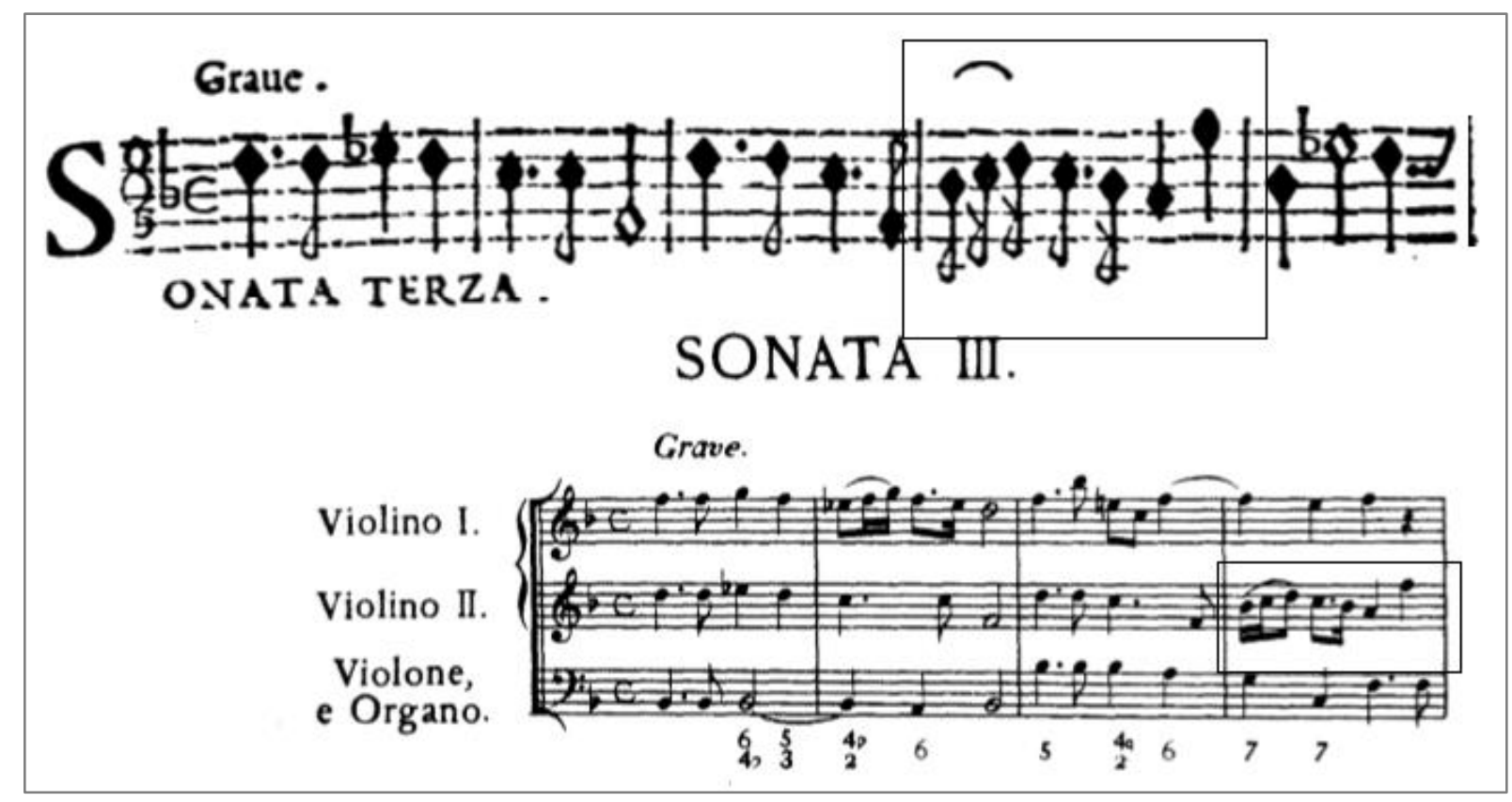

Fonte: Opera terza. Roma: Gio Giacomo Komarek, 1689 e Londres: Joseph Joachim e Friedich Chrysander, 1888

$\mathrm{Na}$ anacruse do compasso cinco o segundo violino inicia uma nova sessão em quarta espécie, com um intervalo de quinta que será imitado pela primeira voz no compasso seguinte. Neste trecho compete ao primeiro violinista ouvir atentamente o colega durante a anacruse e emular os ornatos na sua vez, caso eles ocorram, assumindo o comando das suspensões no compasso seis. 
Figura 61: Recorte do compasso 4 ao 11.

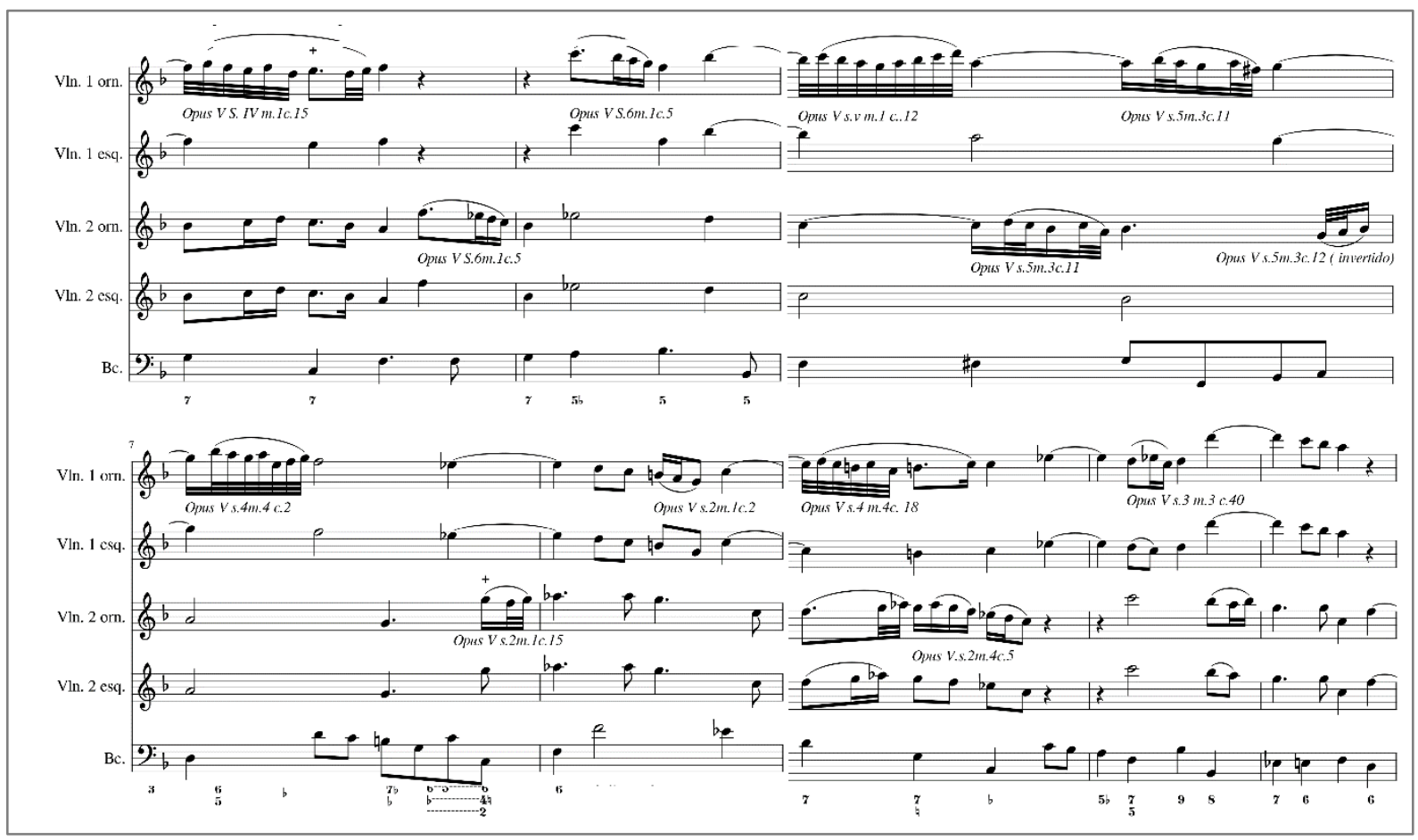

Fonte: A. Corelli Opus III, 2020. Edição e recorte nosso.

Se o primeiro violinista optar por ornamentar suas suspensões a partir do sexto compasso, deverá ter em mente a necessidade de se cumprir os ornatos até a cadencia em dó menor no compasso nove. Ao segundo violino, caso seu colega opte por ornamentar, cabe uma ornamentação sempre mais discreta que evite o confronto, visto que a textura e o ritmo harmônico deste trecho é bastante carregado e há o risco grande de se criar o que Quantz denomina "dissonâncias indesejadas" ou se incorrer na supra citada perierghía.

Entretanto após a cadência do compasso nove está escrito para o segundo violino um acabamento em terça, que na literatura ornamental Corelliana tem vários exemplos ornados, sendo desejável um pequeno enfeite de acabamento que deve ser complementado pelo contínuo nos dois últimos tempo do compasso.

Essa nova sessão com uma harmonia bastante tortuosa faz parte de uma contestação ( confutatio) do movimento que se inicia na anacruse do compasso cinco e vai até o segundo tempo do compasso 11. A partir deste momento o grave da sonata retorna ao seu argumento principal, confirmatio, tendo finalmente sua peroração na cadencia perfeita dos dois compassos finais. 
Do ponto de vista da ornamentação é preciso ter cautela no stretto temático entre os violinos nos compassos 11 e 12 de forma que a mesma não atrapalhe a cativa entrada do segundo violino em um registro agudo em uma dissonância não preparada e ainda agravada pela cifra do continuo que comtempla uma sétima não escrita entre as vozes. Se o primeiro violinista optar por um pequeno ornato a exemplo do modelo proposto figura 62, é desejável que o segundo emule o mesmo de forma a conservar o caráter imitativo proposto pela versão esqueleto.

Figura 62: Trecho do compasso 11 até o final

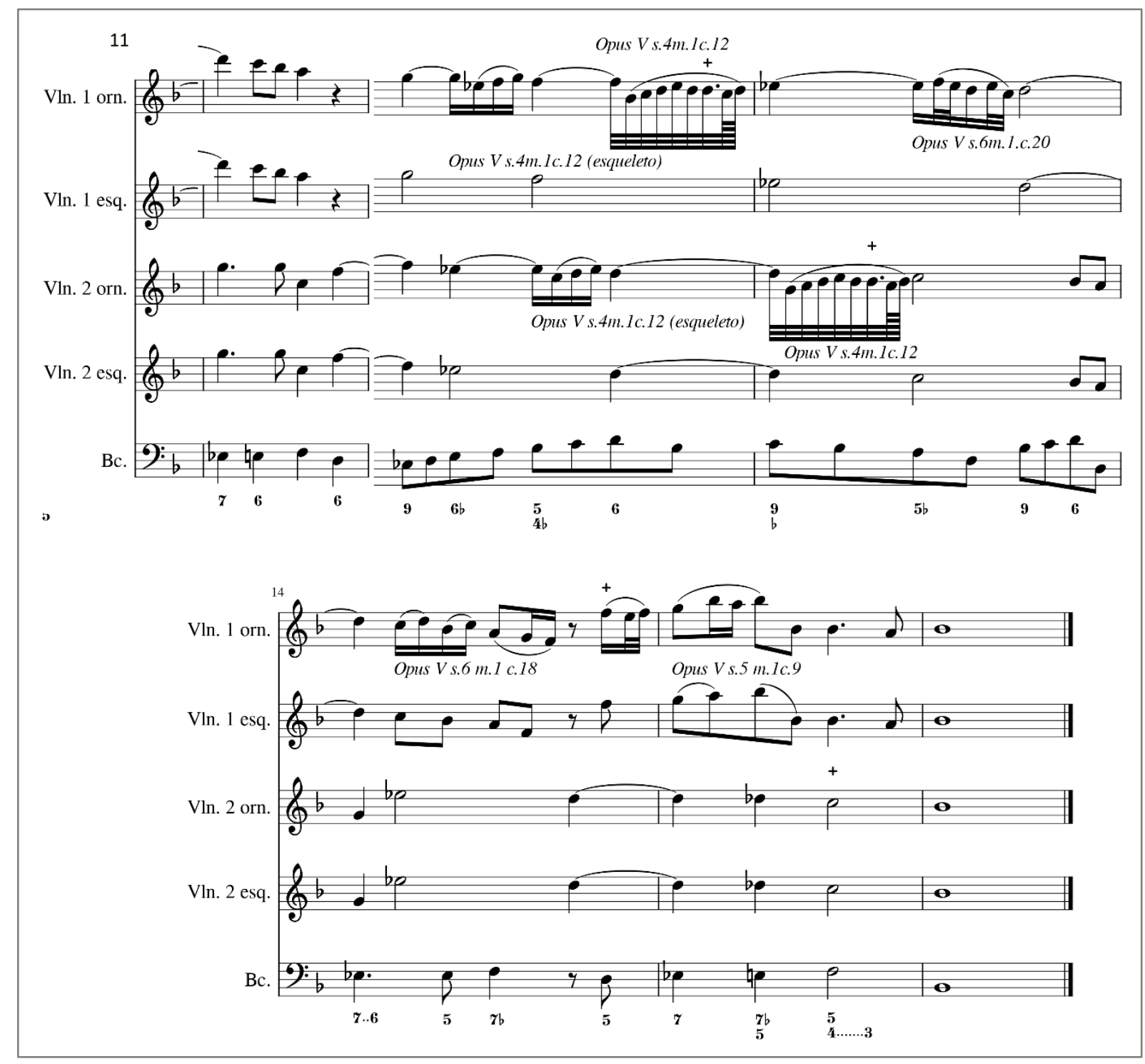

Fonte: A. Corelli Opus III, 2020. Edição e recorte nosso.

No início do compasso 13 até o compasso 15, o baixo inicia uma marcha em colcheias até a dominante da peça em fá, os violinos novamente em quarta espécie podem se atrever a um confronto de ornamentação moderado que não descaracterize o caráter solene do grave. No 
compasso 15 a terminação da frase fica a cargo do primeiro violinista a exemplo do compasso 9.

Por fim a exuberância da cadência do peroratio do movimento fica por conta da maestria do compositor, que a ornou com alguns cromatismos, ou prolongamento da dissonância, de forma que aos interpretes cabe apenas ornamentos simples, evitando passagi que descaracterize a obra e em linguagem geminianesca significa "perder a força da expressão."

\subsubsection{Sonata Op. 3 n $^{0} 3$ terceiro movimento}

O presente movimento, ao contrário dos outros movimentos lentos encontrado no meio das sonatas, não se trata de um confutatio e sim do cerne da sonata como um todo, a narratio.

Sua textura contrapontística e imitativa, abre pouco espaço para a ornamentação livre, porém emulando os modelos do opus $\mathrm{V}$ e dos trietti, é possível achar um caminho para uma boa expressão. Neste movimento é importante considerar as advertências das preceptiva de Quantz e Geminiani em primeiro lugar. Por ser um movimento também bastante expressivo, o preço do risco só compensará se os ornatos contribuírem para este caminho. Dessa forma, de maneira alguma se trata de um movimento para interpretes incautos exibirem "notas ou dedos." 
Figura 63: Largo da trio-sonata Opus III n³

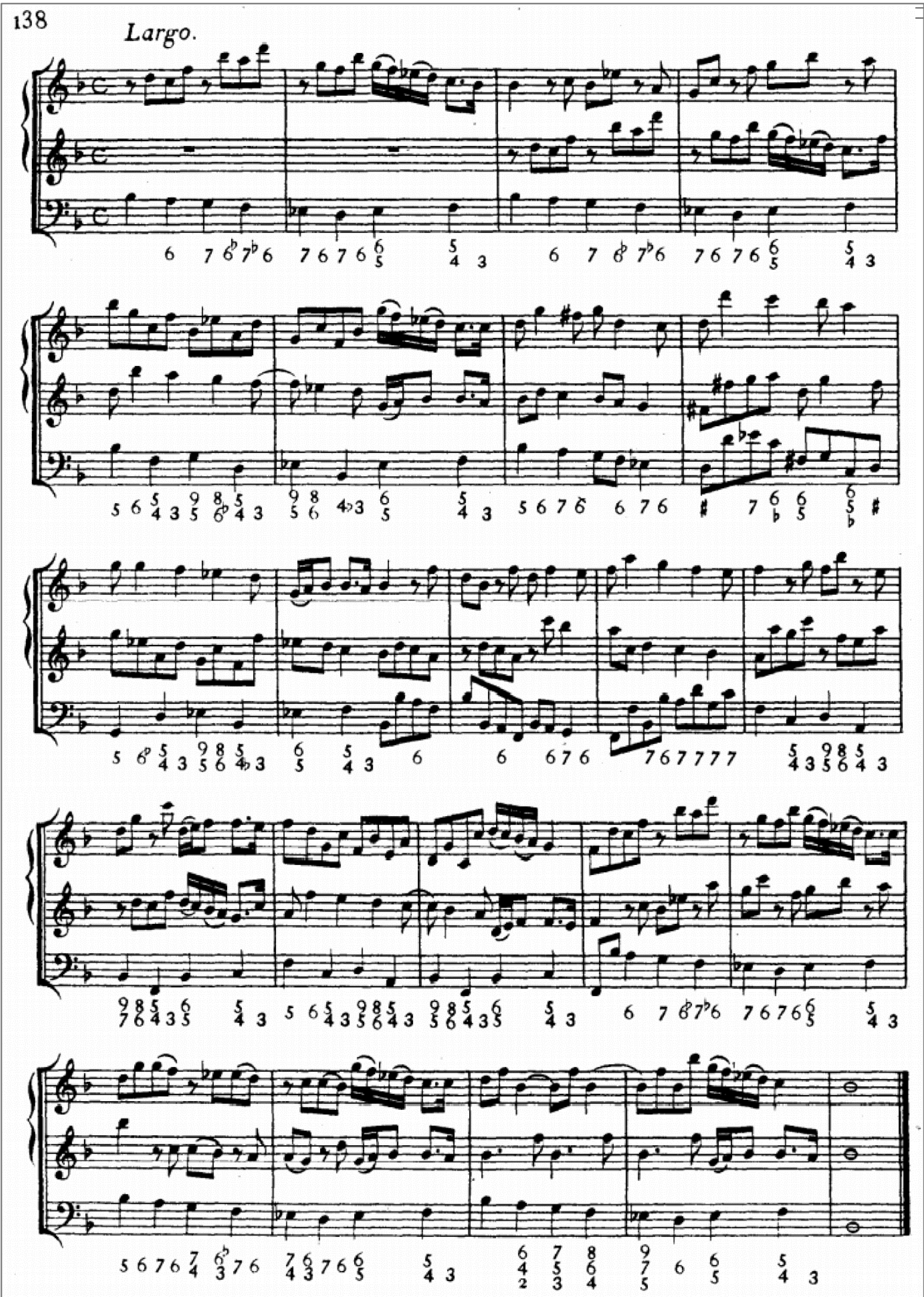

Fonte: Opera terza. Londres: Joseph Joachim e Friedich Chrysander, 1888 
Os primeiros quatro compassos representam o exordium do Largo, com o tema apresentado pelo primeiro violino nos dois primeiros compassos e imitado pelo segundo nos dois próximos. O principal inciso de toda obra, acéfalo, se trata de um suspiratio e qualquer ornato improvisado pelo interprete deve priorizar esse aspecto em primeiro lugar. Baseado nos modelos do próprio Opus V de Corelli foi proposto uma ornamentação para o tema que contribua para a variatio do tema (de forma a ajudar a não repetir mais de três vezes seguidas o mesmo inciso conforme adverte Quantz). Outro recurso utilizado foi a aumentação (aumento da duração de uma nota) no final do contracanto do primeiro violino de forma a acentuar a expressividade da cadência perfeita.

Figura 64: Exordium do largo da terceira sonata do opus III de Corelli

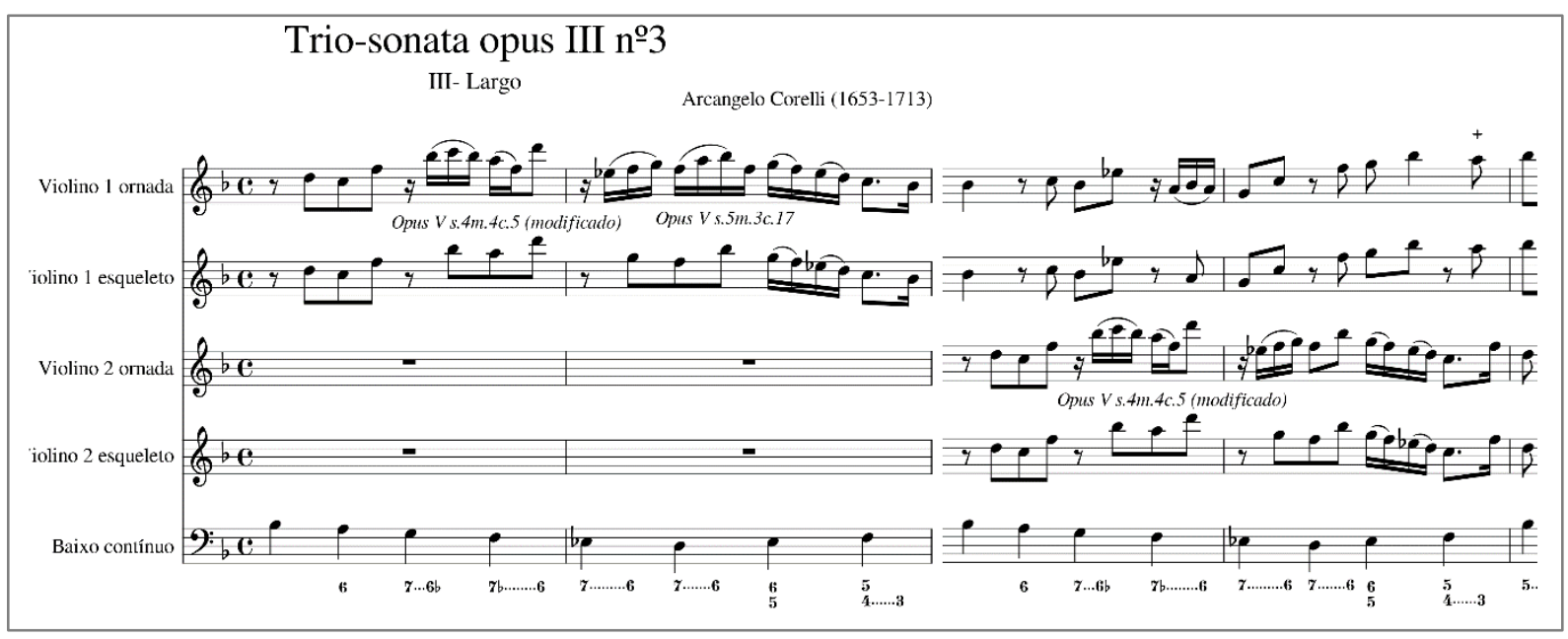

Fonte: A. Corelli Opus III, 2020. Edição e recorte nosso.

A narratio do movimento se inicia no compasso quatro, quando as pausas dos suspiros abrem espaço para suspensões harmônicas bastante curta. Trechos parecidos são bastante recorrentes durante o movimento conduzindo a cadências perfeitas em outras tonalidades, o contraponto dessas suspensões não abre espaço para passaggi, porém pequenos ornatos a exemplo do modelo da quarta sonata do Opus V (Figura 65) podem ser utilizados no intuito de contribuir para a variedade. 
Figura 65: Modelo de ornamentação do quarto movimento da sonata opus V nº 4 c. 17

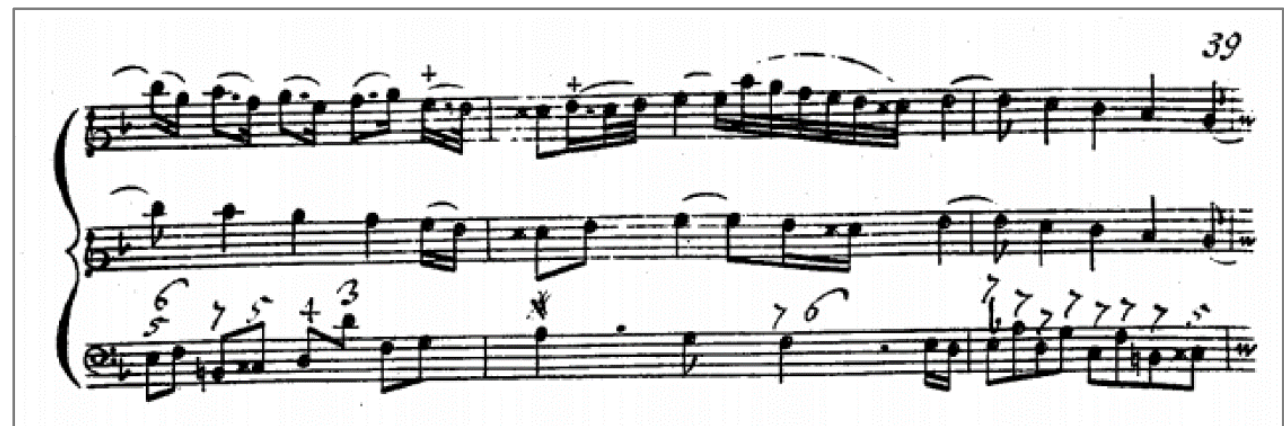

Fonte: Corelli opus V, 1711,edição por Estienne Roger

Do compasso 7 ao compasso 10 há o confutatio do movimento. Sua força expressiva se encontra nos deslocamentos rítmicos, sendo importante para a clareza da obra os ataques das notas longas deslocadas (exemplo no primeiro violino do compasso 9) e nesse sentido qualquer ornamentação improvisada não deve contrariar este princípio.

Figura 66: Trecho do compasso 5 ao 10

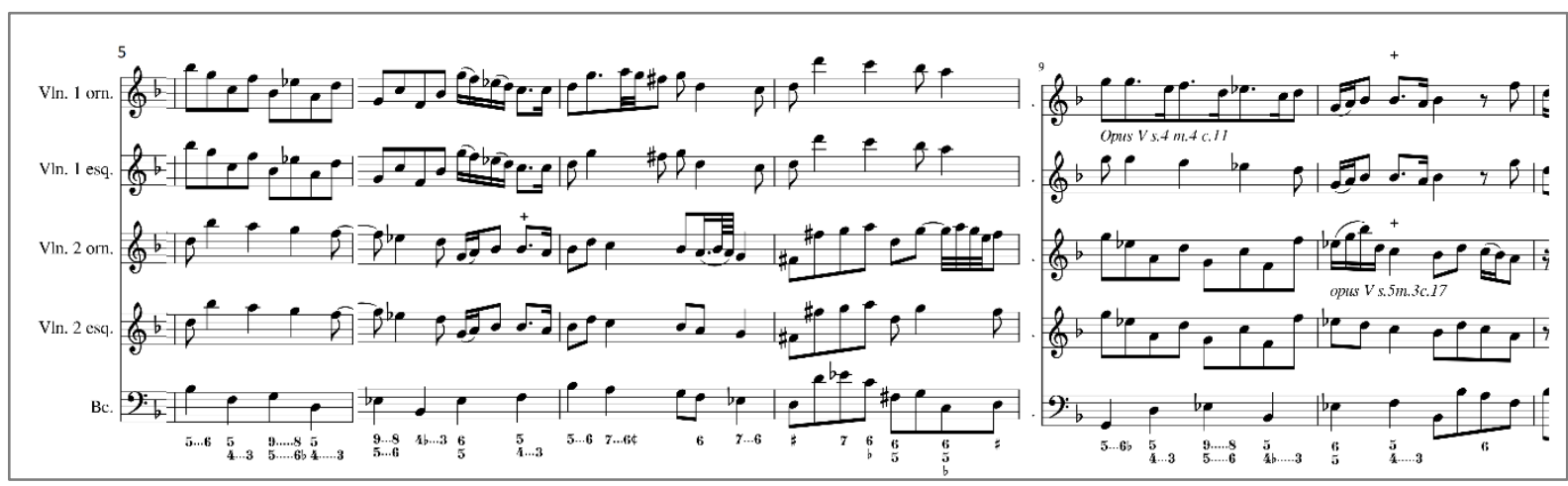

Fonte: A. Corelli Opus III, 2020. Edição e recorte nosso.

A partir do compasso 10 o movimento retorna ao seu argumento principal, confirmatio, intercalando sessões em quarta espécie, cadencias e o tema com os suspiratio, no modelo proposto, pelo fato de as primeiras versões do tema já serem variadas no exordium, um recurso de variação bastante expressivo pode ser não fazer ornamento em uma sessão conforme o exemplo proposto: 
Figura 67: Trecho do compasso 10 ao 17

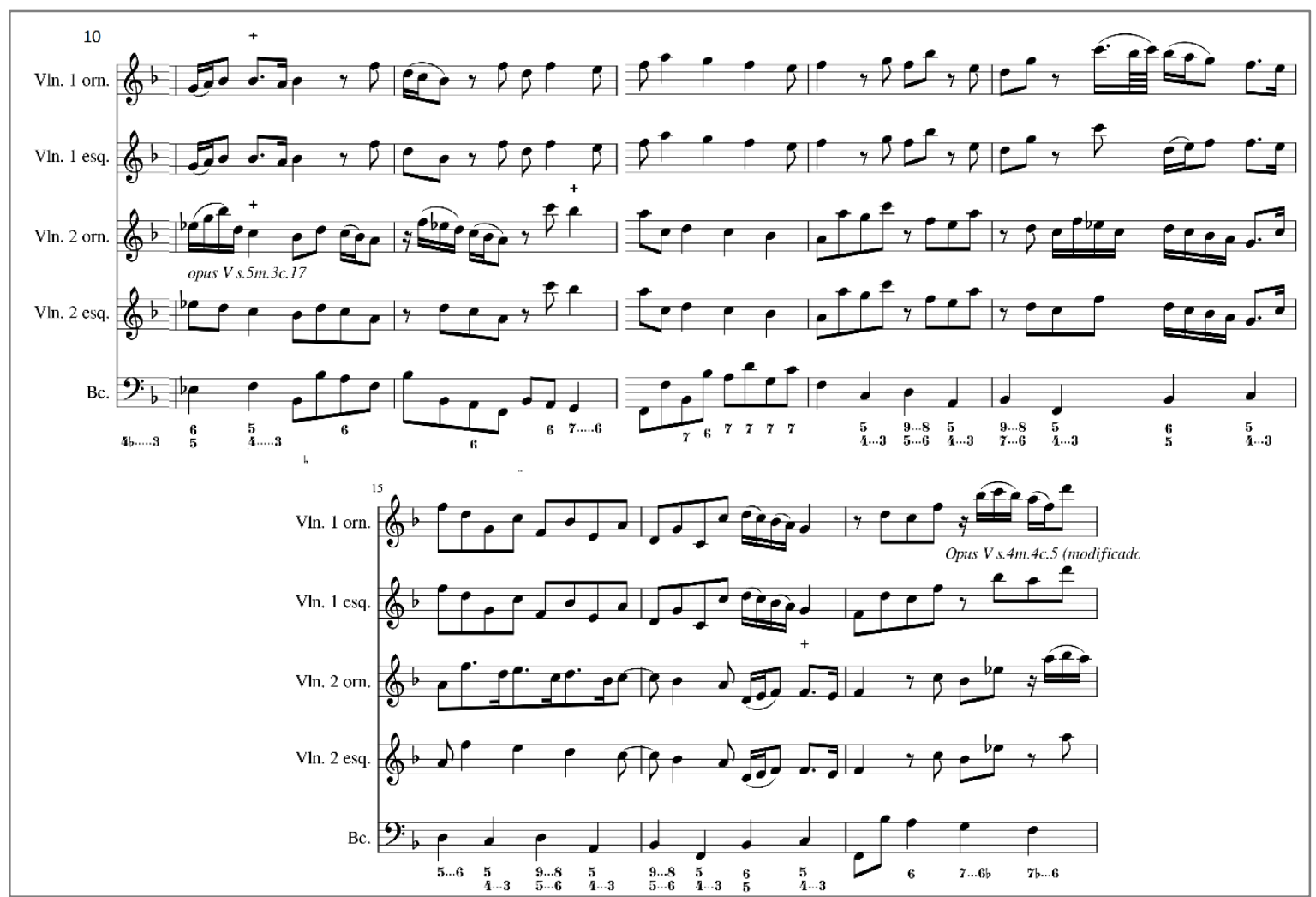

Fonte: A. Corelli Opus III, 2020. Edição e recorte nosso.

Do compasso 17 até o final tem inicio a peroração, peroratio, em 3 etapas: A primeira, uma rexposição do tema, podendo ou não ser variada; Na segunda, com suspiratio contendo appogiaturas, é recomendável não ornar ; Na terceira, há alternados saltos de oitava, que permitem passaggi expressivas, no mesmo modelo e progressão harmônica da peroratio do primeiro movimento da sonata 3 do Opus V, já analisada.

Figura 68: Peroratio do primeiro movimento da sonata opus $\mathrm{V} \mathrm{n}^{\circ} 3$

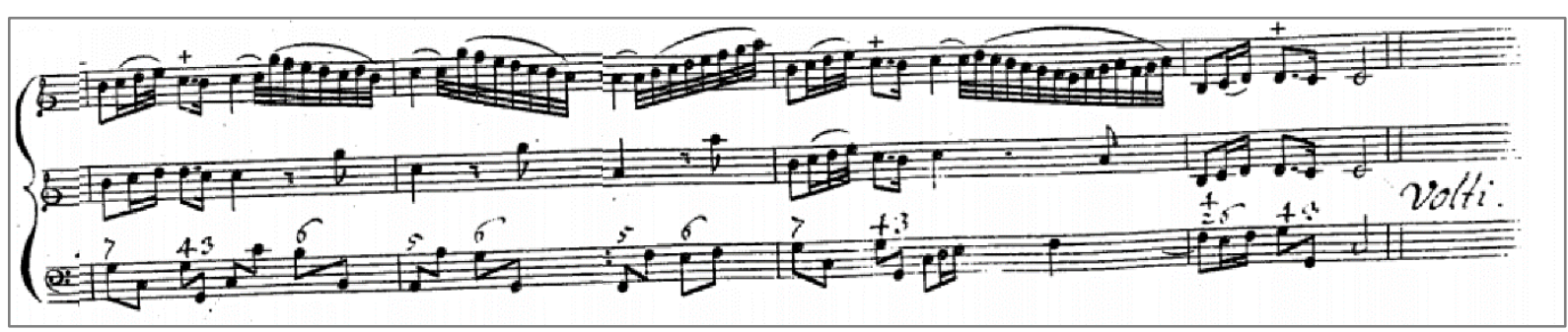

Fonte: Corelli opus V, 1711,edição por Estienne Roger 
Figura 69: Trecho do compasso 17 até o final do terceiro movimento da trio-sonata opus III $\mathrm{n}^{\circ} 3$

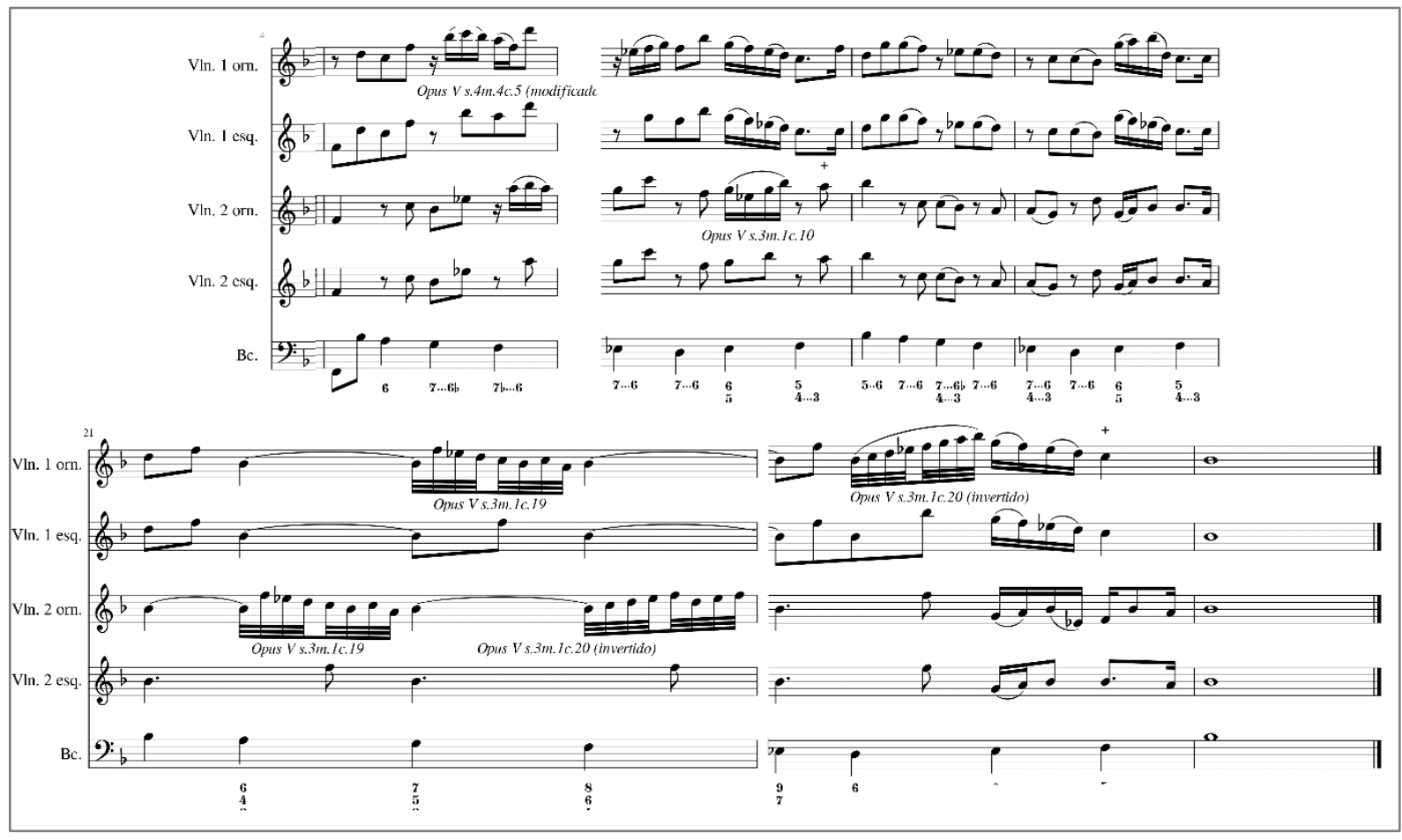

Fonte: A. Corelli Opus III, 2020. Edição e recorte nosso. 


\section{PROPOSTA DE EDIÇÃO DIDATICAMENTE ORNAMENTADA}

Neste Capítulo será apresentada a proposta de edição didaticamente ornamentada elaborada pelo autor desta dissertação. 
Figura 70 - Proposta de edição didaticamente ornamentada para a Sonata opus III, n.1 de Corelli (parte 1)

\section{Trio-sonata Opus III №1 \\ Grave}

Arcangelo Corelli (1653-1713)
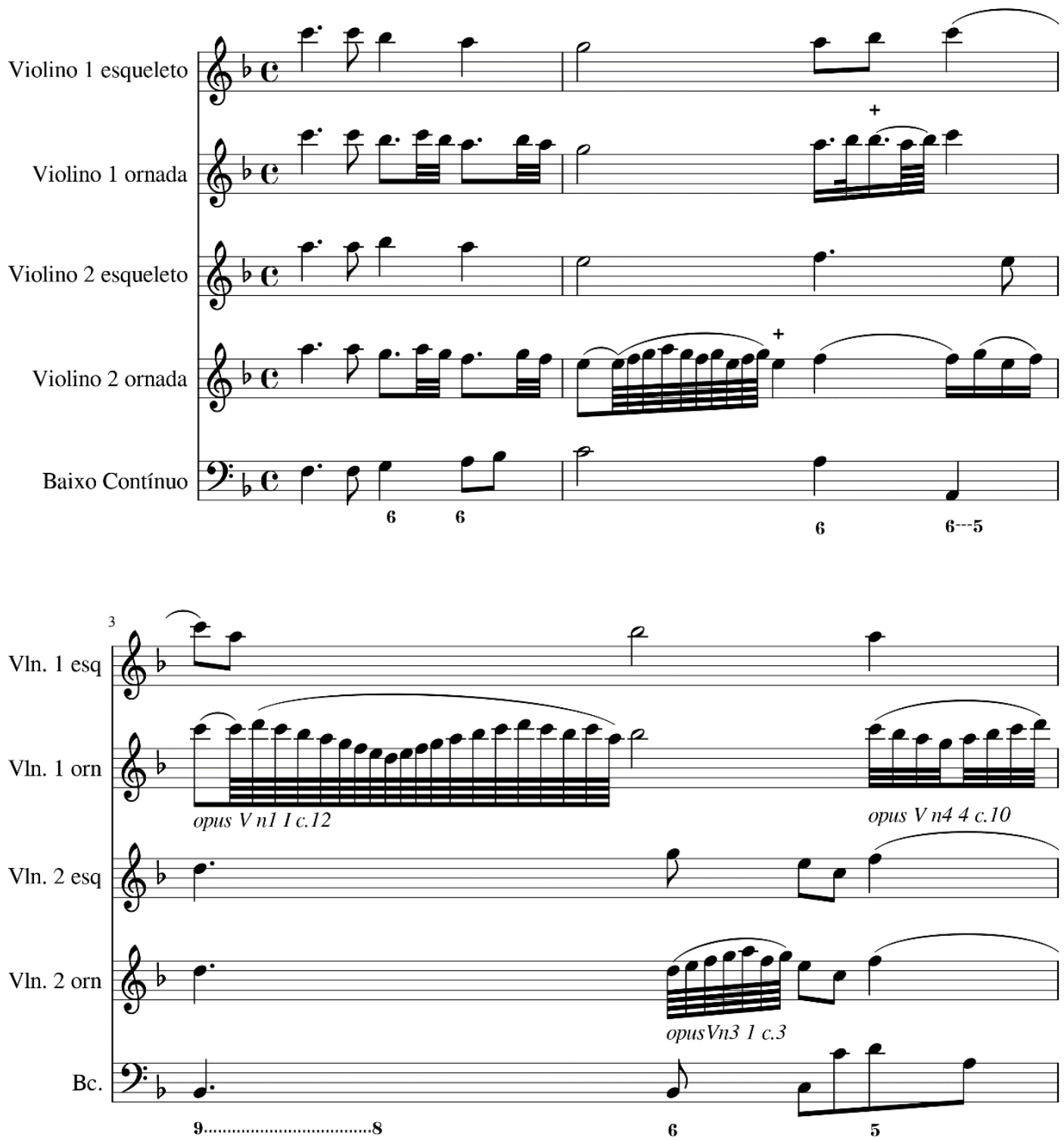
Figura 71 - Proposta de edição didaticamente ornamentada para a sonata 1 opus III de Corelli (parte 2)
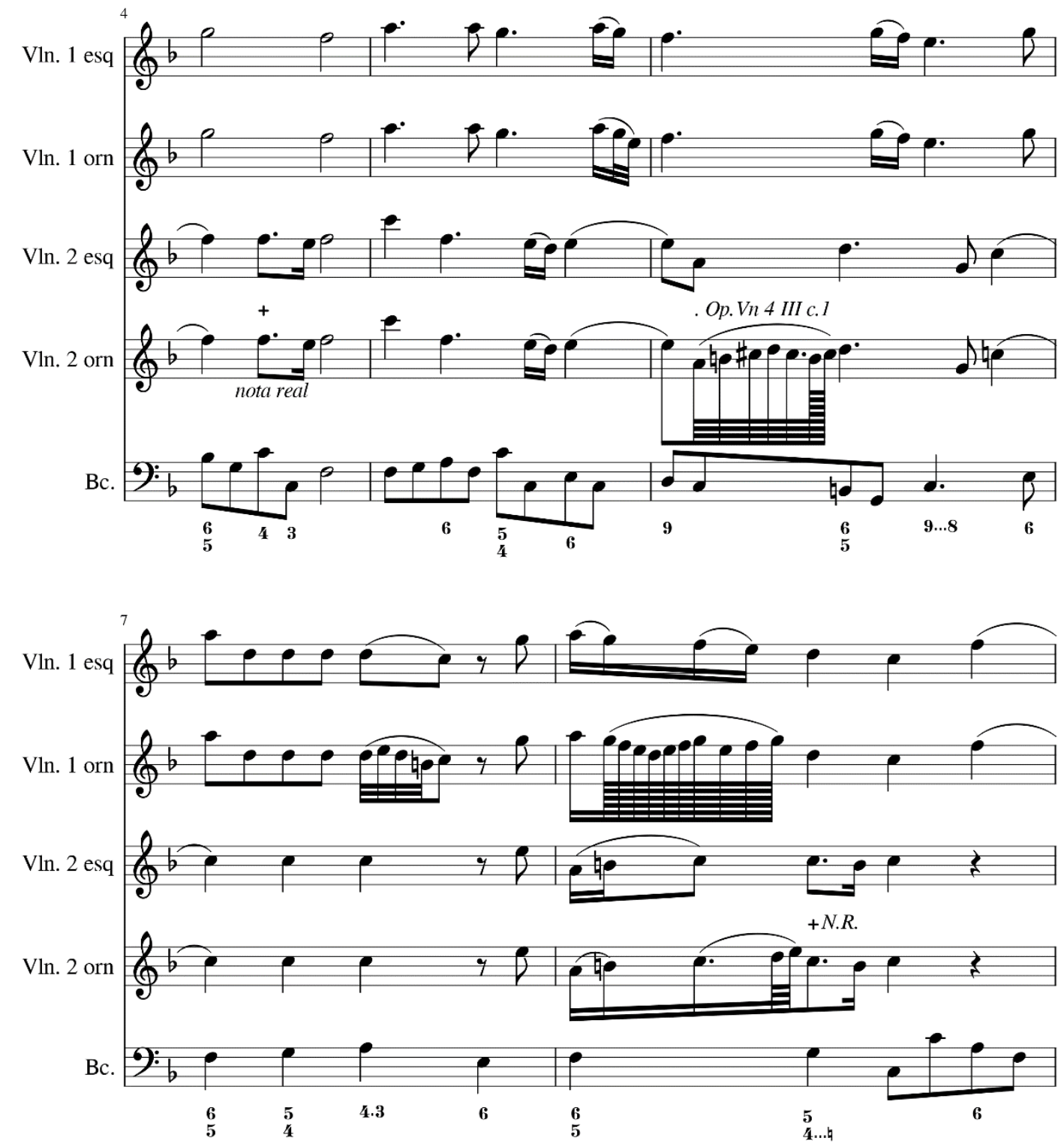
Figura 72 - Proposta de edição didaticamente ornamentada para a sonata 1 opus III de Corelli (parte 3)
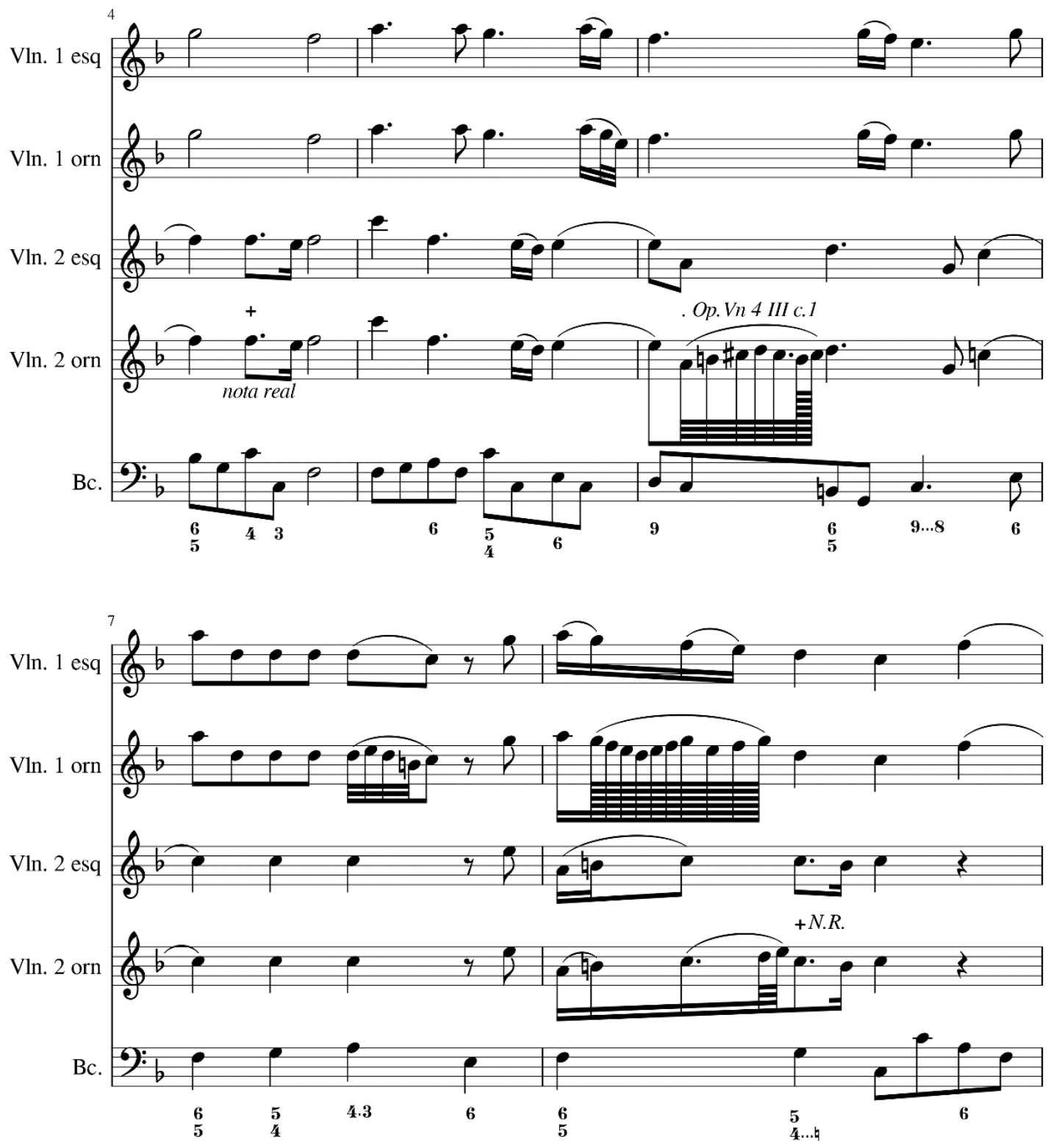
Figura 73 - Proposta de edição didaticamente ornamentada para a sonata 1 opus III de Corelli (parte 4)
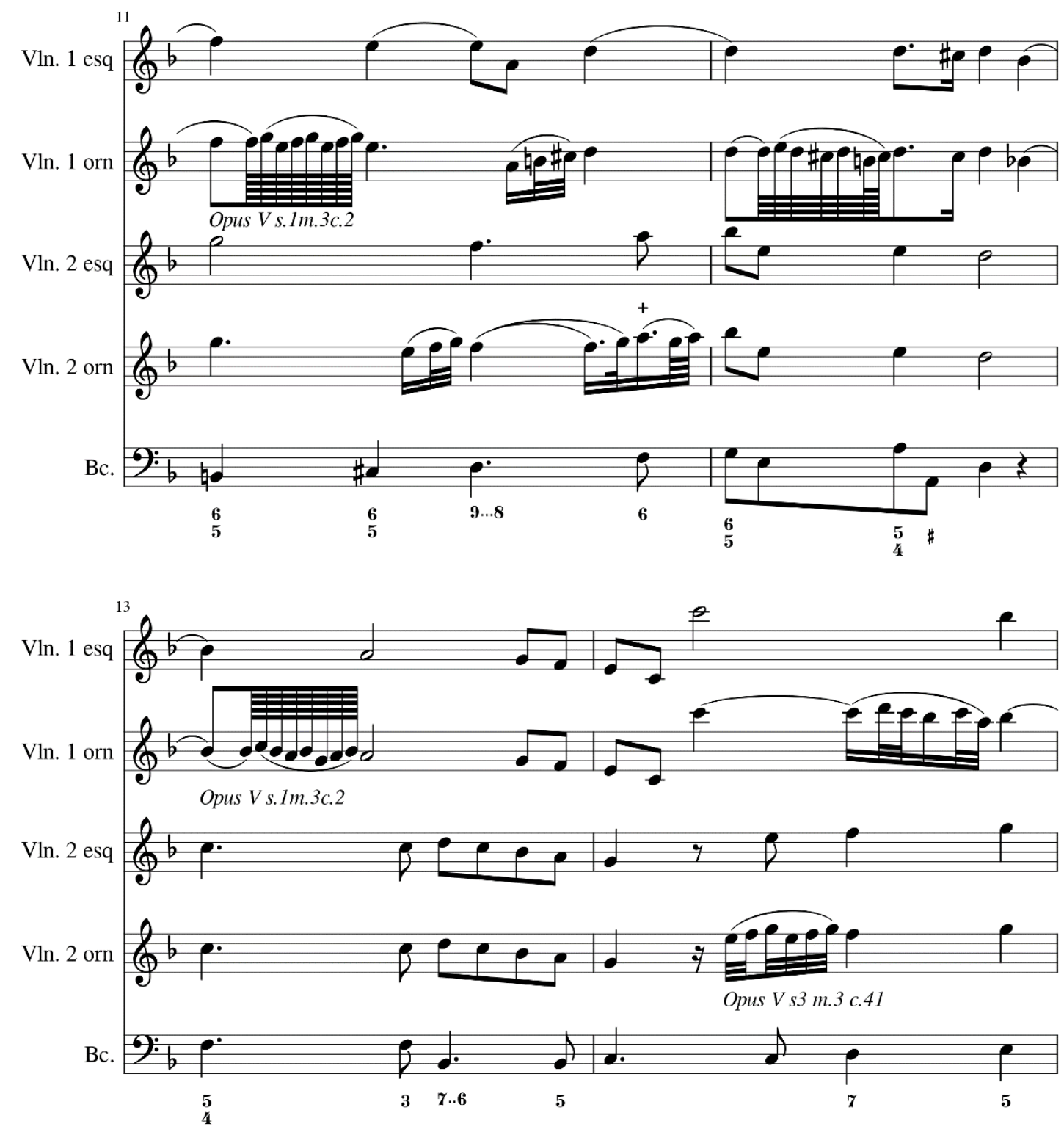
Figura 74 - Proposta de edição didaticamente ornamentada para a sonata 1 opus III de Corelli (parte 5)
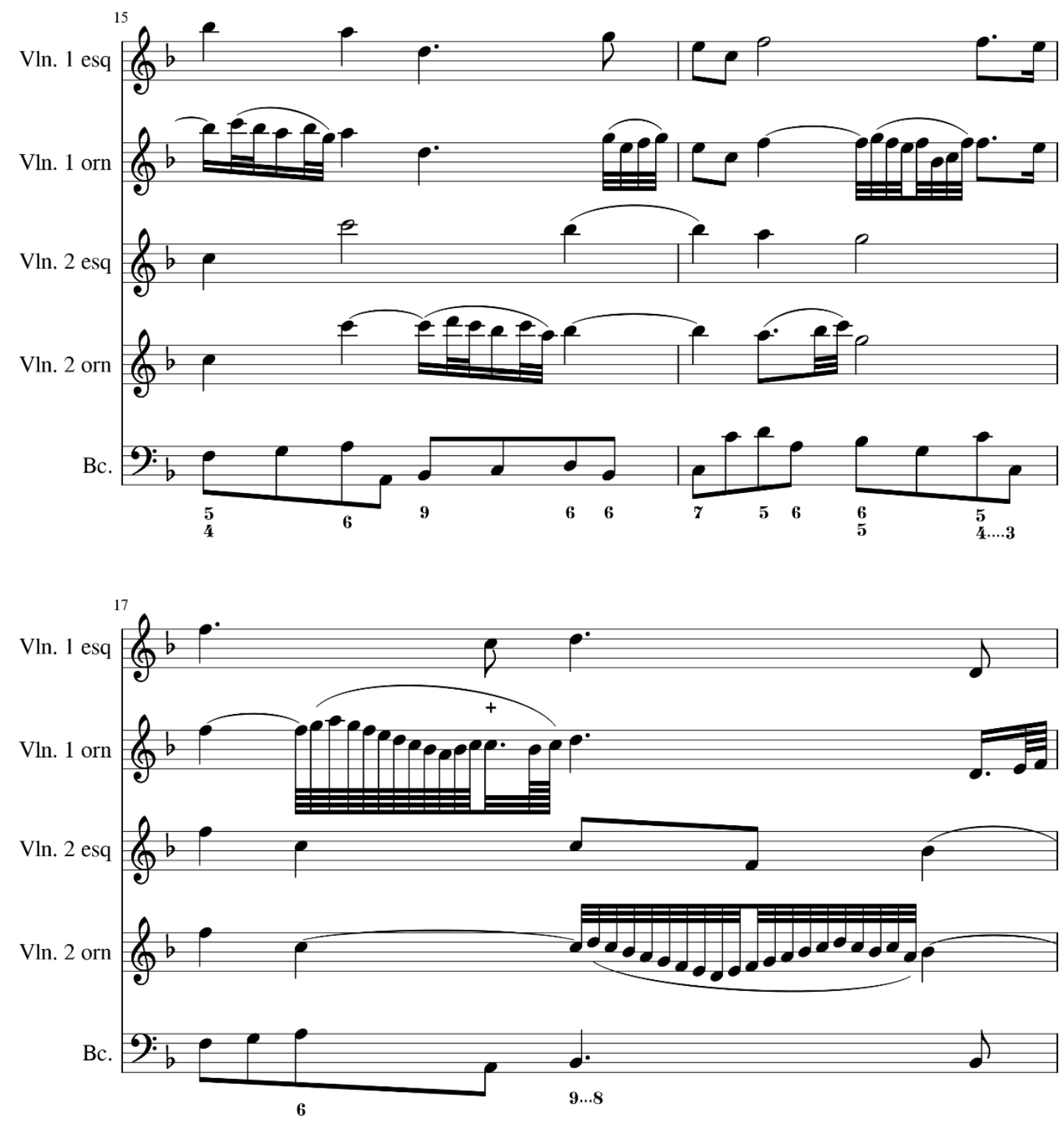
Figura 75 - Proposta de edição didaticamente ornamentada para a sonata 1 opus III de Corelli (parte 6)

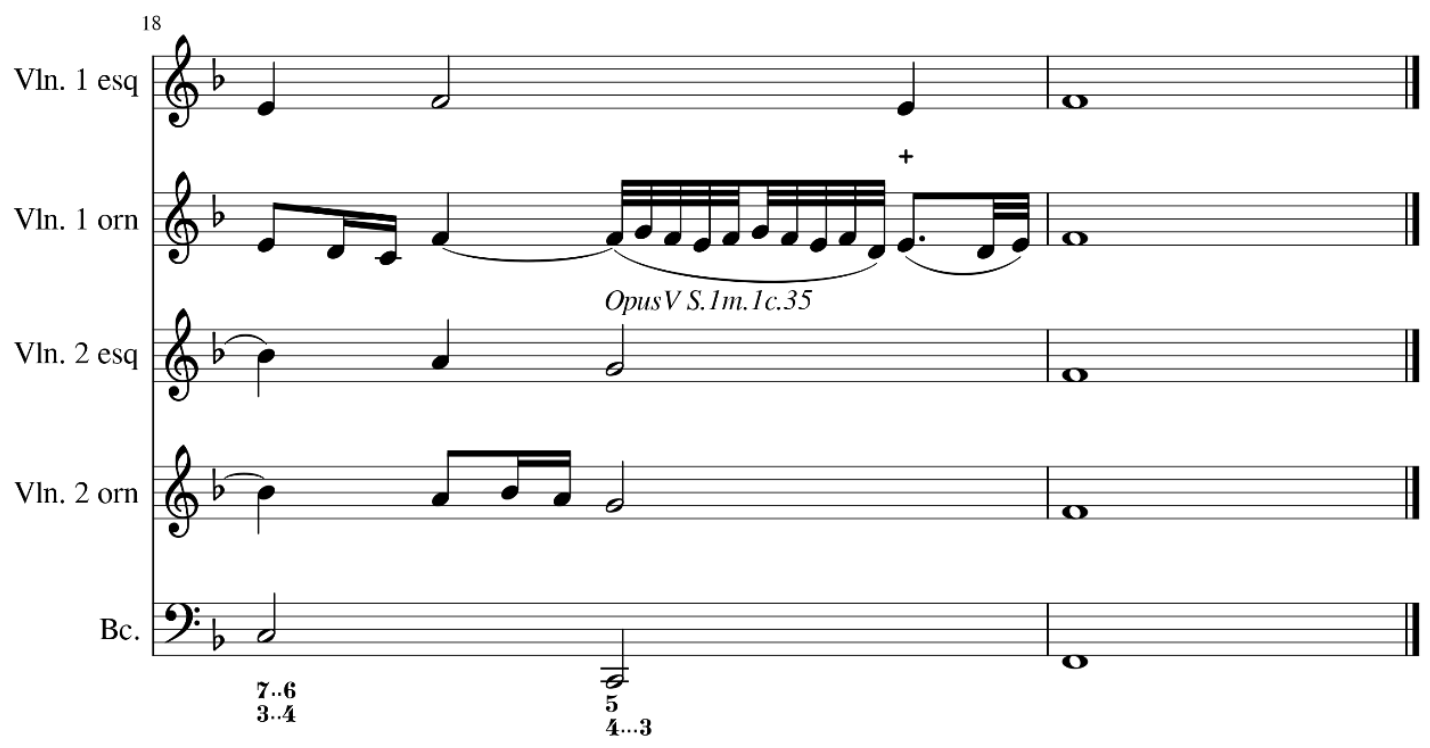


Figura 76 - Proposta de edição didaticamente ornamentada para a sonata 2 opus III de Corelli (parte 1)

\section{Trio-sonata Opus III n⿳2 2 \\ 1- Grave}

Arcangelo Corelli (1653-1713)
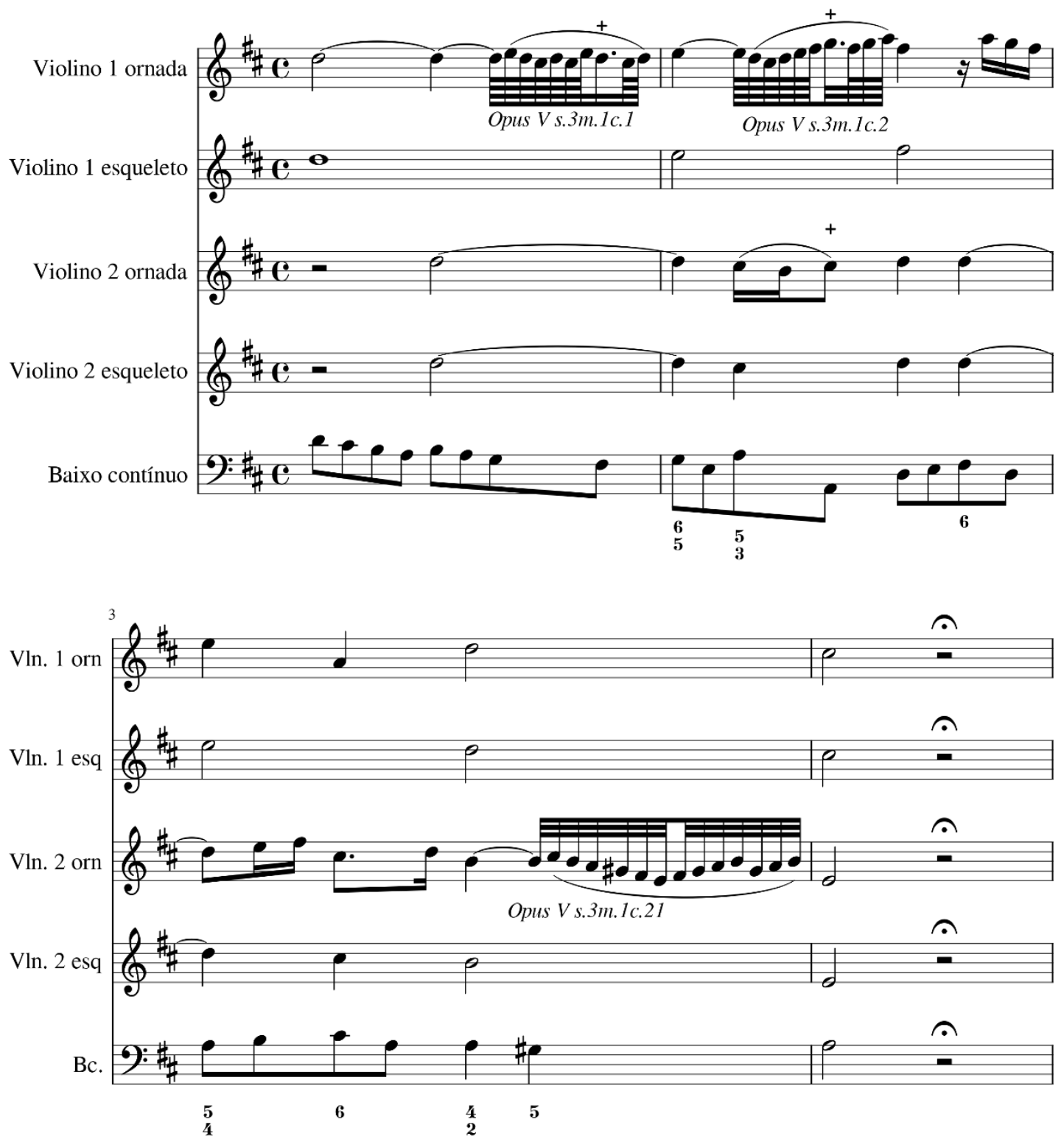

Edição e ornamentação proposta por Roger Ribeiro 
Figura 77 - Proposta de edição didaticamente ornamentada para a sonata 2 opus III de Corelli (parte 2)
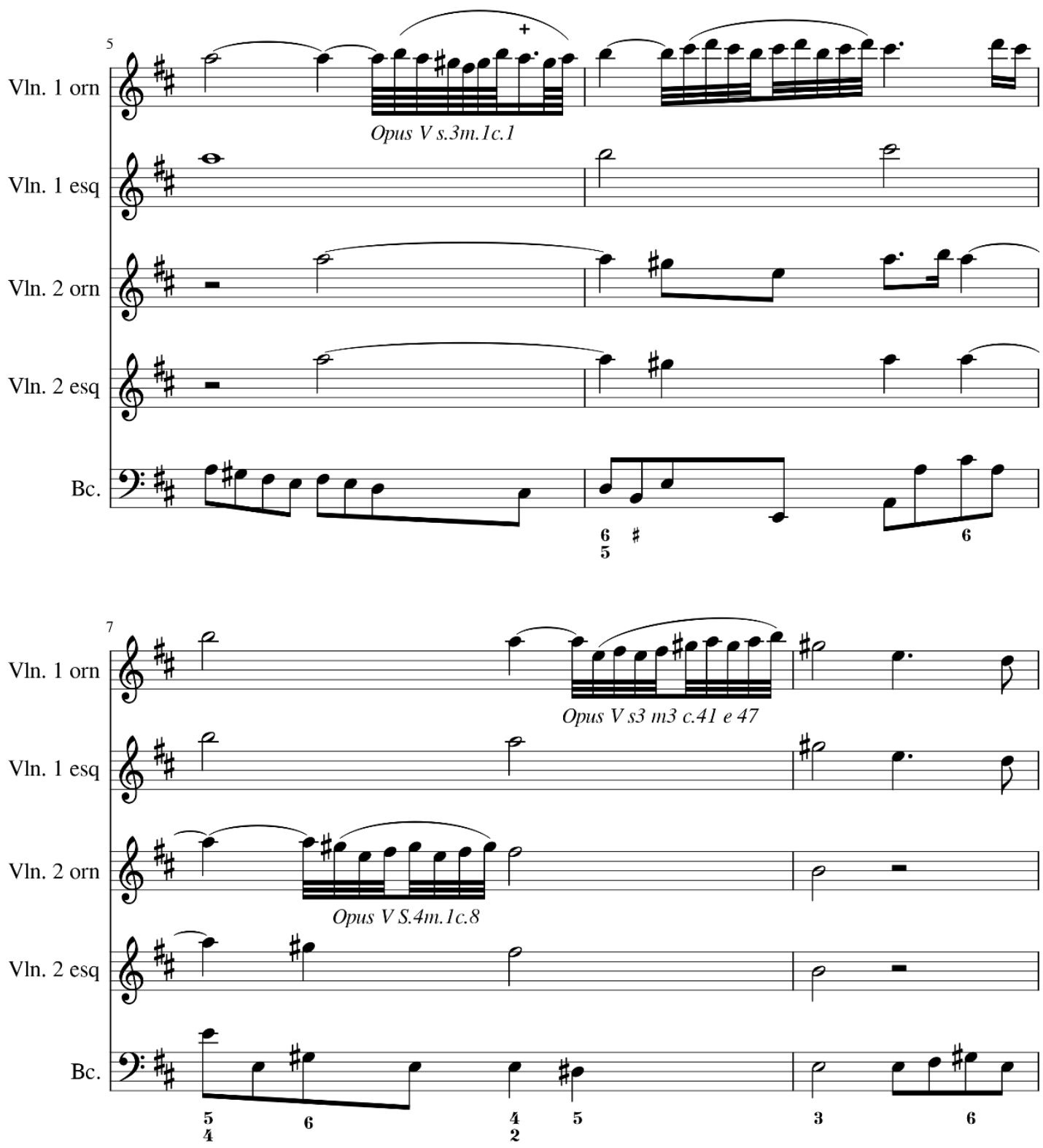
Figura 78 - Proposta de edição didaticamente ornamentada para a sonata 2 opus III de Corelli (parte 3)
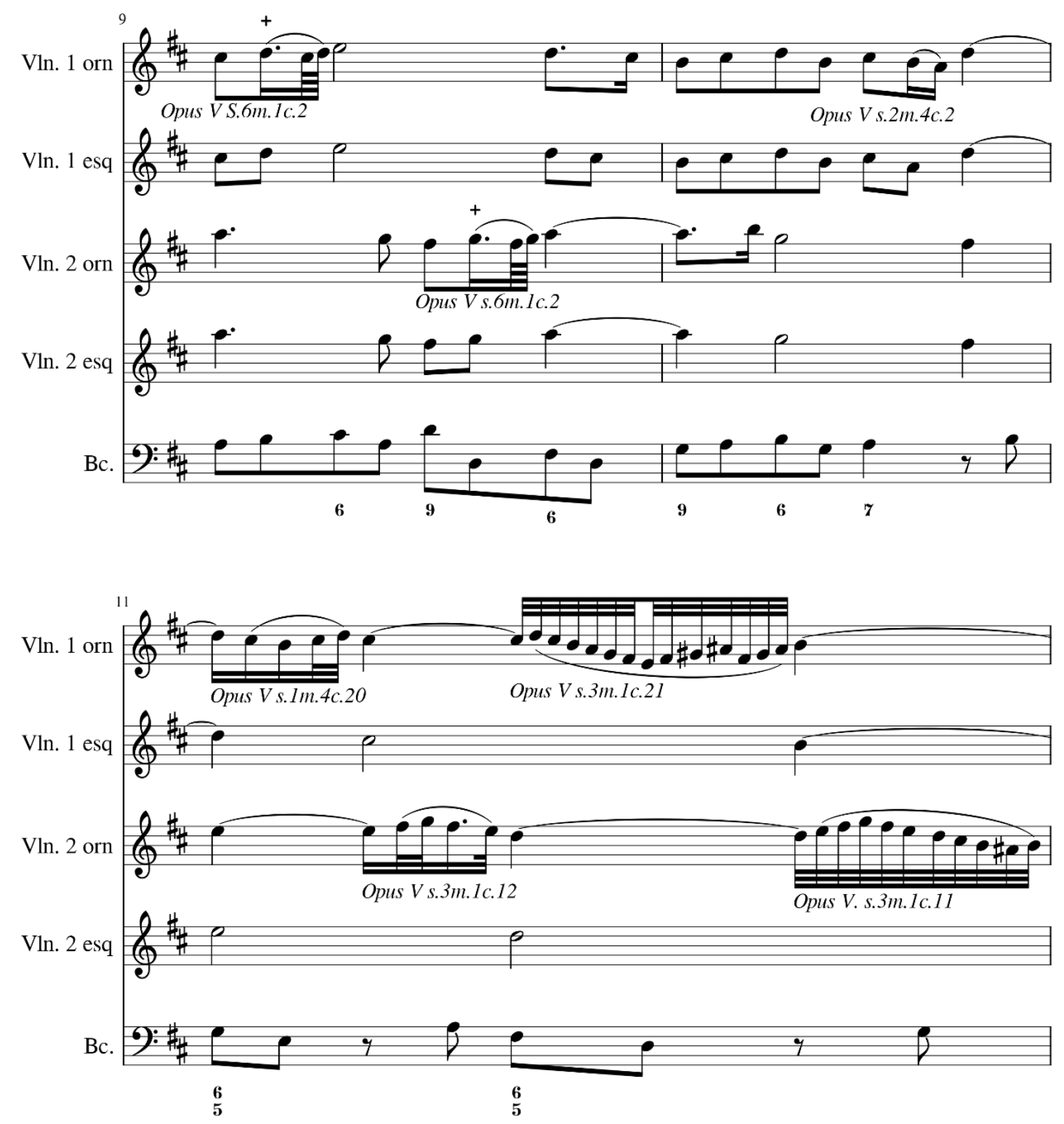
Figura 79 - Proposta de edição didaticamente ornamentada para a sonata 2 opus III de Corelli (parte 4)
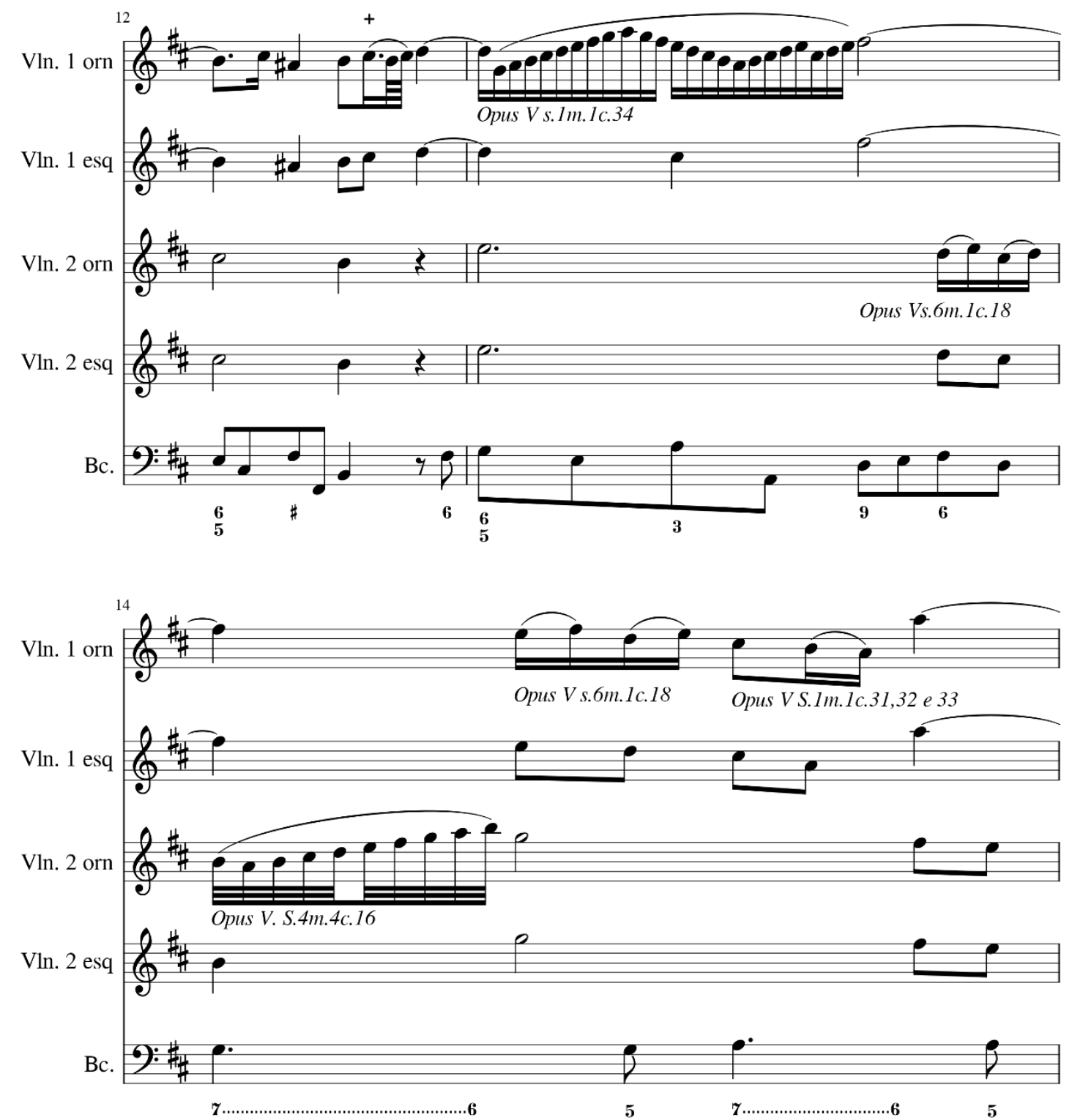
Figura 80 - Proposta de edição didaticamente ornamentada para a sonata 2 opus III de Corelli (parte 5)
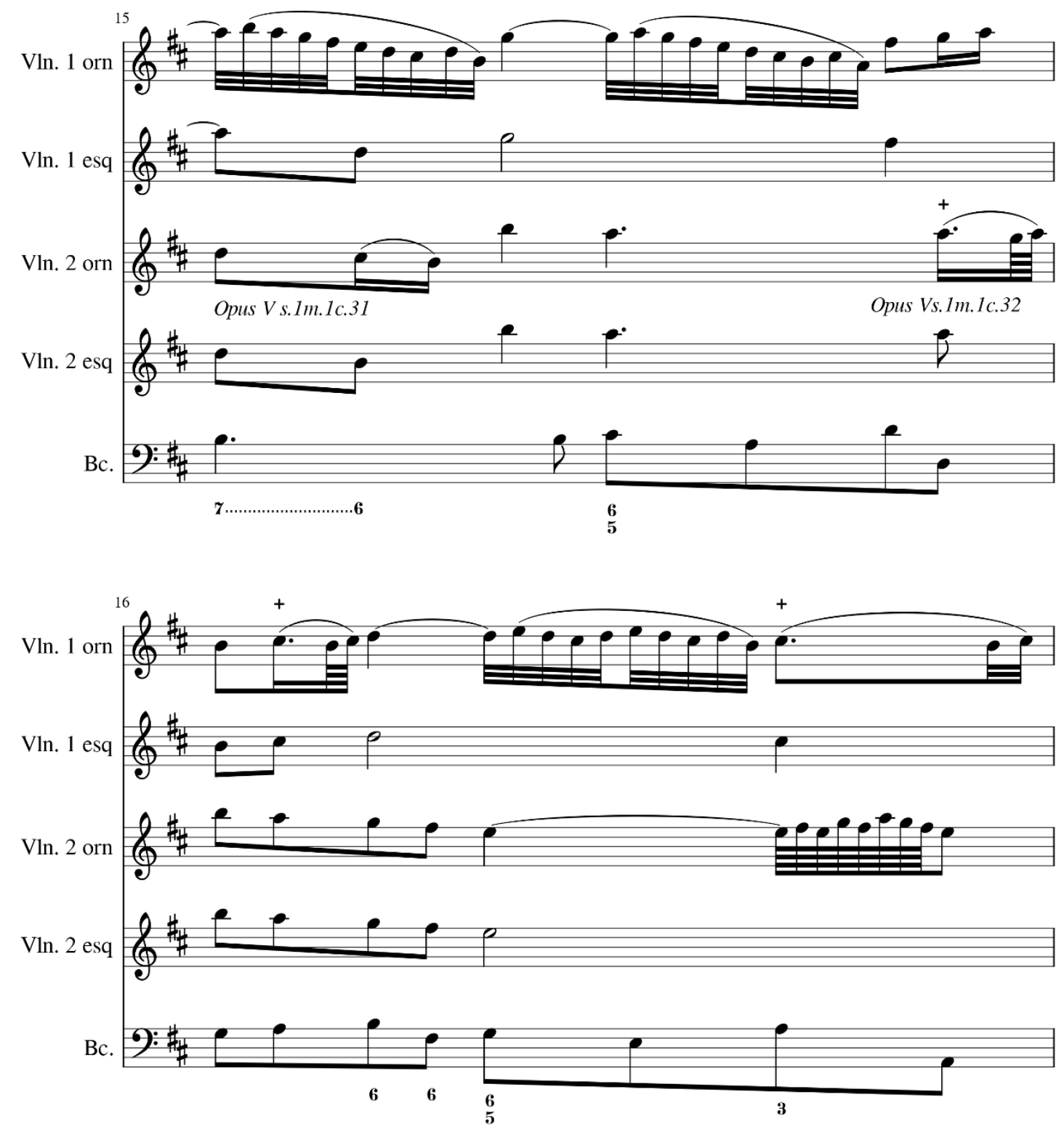
Figura 81 - Proposta de edição didaticamente ornamentada para a sonata 2 opus III de Corelli (parte 6)
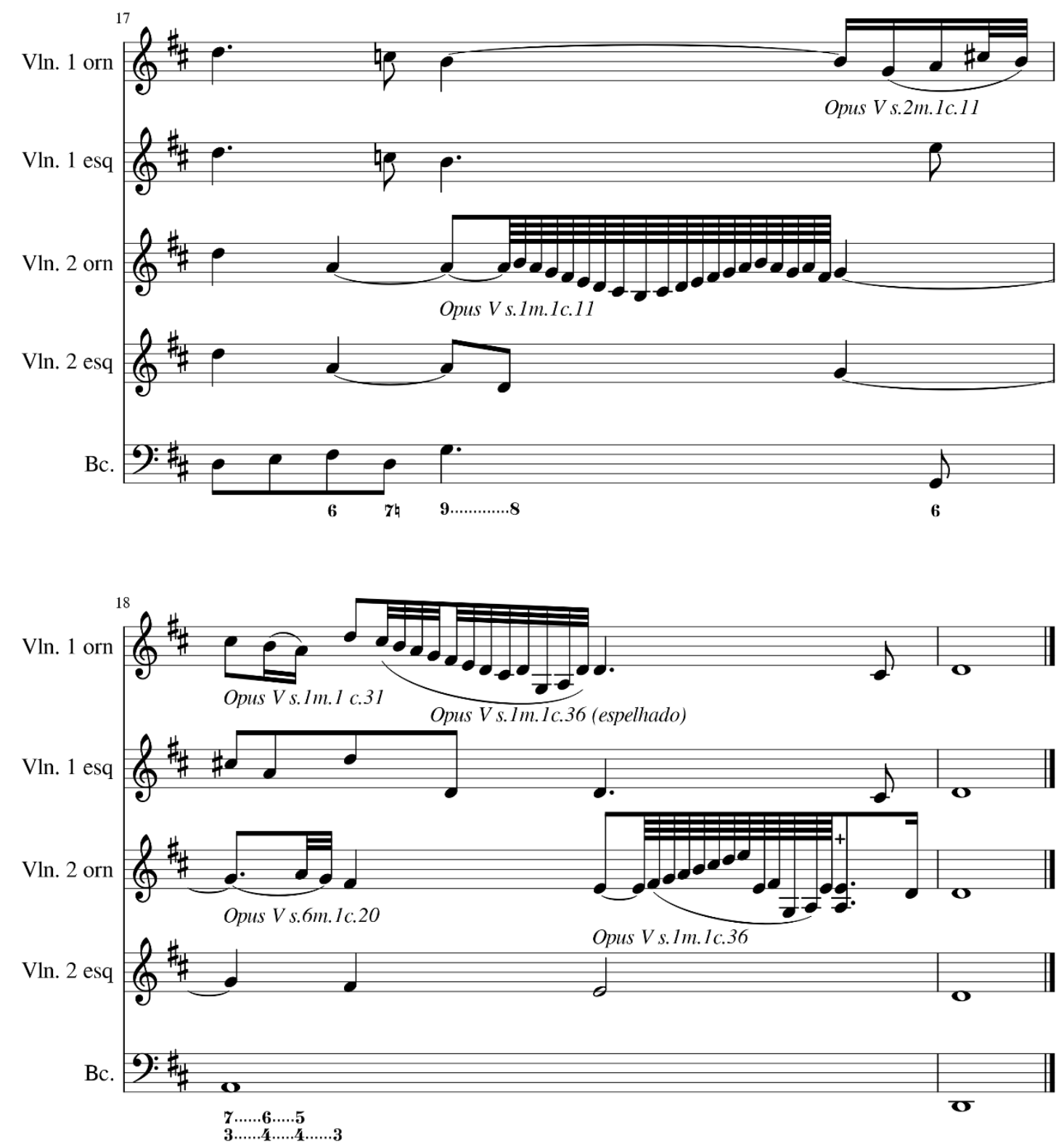
Figura 82 - Proposta de edição didaticamente ornamentada para a sonata 2 opus III de Corelli terceiro movimento (parte 7)

\section{Trio-sonata Opus III no-2 \\ 3- Adagio}

Arcangelo Corelli (1653-1713)
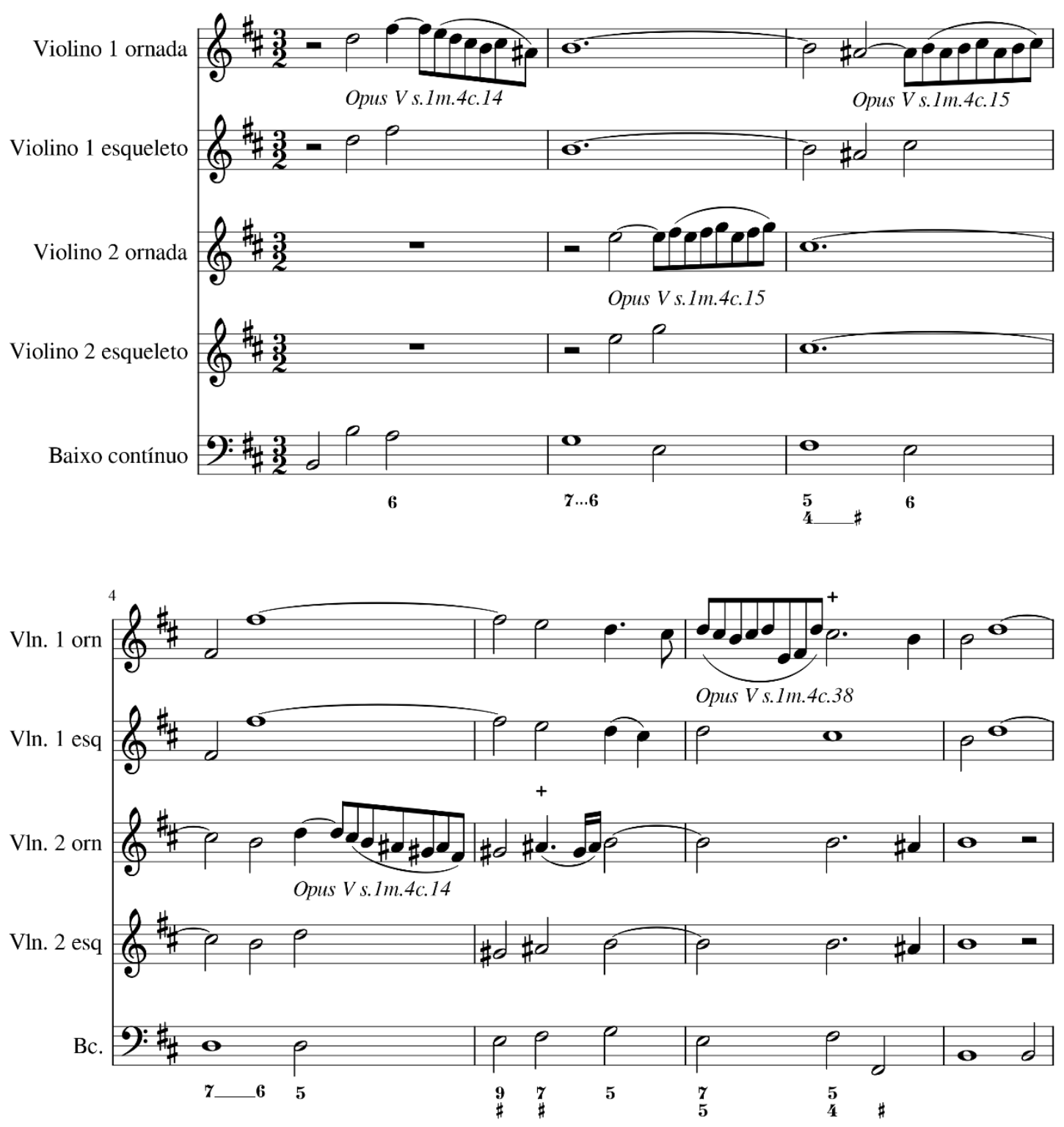
Figura 83 - Proposta de edição didaticamente ornamentada para a sonata 2 opus III de Corelli terceiro movimento (parte 8)
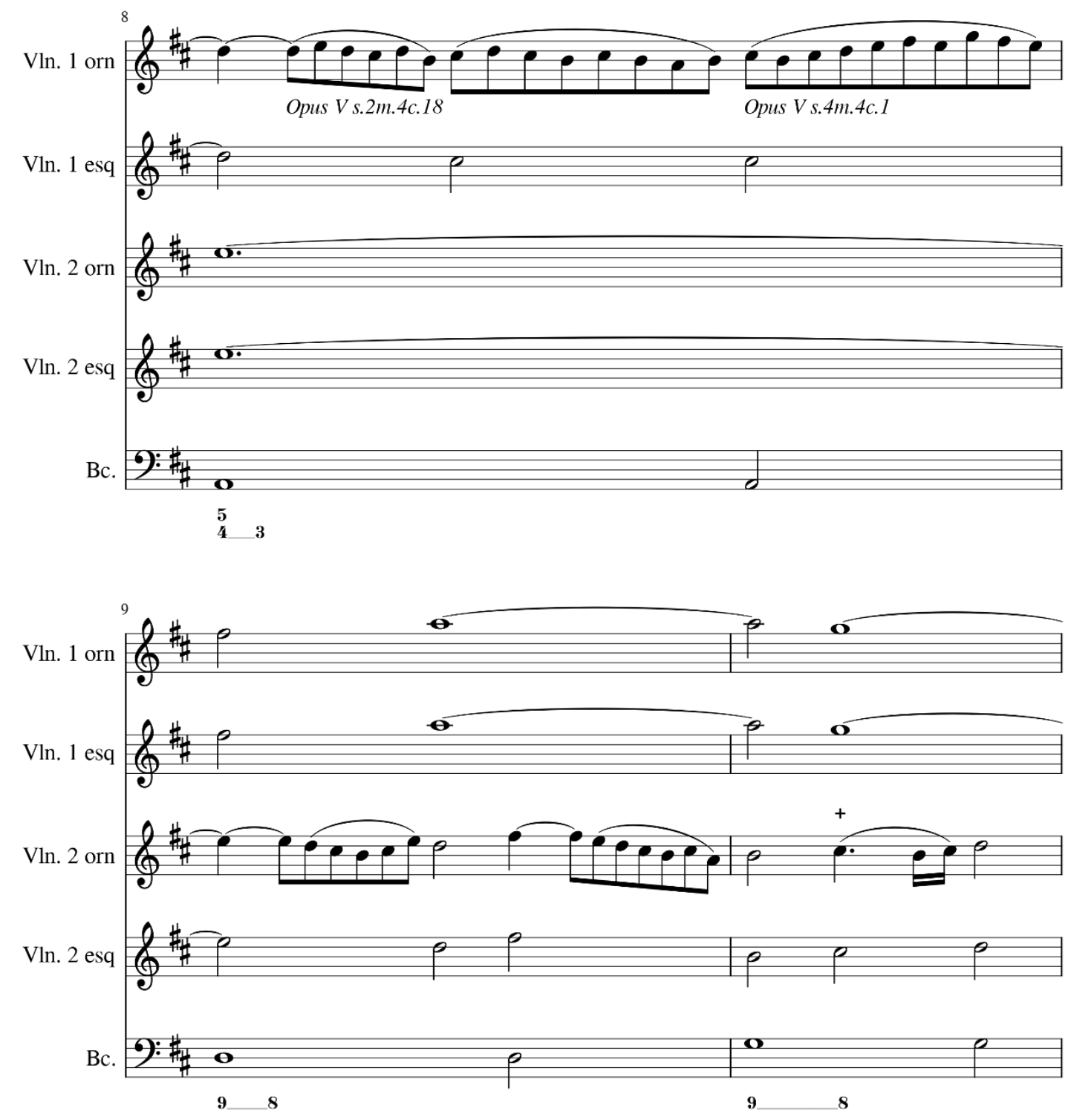
Figura 84 - Proposta de edição didaticamente ornamentada para a sonata 2 opus III de Corelli terceiro movimento (parte 9)
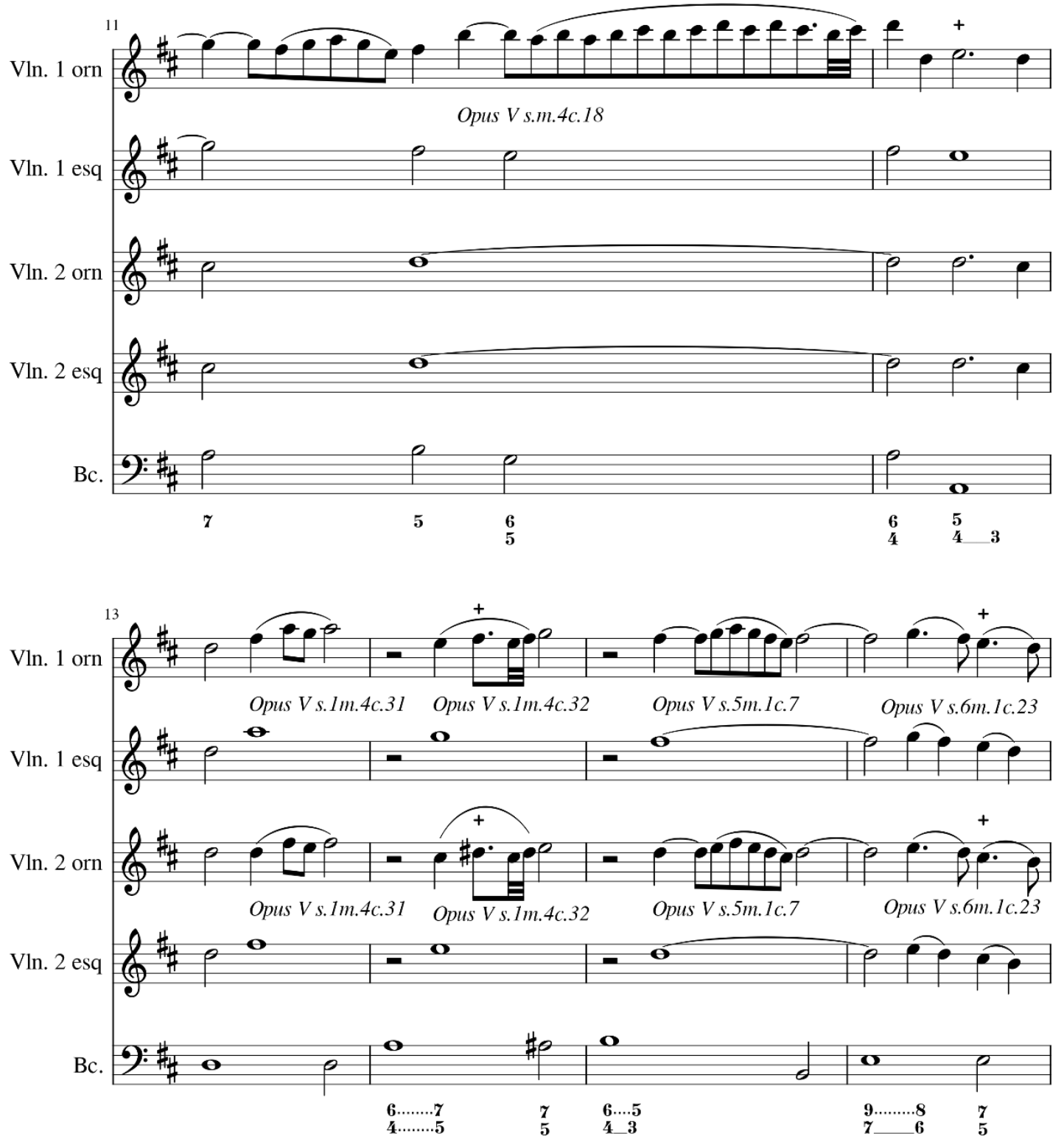
Figura 85 - Proposta de edição didaticamente ornamentada para a sonata 2 opus III de Corelli terceiro movimento (parte 10)
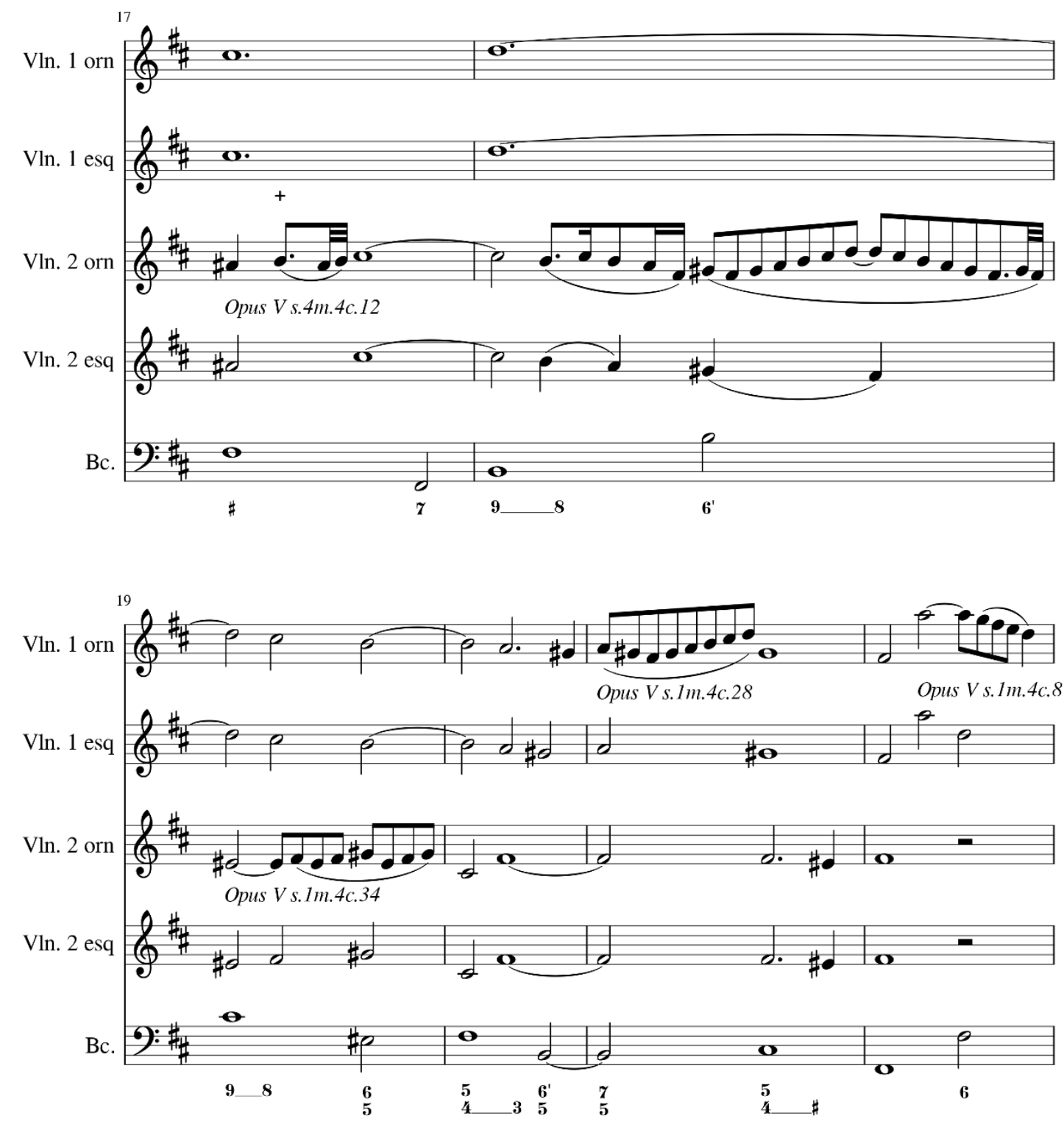
Figura 86 - Proposta de edição didaticamente ornamentada para a sonata 2 opus III de Corelli terceiro movimento (parte 11)
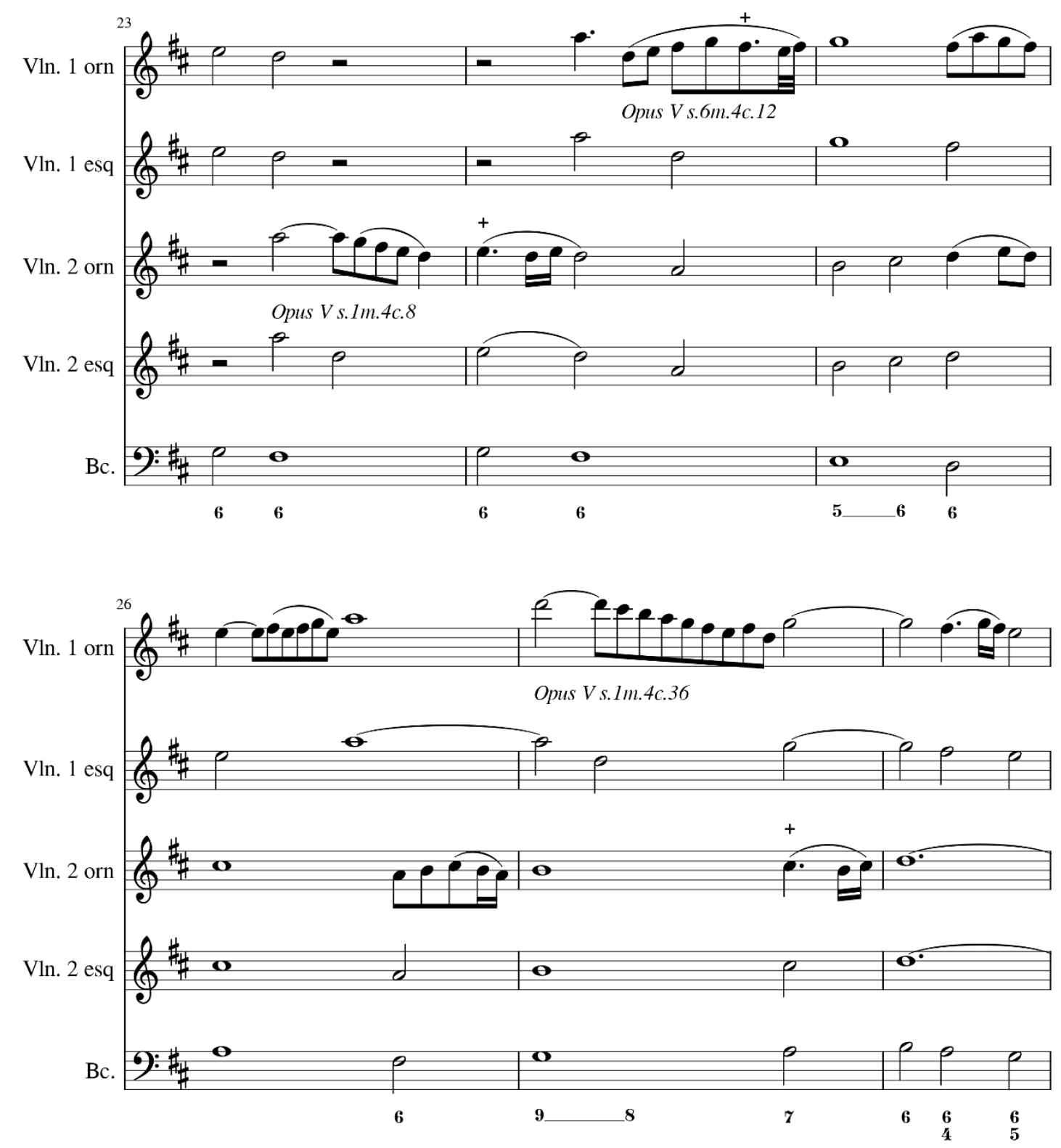
Figura 87 - Proposta de edição didaticamente ornamentada para a sonata 2 opus III de Corelli terceiro movimento (parte 12)
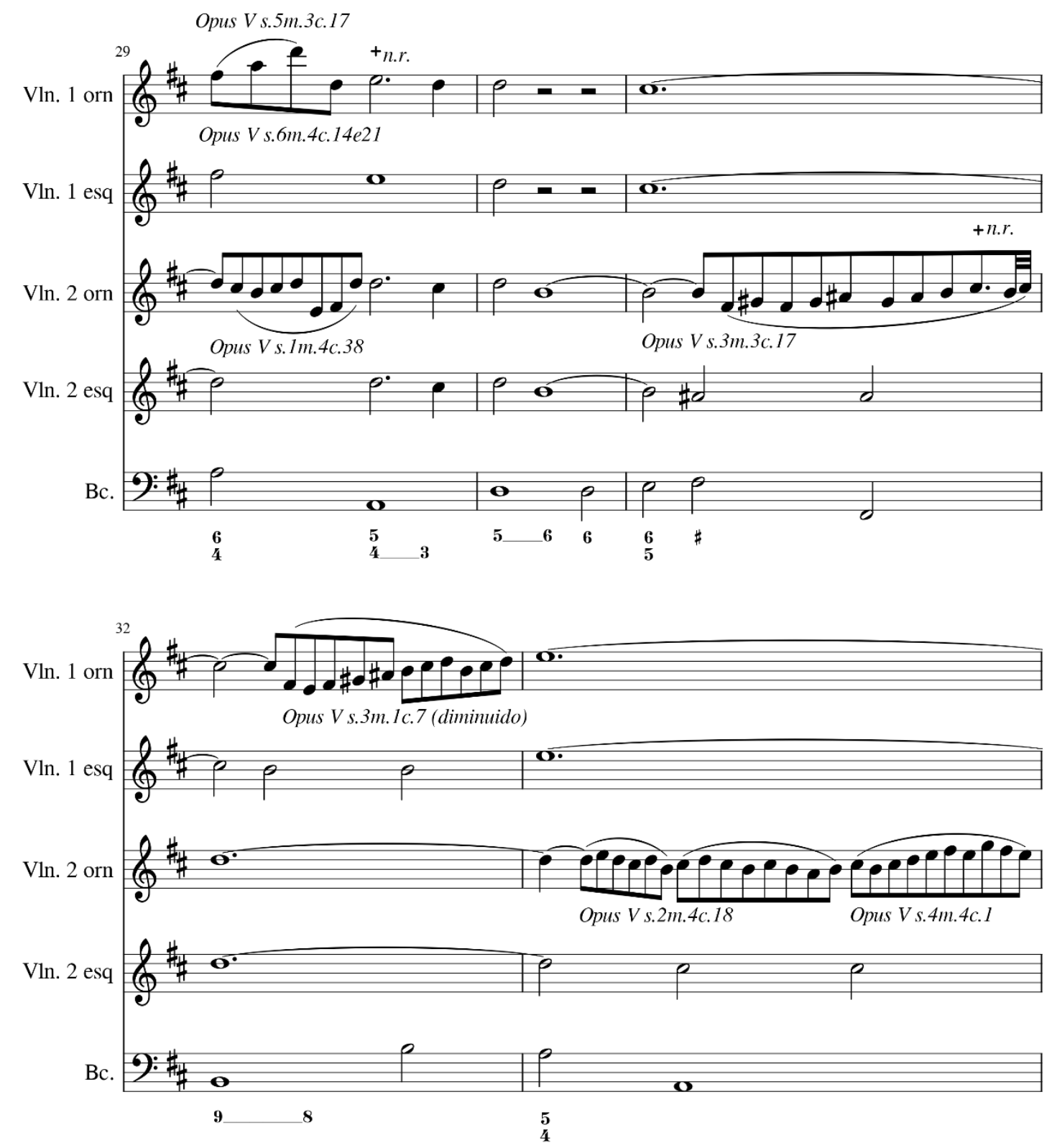
Figura 88 - Proposta de edição didaticamente ornamentada para a sonata 2 opus III de Corelli terceiro movimento (parte 13)
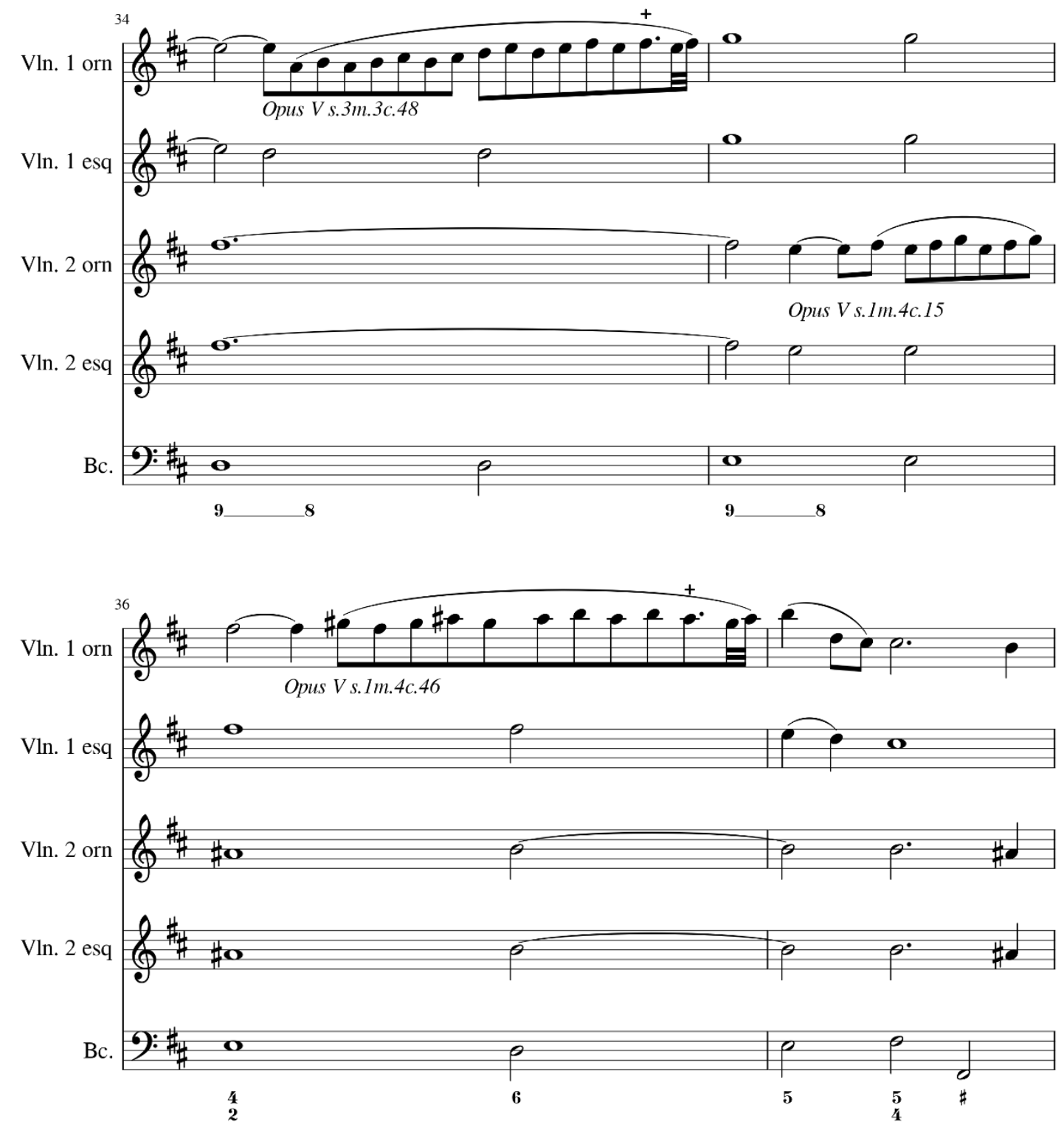
Figura 89 - Proposta de edição didaticamente ornamentada para a sonata 2 opus III de Corelli terceiro movimento (parte 14)
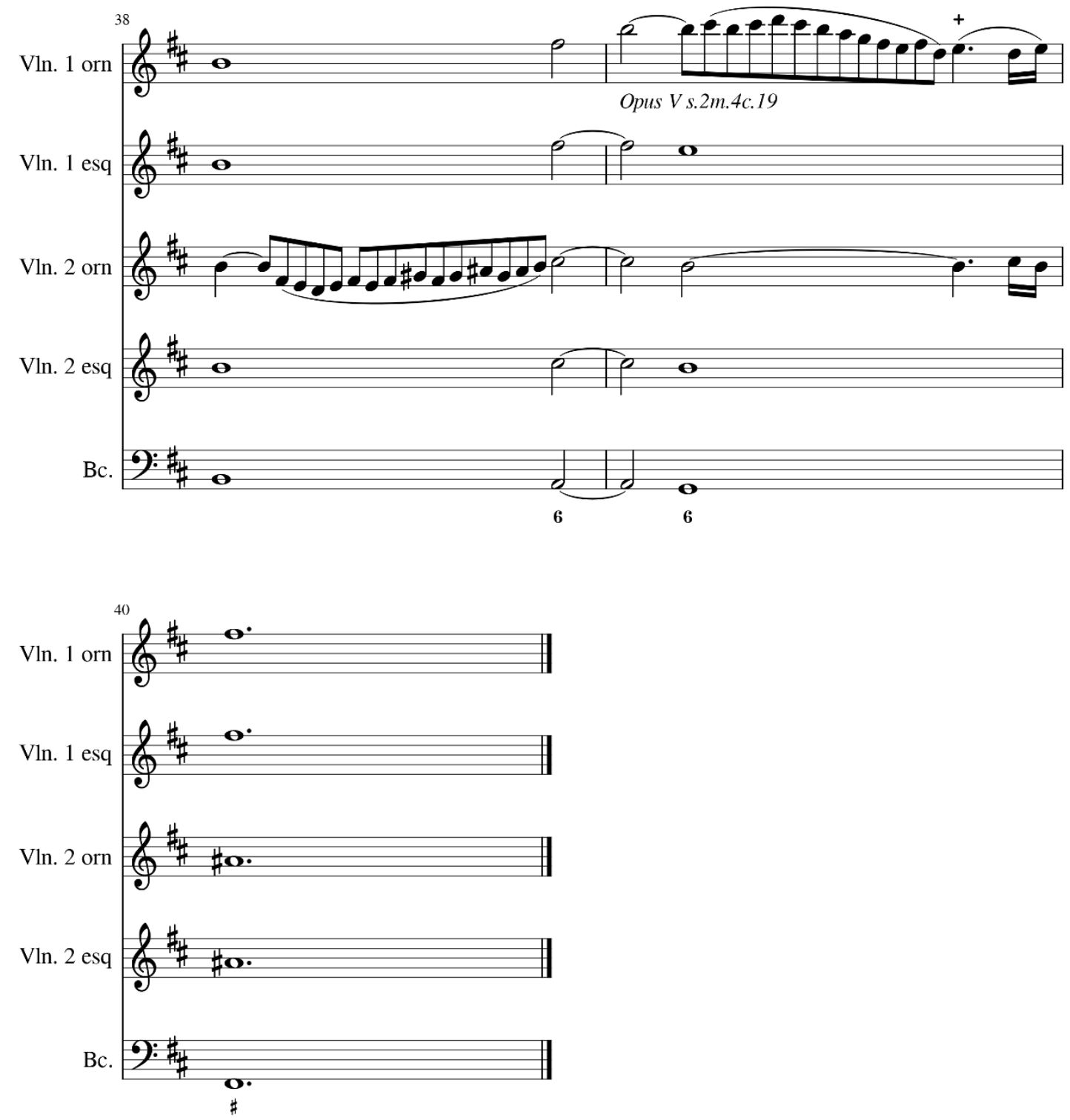
Figura 90 - Proposta de edição didaticamente ornamentada para a sonata 3 opus III de Corelli primeiro movimento (parte 1)

\section{Trio-sonata opus III $n^{-} \mathbf{3}$}

I- Grave
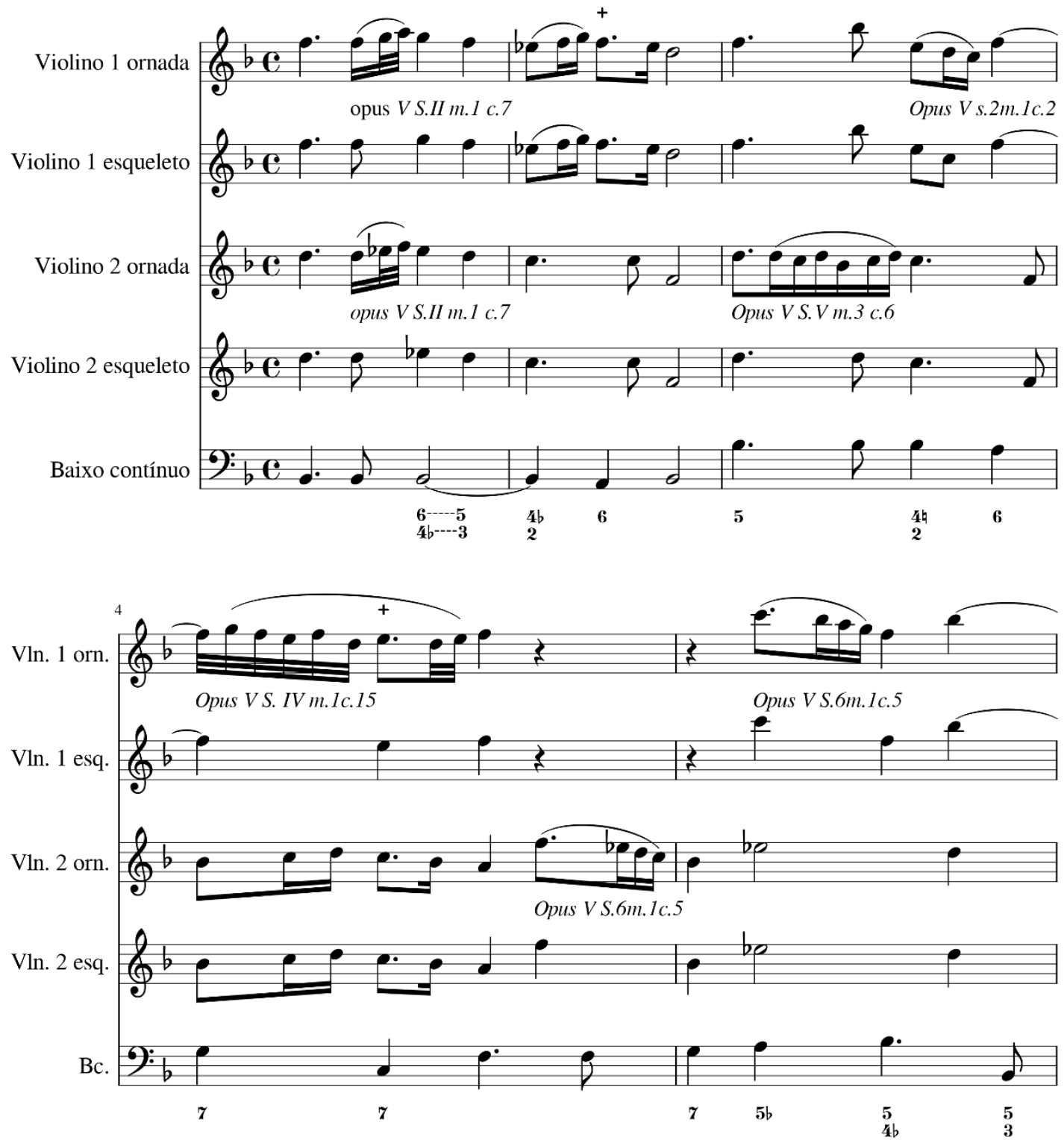
Figura 91 - Proposta de edição didaticamente ornamentada para a sonata 3 opus III de Corelli primeiro movimento (parte 2)
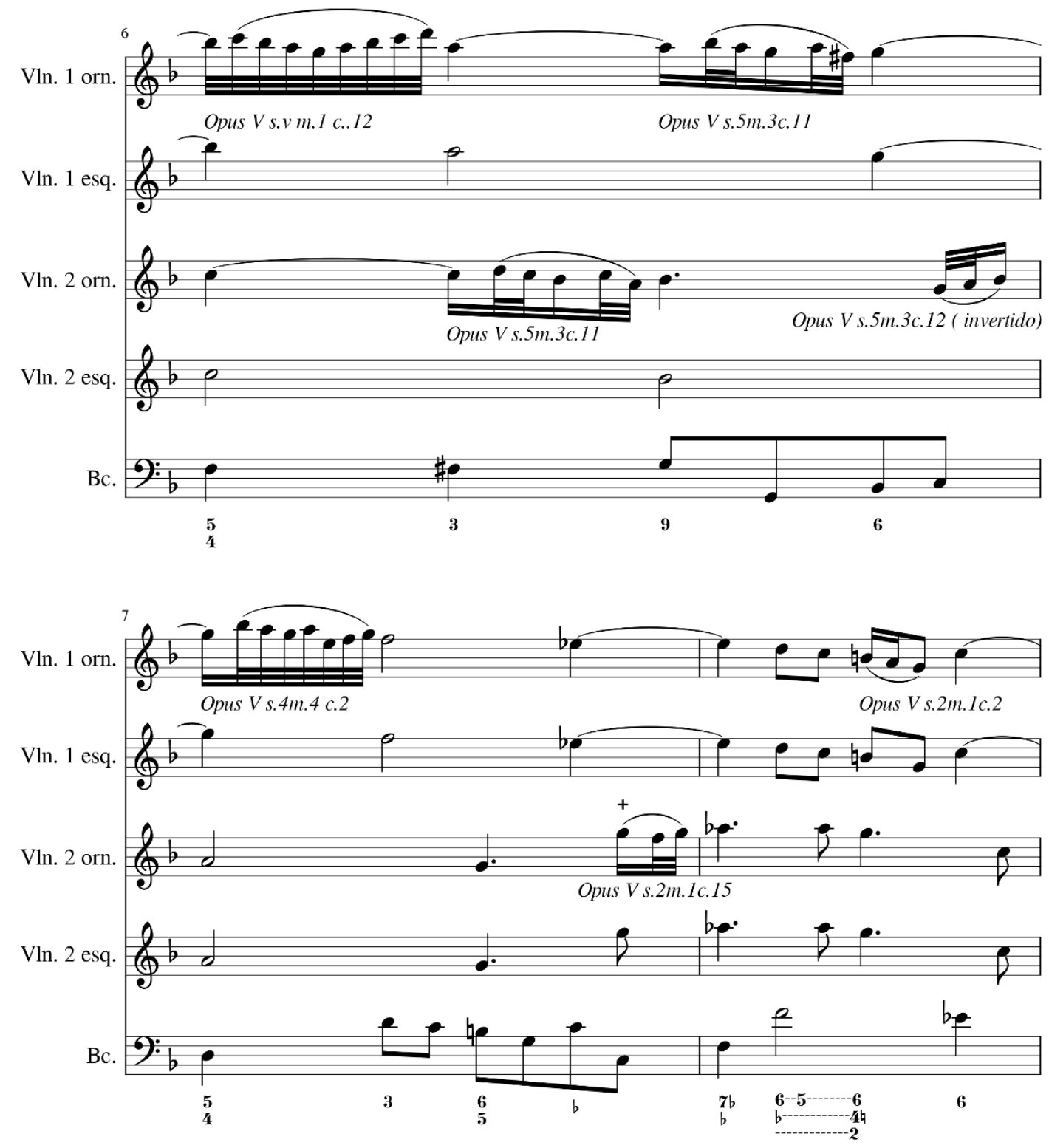
Figura 92 - Proposta de edição didaticamente ornamentada para a sonata 3 opus III de Corelli primeiro movimento (parte 3 )
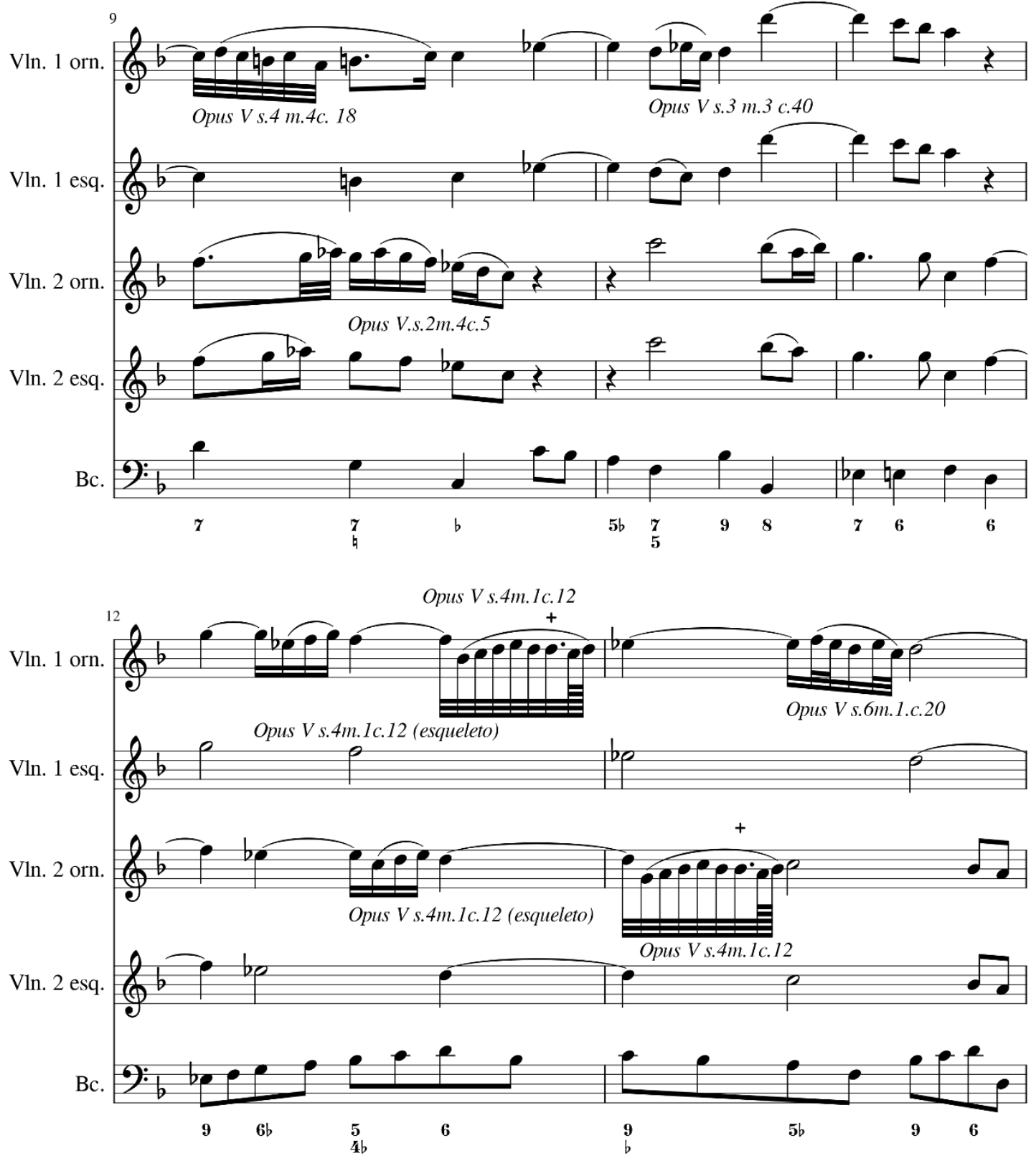
Figura 93 - Proposta de edição didaticamente ornamentada para a sonata 3 opus III de Corelli primeiro movimento (parte 4)

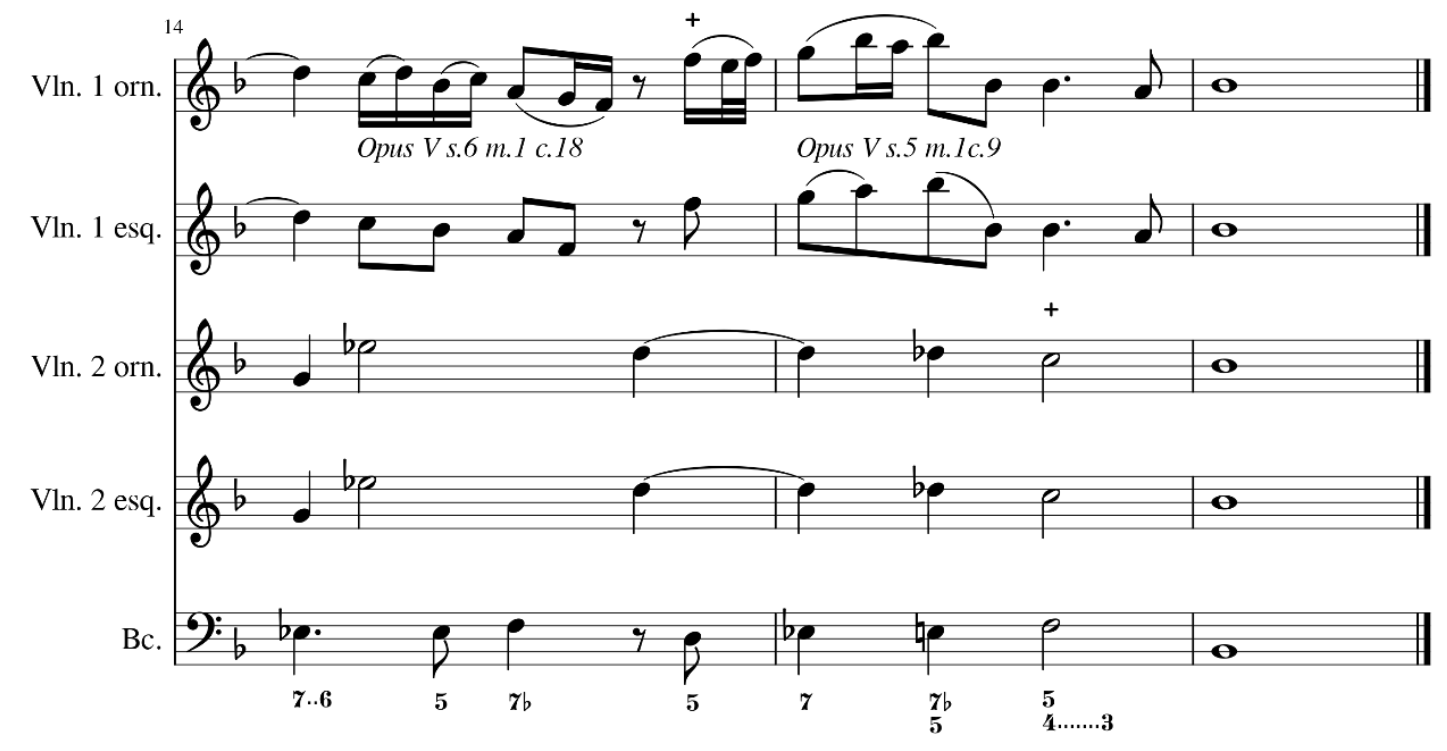

Edição e ornamentos por Roger Ribeiro 
Figura 94 - Proposta de edição didaticamente ornamentada para a sonata 3 opus III de Corelli terceiro movimento (parte 5)

\section{Trio-sonata opus III n³ \\ III- Largo}

Arcangelo Corelli (1653-1713)
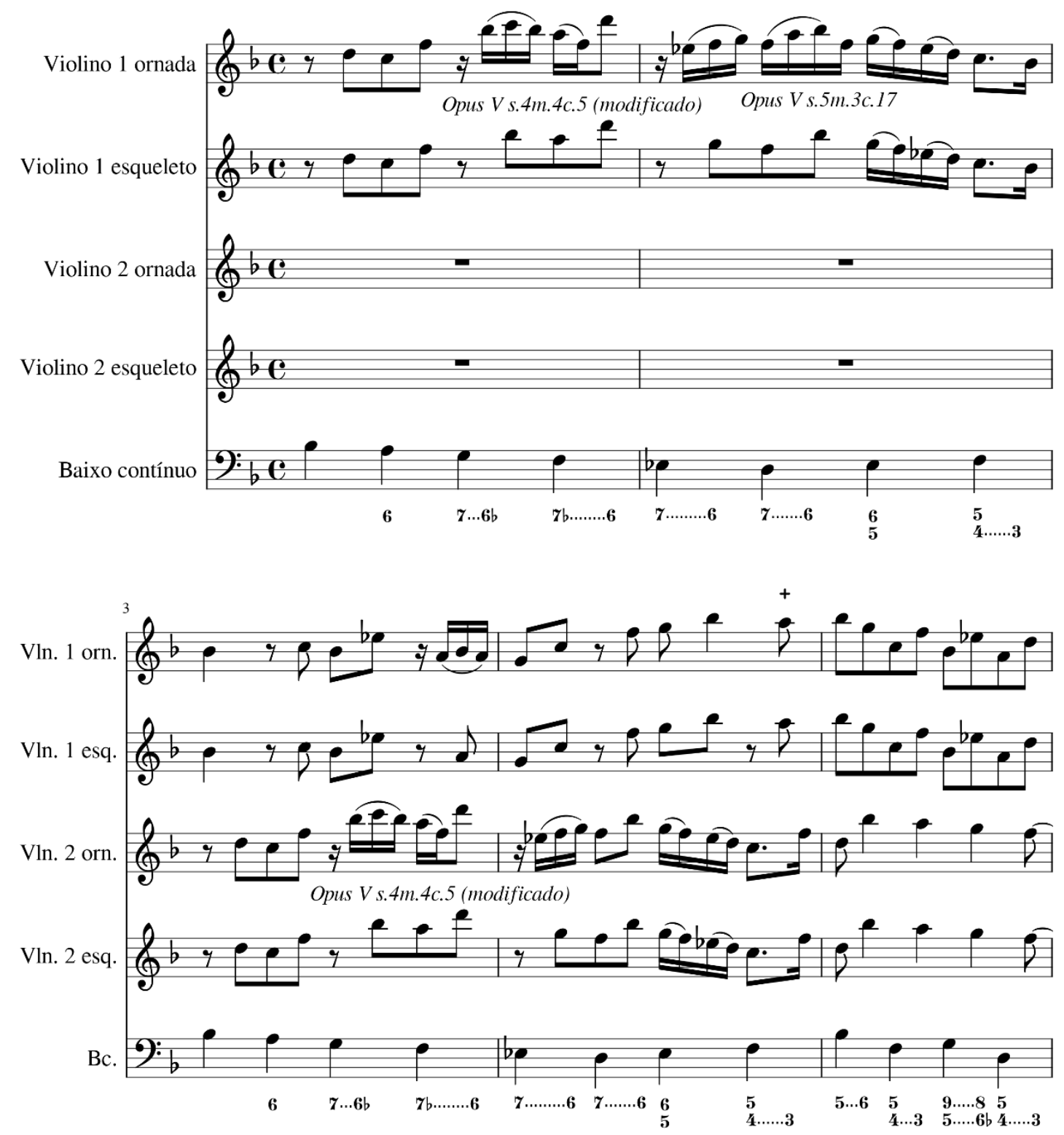
Figura 95 - Proposta de edição didaticamente ornamentada para a sonata 3 opus III de Corelli terceiro movimento (parte 6)
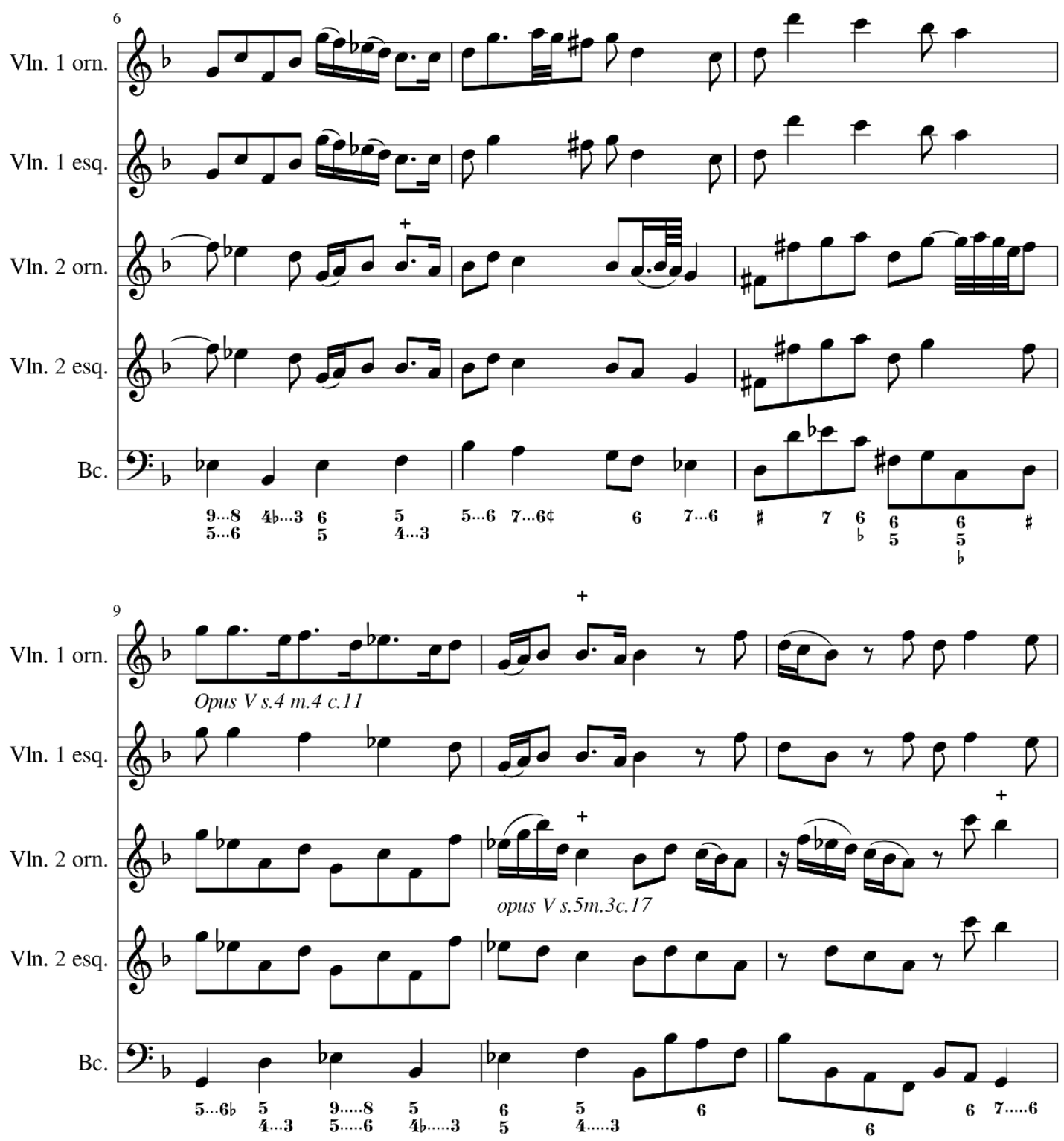
Figura 96 - Proposta de edição didaticamente ornamentada para a sonata 3 opus III de Corelli terceiro movimento (parte 7)
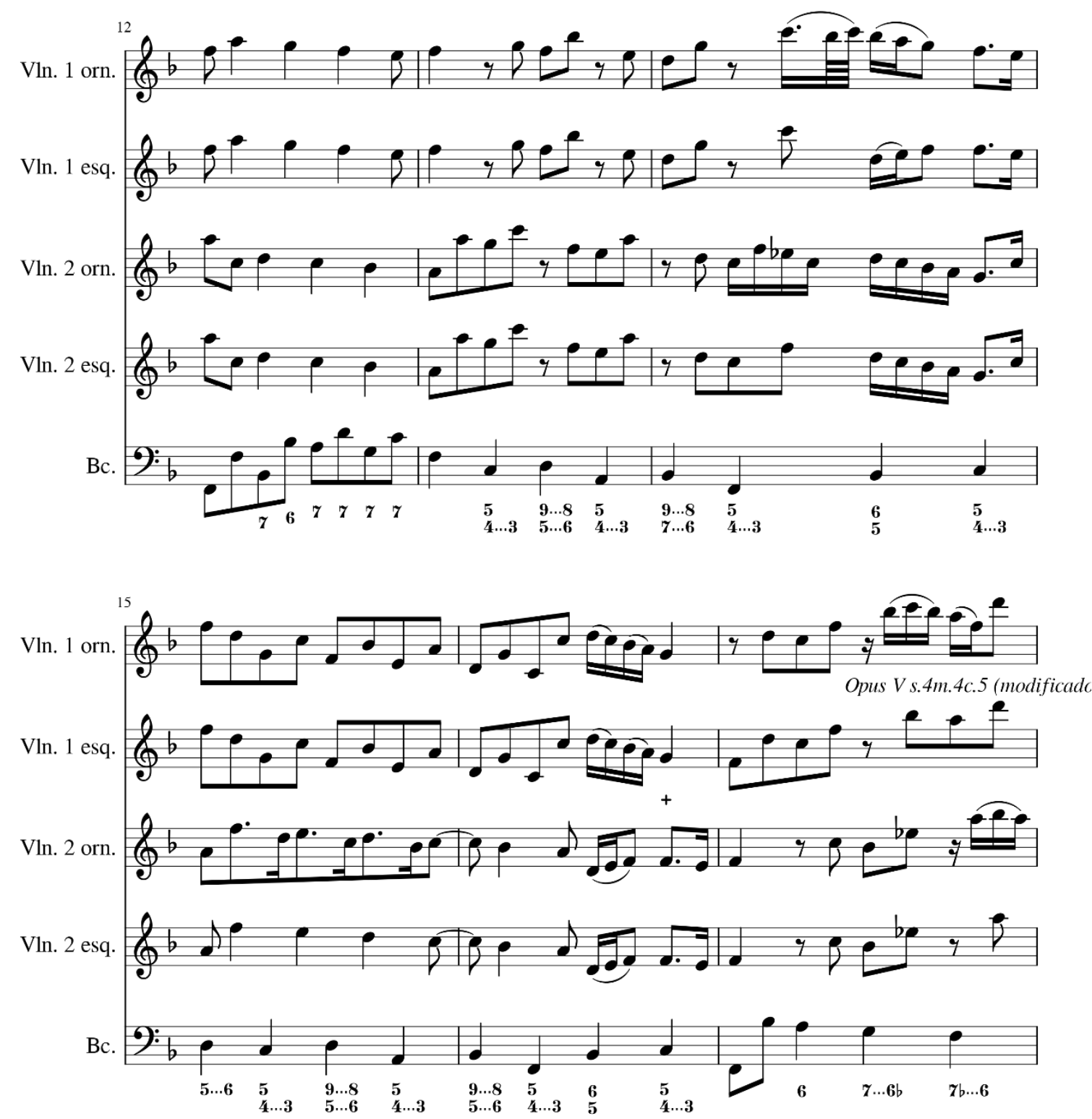
Figura 97 - Proposta de edição didaticamente ornamentada para a sonata 3 opus III de Corelli terceiro movimento (parte 8)
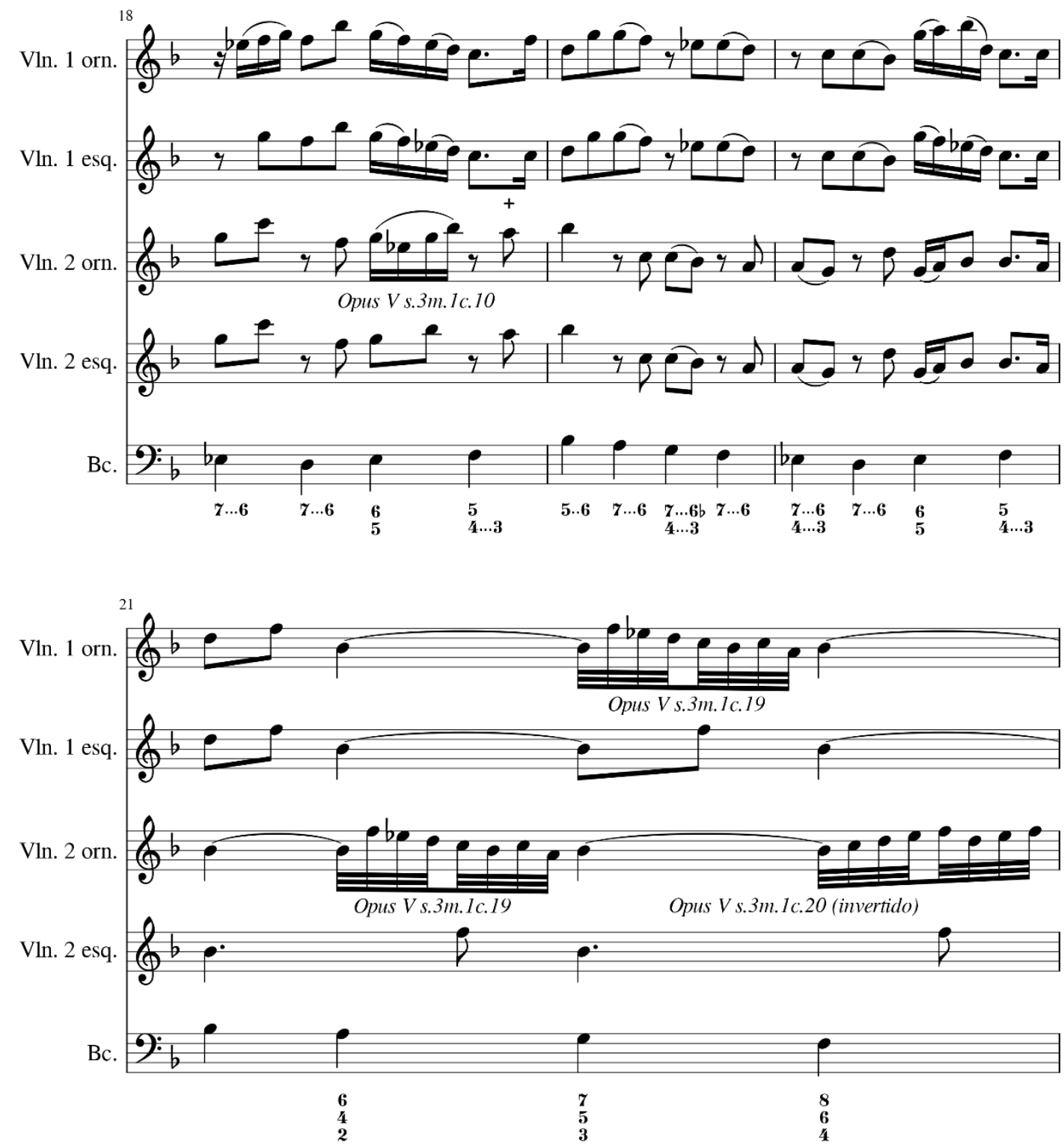
Figura 98 - Proposta de edição didaticamente ornamentada para a sonata 3 opus III de Corelli terceiro movimento (parte 9)

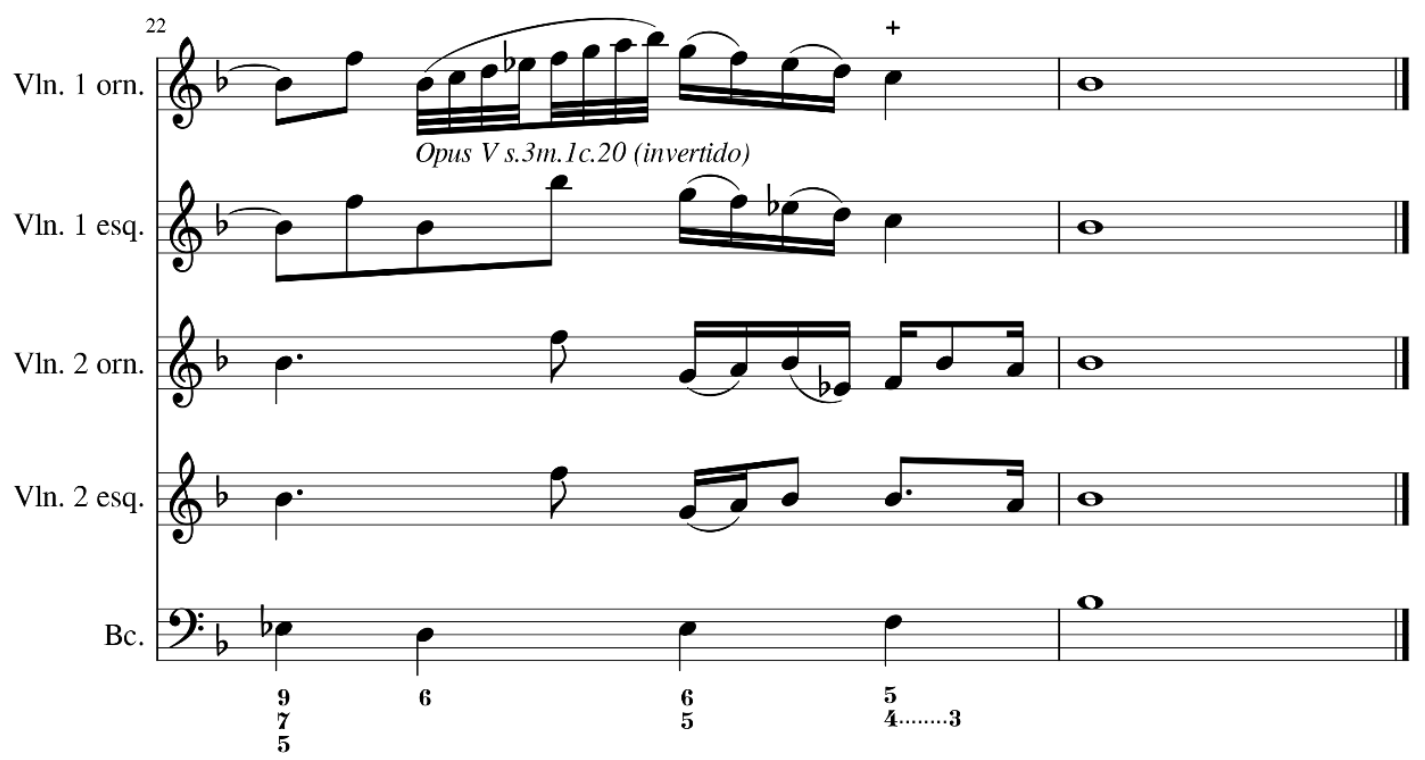




\section{CONCLUSÃO}

Vimos nesta dissertação a importância modelar da obra de Corelli, tanto do seu Opus V como de suas 48 trios-sonatas. Assim o "Orpheu romano" é uma importante referência para a música barroca italiana de seu período, exaltado em vida e por um século após seu falecimento. Porém, alguns aspectos de sua obra permanecem obscuros. Enquanto o Opus $V$ evidencia práticas interpretativas e composicionais chaves para a compreensão deste repertório, as triosonatas, que são a maior parte de sua obra editada, permanecem como um terreno incerto quanto suas práticas, pois exigem um estudo mais cuidadoso e aplicado do referencial didático deixado pelo compositor na terceira edição do Opus V.

Conforme as referências analisadas, a prática da ornamentação livre nos movimentos lentos da música italiana da virada dos séculos XVII e XVIII estava a todo vapor. As preceptivas levantadas sugerem boas evidências dessa prática, bem como sugerem importantes fundamentos para o intérprete que vise reproduzi-la com bom gosto. Ao compará-las com modelos contemporâneos, resultados substanciais puderam ser alcançados. Também foi possível catalogar diversos relatos de prática interpretativas atreladas ao compositor que sugerissem essa prática fundamentando uma hipótese levantada já pela simples existência da terceira edição do Opus V.

Retonarmos à já exposta frase de Quintiliano em sua Institutio oratoria ("Instituição oratória"): "Portanto, é útil ter primeiramente a quem imitar, caso queiras depois superá-lo: assim, aos poucos, haverá esperança de chegar a pontos mais altos" (Quintiliano, op. cit. I-ii29 p. 54). Dessa forma, recorrer aos modelos, construir um próprio e propor um modelo de ornamentação para um gênero com poucos estudos que unam essa prática a ele se revela um caminho útil não só do ponto de vista musicológico, mas também para a pratica interpretativa.

Temos no Opus $V$ de Corelli um inquestionável modelo de ornamentação livre contemporâneo ao seu autor e, nos Trietti de Telemann, um modelo setecentista preservado de ornamentação livre em trio-sonatas. As possibilidades oriundas da imitação atenta das obras desses mestres (através de uma análise minuciosa dos princípios explícitos e implícitos em suas exposições) conforme demonstrado acima, são infinitas e se abrem ao estudo e interpretação do repertório barroco italiano, podendo assim contribuir para explicitar a responsável inventividade oculta de diversos intérpretes, aproximando tanto a atual teoria, como a prática interpretativa do século XXI, de um componente indispensável ao gosto musical do barroco italiano: a ornamentação livre. 
Também concluímos que o ato de ornamentar uma música (com ornamentos e diminuições, bem como outros recursos expressivos adequados ao gosto exigido pelo repertório) exige um domínio amplo, consciente ou inconsciente ${ }^{89}$, da retórica musical como um todo; também, neste sentido esta dissertação se pretende uma ferramenta a mais para a construção do discurso musical do intérprete do século XXI. Acreditamos que o ornato, conforme verificamos nas referências, é mais do que um simples embelezamento acessório, é por si só uma arte da expressividade dentro de outras, a retórica e a música.

Assim, a retórica sem o ornato (oratio inornata) é, além de um vício, não mais do que um corpo sem vida; a música barroca, sem a retórica, idem. Dessa forma, o ornato é uma virtude pelo qual vale correr inúmeros riscos de se aproximar da demasia (mala affectatio), pois o sabor do comedimento (uma virtude idealizada por qualquer orador) nunca será alcançado por aqueles que se contentam com o vício da ausência de expressão e os falsos confortos que ela lhes oferece.

Por fim vale lembrar que nossa plateia do século XXI não é a mesma do século XVIII, tendo um gosto diverso. Nesse ponto, independentemente da nacionalidade, somos todos estrangeiros querendo adentrar a Roma corelliana. Assim, que o modelo de ornamentação de Corelli seja emulado (como foi no século XVIII, conforme demonstrado pelo artigo de Zaslaw em 1996) e o brilho dos ornatos do discurso musical apropriados pelos intérpretes de música de câmera do século XXI façam de suas plateias "Raguenets", “ Brossards" e "Rogers" que convencidos, adquiram as virtudes do gosto musical italiano do Orfeu de Roma.

89 Aqui acreditamos também na imitação como base da aquisição do bom gosto. 


\section{REFERÊNCIAS BIBLIOGRÁFICAS}

\section{Fontes Primárias}

BASSANO, Giovanni. Ricercate, Passaggi et cadentie. Venezia: Giacomo Vincenzi \& Ricciardo Andimo, 1585. Disponível em: <http://imslp.org/wiki/Ricercate\%2C_passaggi_et_ cadentie_(Bassano\%2C_Giovanni)>. Acesso em15 out. 2017.

BENDA, Franz. 33 sonatas. Berlin: Wolf [Manuscrito atribuído ao compositor], 1919 [1780]. Disponível em: em: <https://opac.rism.info/metaopac/search?q=rism452003334\&db=251\& View=rism\&Language=en>. Acesso em: 15. out. 2018.

CORELLI, Arcangelo. Opera quinta. Firenze [Roma-Amsterdan]: Arquivum Musicum [Gasparo Pietra Santa- Estienne Roger], 1979 [1700-1711]. Fac-simile.

. Opera terza. Roma: Gio Giacomo Komarek, 1689. Disponível em: <http://imslp.org/wiki/ 12_Trio_Sonatas,_Op.3_(Corelli,_Arcangelo)>. Acesso em 15 out. 2017.

Opera terza. Londres: Joseph Joachim e Friedich Chrysander, 1888. Disponível em: <http://imslp.org/wiki/ 12_Trio_Sonatas,_Op.3_(Corelli,_Arcangelo)>. Acesso em 15 out. 2017.

CRESCIMBENI, Giovanni mario. L'Arcadia del can. Gio. Mario Crescimbeni custode della medesima Arcadia, e accademico fiorentino. Antonio de Rossi alla Piazza di ceri, Firenze, 1708.

DALLA CASA, Girolamo. Il vero modo di diminuir. Venezia: Angelo Gardano, 1584. Disponivel em: <http://www.imslp.org/wiki/Il_vero_modo_di_diminuir_(Dalla_Casa, Girolamo)>. Acesso em 15 out. 2017.

GEMINIANI, Francesco. Le Prime Sonate a violin e basso. OP. 1. London: Jeanne Roger, 1716-1722. Disponivel em: <http://imslp.org/wiki/12_Violin_Sonatas\%2C_Op.1_ (Geminiani\%2C_Francesco)>. Acesso em 15 out. 2017.

.XII Solos for a Violin with a Thorough Bass of Harpsichord or Bass Violin OP.

1. London: Francesco Geminiani, 1739. Disponivel em: <http://imslp.org/wiki/ 12_Violin_Sonatas\%2C_Op.1_(Geminiani\%2C_Francesco)>. Acesso em: 15 out. 2017.

. A treatise of good taste in the art of musick. [London:1749]. Tradução Marcus Held. 2017. Dissertação mestrado Programa de Pós-Graduação em Música - Escola de Comunicação e Artes/Universidade de São Paulo, São Paulo, 2017.

The art of playing on the violin. [London: 1751]. Tradução Marcus Held. 2017. Dissertação mestrado Programa de Pós-Graduação em Música - Escola de Comunicação e Artes/Universidade de São Paulo, São Paulo, 2017.

MATTHESON, Johann. Der Volkommene Capellmeister. Kassel [Hamburg]: Bärenreiter [Christian Herold], 1996 [1739]. Fac-simile

MOZART, Leopold. A treatise on the fundamental principles of violin playing [Versuch einer gründlichen Violinschule]. Oxford [Augsburg]: Oxford University Press [Johann Jacob Lotter], 1985 [1756]. Tradução de Editha Knocker. 
PENNA, olivio. Aggregazione di Antonio Bernacchi all'Accademia Filarmonica, in Olivo Penna,

Cronologia o sia istoria generale di questa Accademia, Bologna, 1736, vol. III, p.579. Bologna: Archivio dell'Accademia Filarmonica

QUANTZ, Johann Joachim. Easy and Fundamental Instructions. London: Welcker, n.d. (1780).

Versuch einer Anweisung die Flöte Traversière zu spielen. Leipzig [Berlin]: Deutscher Verlag für Musik [Voss], 1983 [1752].

QUINTILIANO, Marcus Fabius. Instituição oratória. Tradução de Bruno Bassetto. Campinas: Editora da UNICAMP, 2015. V. 12 , 3 e 4.

ORTIZ, Diego. Trattado de Glossas. Roma: Valerio Dorico \& Luigi Dorico, 1553. Disponível em: 〈http://imslp.org/wiki/Trattado_de_Glosas_(Ortiz\%2C_Diego)>. Acesso em 15 out. 2017.

Raguenet, François. A Comparação entre a Ópera Italiana e a Francesa, [Paris, 1702]. Tradução Paulo kühl. Revista Música, 14(1), 147-195. Dísponível em: <https://doi.org/10.11606/rm.v14i1.115251> acessso em: 15 jul. 2020.

RAMEAU, Jean. phillipe. Traité de l'harmonie réduite à ses principes naturels, Paris De l'imprimerie de Jean-Baptiste-Christophe Ballard. M.DCC XXII, 1722. Fac-simile disponível em: < https://gallica.bnf.fr/ark:/12148/btv1b86232459> Acesso em 02 Jun. 2020.

TARTINI, Giuseppe.: Lettera del defonto Signor Guiseppe Tartini alla signora Maddalena Lombardini inserviente ad uma importante lezione per i suonatori di violino. London: Robert Bremner, 1779 [1760]. Edição em italiano e tradução para o inglês de Charles Burney, Disponível em: <http://imslp.org/wiki/Tutorial_Letter_to_Maddalena_Lombardini_(Tartini\% 2C_Giuseppe)>. Acesso em 15 out. 2017.

Regole per arrivare a saper ben suonar il violin, col vero fondamento di saper sicuramente tutto quello, Che si fa; buono ancora a tutti quelli, ch'esercitano la musica siano cantati o suonatori (manuscrito sem data). Firenze: Marco Giustini, 2012. Disponível em:<http://imslp.org/wiki/Trait\%C3\%A9_des_agr\%C3\%A9mens_de_la_musique_(Tartini\% 2C_Giuseppe)>. Acesso em 15 out. 2017.

Traité des agréments Paris: Pierre Denis, 1771. Primeira publicação mundial e tradução para o Frances de Pierre Denis. Disponível em: <http://imslp.org/wiki/Trait\%C3\%A9_des_agr\%C3\%A9mens_de_la_musique_(Tartini\%2C_ Giuseppe)>. Acesso em: 15 out. 2017.

L'arte del arco. (1747). Paris: Leclerc, n.d, 1758. Disponível em: http://imslp.org/wiki/L'arte_del_arco_(Tartini\%2C_Giuseppe) Acesso em15 out. 2017.

TELEMANN, Georg Philipp. Trietti Metodichi. Hamburg: Georg Christian Gund, 1731. Disponível em: <http://imslp.org/wiki/3_Trietti_methodichi_e_3_Scherzi_(Telemann\% 2C_Georg_Philipp)>. Acesso em15 out. 2017.

USSHER, James. Clio: or, A discourse on taste (1772- 3 ed.) (fac-simile) disponível em: <https://play.google.com/store/books/details/James_USHER_Schoolmaster_Clio_or_A_disco urse_on_ta?id=SsgKmkdaaxoC $>$ acesso em 21 mar. 2020.

ZACCONI, Ludovico. Prattica di musica. Venezia: Bartolomeo Caram Pello, 1596. Disponível em: <http://imslp.org/wiki/Prattica_di_musica_(Zacconi,_Ludovico)>. Acesso em 
15 out. 2017.

ZUCCARI, Carlo. The true method of playing an adagio. London: Robert Bremner, n.d., 1762. Disponível em:<http://imslp.org/wiki/The_True_Method_of_Playing_an_Adagio_ (Zuccari\%2C_Carlo)>. Acesso em 15 out. 2017.

\section{DICIONÁRIOS}

BROSSARD, Sébastien de. Dictionnaire de musique. Paris, Christophe Ballard, 1703. Disponível

em:<https://imslp.org/wiki/Dictionnaire_de_musique_(Brossard\%2C_S\%C3\%A9bastien_de) $>$ Acesso em: 15 JUL. 2019

Dictionnaire de musique. Amsterdam. Estienne Roger, 1708. Disponivel em: <https://imslp.org/wiki/Dictionnaire_de_musique_(Brossard\%2C_S\%C3\%A9bastien_de)> Acesso em: 15 JUL. 2019

BRUSCAROLLI, Pietro. Dizionario Biografico degli Italiani. Treccani, 1983. Disponível em: $<\mathrm{h}] \mathrm{Mttp}: / / \mathrm{www}$. treccani.it/enciclopedia/arcangelo-corelli_(Dizionario-Biografico)>. Acesso em 15 out. 2017.

BLUTEAU, Raphael. Vocabulario portuguez \& latino: aulico, anatomico, architectonico ... Coimbra: Collegio das Artes da Companhia de Jesu, 1712 - 1728. 8 v. Disponível em:<http://dicionarios.bbm.usp.br/pt-br/dicionario/edicao/2> acesso em: 15 jul. 2019

COUTO, Antonio Maria. Dicionario da maior parte dos termos Homonymos, e equívocos da língua portuguesa. Lisboa (1842). (fac-simile) Disponível em: http://purl.pt/13930 . Acesso em22 mar. 2020.

HOUAISS, Antônio. Dicionário Houaiss da Língua Portuguesa. Rio de Janeiro: Ed. Objetiva, 2001.

MICHAELIS. Moderno dicionário da língua portuguesa. São Paulo: Melhoramentos, 1998.

PINTO, Luiz Maria da Silva. Diccionario da Lingua Brasileira por Luiz Maria da Silva Pinto, natural da Provincia de Goyaz. Na Typographia de Silva, 1832. Disponível em:<http://dicionarios.bbm.usp.br/pt-br/dicionario/edicao/2> acesso em: 15 JUL. 2019

SILVA, Antonio Moraes. Diccionario da lingua portugueza - recompilado dos vocabularios impressos ate agora, e nesta segunda edição novamente emendado e muito acrescentado, por ANTONIO DE MORAES SILVA. Lisboa: Typographia Lacerdina, 1813. Disponível em:<http://dicionarios.bbm.usp.br/pt-br/dicionario/edicao/2> acesso em: 15 jul. 2019

\section{Fontes secundárias}

ALSOPP, Peter. Arcangelo Corelli: new Orpheus of our Times. Oxford University press, 1999.

BARTEL, Dietrich. Musica Poetica: Musical Rhetorical Figures in German Baroque, Google books, 1984.

BENSON, Bruce Ellis. The improvisation of musical dialogue: a Phenomenology of music. Cambridge: Cambridge university press, 2003.

BREMNER, Robert, "Some Thoughts on the performance of Concert Music", the preface to his edition of Schetky, six quartetos...opus VI London, 1777. 
CHICO-RICO, Francisco. "Some (semiotic) aspects of elocutio." Quintiliano and the law, The Art of Persuation in Law and Politics, Olga Tellegen-Couperus, Leuven,:Leuven university press, 2003

COOK, Nicholas. At the Borders of Musical identify: Schenker, Corelli and the Graces. Music analysis, v. 18, n. 2, p. 179-233, jul. 1999.

DRATWICKI, Benoît. La musique à la cour de louis XV: François Colin de Blamont (16901760): une carrière au servisse du roi. Rennes: Presses Universitaires de Rennes, 2017.

DOS ANJOS, Guilherme Herdade Linberger. As Sonate Metodiche de Georg Philipp Telemann: um estudo sobre ornamentação e estilo no final do barroco. São Paulo: Dissertação mestrado Programa de Pós-Graduação em Música - Escola de Comunicação e Artes/Universidade de São Paulo, 2014.

DONNINGTON, R. Baroque music: Style and performance. A handbook. New York, London: W. W. Norton \& company, 1982.

D’Ovidio Antonella. Alle soglie dello strumentalismo Corelliano: Collista, Lonati, Stradella e Manelli..studio storico analítico ed edizione critica dele sonate a três.Tese de doutorado do departamento de Musicologia e ciências filológicas da Universitá degli studidi Paiva.

ELLENDERSEN, Atli. 'Em todas as coisas a mudança é doce': Varietas e paixão na música italiana renascentista. Revista Vórtex, [S.1.], v. 7, n. 1, abr. 2019. ISSN 2317-9937.Disponível em: <http://periodicos.unespar.edu.br/index.php/vortex/article/view/2681/1777> . Acesso em 02 Junho 2020.

Imitare la voce humana: aspectos expressivos do violino no século XVI e início do século XVII. Tese (Doutorado em Música) - Universidade Federal do Paraná, Setor de Artes, Comunicação e Design, Programa de Pós-Graduação em Música. Disponível em: <https://acervodigital.ufpr.br/bitstream/handle/1884/65717/R\%20-\%20T\%20-20ATLI\% 20ELLENDERSEN.pdf?sequence=1\&isAllowed=y>. Acesso em 02 Jun. 2020.

GARAVELLI, Bice Mortara. Manual de retória. Ediciones Catedra, Madrid, 1988

HARRÁN, Don; Toward a Rhetorical Code of Early Music Performance. Journal of Musicology 1 January 1997; 15 (1): 19-42. Disponível em: < https://doi.org/10.2307/763902> Acesso em 02 Jun. 2020.

HARNONCOURT, Nikolaus. O Discurso dos Sons: caminhos para uma nova compreensão musical. Rio de Janeiro: Jorge Zahar, 1988. Tradução Marcelo Fagerlande.

HAYNES, Bruce. The End of Early Music: A Period Performer's History of Music for the Twenty-First Century, Oxford, Oxford University Press, 2007.

HELD, Marcus. Francesco Geminiani (1687-1762): comentários e tradução da obra teórica completa. 2017. Dissertação mestrado Programa de Pós-Graduação em Música - Escola de Comunicação e Artes/Universidade de São Paulo, São Paulo, 2017.

JUSTI, Katia Regina Kato. (2013). O tropo retórico como artificio musical e trágico e sua utilização na missa em Si menor de Bach. Revista Música e Linguagem - Vitória/ES. Vol.1 $\mathrm{n}^{\circ} \quad 3$ (2013), $\quad$ p. 52-72. Disponível em: <https://www.periodicos.ufes.br/musicaelinguagem/article/view/6513/4758> acesso em: 15 julho, 2020. 
KÜHL, Paulo. (2014). A Comparação entre a Ópera Italiana e a Francesa: Raguenet e a Irredutibilidade de Duas Tradições. Revista Música, 14(1), 147-195.Dísponível em: <https://doi.org/10.11606/rm.v14i1.115251> acessso em: 15 julh. 2020.

LAUSBERG, Heinrich. Elementos de retórica literária; trad., pref. e aditamentos R. M. Rosado Fernandes. - $5^{a}$ ed. - Lisboa: Fundação Calouste Gulbenkian, 2004. - 294, [1] p.; 23 cm. - (Manuais universitários). - Tít. orig.: Elemente der literarischen rhetorik. - Contém bibliografia. - ISBN 972-31-0119-X.

LUCAS, Monica. Humor e agudeza em Joseph Haydn. Quarteto de cordas op. 33. São Paulo: Annablume/Fapesp, 2008.

NEUMANN, Frederick. Ornamentation in Baroque and Post-Baroque Music: with Special emphasis on J. S. Bach. New Jersey: Princeton University Press, 1983.

OLIVERI, Guido; VANSCHEEUWIJCK, Marc. Arcomelo 2013: Studi nel terzo centenário dela morte di Arcangelo Corelli (1653-1713). Lim, Fusignano, 2015. xxviii ISBN 9788870967975 .

PAOLIELLO, Noara. Gosto e estilo na música do XVIII: os concertouvertures de Georg Philipp Telemann. São Paulo: Annablume/Fapesp Clássica, 2017.

Piperno, Franco. Corelli e il "concerto" seicentesco. Lettura e interpretazione dell'Opera VI. Studi corelliani IV: atti del quarto congress internazionale (Fusignano, setembre 1986). Pierluigi Petrobelli, Gloria Staffieri, 1990, JSBN 88-222-3820-6, p. 359-380

. "L'armoniose idee della sua mente": Corelli, the Arcadians, and the primacy

of Rome. Passsagio in Italia. Music on the Grand tour in the Seventeenth Century. Editado por: Dinko Fabris e Margaret Murata. Foudation for historical performance Practice, Utrecht 2015.pag 217-227.

RATNER, Leonard G. Classic Music - Expression, form and Style. New York: Schirmer Books, 1980.

RÓNAI, Laura. Em busca de um mundo perdido: métodos de flauta do Barroco ao século XX. Rio de Janeiro: Topbooks, 2008.

REBOUL. Introdução à Retórica, 1925, tradução Benedetti, Ivone Castilho - São Paulo: Martins Fontes1998.

SANNA, Alberto. Arcangelo Corelli and friends: kinships and networks in the Papal State, Early Music, Volume 41, Issue 4, Novembro 2013, pp. 645-655, Disponível em: <https://hira.hope.ac.uk/id/eprint/169/7/Arcangelo\%20Corelli\%20and\%20friends\%20po stprint.pdf> Acesso em 21 mar. 2020.

SANTOS, Luís Otavio. A chave do artesão: um olhar sobre o paradoxo da relação mestre/aprendiz e o ensino metodizado do violino brarroco. 2011. 189 p. Tese (doutorado) Universidade Estadual de Campinas, Instituto de Artes, Campinas, SP. Disponível em: <http://www.repositorio.unicamp.br/handle/REPOSIP/284454>. Acesso em20 ago. 2018.

SETA, Fabrizio dela. La musica in Arcadia al tempo di Corelli. Nuovissimi studi corelliani, Atti del terzo congresso Internazionale (Fusignano, set. 1980).p.123-150.

TARLING, Judy. Baroque string playing for ingenious learners. Michigan: Corda music, Universidade de Michigan, 2010. 
SPITZER, John; ZASLAW, Neal. The Birth of The Orchestra: History of an institution, 1650-1815. New York: Oxford University Press, 2004.

ZASLAW, Neal. Ornaments for Corelli’s violin sonata, op. 5. Early music, v. 24, n. 1, p. 95116, fev. 1996. 